
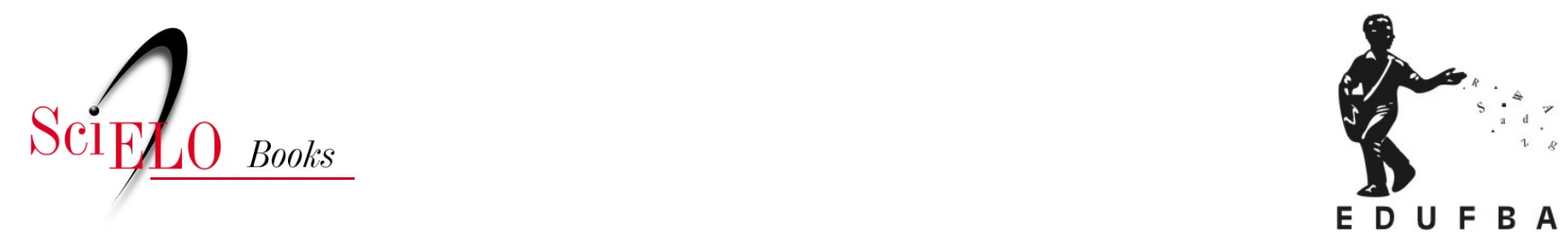

\title{
A cidade-atração \\ a norma de preservação de áreas centrais no Brasil dos anos 1990
}

\author{
Marcia Sant'Anna
}

\section{SciELO Books / SciELO Livros / SciELO Libros}

SANT'ANNA, M. A cidade-atração: a norma de preservação de áreas centrais no Brasil dos anos 1990 [online]. Salvador: EDUFBA-PPG-AU FAUFBA, 2017, 503 p. ISBN: 978-85-232-1871-3. https://doi.org/10.7476/9788523218713.

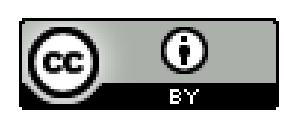

All the contents of this work, except where otherwise noted, is licensed under a Creative Commons Attribution 4.0 International license.

Todo o conteúdo deste trabalho, exceto quando houver ressalva, é publicado sob a licença Creative Commons Atribição 4.0. 


\section{A cidade-atração}

a norma de preservação de áreas centrais no Brasil dos anos 1990 


\section{UNIVERSIDADE FEDERAL DA BAHIA \\ Reitor \\ João Carlos Salles Pires da Silva}

Vice-reitor

Paulo Cesar Miguez de Oliveira

Assessor do Reitor

Paulo Costa Lima

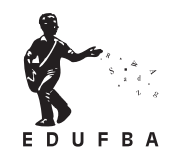

EDITORA DA UNIVERSIDADE FEDERAL DA BAHIA

Diretora

Flávia Goulart Mota Garcia Rosa

Conselho Editorial

Alberto Brum Novaes

Angelo Szaniecki Perret Serpa

Caiuby Alves da Costa

Charbel Ninó El-Hani

Cleise Furtado Mendes

Evelina de Carvalho Sá Hoisel

José Teixeira Cavalcante Filho

Maria do Carmo Soares de Freitas

Maria Vidal de Negreiros Camargo

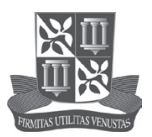

FACULDADE DE ARQUITETURA

Diretora

Naia Alban Suarez

Programa de Pós-Graduação em Arquitetura e Urbanismo

Coordenador

Luiz Antonio Fernandes Cardoso

Vice-Coordenadora

Marcia Sant'Anna

Coleção PPG-AU FAUFBA

Conselho Editorial

Francisco de Assis da Costa [coordenação editorial]

Gilberto Corso Pereira

Marco Aurélio A. de F. Gomes

Mário Mendonça de Oliveira

Odete Dourado Silva

Paola Berenstein Jacques

Pasqualino Romano Magnavita

Apoio

fapesb
Fundaçáo de Amparo
à Pesquisa do Estado da ahia 
Marcia Sant'Anna

\section{A cidade-atração}

a norma de preservação de áreas centrais no Brasil dos anos 1990 
2017, Marcia Sant'Anna.

Direitos de edição cedidos à EDUFBA.

Feito o depósito legal.

Grafia atualizada conforme o Acordo Ortográfico da Língua Portuguesa de 1990, em vigor no Brasil desde 2009.

Capa e Projeto Gráfico: Angela Garcia Rosa

Editoração e arte-final da capa: Amanda Lauton Carrilho

Revisão e normalização: Eduardo Ross e Juliana das Virgens Rufino

Imagem da capa: Marcia Sant'Anna

\section{Sant’Anna, Marcia.}

A cidade-atração: a norma de preservação de áreas centrais no Brasil dos anos 1990 / Marcia

Sant’Anna. - Salvador: EDUFBA-PPG-AU FAUFBA, 2017.

$503 \mathrm{p}$.

ISBN 978-85-232-1580-4

1. Patrimônio cultural - Brasil. 2. Patrimônio cultural - Proteção - Brasil. 3. Cidades e vilas - Brasil - 1990-1999. 4. Planejamento urbano - Brasil. I. Título.

CDD - 306.0981

\section{Editora filiada à}

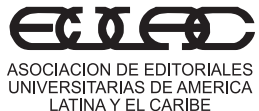
LATINA Y EL CARIBE
LATI

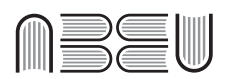

Associação Brasileira das Editoras Universitárias

\section{$\mathrm{CBaL}$ \\ Câmara Bahiana do Livro}

EDUFBA

Rua Barão de Jeremoabo, s/n, Campus de Ondina, 40170-115 Salvador-BA Brasil

Tel/fax: 55 (71)3283-6160/3283-6164 www.edufba.ufba.br|edufba@ufba.br
PPG-AU FAUFBA

Rua Caetano Moura, 121, Federação 40210-905 / Salvador-BA / Brasil Tel: 55 (71) 3283-5900 
Ao Instituto do Patrimônio Histórico e Artístico Nacional, nos seus 80 anos. 


\section{Agradecimentos}

Um livro nunca é um trabalho rigorosamente individual. Por mais solitário que seja quanto à responsabilidade pelas ideias que apresenta e defende, é sempre tributário dos autores com os quais dialoga, e também de um sem-número de pessoas que apoiaram a sua produção, discutiram o seu conteúdo e, com seus conhecimentos, iluminaram questóes e permitiram a superação de obstáculos aparentemente intransponíveis. Assim, agradeço a todos que, com sua colaboração inestimável, tornaram possível levar a pesquisa e a reflexão que fundamentam este trabalho a bom termo.

Ana Fernandes, Paulo Ormindo Azevedo, Lílian FesslerVaz, Heloísa Helena F. G. Costa e Nadia Somekh, como membros da banca examinadora da tese que deu origem a este livro, contribuíram enormemente para o rigor conceitual deste trabalho, para sua clareza e qualidade. Adalgiza Maria Bonfim d’Eça, Adriana Almeida Couto de Castro, Antonio Augusto Arantes, Augusto Ivan de Freitas Pinheiro, Cássia Magaldi, Cecília Rodrigues, Cristina Figueiredo, Cyro Correa Lyra, Décio Amadio, Elisa Leonel, Francisco Soares Senna, Helena Galiza, Helena Menna Barreto Silva, José Saia Neto, Jurema Machado, Lia Motta, Lucia Basto, Marco Antônio Galvão, Marcelo Brito, Maria Cecília Londres Fonseca, Maria Helena MacLaren, Mirthes Baffi, Paulo Damasceno Silva, Raul L. de Carvalho, Regina Orsi, Rita Márcia Sacramento, Sylvia Nelo Braga, Thays Pessoto Zugliani, Valfredo de Assis Ribeiro, Walter Pires e demais especialistas, dirigentes, técnicos e/ou responsáveis por ações analisadas neste livro, prestaram inestimáveis informações, disponibilizaram dados, forneceram importantes indicações, facilitaram e tornaram produtivas as pesquisas de campo realizadas em Salvador, Rio de Janeiro, São Paulo e Brasília entre 2002 e 2003. A todos, meu mais sincero agradecimento. Agradeço também a Daniel Duché, Leonardo Mesentier e Roberto Anderson Magalhães pelo envio de documentos, publicações e teses cujo conteúdo foi de grande importância para o desenvolvimento deste 
trabalho. Registro também o meu agradecimento à Fundação de Amparo à Pesquisa do Estado da Bahia pela disponibilização dos recursos que possibilitaram esta publicação e à EDUFBA pelo trabalho cuidadoso e competente de revisão e edição.

Silza e Dirk Tütken, queridos amigos radicados em São Paulo, tornaram mais fácil e produtiva a pesquisa naquela cidade, com o apoio emocional e logístico que generosamente me deram. Por fim, um agradecimento muito especial a Raimundo Luedy, que, com sua revisão cuidadosa e crítica dos originais e com o apoio e carinho que me deu em todos os momentos, tornou possível a conclusão dessa tarefa. 


\section{Sumário}

Prefácio: Movimentos e conjunturas da cidade-atração em três capitais brasileiras| 13

Introdução: o patrimônio e sua norma | 17

Da invenção do "patrimônio nacional" à expansão das práticas preservacionistas | 17

0 dispositivo de patrimônio e a norma de preservação | 21

A norma brasileira de preservação do patrimônio urbano até os anos 1980 | 28

Os anos 1990 | 33

Operacionalização da pesquisa e estrutura geral do texto | 36

A cidade-atração nos países centrais | 45

As transformações econômicas, sociais e urbanas nas três últimas décadas do século XX | 45

Cultura, comunicação e cidade $\mid 52$

0 patrimônio e os novos empreendimentos urbanos $\mid 57$

0 patrimônio como fenômeno de massa| 62

Patrimônio, relações de poder e formas de dominação na sociedade contemporânea | 66

Salvador: patrimônio como insumo do turismo e do lazer urbano | 71

0 centro da cidade de Salvador: preservação e desenvolvimento urbano na primeira metade do século XX $\mid 71$ 
Industrialização e formação de novas centralidades | 74

Turismo e patrimônio | 77

Os projetos de revitalização do Centro Histórico nos anos 1970 e 1980 | 80

A revitalização comercial do centro e os últimos impactos

do deslocamento de funções | 85

0 Programa de Recuperação do Centro Histórico de Salvador:

implantação, números e fases | 89

0 uso habitacional no Centro Histórico | 96

Resultados e sentidos das intervenções realizadas nos anos 1990 | 102

A noção de patrimônio e as características da prática de preservação | 113

Rio de Janeiro: patrimônio e cultura no fortalecimento do centro | 115 0 centro do Rio de Janeiro: formação e hegemonia na estrutura urbana | 115

Patrimônio e modernização | 126

Preservação e fixação de funções centrais: o Corredor Cultural | 129

A ampliação do território preservado na área central | 135

Os centros culturais | 138

As intervenções no núcleo dinâmico do centro | 141

0 desenvolvimento do uso habitacional na periferia do centro | 145

0 Programa Novas Alternativas | 148

0 Projeto Morro da Conceição | 150

Os projetos de dinamização econômica nos bairros centrais | 152

A revitalização da Praça Tiradentes| 156

0 processo de valorização e requalificação do centro nos anos 1990: resultados e sentidos $\mid 159$

A noção de patrimônio e as características da prática de preservação | 166 
São Paulo: patrimônio e centralidade em disputa | 171

0 centro de São Paulo: formação, hegemonia e fragmentação | 171

Patrimônio e progresso | 178

A Operação Urbana Anhangabaú| 187

A Associação Viva o Centro e a "requalificação estratégica" do centro | 191

O ProCentro | 193

A Operação Urbana Centro | 195

A revitalização da região central e o Projeto de Recuperação

do Bairro da Luz | 201

Os novos centros culturais de São Paulo | 206

A nova política habitacional do município e o Plano “Reconstruir

o Centro" | 207

0 Programa de Reabilitação do Centro | 213

Resultados e sentidos das intervenções realizadas nos anos 1990|216

A noção de patrimônio e a prática de preservação | 222

Caderno de imagens | 227

Tabelas e quadros | 267

0 financiamento da preservação do patrimônio nos anos 1990 | 303

0 Programa Nacional de Apoio à Cultura - PRONAC | 303

0 Programa Monumenta e seus antecedentes | 318

0 Programa de Revitalização de Sítios Históricos - PRSH

e seus antecedentes | 337

A prática de preservação urbana nos anos 1990 | 349

Considerações preliminares | 349

Os solos históricos das intervenções nas áreas centrais de Salvador,

Rio de Janeiro e São Paulo | 350 
Os programas nacionais: rupturas, continuidades e identidades | 373

As relações entre programas e intervenções | 388

Sobre a importação de modelos | 389

0 patrimônio urbano produzido e preservado nos anos 1990 | 395

Os usos do patrimônio | 395

A noção de patrimônio | 399

As transformações da prática de preservação | 406

Posfácio: Depois dos anos 1990| 411

Capitalismo contemporâneo e produção do espaço urbano | 412

Salvador | 418

0 Rio de Janeiro | 428

São Paulo | 436

Breve balanço e perspectivas do momento atual | 440

Referências | 445

Apêndices | 469

Apêndice A | 469

Apêndice $B$ | 473

Apêndice C | 475

Apêndice $D$ | 481

Apêndice E | 483

Anexos | 495

Anexo A | 495

Anexo B | 499

Anexo C | 501 


\section{Prefácio: Movimentos e conjunturas da cidade-atração em três capitais brasileiras}

O século XXI, em suas duas primeiras décadas, reafirma o papel âncora das cidades, com suas exacerbadas hierarquias e desigualdades, nos processos globais de reprodução, centralização e rentabilização de capitais associados em sua forma financeira e corporativa. Em movimentos de expansão e retração, crescimento e crise, o espaço urbano vem sendo objeto de investimentos volumosos, guiados, no entanto, por lógicas que, embora felizmente múltiplas, evidenciam-se como eminentemente privadas e de regulação pública cada vez mais frágil e permissiva. A produção sequenciada de outorgas e de novos instrumentos legais que validam a ação privada na definição de políticas é marca contundente desse processo. As Manifestações de Interesse Privado (MIPs) são exemplares a esse respeito.

Nesses processos de intervenção imperial sobre as cidades, merece ser ressaltado o protagonismo que organismos e corporações internacionais ocupam tanto no financiamento de programas quanto na sua definição e implementação. Uma espécie de política urbana às avessas, vinculada mais à circulação e rentabilização de recursos econômicos crescentemente tornados "imateriais", 
pela sua redução ao valor de troca e suas possibilidades de especulação global, do que propriamente a horizontes de mudanças socialmente relevantes no âmbito das cidades e dos territórios.

Subjugado pelas lógicas restritas e vorazes do mercado, o processo de produção de novos empreendimentos passa a ser espelho também da produção de obsolescência urbana. Ou seja, a lógica perversa dos processos recentes de urbanização do território, sua dispersão, difusão e produção em escala industrial, têm levado, de forma crescente, à produção precoce de espaços esvaziados, particularmente em áreas centrais. São assim gerados, ao mesmo tempo, espaços novos - muitos avançando em territórios rurais às franjas da urbanização - e espaços centrais em crise, crescentemente degradados. Trata-se da produção ampliada de vazios construídos, enorme desperdício de território social e urbano coletivamente produzido.

Não por acaso, nas cidades brasileiras, o número de unidades vazias iguala, ou mesmo supera, o déficit habitacional existente e, raras exceções à parte, os centros urbanos tradicionais vivem uma crise crescente de reprodução, com processo de despovoamento que tarda a ser revertido.

A questão dos centros vai então progressivamente se constituir em problema público no Brasil e, a partir dos anos 1990, políticas de governo, bem como estratégias privadas e sociais, sob diferentes perspectivas, vão buscar equacionar e enfrentar essa questão.

A cidade-atração, objeto do presente livro, busca analisar esse processo a partir das questões relativas ao patrimônio em 3 cidades brasileiras: Salvador, Rio de Janeiro e São Paulo. Trata-se de compreender os sentidos subjacentes à proliferação, banalização e funcionalização da ideia e da prática patrimoniais que invadiram as cidades - no mundo e no Brasil - e se intensificaram a partir da última década do século XX, sobretudo concentradas nas áreas centrais das cidades.

Encadeando com a reflexão teórica desenvolvida em seu trabalho anterior, Da Cidade-Monumento à Cidade-Documento, obra publicada em 2014, Márcia Sant’Anna compreende essa generalização da lógica patrimonial como a plenitude de sua vigência enquanto dispositivo de poder, agora alimentado essencialmente por sua função econômica. Assim, ao alegre consumo da urbanidade contemporânea, festejado por aparatos midiáticos, governamentais e corporativos, contrapõe-se aqui uma análise rigorosa de vínculos, lógicas, articulações e hierarquias 
que moldam a compreensão de uma forma dominante de produzir patrimônio - a cidade-atração -, cada vez mais distanciada de sentidos sociais e culturais mais amplos e inclusivos.

Para realizar seu intento, a autora se utiliza da conceituação foucaultiana de dispositivos e de sua tradução/explicitação em normas, assim como da formulação deleuziana dos regimes de visibilidade. A isso se soma tanto um percurso cuidadoso sobre a literatura que trata dos temas do patrimônio e da dinâmica urbana quanto um extenso e rico trabalho de levantamento e sistematização de dados sobre as três cidades escolhidas para análise e sobre os programas nacionais de financiamento a ações de preservação/requalificação.

A cidade-atração, a meu ver, pode ser entendida como uma relevante contribuição ao estudo das políticas de preservação, assim como dos processos patrimoniais em curso nas metrópoles brasileiras, teórica e empiricamente falando. Isso é tão mais importante quanto se generaliza atualmente uma certa idealização e extensão da ideia de patrimônio, que tende a substituir in tótum a complexidade dos embates sociopolíticos na produção do espaço.

Assim, o fenômeno da patrimonialização dos centros urbanos aqui descrito nos coloca frente a possibilidades sensivelmente distintas para o destino de nossas centralidades e cidades. Por um lado, a relação cada vez mais íntima que se tece entre a ideia de patrimônio e as possibilidades de reproposição/requalificação/renovação de espaços nas cidades, tensionados por relações verticais de forças, marcadas pela lógica do negócio, fortemente ancorada em articulações restritas entre o poder público e o privado. Por outro, através da associação e sincronia entre ativismos sociais de diversas ordens, um tensionamento crescente do patrimônio enquanto esfera da construção do direito à cidade, por meio de movimentos de contestação da ordem hegemônica e de defesa de uma partilha mais horizontalizada da cidade e dos seus bens e espaços.

Em Salvador, por exemplo, a lógica patrimonial redesenha continuamente limites entre o público, o coletivo e o privado, com forte protagonismo do último. A $7^{a}$ etapa do Pelourinho, o Centro Antigo, a borda da Baía de Todos os Santos sintetizam com clareza essa ambiguidade da questão patrimonial e seu desdobramento em política pública, agrupando ou desconhecendo setores intelectuais, sociais, políticos e econômicos completamente diversos num ou noutro caso. 
Ao mesmo tempo, fissuras e cisões gritantes se apresentam em torno das definições, significados e usos a serem atribuídos às heranças e processos culturais (i)materiais, constituindo frentes de batalha significativas na luta pelo espaço. As mobilizações crescentes em torno do centro de Salvador ou as comunidades de memória, presentes em diversos bairros soteropolitanos, articuladas e incentivadas por coletivos de diferentes tipos de organização política e cidadã, parecem concentrar esperanças de disrupção na norma e no dispositivo.

O processo aponta para a possibilidade de uma nova conjunção de linhas de força e de interesse coletivo, ampliando o leque de opções na construção de políticas públicas que possam dar conta da confluência entre patrimônio, preservação e urbanismo, que enriqueçam social e culturalmente a cidade brasileira em sua multiplicidade e complexidade.

A inquietação intelectual da autora, seu rigor conceitual e sua capacidade de compreensão dos processos vigentes na conformação e desdobramentos de seu objeto de análise nos conduzem por percursos que revelam de forma agradável e inteligente as hegemonias e os meandros da cidade-atração.

Sem dúvida, uma leitura que nos oferece campos estimulantes para refletir, explorar e propor...

\section{Ana Fernandes}

Salvador, 07 de maio de 2017 


\title{
Introdução: o patrimônio e sua norma
}

\section{Da invenção do "patrimônio nacional" à expansão das práticas preservacionistas}

\begin{abstract}
A função original dos monumentos é marcar determinados acontecimentos, pessoas ou feitos e constituir intencionalmente uma memória coletiva mediante a atribuição de status especial àquilo que os representa. Marcada ou não por um evento singular, a instituição de monumentos, além de um universal cultural (SERRA, 1991, p. 45), é sempre, portanto, um fato político. Selecionar, separar do conjunto, atribuir valor e dar visibilidade são operações essenciais dessa prática ancestral, e também atos de poder. A instituição de monumentos, entretanto, não evita que eles desapareçam, sejam destruídos ou ultrajados em consequência de disputas ou de transformações sociais e culturais. Sobre essa forma de representação e comunicação ancestral, que não implica necessariamente a preservação do objeto que a incorpora, a modernidade construiu uma nova prática.
\end{abstract}


Essa prática tem suas raízes mais remotas no Renascimento, quando valores documentais e cognitivos começaram a ser atribuídos a objetos e obras do passado por colecionadores e construtores que, assim, os colocaram em perspectiva histórica, técnica e artística. Monumentos da Antiguidade Clássicaque, até então, eram pilhados, proporcionavam fundações para novos edifícios ou serviam como locais de extração de materiais de construção - surgiram como modelos artísticos, fontes de conhecimento e testemunhos que lançavam luz sobre um passado remoto. (CHOAY, 1996, p. 52-74)

O estudo, a documentação e o recolhimento de antiguidades tiveram, contudo, até o século XVIII, um caráter restrito e quase marginal, envolvendo apenas historiadores, colecionadores, construtores, estetas e caçadores de tesouros. Era mesmo, muitas vezes, algo feito em sigilo, como as pesquisas de Brunelleschi nas ruínas de Roma e no Panteão de Adriano, que the permitiram projetar e construir a cúpula de Santa Maria del Fiore. (KING, 2000, p. 21-31) Os novos valores atribuídos aos monumentos e às obras do passado não promoveram, contudo, sua preservação de forma sistemática. Foi preciso aguardar o surgimento de um interesse político e econômico associado às antiguidades para que a preservação se consolidasse como prática governamental e social.

As operações ancestrais vinculadas à instituição de monumentos e ao estudo das antiguidades - até então, rigorosamente independentes - foram postos em contato apenas no final do século XVIII, quando as antiguidades ganharam um papel político importante para a nova forma de Estado que se implantou no Ocidente com a Revolução Francesa. Esse contato resultou da necessidade de salvar da destruição, do saque e do vandalismo, imóveis e obras de arte pertencentes à nobreza e ao clero que haviam sido confiscados pelo Estado revolucionário. Uma interação que deu origem à expressão "monumento histórico" e à noção de "patrimônio nacional".

A noção de "monumento histórico" colocou bens da aristocracia em perspectiva histórica e lhes atribuiu o papel político de representar uma nova nação, identificada com o povo que os construiu. Por meio da sua associação à ideia de "patrimônio nacional", esses monumentos históricos adquiriram, também função econômica, como propriedade e riqueza dessa nação. Essa ideia tornou pública (isto é, do Estado e de todos) a responsabilidade pela preservação dos 
monumentos históricos. (SANT’ANNA, 2014, p. 22) Possibilitou ainda o surgimento dos saberes, procedimentos, operações e instituições que conformaram, primeiramente no Ocidente, e, depois, em todo o mundo, a prática de preservação em sua feição moderna.

Ao longo do século XIX, a noção de monumento histórico se consagrou nos países europeus paralelamente à consolidação da ideia de patrimônio nacional como entidade totalizadora desses bens no nível do Estado. Em torno dessas noções, que se confundem e se diferenciam conforme a situação, foram mobilizadas disciplinas como a Estética, a História e a Arqueologia, e criados aparelhos estatais, como inspetorias e museus, com o objetivo de desenvolver na sociedade uma conduta de preservação de determinados imóveis e objetos, em resposta ao "interesse público". Desenvolveu-se, em suma, uma estrutura voltada, no plano coletivo, para a construção de uma memória nacional e para a promoção de uma atitude de preservação no seio da sociedade; e, no plano individual, para a formação de cidadãos conscientes de sua nacionalidade.

A integração das noções de monumento histórico e patrimônio nacional ensejou ainda toda uma produção discursiva e a adoção de procedimentos legais e práticos com vistas à seleção, classificação, proteção e conservação dos bens assim nomeados. A excepcionalidade artística, uma ideia de monumentalidade relacionada à beleza e à grandeza, e a vinculação à história nacional comandavam a escolha. A partir do final do século XVIII e ao longo do século XIX, quando essa prática se institucionalizou, eram selecionados como monumentos históricos, basicamente, vestígios da Antiguidade Clássica, edifícios religiosos e castelos da Idade Média. Praticava-se, então, uma preservação altamente seletiva e voltada para as grandes obras que mereceriam, segundo a concepção da época, representar o passado e a excelência do engenho de cada nação.

Essa configuração funcional e tipológica dos monumentos históricos permaneceu mais ou menos inalterada até a Segunda Guerra Mundial, quando uma grande expansão se processou nesse universo, como resultado de um novo uso estratégico atribuído ao patrimônio e de uma noção ampliada de objeto histórico propiciada por avanços nos campos da História e da Antropologia. Todas as formas de arte e de construção, eruditas ou populares, recentes ou antigas, foram, a partir de então, incluídas no rol do patrimônio. (CHOAY, 1996, p. 10) As práticas 
preservacionistas, restritas à Europa no século XIX, também se expandiram mundialmente no século XX, impulsionadas pela difusão do modelo institucional europeu. Paralelamente a essa expansão, ampliou-se também o público do patrimônio. (CHOAY, 1996, 155-156) Os monumentos históricos transformaram-se num fenômeno de massa que, impulsionado pelo turismo cultural, extrapolou as fronteiras nacionais. Inflado por técnicas promocionais, o "patrimônio histórico" tornou-se, nas últimas décadas do século XX, um importante insumo da indústria do turismo, associada ao entretenimento, e, em consequência do seu sucesso de público, tornou-se também uma condição que agrega valor econômico e que, por meio de seu poder simbólico, constrói poderosas imagens publicitárias.

A extensão das práticas preservacionistas ao meio urbano consolidou-se, na Europa, por volta dos anos 1930, mas ainda com um caráter pontual e marginal. De início muito voltadas para a valorização da "moldura" urbana de grandes monumentos, também ganharam corpo após a Segunda Guerra Mundial, como reação às reconstruções urbanas massificadas, realizadas nos países atingidos pelo conflito. Ganharam ainda um novo alcance, a partir da década de 1960, ao serem incorporadas, na Europa, às políticas de desenvolvimento urbano e habitacional. Ocorreu então, nesse momento, a transformação da cidade no objeto patrimonial por excelência e, ao mesmo tempo, a disseminação, nesse continente, de uma conduta de preservação no seio do planejamento e da gestão urbana que ampliou a inclusão do patrimônio urbano no circuito da mercadoria. A preservação sedimentou-se nos países europeus, a partir dos anos 1980, como uma norma que orienta processos de produção e de gestão urbana, consolidando-se, por fim, como uma das formas preponderantes de urbanização.

Nas últimas décadas do século XX, a função econômica do patrimônio, presente desde sua constituição, prevaleceu, finalmente, sobre as cognoscitivas, de formação e de coesão social, que também o integram. Setores urbanos e bairros antigos, então abandonados, se tornaram importantes fronteiras de reprodução do capital imobiliário, e o título de patrimônio, um instrumento-chave de estratégias de valorização imobiliária. Cidades como Nova York, construídas sobre imagens de progresso, transformação e modernidade, lançaram-se ao resgate dos remanescentes de sua história, pois o patrimônio se tornou um item fundamental na construção da identidade urbana. No final do século XX não havia, 
como houve antes, cidade sem patrimônio. Originalmente seletiva e excepcional, a preservação do patrimônio urbano se tornou regra.

\section{0 dispositivo de patrimônio e a norma de preservação}

O modo como surgiu, o fato de colocar em relação saberes e práticas de origem e naturezas díspares, os discursos e objetos que produz, a conduta que institui e a maneira como esta se generalizou e invadiu outros domínios - são elementos que permitem associar o fenômeno do patrimônio, enquanto instituição e prática social, às noções de dispositivo e norma desenvolvidas por Michel Foucault em suas reflexões sobre o exercício do poder e sobre os instrumentos de formação de padrões de conduta nas sociedades modernas.

Essas noções decorrem da análise de uma nova mecânica de poder e sujeição que se instalou no mundo ocidental com o desenvolvimento do capitalismo industrial, mecânica esta que visa ao indivíduo e à coletividade em seus comportamentos e produtividade. (FOUCAULT, 1984b, p. 187) Essa nova modalidade de poder, que retira seu modo de operar de antigos procedimentos disciplinares, de gestão familiar e de condução espiritual, tem como objetivos aumentar o desempenho e a docilidade dos indivíduos e, no plano coletivo, regular e gerir fenômenos vinculados à população. Ao exercer-se, produz também novos campos de saber. (FOUCAULT, 1984a, p. 291, 1987, 1997, 2000) A partir do estudo desses processose de sua lógica de funcionamento, Foucault pôde compreender o poder como uma relação e conceber a genealogia, isto é, o estudo das condições de surgimento dos mecanismos de poder, como um método de análise social.

Segundo essa concepção, o exercício do poder se dá por meio de práticas sociais, estando presente em todas as relações, sejam econômicas, sociais, familiares, de conhecimento ou sexuais. Em suma, o poder é "o nome dado a uma situação estratégica complexa, numa sociedade determinada". (FOUCAULT, 1988, p. 89) O que há, então, não é "o poder", mas poderes ou procedimentos de poder que se concretizam em técnicas ou formas de sujeição, cuja racionalidade éa das táticas que se encadeiam e se propagam e que, encontrando condição, esboçam "dispositivos de conjunto". (FOUCAULT, 1988, p. 90-91) 
No sentido de passagem ao ato.
A partir, então, do advento das sociedades industriais modernas, no plano individual ou coletivo, as intervenções no corpo social se dão sempre, segundo Foucault, por meio de "dispositivos de poder". Esses "agenciamentos concretos" (DELEUZE, 1991, p. 46) de saberes, discursos, procedimentos e objetos físicos são meios para o exercício do poder e, assim, constituem também instâncias de percepção do seu funcionamento num dado momento. Em uma entrevista publicada em 1978, Foucault explicitou que, com este termo, tentava demarcar "um conjunto decididamente heterogêneo que engloba discursos, instituições, organizações arquitetônicas, decisões regulamentares, leis, medidas administrativas, enunciados científicos, proposições filosóficas, morais, filantrópicas”, e, também, a "natureza da relação que pode existir entre esses elementos heterogêneos". (FOUCAULT, 1984C, p. 243-276) Dispositivo que designaria, desse modo, a "rede que se pode estabelecer entre esses elementos" e, ainda, "um tipo de formação que, em um determinado momento histórico, teve como função principal responder a uma urgência”. (FOUCAULT, 1984C, p. 243-276) A função estratégica do dispositivo de poder é, assim, constitutiva e dominante, caracterizando-o ainda o fato de desencadear, em seu funcionamento, o que Foucault (1984C, p. 243-276) denominou de processos de "sobredeterminação funcional" e de "perpétuo preenchimento estratégico". Estes dizem respeito à capacidade que esses agenciamentos de produção de padrões de comportamento têm de rearticular e reajustar permanentemente seus elementos constitutivos como resultado de efeitos contraditórios ou inesperados que possam vir a produzir, inserindo esses efeitos em novas estratégias que permitem sua utilização política e econômica. Em suma, o dispositivo de poder se adapta a novas estratégias, se transforma e, por fim, pode ficar latente ou desaparecer quando não tem mais finalidade, ou quando um novo conjunto de forças o substitui por outro.

Os dispositivos ou agenciamentos concretos são, portanto, formas de exteriorização e atualização' das forças presentes no corpo social, que operam por meio da integração de elementos discursivos e não discursivos - ou, como prefere Deleuze, (1991, p. 51) de "enunciados" e "visibilidades" - com vistas a produzir algo que instrumentaliza e propaga o poder. As visibilidades (ou elementos não-discursivos), como arquiteturas, objetos ou agenciamentos espaciais, são instrumentos de "fazerver" ou 
de colocar sob a luz o que deve ser visto; e na obscuridade, o que deve estar ocultado. (DELEUZE, 1991, p. 66-68) São, como aponta Deleuze, (1991, p. 89-92), regimes de distribuição de luz e, por isso, juntamente com os discursos que integram o dispositivo, constituem "arquivos visuais" que informam sobre as relações de poder em jogo num determinado momento.

O dispositivo de saber-poder é, desse modo, uma "tecnologia" de manipulação de forças, de intervenção no corpo social e de produção de "algo" que se articula ao poder. Em A Vontade de Saber, Foucault mostrou que o dispositivo de sexualidade - integrando historicamente instituições como a Religião e o Casamento, enunciados médicos diversos, práticas confessionais e espaços como a alcova - produziu o "Sexo" enquanto conjunto de comportamentos, ações e condutas, próprio de um estágio da modernidade e vinculado a determinados objetivos. (FOUCAULT, 1988, p. 73-109) Um produto, enfim, que gera efeitos de disciplinamento de desejos e impulsos, no plano individual e, no coletivo, de controle e regulação de fenômenos, como, por exemplo, a taxa de natalidade. O dispositivo de poder constitui assim uma tecnologia de controle social que tem poder normalizador, isto é, opera por meio da produção e da propagação de uma norma. Integrando mecanismos diversos - disciplinares, de regulação, de governo, padronização ou controle -, os dispositivos operam em diferentes escalas e sobre distintos objetos mediante a instauração de uma lógica normativa. (EWALD, 2000, p. 36) Por esta razão, as sociedades modernas foram nomeadas por Foucault de "sociedades de normalização", já que estão submetidas à ordem da norma - ou seja, nelas o poder se expressa e funciona como norma, ou seja, por meio da instituição de um padrão. (EWALD, 2000, p. 77-78) Foucault esclarece:

o elemento que vai circular entre o disciplinar e o regulamentador, que vai se aplicar [...] ao corpo e à população, que permite a um só tempo controlar a ordem disciplinar do corpo e os acontecimentos aleatórios de uma multiplicidade biológica, esse elemento que circula entre um e outro é a 'norma'. (FOUCAULT, 2000, p. 302)

A transformações ocorridas nas sociedades contemporâneas, decorrentes de uma nova revolução científico-tecnológica, do advento de um novo estágio do modo de acumulação capitalista e da instauração de uma nova ordem mundial 
globalizada não alteraram essa forma básica de exercício de poder, nem sua lógica de funcionamento. As novas tecnologias de informação e comunicação, ao contrário, tornaram mais eficazes esses instrumentos de intervenção social e sujeição, e mais amplo o seu poder de atuação sobre a matéria individual ou coletiva. (DELEUZE, 1992, p. 209-226) Seus elementos constitutivos, naturalmente, mudaram, e as arquiteturas já não constituem, como antes, instrumentos essenciais para sua operação. As formas de dominação nas sociedades contemporâneas, que Deleuze define como de "controle e comunicação", operam no "espaço aberto", não necessitam mais de confinamentos, mas estão, aparentemente, diminuindo ainda mais o espaço de liberdade. As novas tecnologias de comunicação e informação estão proporcionando uma flexibilidade, uma penetrabilidade e uma eficiência suplementar aos mecanismos disciplinares e reguladores. Sejam mais poderosos ou não, entretanto, é certo que os novos dispositivos continuam efetuando relações de poder e visando a instituir e propagar uma norma. Atualmente, essa norma pode não ter mais como fim último um desempenho individual e coletivo adequado à produção de bens, mas tem certamente como alvo a "produção" do consumo.

Em qualquer tempo, o estudo das condições de surgimento e do funcionamento dos mecanismos de poder demanda precauções metodológicas. (FOUCAULT, 1988, p. 93-96) Partindo do pressuposto de que não há exterioridade entre técnicas de saber e estratégias de poder, Foucault recomenda que, na análise de uma dada formação social e de seus dispositivos, se busque identificar e se parta sempre de "focos locais de saber-poder". Estes são nós que concentram e efetuam relações de poder e provocam uma produção discursiva e determinadas práticas, por meio das quais as "ações e reações vêm à luz", juntamente com seus objetivos e estratégias. (DELEUZE, 1991, p. 68) Nesses nós, ou focos, se deve selecionar, de acordo com a problemática a ser analisada, o corpus de textos e objetos por meio do qual se poderá ter acesso aos enunciados e visibilidades que conformam e propagam a norma produzida pelo dispositivo.

Uma segunda precaução metodológica diz respeito à constatação de que as relações de poder são "matrizes de transformação" e que, em consequência disso, a repartição entre saber e poder nunca é fixa, representando apenas um corte instantâneo num processo. (FOUCAULT, 1988, p. 93-96) Por fim, em decorrência 
de sua "polivalência tática", não se deve tomar o discurso como uma simples tela de projeção do poder, e sim como uma multiplicidade de elementos discursivos que podem participar de distintas estratégias.

Como visto, a noção de patrimônio nacional surgiu no nascimento da República Francesa, como um mecanismo de governo destinado a proteger e conservar bens que haviam sido transformados em propriedades da nação. Propiciaram o surgimento dessa estratégia o moderno discurso histórico, que então se constituía como instrumento de luta política; as práticas ancestrais de comunicação e representação simbólica, por meio da instituição de monumentos; e, ainda, os procedimentos de recolhimento, documentação, classificação e registro de antiguidades, elaborados por eruditos e colecionadores. Esses elementos, de origens e funções distintas, foram integrados naquele momento com a finalidade de proteger propriedades públicas e também de controlar a construção de uma memória coletiva relacionada a uma nova identidade nacional. A ideia de patrimônio ensejou a implantação de aparelhos de Estado e regulamentos que, ao longo do século XIX, se consolidaram e especializaram (CHASTEL, 1984, p. 412; CHOAY, 1996)² gerando, com seu funcionamento, saberes específicos, como a restauração de monumentos e obras de arte e a conservação de museus. A noção de patrimônio nacional permitiu, em suma, a instauração de um dispositivo disciplinar e de governo que, reunindo elementos heterogêneos, passou a produzir e reproduzir "patrimônio" como uma qualidade que enobrece objetos das mais variadas origens, naturezas e destinações, e, ainda, como um padrão do que representaria a arte, a história e o engenho de uma nação.

Durante o século XIX, instituições, regulamentos e procedimentos voltados para a seleção, proteção e conservação do patrimônio se instalaram em quase todos os Estados europeus, consolidando uma prática que, contudo, atingia um universo ainda restrito. Esse alcance foi se ampliando em decorrência do desenvolvimento de dois processos que propiciaram o aumento da utilidade e da função estratégica desse dispositivo. O primeiro, decorrente da forma cada vez mais institucionalizada e regulamentada assumida por essa prática, possibilitou o uso do patrimônio como instrumento de legitimação e também de resistência à nova ordem econômica, política e social em implantação na Europa. O segundo,
2 O Museu do Louvre foi fundado pela República Francesa em 1793 e vários regulamentos disciplinando a preservação de monumentos históricos foram baixados pelos comitês revolucionários. 
vinculado ao desenvolvimento das ciências humanas no século XIX, permitiu uma crescente incorporação de novos objetos ao seu universo.

Ao estabelecer e legitimar uma repartição entre o que podia ser destruído e o que devia ser preservado, o dispositivo de patrimônio provou ter grande utilidade socioeconômica. Valorizando e protegendo determinados bens, identificava raízes históricas e contribuía para o equilíbrio emocional de uma sociedade imersa em mudanças profundas no seu ambiente. Ao mesmo tempo, ao desvalorizar outros, autorizava sua destruição e permitia que as transformações requeridas pela industrialização se processassem sem maiores dificuldades.

O desenvolvimento industrial e tecnológico, ao invés de tornar obsoleto, foi tornando o dispositivo de patrimônio cada vez mais importante. Até a primeira metade do século XX, como estratégia de legitimação e racionalização de destruições para a modernização urbana. Na segunda metade, como fundamento de uma preservação ampla e ilimitada, relacionada à necessidade de poupar recursos, de ocupar áreas urbanas esvaziadas e depreciadas, e de vincular, para a ampliação do consumo e para a dinamização da economia urbana, produtos e cidades a uma identidade cultural e histórica.

O modo eficiente como, há dois séculos, o dispositivo de patrimônio vem concretizando relações de força presentes no corpo social explica a notável expansão desse conceito e da norma de preservação que instituiu, assim como sua permanência e atualidade após as transformações sociais, tecnológicas e econômicas ocorridas nesse longo período. A ideia de patrimônio, nas últimas décadas do século XX, penetrou todos os campos, perpassando os mais variados domínios e instituições. Essa explosão revela-se na "inflação do patrimônio", apontada por Choay (1996) nos anos 80; na transposição da lógica dos museus para o espaço urbano, conforme observado por Huyssen (2000); e também na invasão da gestão urbana pelas práticas patrimoniais, conforme criticado por Jeudy (2001). Surge ainda nos equipamentos comerciais que adotam signos do patrimônio e nas cidades que, literalmente, constroem patrimônio. No final do século XX, tornaram-se também objeto de preservação reservas naturais, animais, espécies vegetais, práticas sociais e seres humanos. 
Abordar o patrimônio dessa maneira significa assumir que o bem patrimonial é um objeto produzido por uma norma instituída por um dispositivo de poder que se configura e reconfigura de acordo com as correlações de força existentes em um determinado momento, as quais dão sentido e utilidade a esse objeto. Em cada época, portanto, o patrimônio constituído pelo Estado é aquele que determinado corpo de falas e textos diz que é, e o que uma série de objetos e práticas faz ver. Textos e quadros visuais cuja mobilização e produção se articulam a determinada estratégia e cuja integração tem sempre uma utilidade e uma função.

A produção e a preservação do patrimônio supõem procedimentos de seleção, de proteção, de conservação e de promoção que são também pontos de concentração de forças e de mobilização de saberes, já que são operações que concentram escolhas, promovem a elaboração de regras e desencadeiam ações. Assim, constituem focos de produção dos discursos e visibilidades por meio dos quais se pode penetrar no sentido e na utilidade estratégica do patrimônio e compreender a norma que o institui em cada período.

Este trabalho se organiza, portanto, em torno da ideia de que o patrimônio é produto de um dispositivo de poder. Assim, como entidade totalizadora dos bens que narram a história e identificam a cultura de um grupo ou de uma nação, o patrimônio não existe como algo pronto - é uma construção social permanente. É ainda um campo de forças em permanente devir, cujo sentido político e social mais amplo se configura quando produz conhecimento e informação; quando abre horizontes e amplia noções de pertencimento; e, ainda, quando funciona como um recurso para o desenvolvimento socioeconômico. Os bens culturais declarados "patrimônios" não são repositórios estáticos dos valores, funções e representações que thes são atribuídos em cada período. Os processos históricos e sociais criam novos patrimônios, assim como atribuem novos valores, funções e significados ao patrimônio já instituído. A realização da sua função social plena é sempre, portanto, uma possibilidade e uma esperança. 
3 Hoje Instituto do Patrimônio Histórico e Artístico Nacional IPHAN.

4 Ouro Preto, Mariana, Diamantina, Serro, Tiradentes e São João del-Rei, em Minas Gerais.

5 Apenas o município de São Paulo organizou um Departamento de Cultura nos anos 1930, mas sua função de preservação não chegou a ser desenvolvida.

\section{A norma brasileira de preservação do patrimônio urbano até os anos 1980}

A noção de monumento histórico começou a se desenvolver no Brasil no início do século XX, num período marcado por reformas urbanas modernizadoras, deflagradas em várias cidades. Surgiu, portanto, contemporânea da primeira arrancada industrial do país, da preparação das suas maiores cidades para esse desenvolvimento, e, também, como reação à perda de edifícios históricos, no bojo dessas intervenções. Em estados como Bahia, Minas Gerais e Pernambuco, medidas de proteção a esses bens foram tentadas, mas não tiveram sucesso ou continuidade devido à falta de dispositivo legal que permitisse uma intervenção estatal dessa natureza na propriedade privada. A institucionalização do patrimônio no Brasil teve de esperar até 1937, somente, portanto, após a incorporação do princípio da função social da propriedade pela Constituição Federal de 1934.

Em 1938, como uma das primeiras medidas adotadas pelo então recém-criado Serviço do Patrimônio Histórico e Artístico Nacional, ${ }^{3}$ seis cidades do estado de Minas Gerais foram protegidas e declaradas patrimônio nacional. ${ }^{4}$ No Brasil, portanto, a prática de preservação urbana tem quase 80 anos e é possível identificar, até os anos 1980, três momentos e três situações político-econômico-culturais específicas que desencadearam determinadas operações de seleção, salvaguarda, conservação e promoção do patrimônio. Ou seja, que produziram uma determinada noção de patrimônio e uma determinada norma de preservação.

O primeiro momento dessa trajetória, que vai dos anos 1930 ao final dos anos 1960, se caracterizou por uma ação estatal fortemente centralizada e pelo uso do patrimônio em estratégias de construção de uma identidade nacional e de uma arte genuinamente brasileira. O campo institucional ativo do patrimônio era então restrito ao plano federal. ${ }^{5}$ Estados e municípios mantinham uma posição passiva, uma vez que toda a responsabilidade pela seleção e salvaguarda do patrimônio cabia unicamente à União, por intermédio do SPHAN. Cabia também a este organismo a gestão da preservação do patrimônio, exercida por meio do estabelecimento de regras para a restauração e conservação dos bens protegidos, e pela fiscalização constante das ações particulares e municipais. Embora alguns 
nichos intelectuais e artísticos também se interessassem pelo tema, a produção da norma de preservação concentrava-se neste aparelho estatal. As operações de seleção, proteção, conservação e promoção do patrimônio, ocorridas no seu âmbito, constituíram, durante todo o período, os principais focos dessa produção.

Naquele primeiro momento, a área ou setor urbano merecedor do título de patrimônio nacional era concebido como um monumento artístico, uma obra de arte acabada, que deveria ser preservada como tal. A cidade-patrimônio era, então, correntemente denominada de "cidade-monumento" e as operações de conservação eram realizadas com vistas a reforçar uma unidade estética vinculada ao que os intelectuais modernistas que fundaram o antigo SPHAN concebiam como valor artístico. Essa ideia era concretizada mediante a aplicação de regras rígidas para o controle de intervenções e por meio da restauração dos imóveis do conjunto a um estado identificado com a produção arquitetônica do período colonial. Por meio dessas operações eram eliminados os elementos julgados "bastardos" ou não pertencentes à tradição construtiva luso-brasileira. Para exercer esse controle, a instituição mantinha, nas áreas tombadas mais importantes, representações que tinham a função de fiscalizar o cumprimento dessas regras, autorizar e aprovar intervenções, embargar obras irregulares e manter sob vigilância constante o patrimônio protegido.

O processo de industrialização, ampliado a partir dos anos 1950, provocou o crescimento acelerado de várias capitais de estados e de algumas cidades do interior do país, criando novas e urgentes demandas e pondo em crise, pela primeira vez, o modelo existente de seleção e gestão do patrimônio. Pôs também em risco o que restava de patrimônio arquitetônico nas grandes cidades, onde, desde os anos 1930, o IPHAN desenvolvia uma política voltada para a proteção de monumentos destacados e de pequenos conjuntos arquitetônicos, a fim de não impedir a modernização desses centros. Iniciou-se então, nesses núcleos, um processo de seleção de conjuntos maiores para proteção, geralmente em suas áreas centrais, alguns dos quais vieram a conformar, mais tarde, "centros históricos". Embora essa nova situação política e econômica tenha imprimido alterações na norma de preservação vigente, esses conjuntos foram ainda selecionados com base nos mesmos critérios artísticos praticados nos anos 1930. 
Até os anos 1960, a preservação de exemplares da produção arquitetônica e artística mais significativa do período colonial, e de obras representativas do modernismo brasileiro, destinou-se à construção de uma identidade e de uma arte nacional, bem como ao estabelecimento de limites entre o que poderia ou não ser destruído em nome da modernização e do progresso de nossas cidades. A preservação praticada era então seletiva, localizada e, ainda que mantendo essa importante função no processo de modernização urbana, de natureza eminentemente política e cultural. O principal efeito do patrimônio, como um dispositivo do poder governamental, era selecionar os bens que seriam postos a salvo da dinâmica de transformação urbana, mas, ao poupá-los, produzia, muitas vezes, sua desvalorização, abandono e destruição. Enfim, um efeito contrário, que necessitava ser modificado e absorvido.

O segundo momento da trajetória da preservação do patrimônio urbano no Brasil teve início nos anos 1970 e correspondeu ao período em que o dispositivo de patrimônio se adaptou e se transformou para corrigir esse efeito indesejado e criar uma mais-valia para o patrimônio. Nesse processo, seus elementos discursivos e visíveis foram reestruturados e outros foram mobilizados para firmar o patrimônio como um recurso econômico. Nos anos 1970, as pressões do crescimento urbano, decorrentes do chamado "milagre econômico brasileiro", levaram o IPHAN a buscar alternativas para a preservação do patrimônio numa gestão descentralizada e no seu aproveitamento econômico. O Programa de Cidades Históricas - PCH, estruturado, à época, em consonância com a política então preconizada pelas agências multilaterais de desenvolvimento atuantes na América Latina, buscou promover esse aproveitamento através do turismo, aliando o patrimônio às políticas desenvolvimentistas do período. O programa induziu a criação dos órgãos estaduais de preservação, que passaram a compartilhar com o IPHAN a função de preservar o patrimônio brasileiro, mas a posição do organismo federal, em termos do comando das operações de seleção e salvaguarda do patrimônio, se manteve central. Embora as operações de conservação tenham sido, em grande parte, descentralizadas, suas regras continuaram emanando dessa instituição federal.

A década de 1970 se caracterizou, então, pela descentralização da função estatal de preservação, por uma significativa ampliação do campo institucional do patrimônio e pela busca de alternativas para a promoção de uma preservação 
permanente e, sobretudo, rentável do patrimônio urbano, mediante sua integração a políticas de desenvolvimento econômico. O potencial turístico surgiu como um valor incorporado às operações de seleção, promovendo a ampliação do número de tombamentos na região Nordeste - na época, o principal foco das políticas nacionais de turismo. Os mecanismos de salvaguarda, entretanto, não sofreram alterações, registrando-se apenas o surgimento de propostas que enunciavam o tombamento de bens privados como uma ação governamental geradora de compensação financeira, e a preservação como uma prática a ser socialmente incentivada.

Esses discursos, entretanto, só vieram a produzir medidas concretas no final daquela década, ainda que de modo muito restrito e localizado. As operações de conservação, por sua vez, mantiveram as regras do período anterior, enfatizando ainda a herança construtiva luso-brasileira e um valor artístico concebido segundo os cânones modernistas. As operações de promoção do patrimônio, que, ao longo de todo o momento inicial de implantação da prática de preservação no Brasil se desenvolveram exclusivamente no plano editorial, fizeram uso, pela primeira vez, de campanhas publicitárias. Por meio das campanhas de divulgação de lugares turísticos e das novelas de televisão que tomavam o Nordeste como tema, imagens do patrimônio, antes presentes apenas em livros e revistas especializadas, ganharam os meios de comunicação de massa. A cidade-monumento surgia, então, como um produto turístico.

Nos anos de 1970, teve início também a formação de aparelhos municipais de preservação nas cidades do Rio de Janeiro, São Paulo e Recife. Diferentemente das instituições estaduais, que, em sua grande maioria, foram organizadas sob a tutela do IPHAN, as instâncias municipais surgiram de modo independente, instaurando novos mecanismos para a seleção e proteção do patrimônio e esboçando uma nova prática de preservação, vinculada ao planejamento urbano. Essa ampliação institucional multiplicou os focos deflagradores de operações de seleção, salvaguarda e conservação do patrimônio, mas, na prática, o órgão federal continuou mantendo a primazia na produção da norma que comandava essas operações. Apesar das novas práticas introduzidas no plano municipal, o caráter pontual dessas iniciativas não lhes permitia ainda confrontar essa hegemonia. 
O terceiro momento a se destacar corresponde aos anos 1980, especialmente a partir da segunda metade dessa década, e se caracteriza como uma fase de grande produção discursiva sobre o sentido da proteção de sítios urbanos e sobre os recursos que deveriam ser mobilizados em sua proteção e gestão. Redefiniu-se, no período, o conteúdo do valor histórico das áreas constituídas como patrimônio, passando-se a selecioná-las não mais apenas como monumentos artísticos, mas como documentos de processos históricos, econômicos e sociais de produção do espaço urbano. Esta nova concepção, adequada ao aproveitamento econômico do patrimônio e ao seu uso como instrumento de política urbana, implicou significativas alterações na norma de produção e preservação patrimonial. O valor artístico e monumental deixou de presidir os critérios de seleção, dando lugar à capacidade de determinado bem concentrar, em si, informações históricas. A cidade-patrimônio tornava-se uma cidade-documento cuja importância não era mais conferida por uma unidade estética idealizada ou pela reunião de determinados atrativos turísticos.

A noção de documento, como enunciado de seleção, implicou uma ampliação considerável das áreas urbanas colocadas sob proteção, induzindo a inclusão de novos objetos no rol do patrimônio. As regras de conservação também se alteraram, colocando-se em xeque a prática de restauração corrente e reivindicando-se uma intervenção respeitosa dos diversos estratos históricos presentes nos monumentos, o que também facilitou sua inserção em dinâmicas de uso atuais. Essas regras, entretanto, não alcançaram grande desenvolvimento prático e disseminação, pois, em decorrência da estagnação econômica do país, as intervenções de preservação realizadas foram poucas, assim como menos intensas as operações de promoção. Tais intervenções adotaram, no período, um caráter menos publicitário e mais educativo, voltado para o reforço da conduta de preservação na sociedade, através do conhecimento do patrimônio e da ênfase no seu papel na construção da cidadania. Os mecanismos de incentivo fiscal, propostos nos anos 1970, começaram a tomar uma forma mais concreta, mas permaneceram restritos ao plano municipal. Consolidou-se, no período, entretanto, uma concepção da preservação não mais como um dever cívico imposto pelo Estado, mas como uma prática a ser incentivada pelo governo em razão de seu valor educacional, social e econômico. 
A falta de investimentos públicos significativos para a execução de programas de preservação, associada ao processo de redemocratização do país, favoreceu, nos anos 1980, a apropriação do patrimônio como instrumento de política urbana, de construção de cidadania e de afirmação social. Minorias e grupos étnicos, que reivindicavam um lugar na história nacional, e segmentos médios, que protestavam contra um modelo de desenvolvimento urbano destruidor do ambiente, tomaram o patrimônio como bandeira de luta e promoveram a proteção de novos objetos e áreas. Essas forças reorganizaram os elementos do dispositivo e introduziram novos, promovendo uma ampliação conceitual, temática e tipológica do seu universo de bens, assim como do seu campo institucional, o qual passou, a partir desse momento, a incluir associações civis. Isso não significou, contudo, o surgimento da preservação como um fenômeno de massa ou que fosse grandemente difundido na sociedade. Apesar dos avanços nesse sentido, a preservação urbana permaneceu, no período, ainda uma prática essencialmente estatal ou restrita a nichos bem delimitados e engajados da sociedade civil. A nova ampliação do campo institucional do patrimônio e seu uso como instrumento de política urbana não promoveram, portanto, a valorização de áreas e imóveis antigos no mercado nem o crescimento da demanda por esse tipo de bem cultural. Cresceu, entretanto, o número de municípios com aparelhos de preservação, e a função se implantou em organismos de todos os estados. Os focos que desencadeiam operações de preservação e produção do patrimônio mais uma vez se ampliaram, mas a crise financeira freou sua atuação, restringindo-a a operações de seleção e proteção. Embora com sua hegemonia já seriamente posta em questão, o aparelho federal de preservação, suas operações e mecanismos continuaram, no período, fornecendo os principais contornos da norma de preservação.

\section{Os anos 1990}

A investigação da norma de preservação do patrimônio urbano produzida nos anos 1990 partiu da percepção, apoiada na análise preliminar de fatos ocorridos nessa década, de que mudanças profundas haviam sido deflagradas no 
campo patrimonial brasileiro. Esses acontecimentos indicavam que os anos 1990 inauguravam um novo período de transformação da prática de preservação, e em torno dessa ideia se estruturou a hipótese da presente pesquisa. O conhecimento reunido sobre o tema durante o curso de mestrado em Arquitetura e Urbanismo da UFBA - oportunidade na qual pude investigar o assunto entre os anos 1930 e 1980 -, animou o empreendimento dessa nova pesquisa e forneceu a perspectiva histórica necessária para responder à questão colocada. Assim, menos do que um estudo circunscrito, este trabalho foi concebido como mais um elo dessa cadeia de investigações que narra e analisa a trajetória da norma de preservação urbana no Brasil. Em suma, um novo estudo que complementa os precedentes e busca identificar os objetivos, características e sentidos dessa prática no final do século XX.

A observação do cenário urbano europeu e norte-americano, onde a preservação "explodiu", nos anos 1980, como uma importante lógica de produção e gestão urbana, mostrava que a existência de diferenciais de identidade vinculados ao patrimônio urbano tornara-se algo essencial para a localização de certas atividades na cidade, bem como para a valorização imobiliária. Os anos 1990 apresentavam vários indícios de que, ainda que com contornos bastante específicos, uma tendência semelhante estava se configurando ou buscando se implantar no Brasil.

O primeiro desses indícios diz respeito à onda de "requalificações urbanas" executadas pelo poder público em áreas centrais das capitais de vários estados do Nordeste, na esteira do projeto de "recuperação" do Pelourinho, em Salvador, após dez anos de relativa inação. A Rua do Bom Jesus, em Recife; o bairro da Ribeira, em Natal; e a Praia de Iracema, em Fortaleza, estão entre as intervenções do gênero que eclodiram na primeira metade da década de 1990. Essas intervenções - que produziram espaços semelhantes, destinados ao turismo e ao lazer alcançaram estrondoso sucesso de público, colocando rapidamente em evidência nacional as cidades onde foram executadas. Iniciativas de governos municipais ou estaduais, essas intervenções funcionaram como poderosas peças promocionais dessas cidades, do seu patrimônio e de suas administrações, desempenhando importante papel nos pleitos eleitorais subsequentes. Ao lado dessas intervenções nordestinas, verificou-se, em metrópoles como Rio de Janeiro, São Paulo, 
Porto Alegre e Belo Horizonte, a retomada de projetos e investimentos públicos nos centros antigos, acompanhada de uma farta produção discursiva relacionada ao caráter estratégico dessas áreas e de seu patrimônio para a economia urbana.

Os anos 1990 se caracterizaram no Brasil, e no mundo, pela enxurrada de expressões precedidas do prefixo "re", destinadas a designar intervenções arquitetônicas e urbanísticas dos mais variados tipos, cujo traço comum reside no fato de constituírem ações que se sobrepõem a situações urbanas preexistentes. As expressões "revitalização", "renovação", "recuperação", "reutilização", "reconquista", "reciclagem", e, mais recentemente, "reestruturação" e "regeneração", vêm sendo objeto de discussões e definições há vários anos em estudos e congressos, sem que se construa nenhum consenso sobre o seu sentido técnico ou se esclareça seu papel conceitual. O que se verifica, como observam Vasconcellos e Mello (2003, p. 60-63), é apenas uma grande variação de significados que espelham os modismos vigentes no campo arquitetônico e urbanístico ou comunicam a carga ideológica que está embutida nas definições e redefinições desses termos. Uma vez que a este trabalho interessa mais investigar os objetivos e sentidos dessas intervenções e seus efeitos reais, do que inventariar os vários significados das expressões que as designam, optou-se por não enveredar numa discussão conceitual que pouca contribuição traz para a compreensão desses processos. Assim, neste livro, o sentido dessas expressões é dado pelo contexto ou pelo seu significado comum. Devido ao fato de designarem, muitas vezes, intervenções semelhantes, alguns desses termos são, inclusive, eventualmente utilizados como sinônimos.

No rastro das intervenções realizadas nas áreas centrais de grandes cidades, surgiu, no âmbito do Governo Federal, a partir da segunda metade dos anos 1990, uma série de programas que trouxeram novas fontes de financiamento para projetos culturais e de preservação, que introduziram novos atores nos processos locais em curso e iniciaram novos processos. Baseados em recursos orçamentários do Governo Federal, renúncia fiscal, empréstimos externos e poupança interna, esses programas passaram a financiar boa parte das intervenções de preservação então em andamento, colocando no centro da cena patrimonial e urbana agências financeiras nacionais e multilaterais - como a Caixa Econômica Federal, o BNDES e o BID -, além de parceiros internacionais, como a UNESCO 
e o governo francês. Esses programas implantaram procedimentos e regras que, além de instituírem modelos de intervenção e abrirem caminho para a expansão de novos negócios e serviços, produziram impactos significativos nas operações de seleção, proteção, conservação e promoção do patrimônio.

Intervenções e programas mostravam, portanto, que, no Brasil do final do século XX, o patrimônio surgia como um importante recurso para a economia urbana, como porta de entrada para investimentos externos e como um instrumento promocional de grande força e apelo. Mostravam também que o sítio urbano declarado patrimônio crescentemente adquiria a função de atrair pessoas e atividades. Os anos 1990 mostravam que, após ter sido apropriada como monumento da arte nacional, produto turístico e documento da nossa formação histórica e urbana, a cidade-patrimônio firmava-se como cidade-atração. Revelavam ainda que, pela primeira vez na história da prática de preservação brasileira, os principais focos de produção da norma de preservação do patrimônio haviam se deslocado do plano federal para os planos estadual e municipal, e, no nível do governo central, do IPHAN para o Ministério da Cultura e seus novos parceiros. Nos anos 1990, os pontos deflagradores de operações de produção e preservação do patrimônio efetivaram-se, finalmente, no plano regional e local, e deslocaram-se, no nível do poder central, para as instituições executoras dos programas implantados. Esvaziado, com funções reduzidas e com uma estrutura operacional que foi tornada precária em todos os sentidos, o IPHAN deixou de ser, nesse momento, o locus central de exteriorização da norma preservacionista.

\section{Operacionalização da pesquisa e estrutura geral do texto}

As constatações registradas nas linhas anteriores levaram à proposta metodológica de investigar a norma de produção e preservação do patrimônio urbano nos anos 1990, não mais a partir dos focos de saber-poder localizados no IPHAN, mas do que tomou, concretamente, o seu lugar nessa década, ou seja, as intervenções executadas por instâncias regionais e locais e os programas nacionais de preservação. Essa escolha de indicadores colocou, logo de início, o problema de quais intervenções e programas escolher como amostra representativa do 
que se passou na década em causa, com capacidade, a um só tempo, de ser operacional e de fornecer os contornos básicos da norma instituída no período. As intervenções executadas nas áreas centrais de Salvador, Rio de Janeiro e São Paulo foram julgadas representativas e informativas por uma série de razões.

Em primeiro lugar, segundo o Censo 2000, essas eram as três cidades mais populosas do país, o que permitia investigar, de modo privilegiado, o relacionamento que se estabeleceu entre a preservação do patrimônio e as questões suscitadas por dinâmicas urbanas e metropolitanas importantes. Ao lado disso, Salvador, Rio de Janeiro e São Paulo estão entre as cidades mais antigas do país e já abrigaram, em épocas sucessivas, seus polos político e econômico mais importantes. Tal fato possibilitaria uma visão, na longa duração, dos processos de permanência e transformação - em sua relação com a dinâmica cultural, política e econômica nacional - de uma materialidade que, no século XX, foi constituída como patrimônio.

Em segundo lugar, políticas de preservação foram implementadas nessas três cidades, com distintos graus de intensidade e abrangência, desde os anos 1930, instituindo relações diversas com a herança construída. Somadas ao papel, mais central ou menos central, desempenhado por cada uma dessas cidades no cenário nacional, tais políticas produziram distintas configurações espaciais e funcionais que, nos anos 1990, defrontaram-se com intervenções de preservação muito semelhantes, em termos de usos promovidos, estratégias de projeto, recursos e atores mobilizados.

Salvador, com uma grande área contínua protegida pelo IPHAN, possui, entre as três cidades, o único centro histórico de configuração morfológica relativamente homogênea e não renovada, contendo apenas um setor de tecido modernizado no seu interior. Essa grande área, de uso predominantemente habitacional e popular, abriga, em seu centro, no referido setor modernizado, os remanescentes funcionais de uma antiga centralidade dominante; apresentava-se bastante esvaziada na maioria dos setores, sendo rodeada por um tecido urbano de características heterogêneas, mas ainda relativamente bem ocupado e de uso também marcadamente popular. A antiga área central de negócios, localizada na Cidade Baixa, no bairro do Comércio, atualmente bastante esvaziada, tangencia a grande área protegida, ocupando um território renovado, que, no período em 
que a polaridade do centro antigo ainda era grande, funcionou como elemento de preservação do setor histórico localizado na Cidade Alta. Apenas ali há acesso por meio de avenidas de trânsito rápido. O transporte náutico remanescente na área portuária não se vincula à dinâmica da área central, que tampouco possui transporte de massa. Uma linha de metrô apenas tangencia a área histórica, na Cidade Alta, que abriga ainda terminais de transportes públicos e concentra uma dinâmica comercial popular importante.

O Rio de Janeiro, por sua vez, apresenta um caso de configuração espacial quase inversa à de Salvador, com uma área central de negócios moderna e ainda dinâmica localizada bem no coração do centro antigo, pontuada por monumentos individualmente tombados e que foi, a partir dos anos 1980, sendo progressivamente cercada de áreas protegidas. Constitui, atualmente, uma espécie de "ilha" moderna, cercada de sítios de valor patrimonial por todos os lados, os quais são mais ou menos homogêneos em termos morfológicos e funcionais. Esse conjunto tem uso predominantemente comercial e institucional, e mantém uma boa dinâmica - apesar de apresentar também um certo esvaziamento. Habitações de classe média baixa e de baixa renda ocorrem apenas nos setores periféricos que não são alcançados pela dinâmica central. Avenidas de trânsito rápido, sistemas de transporte de massa - trem e metrô - e de transportes náutico e aéreo ligam o coração comercial e financeiro do centro antigo ao resto da cidade, à região metropolitana e a outras regiões do país.

O centro de São Paulo, por fim, constitui um caso de setor modernizado, pontilhado de bens patrimoniais em boa parte de sua extensão que não formam, entretanto, conjuntos homogêneos, a não ser em pequenos fragmentos. Toda essa área tem uso predominantemente comercial e de serviços, mantendo em seu centro geográfico um setor ainda relativamente importante, que abriga os remanescentes da atividade financeira, administrativa e de negócios, característicos da centralidade até os anos 1960. De modo análogo ao Rio, o uso habitacional de classe média baixa e de baixa renda predomina apenas nas áreas esvaziadas dos bairros periféricos a este núcleo central. A acessibilidade por meio de avenidas de trânsito rápido e transporte de massa é muito boa, ligando a área a todos os 
setores da cidade e à região metropolitana. Não existem, entretanto, campos de pouso que estabeleçam uma ligação aérea sistemática do setor com o estado de São Paulo e outras regiões do país.

Em todas as três cidades, entre os anos 1960 e 70, ocorreram processos de esvaziamento, fragmentação e deslocamento de funções, bem como de popularização dos centros antigos. A centralidade mais atingida foi a de Salvador, seguida de São Paulo e, por último, do Rio de Janeiro. No que toca à estrutura urbana e ao sistema de centralidades, as três cidades também apresentavam, no início dos anos 1990, situações muito diversas, com o Rio de Janeiro exibindo uma estrutura e um sistema de centros ainda claramente polarizados no centro antigo; Salvador, com uma situação ainda bipolar, mas com forte tendência de transferência total de polaridade para um novo centro; e São Paulo, dividida entre três centralidades que disputavam, entre si, polaridade, dinâmica e investimentos. Essas situações permitiram avaliar como as intervenções de preservação se relacionaram com diferentes contextos urbanos e com que potencial e peso atuaram nas dinâmicas que foram chamadas a incrementar. Em suma, como essas ações foram estruturadas, localizadas e que efeitos produziram.

Além dessas considerações, pesaram ainda na identificação das cidades que comporiam a amostra a ser investigada questões vinculadas à própria história passada e recente das políticas de preservação urbana implementadas no país e relativas aos processos de apropriação do patrimônio verificados nos centros antigos de outras cidades.

Salvador, a primeira cidade objeto deste estudo, foi também a primeira grande cidade brasileira a ter boa parte do tecido urbano da área central declarado patrimônio, já nos anos 1950, ${ }^{6}$ e o lugar onde políticas voltadas para sua preservação global primeiro se estruturaram, no final dos anos 1960. Foi ainda na capital baiana que primeiro se executou (nos anos 1990) uma intervenção maciça sobre o patrimônio protegido, intervenção esta que, deliberadamente, rompeu com aspectos importantes das políticas traçadas anteriormente e buscou implantar um novo modelo. O sucesso dessa intervenção como ferramenta de marketing político e urbano ensejou a execução de várias outras na área central da cidade e incentivou intervenções semelhantes em alguns estados do Nordeste.
6 Até então, uma preservação urbana de caráter mais largo havia sido praticada apenas em cidades pequenas do interior estagnadas economicamente e que se encontravam, de certa forma, à margem das dinâmicas econômica e urbana mais importantes de suas regiōes. 
7 Os estudos para a proteção de manchas urbanas no centro de São Paulo datam de 1974, e sua proteção legal, de 1975, enquanto as medidas de proteção de conjuntos no Rio de Janeiro só tiveram início em 1977, com - Plano Urbanístico Básico do Rio de Janeiro - PUB-RIO, efetivando-se com o Decreto $n^{0} 1.707$, de 1978.
O Rio de Janeiro, a segunda cidade estudada, embora tenha começado a proteger conjuntos da área central depois de São Paulo,? foi a primeira a formular, implantar e executar, no final dos anos 1970, uma política de preservação baseada em vínculos urbanísticos, incentivos fiscais e orientação técnica, que se tornou referência nacional. A cidade constituiu ainda uma referência para os que pensaram e projetaram a requalificação do centro de São Paulo, influenciando, em boa medida, o modelo adotado nas intervenções realizadas nessa cidade na década de 1990. O processo de requalificação do centro do Rio de Janeiro foi o primeiro a começar, em moldes contemporâneos, e o que mais manteve, apesar dos novos contornos adquiridos nos anos 1990, uma linha clara de continuidade.

Em São Paulo, o processo de valorização do patrimônio do centro só começou no final dos anos 1980, tendo, em vários aspectos, como já mencionado, o Rio de Janeiro como referência. São Paulo foi a única das três cidades onde ocorreu, nos anos 1990, disputa pela definição dos rumos desse processo, cujo desenvolvimento propiciou, a partir desses embates, a produção de soluções que começaram a funcionar como referências para outras localidades. Esta foi também a cidade onde mais se desenvolveu um aspecto central das intervenções urbanas da década de 1990, correspondente à flexibilização da legislação urbanística e à criação de incentivos fiscais, e onde as operações tradicionais de salvaguarda mais foram postas em questão.

Analisar três cidades igualmente inseridas em realidades metropolitanas de um país periférico, com problemas urbanos e sociais semelhantes, mas com configurações patrimoniais, situações funcionais e de estrutura urbana diferentes, possibilitaria estabelecer comparações e cobrir, senão o todo, parte essencial do espectro das estratégias, atores e efeitos que caracterizaram a prática de preservação urbana e de produção de patrimônio nos anos 1990. Um rápido olhar sobre as intervenções realizadas posteriormente nas áreas centrais e sítios históricos de diversas cidades do país revela que os respectivos modelos de intervenção desenvolvidos mantiveram fortes vínculos com o que foi posto em prática em Salvador, Rio de Janeiro e São Paulo. Sob o impulso de programas de financiamento implantados na década em exame, cidades médias e até de pequeno 
porte também adotaram esses modelos. Em localidades como Icó e Sobral, no sertão cearense, por exemplo, sítios históricos foram trabalhados como atrações turísticas e de lazer por meio de intervenções que adotaram estratégias muito semelhantes às implementadas nas três cidades selecionadas.

Os programas nacionais foram selecionados a partir do grau de centralidade da questão da preservação urbana no seu escopo, e do grau de relacionamento de suas ações com as intervenções locais selecionadas para exame. Assim, foram privilegiados programas exclusivamente voltados para a questão da preservação urbana, como o Programa Monumenta e o Programa de Revitalização de Sítios Históricos. Entre os que apenas contêm componentes relativos à preservação do patrimônio, foi selecionado o Programa Nacional de Apoio à Cultura - PRONAC, em decorrência do papel central que seus mecanismos desempenharam no processo de valorização do centro do Rio de Janeiro - e, ainda que com menor poder, em São Paulo.

Com vistas a tornar inteligíveis as características, os sentidos, os objetivos e os efeitos da norma de preservação e de produção de patrimônio instituída nos anos 1990, o conjunto de enunciados e visibilidades mobilizado no âmbito das intervenções e programas selecionados foi analisado segundo alguns eixos principais. O primeiro deles diz respeito às noções de patrimônio embutidas no projeto e no resultado concreto das intervenções ou ações programadas, avaliando-se correspondências e divergências entre estas. Em seguida, a distribuição (em termos de papel e predominância dos diferentes atores públicos e privados na formulação), financiamento, execução e gestão de ações, bem como na apropriação de seus resultados. Em outras palavras, foi realizada uma investigação sobre quem fala, quem faz e quem se beneficia - com que poder e a partir de que lugar -, no âmbito das intervenções e programas implementados na década em exame. Intervenções e programas foram ainda analisados em relação aos discursos e ações produzidos no passado, a fim de se identificar permanências e transformações, rupturas e mudanças de sentido que permitissem avaliar, de modo mais acurado, a hipótese de periodização lançada no projeto dessa pesquisa - isto é, de que os anos 1990 produziram uma nova norma e constituíram 
8 Nessa cidade se localiza a maioria das coordenações centrais dos programas de preservação estudados. um novo período na trajetória da preservação do patrimônio urbano brasileiro. Por fim, as operações executadas no âmbito dos indicadores selecionados foram analisadas quanto ao seu peso e desempenho em face da dinâmica e dos processos urbanos instalados nas áreas atingidas, com vistas a se investigar, para além de suas intenções declaradas, a capacidade que suas estratégias e táticas tiveram, efetivamente, de produzir os efeitos previstos. Esse desempenho foi ainda investigado com o objetivo de identificar a ocorrência de efeitos inesperados que obrigaram o reordenamento de táticas e procedimentos.

A pesquisa de campo desenvolveu-se, ao longo de todo o ano de 2002, em Salvador, Rio de Janeiro, São Paulo e Brasília, ${ }^{8}$ envolvendo levantamentos em arquivos, entrevistas e avaliações in loco de intervenções executadas. As principais fontes documentais foram obtidas nas instituições envolvidas na coordenação e execução de intervenções e programas. Nas várias instituições percorridas, cuja lista se encontra no Apêndice $E$, foram contatadas cerca de 80 pessoas - entre dirigentes, técnicos e responsáveis por ações. Por meio de conversas informais e entrevistas abertas, buscou-se, nesses contatos, obter informações sobre experiências passadas, dificuldades enfrentadas e perspectivas das ações em andamento, bem como informações sobre estudos e documentos elaborados para sua preparação. Como resultado desse trabalho, mais de uma centena de documentos foi recolhida, entre leis, decretos, regulamentos, relatórios, levantamentos, projetos e publicações.

A pesquisa bibliográfica, empreendida em complementação à pesquisa de campo, privilegiou a leitura de obras e trabalhos sobre o relacionamento entre patrimônio e cidade, bem como o que foi produzido sobre a natureza econômica, social e cultural dos processos urbanos do final do século XX, especialmente aqueles que envolvem setores antigos e áreas centrais. Privilegiou-se também a leitura de trabalhos que investigam os modelos de intervenção urbana implementados nos países centrais no mesmo período, com vistas a se avaliar a relação desses modelos com os que aqui foram praticados e a extensão de sua transposição. Por fim, uma vasta pesquisa foi realizada nas bibliotecas dos principais programas de pós-graduação desenvolvidos em Salvador, Rio de Janeiro e São Paulo para identificar os trabalhos de mestrado e doutorado que, durante os anos 1990, investigaram o assunto e suas interfaces. 
O produto dessas investigações e seus resultados foram organizados de modo a facilitar o entendimento do desenrolar do processo de produção da norma brasileira de preservação do patrimônio urbano nos anos 1990, contra o pano de fundo dos modelos desenvolvidos nos países centrais que, de algum modo, thes serviram de referência. Assim, na primeira parte desse trabalho, se informa sobre as mudanças econômicas, sociais e culturais ocorridas nas últimas décadas do século XX e suas relações com a expansão da norma preservacionista, bem como se discorre sobre a transformação desta última em uma das lógicas hegemônicas de produção e gestão do espaço urbano nos países centrais. Nessa parte, se busca ainda identificar e analisar rapidamente os modelos de intervenção, implementados nos países desenvolvidos, que conjugam patrimônio, renovação e reabilitação urbana, com vistas, como já mencionado, a avaliar o desempenho e os efeitos de sua transposição para o Brasil. A segunda parte apresenta e analisa, segundo os eixos já mencionados, as intervenções realizadas nas áreas centrais das cidades de Salvador, Rio de Janeiro e São Paulo, e a terceira, os programas nacionais de preservação selecionados. Por fim, uma parte final reúne as observações, perplexidades e conclusões que foram possíveis amealhar nesse percurso. 


\section{A cidade-atração nos países centrais}

\section{As transformações econômicas, sociais e urbanas nas três últimas décadas do século XX}

A maioria dos autores localiza nos anos de 1970 a emergência de um novo estágio do capitalismo, em decorrência da crise do modelo industrial de produção desenvolvido no pós-guerra. Este modelo teria se mostrado incapaz de responder adequadamente aos desafios colocados pela crescente competição internacional, pela recessão que se instalou naquela década e pela alta inflacionária. (ANDERSON, 1999; CASTELLS, 1999b; HARVEY, 1993; JAMESON, 1997) Alguns autores relacionam ainda essa crise a uma "inabilidade" do setor público de continuar promovendo a expansão de mercados - e a geração de empregos - sem onerar o capital com o aumento de impostos, e sem gerar endividamento público. (CASTELLS, 1999b) Ou seja, uma conjuntura econômica adversa, um modelo de produção industrial rígido e um Estado pesado, ineficiente e em crise (SANTOS, B., 2000) teriam promovido uma reestruturação do sistema, que encontrou apoio e condição de desenvolvimento na revolução tecnológica que se iniciava 
naquele momento. Como observa Castells (1999b), nos anos 1970, as empresas se reorganizaram em busca de mais lucratividade e as novas tecnologias facilitaram essa reorganização, abrindo-lhes novas e amplas possibilidades de acumulação.

Denominado sucessivamente de capitalismo "multinacional", "tardio", "avançado", "de acumulação flexível”, "desorganizado" ou "informacional”, esse estágio, que sucedeu o chamado capitalismo "monopolista", tinha suas características já claramente perceptíveis nos anos 1980. Nessa década surgiram novas formas de organização empresarial, multinacionais e transnacionais, que logo passaram a predominar no cenário econômico; formou-se um mercado financeiro internacional que promoveu o crescimento exponencial da especulação e aumentou as possibilidades de giro de capital; alterações significativas nos processos de produção, circulação e comercialização de mercadorias foram introduzidas, e megaconglomerados de comunicação foram constituídos. Desregulamentações operadas, simultaneamente, nos campos trabalhista, financeiro e empresarial, e as novas possibilidades de armazenamento e transmissão de dados em tempo real permitiram essas mudanças que, em última análise, "recapitalizaram" o capitalismo. Essas medidas e a tecnologia desenvolvida possibilitaram ao sistema recuperar sua lucratividade e seu poder de investimento, bem como explorar novos campos e territórios. (CASTELSS, 1999b, p. 100-101) Nesse processo, entretanto, como já havia notado Harvey (1993, p. 15), as regras básicas da acumulação capitalista não mudaram. Apenas os controles sobre a lucratividade e as contrapartidas sociais, antes exigidas, se evanesceram, na medida em que o sistema passou a funcionar na escala global e o capital financeiro tornou-se a principal forma de acumulação. Como nota Castells (1999b, p. 500-502), e como antes o havia notado Jameson (1997, p. 29-30), o capitalismo, nesse estágio de desenvolvimento, ressurgiu em sua "expressão mais pura [...] da busca do dinheiro pelo dinheiro, por intermédio da produção de commodities por commodities".

Portanto, como modo de produção e acumulação, o capitalismo não mudou em essência, mas seu funcionamento em escala global, propiciado pelo novo paradigma tecnológico, promoveu mudanças e adaptações significativas no plano econômico, político, social e cultural, com reflexos importantes no relacionamento Estado - sociedade, na divisão internacional do trabalho, na estrutura do emprego, no consumo, nas relações sociais e nas formas de dominação. 
A primeira grande mudança é que a economia passou a funcionar, na escala do planeta, como uma "unidade em tempo real" (CASTELLS, 1999b, p. 111), em decorrência do fato de que os principais segmentos da maioria dos setores econômicos passaram a organizar, mundialmente, seus procedimentos operacionais através de redes de produção e comercialização. Essas redes são formadas por empresas de variados portes, procedências e localizações, sob o comando de grandes corporações multinacionais ou transnacionais que estendem seus tentáculos por todo o mundo. Estas, por sua vez, fixam a localização e o posicionamento dos elos e conexões dessas redes de acordo com seus interesses de produtividade e lucratividade, o que confere às cadeias produtivas uma unidade, mas também uma "geometria" variável e mutante, na qual a manutenção de uma "posição" exige, permanentemente, o oferecimento de grandes vantagens competitivas. (CASTELLS, 1999b, p. 114) Essa estrutura dominou os processos produtivos e impôs ao mundo uma lógica única de funcionamento, baseada na mais extrema competitividade. Submeteu Estados nacionais e influenciou suas políticas, rompeu os liames entre riqueza e bem-estar social e esgarçou a noção de solidariedade entre os homens e entre os povos. (SANTOS, M., 2001, p. 46-48) Apesar de não abarcar rigorosamente todos os territórios e processos econômicos do planeta, essa lógica submeteu a todos, afetando diretamente a vida da humanidade. (CASTELLS, 1999b, p. 120)

A estrutura e a lógica de funcionamento dessa nova economia globalizada, assim como os fluxos de capital, serviços e tecnologia que promoveu, colocaram em xeque a soberania dos Estados nacionais e enfraqueceram seu poder de controle sobre processos econômicos, sociais e culturais. Com a produção tornada móvel e "migrável", os Estados perderam ainda grande parte do poder de assegurar, em seus territórios, uma base produtiva fixa para geração de receita, (CASTELLS, 1999a, p. 287-289) o que tornou os sistemas tributários obsoletos e inoperantes, diante, inclusive, da internacionalização dos investimentos e da fuga de capitais para paraísos fiscais. Em consequência de uma incapacidade, ou opção política-ideológica, de colocar barreiras a essa situação, uma grave crise fiscal e uma crescente dependência do mercado financeiro internacional tornaram inviável a continuidade da política de bem-estar social, que sustenta a legitimidade dos Estados de países desenvolvidos, bem como a promessa de que, 
algum dia, essa política viria a ser executada nos países periféricos. (SANTOS, B., 2000; SANTOS, M., 2001) Contudo, apesar das perdas de poder, controle e receita sofridas, os Estados nacionais preferiram exercer o seu papel econômico promovendo o desenvolvimento dessa estrutura e a derrubada das barreiras legais, institucionais e fiscais que lhes criavam constrangimentos.

A internacionalização, a privatização e a diversificação dos meios de comunicação, bem como a formação de grandes conglomerados nesse segmento econômico, subtraíram, em grande parte, a capacidade dos Estados de controlar informações e gerar imagens. Ao escaparem ao controle estatal, os meios de comunicação aumentaram consideravelmente seu poder de influenciar a formação de atitudes e comportamentos, tornando-se ainda o principal palco do jogo político. Essa perda de controle sobre o fluxo das informações e imagens que circulam nos meios de comunicação contribuiu, juntamente com a perda de controle sobre processos econômicos, para a consolidação de uma percepção do Estado como uma estrutura onerosa e ineficiente que deveria ser diminuída e reformulada. (CASTELLS, 1999a, p. 298-303; MARCONDES FILHO, 1996, p. 181-205)

As mudanças no plano da produção - automação de processos, instalação de um regime de produção acelerada e sob encomenda e, principalmente, segmentação e deslocamento de operações industriais para países periféricos -, somadas às que ocorreram na organização empresarial - fechamento de unidades produtivas, diminuição de quadros de pessoal, terceirização de serviços e de etapas do processo produtivo -, promoveram impactos diretos e significativos não apenas na divisão internacional do trabalho, mas também na estrutura do emprego e no mercado de trabalho. A segmentação e o deslocamento da produção, juntamente com a desregulamentação e a flexibilização das relações trabalhistas, deslocaram ou diminuíram empregos permanentes, fazendo crescer os temporários, os de meio turno e o trabalho autônomo. Tal situação levou as negociações relativas à remuneração, às condições de trabalho e à dispensa para o plano individual, enfraquecendo e tornando sem sentido as organizações trabalhistas, e desonerando o capital de encargos sociais. As resistências institucionais relativas à proteção do trabalhador foram derrubadas em nome da flexibilidade gerencial necessária à manutenção da competitividade e da produtividade, assim como da criação de 
novos postos de trabalho. Instabilidade, individualização, falta de proteção institucional e enraizamento local tornaram-se, então, as principais características do trabalho no chamado capitalismo avançado. (CASTELLS, 1999a, p. 353-401)

A competitividade, posta a serviço de uma lucratividade máxima e o seu exercício sem freio ou controle social aprofundou e ampliou os processos de exclusão e concentração próprios do sistema capitalista. Ao invés de um maior número de pessoas incluídas na sua dinâmica, as novas práticas econômicas concentraram ainda mais a riqueza e aumentaram a escala dos excluídos dos seus benefícios. (SANTOS, M., 2001, p. 38-78) A automação, a flexibilização das relações trabalhistas e, especialmente, o deslocamento de parte substancial do processo produtivo para países periféricos aumentaram o nível do desemprego nos países centrais e criaram o exército de desempregados que alimenta ainda, nesses países, a informalidade, os baixos salários e os empregos precários. (KLEIN, 2002, p. 195-275) Nos países menos desenvolvidos, em decorrência das vantagens competitivas exigidas para que se efetive sua conexão nas redes produtivas, os salários mantiveram-se muito baixos e os empregos precários. Como consequência da concessão de incentivos com vistas à atração de investimentos e atividades, os investimentos públicos em bem-estar social, nos países periféricos, foram prejudicados pela perda de arrecadação fiscal. Como mostra Klein (2002, p. 195-275), os bons empregos das indústrias do primeiro mundo não foram transferidos para a periferia, pois o que surgiu aí, especialmente nas export processing zones, foi outro tipo de emprego, baseado em alta rotatividade da mão de obra, remuneração baixíssima e pouca ou nenhuma proteção institucional. Como apontou Sassen (1998, p. 26-45), as zonas de processamento para exportação, que proliferaram em vários países do terceiro mundo, foram estratégicas para a economia global porque permitiram manter muito baixos os custos de produção, e muito alta a lucratividade final das empresas multinacionais que compram o que é produzido nessas zonas. Contudo, apesar dessa importância estratégica, o poder de barganha dos países que as abrigam é pequeno porque as unidades de produção, implantadas para realizar etapas do processo produtivo controlado por grandes corporações, não detêm know how específico, são precárias, e deslocáveis, 
rapidamente, para outro país que ofereça mais "vantagens". O surto industrial dos países periféricos não significou, portanto, melhoria de qualidade de vida, nem maiores índices de bem-estar social nessas regiões.

A estrutura em rede da economia globalizada se organizou em torno de centros de comando e controle de atividades que, preferencialmente, como mostram vários estudos, localizaram-se em grandes cidades das regiões polarizadoras dessa economia, ou seja, na América do Norte, Europa e Pacífico Asiático. (CASTELLS, 1999b) Esta preferência, num momento em que a tecnologia permitiria a localização desses centros em qualquer lugar, decorreu de fatores históricos e estratégicos. A maioria das sedes controladoras das corporações multinacionais e transnacionais já se localizava em metrópoles dessas regiões. Ao lado disso, a história dessas cidades, como importantes núcleos comerciais e financeiros, o fato de serem centros fornecedores de mão de obra para serviços qualificados, com amplas possibilidades de aperfeiçoamento e acesso ao entretenimento, à arte e ao consumo, pesou bastante nessa localização. Em suma, a despeito de muitas atividades produtivas terem se dispersado, deslocado ou segmentado, aquelas relacionadas às funções superiores de comando, criação, finanças, marketing, projetos, consultorias, assessoria jurídica e inovação científica, entre outras, se concentraram nos grandes centros urbanos dos países centrais, compondo o seleto grupo que Sassen denominou de "cidades globais". Essas cidades, não por acaso, também já concentravam altos investimentos imobiliários cujo abandono, numa nova dispersão, significaria perda de patrimônio e recursos para muitas e importantes corporações.

Assim, na era da comunicação e da informação em tempo real, que supostamente favoreceria um processo de dispersão urbana, assistiu-se, ao contrário, ao renascimento do papel econômico das cidades como espaços essenciais ao funcionamento das redes produtivas globais. Entretanto, para desempenhar esse papel, foi necessário que o núcleo urbano se tornasse um "nó", ou um ponto de conexão, das redes que movimentavam e dominavam a economia. Só constituíram, portanto, centros de concentração e irradiação de fluxos e atividades econômicas de peso as cidades que se mantiveram conectadas às grandes redes de produção e 
comercialização, seja como seus centros principais, seja como conexões dessas cadeias. Assim, participar do grupo das "cidades globais" ou da teia de núcleos urbanos regionais e locais que comandavam tornou-se o grande objetivo das municipalidades. Como a posição nessa rede de cidades não seria, em princípio, estável ou garantida, a competição urbana foi acirrada, com a formação de todo um aparato técnico voltado para a criação de diferenciais competitivos e com o oferecimento de vantagens locacionais, fiscais e de recursos humanos. Deflagrou ainda, como se verá adiante, processos de transformação e de reestruturação espaciais bastante semelhantes. (CASTELLS, 1999b, p. 405-410)

Além de pontos estratégicos de comando, comunicação ou conexão de redes produtivas, as cidades do capitalismo avançado tornaram-se também o lugar, por excelência, de residência permanente ou temporária das elites que gerenciam as atividades que movimentam a economia. Estas organizam seu espaço residencial, de lazer, de compras e de trabalho sob a lógica da segregação espacial, do acesso fácil e do controle de segurança, caracterizando-o ainda por um estilo de vida, um modo de projetar formas e de selecioná-las entre as existentes que se tornou responsável por uma crescente homogeneidade desses espaços, em todo o mundo. (CASTELLS, 1999b, p. 440) Nos países centrais, especialmente europeus, a elite política, empresarial e tecnocrática organizou e produziu seu espaço residencial, preferencialmente, em áreas preservadas ou reabilitadas de grandes metrópoles.

A competição interurbana por capitais e atividades, o crescimento do turismo cultural e a crescente preferência das elites gerenciais por áreas históricas deflagraram um fenômeno de construção, mudança ou reforço de imagens urbanas com base em materiais fornecidos pela cultura e pelo patrimônio, bem como o aumento, nos países centrais, do valor comercial de imóveis localizados em setores e bairros antigos. Cultura e patrimônio passaram a ser vistos como aspectos que "vendem" e valorizam localizações, o que implicou a execução de um sem-número de intervenções urbanas semelhantes, vendidas e defendidas, em todo o mundo, como a solução para os mais diversos problemas urbanos. Nesse trabalho, entre outras coisas, se tentará mostrar que, fora dos circuitos centrais da economia, esses modelos de intervenção não funcionam da mesma maneira. 


\section{Cultura, comunicação e cidade}

A estrutura em rede e o alcance global da nova economia mundial propiciaram o aumento da lucratividade de certos segmentos econômicos, mas, ao colocarem de lado o que não tem importância estrutural para seu funcionamento, aprofundaram a exclusão social, aumentaram o desemprego e promoveram, consequentemente, a concentração do mercado consumidor. As redes de produção e comercialização que dominam a economia passaram a trabalhar para faixas de renda cada vez mais reduzidas e segmentadas, o que resultou numa espécie de superexploração de nichos de mercado, mediante a introdução constante de inovações e o desenvolvimento de estratégias de marketing sofisticadas, com vistas a programar e induzir o consumo. A cultura tornou-se a principal fonte de materiais e inspiração para a inovação de produtos e para a formulação de estratégias de venda, o que a tornou altamente funcional para a reprodução e acumulação capitalista. (JAMESON, 1997; KLEIN, 2002, p. 108-124) Já nos anos 1980, Jameson assinalava que entre a cultura e o novo modo de produção existia "uma interação recíproca, um circuito de realimentação" que indicava que a base produtiva estava gerando sua superestrutura segundo um novo tipo de dinâmica. (JAMESON, 1997, p. 18-25) Ao se tornar parte do processo produtivo, a cultura teria mudado de função social, isto é, teria deixado de ser uma esfera de produção de ideias e práticas voltadas para o crescimento e o aprimoramento pessoal e coletivo, e se tornado uma mercadoria como outra qualquer.

As mudanças no processo produtivo permitiram que as energias e as principais formas de reprodução e acumulação de riqueza se deslocassem para a esfera da comercialização e da circulação. O deslocamento e a segmentação da produção permitiram que grandes corporações, antes envolvidas também na fabricação de produtos, se livrassem desses encargos e se transformassem em empresas compradoras e, especialmente, em empresas administradoras de marcas. Essa liberação dos encargos da produção, aliada à possibilidade de comprar componentes e produtos a preços baixíssimos de "fornecedores" localizados em países periféricos, permitiu às grandes corporações investir mais na inovação de produtos e, principalmente, em estratégias custosas de fortalecimento e expansão de suas marcas. (KLEIN, 2002, p. 195-275) "Fornecedor" é, na realidade, o nome dado aos 
verdadeiros produtores, os quais podem ser redes de pequenas e médias empresas ou redes de microempresas de caráter inclusive familiar, que trabalhavam sob regime de encomenda e obedeciam aos controles estritos de qualidade e execução exercidos pelos "compradores". Estes últimos são as corporações que colocam uma marca ou logotipo sobre o produto ou componente assim produzido, cujos preços baixos são obtidos mediante regimes de exploração e aviltamento do trabalho semelhantes aos existentes nos piores momentos da indústria europeia no século XIX. Como mostra Klein (2002, p. 195-275), o processo de produção mudou não somente para "salvar" a indústria - e o capitalismo - dos constrangimentos de um modelo de produção rígido e regulado, mas também para que sobrassem recursos e energia para se investir no que, a partir desse momento, agrega valor, ou seja, inovação e marketing.

O deslocamento da principal fonte de mais-valia para a esfera da comercialização e da circulação lançou corporações numa busca frenética por formas eficazes de construir e reforçar suas marcas, as quais vão bastante além das conhecidas campanhas publicitárias. A essas estratégias avançadas de comercialização, Klein deu o nome de branding e com esse termo designa o conjunto de técnicas de construção e fortalecimento de marcas comerciais, que incluem a publicidade, mas envolvem, principalmente, ações de patrocínio, licenciamento e intervenção direta no campo cultural. O branding é, sobretudo, uma estratégia que visa a conferir identidade a uma marca, tornando-a parte da vida e do ambiente cultural do consumidor. Dito de outro modo, é uma estratégia que faz com que uma marca comercial produza cultura ou crie, em torno de si, uma cultura. Na montagem dessas estratégias surgiram como veículos privilegiados o espaço público, as identidades sociais, a educação e a própria produção cultural.

Produzir identidade para alguma coisa significa criar ou encontrar um diferencial, enfim, algo especial que a distinga das outras. Significa encontrar uma essência que the dê significado, e ainda selecionar e ressaltar atributos que possam the ser associados de modo específico. Nos anos 1980, quando companhias foram adquiridas unicamente pelo valor de suas marcas, essa atividade passou a se tornar economicamente crucial. Nos primórdios da produção em massa, esse diferencial era, muitas vezes, encontrado na qualidade do produto, na excelência de sua fabricação ou num atributo qualquer, normalmente de
Do inglês "brand", que significa rótulo ou marca. A expressão "branding" pode ser traduzida então, grosso modo, como o ato de rotular ou de colocar uma marca em algo. (KLEIN, 2002, p. 7-8) 
efeito psicológico, que the era associado. Com o recente desenvolvimento tecnológico, os processos de fabricação e os produtos se tornaram cada vez mais iguais, levando para a marca a função de produzir esse diferencial. Como observa Klein (2002, p. 8), no momento em que as corporações passaram a se dedicar, prioritariamente, a "produzir", "estender" e valorizar suas marcas, a paisagem cultural tornou-se a principal fonte do "oxigênio" necessário para inflá-las. Nesse processo, descobriu-se que construir e fortalecer uma marca tinha mais a ver com inoculá-la como um vírus no campo cultural do que anunciar seus produtos do modo convencional. Os publicitários logo entenderam que, nesse contexto, o segredo da venda ou do uso de um produto passara a residir não mais em suas qualidades intrínsecas, mas no estabelecimento de "vínculos emocionais" entre a marca e o consumidor. Em suma, na criação de uma "experiência” com a marca. (KLEIN, 2002, p. 20)

Klein (2002, p. 29-30) mostra ainda que o branding invadiu a cultura e o espaço público por meio do patrocínio de eventos culturais, da apropriação de signos comunitários e de bandeiras políticas - vide as famosas campanhas da multinacional italiana Benetton nos anos 1980 - e também do uso da paisagem urbana como suporte e fonte de significado. Sugar ideias e iconografias culturais para projetá-las de novo na cultura através de uma marca comercial tornou-se uma estratégia usual. A marca, ou a corporação que ela representa, não é mais, então, aquilo que patrocina um evento ou se associa a um fenômeno cultural, mas algo que almeja tornar-se o próprio fenômeno cultural. O objetivo final dessas estratégias era fazer com que quem compra Nike ou Benetton, por exemplo, não compre somente um produto, mas algo que traz embutida uma atitude, uma concepção, um modo de compreender e levar a vida - em suma, um estilo.

Essas estratégias de marketing voltaram-se também para o espaço urbano, inicialmente de modo ainda convencional - mediante o uso de mobiliário urbano e edifícios como suporte de peças publicitárias -, mas logo evoluindo para a utilização da cidade como uma peça publicitária em 3D. Essa apropriação se deu por meio do uso de ruas inteiras como espaços associados a uma marca; mediante o patrocínio da revitalização de áreas degradadas; da "adoção" de praças e ruas ou, ainda, da construção de novos espaços. O condomínio fechado que tomou a forma de uma pequena cidade utópica, sem insegurança ou caos, denominado 
Celebration, construído pela Disney Corporation, ${ }^{2}$ não é somente um empreendimento imobiliário. É também um exemplo e um resultado dessa estratégia. (KLEIN, 2002, 37-38) Ao usarem o espaço urbano como veículo de marketing, as corporações passaram também a produzi-lo, especialmente, na medida em que se tornou importante para os negócios propiciar uma "experiência” com a marca, associando-a a emoções e estilos de vida. Nesses espaços corporativamente produzidos, a publicidade, na sua forma convencional, não é importante e nem mesmo necessária. Para a marca, o essencial era que o consumidor/usuário soubesse quem está por trás e quem está proporcionando aquele espaço e, com isso, passasse a associá-lo à corporação que o recuperou ou produziu. Como nota Klein (2002, p. 146-158), as corporações, e não mais os urbanistas, arquitetos e sociólogos, são as instâncias que estão fornecendo as novas utopias espaciais exclusivas, segregadas e totalmente controladas.

Sejam espaços construídos ou recuperados, as intervenções urbanas produzidas ou patrocinadas por marcas comerciais passaram a cumprir, de todo modo, uma função mercadológica de atrair a atenção e de mobilizar emoções caras ao público. Por essa razão, áreas históricas e empreendimentos que se apoiam em referências históricas tornaram-se tão adequados ao desenvolvimento desse tipo de estratégia. Apropriando-se de espaços construídos ou vazios, o branding passou a construir áreas que funcionassem como atrações urbanas.

O marketing é considerado pelos estudiosos a principal forma de comunicação, o que tem tornado a mídia o verdadeiro lócus da esfera pública, bem como o palco da disputa pelo poder. (MARCONDES FILHO, 1996, p. 78) O declínio do espaço físico da cidade como lugar de relacionamento público está vinculado a esse fenômeno de midiatização do social, que transferiu a cena pública da "praça" para os meios de comunicação. (ARANTES, 1993, p. 95-155) Contudo, ao oferecer múltiplas opções de programação, a mídia eletrônica permite que os receptores evitem as formas mais tradicionais de propaganda, o que fez com que o espaço urbano - na medida em que a circulação no seu interior é obrigatória - surgisse como um veículo poderoso. Por essa razão, tem sido desde então, preferencialmente, utilizado não mais como lugar do debate público, mas como veículo de transmissão de mensagens publicitárias.
2 Na Flórida, Estados Unidos. Neste condomínio, as edificações obrigatoriamente construídas em estilos tradicionais - fazem também apelo a uma visão romântica do passado. 
Vários autores, especialmente os de tradição marxista, já ressaltaram as estreitas relações entre cultura e mercado, estabelecidas com o advento do chamado capitalismo avançado e com o desenvolvimento tecnológico mais recente. A expansão do campo da cultura e a transformação de todo bem cultural em produto para consumo tornaram menos nítida ou quase indistinta a fronteira entre cultura superior e cultura de massa. A obra de arte ou o produto cultural contemporâneo, mesmo como produção de elite, já traz em si, como elementos constitutivos, materiais da indústria cultural. Assim, há um razoável consenso entre os teóricos quanto à importância do "visual" e da imagem na cultura contemporânea. Aspectos que se vinculam diretamente à linguagem dos meios de comunicação eletrônicos e à influência que esta exerce na experiência estética e na percepção são enfatizados pelos estudiosos, que revelam uma preocupação crescente com o problema da hegemonia da linguagem da mídia e suas consequências na estrutura do sentimento e da percepção. A "mediascape", ou paisagem mediada por veículos eletrônicos, passou a constituir a principal forma de se ver e de se ter acesso ao mundo, o que promoveu mudanças na maneira de vê-lo e percebê-lo. (KROKER \& COOK apud MARCONDES FILHO, 1996, p. 108) Ao lado disso, ao tornar-se independente de julgamentos ou valorações e ao não estar mais confinada a espaços específicos ou a categorias predefinidas, a arte criou também um terreno favorável à recepção estética adequada aos apelos de consumo e à linguagem publicitária. Essa contaminaçãa entre arte e consumo forçou a transformação de espaços especializados, como museus, centros culturais, galerias etc, em espaços que apelam constantemente ao lúdico e ao sensório, como forma de aproximar, à maneira da linguagem dos media, o público do objeto em exibição. O mesmo se verifica na esfera urbana, onde igualmente se explora a aparência, os efeitos, as sensações e tudo o mais que diz respeito à ambientação e ao sensório. (MARCONDES FILHO, 1996, p. 321-348) A hegemonia da mídia eletrônica como principal meio de comunicação produziu, enfim, uma cultura na qual o visual ocupa o centro. 


\section{0 patrimônio e os novos empreendimentos urbanos}

A produção e a reestruturação do espaço urbano nos países centrais se processaram, nas últimas décadas do século XX, em grande parte, sob a égide da cultura e do patrimônio. Como foi notado por vários autores, esse processo originou-se na crise do modernismo como projeto urbano, social e estético, a partir

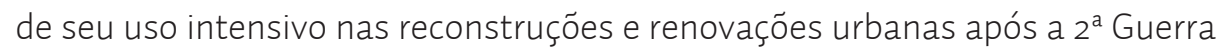
Mundial, e de sua vulgarização por meio do "estilo internacional". A descrença no planejamento urbano e nos grandes gestos arquitetônicos modernistas como solução para as mazelas das cidades levou arquitetos e urbanistas a propugnarem a eficiência das intervenções discretas e pontuais, baseadas no respeito à morfologia urbana e na reabilitação do estoque imobiliário existente. Nesse processo, retomou-se a defesa da função comunicadora da arquitetura, em oposição ao "silêncio" formal modernista, e realizou-se um retorno à questão dos princípios artísticos que deveriam reger a estética da cidade.

Nesse contexto de desencanto com as promessas do movimento moderno, o patrimônio urbano surgiu como um valor indiscutível, um testemunho de uma arte de construir cidades e como algo que deveria ser, por todos os meios, preservado. Nos países europeus, essa abordagem resultou, de imediato, numa ampliação significativa da proteção concedida às cidades e setores urbanos antigos, e na proposição de políticas para seu aproveitamento e inserção na vida urbana. Contudo, o que começou, na Europa, como um genuíno movimento de resistência às destruições perpetradas em nome da racionalidade e do progresso transformou-se, sob a égide das reestruturações urbanas impostas pelo reordenamento econômico a partir dos anos 1970, e do crescimento de uma demanda por patrimônio, em mais uma forma de promover a valorização imobiliária e o desenvolvimento desigual do espaço urbano. (ARANTES, 1993, 1998)

Vários autores localizam também o germe dessa nova apropriação do patrimônio urbano em intervenções, do final dos anos 1960, que buscaram reincorporar ao mercado e valorizar áreas centrais e portuárias de cidades norte-americanas, afetadas pela crise do modelo industrial fordista e pelos conflitos sociais que a acompanharam. (ARANTES, 2000; HALL, 1995; HARVEY, 1993) Essas iniciativas, que têm como precursora a Baltimore City Fair, promoveram uma compreensão do 
projeto urbano como a produção de "locais de sucesso" que favorecem a imagem da cidade e atraem investimentos. Com essas intervenções, um novo pensamento de fundo pragmático e financeiro começou a se apoderar das cidades. (ARANTES, 2000, p. 24; HALL, 1995, p. 407-428)

A recessão dos anos 1970 ajudou a formação desse pensamento, na medida em que, ao invés do crescimento acelerado, típico do pós-guerra, as cidades americanas entraram, de um modo geral, em processo de esvaziamento e empobrecimento, em decorrência da reestruturação econômica. (HALL, 1995, p. 407) Acusado de participar da eclosão dessa crise urbana ao inibir as forças do mercado, o planejamento urbano, já em descrédito e quase arquivado, foi chamado a participar da solução do problema, desregulamentando áreas e criando instrumentos urbanísticos para incentivar a produção imobiliária. Esse novo modelo de intervenção, baseado no aproveitamento de estruturas antigas e na introdução de novas atrações no tecido urbano, foi, ao longo dos anos 1970 e 80, incorporando, crescentemente, materiais da cultura e do patrimônio.

Essas intervenções pontuais foram definidas como preservadoras da diversidade urbana e saudadas por muitos como um antídoto contra o planejamento tecnocrático anterior. Logo, entretanto, ficou claro que, comandadas pela lógica do mercado, produziam o mesmo efeito homogeneizador das criticadas intervenções modernistas. Como observou Harvey (1993, p. 73-75), "novos padrões de conformidade" foram logo gerados por esse planejamento comandado pela capacidade de pagar, dividindo-se a cidade em espaços gentrificados de classe média, e espaços onde imperavam a insegurança e a falta de habitação. No final dos anos 1980, já estava claro que a retórica da diversidade, da identidade e do patrimônio urbano apenas reproduzia, com outra linguagem formal, o mesmo espaço desigual e segregado da urbanização capitalista. Essa apropriação da preexistência também se concretizava com a ajuda dos governos.

Hall (1995) mostra que, no final da década de 1970, os investimentos governamentais nos EUA migraram das novas cidades e subúrbios de classe média para as áreas intraurbanas, vistas então como fronteiras ideais para um novo desenvolvimento. Na década seguinte, escritórios públicos especiais, como o montado no centro de Boston, promoveram, apoiados em subvenções federais, a parceria entre municipalidades e setor privado para a execução das mais variadas intervenções 
de "revitalização urbana". (HALL, 1995, p. 411) A subvenção federal, entretanto, só era liberada se o projeto comprovasse a mobilização de investimentos privados de grande monta, o que, geralmente, ocorria. Como ainda informa Hall, em 1983, mais de 1.900 projetos desse tipo estavam em curso em cerca de goo cidades americanas, as quais, em média, levantavam, no setor privado, 3,9 unidades de investimento "novo" para cada uma de investimento público concedido sob a forma de subvenção. ${ }^{3}$ Esta fórmula americana, que combinava a reciclagem de antigas estruturas físicas com a mobilização de investimentos privados incentivados por subvenções públicas, foi também amplamente adotada na Inglaterra, nas intervenções em Covent Garden e Docklands, em Londres, propagando-se por várias cidades europeias como Paris, Barcelona, Bilbao e Lisboa.

Nos países centrais, embora tenha, na maioria dos casos, elitizado áreas e operado segundo uma lógica de valorização, segregação e controle do acesso, ${ }^{4}$ esse modelo de intervenção conheceu grande sucesso comercial e imobiliário, abriu novas áreas ao púbico, atraiu turistas e investimentos privados. Em casos como o de Baltimore, que, nos anos 1980, já atraía 22 milhões de visitantes por ano, e de Barcelona, que multiplicou também seu número de turistas e atraiu investimentos significativos para sua antiga zona portuária, as revitalizações forneceram ou agregaram novas bases econômicas às municipalidades. Produziram também novas imagens para essas cidades e as promoveram como exemplos de urbanismo e de qualidade de vida no cenário mundial. Esses sucessos impulsionaram a transformação dessa estratégia em um novo discurso de planejamento que logo ultrapassou as fronteiras americanas e europeias.

A fórmula acima descrita, entretanto, não é, na realidade, tão exclusivamente americana e, ainda que com contornos específicos, tem um correspondente europeu, por exemplo, nos projetos de mise-en-valeur desenvolvidos para setores preservados de Paris, a partir da promulgação da Lei Malraux, em 1962. ${ }^{5}$ Embora reabilitados basicamente para uso habitacional, em decorrência da valorização imobiliária deflagrada pelas restaurações, e do consequente aumento no valor dos aluguéis, populações de menor renda que habitavam esses setores foram, muitas vezes, deslocadas. O caso mais célebre e antigo é o do bairro do Marais, em Paris, que possui, atualmente, um dos metros quadrados mais caros da cidade.
3 As subvenções eram concedidas através das Urban Development Action Grant - UDAG, o que pode ser traduzido como Subvenção à Ação Urbanizadora. (HALL, 1995, p. 413)

4 Ver também a respeito dos efeitos de expulsão e segregação gerados por essas intervenções. (DEUTSCHE, 1996)

5 A Lei Malraux criou os Setores Salvaguardados ou setores urbanos protegidos como patrimônio, instrumento que se encontra incorporado ao Código de Urbanismo francês. 
Embora a apropriação de setores antigos para uso residencial das elites seja, desde os anos 1970, uma das formas dominantes da urbanização europeia, a existência de um vasto parque patrimonial protegido e de uma política de subsídios voltada para a produção de habitações sociais tem, de algum modo, compensado os processos de valorização acompanhados de expulsão. Na realidade, a partir dos anos 1960, convivem na Europa duas formas básicas de aproveitamento do patrimônio urbano. Uma, de reabilitação subsidiada do estoque imobiliário existente para melhoria do habitat e do déficit habitacional; e outra, que reconquista setores para a elite no jogo livre do mercado, a partir do aumento do valor imobiliário e dos aluguéis. Nos anos 1980, sobre essa base de aproveitamento econômico e social do patrimônio urbano, assistiu-se, na Europa, especialmente em cidades que sofreram mais agudamente os impactos da reestruturação econômica, a entrada do modelo americano de criação de atrações e empreendimentos urbanos, a partir da cooperação entre setor público e iniciativa privada.

Na década de 1980, residir em edifícios e setores antigos já havia se tornado um must na Europa, o que reforçou uma crescente apropriação estética e visual do patrimônio, com fins mercadológicos. Verificou-se também o retorno, pelas mãos do poder público, de uma arquitetura monumental, baseada em design contemporâneo e no uso de tecnologia construtiva de ponta, que, acoplada ou não ao patrimônio, logo também funcionou como instrumento de promoção de cidades. Bilbao, na Espanha, e a própria Paris, que renovou sua imagem de capital mundial da cultura por esses meios, foram os exemplos mais comentados. (ARANTES, 1993, p. 159-164) A produção de objetos arquitetônicos estética e tecnologicamente espetaculares no interior de conjuntos preservados foi, desde então, largamente utilizada como estratégia de valorização de ambientes urbanos e ferramenta de promoção. Além de funcionarem como "implantes regeneradores" (CHOAY, 1996, p. 157-165) de áreas deterioradas - a exemplo do Museu Guggenheim, de Frank Gehry, em Bilbao - tornaram-se também instrumentos de renovação do interesse pelas estruturas antigas, como bem ilustra a pirâmide de Pei, no Louvre.

Nos Estados Unidos, o patrimônio e o valor cultural também se tornaram peças-chaves para a reconquista de áreas degradadas e para o desenvolvimento de novos empreendimentos imobiliários nas últimas décadas do século XX. Enfatizando o quanto a atribuição de valor cultural tornou-se, assim, um meio 
de aumentar o valor de certas áreas urbanas, Zukin (200ob, p. 80) identificou os dois processos por meio dos quais os setores urbanos se reestruturaram nos EUA. O primeiro, relacionado a cidades mais antigas como Nova York, se desenvolveu a partir da apropriação de áreas degradadas ou abandonadas por uma elite intelectual que, ao colocá-las em evidência, abriu caminho para sua transformação em locais altamente disputados no mercado imobiliário. O outro, típico de cidades mais novas ou consideradas "sem patrimônio", como Los Angeles e Miami, tomou forma semelhante à do "urbanismo" fantasioso e higiênico da Disney World (ZUKIN, 200ob, p. 88), adotando-se, em grande parte, a estética, o imaginário e as estratégias de atração próprios desse tipo de empreendimento. Os dois processos - o segundo, na origem, e o primeiro como consequência - resultam numa "limpeza" de usos e usuários indesejáveis, passando a predominar, na área afetada, a lógica de segregação e controle típica da organização dos espaços das elites. Nos casos de áreas antigas, essa “limpeza” foi, muitas vezes, induzida por meio de estratégias de desenho urbano, de inserção de obras de arte e do agenciamento de espaços públicos que implantaram elementos típicos do processo de "disneyficação". (DEUTSCHE, 1996, p. 60-70)

A estetização do ambiente urbano com fins mercadológicos e de valorização imobiliária não constitui, entretanto, uma experiência da ordem da representação, pois não exige a colocação do objeto em perspectiva histórica ou social. Trata-se, como observa Zukin (200ob, p. 81), de uma estetização para "consumo visual", na qual a aparência é mais importante do que o significado. Este tipo de consumo se verifica, entretanto, quando as áreas históricas já foram descobertas pelo mercado e já estão se reproduzindo, dentro de si mesmas, como empreendimentos turísticos, de entretenimento e lazer, ou como lócus de aquisição de estilos de vida. Isso significa que, no início do processo de apropriação e valorização, há uma apropriação cultural "legítima”, decorrente da atribuição, por um grupo, de um valor cultural à área, mas, no final, há apenas a imposição de uma visão e de uma lógica excludentes. Esses processos impõem também uma visão única do patrimônio, pois anulam o poder de representação e de informação das áreas históricas e, assim, a função política do patrimônio num sentido mais amplo.

Os modelos de reestruturação urbana, por gentrificação ou disneyficação, se tornaram hegemônicos no mundo desenvolvido, tanto nas operações de 
revitalização e reabilitação de áreas antigas quanto nas que lançam novos empreendimentos imobiliários. (FERNANDES, 1999, p. 163-170) Contudo, em alguns lugares, esses modelos já davam mostras de esgotamento nos anos 1990, indicando uma saturação do público e uma frustração de seu desejo de ter uma experiência autêntica com o passado, diante de ambientes tão semelhantes e artificiais. Alimentando esses processos e sendo realimentada por eles, encontra-se uma ideia expandida de patrimônio associada ao consumo, ao turismo, ao entretenimento e ao lazer. Ideia que também está na origem da transformação da preservação em uma das lógicas predominantes de urbanização e gestão do espaço urbano no Primeiro Mundo, ao lado da produção de novos espaços na periferia de grandes cidades.

\section{0 patrimônio como fenômeno de massa}

As razões do crescimento do valor de mercado do patrimônio e da consolidação da preservação como lógica dominante de urbanização nos países mais desenvolvidos não se esgotaram na crítica às renovações urbanas modernistas; no sucesso comercial de um pós-modernismo historicista; no uso do patrimônio em estratégias de marketing; nem, por exemplo, no crescimento do desejo de estabelecer uma relação com o passado num mundo de crescente descarte. Esses fenômenos se relacionaram também a processos que se desenvolveram no interior do campo preservacionista a partir dos anos 1960, destacando-se, entre eles, a mundialização, promovida por instituições internacionais como UNESCO e ICOMOS, dos valores e das práticas patrimoniais ocidentais. A mundialização dessas práticas, como aponta Françoise Choay (1996, p. 153-157), tornou a preservação um item de prestígio no concerto das nações e constituiu uma via importante para a inserção do patrimônio na dinâmica da globalização econômica, ao promover uma certa organização dessas práticas, que favoreceu, em muito, sua reprodutibilidade. A expansão do campo cronológico e tipológico do patrimônio, a partir dos avanços conceituais propiciados pela Nova História e pela Antropologia, bem como a democratização do saber, o desenvolvimento de uma sociedade de lazer e a transformação do turismo numa das principais 
indústrias nos países centrais, colaboraram igualmente para a transformação de uma prática restrita numa lógica dominante e num fenômeno de massa. (CHOAY, 1996, p. 153-157)

Ao longo desses processos, o acesso ao saber e ao prazer proporcionados pelo patrimônio foi ampliado, mas o aumento de demanda criou também um negócio apoiado numa espécie de indústria que fabrica, embala e difunde produtos culturais com vistas ao consumo. A valorização do patrimônio no mercado ainda foi propiciada, como mostra Choay (1996, p. 157), por uma "engenharia cultural", de natureza pública e privada, que, através de animadores, comunicadores, agentes de desenvolvimento e mediadores culturais, explorou de todas as maneiras monumentos e sítios históricos com o objetivo de multiplicar indefinidamente seus visitantes.

Essa produção "industrial” do patrimônio, ou sua transformação em item da indústria turística e cultural se deu, principalmente, mediante certas operações de valorização e utilização que ajudaram a transformá-lo num produto "médio" adequado ao consumo de massa. Entre essas operações, encontram-se as reconstituições fantasiosas, que realçam determinadas características estilísticas e plásticas; certas ambientações, como os espetáculos de luz e som, que banalizam o conteúdo histórico e artístico do patrimônio; atividades de animação, como shows e eventos, que cultivam a passividade do público e usam o patrimônio como um mero cenário; e a inserção de objetos modernos em ambientes antigos, como já comentado, para que atuem como "implantes regeneradores”, criem uma familiaridade baseada no presente e atraiam um público médio sempre interessado em novidades. (CHOAY, 1996, p. 157-165) Além dessas estratégias, tem-se ainda a venda de produtos de todo tipo em edifícios históricos e sua utilização em estratégias publicitárias.

A conservação museológica de áreas urbanas com usos voltados para o entretenimento, o comércio e o lazer tornou-se interessante para a indústria do turismo cultural porque facilita e mantém acelerada a dinâmica entre fluxo de visitantes, serviços e atrações oferecidas. Nesse processo de apropriação turística, entretanto, a dimensão urbanística do patrimônio, como parte da organização e da vida cotidiana das cidades (GIOVANNONI, 1998), se perdeu ou se esgarçou, 
abrindo espaço para o uso de sítios históricos como empreendimentos comerciais voltados principalmente para gerar receita. Como ainda mostra Choay (1996, p. 168-169), os "procedimentos de embalagem", que permitem fornecer centros e bairros históricos prontos para consumo visual e turístico, já foram testados e padronizados, desde os anos 1960, sendo utilizados por governos e iniciativa privada, em graus variados, conforme seus interesses. As estratégias de agenciamento espacial utilizadas nesses casos estão voltadas, basicamente, para atrair e reter os interessados, inserindo-os num ambiente de familiaridade e segurança por meio de sistemas padronizados de sinalização e orientação gráfica, além do uso do desenho e do mobiliário urbano para produzir espaços semelhantes a shopping centers. O ar pitoresco - que, em última análise, responde pelo ambiente tão semelhante que se verifica entre os sítios históricos dedicados ao turismo em diferentes partes do mundo - resulta também dessas estratégias de projeto. Pracinhas, ruas e passagens de pedestres dotadas de materiais e acabamento novos e mobiliário padronizado; obras de arte, fontes e floreiras para alegrar o espaço; calçadas com mesinhas para cafés, restaurantes e barracas de artesanato - são elementos comuns a todos eles.

Os efeitos perversos dessa forma de apropriação do patrimônio urbano, além da exclusão e da expulsão de populações locais e de suas atividades cotidianas, são a homogeneização do espaço, a banalização dos modos de vida e uma virtual destruição de práticas tradicionais, que, aos poucos, matam a galinha dos ovos de ouro que deu origem a essas intervenções. Esse abuso do patrimônio leva a uma satisfação imediata de investidores e consumidores, mas, ao mesmo tempo, leva à já mencionada e inevitável frustração do público que espera algo mais da experiência de conhecer esses lugares, além de comer, fotografar e comprar.

Ao adaptar-se às necessidades e à dinâmica da indústria do turismo cultural, o patrimônio urbano passou, nas últimas décadas do século $X X$, pelo processo que Jameson (1997, p. 35-75) chama de "perda de historicidade", adquirindo a falta de profundidade típica dos produtos industriais. Tornou-se uma espécie de imagem idealizada de si mesmo, perdendo, assim, boa parte do seu poder de representar ou testemunhar processos históricos, culturais e sociais, bem como de possibilitar a experiência "aurática” e de distanciamento que, como aponta Huyssen (1994, p. 40-57), permite estabelecer uma articulação com o passado e 
uma negociação com a identidade cultural. O uso do patrimônio como empreendimento turístico, suporte publicitário, instrumento de marketing ou, ainda, como meio de produção de mercadorias valorizadas, dificulta essa negociação, impõe uma visão e uma apropriação. Esses usos, entretanto, significam que o patrimônio não está abandonado e constitui ainda um campo de interesses e de luta para forças importantes da sociedade. Significa também, por outro lado, que sua função política e formadora, num sentido mais amplo, foi esvaziada.

Os especialistas e amantes "desinteressados" não deveriam ter, contudo, razão de queixa, pois esse destino do patrimônio há muito já havia sido traçado pelo próprio campo preservacionista e pela preservação oficial. Desde os anos 1960 se reivindica e se tenta promover, em todo o mundo, e, especialmente, nos países menos desenvolvidos, a valorização do patrimônio via turismo e namoros não muito discretos com a indústria cultural. Cabe ainda lembrar que valor econômico e patrimônio nunca foram estranhos um para o outro, já que uma função econômica, como visto, estava inscrita na própria origem do dispositivo quando do seu surgimento no final do século XVIII.

Nas três últimas décadas do século XX, o patrimônio foi simultaneamente apropriado e utilizado nos países centrais como instrumento de política urbana e social, chamariz para o turismo, palco do lazer urbano, instrumento de marketing, "oxigênio" para inflar marcas comerciais e como atributo para a exploração de diferenciais competitivos com vistas à valorização econômica e à geração de renda. A disseminação desses usos e apropriações foi proporcionada, em grande parte, pela criação de um importante mercado consumidor de patrimônio; pela indústria do turismo; pela difusão das práticas patrimoniais ocidentais; e pela configuração, nessas sociedades, do que Huyssen (1994) chama de uma "sede generalizada" pelo estabelecimento de uma relação negociada com o passado e por um espaço para reflexões sobre a temporalidade, a subjetividade, a identidade e a alteridade. Nesse processo, o valor de mercado do patrimônio cresceu exponencialmente e a preservação tornou-se uma das normas que domina a produção e a gestão do espaço urbano. Mas esse genuíno anseio por uma relação com o passado, somado às estratégias que buscaram a valorização do patrimônio, configurou, nesses países, uma espécie de explosão de demanda que, ao ser atendida, tem condenado esse desejo à frustração. Frustração decorrente 
do fato de que o patrimônio que se produziu dessa maneira tornou-se uma mercadoria rapidamente consumida e não algo capaz de mediar e promover aquela almejada relação.

\section{Patrimônio, relações de poder e formas de dominação na sociedade contemporânea}

A estrutura em rede, como aponta Castells (1999b, p. 498-499), provou-se adequada a uma economia baseada na inovação, na expansão em escala global e na segmentação, assim como para uma cultura que se constrói e desconstrói continuamente. Evocada, no fim do século XX, como lógica organizadora do funcionamento da sociedade, a estrutura em rede já havia sido utilizada por Foucault, nos anos 1970 e 80, para descrever o exercício do poder nas sociedades modernas. Segundo sua concepção, o poder se exerce em rede, mediante um esquema apoiado em múltiplos focos, conexões e dispositivos que, ao produzirem padrões de abordagem e comportamento, propagam relações de dominação. A estrutura em rede das principais atividades econômicas, financeiras e de comunicação que caracterizam a sociedade contemporânea tornou explícita e, pela primeira vez, claramente perceptível a mecânica que caracteriza o próprio exercício do poder nas sociedades capitalistas. O advento das novas tecnologias da informação e comunicação ampliou o alcance, sofisticou, potencializou e generalizou o funcionamento desse esquema, que, agora, organiza também o funcionamento concreto da economia. A revolução eletrônica e digital ampliou sua capacidade e eficiência, possibilitando uma maior individualização e coletivização de seus efeitos, o que é claramente visível na esfera do trabalho - agora, como antes, a principal instância de visibilidade e exteriorização das formas de dominação.

A busca de mais produtividade e lucratividade no capitalismo avançado introduziu, como visto, importantes alterações no processo de produção e no universo do trabalho. Neste universo, se passou a conviver com horários mais flexíveis, com unidades dotadas de grande mobilidade, iniciativa humana mais valorizada, mas também com um alto nível de exclusão e instabilidade, e com controles extremamente minuciosos no que toca ao desempenho individual, 
à capacitação e à obediência a procedimentos padronizados. A reprogramação e a constante adaptação da produção a novas situações e demandas, os esquemas de fornecimento imediato para várias partes do mundo, e uma comercialização que atende a mercados territorialmente dispersos e crescentemente segmentados, implicaram a necessidade de um controle absoluto sobre o desempenho dos que põem em marcha esses processos, com vistas a se evitar desvios, rupturas e interrupções. Implicaram ainda a necessidade de um monitoramento permanente do funcionamento das redes de produção, circulação e comercialização, a fim de se garantir que funcionem como uma unidade. Tudo isso implicou, naturalmente, um aumento considerável do aparato normativo que articula, ajusta, compatibiliza e padroniza esses processos, e que controla os que os executam.

Essa situação, que poder-se-ia chamar de "autonomia sujeitada", exige que o indivíduo (mas também o grupo ou a empresa) que opera em algum ponto das redes produtivas esteja sempre em prontidão para atender a uma demanda imprevista; disponível, em qualquer hora; capacitado e apto a atendê-la com eficiência. Assim, embora o tempo dedicado diretamente ao trabalho possa ter se tornado flexível, a mobilização e a preparação para o trabalho tomou a forma de um stand by permanente, em função da inovação constante e da variabilidade das demandas. Alimentada pela situação de instabilidade e competição que permeia tudo, pela escassez de postos e pela individualização das negociações trabalhistas, essa prontidão se apossou, literalmente, do cotidiano dos indivíduos. Este cotidiano passou a girar em torno de uma qualificação e atualização permanentes e da espera ou mobilização para um trabalho que exige, cada vez mais, ótimo desempenho e capacidade de adaptação. Para que a rede produtiva da economia globalizada funcione em sua "flexibilidade" e eficiência finais é necessário, portanto, que os processos de base, que lhe dão suporte, funcionem sob estrito controle, o que exige daqueles que os colocam em marcha uma extrema disciplina.

Embora se tenha anunciado continuamente, no final do século XX, a morte da sociedade industrial e, portanto, o fim dos seus mecanismos de poder, não é isso o que se verifica presentemente. As formas de dominação na esfera do trabalho, por exemplo, continuaram se valendo de dispositivos disciplinares e reguladores que funcionam de modo análogo aos da primeira revolução industrial. 
A diferença é que, com o apoio das novas tecnologias, se ampliou e individualizou ainda mais a possibilidade de controle, mas sem a necessidade de confinamentos ou esquemas fechados. Ou seja, as organizações arquitetônicas já não são mais essenciais ao funcionamento desses mecanismos de poder, que agora operam também no "espaço aberto", por meio do armazenamento de informações, do acesso instantâneo e do conhecimento da posição exata da matéria a ser controlada. (DELEUZE, 1992, p. 224) A característica normalizadora das sociedades modernas, portanto, aprofundou-se nas sociedades contemporâneas. O novo é que, agora, a norma produzida pelos dispositivos de poder não se destina mais à instituição de um referencial comum a todos, mas à construção de um padrão baseado na exploração de "diferenças". Ao lado disso, a normalização não visa mais a abarcar todo o corpo social - dirige-se apenas a segmentos estrategicamente selecionados, isto é, aos que têm função estrutural ou que importam como produtores/consumidores. O restante é, automaticamente, descartado. Entretanto, é nesse descarte - que implica uma exclusão da norma - onde se localiza o potencial de transformação.

Em essência, portanto, a mecânica de poder das sociedades capitalistas modernas não mudou com as transformações operadas no modo de produção e acumulação do capitalismo contemporâneo. Seu objetivo continuou sendo aumentar a docilidade e a submissão, no plano individual e coletivo, e esse objetivo ainda é alcançado por meio da instituição de normas que constroem subjetividades e padróes de comportamento. Se, na modernidade, o poder exerceu-se, basicamente, mediante a inclusão de indivíduos e populações numa norma que instituía uma medida comum relativa ao ser è conduta, na contemporaneidade, se exerce também, como apontaram Deleuze (1992) e Castells (1999b), por meio de operações de inclusão-exclusão nas redes de produção, comercialização ou informação. Como observa este último autor, a presença na rede ou a ausência dela, e a dinâmica de cada rede em relação às outras, são, atualmente, as "fontes cruciais de dominação e transformação" da sociedade. (CASTELLS, 1999b, p. 497)

A presença e a posição numa rede está vinculada, contudo, à capacidade de competir e também de obter, gerar e processar informaç̧óes sobre processos, mercados e tendências, com vistas ao seu monitoramento, preparação e anexação. 
Assim, a produção ou o acesso a informações, aliados a modernas técnicas de promoção e marketing, tornaram-se instrumentos essenciais para a criação de padrões de comportamento coletivos, tornando-se elementos fundamentais da estrutura geral de dominação. Na medida em que no late capitalism a acumulação se dá, principalmente, nas esferas da circulação e do consumo, os dispositivos normalizadores se destinam não somente à formação de subjetividades para o trabalho produtivo, mas também de coletividades para o consumo. Por essa razão, como já apontou Deleuze (1992, p. 224), o marketing se tornou um dos instrumentos de controle social mais importantes da atualidade.

A possibilidade de acumulação concentrada nas esferas da circulação e do consumo fez crescer, no capitalismo avançado, a necessidade de novos campos de investimento financeiro, de produtos constantemente renovados e de novas técnicas de comercialização. A inovação e a renovação de produtos, bem como o aumento do consumo, passaram a ser obtidos mais pela criação, ou captura, de um diferencial no campo da cultura, e por meio de técnicas avançadas de promoção e venda, do que por meio de avanços na produção ou pelo ingresso de novos consumidores no mercado. A construção de "identidades" comerciais tornou-se, como já comentado, uma das operações centrais da acumulação capitalista, movimentando recursos e energias consideráveis. A identidade tornou-se valiosa não somente no plano social e político, mas também no comercial, o que ampliou e estendeu a importância e utilidade dos dispositivos que a produzem, como é o caso do patrimônio.

Como visto na introdução desse trabalho, o patrimônio é um dispositivo de poder que mobiliza materiais discursivos e não discursivos com o objetivo de produzir significados associados a determinados objetos e práticas, e de fixar uma conduta de preservação com relação a eles. Longamente utilizado para a produção de identidades associadas à ideia de nação, na contemporaneidade, o dispositivo tem sido integrado à produção de identidades com fins econômicos e comerciais, e é isso o que explica o seu notável crescimento e a expansão da lógica da preservação a novos campos. A partir do final do século XX, o patrimônio possibilitou unir, com grande eficiência, objetivos comerciais e políticos - e isso, sem dúvida, ampliou sua importância e poder como mecanismo de dominação e de 
construção de padrões de comportamento. A produção de significados adquiriu, na sociedade contemporânea, um valor comercial que tornou esse dispositivo ainda mais estratégico, na medida em que passou, nos países centrais, a mediar concretamente a produção de riqueza.

Ao produzir significado, o dispositivo de patrimônio produz identidade e produz diferencial, isto é, algo que tem, atualmente, tanto valor de mercado quanto importância como estratégia de valorização. Por essa razão, mais e mais objetos e práticas reivindicam o status de patrimônio. Por isso, a lógica da preservação se estende a tudo e seu universo de aplicação, tradicionalmente seletivo e restrito, se expandiu para todo o campo da produção cultural, assim como ao domínio da natureza. Ao atingir a máxima generalização, entretanto, e ao inserir-se em estratégias relacionadas ao consumo, o dispositivo produz uma mercadoria sujeita aos processos de saturação, vulgarização e desvalorização, inerentes à superexposição e à oferta excessiva no mercado. Assim, ao atingir o seu ápice, o dispositivo de patrimônio encontra também seu ponto de saturação, o que poderá, em futuro próximo, enfraquecer seu papel econômico e inviabilizar seu papel político. Entretanto, na medida em que a história e a cultura - suas matérias básicas - estão em permanente devir, sempre haverá produção de patrimônio e, assim, a possibilidade de que esse dispositivo adquira novos sentidos e novas funções. 


\section{Salvador: patrimônio como insumo do turismo e do lazer urbano}

\section{0 centro da cidade de Salvador: preservação e desenvolvimento urbano na primeira metade do século XX}

As primeiras transformações significativas no centro de Salvador ocorreram no final do século XIX, quando, por ocasião de um breve soerguimento da agroindústria baiana, ' a cidade passou por um novo surto de crescimento. A implantação de serviços de transporte urbano permitiu a expansão da urbe para além das colinas que rodeiam o núcleo mais antigo e o surgimento de novos bairros. Em resposta ao crescimento das atividades comerciais no centro, à obsolescência e à manutenção cara dos antigos casarões coloniais, e em decorrência de uma nova mentalidade que alterou profundamente os hábitos de morar, as famílias abastadas que, até então, habitavam bairros centrais migraram em massa para os novos loteamentos abertos ao sul da cidade. A partir de então, a especialização terciária do centro foi crescente, com a cidade assumindo a forma de um aglomerado de bairros residenciais organizados em torno de uma forte
Gerado por política de incentivos do governo e pela melhoria nos preços internacionais do açúcar e do cacau. 
2 Hoje Instituto do Patrimônio Histórico e Artístico Nacional IPHAN. centralidade, localizada na área correspondente ao núcleo fundado em 1549 e ao seu porto. Essa estrutura foi alterada nos anos 1960, quando os novos rumos tomados pela economia estadual começaram a transformá-la radicalmente.

Antes disso, durante toda a primeira metade do século XX, Salvador crescera pouco, já que refém de uma economia agroexportadora e sem indústrias modernas, constantemente em crise devido às flutuações dos preços internacionais. As reformas urbanas promovidas por J. J. Seabra, entre 1912 e 1916, e outras que pontuaram o centro da cidade até os anos 1930, resultaram da crescente importância adquirida pela área central na estrutura urbana e do fato de ser o principal polo terciário de toda uma região. (GOMES; FERNANDES, 1995, p. 47-58; SAMPAIO, 1999, p. 74-101) A modernização da cidade nesse período não decorreu de nenhuma grande transformação política ou econômica, mas constituiu uma primeira tentativa de mudança de imagem, destinada a superar um passado colonial ao mesmo tempo glorioso e fracassado.

Os melhoramentos urbanos de Seabra retificaram e alargaram algumas ruas do centro, mas não alteraram substancialmente a configuração da cidade colonial. A mutilação e a demolição de algumas antigas e valiosas construções, entretanto, suscitaram protestos da elite intelectual baiana e ensejaram as primeiras propostas de proteção do patrimônio urbano de que se tem notícia no país. Em 1917, Wanderley Pinho já propunha a instituição de uma comissão para proceder ao inventário do patrimônio histórico estadual, como forma de pôr um freio nessa sanha modernizadora. A demolição da Igreja da Sé, em 1933, para a passagem do bonde elétrico, aumentou as pressões sobre o poder público e deflagrou, a partir da criação, em 1937, do antigo Serviço do Patrimônio Histórico e Artístico Nacional, ${ }^{2}$ as primeiras medidas efetivas de preservação da herança, simultaneamente admirada e desprezada, do período colonial.

Entre 1938 e 1945, cerca de 50 edifícios antigos foram tombados na área central de Salvador, marcando o início de uma progressiva incorporação do centro da cidade ao patrimônio histórico nacional. O grande número de prédios tombadose a proximidade entre eles fizeram com que, já no final dos anos 1930, as disposições legais relativas à proteção de sua ambiência funcionassem como um obstáculo à expansão e à modernização total do centro, o que, sem dúvida, contribuiu para aprofundar a marginalização de alguns setores em relação à dinâmica terciária 
em curso. Correspondentes às áreas em torno da Sé e do Terreiro de Jesus, esses setores, entretanto, já estavam em decadência desde a saída das famílias ricas da área central, e o tombamento, portanto, apenas se sobrepôs a uma situação de deterioração existente.

A decadência das lavouras de açúcar e fumo e os altos e baixos do preço do cacau não permitiam a geração de capital excedente para investimentos em indústrias, ficando o capital em circulação absorvido por atividades financeiras especulativas e pelo comércio. (SAMPAIO, 1999, p. 78-88) O almejado desenvolvimento industrial baiano esteve, desde então, à mercê da atração de capitais externos e de políticas de incentivo do governo central que não se materializavam, pois todos os esforços nesse sentido estavam dirigidos para o Sudeste. Mesmo assim, o primeiro plano urbanístico delineado para a capital, em 1943, preparava a cidade para a inevitável industrialização.

O Escritório do Plano de Urbanismo da Cidade do Salvador - EPUCS propôs um desenho radioconcêntrico que tomava a área central como polo irradiador de um sistema de grandes avenidas, ao longo dos vales, com vistas à articulação das várias zonas da cidade ao centro. (SANTOS NETO, 1991, p. 47-49) Em consonância com o ideário do movimento moderno, seriam preservados nesta área apenas os monumentos e edifícios mais importantes, propondo-se a transformação de grande parte da malha viária e do tecido urbano antigo para a construção de uma Estação Central de Tráfego. Embora não tenha sido implantado, o plano do EPUCS (que foi, mais tarde, parcialmente aproveitado) informa claramente sobre a importância e o protagonismo exercido pelo centro na estrutura da cidade. Como bem observou Milton Santos, até os anos 1950, Salvador tinha um "centro monopólico", que concentrava todas as funções urbanas mais importantes da cidade e também da região. (SANTOS, M., 1959)

Sob o impacto do surto de industrialização deflagrado na década de 1950, as pressões para a expansão do centro ao norte, onde se encontrava a maior parte dos monumentos protegidos, levaram o IPHAN a rever sua antiga atuação pontual, em favor de uma preservação urbana mais larga. Em 1959, a proteção do tombamento foi estendida aos conjuntos arquitetônicos mais preservados existentes nos subdistritos da Sé, do Passo e da Conceição da Praia, bem como nos bairros da Saúde e Palma, tombando-se ainda o sítio do Dique do Tororó. 
A ideia de centro histórico em Salvador começou, assim, a ser construída quando o centro da cidade estava em seu apogeu, pressionado para expandir-se e verticalizar-se. Em razão dessas pressões e das limitações construtivas impostas pelo tombamento, o processo de abandono das velhas edificações aguçou-se nos setores protegidos, iniciando-se também um movimento crescente de transferência de recursos para outras áreas da cidade - movimento que, ainda que por razões diversas, foi também, como se verá em seguida, incentivado pelo planejamento urbano e regional.

\section{Industrialização e formação de novas centralidades}

A industrialização sonhada pelas elites baianas dos anos 1940 e pelos técnicos do EPUCS só começou a ser viabilizada no final dos anos 1950, com a instalação da Petrobrás no município de Simões Filho. Em seguida, nos anos 1960 e 70, consolidou-se com as implantações do Centro Industrial de Aratu e do Polo Petroquímico de Camaçari. A atividade industrial atraiu e concentrou uma grande massa de investimentos e renda na região metropolitana de Salvador, mudando o perfil tradicional da economia do estado e forçando a reordenação do território da cidade e de sua região. Alavancada por incentivos públicos, essa industrialização baiana tardia inseriu-se numa política nacional de desenvolvimento do Nordeste, no âmbito da qual o estado, em função das articulações de sua oligarquia política com o governo central, foi o mais beneficiado.

É importante ressaltar que a ocupação industrial da região em torno de Salvador foi planejada de modo a se criar núcleos autônomos e autossuficientes, com o objetivo de beneficiar a capital e preservar seu território dos inconvenientes da industrialização, como ocorrido nas metrópoles do Sudeste. (SAMPAIO, 1999, p. 111-199) Estabeleceu-se para a cidade o papel de centro de turismo e lazer, ancorado num terciário forte, como forma de se aproveitar ao máximo seus recursos naturais e patrimoniais e de promover sua integração nos circuitos nacional e internacional. A partir de então, o planejamento municipal e as ações do Governo do Estado buscaram incorporaressas diretrizes. Os núcleos industriais projetados e implantados na região metropolitana não lograram, entretanto, a autonomia ou a autossuficiência planejada em relação 
à capital, nem tampouco conseguiram fixar grande parte da população empregada, que permaneceu residindo maciçamente em Salvador. A cidade sofreu, assim, os impactos da industrialização que se queria evitar, ou seja, atração de grande contingente populacional, crescimento acelerado e inchamento da periferia.

Como consequência desse processo e da generalização do uso do automóvel, Salvador teve seu território completamente reordenado e expandido. O surgimento de subcentros e de novas zonas residenciais, comerciais e administrativas mudou a configuração da cidade, fazendo-a adquirir a estrutura policêntrica com que chegou aos anos 1990 (Mapa 1). O sistema de avenidas de vale proposto pelo EPUCS foi parcialmente executado, a partir da década de 1960, o que, juntamente com a privatização de terras públicas (GOMES; FERNANDES, 1995, p. 50), impulsionou a expansão urbana em direção aos novos vetores próximos à orla do Atlântico. O crescimento da cidade na direção desses novos vetores de expansão foi também favorecido pela transferência do Centro Administrativo do Estado da Bahia para essa zona, bem como pela mudança da estação rodoviária para o vale do Camarajipe. (AZEVEDO, 1984, p. 223) Nesta zona, com a implantação do novo complexo viário de acesso à cidade e do Shopping Iguatemi (hoje Shopping da Bahia), surgiu uma nova centralidade, que, contemplada na legislação urbanística com um padrão de parcelamento e uso do solo adequado a grandes empreendimentos, logo se firmou como alternativa ao congestionado centro antigo. Outras nucleações terciárias, como as da Calçada, Barra, Liberdade e Água de Meninos, foram também favorecidas com maiores índices de aproveitamento do solo como forma de desafogar a área central. O Plano Diretor de Desenvolvimento Urbano, elaborado em 1975, mas efetivado apenas em 1985, já estabelecia para a cidade uma estrutura polinuclear, na qual destinava-se à centralidade surgida no vale do Camarajipe um importante papel. (CARVALHO, 1997, p. 30-52)

Nos anos 1970, o centro antigo - cada vez mais um "centro histórico" ainda era o principal polo de atividades da cidade, mas já se encontrava em pleno processo de esvaziamento, em decorrência das novas centralidades e dos novos vetores de expansão da cidade. Reestruturou-se, entretanto, conforme a intensidade do impacto desse deslocamento de funções em suas diversas áreas. De um modo geral, no começo, as mudanças ocorreram mais intensamente na 
Cidade Alta, (GOMES; FERNANDES, 1995, p. 49) nas imediações da Ajuda e da Rua Chile, onde se concentravam funções administrativas e um comércio varejista fino, que logo migrou para os subcentros da Barra e do Iguatemi, por estarem mais próximos das zonas residenciais de classe média alta. Em seu lugar foi, aos poucos, se instalando um varejo voltado para o atendimento das camadas mais pobres da população, o que fez com que esses setores assumissem um perfil semelhante ao existente nas áreas de comércio popular da Baixa dos Sapateiros e do Taboão (Mapa 2). A zona do Comércio, na Cidade Baixa, tradicional área de concentração de atividades exportadoras, atacadistas e financeiras, não sofreu grande impacto nesse momento, pois, de início, foram deslocadas apenas atividades administrativas e as comerciais ligadas ao apoio das zonas residenciais em expansão. Contribuiu também para a imunidade inicial do Comércio ao processo de fragmentação do centro o fato de estar fora do alcance das limitações construtivas das áreas protegidas da Cidade Alta, o que lhe permitiu uma expansão vertical que preservou sua hegemonia como polo financeiro e de negócios até os anos 1990. Nessa altura, contudo, atraídas pela crescente dinâmica imobiliária do novo centro da região do antigo Iguatemi, as instituições financeiras também para lá migraram.

Nos conjuntos tombados ao norte do centro, que vinham em contínuo processo de deterioração desde a saída dos segmentos de alta renda no final do século XIX, a situação agravou-se, pois a fuga de funções administrativas e comerciais esvaziou as áreas mais dinâmicas e economicamente fortes em suas imediações. Entretanto, no destino turístico e terciário traçado para Salvador havia lugar para essas áreas, e, assim, no momento em que os vetores mais importantes de expansão, investimentos e crescimento da cidade deslocavam-se para outra direção, foram concebidos os primeiros planos e programas com vistas à recuperação econômica e social do núcleo histórico. 


\section{Turismo e patrimônio}

O primeiro plano de refuncionalização da área mais degradada do centro antigo surgiu no final dos anos 1960, no mesmo momento em que, em decorrência da política nacional de incentivos para o setor, se implantava toda uma estrutura pública para o desenvolvimento do turismo na Bahia. Calcado em sol, praia, patrimônio e cultura popular, o produto turístico "Salvador-Bahia", cuja concepção geral ainda perdura, se concretiza, desde então, pela promoção de lugares de representação e de encontro com uma Bahia idealizada, alegre, colorida e festeira, cuja invenção pela indústria cultural e pelos meios de comunicação de massa data também dessa época. No centro antigo, o Pelourinho foi sempre visto e projetado como um desses lugares. A aliança entre turismo e patrimônio na Bahia, portanto, não é recente. Ela está no cerne da vocação econômica traçada para Salvador pela política de desenvolvimento industrial do estado, fez parte dos investimentos do Programa de Cidades Históricas no Pelourinho, durante os anos 1970, e também do discurso inaugural da EMBRATUR. ${ }^{3}$

Em decorrência, ainda, do sucesso nacional de artistas baianos como Caetano Veloso, Gilberto Gil, Gal Costa e Maria Bethânia, e das telenovelas ambientadas na região, o turismo na Bahia experimentou significativo crescimento entre 1971 e 1975. No final dos anos 1970, contudo, em função de uma conjuntura econômica nacional desfavorável e da saturação deste destino no mercado interno, já se verificava acentuada redução no fluxo de visitantes em Salvador. A Bahia saía de moda, o que levou o Governo do Estado a definir nova estratégia baseada no aumento da oferta turística, no incremento do fluxo internacional e no maior aproveitamento dos recursos turísticos do interior. Essa política teve relativo êxito até 1986, quando se começou a registrar progressiva queda nos indicadores, devido ao aprofundamento da crise econômica, à aceleração inflacionária, à deterioração da ação estatal e à carência de recursos para investimento no produto "Salvador - Bahia", fosse para sua renovação ou preservação, fosse para a criação de novos atrativos. (SILVA, 1991, p. 194-213) No período de 1986 a 1990, a política estadual de turismo sofreu, pela primeira vez, descontinuidade, dispersão institucional e baixo investimento, mas, a partir de 1991, o esforço foi retomado, com investimentos em publicidade e melhoria dos
3 Empresa Brasileira de Turismo, criada nos anos 1960, é o organismo federal responsável pela política nacional de turismo. O Programa de Cidades Históricas - PCH foi criado pelo Governo Federal, em 1973, para a realização de investimentos públicos em áreas urbanas tombadas, com vistas ao seu aproveitamento econômico através do turismo. 
4 Considera-se aqui o fluxo hoteleiro e extrahoteleiro, com base em pesquisa de turismo receptivo, apesar dos questionamentos a esse tipo de avaliação, que aceleraria artificialmente o fluxo global, na medida em que incluiria os que vieram por rodovia e os que ficaram hospedados em lugares de difícil avaliação.

5 Otempo de permanência do turista também aumentou muito pouco, saindo de 3,5 dias, em 1991, para 3,7 dias, em 2000. Ver também Mendonça (2002) e Empresa de Turismo da Bahia (2001a).

6 A Argentina é um importante país emissor de turistas para a Bahia. serviços turísticos, e com a captação de recursos nacionais e estrangeiros para aplicação em equipamentos de hotelaria e lazer. Foi realizado grande volume de investimentos públicos em infraestrutura, inicialmente com recursos do estado, e, a partir de 1995, com recursos do BNDES e do BID, por intermédio do Programa de Desenvolvimento do Turismo do Nordeste - PRODETUR.

A estratégia do governo para incremento do turismo, durante os anos 1990, pautou-se na criação de novos produtos e novos destinos, mediante investimentos nos litorais Norte e Sul de Salvador; na renovação do Pelourinho; na criação de equipamentos do tipo resort para concorrência com destinos internacionais, como Cancún; e no relançamento do "produto Bahia" por meio da criação de um "cluster de entretenimento", que buscava aliar cultura, turismo e lazer com vistas ao atendimento segmentado do mercado e à atração de turistas nacionais e internacionais de poder aquisitivo mais elevado.

Apesar de todos esses investimentos, nos quais se incluem os realizados no centro histórico de Salvador, os indicadores não registraram um grande desempenho ou modificação no comportamento geral da atividade turística no estado da Bahia, ou em Salvador, durante os anos 1990. Embora o fluxo global de turistas estrangeiros e nacionais tenha crescido, ${ }^{4}$ em comparação com os números registrados na década anterior, o crescimento não foi tão expressivo. A média dos anos 1990 ficou apenas ligeiramente superior aos números de $1986 \mathrm{e}$ a participação relativa de turistas estrangeiros no fluxo de visitantes permaneceu estagnada (Tabelas 1 e 2 ). ${ }^{5}$

Nos primeiros anos do século XXI, essa estagnação nos números do turismo permaneceu e foi agravada por uma tendência mundial de queda. Mesmo com a desvalorização do real frente ao dólar, em razão da escalada do terrorismo, a partir de 2001; da ameaça de "apagão" no Brasil; e do agravamento da crise econômica na Argentina, ${ }^{6} \mathrm{O}$ fluxo de turistas estrangeiros, no primeiro semestre de 2002 , caiu 33,8\% em relação ao mesmo período em 2001. Embora o fluxo nacional tenha crescido $2,7 \%$ nesse período, o desempenho, diante da retração do fluxo internacional, não modificou o quadro geral de estagnação. (BORGES, 2002, p. 135-140)

Os números relativos à receita gerada pelo turismo na Bahia, durante os anos 1990, tampouco foram animadores. O gasto diário médio se manteve mais 
ou menos o mesmo ao longo da década, o que mostra também uma situação de estagnação nesse indicador.7 Segundo dados da Bahiatursa (EMPRESA DE TURISMO DA BAHIA, 2001a), a receita total do turismo na Bahia cresceu de modo constante até 1996, mas caiu progressivamente desde aquele ano até 2000, o que demonstra que o gasto do turista não cresceu de modo correspondente ao crescimento do fluxo (Tabela 3). O estado, contudo, melhorou sua posição no cenário turístico nacional, com Salvador saindo do $7^{\circ}$ para o $4^{\circ}$ lugar no ranking das cidades mais visitadas por turistas estrangeiros, atrás apenas do Rio de Janeiro, Florianópolis e São Paulo. (EMBRATUR, [2002?])

Nos anos 1990, os números do turismo baiano, considerando-se Salvador como o principal polo de atração, mostram, em suma, que os investimentos realizados no período reverteram a tendência de declínio registrada na segunda metade dos anos 1980, mas não foram capazes de mudar significativamente nem a progressão do fluxo turístico, nem o perfil do visitante do estado. Este continuou sendo um turista proveniente do Sudeste do país (a maioria de São Paulo), de classe média, e que, em grande parte, veio motivado pelas belezas naturais da terra. (EMPRESA DE TURISMO DA BAHIA, 2001b) $)^{8}$ O fluxo de turistas estrangeiros, como visto, permaneceu estacionado em números próximos aos dos anos 1980, refletindo um problema que não é somente da Bahia, mas de todo o Brasil. Entre 1992 e 2002, o país recebeu, em média, apenas 3,3 milhões de turistas estrangeiros por ano, o que representou 0,54 \% do fluxo mundial, (MINISTÉRIO DO TURISMO, 2002)9 ficando atrás da Argentina e do México, (MENDONÇA, 2002) e muito aquém do desempenho de países como França e Espanha, que receberam no período, respectivamente, uma média de 70 e 40 milhões de turistas por ano.

A verdade é que, tanto no Brasil como na Bahia, o turismo encontrou, no período em foco, dificuldades para transformar-se numa atividade de peso na economia, em decorrência de conjuntura econômica permanentemente frágil; do nível muito baixo de distribuição de renda; de problemas ligados à pobreza e à violência urbana; da carência de um empresariado dinâmico, atuante e disposto a investir sem subsídios públicos, além da política nacional para o setor, que, entre outras falhas, não investia adequadamente na imagem do país. Além disso, os destinos turísticos internacionais baseados em atributos como sol, praia
7 O crescimento anual da receita gerada pelo turismo no estado foi ligeiramente menor que o crescimento anual do fluxo turístico, com um aumento de $8,5 \%$ para o fluxo e de $8,2 \%$ para a receita. (MENDONÇA, 2002, p. 15)

8 Pesquisa de demanda turística da Bahiatursa, de 2001, registrou que, apesar da recuperação do Pelourinho, 99\% dos turistas vieram motivados por atrativos naturais.

9 Nos anos 1980, o país também teve uma participação que pode ser definida como insignificante no turismo mundial, abocanhando apenas $1,7 \%$ do faturamento global do setor. Em 1988, essa participação caiu para 0,8\% e o país recebeu apenas $0,3 \%$ do fluxo de turistas estrangeiros no final daquela década. (SILVA, 1991, p. 189) 
e patrimônio eram (e continuam sendo) numerosos e muitos deles, localizados mais próximos dos grandes países emissores. Somando-se a isso os altos preços das passagens que eram cobrados pelas companhias aéreas brasileiras e a falta de voos internacionais regulares e diretos para os destinos do Nordeste, se compreende por que complexos turísticos como Sauípe, no litoral Norte de Salvador, e empreendimentos turístico-comerciais como o novo Pelourinho passaram dificuldades nos anos 1990 e 2000.

De todo modo, e apesar desse desempenho não muito encorajador, o turismo foi, desde os anos 70, a grande esperança de desenvolvimento, dinamização e valorização econômica das áreas históricas do estado da Bahia. As políticas e programas de revitalização do centro tradicional da cidade, iniciadas no final dos anos 1960, ilustram bem esse percurso.

\section{Os projetos de revitalização do Centro Histórico nos anos 1970 e 1980}

A nova política de preservação traçada pelo Governo Federal com o apoio dos governos dos estados do Nordeste, no final da década de 1960, tinha como objetivo central o desenvolvimento econômico da região mediante o aproveitamento turístico do seu patrimônio histórico e natural. A expansão da classe média, promovida pela aceleração da industrialização, e o incremento da rede rodoviária do país animaram essas projeções que, ademais, encontravam suporte no discurso de agências internacionais ligadas ao patrimônio e ao desenvolvimento. As Normas de Quito, resultantes de encontro promovido pela Organização dos Estados Americanos em 1967, sacramentaram a ideia de que o turismo cultural era a saída para a reversão do quadro de deterioração física e depressão econômica vigente nas cidades históricas da América Latina. (AZEVEDO, 2001, p. 303-305)

A política internacional então preconizada, e logo assumida pelo governo brasileiro, foi perfeitamente ao encontro da vocação determinada para Salvador pelo planejamento regional. Para as áreas tombadas no centro da cidade foi recomendada, pela UNESCO, a criação de uma fundação pública para gerir e coordenar as operações de um plano de revitalização e valorização, o que resultou, 
em 1967, na criação da Fundação do Patrimônio Artístico e Cultural da Bahia. ${ }^{10}$ A fim de colocar em prática as novas diretrizes e captar recursos junto ao Banco Interamericano de Desenvolvimento - BID, a fundação elaborou, em 1969, o "Plano Geral de Recuperação da Área do Pelourinho", o primeiro de uma série de projetos de refuncionalização da área preservada do centro para uso turístico e reanimação do setor terciário. (FUNDAÇÃO DO PATRIMÔNIO ARTÍSTICO E CULTURAL DA BAHIA, 1970)

O plano de 1969 propunha remover a população pobre e destinar os imóveis para usos turísticos, comerciais e de serviços, capazes de dinamizar economicamente os bairros do Maciel e do Pelourinho, os quais constituíam, há muito tempo, os focos de maior deterioração física do centro antigo. A população da área era vista então como um entrave ao sucesso de um plano de revitalização. A concentração de prostitutas no Maciel, por exemplo, era uma fonte de pressões e problemas para os governantes, pois a cidade reclamava e os jornais da época estavam em franca campanha para a retirada do meretrício dessa área muito próxima do então movimentado terminal de ônibus da Praça da Sé. (BAHIA, 1997, p. 25-27) Assim, os primeiros planos de recuperação das áreas protegidas do centro tinham como objetivo integrá-las à dinâmica do turismo e também "limpá-las" de uma população julgada incompatível com o centro da cidade e com qualquer projeto de valorização. Previa-se financiamento da prefeitura para aquisição de casa própria apenas para aqueles que concordassem em sair do bairro, e já se cogitava o uso de indenizações para os que não preenchessem os requisitos financeiros.

Em termos de intervenção física, o plano de 1969 apoiava-se na concepção ambiental de patrimônio instituída pela Carta de Veneza (1964), que considera o monumento histórico inseparável do seu meio. Propunha-se então a restauração dos edifícios mais importantes, o agenciamento de praças e ruas, e a recuperação dos imóveis do conjunto. Propunham-se ainda intervenções no interior dos quarteirões para a criação de áreas livres para ajardinamento e implantação de serviços higiênicos, dotando-os de espaços de uso comum semelhantes às quadras residenciais modernistas. (FUNDAÇÃO DO PATRIMÔNIO ARTÍSTICO E CULTURAL DA BAHIA, 1970, p. 22) A ideia era também motivada pela mesma vontade de "limpeza" social, pois os miolos dos quarteirões do centro histórico
10 A criação da antiga fundação, hoje Instituto do Patrimônio Artístico e Cultural da Bahia IPAC, foi recomendada por Michel Parent, Inspetor Principal dos Monumentos Franceses, quando de sua missão ao Brasil, em 1966 e 67, para assessorar o IPHAN na montagem de uma nova política de preservação e gestão do patrimônio urbano brasileiro. (SANT'ANNA, 2014, p. 207-210) 
11 Ver Projeto de Restauração, Conservação e Adaptação do Quarteirão 10 do Maciel. eram ocupados por serviços e cômodos de aluguel típicos dos cortiços. Embora não implantada naquele momento, a transformação do miolo dos quarteirões em espaços de uso comum permaneceu como uma solução adequada, tendo sido adotada em projetos subsequentes, a exemplo do proposto para um quarteirão do Maciel em 1979. (FUNDAÇÃO DO PATRIMÔNIO ARTÍSTICO E CULTURAL DA BAHIA, 1979)"1

As primeiras iniciativas de "revitalização" do centro histórico ocorreram, portanto, quando a cidade assumia uma nova configuração e deixava de estar polarizada em torno do centro antigo. Surgiram também, como visto, quando se estabelecia para Salvador o papel de polo turístico e terciário do estado, e quando o turismo era definido pelas agências de desenvolvimento nacionais e internacionais como a panaceia para a solução dos problemas do patrimônio histórico, e sua principal esperança de desenvolvimento econômico e social. Relacionam-se a esse contexto, configurado entre o final dos anos 1960 e o princípio dos 70, as duas vertentes de atuação, às vezes complementares, às vezes contraditórias, que caracterizarão a atuação do poder público na área protegida do centro da cidade: a que vislumbrava, numa perspectiva de reforço da área central, o desenvolvimento do turismo e de outras atividades terciárias como saída para o seu quadro de esvaziamento e desvalorização; e a que investia no desenvolvimento social da população residente como base para a formação de um bairro residencial, no qual o turismo atuaria como fonte de atividade e emprego. Embora os projetos vinculados a uma ou outra vertente jamais tenham obtido os resultados esperados, sempre houve mais recursos e atenção para os vinculados à especialização turística e terciária do setor.

O plano delineado em 1969 nunca foi completamente executado, mas ao longo dos anos 1970, com recursos do Tesouro Estadual, da EMBRATUR e do Programa de Cidades Históricas, foram realizadas obras de restauração em alguns monumentos destacados; na adaptação de imóveis para a implantação de equipamentos turísticos e instituições públicas; e na recuperação de fachadas ao longo da Rua Alfredo Brito, no Largo do Pelourinho e na Ladeira do Carmo, formando-se uma espécie de "corredor turístico" onde se podia transitar sem muito contato com a pobreza do entorno. Os investimentos em habitação e desenvolvimento social da população local, por seu turno, seguiam sendo feitos, mas com muita 
dificuldade, já que o $\mathrm{PCH}$ relutava em investir nesse tipo de projeto, e a renda da população não permitia ao governo pleitear financiamentos ao antigo Banco Nacional de Habitação. Apesar de, em Olinda, se ter desenvolvido uma bem-sucedida experiência-piloto que contornou este problema, em Salvador, nada foi tentado nesse sentido. ${ }^{12} \mathrm{O}$ fato é que os projetos habitacionais no centro antigo se fundamentavam numa política assistencialista e de caráter demagógico, que não criava mecanismos reais de promoção social mediante, por exemplo, a aquisição de moradia. Ao lado disso, protegiam os interesses dos proprietários de imóveis da área, os quais, sem pressão contrária, continuavam deixando com o Estado a responsabilidade da conservação dos casarões. Essa atitude paternalista do governo estadual ajudou a sedimentar junto aos proprietários, como se verá adiante, uma cultura de não investimento, ancorada na espera de uma próxima intervenção estatal.

O fim do Programa de Cidades Históricas nos anos 1980 e a crise econômica que se instalou no país naquela década diminuíram, consideravelmente, as perspectivas de melhoria das áreas deterioradas do centro, mesmo no que diz respeito aos projetos turísticos. Nesse período, entretanto, foram realizados estudos para a ampliação da área protegida, com vistas à sua declaração como Patrimônio da Humanidade pela UNESCO, sendo finalmente delimitado, em 1984, o Centro Histórico de Salvador (Mapa 3). A área ampliada incluiu os conjuntos tombados pelo IPHAN em 1959, o núcleo correspondente à cidade murada de Tomé de Souza, ao Sul, e, ao Norte, os bairros residenciais de Santo Antônio Além do Carmo e Perdões.

A preservação do centro histórico de Salvador, no plano local, sempre foi conduzida pelo governo estadual, por meio do órgão especialmente criado para esse fim em 1967. A não ser por uma pequena participação no primeiro plano de recuperação do Pelourinho em 1969, a Prefeitura Municipal de Salvador não se envolveu no processo até meados dos anos 1980. A legislação urbanística municipal, por exemplo, só começou a conter disposições para a preservação do patrimônio histórico do centro a partir de 1972, e somente em 1983 passou a conferir à área um tratamento de centro histórico por meio da Lei Municipal $n^{\circ}$ 3.289/83. Esta lei, que criou a Área de Proteção Cultural e Paisagística do Centro, englobou os conjuntos tombados em 1959, a área que resultou da
12 A Prefeitura de Olinda, em 1983, deu garantias ao $\mathrm{BNH}$ e assumiu o empréstimo, repassando os recursos através de promissórias aos moradores que não preenchiam os requisitos do banco para endividamento. $O$ índice de inadimplência foi considerado baixo, mas a experiência não se desenvolveu por causa da extinção do BNH. (SANT'ANNA, 2014, p. 279-284) 
13 Decreto Municipal $n^{\circ} 7.838 / 87$.

14 Lei $n^{\circ} 7.505$, de 2 de Julho de 1986, que introduziu no país a possibilidade de se abater do imposto de renda devido investimentos em projetos culturais ou artísticos. ampliação desses tombamentos em 1984 e uma grande zona de proteção em torno dela, tornando protegido, sob regime urbanístico específico, quase todo o território da Região Administrativa I, que corresponde à área central da cidade (Mapa 03). Nos anos 1980, como visto, o centro antigo já não era mais a única centralidade importante de Salvador, mas seu valor simbólico e como referência urbana continuava grande, o que ensejou essa proteção municipal e, nas eleições municipais de 1985, sua exploração como um dos eixos da campanha eleitoral. (VIEIRA, 2000, p. 169-171)

O Programa Especial de Recuperação dos Sítios Históricos da Cidade do Salvador, o primeiro elaborado exclusivamente pelo município em 1986, como resposta a promessas de campanha, propunha para o centro histórico a função de ponto de encontro, trabalho, moradia e lazer para a população da cidade. (FUNDAÇÃO GREGÓRIO DE MATTOS, 1987) Os imóveis seriam recuperados mediante o uso de elementos pré-fabricados, após a identificação dos proprietários e a efetivação de compra ou desapropriação. Os recursos viriam de um fundo municipal criado especialmente para este fim, ${ }^{13}$ que operaria com doações de fundações, empresas e governos estrangeiros contemplados com incentivos fiscais previstos na antiga Lei Sarney. ${ }^{14}$ Com o objetivo de estimular proprietários e a iniciativa privada a investir no centro histórico, foram também promulgadas as Leis Municipais n³.805/87 e 3.813/87, que, respectivamente, instituíram a Transferência do Direito de Construir para fins de preservação de áreas de interesse patrimonial, e a isenção de impostos municipais para os que investissem na recuperação de imóveis protegidos.

A Lei nº 3.805/87 marca, em Salvador, a primeira tentativa governamental de criar mais-valia para o patrimônio edificado, vinculando-o a vantagens imobiliárias resultantes da flexibilização de parâmetros urbanísticos, com vistas a conferir-lhe um valor mensurável e utilizável no mercado. Marca ainda o início da utilização do patrimônio pela municipalidade como justificativa para a modificação desses índices sem a necessária aprovação legislativa, expediente que atingiu seu ápice com a Lei n³.993/89, também conhecida como "Lei da Contrapartida”. Esta lei permitia ao Executivo municipal receber recursos em espécie para investimento nos sítios históricos da cidade, em troca da definição de parâmetros mais permissivos em áreas que fossem objeto de novos planos urbanísticos. 
Em Salvador, por força do tombamento de uma grande área para a qual não foram instituídos parâmetros urbanísticos voltados para sua renovação, a transferência de um direito de construir, em rigor, inexistente, transformou-se na possibilidade de se autorizar a modificação de índices urbanísticos em outras áreas, mediante a doação à prefeitura de imóveis localizados no centro histórico. Com isso, o município esperava diminuir os custos de desapropriação e atrair o interesse do setor privado para a área. Contudo, não houve, à época, interesse do mercado imobiliário no uso desse dispositivo e nem do artifício criado pela Lei da Contrapartida. (GUERRA, 1996) Da maneira como foram concebidos em Salvador, ao invés de gerar mais-valia para o patrimônio, esses dispositivos funcionaram como fator de elevação do preço do solo nas áreas passíveis de alteração de parâmetros, o que esfriou o interesse do mercado. Ao lado disso, as reações populares contrárias levaram à revogação da Lei da Contrapartida em 1993.

O programa municipal elaborado em 1986 foi o primeiro a utilizar os meios de comunicação de massa para alavancar a recuperação do centro histórico e auferir ganhos políticos por meio de campanhas publicitárias. Entretanto, apesar dos recursos de marketing e dos instrumentos de captação de recursos postos em prática, não se conseguiu reunir fundos suficientes para a execução de todo o plano. Apenas alguns projetos considerados estratégicos foram executados, como as obras de complementação da infraestrutura em rede na área do Maciel/ Pelourinho; a estabilização de ruínas; a restauração de imóveis na Ladeira da Misericórdia; a instalação das Casas do Benin e do Olodum, no Pelourinho; e a reativação do Cine Guarani. Além dessas ações, o retorno da sede da prefeitura para o centro da cidade constituiu, talvez, o gesto mais importante então realizado no sentido do reforço da centralidade abalada do núcleo antigo.

\section{A revitalização comercial do centro e os últimos impactos do deslocamento de funções}

Nos anos 1980, enquanto se aprofundava a deterioração do setor mais importante do centro histórico, algumas áreas comerciais do centro que, nos anos 1970, haviam entrado em processo de reestruturação, começaram a se recuperar. 
Contribuiu para essa recuperação a implantação da Estação de Transbordo da Lapa, em 1982, em substituição ao antigo terminal da Praça da Sé. (HEINONEN, 2000, p. 53) A estação, localizada próxima à Avenida Joana Angélica e à Praça da Piedade, fez com que, em trechos dos bairros dos Barris e do Tororó, e na Avenida Sete de Setembro, se desenvolvesse um agitado comércio popular (Foto 01), que se tornou responsável, em grande parte, pela manutenção da dinâmica comercial do centro antigo, ao longo dos anos 1980 e 90, como importante polo de atração de atividades. (CARVALHO, 1997; FRANCO, 1995, p. 31-46) Em 1985, aproveitando-se o poder de consumo da grande massa usuária da Estação da Lapa, foi inaugurado o Shopping Piedade, o primeiro da cidade voltado para uma clientela popular. O sucesso comercial desse empreendimento foi tamanho que, em sua esteira, outros dois surgiram na área central com esse mesmo perfil: o Shopping da Baixa dos Sapateiros, por volta de 1993, e o Shopping Lapa (Foto 2), em 1996 (Mapa 2).

Os shoppings populares reforçaram a centralidade comercial do núcleo antigo, tornando-a mais competitiva no conjunto da cidade e redistribuindo espacialmente o varejo segundo dois polos principais: o da Pituba e Iguatemi, voltado para uma clientela de classe média alta, e o do centro, voltado para a população de renda média baixa e baixa. As demais nucleações comerciais da cidade-Mares e Calçada, Liberdade, Barra e Itapuã - mantiveram características de comércio especializado ou de bairro, em contraste com a diversidade e a heterogeneidade encontradas nos núcleos comerciais do centro novo e do centro antigo.

Apesar das ações governamentais que, a partir dos anos 1960, provocaram e aceleraram o esvaziamento funcional do centro antigo, este chegou aos anos 1990 com um significativo dinamismo econômico. (FRANCO, 1995, p. 31-46) Comparando-se a concentração e especialização funcional, os fluxos de transporte e o valor imobiliário no centro tradicional e na zona do antigo Iguatemi, verificou-se que, na primeira metade dos anos 1990, o centro constituía ainda o principal núcleo comercial da cidade, com três vezes o volume registrado de estabelecimentos, empregos e viagens. (CARVALHO, 1997, p. 61-111) Contudo, a evolução dos dados relativos à arrecadação de ICMS mostra que as empresas sediadas na zona da Pituba e do Iguatemi, embora em menor número, tinham faturamento superior às da área central. De fato, conforme dados da Secretaria 
da Fazenda do Estado da Bahia, a arrecadação no centro antigo apresentou queda entre 1985 e 1993, com recuperação no período até 1998, sem, contudo, retornar aos índices de 1985 (Tabela 4). Em contrapartida, a zona do Iguatemi apresentou, no mesmo período, um crescimento grande e constante, ultrapassando largamente, em 1998, a arrecadação da zona de São Pedro, a mais dinâmica do centro. Segundo Heinonen (2000, p. 74), os dados mostram, claramente, "o deslocamento do ponto de gravidade comercial da cidade em direção à zona do Iguatemi e a consolidação do novo centro".

Embora a Avenida Sete ainda fosse um ponto de compras importante para a população de menores ingressos, o esvaziamento do comércio varejista nessa área e, especialmente, na Baixa dos Sapateiros, no início dos anos 2000, era patente. Em 2002, diversas lojas estavam fechadas na Baixa dos Sapateiros e a crise também era visível na Av. Sete, na Liberdade e na Calçada. Essa retração espelhou, sem dúvida, a perda de dinâmica do varejo em todo o estado - onde o fechamento de empresas, entre 1998 e 2000, aumentou $40 \%$ - e, certamente, decorreu das altas taxas de desemprego da cidade e da perda geral de poder aquisitivo da população. (NASCIMENTO, 2002, p. 71-84) Relacionou-se também à concentração do varejo nos shoppings próximos à Estação da Lapa e à perda geral de dinâmica do centro antigo, acentuada a partir da segunda metade dos anos 1990 com a progressiva fuga de atividades da área do Comércio. A saída em massa das instituições financeiras ali sediadas para a área do antigo Iguatemi deixou o setor esvaziado e sem função clara na estrutura urbana.

De acordo com levantamento feito pela Associação de Empresários do Comércio - AECOM, em 2002, 89 prédios e lojas encontravam-se fechados ou

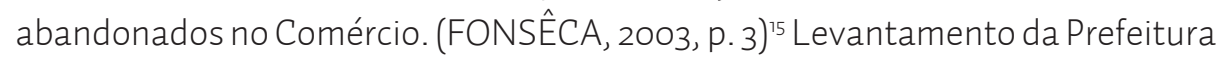
Municipal de Salvador apontou, por sua vez, 113 imóveis em estado precário de conservação. A importância do patrimônio imobiliário concentrado no Comércio, entretanto, engajou o município, proprietários e empresários com interesses no setor na busca de soluções. Como se detalhará adiante, a partir de 2000, intervenções de requalificação de espaços públicos foram aí realizadas e projetos para a melhoria da acessibilidade e introdução da função habitacional foram propostos (Foto 3 e Apêndices A e B). Além disso, a Lei Municipal n 6.064, de 28/12/2001, a fim de favorecer o investimento privado na área central e estancar o esvaziamento
15 "Nobre ou pobre, o Comércio resiste", reportagem de Adilson Fonsêca, 23 jul. 2003, Caderno Local. 
16 Ver artigos $6^{\circ}, 7^{\circ}$ e $8^{\circ} \mathrm{da}$ Lei $n^{\circ} 6.064$ /o1. do Comércio, isentou de taxas de licenciamento e impostos municipais os imóveis localizados nos setores deteriorados da Região Administrativa I que fossem objeto de intervenção para uso habitacional ou instalação de empreendimentos hoteleiros, educacionais ou culturais. ${ }^{16}$ Segundo a AECOM, essa medida animou, à época, a volta de empresários ao setor.

Diante do crescente poder de atração do centro novo nas imediações do antigo Iguatemi, da tradicional atitude oportunista de espera pela ação estatal, que caracteriza o setor privado no Brasil, e da dinâmica urbana e de expansão imobiliária existente à época, as perspectivas de revalorização e dinamização do antigo setor financeiro eram poucas. A implantação de unidades da administração pública e o desenvolvimento de outros usos institucionais, e mesmo habitacionais, bem como a fixação das atividades tipicamente centrais que ainda permaneciam no Comércio não chegaram a ser trabalhados como forma de alavancar esses processos e de se construir uma situação de mais equilíbrio entre o centro novo e o centro antigo.

A degradação econômica da área central, devido, principalmente, à dinâmica comercial existente no entorno da Estação da Lapa, não chegou a se concretizar, tendo, na verdade, ocorrido, especialmente nos anos 1970 e 80, a degradação da sua qualidade urbana, em decorrência da mudança do perfil de seus consumidores e, como visto, do direcionamento dos investimentos públicos para outras áreas da cidade. (FRANCO, 1995, p. 31-46) Esse panorama, contudo, mudou bastante nos anos 1990, quando a área central passou a receber recursos públicos e a ser foco de vários projetos. Esses investimentos, entretanto, tiveram pouco a ver com a dinâmica comercial e residencial instalada e foram voltados, em termos gerais, à promoção da imagem de Salvador no circuito turístico nacional e internacional e à promoção política da administração estadual. Essas iniciativas ajudaram a atrair alguns investimentos privados que, aos poucos, contribuíram para imprimir algumas mudanças no quadro econômico e social do centro (Apêndice A).

Diferentemente da reestruturação de áreas centrais em outras partes do Brasil e do mundo, em Salvador o investimento público na recuperação do centro histórico, assim como as muitas intervenções pontuais de requalificação de logradouros centrais realizadas nos anos 1990, não deflagraram um processo de volta de funções típicas da zona central. Efeitos dessas intervenções, somados à crescente situação 
de congestionamento e de falta de qualidade urbana existente na zona do centro novo, começaram a abrir, ainda que discretamente, a partir dos anos 2000, novas perspectivas para o centro antigo, como se verá em seguida.

\section{Programa de Recuperação do Centro Histórico de Salvador: implantação, números e fases}

No início dos anos 1990, a despeito do dinamismo do seu comércio popular, a área central de Salvador registrava acentuado processo de esvaziamento populacional, com crescimento negativo de 1,5\%, entre 1980 e 1991, atingindo, em seguida, a marca de -1,9\% no período de 1991 a 1996. Em contraste com outras regiões administrativas periféricas que cresciam de modo significativo, a área central apresentava, de longe, a maior taxa de esvaziamento (Tabela 5). Áreas como Maciel, Passo, Saldanha e trechos da Barroquinha apresentavam um parque edilício profundamente deteriorado e, no "corredor turístico" recuperado nos anos 1970, os sinais de decadência também eram visíveis. A falta de integração viária do centro histórico com o resto da cidade e com seu entorno, a insuficiência de transporte urbano no interior do setor e as dificuldades de estacionamento o tornavam muito pouco atraente para novas atividades. Além disso, a ideia nunca abandonada de destinar o Pelourinho - e, de certa forma, sua população - ao uso turístico contribuía para dificultar sua integração na dinâmica terciária popular do centro, assim como na dinâmica residencial de classe média baixa existente em bairros adjacentes como Saúde, Palma, Barbalho e Nazaré. A partir de iniciativas de agremiações carnavalescas sediadas na área e como consequência dos programas de promoção social da população residente, nasceu e firmou-se no Pelourinho, durante os anos 1980, um forte movimento cultural negro, que passou a animar e a conferir uma nova identidade ao bairro. Apesar da deterioração dos imóveis, o Largo do Pelourinho era frequentado por segmentos da população da cidade admiradora e consumidora da cultura que aí se estava produzindo.

Se o deslocamento de funções não foi capaz, como visto, de tirar todo o dinamismo econômico do centro, acentuou, por outro lado, a deterioração de suas áreas já degradadas, fazendo com que continuassem a atrair segmentos da população 
carente e mais desfavorecida da cidade, que encontravam, no local, vantagens de moradia nos imóveis abandonados, além de oportunidades de trabalho no comércio informal. Levantamento socioeconômico feito pelo IPAC em 1992 mostra que o perfil da população da área não era muito diferente daquele encontrado em 1967, quando dos primeiros levantamentos realizados. (INSTITUTO DO PATRIMÔNIO ARTÍSTICO E CULTURAL DA BAHIA, 1992) Tratava-se de população de inquilinos com tempo de moradia no bairro em torno de 20 anos e renda média entre 1 e 2 salários mínimos, formada, majoritariamente, de vendedores ambulantes, biscateiros e domésticas. A prostituição havia diminuído muito, mas o comércio de drogas tinha tomado o seu lugar.

A situação política no município e no estado da Bahia favoreceu enormemente, no início dos anos 1990, a decisão pelo investimento numa ação agressiva e de grande magnitude na recuperação do coração do centro histórico. O grupo que reassumiu o governo estadual em 1991-e que esteve no poder durante praticamente todo o governo militar - fora responsável pelo planejamento e pela execução da política de desenvolvimento econômico e turístico do estado a partir dos anos 1960. Seus membros vinham de um duro revés nas eleições estaduais de 1986 e retornavam dispostos a pavimentar a permanência no poder, pelo tempo mais longo possível, e a retomar o município de Salvador, então ainda sob controle da oposição.

As razões da implementação do Programa de Recuperação do Centro Histórico de Salvador estão fortemente ligadas a esse contexto político e fazem parte, inicialmente, de estratégia de marketing do governo para diferenciar-se da administração anterior, mediante a construção de uma imagem ancorada na valorização da identidade cultural e das tradições da Bahia, associada ainda às ideias de desenvolvimento e eficiência administrativa. O programa inseriu-se também, especialmente a partir de 1995, numa nova estratégia governamental de desenvolvimento do turismo e de retomada do crescimento do setor que, como já comentado, vinha em declínio desde meados dos anos 1980. Principal polo turístico do estado, Salvador necessitava de renovação e criação de novos "produtos", e, nessa estratégia, tornou-se oportuno continuar a investir na renovação do Pelourinho. Seguindo a tendência mundial, aqui também se apontava a cultura como o diferencial capaz de agregar mais valor ao "produto Bahia" e elevar sua competitividade no contexto nacional e internacional. 
A intervenção teve como guia, além de trabalhos e informações produzidas pelo IPAC ao longo de sua existência, apenas três documentos de caráter sumário e, de certa forma, contraditórios: um rápido levantamento do uso do solo e do perfil da população residente nos quatro quarteirões selecionados para intervenção, no bairro do Maciel; um termo de referência para a elaboração de um plano de ação integrada (que não chegou a ser desenvolvido); e um texto elaborado pela CONDER, ${ }^{17}$ intitulado simplesmente "Centro Histórico de Salvador", que - hoje se verifica - estabeleceu, de fato, as linhas gerais da intervenção. (COMPANHIA DE DESENVOLVIMENTO DA REGIÃO METROPOLITANA DE SALVADOR, 1992)

No documento elaborado pela CONDER, a recuperação do centro histórico foi definida como um poderoso instrumento econômico, que deveria ser realizada a partir de uma perspectiva empresarial. Propôs-se, então, mas sem divulgação ampla dessa ideia, que a área recuperada tomasse as características de um shopping center ao ar livre. Acreditava-se que a aliança entre consumo, lazer e cultura, num ambiente histórico único, igualaria a área do Pelourinho aos outros shoppings da cidade, gerando uma dinâmica que contaminaria "saudavelmente as quadras vizinhas [...], viabilizando o Centro Histórico". (COMPANHIA DE DESENVOLVIMENTO DA REGIÃO METROPOLITANA DE SALVADOR, 1992) $\mathrm{Na}$ montagem desse projeto não houve participação ou atração de parceiros privados. As negociações se restringiram aos proprietários de imóveis da área que foram localizados. Como forma de ressarcimento pelo investimento em suas propriedades, foi proposto, então, um sistema de doações ou cessões de unidades por 5 a 15 anos, o que permitiu ao governo estadual manter o controle da intervenção e, até certo ponto, da utilização da área nos moldes pensados.

O Programa de Recuperação do Centro Histórico não envolveu toda a área tombada, intervindo, de início, apenas nos quarteirões mais deteriorados do Maciel, do Passo e do Carmo, nas imediações do Largo do Pelourinho. Estendeu-se depois para os quarteirões em torno do Terreiro de Jesus, do Terreiro de São Francisco e da Praça da Sé, fechando sua 6 a etapa na área entre o antigo Maciel e a Baixa dos Sapateiros (Mapa 4). Nessas seis etapas, executadas entre 1992 e 1999, cerca de 600 imóveis foram reformados, a infraestrutura em rede foi complementada, três estacionamentos foram construídos, nove monumentos tombados foram restaurados e seis praças agenciadas, num investimento de cerca de R\$ 92

17 Antiga Companhia de Desenvolvimento da Região Metropolitana de Salvador, atualmente vinculada à Secretaria de Desenvolvimento Urbano e denominada Companhia de Desenvolvimento Urbano do Estado da Bahia. 
18 Deve-se ressaltar que, entre 1994 e 1999, o real foi mantido com cotação muito próxima ao valor do dólar.

19 Pesquisa do governo estadual estimou que, até 1994, a iniciativa privada investira cerca de R\$7.300.000,00 no Pelourinho. (COMPANHIA DE DESENVOLVIMENTO DA REGIÃO METROPOLITANA DE SALVADOR, 1995)

$2061,9 \%$ dos habitantes removidos ocupavam imóveis cedidos ou invadidos (respectivamente $37,1 \%$ e $24,8 \%$ ). Ver Companhia de Desenvolvimento da Região Metropolitana de Salvador; Instituto do Patrimônio Artístico e Cultural da Bahia, 1997.

21 Essas pesquisas constam dos seguintes documentos: Instituto do Patrimônio Artístico e Cultural da Bahia,1992; Companhia de Desenvolvimento da Região Metropolitana de Salvador; Instituto do Patrimônio Artístico e Cultural da Bahia,1997; Companhia de Desenvolvimento da Região Metropolitana de Salvador; Instituto do Patrimônio Artístico e Cultural da Bahia, 2000. milhões, ${ }^{18}$ oriundos quase exclusivamente do Tesouro Estadual, que incluiu obras, indenizações e fiscalização (Tabelas 6 e 7). Na $7^{a}$ etapa da intervenção, iniciada nos anos 2000, projetou-se a reforma de mais 130 imóveis na área do Saldanha e quatro monumentos, desta vez agregando-se aos recursos do estado da Bahia, recursos do BID e do Ministério da Cultura, através do Programa Monumenta (1999-2010), bem como da Caixa Econômica Federal, numa previsão de investimento total da ordem de $\mathrm{R} \$ 33,5$ milhóes (Tabela 8).

Não existem dados consolidados sobre quanto o setor privado investiu no conjunto edificado em termos da adaptação de edifícios para a implantação de empreendimentos, da compra de imóveis ou em estoques, aluguéis, pagamento de concessões etc..$^{19} \mathrm{O}$ certo é que investiu muito pouco na manutenção dos casarões, já que, entre 1997 e 2001, a conservação de fachadas e coberturas nas áreas recuperadas foi feita pelo Governo do Estado da Bahia, num investimento que custou aos cofres públicos, em média, R\$1,2 milhão por ano (Tabela 9). Além desses recursos, a Secretaria de Cultura e Turismo da Bahia investiu ainda uma média de R\$ 3,3 milhões por ano na animação do centro histórico por meio do projeto "Pelourinho Dia \& Noite", entre 1996 e 2001 (Tabela 9).

Nas cinco primeiras etapas, a intervenção removeu e indenizou, a um custo médio de R\$1.222,00, cerca de 1.900 famílias, que se transferiram para outros bairros ou se acomodaram em imóveis abandonados no entorno do Pelourinho. Mesmo pagando muito pouco, ou mesmo nada, em prédios invadidos ou cedidos e em péssimo estado de conservação, os moradores não resistiram a sair dos imóveis que ocupavam originalmente. (COMPANHIA DE DESENVOLVIMENTO DA REGIÃO METROPOLITANA DE SALVADOR; INSTITUTO DO PATRIMÔNIO ARTÍSTICO E CULTURAL DA BAHIA, 1997) ${ }^{20}$ Como atestam pesquisas feitas pelo governo estadual entre 1992 e 2000, ${ }^{21}$ essa atitude decorreu da ausência de organização comunitária, do atrativo das indenizações em face da extrema pobreza do grupo, e do fato de não thes ter sido oferecida possibilidade de aquisição de moradia mediante financiamento acessível (Quadro 1).

A única alternativa de permanência oferecida à população residente foi a formalização de contratos de aluguel ou de concessão nos imóveis recuperados, com valores bem mais altos. A opção da grande maioria pela indenização, na realidade, foi vantajosa para o governo estadual, pois assumir a responsabilidade 
do reassentamento dos moradores na própria área ou em outras da cidade, seguindo os princípios recomendados para esse tipo de ação, sairia muito mais caro. Estudos realizados para a $7^{\text {a }}$ etapa do programa e para a área da Barroquinha mostram que, em média, o governo teria que gastar $\mathrm{R} \$ 6.200,00$ para reassentar cada família, ou seja, quase seis vezes mais do que foi gasto em indenizações nas cinco fases anteriores (Tabela 7). (COMPANHIA DE DESENVOLVIMENTO DA REGIÃO METROPOLITANA; INSTITUTO DO PATRIMÔNIO ARTÍSTICO E CULTURAL DA BAHIA, 1998) No ano 2000, a indenização de aproximadamente 1.600 famílias residentes na área da $7^{\text {a }}$ etapa teve, em contrapartida, um custo projetado entre $\mathrm{R} \$ 1.200,00$ e R $\$ 2.800,00$ por grupo familiar. (COMPANHIA DE DESENVOLVIMENTO URBANO DO ESTADO DA BAHIA, 2000)

Após dez anos de implantação, o Programa de Recuperação do Centro Histórico de Salvador apresentava três fases de desenvolvimento. A primeira, de 1992 a 1995, correspondeu, grosso modo, à implantação do shopping a céu aberto entre o Terreiro de Jesus e o Largo do Pelourinho (Foto 4). Este foi se configurando, contudo, sem obediência às regras estritas desse tipo de estabelecimento comercial, tornando-se, por fim, um empreendimento sui generis, onde o critério de seleção dos empresários era mais político do que comercial; onde não havia condomínio ou taxa a ser paga pela propaganda ou pelas promoções feitas pelo Governo do Estado da Bahia; e onde a manutenção do exterior dos imóveis e áreas comuns era realizada pelo poder público, que, além disso, assumia os serviços de limpeza, coleta de lixo, manutenção de vias públicas, segurança e iluminação - todos realizados em moldes especiais e não praticados em qualquer outra parte da cidade.

Diferentemente de outras ações levadas a efeito no Brasil, ${ }^{22}$ no shopping do Pelourinho não foram utilizados mecanismos claros de escolha dos candidatos, de modo a se potencializar o investimento público por meio de empresas com bons desempenhos comerciais (Foto 5). As pressões de correligionários políticos, a falta de critérios e a atitude paternalista do governo estadual favoreceram o oportunismo dos que ali se instalaram, muitos dos quais sem a experiência e o nível de capitalização necessários para enfrentar as dificuldades e os ajustes de uma área em processo de renovação funcional. (FERNANDES, 1998) Além disso, por receio de que os imóveis recém-reformados fossem invadidos pela população
$22 \mathrm{Na}$ Rua 24 Horas de Curitiba, por exemplo, a utilização do espaço público para fins de comércio era, à mesma época, licitada e sujeita a regras de localização estabelecidas no planejamento do setor. 
23 No final de 1994, 62\% das empresas que alugavam imóveis comerciais no Pelourinho pagavam aluguéis inferiores a US\$ 100,00, o que estava bastante abaixo do preço de mercado. (COMPANHIA DE DESENVOLVIMENTO DA REGIÃO METROPOLITANA DE SALVADOR, 1995) pobre da vizinhança, logo que as obras da primeira etapa do programa foram concluídas, o Governo da Bahia correu a buscar, e a incentivar inclusive financeiramente, comerciantes para ocupar as unidades disponíveis, o que o deixou sem possibilidade de negociaçãa. Imóveis recuperados, com boas condições de ocupação e infraestrutura, aluguel barato ${ }^{23}$ e acesso a linha de crédito em banco de fomento estadual foram as condições especiais oferecidas aos candidatos. Mas o modelo de intervenção adotado, centralizado no estado da Bahia, e com investimentos privados reduzidos, não favoreceu uma atitude comprometida dos ocupantes com o sucesso da intervenção. Ao contrário, funcionou como incentivo a uma atitude oportunista e baseada na exploração do momento favorável e no baixo custo de instalação.

Ao fim da $4^{a}$ etapa e passado o primeiro impacto da intervenção, os problemas do modelo adotado já se colocavam claramente. Os empreendimentos voltados para uma clientela mais abastada não logravam manter o seu público, e logo fecharam as portas. $O$ afluxo de turistas também não foi o esperado, fazendo com que as lojas muito voltadas para essa atividade também fossem prejudicadas.

Em 1994, a constatação desses problemas levou setores técnicos do Governo do Estado a buscarem alternativas para a crise instalada, no sentido do estabelecimento de uma maior vinculação do "empreendimento Pelourinho" com a dinâmica turística da região. (FUNDAÇÃO CENTRO DE PROJETOS E ESTUDOS, 1994) Uma série de pesquisas e estudos foi então encomendada para monitorar o uso da área, avaliar a rentabilidade dos empreendimentos e buscar modelos alternativos de gestão. (COMPANHIA DE DESENVOLVIMENTO DA REGIÃO METROPOLITANA DE SALVADOR, 1995, 1996a, 1996c) Verificou-se então que não eram os turistas os principais usuários do novo Pelourinho (Tabelas 10 e 11). O lugar, mesmo em períodos de alta estação, como a semana anterior ao Carnaval, era frequentado principalmente pela população da cidade para fins de lazer e trabalho.

Com vistas a manter uma média de frequência adequada no Pelourinho durante todo o ano e com o objetivo de fixar os empreendimentos instalados, o Governo do Estado da Bahia passou, já em 1994, a investir na animação do local, promovendo eventos e shows nas pequenas praças inseridas no "miolo" de alguns quarteirões (Fotos 6 e 7). Isso veio ao encontro dos anseios dos principais usuários do setor, que passou então a se firmar cada vez mais como um polo de 
lazer da cidade. Em contrapartida, aprofundou-se a relação de dependência dos empresários instalados na área com o governo, que passaram a defender uma gestão estatal do "empreendimento" Pelourinho ${ }^{24}$ e a recusar qualquer tentativa de gestão compartilhada. Essa relação paternalista/oportunista foi reforçada pela decisão governamental de assumir os serviços de conservação e manutenção do exterior dos imóveis, e de não executar a cláusula de manutenção existente em todos os contratos de concessão. Na medida ainda em que não logrou formar condomínios nos quarteirões recuperados, o IPAC - responsável pela administração das unidades em poder do estado da Bahia - teve dificuldades de executar essa cláusula, mesmo no que toca às áreas internas comuns no interior dos quarteirões e às edificações que foram ocupadas por empreendimentos ou usuários distintos.

Na segunda fase da intervenção, de 1996 a 1999, o programa se caracterizou, assim, pela realização de estudos e de avaliações, bem como pela busca de alternativas de gestão e funcionamento. Caracterizou-se, ainda, por todo um esforço do Governo do Estado da Bahia para manter o empreendimento Pelourinho animado e frequentado, inicialmente, adequando-o aos usuários identificadose, depois, a partir de 1997, buscando adaptá-lo, pelo menos em parte, a um público consumidor de eventos culturais e de renda mais elevada. O ritmo da intervenção tornou-se mais lento, desenvolvendo-se durante toda essa fase apenas a $5^{\text {a }}$ etapa do programa, correspondente à área da Praça da Sé, e uma parte da $6^{a}$ etapa, correspondente ao chamado "Quarteirão Cultural", na Rua Gregório de Matos (Mapa 4). Realizada com recursos do Programa de Desenvolvimento do Turismo do Governo Federal (PRODETUR), a $\sigma^{\text {a }}$ etapa cumpriu exigências do Banco Interamericano de Desenvolvimento (BID) - agência financiadora deste programa -, o que obrigou o Governo da Bahia a realizar estudos de viabilidade e de impacto econômico e financeiro, e a desenvolver projetos executivos. Isso não resultou, contudo, em alterações de monta, seja no modelo geral da intervenção, seja no seu modelo de gestão.

As mudanças mais significativas só tiveram início em 1999, com a formulação do "Projeto Habitacional do Centro Histórico" e com a implantação da $7^{a}$ etapa do Programa de Recuperação do Centro Histórico de Salvador. A constatação de que o programa, ao contrário do que pensaram os ideólogos do shopping a céu aberto, até então não havia sido capaz de deflagrar um processo de reabilitação

25 A pesquisa realizada à época indicou que os empresários instalados no Pelourinho eram os mais refratários e reticentes a um processo de participação e parceria na gestão e na manutenção da área. (COMPANHIA DE DESENVOLVIMENTO DA REGIÃO METROPOLITANA DE SALVADOR, 1996C) 
25 Bairros de Santo Antônio, Carmo e Sodré/Preguiça.

26 Convênio nº 017/99, de 25 de maio de 1999 Embora participando da equipe de implantação do projeto desde 2000,

- IPHAN e a Prefeitura de Salvador só foram incluídos oficialmente na renovação do convênio celebrada em 28 nov. 2002.

27 A linha de financiamento mais utilizada foi o Programa de Arrendamento Residencial (PAR), destinado a pessoas físicas com renda bruta familiar de até o6 salários mínimos, limite máximo de financiamento até $\mathrm{R} \$$ 35 mil, taxa mensal de arrendamento de $0,7 \%$ e opção de compra do imóvel arrendado ao fim de 15 anos.

280 Decreto $n^{0} 7.881 / 2000$ declarou de utilidade pública para fins de desapropriação os imóveis selecionados para o projeto piloto do Programa Rememorar, e a Lei Estadual $n^{\circ} 8.218 / 2002$ autorizou sua alienação. nas áreas adjacentes, abriu espaço para o investimento, ainda que cauteloso e discreto, em outra linha de ação. Admitiu-se, enfim, que o enclave comercial e turístico produzido no Pelourinho não havia sido capaz de vencer a deterioração edilícia do seu entorno, e, muito menos, os problemas estruturais do centro histórico. Havia simplesmente, em suma, os colocado em compasso de espera: os proprietários de imóveis continuavam esperando novo investimento do governo estadual e a população carente do entorno, uma chance de permanecer.

\section{0 uso habitacional no Centro Histórico}

A partir de estudos realizados entre 1997 e 1998 sobre o mercado imobiliário em Salvador - linhas de crédito disponíveis, perfil da demanda e situação fundiária e urbanística-, o desenvolvimento do uso habitacional em certas áreas do centro histórico ${ }^{25}$ (Foto 8) começou a ganhar força como um modo mais sustentável de intervir e de inserir o setor numa dinâmica de mercado. (COMPANHIA DE DESENVOLVIMENTO URBANO DO ESTADO DA BAHIA; INSTITUTO DO PATRIMÔNIO ARTÍSTICO E CULTURAL DA BAHIA, 1999a) Com a assinatura de um convênio entre o Governo do Estado da Bahia e a Caixa Econômica Federal, iniciou-se, em 1999, uma experiência-piloto denominada "Projeto Rememorar", ${ }^{26}$ com o objetivo de desenvolver metodologia para a reabilitação de imóveis com participação menor de investimentos públicos diretos e com a participação de aportes privados, mediante o uso de linhas de financiamento da Caixa Econômica Federal (Foto 9). ${ }^{27}$

Diferentemente de experiências desenvolvidas pela Caixa no começo dos anos 2000, no âmbito da sua iniciativa denominada Programa de Revitalização de Sítios Históricos (PRSH), em cidades como Belém, São Luís e Recife, a montagem da operação em Salvador teve contornos específicos. Os imóveis selecionados, que possuíam de pé apenas as fachadas principais e paredes externas, foram desapropriados pelo Governo da Bahia e, por intermédio de legislação especialmente aprovada para esse fim, ${ }^{28}$ alienados à Caixa (Foto 10). Esta financiou algumas operações de reabilitação com base em projetos executivos financiados pelo governo estadual. Apesar dessas condições especiais, os custos das obras, 
segundo a Caixa, ${ }^{29}$ colocaram o valor da unidade habitacional 30\% acima do valor de mercado e dos limites da sua linha de financiamento. Para cobrir esta diferença, foram obtidos incentivos fiscais do Programa Nacional de Apoio à Cultura (PRONAC), do Ministério da Cultura, para a recuperação de fachadas e coberturas, justificando-se que esses elementos constituiriam um bem público a ser devolvido à cidade.

O Projeto Rememorar, em sua primeira etapa, incluiu apenas seis imóveis no bairro de Santo Antônio, (Quadro 2). Embora a ideia inicial tenha sido testar as condições de produção habitacional no centro histórico em condições normais de mercado, a organização da operação demonstrou, devido à situação de propriedade e de documentação dos imóveis, e aos custos de desapropriação, projetos e obras, a dificuldade dessa produção para a faixa de renda almejada (renda bruta familiar de até o6 salários mínimos). Mantidos ainda o sistema usual de financiamento e a taxa de arrendamento então praticada pela Caixa, essa meta provou-se impossível sem outros subsídios. Subsídios que teriam sido, sem dúvida, socialmente mais justos do que os que foram praticados em prol da atividade comercial no centro histórico. ${ }^{30}$

Os projetos arquitetônicos voltados para a produção habitacional no centro histórico, no começo dos anos 2000, contudo, não foram ancorados em um conhecimento mais fino do patrimônio edilício em questão, caindo, como foi a regra no Programa de Recuperação do Centro Histórico, numa concepção fachadista e cenográfica. Ignoraram as relações de parcelamento, intervolumétricas e de ocupação que, entre outros elementos, compõem a substância histórica e documental do espaço urbano (Fotos 11 e 12).

Apesar das dificuldades de natureza documental, fundiária e financeira enfrentadas na montagem da operação-piloto do Projeto Rememorar, seus resultados animaram os parceiros a prosseguir. Uma segunda fase do projeto entrou em andamento, em 2003, envolvendo 48 ruínas espalhadas na área central nos bairros do Santo Antônio, Perdões, Saúde, Soledade, Desterro, Mouraria e, ainda, nas áreas da Avenida Contorno, Conceição da Praia, ladeiras da Montanha e da Misericórdia, Largo 2 de Julho e Gravatá (Quadro 2 e Mapa 5). ${ }^{31}$ O processo de desapropriação desses imóveis pelo governo estadual foi então iniciado e os parâmetros para a elaboração dos projetos arquitetônicos foram fornecidos pelo
29 Informação prestada à autora pela Gerência de Desenvolvimento Urbano da Caixa Econômica Federal, Salvador, em 05 abr. 2002.

30 O valor máximo mensal do aluguel cobrado pelo IPAC gira atualmente em torno de $\mathrm{R} \$ 4,08$ por $\mathrm{m}^{2}$ (dados fornecidos por José Augusto Leal, Diretor Adjunto do IPAC, em contato realizado em 08 abr. 2002). Em outros shoppings da cidade, por exemplo, o preço do aluguel varia entre R\$ 400,00 e R\$50,00 por $\mathrm{m}^{2}$.

37 Escritório Técnico de Licenciamento e Fiscalização (ETELF), Superintendência do IPHAN na Bahia, posição em novembro de 2003. 
32 Escritório Técnico de Licenciamento e Fiscalização (ETELF), Superintendência do IPHAN na Bahia, posição em julho de 2003

33 A pesquisa foi realizada pela empresa Painel Brasil para a Fundação Mário Leal Ferreira.
IPHAN local. A montagem financeira foi a mesma da etapa-piloto e, tal como ocorreu naquela fase, alguns proprietários decidiram investir na recuperação de seus imóveis para evitar as desapropriações, que, no geral, foram feitas em termos vantajosos para o Governo do Estado. A possibilidade de desapropriação serviu, à época, para desestimular uma atitude meramente oportunista e especulativa de alguns proprietários e investidores em áreas atingidas pelo projeto habitacional, como as imediações do convento de Santa Tereza, Sodré, e Avenida Contorno.32 Alguns imóveis localizados nessas áreas vinham sendo adquiridos não para uso, mas com vistas a uma expectativa de valorização advinda do desenvolvimento de uma ocupação de alta renda que já se desenvolvia, logo abaixo, na borda da baía. Ao acenar com a possibilidade de desapropriar os imóveis que se encontrassem sem uso, o Projeto Rememorar desestimulou temporariamente essa prática de "engorda" de terrenos e ruínas, obrigando os especuladores a informar a destinação que seria dada às suas propriedades.

Além do Projeto Rememorar, no âmbito do "Programa de Revitalização de Sítios Históricos", lançado em 2000 pela Caixa Econômica Federal, foram desenvolvidos estudos de viabilidade para a reabilitação de imóveis para uso habitacional no bairro do Comércio, numa parceria entre a Prefeitura de Salvador, a CONDER e o governo francês. A iniciativa se relacionou ao esforço de estancar o esvaziamento e a deterioração do estoque imobiliário dessa área, bem como à tentativa de lhe dar uma nova destinação, já que, diante do poder de atração do novo centro em torno do Iguatemi, não surgia no horizonte uma retomada desse setor como Área Central de Negócios. De fato, uma pesquisa de opinião, então encomendada pela prefeitura e financiada pela Caixa Econômica Federal, mostrou que os operadores do mercado imobiliário - incorporadores e corretores - consideravam difícil a situação do Comércio, pois o mercado, além de não ter experiência com a reciclagem de imóveis, só se mostrava aquecido e com tendência de crescimento nas regiões da Pituba, Iguatemi e Litoral Norte, tanto no segmento residencial quanto no comercial. (FUNDAÇÃO MÁRIO LEAL FERREIRA, 2002)33 A pesquisa também deixou claro que os segmentos de renda mais alta não tinham interesse em residir no setor, mesmo que ele viesse a ser revitalizado e dotado dos requisitos de segurança, equipamentos e infraestrutura associados aos "bairros bons". Caso isso ocorresse, esses segmentos, no máximo, comprariam imóveis na área para 
negócio ou investimento. Em face disso, os operadores do mercado entendiam que, se o caminho para a revitalização do Comércio fosse a introdução do uso habitacional, o foco deveria ser posto nas faixas de menor poder aquisitivo, o que foi corroborado na sondagem realizada com segmentos de renda C e D.

De fato, essa amostra, composta por trabalhadores do Comércio, usuários e funcionários públicos municipais com renda de até cinco salários mínimos, revelou que $30 \%$ dos entrevistados demonstraram interesse em adquirir residência no setor, mesmo diante do seu estado de abandono e do fato de nunca ter abrigado o uso residencial. (FUNDAÇÃO MÁRIO LEAL FERREIRA, 2002) ${ }^{34}$ Os números indicavam, portanto, que, se fosse iniciado um processo de reabilitação no Comércio, a quantidade de interessados subiria nas faixas de renda $C$ e $D$, especialmente se a área fosse dotada da infraestrutura de apoio e dos equipamentos necessários ao desenvolvimento e consolidação do uso residencial. A sondagem demonstrou, por fim, que, fora da dinâmica comercial e residencial vinculada aos segmentos de renda média e baixa que caracterizavam (e ainda caracterizam) a ocupação da área central, seria difícil encontrar saídas economicamente sustentáveis para seu repovoamento e dinamização.

A despeito de alguns seminários realizados para sensibilizar empresários da construção civil e desses estudos de viabilidade, o projeto de introdução do uso habitacional na antiga região portuária de Salvador não foi efetivamente deslanchado. Os entraves à conclusão da montagem financeira foram, principalmente, a situação documental dos imóveis e as enormes dívidas de IPTU relativas a alguns deles. Entretanto, apesar dessa movimentação incipiente, algumas empresas construtoras declararam à prefeitura seu interesse na reciclagem de imóveis no Comércio. ${ }^{35}$

A $7^{a}$ etapa do Programa de Recuperação do Centro Histórico também se ancorou no uso habitacional e teve um esquema de preparação e execução diferente das etapas anteriores desse programa. O modelo de intervenção se alterou, não como decorrência de um questionamento do que vinha sendo feito, mas em função das exigências que acompanham os financiamentos do BID - no caso, vinculados ao Programa Monumenta, lançado pelo Ministério da Cultura no final de 1999. Concentrada em oito quarteirões do Saldanha, que foram destinados ao uso misto e habitacional, a etapa incluía ainda a restauração de alguns monumentos
$3429 \%$ dos trabalhadores do Comércio, $24 \%$ dos usuários e $43 \%$ dos funcionários públicos.

35 Informações fornecidas pela arquiteta Elisabeth Lepikson, da Fundação Mário Leal Ferreira, em 13/08/2003. 
36 Decreto $n^{\circ} 8.170$, de 25 de fevereiro de 2002.

37 Convênio n³34/2002, publicado no D.O.U de 04 jul. 2002

38 O FUNDOCENTRO foi criado pela Lei Municipal $n^{\circ} 5.853 / 2000$ devendo seus recursos ser aplicados na conservação dos imóveis existentes na área da $7^{a}$ etapa. Estes seriam provenientes de receitas geradas pelos imóveis recuperados, dotações orçamentárias específicas, retorno de recursos do Monumenta aplicados na recuperação de imóveis privados doações, entre outras.

39 A pesquisa foi realizada pela empresa Duplamente Pesquisas de Mercado. individualmente tombados, localizados neste setor, e a construção de um estacionamento (Mapa 4). Do mesmo modo como ocorreu no piloto do Projeto Rememorar, foram desapropriados pelo Governo do Estado os imóveis cujos proprietários não foram localizados, ${ }^{36}$ e, após as obras, as unidades habitacionais, que teriam, em média, $37 \mathrm{~m}^{2}$, gerariam uma prestação média de R\$154,00. O convênio para o repasse dos recursos foi assinado, ${ }^{37}$ e foram realizados pelo governo estadual e pelo Ministério da Cultura investimentos em projetos e estudos preparatórios, bem como em obras emergenciais de escoramento e limpeza (Fotos 13 e 14).

A intervenção da $7^{a}$ etapa deveria, assim, romper com o esquema concentrado de propriedade existente na área recuperada do Pelourinho e com o regime de ocupação predominante via inquilinato. O Governo do Estado da Bahia não seria mais responsável pela administração dos imóveis ou por sua manutenção, que ficariam a cargo dos proprietários e do fundo especialmente criado para garantir a sustentabilidade financeira da intervenção - o FUNDOCENTRO -, componente obrigatório das ações financiadas pelo Monumenta. ${ }^{38}$ Romperia também com os subsídios diretos dados aos proprietários, na medida em que as intervenções em seus imóveis, de acordo com o regulamento deste programa, só poderiam ser feitas via empréstimo, cujo pagamento seria revertido para o citado fundo, o qual, por sua vez, direcionaria suas receitas para a continuidade do próprio projeto. A intervenção promoveria, ainda, um uso mais permanente dos imóveis, beneficiando um público de renda média baixa que já habitava bairros adjacentes ao centro e constituía uma demanda real, e se inseriria na dinâmica social e econômica existente na área central.

Pesquisa então realizada em outros bairros da área central para testar a viabilidade do projeto da $7^{\text {a }}$ etapa revelou que, de fato, havia uma significativa demanda por habitações reabilitadas nessa área, correspondendo a um potencial de 50,6\% da amostra. Desse público potencial, cerca de $20 \%$ se encaixavam nas normas do PAR (entre 3,5 a 6,0 salários mínimos de renda familiar bruta). Projetando-se esses dados para a área central, verificou-se a existência de cerca 700 famílias sem casa própria, mas aptas a participar do financiamento. (COMPANHIA DE DESENVOLVIMENTO URBANO DO ESTADO DA BAHIA, 2001) ${ }^{39}$

$A 7^{a}$ etapa se apoiou em estudos prévios que lhe conferiam mais segurança e garantia de controle na execução, tendo constituído, portanto, um avanço em 
relação às demais etapas do Programa de Recuperação do Centro Histórico. Contudo, alguns equívocos das etapas anteriores se prolongaram nesta última. Apesar de os estudos elaborados para equacionar a questão do reassentamento da população da área do Saldanha terem indicado que as indenizações deveriam ser um último recurso, as 1.674 famílias cadastradas seriam majoritariamente indenizadas ou realocadas em Coutos - um bairro muito distante do centro histórico. (COMPANHIA DE DESENVOLVIMENTO URBANO DO ESTADO DA BAHIA, 2000) $)^{40}$ Ao lado disso, cerca de $80 \%$ dessas pessoas, quando perguntadas se teriam interesse em comprar um imóvel no centro histórico caso houvesse um financiamento acessível, responderam afirmativamente, mas tal informação simplesmente não foi levada em conta. (COMPANHIA DE DESENVOLVIMENTO URBANO DO ESTADO DA BAHIA, 2000) Como o aluguel médio pago nesta área, em imóveis em condições extremamente precárias, era de R\$132,00, vê-se que parte dessa população teria condições de permanecer, mesmo com o financiamento restritivo da Caixa.

O partido físico da intervenção também pouco diferiu do anterior, no sentido de que uma importante documentação arquitetônica e urbanística, mais uma vez, seria perdida, com a eliminação indiscriminada de anexos (alguns dos quais constituíam "avenidas" de casas construídas para abrigar os negros libertos depois da escravidão) e o rompimento de relações de parcelamento, entre cheios e vazios e de ocupação do conjunto. Consoante com a concepção fachadista de patrimônio, que caracterizou as intervenções no centro histórico, os interiores dos imóveis seriam barbaramente retalhados para dar lugar aos pequenos apartamentos que se encaixavam na montagem financeira, apesar dos subsídios públicos que foram mobilizados. Além disso, dificilmente uma família baiana de classe média baixa seria estável a ponto de se adaptar sem promover ampliações ou novas subdivisões, a um espaço habitacional tão exíguo. ${ }^{41}$ Assim, tudo indicava que as perdas para o patrimônio seriam grandes e não se limitariam ao que estava previsto nos projetos.

Em suma, nessa terceira fase do Programa de Recuperação do Centro Histórico de Salvador verificou-se uma guinada significativa no modelo de intervenção, na medida em que as áreas por onde ele deveria se prolongar deixaram de ser tratadas como enclaves e voltaram a ser tratadas como espaço urbano.
$4054,8 \%$ dos residentes declararam querer ir para um bairro próximo.

41 Diferentemente do projeto que foi desenvolvido no Rio de Janeiro nesta mesma época, na $7^{a}$ etapa do Programa de Recuperação do Centro Histórico e no Projeto Rememorar não se focalizou um público idoso ou composto apenas de casais sem filhos. Considerando-se as experiências habitacionais realizadas em Salvador com a mesma faixa de renda focalizada nessa etapa, alterações de monta nos imóveis recuperados deveriam ser esperadas. (MAGALHÃES, 2002) 
Essa guinada, contudo, não promoveu a integração da população residente no processo ou um maior cuidado para com o patrimônio existente. Decorreu, basicamente, da entrada em cena de agências de financiamento, no caso o BID e a Caixa Econômica Federal, e, em última análise, visou a conferirviabilidade financeira às novas operações e a garantir sua sustentabilidade econômica.

Enquanto isso, o shopping a céu aberto nas imediações do Pelourinho continuou intocado em seu modelo centralizado de funcionamento, embora ali também já se notassem algumas mudanças. O excesso de bares instalados na segunda fase do programa foi, aos poucos, dando lugar a serviços, instituiçóes e equipamentos culturais. Também aos poucos, em consonância com as diretrizes para o desenvolvimento do turismo na Bahia e com vistas a se manter a rentabilidade das empresas, passou-se a investir mais no turista nacional do que no turista estrangeiro abastado. (GAUDENZI, 2001) O resultado dessas gestões, entretanto, continuou incerto, como demonstram os números do turismo da época.

\section{Resultados e sentidos das intervenções realizadas nos anos 1990}

As razões da manutenção do Pelourinho como um empreendimento em permanente estado de coma e plugado no oxigênio dos cofres públicos são políticas, de concepção e de desenho, além de vinculadas a fatores externos ligados à dinâmica urbana e econômica da região metropolitana de Salvador. Mas foi sua utilização como instrumento de promoção do governo estadual e como vitrine de sua capacidade e eficiência, durante os anos 1990, o que explica, em última análise, a permanência de um esquema de gestão insustentável. O excelente acolhimento inicial junto à população reforçou a ideia do governo de manter a intervenção totalmente sob seu controle, evitando parcerias para maximizar os ganhos políticos e de imagem dela decorrentes. Mesmo quando o modelo de gestáo começou a ser criticado dentro da própria administração estadual como paternalista e oneroso, não houve interesse real em modificá-lo. Em parte porque o paternalismo tem sido um traço recorrente do Estado baiano e, além disso, por não haver confiança na capacidade do empresariado 
instalado de assumir as ações de manutenção no ritmo desejado pelo governo. Em parte, também, porque se temia que a perda dos incentivos causasse uma debandada geral dos comerciantes, agravando a situação da área. Contudo, o que pesou, aparentemente, de modo decisivo, na manutenção dessa forma de gestão, foi a possibilidade de controlar e de manter a área recuperada como uma espécie de outdoor permanente da administração estadual. Para tanto, o Pelourinho tinha de ser pintado constantemente e parecer-se, o tempo todo, com uma fotografia. Tinha de ser um hiper Pelourinho, sempre novo em folha e isento das marcas de seus usuários e de suas próprias contradições, a fim de cumprir a função midiática de signo da baianidade, ícone do turismo e do lazer, símbolo do bom governo e anteparo visual que esconde a pobreza localizada atrás (Foto 15). Se levarmos em conta que a conservação e a pintura periódica das fachadas dos imóveis recuperados custava, no começo dos anos 2000, em média, R\$ 1,1 milhão por ano, e que qualquer campanha publicitária de curta duração custaria muitíssimo mais, fica fácil entender que, não para o Estado, mas para o grupo político que o ocupava, era vantajoso manter o modelo, evitando-se, inclusive, que o mercado e a realidade operassem os seus ajustes.

A concepção da área como um shopping, mas sem as regras comerciais desse tipo de empreendimento e sem a adesão de todos os envolvidos, também não permitiu que a intervenção caminhasse com os próprios pés. O desenho urbano adotado, por sua vez, tampouco funcionou como se esperava, ou seja, como um instrumento a promover essa integração. O programa retomou e executou o projeto de aproveitamento do interior dos quarteirões como área de uso comum - projeto que, como visto, estava proposto para o Pelourinho desde os anos 1970. De acordo com essa ideia, os quarteirões deveriam funcionar como unidades de vizinhança dotadas de áreas comuns de lazer, descanso e convivência, formando minicomunidades solidárias. Para tanto, as divisões de parcelamento ainda existentes deveriam ser eliminadas, assim como os anexos construídos ao longo do tempo, abrindo-se áreas nos centros dos quarteirões (Foto 16). Em 1992, conjugada à intenção de evitar ocupações irregulares nos fundos dos lotes, a ideia foi posta em prática mediante a doação desses terrenos ao Governo do Estado, como uma das modalidades de contrapartida dos proprietários à recuperação de seus imóveis. Para a manutenção desses miolos de quadra, foi proposta a formação de condomínios, projetando-se, 
inclusive, um reservatório d’água comum a cada um. Os ocupantes, entretanto, recusaram-se a formar tais condomínios, uma vez que nem todos mantinham contratos de concessão com o IPAC, o que fez com que, na prática, essas praças internas resultassem em mais área a ser mantida pelo poder público. Assim, o desenho de inspiração higienista/modernista, além da destruição que operou no patrimônio local, acabou funcionando como mais um entrave à passagem da gestão do setor aos seus atuais ocupantes.

A sustentabilidade econômica dessa intervenção comercial no centro histórico vinculou-se, ainda, à dinâmica da cidade após esta ter completado o processo de fragmentação de suas funções centrais, que foi iniciado nos anos 1960. Enquanto um novo centro de comércio, animação e lazer, o Pelourinho tinha também, nos anos 1990, concorrentes de peso - como o antigo Shopping Iguatemi, o bairro do Rio Vermelho, a Barra e o Shopping Aeroclube -, que, por estarem mais próximos dos bairros de classe média alta, tendiam a absorver esse tipo de consumidor. Conforme as pesquisas da época mostram, o Pelourinho era frequentado para fins de lazer, principalmente, por moradores da própria área central e de outros bairros próximos, como Liberdade e Brotas, que eram e ainda são muito carentes desse tipo de espaço. (COMPANHIA DE DESENVOLVIMENTO DA REGIÃO METROPOLITANA DE SALVADOR, 1996a) Esse público animava bastante e dava vida ao lugar, mas não consumia muito. Ou melhor, consumia, em geral, o que vendiam os vendedores ambulantes que acorriam ao local nos fins de semana e nas noites de festa.

Além disso, o enclave comercial criado, muito centrado em lojas de artesanato, joias, bijuterias e galerias de arte, não se relacionava com esse público, nem com a dinâmica terciária do entorno, voltada também para o consumo popular. Apesar dos esforços feitos no final dos anos 1990, relacionava-se ainda menos com os consumidores de alta renda da cidade. Estes, além de não se interessarem pelo tipo de produto muito turístico comercializado no Pelourinho, já haviam enraizado, desde os anos 1970, seus hábitos de compras em outras áreas da cidade. Por sua vez, os turistas - para os quais, em rigor, este enclave foi desenhado - correspondiam, na alta estação, a menos de 20\% dos usuários (Tabelas 10 e 11). Mesmo que quisessem, entretanto, eles também não teriam como consumir muito, pois o que se 
oferecia nas cerca de 70 lojas de artesanato instaladas no centro histórico era, em geral, muito igual, sem qualidade ou originalidade. (INSTITUTO DO PATRIMÔNIO ARTÍSTICO E CULTURAL DA BAHIA, 2002)

Não é nova, como se viu, a ideia do turismo como atividade essencial para o desenvolvimento da economia das cidades do Nordeste. Remonta aos anos 1960 e, desde então, nunca parou de ser perseguida, apesar de seus parcos resultados em termos de desenvolvimento real e de preservação de áreas históricas. (AZEVEDO, 2001; SANT'ANNA, 2014) Na Bahia, sua permanência no horizonte dos planos de refuncionalização do centro histórico nos anos 1990 se vinculou ao fato de Salvador ter sido sempre, mesmo quando do desenvolvimento da indústria no estado, uma cidade eminentemente terciária, com forte ancoragem no setor de serviços - tendência geral que se reforçou ao longo da década em exame. ${ }^{42}$ Apesar desse traço, a atividade turística sempre encontrou dificuldades para se desenvolver plenamente na cidade, devido a problemas semelhantes aos que ainda ocorrem no plano nacional, como grande distância dos mercados emissores mais importantes, conjunturas socioeconômicas desfavoráveis e problemas urbanos estruturais, assim como outros relacionados à má distribuição de renda, à pobreza e à violência urbana. Embora na década de 1990, com os investimentos feitos pelo Estado da Bahia, o fluxo turístico tenha aumentado, esse incremento, como já observado, não foi significativo, inclusive em termos de receita, o que explica as dificuldades de consolidação deste e dos outros enclaves turísticos criados nesse período.

No começo dos anos 2000, a conjuntura ainda não apontava para um nível de crescimento da atividade turística que permitisse torná-la o eixo principal de sustentação do centro histórico e nem mesmo de um setor como o Pelourinho. Apesar dos grandes esforços então feitos pelo Governo da Bahia para aumentar a participação do turismo na economia do estado, a conjuntura econômica e social do país, bem como o cenário de insegurança no plano mundial após os eventos de 2001, não autorizavam grandes expectativas. (EMPRESA DE TURISMO DA BAHIA, 2001a)

O Programa de Recuperação do Centro Histórico de Salvador, em sua face comercial e turística, enfrentou, assim, fatores internos e externos importantes para se consolidar. Como lugar turístico apartado do cotidiano da cidade, o projeto
42 Entre 1990 e 1996, as taxas de emprego/ ocupação em Salvador, no setor de serviços, oscilaram entre 52\% e $56 \%$. (FERNANDES, 1998, p. 29) 
não foi capaz de se sustentar nem de vencer as dinâmicas de esvaziamento e degradação que o ameaçavam. Apresentado, em 1992, como a "solução" para o centro histórico, o "empreendimento" Pelourinho já mostrava no começo da década de 2000 toda a sua fragilidade e incapacidade de promover uma preservação sustentada da área. A face habitacional do programa, contudo, parecia ter horizontes mais claros. Pesquisas mostravam que havia uma demanda significativa por unidades habitacionais reabilitadas no centro histórico e no Comércio, na faixa de renda que se encaixava nas operações que estavam sendo montadas. (COMPANHIA DE DESENVOLVIMENTO URBANO DO ESTADO DA BAHIA, 2001) Além disso, a dinâmica habitacional dos bairros vizinhos e a dinâmica comercial da área central apontavam, melhor do que qualquer estudo então encomendado, a viabilidade desse tipo de intervenção.

A "recuperação" no centro histórico, entretanto, não foi utilizada como um instrumento de política urbana e emancipação social. À época, a atitude do Governo da Bahia com relação aos graves problemas sociais existentes na área foi de simplesmente empurrá-los para fora, sem aproveitar a oportunidade para desenvolver uma social consistente, ainda que isso implicasse o reassentamento da população moradora. A indenização pura e simples das pessoas foi uma forma de eximir-se de responsabilidades e baratear custos.

No Programa de Recuperação do Centro Histórico nem todos os atores interessados foram envolvidos ou mesmo levados em consideração, e o grande ausente foi, com certeza, a população moradora. Sua única forma de participação nos anos 1990 foi não criar problemas e se retirar o mais rapidamente possível da área, para que as obras começassem e a roda da renovação fosse posta em marcha. Até 1999, a intervenção foi o resultado do desempenho de um só ator: o Governo do Estado da Bahia. A partir de 1999, contudo, outras instâncias do poder público e algumas agências de financiamento entraram em cena, alguns enfoques mudaram, buscaram-se soluções mais sustentáveis e mais coerentes com a dinâmica da área central, mas a população residente continuou fora da cena. Sob o peso do fracasso das políticas assistencialistas de outrora, a população foi vista como um entrave, e não como uma parceira da recuperação.

O programa, em suas seis primeiras etapas, constituiu, sob certos ângulos, quase um anacronismo. Foi uma intervenção típica dos anos 1970, correspondendo 
a um modelo de Estado, de governo e de política de desenvolvimento econômico bem diferentes dos apregoados nos anos 1990. Diferentemente do que então ocorria em outras cidades brasileiras, nesta intervenção não houve corporações empresariais atuando diretamente - nem mesmo com a máscara de sociedade civil -, nem houve a associação entre setor público e setor privado típica do então chamado "empresariamento urbano". O Pelourinho dos anos 1990, em seus aspectos arquitetônicos, urbanísticos e de gestão, era mais modernista e autocrático do que "pós-moderno" e "neoliberal". O projeto de aproveitamento turístico era também antigo e tributário de uma concepção ultrapassada. Embora, como outras intervenções da época, usasse as cores como parte de uma estratégia promocional, seu projeto visual vinculava-se ao momento em que os meios de comunicação de massa se desenvolveram no país e passaram a construir, a partir de um centro hegemônico no Sudeste, a identidade da região onde se situa. Nos anos 1970, através das telenovelas, coube à Bahia e ao Nordeste essa imagem supercolorida e festiva que se reproduziu em todas as intervenções realizadas na região durante os anos 1990.43 O que foi novo na intervenção do Pelourinho foi o seu uso direto como mídia, como instrumento de marketing e vitrine governamental, mantida, artificialmente, para fins promocionais. Nos anos 1970 montava-se uma intervenção desse tipo, em que pesem todos os equívocos, para "desenvolver". Nos anos 1990, montou-se para convencer e vender uma imagem.

É curioso notar que a intervenção de mais peso sobre o patrimônio urbano brasileiro que marcou, no início dos anos 1990, sua utilização como tema de renovação, requalificação e reestruturação urbana foi, na realidade, uma intervenção desenhada em outra época, mas que somente então encontrou condições para se realizar. Essa intervenção mostrou que uma nova valorização econômica do patrimônio também podia ser feita com velhas ideias - ideias cujo potencial imagético e de comunicação, entretanto, não havia sido percebido antes.

O Programa de Recuperação do Centro Histórico teve o mérito, contudo, de paralisar o processo de arruinamento e deterioração em que se afundava uma das partes mais valiosas da área tombada do centro antigo de Salvador - produzindo alguns efeitos de reversão do seu quadro de desvalorização imobiliária. Tais efeitos apontavam, no começo da década de 2000, para o recrudescimento de um processo de gentrificação que já havia se instalado em alguns pontos, mas também
43 No bairro do Recife, no bairro da Ribeira, em Natal, e na Praia de Iracema, em Fortaleza, utilizaram-se, sem exceção, cores vivas e chamativas nos imóveis, como em Salvador. Cores que são as mesmas dos cenários das novelas transmitidas em cores nos anos 1970, como O Bem Amado e Gabriela, e que seguiam sendo reproduzidas em produções mais recentes, como a novela Tropicaliente. 
44 Para dar

cumprimento a essa determinação, foi celebrado, em 1985 , o convênio entre Prefeitura Municipal,

Governo do Estado e IPHAN, que criou o Escritório Técnico de Licenças e Fiscalização ETELF. Por falta de apoio dos órgãos envolvidos, entretanto, esse escritório limitavase, nos anos 1990, a realizar trabalhos urgentes de fiscalização e aprovação de intervençóes caso a caso. As normas produzidas nos anos 1980 para as subáreas dos Perdões, Santo Antônio e Carmo nunca foram oficializadas.

45 Convênio nº03.99, publicado no Diário Oficial do Estado da Bahia, em 7 fev. 1999 para uma diversificação de usos e de população, a depender dos resultados dos projetos habitacionais que estavam em curso na sua $7^{a}$ etapa e das experiências então financiadas pela Caixa Econômica. Já era perceptível que a permanência de uma população de menor renda no centro histórico dependeria inclusive dos mecanismos de fixação que esses projetos pudessem ensejar.

A participação da Prefeitura Municipal de Salvador nos projetos de revitalização e recuperação do centro histórico teve sempre um caráter marginal, exceto por um curto período na segunda metade dos anos 1980. Esse divórcio do município em relação às políticas de preservação do patrimônio tem raízes no regime militar, quando as municipalidades foram completamente submetidas aos governos estaduais. Estes atuavam nos territórios das capitais por meio de agências de desenvolvimento, como a CONDER, no caso da Bahia. Enquanto no Rio de Janeiro, a partir do processo de redemocratização do país, o município foi o grande promotor das ações de preservação do patrimônio urbano, em Salvador, devido a um enraizamento maior dessa herança autoritária, a tarefa permaneceu ligada ao Governo do Estado e totalmente alienada da gestão municipal.

A legislação de uso do solo, por exemplo, mantém um vazio no centro histórico de Salvador, pois a Lei n 3 .289, de 1983, que criou a Área de Proteção Cultural e Paisagística do Centro, jamais foi regulamentada no sentido da produção de parâmetros urbanísticos e critérios de intervenção específicos para esta área. ${ }^{44}$ Ao lado disso, embora exista considerável massa de informações sobre seus monumentos e edifícios mais destacados, o conhecimento produzido sobre as características morfológicas do tecido urbano do centro histórico tem sido parco e tem feito com que a maioria das intervenções ignore, sistematicamente, relações tipológicas e de ocupação que caracterizam essa área, e introduza elementos que, pouco a pouco, vão lhe tirando o caráter.

Quando o grupo político que se mantinha no governo estadual desde 1991 venceu as eleições municipais de 1996, a prefeitura passou a ser oficialmente parceira do Programa de Recuperação do Centro Histórico. ${ }^{45}$ Seu papel, entretanto, permaneceu secundário, ligado a serviços de manutenção, iluminação e limpeza do espaço público e ao agenciamento de algumas praças. As ações de reabilitação de imóveis que o município tentou iniciar no âmbito do Programa de Revitalização de Sítios Históricos da Caixa Econômica Federal localizaram-se 
no Comércio e na periferia da área tombada, em decorrência de uma espécie de divisão de trabalho estabelecida pelo comando do grupo político comum. Apesar das requalificações de espaços públicos e das restaurações de monumentos comemorativos que desenvolveu à época, a Prefeitura de Salvador se manteve numa atitude passiva em relação ao governo estadual, que continuou exercendo grande influência sobre os rumos do desenvolvimento da cidade.

Sucesso de público, o Programa de Recuperação do Centro Histórico extrapolou as fronteiras do setor e se inspirou em ações voltadas para a promoção da cidade como um todo. Através da CONDER e, em seguida, da prefeitura, o poder público projetou e realizou, especialmente a partir da segunda metade dos anos de 1990, várias outras intervenções de requalificação de espaços públicos e de criação de atrações na cidade, boa parte delas na área central (Mapa 5). Essas intervenções, muitas das quais derivadas de propostas dos anos 1980, voltaram-se basicamente para a retirada e o ordenamento de ambulantes das áreas comerciais do centro, para a recuperação de praças e logradouros públicos, para a instalação, recuperação e iluminação cênica de monumentos, para serviços de pavimentação, iluminação pública e paisagismo (Apêndice A e Foto 17). Além dessas intervenções pontuais, teve início a construção do metrô da cidade, cuja primeira linha previa ligar bairros da periferia ao centro. Nesta área começaram a ser construídas duas estações: uma no Campo da Pólvora e a outra na Lapa, fortalecendo o polo comercial existente nessas imediações. Essa linha do metrô, que teve o seu trajeto original deslocado do coração para a periferia do centro, não funcionará, portanto, como um elemento de melhoria da acessibilidade e, consequentemente, de dinamização dos setores mais esvaziados do centro histórico, como as imediações da Rua Chile, da Ajuda e do Comércio (Mapa 5). ${ }^{46}$

Como mostra a listagem constante do Apêndice A, os investimentos privados de maior monta não foram muitos, embora alguns deles tenham sido fundamentais para a revitalização do comércio do centro, a exemplo dos shoppings. De início, especialmente por parte da prefeitura, foram buscadas parcerias com o setor privado para a execução de ações de requalificação através do Programa Municipal de Adoção de Praças, Áreas Verdes, Monumentos e Espaços Livres, criado em 1997. Contudo, como praticamente não houve resposta deste setor, os investimentos acabaram sendo feitos pelo setor público. ${ }^{47}$
46 No projeto original do metrô, a linha cruzava o centro antigo sob o seu conjunto de praças e logradouros historicamente mais importantes, com estações previstas no Taboão, na Praça Municipal, na Praça da Piedade e no Campo Grande.

47 Segundo Relatórios Anuais da Secretaria Municipal do Planejamento, Meio Ambiente e Desenvolvimento Econômico SEPLAM, apenas na requalificação da Praça da Inglaterra, no Comércio, estabeleceu-se parceria com o antigo Banco Excel - Econômico. (SALVADOR, 1997, 1998, 1999, 2000) 
Em nenhuma outra década, como na de 1990, se investiu tanto e em tão pouco tempo na área central, notadamente em açóes de embelezamento, com vistas a torná-la um ambiente visualmente agradável e a preparar a cidade para ocupar um lugar mais importante na preferência dos visitantes que têm o Nordeste como destino, além de uma posição mais competitiva na atração de investimentos. Considerando-se a estrutura e dinâmica da cidade à época, contudo, a intervenção no centro histórico e as outras realizadas na área central - por sua própria natureza epidérmica e por não estarem conjugadas a outras medidas de planejamento urbano - não tiveram força para deflagrar um processo de retorno de antigas funções ou para redirecionar para a área central vetores importantes de crescimento, investimento e circulação de mercadorias. Estes continuaram tomando o rumo do Vale do Camarajipe e da orla norte do Atlântico. O estado de abandono e esvaziamento em que se encontrava a área do Comércio mostrava que era preciso muito mais do que intervenções de embelezamento e de reformulação do sistema viário para ressuscitá-lo.

Entretanto, o Programa de Recuperação do Centro Histórico contribuiu para reforçar a antiga centralidade, especialmente em seus aspectos simbólicos, abrindo o setor, e consequentemente o centro, para um espectro mais amplo e variado da população. Ainda que discretamente, funcionou também como estopim de alguns processos espontâneos de renovação e de especulação imobiliária no seu entorno, que apontavam para novas tendências de ocupação da área central.

Foram ações e projetos privados que tentaram se beneficiar da renovação feita pelo governo (Apêndice B), tanto em termos da infraestrutura instalada como da nova ocupação promovida. Entre essas se destacam o Projeto Portal da Misericórdia (Foto 18); a renovação da Pousada do Carmo (Foto 19); a compra do antigo Cine Pax, na Baixa dos Sapateiros, para instalação de uma casa de shows; a compra do antigo prédio do jornal A Tarde e do Cine Guarani, para a instalação de hotel e centro de convençóes; a realização de construções de alto padrão na encosta de Santa Tereza; a construção de marinas e restaurantes finos na orla da baía, na Cidade Baixa (Foto 20); e a maciça aquisição de casarões na Rua Direita de Santo Antônio por estrangeiros, fazendo com que a área começasse a ser popularmente conhecida como "gringolândia" (Fotos 21 e 22). 
Nesse bairro, onde o valor dos imóveis esteve por muito tempo depreciado, verificou-se um considerável aumento, com casarões sendo adquiridos por preços três a quatro vezes mais altos do que no início dos anos 1990.48 Ou seja, as intervenções do poder público contribuíram para a elevação do preço do solo e dos imóveis em certos setores, beneficiando proprietários que nada investiam ou que haviam abandonado seus imóveis há muito tempo. Beneficiou também comerciantes e empresários instalados nas áreas recuperadas, os quais, apesar da elevação dos aluguéis em relação ao que era praticado anteriormente, operaram com custos de implantação e manutenção muito baixos, graças aos subsídios diretos e indiretos do governo. Esse quadro e a ausência de mecanismos de controle eficazes apontavam para uma crescente mudança no perfil dos habitantes das áreas mais cobiçadas, como as que têm vista para o mar.

Portanto, os fatos demonstravam que as intervenções de recuperação ou requalificação realizadas pelo poder público na área central de Salvador, apesar de terem melhorado a qualidade do espaço urbano e aberto a área para um espectro mais amplo da população, favoreceram basicamente os proprietários do solo. Em outras palavras, seus resultados econômicos foram apropriados principalmente por estes e pelos empresários que operavam no centro histórico renovado. O alcance econômico desses investimentos foi ainda curto e localizado, como ilustram os parcos benefícios que geraram para os polos comerciais da Baixa dos Sapateiros e das imediações da Lapa/Piedade, apesar de sua proximidade do Pelourinho. Além de nunca terem sido utilizadas como instrumentos de emancipação ou desenvolvimento social, como já apontado, as intervenções realizadas no centro histórico de Salvador pelo poder público nos anos 1990 se destinaram, em sua grande maioria, a "limpá-lo” de uma população pobre (e de suas formas de sobrevivência), cuja presença é considerada indesejável e inadequada às funções comerciais, turísticas e midiáticas que lhe estão destinadas.

Cabe, porfim, observar que o conjunto dessas intervenções - provavelmente devido à sua função eminentemente promocional, bem como à sua desvinculação de questões urbanas ou sociais - não se fundamentou em planos urbanísticos ou projetos globais, nem gerou a produção de dados sistematizados que permitissem monitorar seu impacto nos processos de esvaziamento e disfunção que caracterizavam boa parte da região. É surpreendente constatar que, após dez anos de

48 Segundo informações de moradores do Santo Antônio, casarões, muitas vezes em ruínas, localizados na Rua Direita e com vista para a baía eram vendidos em média por US\$ 40.000. No final dos anos 1980, o valor não ultrapassava US\$10.000,00. 
investimentos contínuos em "recuperação" e "requalificação" do centro histórico, nenhum setor do Governo do Estado da Bahia ou do Município de Salvador produziu ou reuniu dados atualizados que permitissem avaliar como, realmente, se comportaram os processos em curso na área central após as intervenções realizadas, e que possibilitassem propor correções de rumos. A política foi montada com base, principalmente, no plano estadual de turismo. Mesmo no âmbito dos novos projetos habitacionais, em que pesem as pesquisas de demanda realizadas, se trabalhou sem plano de conjunto e sem dados essenciais como, por exemplo, número de domicílios residenciais e comerciais vagos por setor. As informações, quando existiam, se encontravam dispersas e dificilmente mapeáveis. A Prefeitura de Salvador não dispunha, por exemplo, de dados sobre a arrecadação de ISS e IPTU por bairro ou região administrativa, o que, naturalmente, a impedia de avaliar até que ponto, no final dos anos 1990 e depois do esvaziamento do Comércio, o centro antigo como um todo havia perdido ou mantido centralidade. Em Salvador, as políticas urbanas eram ainda marcadamente voluntaristas e cientificamente pouco fundamentadas. A análise dos processos de esvaziamento, de perda de função, de transformação de padrões de ocupação, entre outros que afetam a área central, assim como o estudo aprofundado de sua dinâmica residencial, comercial e de suas carências urbanas, raramente fundamentaram as políticas de refuncionalização ou revitalização empreendidas.

Embora a revalorização do centro antigo tenha se tornado, no começo dos anos 2000, uma prioridade dos governos estadual e municipal, nenhum deles cogitou voltar para lá - fato que constituiria uma ação com poder de impacto sobre alguns processos negativos instalados. Mesmo a prefeitura, que tinha unidades espalhadas pela cidade e, há anos, dispunha de um projeto para implantar seu centro administrativo na cidade velha, não fez qualquer movimento concreto nesse sentido. Apesar de a situação de esvaziamento e desvalorização do Comércio oferecer atualmente uma oportunidade quase perfeita para esse projeto, até meados de 2003 nada havia sido proposto nesse sentido dentre as muitas intervenções previstas para a área central (Apêndice B). 


\section{A noção de patrimônio e as características da prática de preservação}

O patrimônio é um dispositivo ou uma espécie de forma vazia que as forças em embate no corpo social vão moldando, dando sentido e direção a cada momento. Nos anos 1980, o processo de redemocratização do país, a crise financeira e a falência do modelo de desenvolvimento eclipsaram temporariamente as políticas de aproveitamento turístico e econômico do patrimônio, elaboradas nos anos 1970, e o inseriram em lutas por melhor qualidade de vida, resgate da memória popular e conquista da cidadania. Buscava-se, então, com o patrimônio, resgatar testemunhos históricos de processos sociais e culturais, bem como as marcas que esses processos deixavam impressas em bens materiais e no espaço urbano. Ainda que constante apenas no discurso e já em descompasso com uma tendência mundial de banalização dessa prática, buscava-se, enfim, uma perspectiva histórica e social através do patrimônio. Uma fábrica, por exemplo, era restaurada para ter uma nova utilização, mas também para resgatar a memória da industrialização no país. Por isso, mesmo adaptada, não apenas sua fachada, mas a preservação dos seus elementos constituintes era considerada importante. Por isso também - embora nem sempre com sucesso - se procurava dar ao imóvel de interesse patrimonial um uso que favorecesse a passagem dessas informações.

Nos anos 1990, as intervenções que tomaram o patrimônio como tema e destinação decorreram de outras relações de força. Ao invés de repositório da memória social, o patrimônio voltou a ser, como nos anos 1970, atributo para valorização imobiliária, insumo para desenvolvimento de mercados, enfim, algo para ser consumido ou para promover outros produtos, seja como abrigo ou como chancela. Para tanto, de modo análogo às produções artísticas e culturais pós-modernas, o patrimônio foi despojado de qualquer profundidade estética ou histórica, ficando reduzido a uma aparência. Nesse contexto, importava apenas comunicar eficientemente e facilmente uma condição de "patrimônio", ainda que desprovida de sentido histórico ou cultural, o que redundou na supervalorização do "estilo", o que, no caso do patrimônio urbano, expressou-se no apreço especial pelas fachadas. Uma vez que não se pretendia informar sobre um outro tempo ou sobre as relações que o animavam, divisões internas dos imóveis podiam ser 
eliminadas, assim como as formas de parcelamento, ocupação e apropriação do solo urbano, as marcas dos usos e suas transformações. Esses elementos não foram considerados necessários à função que o patrimônio foi então chamado a desempenhar, e, por essa razão, somada às limitações dos financiamentos disponíveis, é que a maioria dos projetos tomou o patrimônio apenas como uma "casca" que serviria para abrigar qualquer coisa, ou como um cenário vazio que serviria, fundamentalmente, como pano de fundo para o consumo.

Em Salvador, as intervenções no patrimônio urbano se inseriram nesse modelo, mas mostraram também, em especial no caso do Programa de Recuperação do Centro Histórico, que o patrimônio serviu de justificativa para a instauração de um novo higienismo que, como o antigo, visava também a remover, das áreas que se desejava valorizar, uma população que atrapalhava e dificultava esses propósitos. A despeito dos protestos de atualidade e da imitação de modelos realizados em países desenvolvidos, as intervenções na área central de Salvador mostraram que, no Brasil, em muitos aspectos, os anos 1970 ainda não haviam acabado, e que os processos urbanos de reconquista de setores antigos nos anos 1990 ganharam contornos não exatamente iguais aos do primeiro mundo. Aqui o Estado que promoveu isoladamente esses processos e o valor econômico do patrimônio, por falta de mercado, continuou ainda artificialmente forjado. 


\section{Rio de Janeiro: patrimônio e cultura no fortalecimento do centro}

\section{0 centro do Rio de Janeiro: formação e hegemonia na estrutura urbana}

A defesa da costa e do Sudeste do Brasil, então sob constante ameaça de invasão francesa, foi o germe da fundação da cidade do Rio de Janeiro em meados do século XVI. Inicialmente encolhida ao pé do morro do Pão de Açúcar, a segunda cidadela ocupou o Morro do Castelo logo que foram afastados os invasores estrangeiros, confirmando a posse portuguesa da Baía de Guanabara. Com a união luso-espanhola e a derrota dos índios tamoios por volta de 1580, o povoado ganhou segurança para descer e se espalhar pela baixada entre essa elevação e o Morro de São Bento. No início do século XVII, o núcleo urbano já polarizava a administração do açúcar cultivado em seus arredores, bem como do pau-brasil extraído no sul (FRIDMAN, 1999, p. 17-18), ultrapassando, a cada ano, os limites físicos ou naturais que the eram impostos. Muros e valas de defesa mal eram construídos, já ficavam para trás, e, no espaço de um século e meio, a ocupação, 
que se concentrava na estreita faixa de litoral à borda da baía, atingiu toda a várzea entre os morros do Castelo e de Santo Antônio, ao Sul, e os de São Bento e da Conceição, ao Norte.

Com a descoberta das minas de ouro no interior no final do século XVII, a área econômica mais dinâmica da colônia deslocou-se do Nordeste para o Sudeste, impulsionando mais ainda o crescimento da cidade. O principal núcleo de comércio, escoamento de produtos e de geração de impostos migrou de Salvador para o Rio de Janeiro, o que tornou inevitável, em 1763, a mudança da capital colonial para esta última cidade. A expansão urbana, decorrente da riqueza gerada pelo ouro e pelo comércio, se deu principalmente no sentido oeste, mas, em meados do século XVIII, ainda não ultrapassava os mangues e pântanos situados na baixada além dos morros de Santo Antônio e da Conceição. Esses limites só foram ultrapassados definitivamente no século XIX, quando, com a vinda da família real portuguesa para o Brasil, em 1808, a cidade sofreu grande impacto cultural e populacional. (SCHWARCZ, 1998, p. 36) Os pântanos e lagoas que restavam ao Sul e a Oeste foram aterrados, toda a área do rocio foi ocupada e iniciou-se o retalhamento das chácaras localizadas ao Norte e ao Sul. A cidade se dividiu em freguesias centrais e arrabaldes, definindo, em meados daquele século, seus principais vetores de expansão: ao Norte, para além do campo da cidade, e ao Sul, rumo à enseada de Botafogo. Nas freguesias centrais, algumas áreas se especializaram (FRIDMAN, 1999, p. 42) e o núcleo em torno do Largo do Paço, que abrigava também moradias aristocratas, foi mudando de perfil a partir do crescimento das atividades comerciais e portuárias e do deslocamento de boa parte da corte e da aristocracia para São Cristóvão, Glória, Botafogo e Laranjeiras. Assim, em meados do século XIX, o sítio que antes abrigava toda a cidade do Rio de Janeiro se transformou em sua área central, tendo a Rua do Ouvidor como o principal núcleo de atividades econômicas. (MAGALHÃES, 2001, p. 15)

O declínio do preço do açúcar, em decorrência das guerras napoleônicas, e o progressivo esgotamento das minas, não chegaram a arrefecer o crescente dinamismo econômico da província do Rio de Janeiro, pois o café, ao longo do século XIX, se revelou um substituto à altura desses outros produtos, transformando-se no principal item brasileiro de exportação. (LESSA, 2000, p. 103) Em meados do século XIX, a província fluminense produzia 90\% do café brasileiro 
e respondia por 60\% da produção mundial, mas já nos anos de 1870 essa produção entrava em declínio, ocasionado pelo esgotamento do solo, pela alta do preço dos escravos e pela superprodução nacional, que então já incorporava os estados de Minas e São Paulo. (LESSA, 2000, p. 108-115) O café produzido no oeste de São Paulo, de melhor qualidade, com terras melhores e de maior produtividade, foi aos poucos se firmando como produto mais valorizado no mercado internacional e, no final do século, já assumia a dianteira. (LESSA, 2000, p. 123-124) Mesmo assim, o café foi o motor da economia fluminense durante o século XIX, propiciando, analogamente ao ocorrido em São Paulo, o capital para as primeiras aventuras de industrialização.

A independência política do Brasil, a pujança da economia cafeeira, a atração de capitais internacionais e, a partir de meados do século XIX, a chegada crescente de grande número de imigrantes impuseram grandes modificações na forma e nas funções da cidade. (ABREU, 1987, p. 35) O desenvolvimento dos transportes coletivos - bondes e ferrovia - permitiu uma grande expansão territorial e o aprofundamento da especialização da área central, que, então, abrigava também as primeiras indústrias. Apesar dos entraves vinculados à sua dependência do capital agrário, uma indústria de pequenos estabelecimentos pouco mecanizados se desenvolveu no centro da cidade, a partir da segunda metade do século XIX, o que, somado às atividades do porto e dos estabelecimentos comerciais e financeiros, consagrou a área como o grande polo de atividades da região e principal mercado de trabalho da cidade. Escravos libertos, escravos de ganho, imigrantes estrangeiros e migrantes de regiões mais pobres do Brasil apinhavam-se em cortiços, estalagens ou casas de cômodos na área central, em disputa por fregueses ou por qualquer serviço nas pequenas fábricas, trapiches ou armazéns do porto. A proliferação de moradias precárias começou então a preocupar as autoridades. Em 1856, as licenças para a construção de habitações coletivas tornaram-se obrigatórias e difíceis de conseguir. Em 1873, a construção de estalagens no centro foi proibida e, entre 1880 e 1890, vários cortiços foram fechados. (VAZ, 2002, p. 32) A quantidade e a insalubridade das moradias populares tornavam-se incompatíveis com a crescente valorização dos terrenos centrais.

Com a expansão do transporte ferroviário, estabelecimentos do setor industrial deslocaram-se para os subúrbios, drenando boa parte da população 
Como mostra Abreu (1987, p. 50-53), na virada do século XIX para o XX, com a implantação das principais linhas de trens, formaram-se os principais subúrbios do Rio de Janeiro. trabalhadora para essas áreas e diminuindo as pressões sobre o centro. Mas a concentração de atividades na cidade antiga permaneceu alta, o que, juntamente com o nível ainda baixo de industrialização, a preservou como local de trabalho para a população pobre que por lá se fixara.

Na virada do século XIX para o século XX, o núcleo de decisão política e econômica do país e centro de uma cidade cujo território já se estendia até Copacabana, Lagoa, Duque de Caxias e Cascadura' apresentava-se, aos olhos da época, vetusto, insalubre, cheio de cortiços e de animais nas ruas, num quadro em nada condizente com as importantes funções que exercia. Faltava lhe dar uma forma moderna e equipá-lo segundo os novos requerimentos econômicos, demográficos e sociais. Inauguraram essas providências as intervenções realizadas pelos governos federal e local entre 1902 e 1906, que ficaram conhecidas como "Reforma Pereira Passos". Essas obras deram forma concreta à ideia de Área Central de Negócios.

A Reforma Pereira Passos envolveu quatro tipos de intervenção no centro da cidade: abertura, ampliação e embelezamento de vias e praças; obras de saneamento; medidas de "limpeza" social, como a remoção de cortiços, eliminação de quiosques de alimentação e proibição de ambulantes (LESSA, 2000, p. 198); e a construção do novo porto do Rio. Os habitantes dos cortiços e das demais habitações coletivas demolidas durante esta reforma urbana foram engordar o crescimento dos subúrbios ferroviários ou simplesmente se mudaram para os morros que ainda contornavam o centro. Como já observaram vários autores, a reforma impulsionou a formação de favelas no centro e na área urbana consolidada. (ABREU, 1987; LESSA, 2000; SILVEIRA, 1995; VAZ, 2002) Ao eliminar moradias populares, sem desenvolver nenhuma política paralela de compensação, as intervenções obrigaram os trabaIhadores pobres que necessitavam viver perto do seu local de trabalho a ocupar os terrenos não disputados no alto dos morros. Como notou Lessa (2000, p. 192), o objetivo último dessa reforma não foi melhorar a vida das pessoas, mas criar uma imagem moderna e adequada ao papel que o Rio de Janeiro tinha e desejava ter no cenário nacional e internacional.

As cirurgias urbanas e as demolições tornaram-se a norma de intervenção na área central carioca durante quase todo o século XX, prática esta que foi reforçada com a instituição dos Projetos de Alinhamento - PAs e dos Projetos 
de Loteamento - PALs. Implantados no bojo da Reforma Pereira Passos, esses instrumentos urbanísticos determinaram o alargamento e o alinhamento de ruas, bem como o recuo frontal das edificações antigas, funcionando, como observam Vaz e Silveira, como um plano global de demolição que foi sendo executado "em doses homeopáticas". (VAZ, 2002; VAZ; SILVEIRA, 1996, p. 4) Os PAs e PALs funcionaram ainda, na medida em que a renovação do centro não se deu na extensão projetada, como elementos indutores de uma progressiva desvalorização e deterioração do tecido edilício existente.

As grandes avenidas abertas no começo do século XX - Central, Rodrigues Alves, Francisco Bicalho, Beira Mar, Salvador de Sá e Mem de Sá - implantaram um complexo viário moderno em torno da antiga malha da área central que, informalmente, naquele momento e, depois, explicitamente, em sucessivos projetos e planos urbanísticos, estabeleceu o tamanho do centro da capital nacional, em concordância com o seu esperado progresso e desenvolvimento. No interior deste território, cidade, população ou acidente natural que dificultasse esse projeto foi removido por intervenções urbanísticas, ou marcado para substituição no devido tempo. As intervenções viárias do início do século XX delimitaram, em suma, uma grande área de reserva para a expansão do centro decisório e de negócios do país, fixando os limites físicos de um core urbano dilatado que perdurou até os anos de 1970 .

Os pontos mais marcantes e emblemáticos dessa trajetória até o final do século XX foram a Reforma Pereira Passos; o arrasamento do Morro do Castelo, nos anos 1920; a abertura da Avenida Presidente Vargas, nos anos 1940; o desmonte do Morro de Santo Antônio e a construção da Avenida Perimetral, na década de 1950; as intervenções viárias no Estácio e no Catumbi, nos anos 1960; e a construção do metrô e da ponte Rio-Niterói, nos anos 1970. Ao longo desse período, a despeito da perda de polaridade industrial e econômica para São Paulo, da expansão urbana, da formação de subcentros e da perda de centralidade nacional para Brasília, os planejadores do Rio de Janeiro jamais deixaram de acreditar na possibilidade de expansão do centro antigo. Os planos urbanísticose os projetos elaborados apresentaram, invariavelmente, noções dilatadas da Área Central de Negócios e de sua zona de expansão. ${ }^{3}$ Apesar de, nos anos 1970, já ser clara a estagnação da dinâmica do centro e o esvaziamento dos seus bairros
2 As duas últimas resultantes do desmonte do Morro do Senado.

3 O Plano Agache, apresentado em 1930, e o Plano Doxiadis, elaborado entre $1961 \mathrm{e}$ 1965 
4 Instituído pela Lei Complementar $n^{\circ} 16$, de 4 de junho de 1992.

5 Estácio, Botafogo, Ipanema, Leblon, Tijuca, Bonsucesso, Ramos, Penha, Méier, Irajá, Ilha do Governador, Pavuna, Barra da Tijuca e Bangu foram classificados como centros de alcance municipal. periféricos, o Decreto Municipal n³22, de 1976, proibiu o uso habitacional em todo o setor, demonstrando o poder de permanência das visões otimistas do início do século. Essa proibição, que perdurou até os anos 1990, impediu a instalação de residências nas áreas de dinâmica comercial estagnada, bem como inibiu o investimento na conservação das habitações existentes, operando, assim, como um importante fator de aprofundamento da deterioração edilícia dos bairros centrais.

O Plano Urbanístico Básico do Rio - PUB RIO, de 1977, foi o primeiro a delimitar uma Área Central de Negócios próxima de sua abrangência real, mas ainda com área de expansão muito grande. Firmou o conceito de área central como conjunto formado por núcleo polarizador e periferia imediata comprometida com sua expansão, mas manteve a ideia de que essa expansão adentraria os bairros da Saúde, Gamboa, Santo Cristo, Cidade Nova, Estácio e mesmo São Cristóvão. (NASCIMENTO, 2000; SILVEIRA, 1995)

O Plano Diretor Decenal da Cidade do Rio de Janeiro, de $1992,{ }^{4}$ dividiu o município em cinco Áreas de Planejamento, englobando Unidades Especiais de Planejamento, Regiões Administrativas e bairros. A área central ficou contida na Área de Planejamento 01-AP 01, envolvendo a Região Portuária - I RA (bairros da Saúde, Gamboa e Santo Cristo), o Centro - II RA, Rio Comprido - III RA (bairros do Catumbi, cidade Nova e Rio Comprido), São Cristóvão - VII RA, Santa Tereza - XXIII RA e Ilha de Paquetá - XXI RA. Manteve, entretanto, uma concepção de área central semelhante à do PUB RIO, definindo seu núcleo polarizador como o principal centro de alcance metropolitano do sistema de centralidades do município. Outros centros de maior alcance foram também reconhecidos, como Copacabana, Madureira, Tanque/Taquara e Campo Grande, além de vários centros de bairros considerados de alcance municipal (Mapa 6). ${ }^{5}$ Estabeleceu-se que a organização espacial do sistema de centros deveria observar a racionalização do uso do sistema viário e de transportes, tendo como objetivo a redução da atratividade de tráfego para a Área de Planejamento o1. Foram ainda apontados como objetivos a expansão das atividades comerciais e de serviços da Área Central de Negócios para sua periferia e o fortalecimento dos centros de Madureira, Campo Grande e Taquara. Ou seja, apesar de a estagnação do núcleo principal do centro ser patente desde os anos 1970, de as estatísticas apontarem a continuidade do processo de esvaziamento populacional na área central (Tabelas 12 e 13) e do 
visível estado de abandono e desvalorização de boa parte do entorno, o plano diretor de 1992 ainda encarava o centro da cidade como uma área a ser desafogada. Prevaleceu, portanto, durante muito tempo, uma visão do centro antigo como uma centralidade forte e com fôlego para expansão.

As diretrizes de desafogo e de expansão da Área Central de Negócios contidas nos vários planos urbanísticos elaborados ao longo do século XX (a maioria de implementação tardia, incompleta e fragmentada) implicaram importantes ações de desmonte e alteração de elementos naturais, bem como de cirurgias urbanas que transformaram boa parte da forma original da cidade velha. $\mathrm{Na}$ esteira das projeções de crescimento que esses planos continham e dos projetos, nunca concluídos, que ensejaram, um rastro de deterioração, abandono e isolamento foi deixado em certas áreas. Os bairros da Saúde, Gamboa e Santo Cristo, na zona portuária, são exemplos do isolamento e da estagnação que resultaram dos aterros, intervenções viárias e desapropriações promovidos sucessivamente pela Reforma Pereira Passos, pelas obras do porto, pela abertura das avenidas Francisco Bicalho e Presidente Vargas, pela via expressa Laranjeiras/ Santo Cristo e pela ampliação da área da Rede Ferroviária Federal. (BLYTH, 1991; NEVES, 1996; RABHA, 1984, p. 105-119; SILVEIRA, 1995) As vias modernas abertas em torno da malha colonial dos morros centrais, sem ramificações de penetração, os transformaram em ilhas isoladas. Ao mesmo tempo, as desapropriações acarretadas por essas obras expulsaram a população, deslocaram usos tradicionais e promoveram vazios que contribuíram bastante para a degradação de toda a zona. (RABHA, 1984, p. 115)

Processo semelhante também ocorreu nas imediações da rua da Alfândega, no SAARA, ${ }^{6}$ onde os projetos não realizados da Av. Diagonal - que ligaria a Av. Beira Marà Presidente Vargas -, do novo alinhamento da Av. Presidente Vargas e o plano de reurbanização e reloteamento da Rua da Alfândega, promoveram, por meio de desapropriações e expectativas de substituição, o abandono (e também a permanência) de um tecido antigo que, neste caso, não se degradou completamente, devido à forte dinâmica comercial aí existente. Os comerciantes desse setor conseguiram, ainda nos anos 1960, reverter os planos de modernização e substituição traçados pelo poder público e preservar as características de uma atividade comercial adaptada e imbricada no tecido edilício existente. (BLYTH, 1991, p. 62)
6 Quadrilátero entre as ruas dos Inválidos, dos Andradas, Buenos Aires e Av. Presidente Vargas, de uso comercial varejista. O local ficou conhecido como SAARA por causa da Sociedade dos Amigos e Adjacências da Rua da Alfândega, entidade fundada em 1962. 
A Primeira Guerra Mundial impulsionou a indústria e, por volta dos anos 1930, o Rio de Janeiro detinha ainda o parque industrial mais importante do país. (ABREU, 1987, p. 71-72) Muitas empresas se instalaram nos subúrbios, atraindo mão de obra que se acomodou nas novas áreas dotadas de infraestrutura ou em favelas próximas às plantas industriais. (ABREU, 1987, p. 72) O centro se renovou e verticalizou, ainda que de modo concentrado na Av. Rio Branco e imediações, e a Zona Sul da cidade se expandiu rapidamente, impulsionada por investimentos públicos associados ao capital imobiliário. Esse foi um período de crescimento urbano acelerado, cujo dinamismo autorizou os projetos de expansão do centro contidos nos planos elaborados para a cidade. A baixa ocupação da Av. Presidente Vargas, contudo, já demonstrava, nos anos 1940, que a dinâmica de expansão do centro tinha limites menos largos do que os previstos, e mais vinculados aos interesses do capital imobiliário do que se poderia supor à época. O crescimento e o notável sucesso imagético de Copacabana promoveram aí a concentração de investimentos imobiliários e drenaram funções comerciais, de serviço e lazer antes exclusivas do centro. (ABREU, 1987; LESSA, 2000; VAZ, 2002)

O lento processo de deslocamento de funções centrais, iniciado no século XIX com a fuga das residências abastadas e da indústria, se deslanchou e adquiriu rapidez a partir do povoamento de Copacabana e da aceleração do crescimento da cidade. O racionamento de combustível durante a Segunda Guerra reforçou o surgimento de outros subcentros, como o do Méier e o de Nova Iguaçu, acompanhando a expansão dos subúrbios. (LESSA, 2000, p. 250) Esse processo se aprofundou ainda mais nos anos 1950, em consequência do novo impulso industrial recebido durante a guerra e da implantação da política de substituição de importações. Por fim, com a popularização do automóvel e o surgimento dos supermercados e dos shoppings, novos polos comerciais e de serviços foram disseminados na cidade.

Nos anos 1950 e 60, as intervenções viárias realizadas na área central ou que a tinham como destino - a exemplo do complexo de vias do Aterro do Flamengo, da construção da Av. Perimetral, do túnel Santa Bárbara e da via expressa entre Laranjeiras Santo Cristo - tentaram melhorar o acesso e a circulação de automóveis no centro, com vistas a facilitar sua expansão, mas esta não ocorreu. A área central do Rio de Janeiro já estava relativamente estagnada e imersa no processo 
de esvaziamento demográfico que aprofundou a deterioração dos bairros da Saúde, Gamboa e Santo Cristo,? e de outras áreas mais centrais, como Praça Tiradentes, Lapa e Cruz Vermelha (Tabela 13). Mas não foi somente o crescimento de Copacabana, dos subúrbios e demais bairros da Zona Sul que promoveu essa relativa estagnação da área central.

Embora no início do século XX o centro antigo ainda fosse o polo portuário e atacadista mais importante do país, a partir dos anos 1930, com o avanço da industrialização, o Rio de Janeiro perdeu progressivamente polaridade econômica nesse setor e no da agricultura para São Paulo - fato que se aprofundou no segundo período de expansão industrial dos anos 1950, quando as novas indústrias de bens de consumo duráveis se instalaram preferencialmente nessa segunda cidade. Conforme mostra Mesentier (1992, p. 105, 2001, p. 86), durante praticamente todo o século XX, foi constante e progressiva a perda de participação relativa da economia carioca e fluminense no cenário nacional e em relação a São Paulo (Tabela 14). Entretanto, durante os anos 1950, a cidade se manteve próspera como um grande polo de atração de migrantes e imigrantes, além de detentora do mercado consumidor mais importante do país. (LESSA, 2000, p. 237-238) A mudança da capital para Brasília, em 1960, foi, contudo, um golpe importante, pois transferiu atividades administrativas fundamentais, renda e o grosso dos investimentos federais que, até então, aportavam no Rio.

Os impactos da construção de Brasília na área central do Rio de Janeiro não se restringiram, contudo, à perda de funções e investimentos. A transferência do Governo Federal para a nova capital resultou no abandono de imóveis e de projetos de expansão já iniciados, deixando vazios urbanos que, devido a questões burocráticas, não foram absorvidos pelas administrações local e estadual. Ao lado disso, os projetos estaduais e municipais de deslocamento de unidades administrativas do centro para outras áreas da cidade, ainda que nunca completados, propiciaram a formação de novos vazios, que não foram preenchidos ou aproveitados. Esse conjunto de vazios contribuiu para aumentar a escassez e o valor de terrenos disponíveis no centro, inviabilizando investimentos privados e funcionando como mais um fator de abandono e degradação de certos setores, a exemplo das imediações do porto e do entorno da rede ferroviária. (NEVES, 1996)
7 Nesses casos, o esvaziamento foi devido à relativa obsolescência e à perda de importância do porto. 
8 Em estudo dos anos 1990, Bienenstein (2000, p. 279) apurou que empresários sediados no centro mencionam o Aeroporto Santos Dumont como um importante equipamento da Área Central de Negócios. Estatísticas do DAC confirmavam que o Santos Dumont superava em muito o Aeroporto Internacional Antônio Carlos Jobim (antigo Galeão) em movimento de passageiros embarcadose desembarcados em voos domésticos. (BRASIL, 2001а)
Entretanto, em meio à estagnaç̧ão e à falta de renovaçãao de sua periferia imediata, o núcleo financeiro e de negócios do centro - localizado, desde o início do século, nas imediações da atual Av. Rio Branco - renovou-se completamente e verticalizou-se ferozmente nos anos 1960, mantendo um nível alto de valorização imobiliária, que o preservou da deterioração. Essas características específicas da área central do Rio e dos processos de descentralização intra e interurbana que ocorreram na cidade ajudaram a manter esse núcleo, até os anos 1990, como a principal centralidade da região metropolitana, apesar de todos os "ataques" econômicos e de drenagem funcional sofridos ao longo do século XX. Com a construção da ponte Rio/Niterói, que ligou rápida e diretamente os dois principais polos da região metropolitana fluminense, e com a implantação do metrô, nos anos 1970, o centro do Rio se tornou uma das poucas áreas centrais no mundo a contar com todas as modalidades de transporte - ferroviário, rodoviário, metroviário, marítimo e aéreo. A presença do Aeroporto Santos Dumont nessa área é estratégica e tem segurado no centro antigo, pelas facilidades de deslocamento e de comunicação rápida com outras metrópoles nacionais (notadamente São Paulo, Belo Horizonte e Brasília), muitas sedes de empresas que, de outra forma, teriam sucumbido aos apelos dos lançamentos imobiliários "inteligentes" da Barra da Tijuca. ${ }^{8}$ Ao lado disso, o reforço da função cultural no centro da cidade - iniciado com as políticas de preservação do patrimônio dos anos 1980 e reforçado por várias iniciativas nos anos 1990 - foi bem-sucedido, não permitindo que outros golpes (como a perda de centralidade financeira para São Paulo nos anos 1990 e a aceleração do processo de transferência da burocracia federal para Brasília) se tornassem fatais ou destruíssem o equilíbrio alcançado. Cabe ressaltar que apesar da mudança da capital para Brasília, as sedes de empresas estatais, como Petrobrás e BNDES, se encontram ainda firmemente fixadas no centro do Rio, assim como muitos órgãos e unidades da administração pública federal.

Alguns autores reconhecem que o processo de deslocamento de funções dos centros antigos não foi tão violento no Rio de Janeiro quanto em cidades como Salvador e São Paulo. (MAGALHÃES, 2001, p. 39) Embora esvaziado em sua periferia, contido em sua valorização e crescentemente usado por camadas populares, o centro do Rio chegou ao final do século XX mantendo o posto de principal e mais 
importante nó de atividades da cidade. As estatísticas de arrecadação de impostos e a matriz de viagens origem/destino em modo coletivo o atestavam claramente nos anos 1990. A II RA, que corresponde ao centro (Mapa 6), era então a região administrativa que mais arrecadava ISS e ICMS e a terceira em arrecadação de IPTU (Tabelas 15 a 18). É verdade que a participação relativa do setor na arrecadação de impostos no começo dos anos 2000 não havia crescido, ${ }^{9}$ e que o índice de inadimplência no pagamento do IPTU estava alto, em função do esvaziamento populacional e do grande número de unidades imobiliárias vazias. ${ }^{10}$

Entretanto, o centro era ainda uma área dinâmica em termos de comercialização de imóveis, mantendo taxas, no período de 1991 a 2000, próximas às das áreas onde o mercado era o mais aquecido da cidade (Tabela 19). Essa dinâmica imobiliária decorria, sobretudo, de investimentos em recuperação de edifícios antigos, já que os lançamentos imobiliários na área central foram poucos no período, assim como foi muito baixa a renovação edilícia em suas áreas renováveis, mesmo após a liberação do uso residencial a partir de 1994" (Tabela 20).

Apesar das muitas intervenções de requalificação realizadas na Área Central de Negócios do Rio de Janeiro ao longo dos anos 1990, bem como em suas imediações, a chamada periferia do centro (correspondente à zona portuária, Cidade Nova, Catumbi e às áreas da Central do Brasil, Lapa e Cruz Vermelha - Mapa 7) permaneceu em estado renitente de deterioração e má conservação edilícia, o que levou o poder público a propor diversos projetos com vistas à sua renovação, valorização e reanimação funcional. No entanto, até o começo dos anos 2000, o setor imobiliário não havia dado uma resposta à altura desses esforços e os vetores de investimento imobiliário se mantinham os mesmos, ou seja, na Zona Sul e na região da Barra da Tijuca e Recreio dos Bandeirantes, voltados, principalmente, para os segmentos de alta renda. (CARDOSO, 2000, p. 319-350; LAGO, 2000, p. 201-228) Essa situação (Mapa 6), aliada à permanência da tendência histórica de estagnação da economia do estado do Rio de Janeiro, não autorizava grandes expectativas quanto à atração de investimentos privados para a área central, e quanto à renovação ou, menos ainda, à expansão da Área Central de Negócios, com ou sem preservação de estruturas antigas. As estimativas do PIB da cidade mostravam que, apesar de todos os planos e intervenções "estratégicas" com
9 Entre 1997 e 2002, a arrecadação de ISS no centro cresceu apenas $4,6 \%$, enquanto em outros bairros as taxas foram bem mais altas: Barra da Tijuca (68\%), Copacabana (55\%) e Botafogo (33\%). (RIO DE JANEIRO, 2002a, p. 4)

10 Segundos dados da ADEMI, existiam na virada do milênio cerca de 5 mil salas fechadas no centro, sem interessados para transações de aluguel ou compra. (RIO DE JANEIRO, 2002a, p. 4)

11 O Plano Diretor Decenal da Cidade do Rio de Janeiro, de 1992, considerou adequado o uso residencial da área central e a Lei $n^{\circ} 2.236$, de 14 de outubro de 1994, instituiu a Área de Especial Interesse Urbanístico do Centro (II RA) e regulamentou essa norma. 
12 Nessa avaliação, entretanto, não foram considerados o setor financeiro, a indústria petrolífera e a renda imobiliária. vistas ao desenvolvimento econômico e ao aumento da competitividade urbana, a economia carioca se mantinha, em 2001, com o mesmo tamanho que tinha em 1991. (INSTITUTO MUNICIPAL DE URBANISMO PEREIRA PASSOS, 2002)12

Embora nítida e ancorada em sólidos predicados, a primazia da polaridade do centro antigo na estrutura urbana carioca apresentava um equilíbrio precário. Conspiravam contra essa primazia a estrutura polinuclear da cidade; a tendência de especialização de subcentros (como a Barra da Tijuca) nas atividades de negócios e serviços; os entraves fundiários, fiscais e financeiros para reabilitação de imóveis antigos para uso habitacional; e a falta de um planejamento territorial que colocasse limites ao capital imobiliário em sua sanha de incorporar novas áreas à cidade. A falta de solução para as questões estruturais que promovem a segregação social e a violência urbana, e que criam barreiras para a incorporação das camadas populares ao mercado formal de trabalho e da habitação, contribuía também para dificultar a manutenção da dinâmica e da hegemonia do centro, na medida em que travavam o atendimento a uma demanda real que intensificaria o uso da área central. Apesar de bastante avançado na Área Central de Negócios e nas suas imediações, a continuidade e a consolidação do processo de requalificação da área central não estavam garantidas, especialmente em função das dificuldades de desenvolvimento do uso habitacional. Para uma melhor compreensão desse processo, analisam-se, a seguir, as raízes históricas dessa dificuldade e as práticas que recentemente ensejou.

\section{Patrimônio e modernização}

Criado em 1937, o antigo Serviço do Patrimônio Histórico e Artístico Nacional, hoje IPHAN, estruturou sua ação inicial de preservação do patrimônio urbano segundo dois eixos: um voltado para a preservação ampla e integral de pequenas cidades do interior economicamente estagnadas, e outro voltado para o recenseamento e proteção de imóveis e pequenos conjuntos de valor excepcional nas capitais e cidades mais dinâmicas e importantes. No Rio de Janeiro, esta última vertente alcançou o desenvolvimento mais completo e sofisticado.

Igualmente praticada em Salvador e Recife até os anos 1950, essa linha de atuação consistia, em termos gerais, na identificação e tombamento dos 
exemplares arquitetônicos mais significativos do período colonial e do Império. O tecido urbano que articulava esses imóveis - em sua grande maioria, localizados no centro da cidade - não era protegido integralmente, permitindo-se, assim, sua renovação de acordo com as necessidades dos novos tempos. Comprometidos com o ideário urbano do movimento moderno, os fundadores do IPHAN não se opunham, portanto, à modernização das áreas centrais das grandes cidades, o que thes permitiu, no Rio, conviver, relativamente sem conflitos, com pesadas intervenções, como o desmonte do Morro do Castelo e outras cirurgias e intervenções urbanas ocorridas no período. Não apenas conviveram, como, em muitos casos, participaram do redesenho e da reocupação dessas áreas, a exemplo da Esplanada do Castelo, com a edificação do prédio do Ministério da Educação e Saúde, ${ }^{13}$ e com a elaboração dos planos de reurbanização da Esplanada de Santo Antônio (Fotos 23 e 24) e do Aterro do Flamengo.

A maioria dos tombamentos de bens imóveis realizados pelo IPHAN na cidade concentrou-se basicamente no centro. Inicialmente, a proteção da vizinhança dos bens tombados vinculou-se à sua fruição visual desimpedida e ao que se considerava "digno" de participar de sua ambiência. Assim, as normas regulavam, basicamente, as distâncias e o posicionamento de edificações novas em relação às protegidas, seu gabarito e a qualidade ou feição da arquitetura a permanecer ou a ser construída nas imediações dos bens tombados. O julgamento da qualidade arquitetônica se vinculava, naturalmente, às concepções modernistas de arte e arquitetura, que desprezavam as expressões ecléticas e neocoloniais que constituíam, então, a maior parte do tecido urbano na área central. Os quarteirões destruídos para a criação das esplanadas do Castelo e de Santo Antônio, e para a abertura da Av. Presidente Vargas, não foram, portanto, exatamente pranteados pelo antigo SPHAN. Neste último caso, os protestos se restringiram à destruição da Igreja de São Pedro dos Clérigos - bem tombado que foi eliminado com a abertura dessa via.

O grande mentor dos critérios de seleção e de intervenção praticados pelo IPHAN no centro do Rio de Janeiro foi Lúcio Costa. Em razão de sua posição proeminente no seio do movimento modernista e na criação do campo teórico e conceitual da preservação no Brasil, seus pareceres sobre questões relativas ao patrimônio eram reverenciados e ditavam norma, sendo essenciais para o
13 Hoje Palácio Gustavo Capanema. 
14 A DPHA foi criada pelo Decreto "N", n'346, de 31 de dezembro de 1964. Após a fusão do antigo estado da Guanabara com o do Rio de Janeiro, em 1974, a antiga divisão foi transformada em instituto. entendimento da política e das posições técnicas adotadas pelo IPHAN dos anos 1930 aos anos 1970. Lúcio Costa foi o principal responsável pela política que tinha como base uma seleção criteriosa e rigorosa do que então se entendia que valia a pena preservar. E foi também o desenhista, por excelência, da cidade moderna preservada e de sua paisagem. (COSTA, 1999, p. 11-19) O urbanista tornou-se, além disso, a referência do IPHAN no trabalho de harmonizar os conflitos entre preservação e "desejo de construir", sempre presente no Rio de Janeiro e no seu centro. (GUIMARAENS, 1999, p. 68)

Por força dos inúmeros bens tombados no centro da cidade, os arquitetos do IPHAN tinham ingerência sobre uma grande área, sendo responsáveis pela configuração de grande parte do centro do Rio de Janeiro, inclusive em sua área verticalizada. Nessa empresa, como observa Guimaraens (1999, p. 68-69), buscaram não somente concretizar suas concepções de cidade histórica moderna, como também corresponder às expectativas políticas e do setor da construção civil.

Com as ampliações conceituais operadas no campo preservacionista a partir dos anos 1960, em decorrência, inclusive, da homogeneização urbana produzida pelo urbanismo moderno, a prática de preservação do IPHAN no Rio de Janeiro começou a ser crescentemente questionada. As Cartas de Veneza, Avignon e Quito, e as recomendações de Budapeste e Amsterdã, do começo dos anos 1970, incitaram, em seu conjunto, o alargamento da fronteira tipológica e temporal do patrimônio e abriram caminho para o surgimento do tecido urbano como objeto patrimonial. Os primeiros reflexos dessa nova mentalidade chegaram ao Brasil nessa época e logo se estenderam aos segmentos sociais médios mais informados, os quais, diante da verticalização e da densificação verificada nas grandes cidades, do império do asfalto e da poluição gerada pelo número crescente de automóveis em circulação, começaram a exigir mais "qualidade de vida". Essa ideia foi associada em grande parte à preservação do patrimônio, o que fez com que, pela primeira vez, a causa patrimonial se estendesse para além do nicho intelectual e institucional costumeiro. No Rio de Janeiro, o campo institucional do patrimônio também se ampliou no período, com a criação, no final dos anos 1960, da Divisão do Patrimônio Histórico e Artístico do Estado da Guanabara - DPHA, embrião do futuro Instituto Estadual do Patrimônio Cultural - INEPAC, ${ }^{14}$ e do Projeto "Corredor Cultural", no final dos anos 1970, que originou a estrutura municipal de preservação. 
Os primeiros três quartos do século XX, portanto, se caracterizaram, no Rio de Janeiro, por uma grande reestruturação do espaço urbano e, notadamente, do centro da cidade, tanto em termos físicos como sociais. A partir do final dos anos 1970, com a crise econômica, com a descoberta do patrimônio como insumo turístico e com as pressões dos movimentos sociais de classe média por menos especulação e mais qualidade de vida é que esse panorama começou a mudar em direção a um novo modo de intervenção na área central: a da renovação com preservação intensiva do patrimônio. (MESENTIER, 1992)

\section{Preservação e fixação de funções centrais: o Corredor Cultural}

As primeiras instituições culturais públicas do Rio de Janeiro datam da vinda da corte portuguesa, mas aumentaram em número e abrangência ao longo dos séculos XIX eXX, enquanto a cidade manteve a posição de centro político e administrativo do país. Funções de lazer e entretenimento se desenvolveram na área central durante o século XIX, com os teatros da Praça Tiradentes expandindo-se, nos anos 1930, com a criação da Cinelândia no centro financeiro e de negócios da cidade. Com o desenvolvimento de Copacabana e com a formação de outros centros de bairro na Zona Sul, as atividades ligadas, principalmente, ao cinema e ao teatro se deslocaram, acarretando o esvaziamento dessas funções na área central. As instituições culturais públicas, ${ }^{15}$ contudo, aí permaneceram, e essa permanência foi favorecida pela construção de Brasília - que, ao absorver a maior parte dos investimentos federais, impediu a "modernização" e uma possível fuga dessas instituições para a Zona Sul, fixando-as no centro do Rio, enquanto aguardavam transferência para a nova capital. Enfraquecida a partir da década de 1940, a função cultural do centro da cidade fortaleceu-se nos 1980, com as novas instituições criadas na esteira do Corredor Cultural. Apoiada numa tradição de quase dois séculos, na excelente acessibilidade da área e, especialmente, no mar de incentivos fiscais estabelecidos na década de 1990, a atividade cultural tornou-se uma das âncoras do processo de requalificação e reposicionamento estratégico do centro na economia urbana.
15 Entre outras, o Teatro Municipal, a Biblioteca Nacional, o Museu Nacional de Belas Artes, o Museu Histórico Nacional e o Arquivo Nacional. 
16 Informação prestada por Augusto Ivan de Freitas Pinheiro, um dos fundadores do Corredor Cultural, em entrevista realizada em 20 fev. 2002.
A retomada do centro da cidade como importante polo de entretenimento, lazer e cultura começou em 1979, quando foram postas na mesa as primeiras ideias do projeto Corredor Cultural. O documento que apresenta o projeto mostra que a intenção inicial da então Secretaria Municipal de Planejamento era desenvolver um trabalho de reforço da função cultural no centro, como forma de otimizar a infraestrutura implantada, dar mais utilização e vida noturna ao setor, contribuindo ainda para a manutenção de atividades tradicionais julgadas importantes para sua vitalidade. (RIO DE JANEIRO, 1979) Essas atividades, ligadas ao varejo de perfil popular e a funções de recreação e lazer, vinham, há muito, sendo ameaçadas de substituição ou despejo pelos planos de expansão da Área Central de Negócios, estando sua continuidade vinculada à permanência das características morfológicas do tecido antigo da área central. O Corredor Cultural foi o primeiro projeto urbano do Rio a ir contra as práticas de substituição longamente estabelecidas no centro e a propor que se assumisse como fato a falta de demanda de expansão do núcleo central, justificando-se, assim, medidas de consolidação e preservação do estoque edificado existente em seu entorno. (RIO DE JANEIRO, 1979, p. 15-16)

A esse novo enfoque urbanístico acoplou-se o movimento de intelectuais que então se insurgia contra a perda da dimensão cultural relacionada ao ambiente urbano, perpetrada em nome de noções questionáveis de progresso e modernização. Planejadores e intelectuais lançaram então a proposta de preservação dos setores do centro que concentravam ainda grande número de edificações representativas do período colonial, do Império e da República, e que continham, portanto, parte importante da memória urbana sobrevivente a quase um século de transformações. A expressão "Corredor Cultural" foi uma crítica bem-humorada aos corredores viários e de tráfego tão caros ao chamado "urbanismo rodoviarista", cuja ideologia então ainda predominava, marcando-se a diferença de abordagem quanto aos rumos da renovação da área central. ${ }^{16}$

Aárea do projeto compreendeu três núcleos, envolvendo as zonas da Lapa e da Cinelândia, o SAARA, as imediações do Campo de Santana e um setor abrangendo a Praça XV e parte da Esplanada do Castelo, tendo como ponto de articulação e convergência o Largo da Carioca (Mapa 8). O projeto original do Corredor Cultural propunha a preservação do patrimônio edilício existente nesses núcleos, a promoção 
de eventos e a implementação de melhorias nos espaços públicos, estabelecendo-se uma zona de intervenção prioritária que envolvia áreas na Lapa, na Cinelândia e nos largos da Carioca e de São Francisco. Nessas áreas, se propôs a revisão da legislação urbanística, a gravação do uso recreativo e cultural para alguns logradouros, a concessão de incentivos fiscais, a criação de linhas de crédito, a programação de atividades e intervenções de desenho urbano, com instalação de mobiliário e programação visual. As áreas de preservação ambiental que foram delimitadas no SAARA, Campo de Santana, Misericórdia, Rua do Mercado e imediações, não foram consideradas prioritárias para intervenção nesse primeiro momento. (RIO DE JANEIRO, 1979, p. 35-59) A ideia de deslocar terminais de ônibus para a periferia do centro também estava presente como forma de minimizar os atritos entre pedestres e veículos. Como se poderá verificar adiante, o documento inicial do Corredor Cultural, que explicita suas propostas de intervenções físicas, não propunha nada muito distinto do que se executou depois nos anos 1990.

A crise financeira aprofundada nos anos 1980 freou os investimentos previstos no projeto do Corredor Cultural, fazendo com que prosperasse apenas o trabalho de proteção e gestão do patrimônio edificado na zona delimitada, que foi realizado por meio do fornecimento de orientação técnica e de incentivos fiscais à ação privada de conservação. Como o IPTU cobrado no centro era um dos mais altos da cidade (Tabela 21), os incentivos foram bem recebidos por proprietários e ocupantes, que viram como vantajoso o investimento em conservação. Tornaram também mais fácil o trabalho de convencimento dos comerciantes, empreendido pelo Escritório Técnico do Corredor Cultural. Esta estrutura, que não estava prevista no documento inicial do projeto, tornou-se peça-chave do processo, na medida em que o Corredor Cultural foi perdendo, ao longo dos anos 1980, sua característica mais intervencionista e assumindo os contornos de um sistema de preservação municipal, apoiado em legislação urbanística específica, apoio técnico, pesquisa e incentivos. Cabe notar que, nesse percurso, operou-se uma alteração no discurso de sustentação do Corredor Cultural. De início apoiado na racionalização do uso da infraestrutura urbana, na permanência de atividades tradicionais e na complementação de funções da Área Central de Negócios, apoiou-se, ao longo dos anos 1980, na preservação da história da cidade e da memória dos seus habitantes. 
17 No início do trabalho do Corredor Cultural foi realizado o "Levantamento Arquitetônico do SAARA", quando foram fichados 800 prédios, com discriminação de suas características arquitetônicas, estado de conservação, descaracterizações e detalhes de construção. (BLYTH, 1991, p. 69)

18 Declaração de Ítalo Campofiorito, então gerente do Projeto de Preservação e Renovação de Espaços Físicos da Fundação $\mathrm{RIO}$, em reportagem do Jornal do Brasil, de 23 jul. 1981. (BLYTH, 1991, p. 69)
Na construção do sistema de preservação municipal, que o Corredor Cultural inaugurou, foram importantes as pesquisas empreendidas sobre as características do patrimônio do centro da cidade e a elaboração, divulgação e aplicação de normas e critérios de intervenção. ${ }^{77} \mathrm{Na}$ base desses critérios estava uma concepção de preservação urbana baseada no seguinte princípio:

Nenhum bem cultural pode ser preservado integralmente, pois a li já passaram culturas diversas. Nenhum conjunto de bens pode ser conservado em sua totalidade, pois o progresso não pode ser tolhido. Aintenção do Corredor Culturalé preservar a continuidade do processo cultural, sem impedir que a cidade viva o progresso. ${ }^{18}$ (BLYTH, 1991, p. 69)

$O$ atendimento às necessidades dos usos existentes na zona preservada e a possibilidade de transformação são características marcantes das normas criadas pelo Corredor Cultural. O projeto operacionalizou uma ideia de preservação dinâmica, ancorada na identificação e preservação das características essenciais dos conjuntos arquitetônicos protegidos e na liberação das demais para transformação (Fotos 25 e 26). Os critérios de intervenção fundamentaram-se num conhecimento, se não exaustivo, bastante fino das características tipológicas e morfológicas das áreas selecionadas, o que deu importante sustentação técnica ao projeto. As normas buscavam, portanto, reforçar e preservar processos positivos de ocupação já instalados, por meio da manutenção de usos, como o comércio popular do SAARA, visto como tradicional do lugar. (INSTITUTO DE PLANEJAMENTO MUNICIPAL; INSTITUTO MUNICIPAL DE ARTE E CULTURA, 1995, p. 15) Para tanto, não foi exigido dos comerciantes dessa área, por exemplo, a reconstituição dos vãos dos térreos dos imóveis, pois os térreos abertos e o uso da calçada são traços marcantes de sua atividade, tendo sido assumidos como uma característica cultural. Essa visão sofisticada, somada ao processo lento de convencimento dos ocupantes para recuperação dos imóveis, favoreceu um resultado global que não "estetizou" excessivamente a área, especialmente em termos edilícios.

Essa visão, que incluiu a dinâmica de uso dos conjuntos, informou também as reflexões e os critérios construídos sobre o uso da cor na zona do Corredor 
Cultural - fundamentados em importante trabalho de pesquisa e ancorados em entendimentos prévios mantidos com os interessados. (INSTITUTO MUNICIPAL DE ARTE E CULTURA, 1990) Assumida como um elemento mutante e variável conforme a época, a oferta e o local da edificação onde é aplicada (além de influenciada por questóes econômicas, tecnológicas ou de estratégia publicitária), a escolha das cores das fachadas dos imóveis foi deixada livre para os ocupantes, sendo orientada apenas por parâmetros gerais que levam em conta a história, as características arquitetônicas dos edifícios e as relações entre as cores. A intenção foi evitar que um padrão de cor tipo "Corredor Cultural" e normas rígidas gerassem um cenário falso e ascético. Essas orientações gerais visavam também a evitar o "espontaneísmo", visto como prejudicial e descaracterizador.

Como as áreas que compõem o Corredor Cultural envolvem setores morfologicamente heterogêneos, cuidados foram tomados para não homogeneizá-los, utilizando-se estudos de massa para indicar como operar a transição entre eles. Os gabaritos elevados das zonas já renovadas que se encontram dentro do Corredor Cultural foram mantidos, estabelecendo-se, para os lotes vagos localizados entre as áreas preservadas e as verticalizadas, volumes de transição com altura compatível com o conjunto preservado, a fim de se realizar uma "costura" entre as morfologias distintas e diminuir o impacto direto de construções altas no casario. (PINHEIRO, 1987, p. 193) Para os lotes vagos foi estabelecido um gabarito médio de 10,5m, e proposta a inserção da nova edificação no contexto existente, sem repetição de características estilísticas. A regra de inserção, entretanto, não é rígida quanto às características das intervenções, estabelecendo-se como obrigatório apenas o essencial - gabarito e alinhamento - e sugerindo-se o diálogo com o ritmo das aberturas e com as dimensões predominantes das edificações vizinhas. Os materiais das construções novas não foram especialmente regulados e o parcelamento foi respeitado apenas no que impacta as fachadas. Para imóveis descaracterizados ou arruinados, recomendou-se a reconstrução dos elementos remanescentes, sugerindo-se, contudo, a adoção de linguagem contemporânea na reconstrução. A reconstituição estilística completa, entretanto, não foi vedada, sendo até mesmo exigida nos casos de perda total do imóvel em decorrência de negligência ou delito. (PINHEIRO, 1987, p. 192) 
19 Expressão cunhada pela arquiteta Maria Helena MacLaren, do Escritório do Corredor Cultural, em contato realizado em 22 fev. 2002.

20 Estimativa da arquiteta Maria Helena MacLaren, do Escritório do Corredor Cultural, em 22 fev. 2002
No Corredor Cultural as fachadas foram os elementos mais regulados, com descrição e ilustração exaustiva dos elementos que as compõem, assim como dos materiais mais empregados. Os interiores podem ser modificados, desde que a alteração não interfira na fachada nem na volumetria do imóvel. Assim, se estabeleceu que, até 3,50m, a partir do plano da fachada, os níveis dos pisos originais e as divisões básicas dos imóveis deveriam ser preservados, permitindo-se, entretanto, remanejamento e subdivisões daí para trás. Exigiu-se, portanto, a preservação do acesso às esquadrias, balcões e sacadas, recomendando-se, sempre que possível, a preservação de elementos como claraboias, escadas e prismas, característicos da tipologia interna das edificações. (INSTITUTO DE PLANEJAMENTO MUNICIPAL; INSTITUTO MUNICIPAL DE ARTE E CULTURA, 1995)

O Corredor Cultural nos anos 1980 procurou, portanto, através da negociação e do convencimento, preservar ao máximo os elementos importantes dos conjuntos protegidos, abrindo mão dos que não foram considerados fundamentais, a fim de angariar o apoio de proprietários e ocupantes. Buscou-se desenvolver uma prática de preservação diferente da que tradicionalmente decorre do tombamento de sítios urbanos, especialmente no que toca à rigidez normativa e à tendência à estetização. Com um "trabalho de formiguinha", 19 o projeto foi responsável pela proteção, até o começo dos anos 2000, de cerca de 1600 imóveis e pela recuperação de cerca de 1000. Nestes últimos, a iniciativa privada, que teve como contrapartida isenções de IPTU, investiu na conservação e recuperação de fachadas e volumetrias cerca de R\$ 40 mil por imóvel, totalizando, pelo menos, $\mathrm{R} \$ 40$ milhões em 20 anos. ${ }^{20}$

No início dos anos 1990, com a descoberta dos centros urbanos como áreas estratégicas, verificou-se a retomada dos projetos de intervenção no espaço público propostos pelo Corredor Cultural no final dos anos 1970, mas já não foram seu estilo e prática de trabalho que comandaram o espetáculo. Nos anos 1990, ocorreu um afastamento progressivo da equipe técnica do Corredor Cultural da concepção e da execução das intervenções realizadas na área central. Assim, pode-se dizer que o processo de reabilitação do centro do Rio sofreu uma guinada nesse período, mas não porque se passou a intervir nos espaços públicos, e sim porque o compromisso de trabalho junto à população foi esvaziado e porque se desenvolveu uma série de intervençóes que lembraram as "limpezas" sociais da Reforma Pereira Passos. 
Com o esvaziamento do Escritório Técnico do Corredor nos anos 1990, ocorreu, ${ }^{21}$ especialmente fora da sua zona mais estrita de atuação, uma tendência à tecnificação e à aplicação burocrática das normas que inspirou, o que esvaziou seu conteúdo dinâmico e fez aumentar a incidência de soluções fachadistas e "estetizantes", em decorrência, inclusive, das omissóes normativas que visavam a conferir flexibilidade à aplicação dos critérios. O risco de fachadismo, entretanto, existe desde que o tecido urbano foi reconhecido como um bem patrimonial. Sendo este tecido tradicionalmente visto, nas grandes cidades, como o lugar por excelência de renovação das formas, sua preservação conduziu o espaço de transformação e de manifestação do novo para o interior dos imóveis, firmando como "patrimônio" apenas volumes e fachadas. A tendência à constituição de cenários é, assim, muito grande, a menos que um trabalho cuidadoso seja feito, o que exige presença técnica constante, reflexão e discussão. Enfim, tudo o que deixou de haver nos "executivos", "estratégicos" e pouco reflexivos anos 1990.

\section{A ampliação do território preservado na área central}

Sob a influência do projeto do Corredor Cultural, entre 1985 e 2001, uma série de leis e decretos municipais foi promulgada para adequar as regras de ocupação e uso do solo da área central à preservação e à proteção de determinados setores. O primeiro desses instrumentos foi o Decreto $n^{\circ} 5.459$, de $08 / 11 / 85$, que delimitou, para fins de proteção ambiental, parte dos bairros da Saúde, Santo Cristo, Gamboa e Centro, nas I e II RAs. ${ }^{22}$ Nesse decreto, o uso residencial foi considerado adequado em toda a área protegida, contrariando-se a antiga diretriz de planejamento que desestimulava habitações na área central. Embora muito genéricas, influenciadas ainda por antigas diretrizes de renovação e menos sofisticadas que as do Corredor Cultural, essas normas marcaram uma primeira ampliação das disposições de preservação e a adoção, na área de planejamento municipal, de uma crescente atitude preservacionista com relação ao centro.

Na trilha da Área de Proteção Ambiental - APA dos bairros da Saúde, Gamboa e Santo Cristo, outros setores foram preservados pela Prefeitura do Rio na Cidade Nova e no Catumbi. Com a promulgação do Plano Diretor Decenal
21 Durante a gestão de Luís Paulo Conde (19972000), as competências do Escritório Técnico do Corredor Cultural foram repassadas para - Departamento Geral de Patrimônio Cultural - DGPC, permanecendo naquela unidade apenas um técnico.

22 Este decreto foi substituído pela Lei n 971, de 04 de maio de 1987, que instituiu a Área de Proteção Ambiental - APA dos bairros do Santo Cristo, Saúde Gamboa e Centro, e foi regulamentada pelo Decreto $n^{\circ}$ 7.351, de 14 de janeiro de 1988 , que manteve as mesmas disposições estabelecidas no Decreto $n^{\circ} 5.459 / 85$. 
23 Posteriormente, os Decretos $n^{\circ} 12.781$ de 6 de abril de 1994, e $n^{\circ} 12.800$, de 15 de abril de 1994, alteraram o anexo II da APAC da Cruz Vermelha, ampliando o número de imóveis a serem preservados.

$24 \mathrm{Na}$ APAC da Cruz Vermelha, por exemplo, a seleção da área baseou-se na existência de conjuntos representativos das primeiras décadas do século XX no Rio de Janeiro, adjacentes à zona especial do Corredor Cultural.

25 Instituídas respectivamente pelo Decreto $n^{\circ} 16.419$, de 23 de dezembro de 1997, e pela Lei n 3188 , de 19 de março de 2001.

26 Estrutura criada após a implantação do Corredor Cultural. da Cidade, em 1992, essas áreas foram transformadas em Áreas de Proteção do Ambiente Cultural - APAC, nomenclatura que designa, desde então, as zonas preservadas pelo município na cidade (Fotos 27 e 28).

$\mathrm{Na}$ II Região Administrativa (correspondente ao centro), a APAC que complementa e amplia a zona do Corredor Cultural é da área da Cruz Vermelha e Adjacências, instituída pelo Decreto nº 11.883, de 1992 (Mapa 8). ${ }^{23}$ De modo análogo ao Corredor Cultural, nas APACs são identificados e listados os "imóveis preservados", que deverão ter as intervenções mais reguladas, e os "imóveis tutelados", que podem ser modificados e até demolidos, consoante certas regras, tendo em vista a preservação e valorização ambiental. Assim, as APACs instituíram, além de normas específicas, graus de preservação do estoque edificado com base nos critérios de seleção que fundamentaram a delimitação dessas áreas e, ainda, com base no estado de conservação e no nível de descaracterização dos imóveis. ${ }^{24}$

Com relação aos imóveis preservados, as normas destinavam-se à preservação da volumetria, da fachada e de elementos construtivos e arquitetônicos julgados importantes. No caso dos tutelados, as regras visavam sua integração ao conjunto, mediante parâmetros gerais relativos a gabarito, volumetria e alinhamento. No interior das APACs podem existir imóveis tombados individualmente pelo município, os quais, nesse caso, obedecem a normas mais detalhadas e exigentes quanto à conservação de suas características. O uso habitacional é, normalmente, julgado adequado.

Além da APAC da Cruz Vermelha, foram delimitadas na área central, nos anos 1990, as APACs da Rua Teófilo Otoni e Arredores e a dos Arcos da Lapa, ambas na II RA (Mapa 8). ${ }^{25}$ Muitas vezes demandadas por associações de bairro, as APACs surgiam de estudos elaborados pelo então Departamento Geral de Patrimônio Cultural - DGPC ${ }^{26}$ do município, bem como do monitoramento do número de demolições solicitadas numa determinada área de interesse ambiental. Os estudos da APAC de Botafogo, por exemplo, resultaram de um aumento expressivo no número de pedidos de demolição no bairro. As APACs não regulamentavam usos, e seu emprego se relacionava claramente a necessidades de revisão de parâmetros de ocupação do solo, com vistas a um desenvolvimento urbano mais equilibrado e menos orientado pelo capital imobiliário. Por obterem grande espaço de divulgação e debate nos meios de comunicação, essas medidas 
de proteção se revelaram um importante instrumento de marketing para o poder público municipal, o que incentivou o uso do instrumento.

No começo dos anos 2000, o município do Rio de Janeiro possuía 28 APACs, nas quais estavam localizados diversos bens tombados pelo município. ${ }^{27} \mathrm{Na}$ área central, que incluía parte da I RA, toda a II e parte da III, pouco restava de área livre fora das APACs (Mapa 8), o que marca a diferença entre a política de preservação praticada até os anos 1970 e a posterior. Se a primeira pode ser definida como seletiva, baseada em proteções individuais e submetida às necessidades de transformação da cidade moderna, a partir dos anos 1980 a política tornou-se intensiva, abrangente e voltada para a construção de um centro histórico no Rio de Janeiro.

Além dos setores protegidos, a área central concentrava, nos anos 1990, o maior número de bens tombados da cidade, nos três níveis de governo. Conforme mostra a tabela 22, até 2002 haviam sido efetuados 181 tombamentos federais, estaduais e municipais, o que correspondia a 30,50\% do total de bens protegidos no município. Até 1977, a prefeitura efetuou 69 tombamentos na área central (além de instituir as APACs e a Zona do Corredor Cultural), e, até 2002, os governos federal e estadual haviam realizado, respectivamente, 64 e 48 tombamentos. Os tombamentos municipais seguiam uma linha semelhante aos estaduais, complementando a ação do IPHAN no sentido da proteção de bens representativos da evolução mais recente da cidade, das suas tipologias tradicionais de habitação coletiva, além de outros vinculados à história institucional da cidade, à memória urbana ou, simplesmente, ao folclore urbano (Anexo A).

O discurso que, nos anos 1990, apontou os centros antigos como áreas essenciais para a economia da cidade, ensejou, em muitos casos, a liberação de índices urbanísticos e a concessão de incentivos fiscais como forma de promover a produção imobiliária, de criar mais-valia para o patrimônio edificado e atrair atividades. No Rio de Janeiro, entretanto, predominou uma ampliação das disposições de proteção ao patrimônio, as quais são sabidamente mais restritivas do que a legislação urbanística normal. Caminharam nesse sentido o Plano Diretor Decenal, de 1992, e a lei que instituiu, em 1994, a Área de Especial Interesse Urbanístico do Centro. ${ }^{28}$ Esta, por exemplo, não estimulou a verticalização, nem estabeleceu vantagens para construção. Diferentemente da Operação Urbana Centro, de São Paulo, manteve-se o nível de verticalização existente, que foi
27 Informação prestada pelo Diretor do DGPC o arquiteto André Zambelli, em contato realizado em 22 fev. 2002.

28 Lei n ${ }^{\circ} 2.236$, de 14 out. 1994 . 
29 Opinião do arquiteto Augusto Ivan de Freitas Pinheiro, em entrevista concedida em 20 fev. 2002.

30 Embora tenha sido inaugurado para ser um centro cultural, o Paço Imperial só foi formalmente instituído como tal em 1997, através da Portaria IPHAN nº 140 de 21 de julho de 1997 , integrando biblioteca, centro de estudos e referência, circuito de exposições, cinema, teatro, música, eventos e atividades complementares.

31 A Fundaçăo Roberto Marinho e a RODHIA arcaram com boa parte dos custos do projeto e das obras de restauração. restringido nas proximidades das áreas protegidas. Uma possível expansão verticalizada foi deixada para a orla do porto, onde a existência de lotes maiores propiciaria mais liberdade na construção em altura. Nessa área, concentraram-se os esforços municipais de dinamização da produção imobiliária.

\section{Os centros culturais}

Na opinião de vários observadores, os centros culturais implantados na área central no Rio de Janeiro nos anos 1980 exerceram papel fundamental no processo de valorização do seu patrimônio. Esses equipamentos funcionaram como fatores de reversão do quadro de deterioração urbana e edilícia existente e trouxeram novos frequentadores para o centro. ${ }^{29}$ Essa "revolução cultural" começou pela mão do poder público, tendo como marco inicial a restauração do Paço Imperial, na Praça XV, e sua inauguração como centro cultural em 1985 (Foto 29). ${ }^{30} \mathrm{~A}$ Casa França Brasil, instalada no prédio da antiga Praça do Comércio do Rio de Janeiro, na Candelária, foi o segundo centro implantado (Foto 30). Iniciativa igualmente pública, cujo projeto teve início também em 1985, foi o primeiro equipamento do gênero a envolver a participação financeira da iniciativa privada em sua execução. ${ }^{31}$

Com a inauguração do Centro Cultural Banco do Brasil - CCBB, em 1989, formou-se, entre a Praça XV e a Candelária, nas imediações do núcleo financeiro do Rio, um polo cultural cujo sucesso desencadeou outras iniciativas semelhantes, como a abertura do Espaço Cultural dos Correios, em 1993, e do Centro Cultural Light, na Av. Marechal Floriano, em 1994 (Foto 31). Vinculados a organismos públicos ou a empresas estatais, esses equipamentos ocuparam edifícios antigos, esvaziados com a transferência da capital para Brasília, animando-os com atividades de prestígio. Constituíram os primeiros investimentos públicos de maior peso na revitalização do centro do Rio, que, até então, vinha sendo realizada no âmbito do Corredor Cultural apenas com base em investimentos privados e incentivos fiscais municipais. No começo dos anos 2000, a área central contabilizava 32 centros ou espaços culturais (Quadro 3).

A proliferação desses equipamentos encontra explicação no sucesso dos pioneiros, mas, principalmente, nas vantagens criadas pelas leis federais, estaduais 
e municipais de incentivo à atividade cultural, promulgadas na década de 1990. Esses incentivos tornaram os centros culturais um bom negócio, possibilitando sua profissionalização e seu uso como eficientes instrumentos de marketing das empresas que os patrocinam.

No começo dos anos 2000, o CCBB era, de longe, o centro cultural mais frequentado do Rio de Janeiro. Seu público cresceu de 1,6 milhão de pessoas por ano, em 1999, para 2,2 milhões em 2001,32 e esse sucesso decorreu, em grande parte, da programação oferecida pelo centro. Baseado em grandes eventos, o CCBB mobilizava eficazmente os segmentos sociais de maior renda e consumidores de cultura, que, por sua vez, conferiam prestígio ao centro e atiçavam o interesse dos meios de comunicação (Tabela 23). O centro cultural tornou-se grandemente responsável pela imagem positiva associada ao Banco do Brasil, o que levou seus gestores a afirmarem: 33

Nos últimos anos, investir em marketing cultural tem se mostrado uma alternativa mais inteligente e menos dispendiosa que a maioria das campanhas convencionais. Isso porque, além da publicidade, o marketing cultural tem outros instrumentos capazes de dar visibilidade à marca das empresas patrocinadoras, como o merchandising e as ações de divulgação orientadas para veículos de comunicação. Não por acaso, cada vez mais empresas têm dado o seu apoio a manifestações culturais e obtido excelentes resultados, tanto em nível institucional quanto financeiro. Investindo em cultura, elas se aproximam da comunidade, reforçam sua imagem junto ao público e ainda se beneficiam de incentivos fiscais. Ao contrário do que se acredita, é possível mensurar o retorno de projetos dessa natureza por meio de pesquisas de opinião, carta de consumidores, mídia espontânea e efeito multiplicador na memorização da marca. (CENTRO CULTURAL BANCO DO BRASIL, 1999b)

Os incentivos fiscais tornaram, de fato, o investimento em projetos culturais, especialmente no campo das artes visuais e cênicas, um negócio muito bom. A programação anual do CCBB, entre o final dos anos 1990 e o começo da década de 2000, tinha, em média, 48\% do seu valor aprovado para uso de renúncia fiscal, no âmbito do Programa Nacional de Apoio à Cultura - PRONAC, logrando-se uma
32 Dados obtidos em entrevista com o Diretor Adjunto de Comunicação e Marketing do CCBB, José Eduardo Dias de Oliveira, em contato realizado em 27 de fev. 2002.

$3327 \%$ da imagem positiva associada ao Banco do Brasil eram, à época, gerados pelo CCBB, que era, ainda, objeto de $25 \%$ das matérias jornalísticas que eram então publicadas sobre a instituição, das quais $99 \%$ eram positivas. 
captação, junto a patrocinadores, de 60\%, em média, desse valor (Tabela 24). Os patrocinadores mais constantes eram empresas coligadas ao próprio Banco do Brasil, como Brasil Capitalização, Brasil Veículos e Aliança do Brasil, o que, sem dúvida, ampliava as vantagens econômicas e imagéticas da renúncia fiscal. No Brasil dos anos 1990, o poder público financiou, em grande parte, essa estratégia. Reportagem do Jornal do Brasil de fevereiro de 2002 mencionava o surgimento de centros culturais no Rio de Janeiro em "ritmo de redes de farmácias" e perguntava quem via tanta cultura, pois na cidade havia 57 centros culturais. (AZEVEDO, 2002)

Em razão de sua excepcional acessibilidade e visibilidade, o centro do Rio de Janeiro surgiu como o lugar ideal para a implantação desse tipo de empreendimento cultural. O Quadro 3 mostra que, em 2002, 56\% dos centros culturais da cidade localizavam-se na área central. Os equipamentos maiores e de maior sucesso concentravam-se na Área Central de Negócios, ou em suas imediações, e contribuíam grandemente para a atração de um público de maior renda e para a valorização do setor. Os centros culturais de pequeno porte se localizavam, em geral, na periferia da área central, aproveitando a "economia de escala" gerada pelos grandes equipamentos.

No Rio de Janeiro, a tendência mundial de utilização da cultura como fator dinamizador de projetos de valorização urbana verificou-se concretamente nos anos 1990. A capacidade que os centros culturais tinham de induzir a substituição da ocupação de áreas degradadas e trazer novos usos e usuários animou outros governos a investir nessa estratégia, a exemplo do estado de São Paulo, no bairro da Luz. No Rio de Janeiro, os centros culturais contribuíram efetivamente para mudar a percepção da área central como local degradado e de ocupação popular. (MAGALHÃES, 2001, p. 66-67) Foram ainda responsáveis pela atração e fixação, em certas ruas, de um comércio mais sofisticado e promoveram a implantação de universidades privadas em edifícios comerciais esvaziados. Os grandes centros culturais foram, em suma, importantes âncoras do processo de revalorização do centro do Rio, contribuindo também para a manutenção da força dessa centralidade na estrutura urbana e metropolitana. 


\section{As intervenções no núcleo dinâmico do centro}

Embora tenham sido registrados indícios de recuperação econômica no final da década, a economia da cidade do Rio de Janeiro, como observado no início deste capítulo, não cresceu durante os anos 1990. Essa estagnação foi acentuada pela política de estabilização e pelo ajuste econômico deflagrados pelo Governo Federal no início da década, pelo enxugamento da máquina estatal e pela contenção dos gastos públicos. O Rio ainda abrigava o maior contingente de funcionários públicos do país, o que fez com a compressão salarial ocorrida nesse setor imprimisse reflexos negativos no desempenho econômico do município. (LESSA, 2000, p. 354) A busca de saídas para a crise foi, então, o traço principal das políticas desenvolvidas no Rio de Janeiro nesse período, todas estruturadas sob o signo da inserção competitiva da cidade e de sua região metropolitana nos mercados nacional e, especialmente, internacional.

A ideia norteadora foi o desenvolvimento do estado como um centro modal que articulasse países do cone sul e redes mundiais de distribuição e circulação de mercadorias e informações. Projetos como a ampliação do Porto de Sepetiba e o Teleporto vincularam-se a essa proposta. O novo hub mundial seria apoiado, na capital, não somente por um sistema atualizado de hotéis, centros de convenções e facilidades de infraestrutura, mas, também, por um centro urbano dotado de todas as facilidades e com a qualidade de vida das metrópoles dos países centrais. Assim, as intervenções de requalificação de espaços públicos e os projetos elaborados para a área central nos anos 1990 se articularam com esses grandes objetivos.

Qualidade de vida urbana, entretanto, requer investimento e, diante da crise financeira do setor público, prosperaram os modelos de intervenção baseados em parcerias com o setor privado, o que implica organizar a ação como um empreendimento urbano. As municipalidades e grupos técnicos responsáveis por experiências bem sucedidas de aplicação desse modelo nos países ricos se transformaram em referências mundiais, tendo suas ideias e planos replicados por toda parte. Programas de reconquista de áreas centrais, zonas portuárias e industriais esvaziadas do mundo desenvolvido foram transferidos para países periféricos, onde a maior parte dos problemas sociais e urbanos estava longe 
34 Criação e implantação de subprefeituras e Coordenações das Áreas de Planejamento.

35 Como se sabe, a identidade urbana, da qual o patrimônio é um dos mais importantes suportes, também é dinâmica e mutável, em consonância com as forças sociais, econômicas e culturais presentes na sociedade.

36 Requalificação da Rua Uruguaiana, Largo da Carioca, Cinelândia e Largo de São Francisco. de ser equacionada e onde a estagnação econômica tinha se aprofundado nas últimas décadas. Os resultados alcançados em termos de promoção da qualidade urbana foram, obviamente, incompletos, pois atuaram, basicamente, no nível da aparência. Os resultados econômicos e de sustentabilidade ficaram aquém do projetado, pois o setor privado não respondeu da maneira esperada, salvo quando o projeto localizou-se em seus vetores habituais de investimento.

Os principais instrumentos utilizados na consecução dessas novas políticas foram os chamados planos estratégicos, as intervenções pontuais de requalificação urbana, o city marketing, a flexibilização da legislação urbanística, a valorização do patrimônio edificado e a inserção de novidades no tecido urbano para aumentar sua competitividade. (BIENENSTEIN, 2000, p. 131) Tendo como principal referência a cidade de Barcelona, o Rio de Janeiro foi a cidade brasileira que mais logrou seguir esse modelo, apresentando, em 1995, o Plano Estratégico da Cidade, e desenvolvendo intervenções de controle da utilização dos espaços públicos; de requalificação de logradouros; de melhoria da aparência de corredores comerciais e viários; medidas de descentralização administrativa; ${ }^{34}$ e de flexibilização do aparato legal, especialmente através das chamadas "Operações Interligadas”. Além disso, foi criada, em 1997, a Agência de Desenvolvimento da Cidade do Rio de Janeiro para realizar a interface entre iniciativa privada e Executivo municipal, e, assim, viabilizar projetos considerados do interesse da cidade. (BIENENSTEIN, 2000, p. 163-200)

A área central e seu patrimônio surgiram nesse contexto como itens importantes para a divulgação de diferenciais urbanos e para a atualização da identidade da cidade, em concordância com os novos requerimentos da economia urbana. Até pouco tempo antes, o Rio de Janeiro ancorava sua identidade apenas na modernidade e em suas belezas naturais, mas, a partir dos anos 1980, o patrimônio foi ocupando um lugar de destaque ao lado desses predicados. ${ }^{35}$ Assim, no início dos anos 1990, o município começou a investir diretamente no centro, inicialmente retomando antigos projetos do Corredor Cultural, ${ }^{36} \mathrm{e}$, depois, com novos contornos e mais intensidade, na reforma de várias ruas e praças. Excetuando-se o Projeto Rio-Cidade, que requalificou a Avenida Rio Branco, foram investidos, entre 1993 e 1996, cerca de R\$ 100 milhões na II RA, apenas com 
recursos do município (Foto 32). ${ }^{37}$ As intervenções nas áreas protegidas foram executadas por instâncias da prefeitura, como a RIOURBE, ${ }^{38}$ e projetadas por equipes contratadas ou consultores estrangeiros.

A intenção de elevar o nível de renda dos frequentadores do centro por meio de atividades culturais e de entretenimento, que estava presente nos projetos iniciais do Corredor Cultural, adquiriu, nos anos 1990, novos contornos ligados aos modismos urbanísticos da década, aos requerimentos do city marketing e às necessidades de controle da ordem urbana embutidas nesse projeto de valorização. Na concepção dos gestores, para que o centro desenvolvesse seu potencial como área estratégica para a dinamização da economia urbana era preciso afastar da vista os segmentos de baixa renda e suas formas de sobrevivência.

Magalhães (2001, p. 86-117) mostra que, nos anos 1990, o que se poderia denominar como "programa de requalificação do centro do Rio" caracterizou-se, além dos melhoramentos feitos nos espaços públicos, por intervenções de controle do uso e da apropriação dos espaços requalificados. Foi realizada a recuperação de praças; a transformação de calçadões em ruas de serviço; a ampliação de calçadas; a construção de canteiros centrais; o deslocamento de terminais de ônibus; a iluminação de monumentos; a implantação de esculturas, quiosques de flores e de alimentação em espaços públicos; o fechamento de ruas ao trânsito de veículos; a manutenção de áreas públicas e a implantação e agenciamento de mobiliário urbano (Fotos 33 a 39; Apêndice C). As ações de "controle urbano" consistiram no ordenamento de ambulantes e demais praticantes de comércio informal (Foto 40), no disciplinamento de estacionamentos, na retirada de moradores de rua, na realização de eventos de caráter cultural (como feiras de artesanato, de antiguidades, shows etc.), e na implantação, em algumas áreas, de serviços de segurança privada. Muitas vezes, os dois tipos de intervenção estiveram conjugados, com o desenho urbano claramente articulando-se ao controle social. As intervenções realizadas nos Arcos da Lapa, em trecho da Rua do Carmo, na Praça Melvin Jones e na Av. Presidente Wilson constituíram os exemplos mais eloquentes dessa nova modalidade de "limpeza" urbana.

Para manter no centro da cidade a sede da Companhia Sulamérica de Seguros, a prefeitura permitiu, por exemplo, o fechamento com grades do trecho da Rua do Carmo entre as ruas do Ouvidor e do Rosário, eliminando, assim,
37 Informação prestada por Augusto Ivan de F. Pinheiro, em entrevista realizada em 20 fev. 2002.

38 Empresa de urbanização da cidade do Rio de Janeiro, vinculada à Secretaria Municipal de Obras Públicas. 
o dormitório de catadores de papéis que se localizava nesta área. A Sulamérica custeou a obra e as grades passaram a ser cerradas à noite (Foto 41). Na Praça Melvin Jones, o lago artificial, usado para banho por moradores de rua, foi transformado em anfiteatro em parceria com a loja do McDonald's local. O traçado da Av. Presidente Wilson foi alterado para dar mais segurança ao consulado americano-que também pagou pela obra. (MAGALHÃES, 2001, p. 86-117) Portanto, nos anos 1990, a parceria entre o setor público e a iniciativa privada se caracterizou, algumas vezes, pela associação da autoridade pública a recursos privados com vistas ao afastamento de usuários indesejáveis de certas localizações. Esse tipo de intervenção, que correspondeu a 13\% do total, ocorreu de modo concentrado na Área Central de Negócios e vinculou-se a interesses de empresas ou instituições lá sediadas.

O comércio informal na cidade do Rio de Janeiro atingiu grandes proporções já nos anos 1980, com o agravamento da crise econômica e o aumento do desemprego. No início da década de 1990, os camelôs ocupavam praticamente todas as ruas do centro, causando sérios problemas de circulação e de segurança. Esse quadro começou a mudar em 1993, quando, por meio de ações de repressão, iniciou-se o disciplinamento da atividade. No final dessa década, o comércio informal no centro já se encontrava bastante controlado e ordenado em pontos como a Rua Uruguaiana, o Terminal Menezes Cortes, o Largo da Carioca e a Central do Brasil. Contudo, se o problema dos ambulantes foi resolvido de modo razoável, ainda que com conflitos e necessidade de vigilância constante, o mesmo não ocorreu em relação aos moradores de rua. Por meio do desenho urbano e da ação policial, a repressão a esses usuários foi violenta e sem a contrapartida de programas sociais. (MAGALHÃES, 2001, p. 131)

As intervenções em espaços públicos no centro do Rio não fizeram parte de um plano de conjunto e não há um documento conhecido que as articule como um todo. Magalhães defendeu, à época, a ideia de que obedeceram a uma "estratégia implícita" que congregou, informalmente, seus principais atores: os três níveis de governo, empresas estatais e setores da iniciativa privada. (MAGALHÃES, 2001, p. 156) A natureza dessas intervenções e sua localização na área central, entretanto, abriram espaço para algumas outras considerações. 
O mapeamento das intervenções no território do centro mostra uma intenção clara de estender a "qualidade" (e, portanto, a valorização) da Área Central de Negócios para seu entorno próximo, tradicionalmente mais degradado. Conforme mostra a tabela $25,70 \%$ das intervenções realizadas nos anos 1990 localizaram-se neste núcleo e na sua zona de transição, nas imediações da Rua Uruguaiana e do SAARA (Mapa 9). As intervenções voltadas diretamente para o controle de ambulantes e da populaçáo de rua, bem como as intervenções de requalificação dos principais corredores de tráfego e de vias de pedestres concentraram-se no setor mais dinâmico do centro. Na sua zona periférica, ocorreram poucas intervenções (Apêndice C).

O conjunto das intervenções de requalificação urbana, executadas no centro do Rio, no período em foco, constituiu uma espécie de nova reforma urbana sem demolições. Em nenhuma outra cidade do Brasil - exceto, talvez, Salvador as intervenções de requalificação foram usadas tão clara e eficientemente como instrumentos de controle. No Rio de Janeiro, cobrindo quase todo o território do núcleo antigo, elas foram transparentes em informar sobre a estratégia que as comandava: valorizar e atrair quem pode investir e pagar. Por ter um norte tão claro foi que, a despeito da falta de planos, as ações dos distintos atores públicos e privados foram tão convergentes.

\section{0 desenvolvimento do uso habitacional na periferia do centro}

As ações na periferia do centro, incluindo-se a zona portuária e a Cidade Nova, embora em menor número, pautaram-se também pelo objetivo de expandir e dar sustentação ao processo de revalorização do núcleo central. Oscilaram entre políticas de desenvolvimento do uso habitacional e projetos de incentivo à expansão do centro de negócios com vistas à ocupação de vazios e à reabilitação de conjuntos arquitetônicos degradados.

A percepção de que a atuação na periferia do núcleo dinâmico do centro seria fundamental para a sustentação de sua valorização já estava presente no Plano Estratégico de 1995, quando foram repropostos os projetos de revitalização 
39 Recuperação da Praça da Cruz Vermelha e obras do Rio-Cidade na Rua do Riachuelo. dos bairros de Santo Cristo, Gamboa e Saúde; de revitalização do Estácio e da Cidade Nova; de complementação do projeto do Teleporto e de revitalização da Área Portuária (MAGALHÃES, 2001, p. 79) Entre as intervenções efetivamente realizadas ou iniciadas na década de 1990 destacam-se, além das ações pontuais no bairro da Cruz Vermelha, ${ }^{39}$ ações de melhoramento de infraestrutura urbana e espaços públicos nos morros da Saúde, Livramento e Gamboa; algumas intervenções vinculadas ao Projeto de Recuperação Orientada - PRORIO, no Morro da Conceição; e uns poucos empreendimentos habitacionais do Programa "Novas Alternativas".

Embora indicado, desde os anos 1980, nas propostas para a zona portuária, o desenvolvimento do uso habitacional surgiu então como essencial para a reversão de processos de deterioração instalados nas áreas periféricas do centro. No final da década de 1990, chegou a adquirir contornos de ação estratégica da prefeitura voltada para o uso mais racional da infraestrutura instalada e para a ampliação da oferta habitacional na cidade, destinada, ainda, a combater índices persistentes de esvaziamento populacional e de baixa atividade imobiliária na área central. Programas como o "Favela-Bairro", o "Morar Carioca", e, mais especificamente, o "Novas Alternativas", e o "Foco-Local" foram montados com essa finalidade.

O Programa "Novas Alternativas", por exemplo, destinou-se ao desenvolvimento de ações de reabilitação do estoque construído na área central, buscando o aproveitamento de edifícios antigos e a utilização de vazios. (RIO DE JANEIRO, 200ob) Somente no centro, esses vazios correspondiam a 5\% da área total da II RA e eram, na maioria, áreas que sobraram dos desmontes e cirurgias urbanas realizadas ao longo do século $X X$, pertencendo, em grande parte, ao poder público (Tabela 26). Na zona portuária, a proporção desses vazios era ainda mais expressiva e decorrente, principalmente, de uma visão inicial superdilatada das necessidades de ampliação do porto e da rede ferroviária.

Entre 1994 e 2000, a Prefeitura do Rio de Janeiro promoveu modificações no seu aparato legal a fim de incentivar a reabilitação de imóveis na área central para uso residencial. Entre essas mudanças, destacam-se a legislação que instituiu a Área de Especial Interesse Urbanístico do Centro e as alterações introduzidas no Código de Obras do Município. Estas disposições permitiram a aprovação de 
projetos habitacionais sem vagas de garagem, sem portaria e unidades com área inferior a 6om²,40 com vistas à viabilização de empreendimentos para famílias de renda média baixa. Além disso, foi sancionado o decreto que retirou a multa cobrada por atraso de IPTU e parcelou dívidas antigas no caso de imóveis reabilitados, melhorando a viabilidade financeira desse tipo de empreendimento. ${ }^{41}$ Essas medidas foram importantes, pois áreas como a Cruz Vermelha possuíam grande concentração de residências e uma população cujo perfil familiar e de renda condizia com o tipo de empreendimento incentivado. (CRUZ, 2000; NEVES, 1996; SILVEIRA, 1995) Pesquisas do Sindicato da Construção Civil do Rio de Janeiro SINDUSCON informavam que somente este setor tinha cerca de 19 mil casas, das quais 5 mil vazias, existindo ainda um potencial para a produção de 4 mil unidades novas em terrenos não edificados existentes nos morros e baixios da zona portuária. Havia, portanto, espaço para investimentos habitacionais em larga escala.

Apesar desses avanços no plano legal e das vantagens fiscais oferecidas, a promoção do uso habitacional na área central foi uma ação incipiente nos anos 1990 e restrita às iniciativas do município, tendo despertado pouco ou nenhum interesse no mercado imobiliário formal. Embora a legislação urbanística permitisse a edificação de empreendimentos habitacionais no centro desde $1994 \mathrm{e}$ experiências realizadas demonstrassem que, mesmo nas faixas de renda mais baixa, essa ação era economicamente viável, os lançamentos residenciais no centro permaneceram próximos de zero (Tabela 20).

Com financiamento do Programa de Arrendamento Residencial - PAR, da Caixa Econômica Federal, uma experiência apoiada pelo SINDUSCON comprovou, à época, que seria possível reciclar um imóvel tutelado na área da Cruz Vermelha, com unidades habitacionais em torno de $30 \mathrm{~m}^{2}$, auferindo-se margens de lucro de $15,36 \%$ sobre o custo e de $13,31 \%$ sobre a venda, o que era considerado um bom negócio no mercado. Se o empreendimento fosse viabilizado via incorporação, essas margens subiriam para 17,97\% e 14,48\%, respectivamente. ${ }^{42}$ Mesmo a recuperação de fachadas antigas, geralmente apontada como responsável pelo custo alto da reabilitação, correspondeu a apenas 9,23\% da operação, ficando o preço total do metro quadrado em $\mathrm{R} \$ 355,25$, o que foi considerado bastante razoável. ${ }^{43}$ Levando-se em conta que, na experiência em causa, nada foi aprovei-
40 A área mínima da unidade, inclusive para hotéis e residências, foi estabelecida em $30 \mathrm{~m}^{2}$.

41 Em muitos casos, as multas acumuladas equivaliam a 50\% da dívida.

42 Dados do Projeto "Restaurar e Reciclar" do SINDUSCON apresentados no SEMINÁRIO RE-QUALIFICAÇÃO DE IMÓVEIS EM SÍTIOS HISTÓRICOS E ANTIGOS CENTROS URBANOS, promovido pela Caixa Econômica Federal, Prefeitura Municipal de Salvador e governo francês, em Salvador, 28 de novembro de 2002.

43 Preços de junho de 2002. O custo do restauro ficou em $\mathrm{R} \$ 39,39$ por $\mathrm{m}^{2}$ e o da reciclagem interna em $\mathrm{R} \$ 316,00$ por $\mathrm{m}^{2}$. 
tado do imóvel existente além da fachada, das paredes externas portantes e da cobertura, é possível concluir que esse custo poderia ser menor, caso elementos como sistemas de circulação e paredes internas fossem também aproveitados.

É necessário ressaltar a respeito das iniciativas de desenvolvimento do uso habitacional na área central do Rio de Janeiro, durante os anos 1990 e começo da década de 2000, que, diferentemente do restante das ações de requalificação que foram empreendidas nessa área, a liderança da prefeitura local foi tímida, em que pesem os avanços citados no plano legal e programático. Diante dos muitos entraves fundiários, fiscais, burocráticos, jurídicos e financeiros interpostos, a prefeitura não adotou uma postura mais agressiva, nem deflagrou uma política mais sistemática de modo a forçar uma flexibilidade maior por parte das agências de financiamento. Apenas no final de 2002, através do projeto "Foco-Local", que era uma carta de intenções que mantinha interface com o Programa "Novas Alternativas", a prefeitura divulgou a intenção de promover uma política mais ampla, com o uso de incentivos fiscais e financeiros específicos para o uso habitacional, com a utilização dos instrumentos do Estatuto da Cidade que combatem a subutilização e a especulação imobiliária e, ainda, mediante o desenvolvimento de ações de melhoria de serviços públicos e de marketing urbano para reverter a imagem negativa da área central e atrair o interesse do mercado imobiliário.

\section{Programa Novas Alternativas}

O objetivo do Programa "Novas Alternativas", iniciado em 1997, era formular e lançar propostas inovadoras no campo da produção habitacional, mediante o aproveitamento de estruturas existentes, vazios urbanos, edificações e áreas degradadas. $\mathrm{O}$ agente promotor dessas ações foi a Prefeitura do Rio de Janeiro e o agente financeiro, a Caixa Econômica Federal - por intermédio das carteiras de financiamento PAR e Crédito Associativo. Na área central, o destinatário era o público de renda média baixa, que encontrava vantagens de moradia no setor em razão da boa oferta de transportes públicos e da proximidade do local de trabalho. O programa concentrou sua ação nos bairros periféricos do centro, especialmente Lapa, Central do Brasil, Praça Tiradentes, Gamboa, Saúde e Santo 
Cristo, buscando aproveitar as tipologias habitacionais tradicionais existentes, ou seja, cortiços, casas de cômodos, vilas de fundo de lote, pequenos edifícios de apartamentos e casarões unifamiliares.

Para que os empreendimentos coubessem nas condições de financiamento existentes e fossem acessíveis à população-alvo, o programa trabalhava, no começo dos anos 2000, com unidades pequenas, em média de $30 \mathrm{~m}^{2}$, e com soluções habitacionais adaptadas à demanda. Apesar das modificações feitas pela CEF nas linhas de financiamento utilizadas, a fim de adequá-las a esse tipo de produção habitacional, o custo final das unidades variava entre R $\$ 20$ e R 35 mil, com prestações oscilando entre $\mathrm{R} \$ 200,00$ e $\mathrm{R} \$ 400,00$. Um projeto piloto de reabilitação de cortiços permitiu a produção de unidades com custo entre R\$ 6 mil e R\$ 10 mil, e o atendimento a pessoas com renda de até três salários mínimos. Apesar das melhorias introduzidas nas áreas comuns e na relação sanitário/habitante, a população, de um modo geral, rejeitava os cortiços e solicitava banheiros individuais. A falta de subsídios específicos, entretanto, reduziu a margem de atendimento dessas iniciativas.

Os imóveis eram selecionados e adquiridos pela prefeitura, que também desenvolvia os projetos e os aprovava junto aos órgãos fiscalizadores e de tutela. Acompanhava, ainda, os procedimentos para viabilização dos empreendimentos junto à CEF; já as obras e os procedimentos pós-ocupação, mediante convênios com organizações não governamentais, que realizavam o trabalho social e educativo para habilitar moradores a administrar e conservar os imóveis, de modo a conferir sustentabilidade ao projeto. (RIO DE JANEIRO, 200ob, p. 12) Onde havia população residente, era feito um cadastramento, dadas garantias de retorno e, ainda, uma "ajuda-aluguel” durante as obras. Os projetos arquitetônicos, em geral, foram cuidadosos e de muito bom nível, mas com tendência, especialmente no caso das ruínas, ao superaproveitamento do lote. Eram supervisionados pelo DGPC, organismo de preservação do patrimônio do município, e pelo Escritório do Corredor Cultural, tendo sido orientados pela análise das características do conjunto onde se inseriam e, sempre que possível, pela feição original da edificação (Fotos 42 e 43).

Os principais entraves do processo relacionaram-se à questão fundiária na área central, pois os proprietários dos imóveis muitas vezes não podiam ser localizados, não possuíam documentação ou exigiam preços absurdos, o que obrigou 
44 Informações prestadas pelo Subgerente do Programa "Novas Alternativas", Ahmed Nazih Helou, em entrevista realizada em 27 fev. 2002

45 No âmbito do ProjetoPiloto de Reabilitação de Cortiços, no final de 2002, foi também concluído empreendimento na Rua Senador Pompeu, $n^{\circ} 34$ dotado de unidades independentes.

46 Criado pelo Decreto $n^{\circ} 17.109$, de 26 de outubro de 1998 . a prefeitura a realizar desapropriações. Essa medida, entretanto, não constituía uma verdadeira solução no Rio de Janeiro, pois, além do alto custo decorrente de dívidas dos antigos proprietários junto a concessionárias de serviços públicos, a cultura jurídica de proteção à propriedade privada dificultava a imissão de posse dos imóveis para o poder municipal. ${ }^{44}$ Outro problema foi a ausência de linhas de crédito específicas para a reabilitação de imóveis antigos, com taxas de juros razoáveis. O programa foi então obrigado a operar apenas com as linhas disponíveis na CEF, as quais, embora adaptadas, foram originalmente montadas para o financiamento de construções novas.

No final de 2002, o Programa "Novas Alternativas" contabilizava cerca de 78 mil pessoas inscritas, mas havia iniciado apenas oito empreendimentos, dentre os quais apenas dois estavam concluídos e com o habite-se (Quadro 4). (RIO DE JANEIRO, 2002a, p. 14) ${ }^{45}$ Além dessas iniciativas, a prefeitura executou, em terrenos vazios no bairro da Saúde, dois empreendimentos habitacionais para renda média baixa (Mapa o9).

\section{Projeto Morro da Conceição}

O Programa de Recuperação Orientada - PRORIO, ${ }^{46}$ iniciado em 1998, ensaiou, pela primeira vez no Brasil, a organização de uma política integrada de reabilitação do patrimônio urbanístico, paisagístico e arquitetônico em uma grande cidade. No âmbito da experiência-piloto realizada no Morro da Conceição (Foto 44), conduzida em cooperação com o governo da França, tentou-se executar uma operação de reabilitação nos moldes dos setores salvaguardados franceses, com desenvolvimento de metodologia de análise, diagnóstico e montagem de operação (Mapa 10). Nessa experiência, de perfil diferente das intervenções de requalificação realizadas no núcleo mais dinâmico do centro, abordou-se o patrimônio como um instrumento de melhoria do habitat e como um recurso turístico, mas sem submissão do cotidiano da população moradora às distorções dessa atividade.

A operação projetada envolvia intervenções em área públicas; incentivo à recuperação do parque imobiliário privado; revisão das legislações urbanísticas e de proteção; ações de cunho social e ambiental; e capacitação profissional. 
As intervenções propostas respeitavam a lógica do processo de formação e configuração da ocupação do morro, apoiando-se num conhecimento bastante fino de suas características morfológicas. (MORRO DA CONCEIÇÃO, 2000, p. 17) Os técnicos franceses que participaram da experiência contribuíram no estabelecimento da metodologia de recolhimento de dados físico-territoriais e morfológicos, na elaboração de normas e diretrizes de projeto, na formatação da política integrada e na organização de operação de reabilitação do parque privado. Este último, entretanto, foi o aspecto mais frustrante da experiência e o que menos avançou, em razão dos costumeiros entraves documentais e da falta de instrumentos financeiros adequados.

A parte mais desenvolvida e bem sucedida da experiência no Morro da Conceição correspondeu ao desenvolvimento dos instrumentos de análise urbana e ao excelente diagnóstico realizado, que permitiu a elaboração de um corpo de critérios de intervenção bastante sólido para o patrimônio edificado. A elaboração desses critérios baseou-se num inventário cuidadoso das tipologias arquitetônicas existentes no sítio, no estudo dos planos visuais que configuram a relação do morro com a cidade e na análise dos elementos paisagísticos e urbanísticos mais importantes, como áreas verdes, muros, escadarias, vias e áreas públicas. (MORRO DA CONCEIÇÃO, 2000, p. 50-65) Com isso, se pôde ir além da simples regulamentação da feição das fachadas e volumes dos edifícios e caminhar no sentido da compreensão e explicitação da lógica de ocupação e funcionamento da área, o que se tornou o referencial básico para a elaboração dos projetos e para o estabelecimento de parâmetros gerais de intervenção.

O diagnóstico elaborado permitiu ainda o estabelecimento de prioridades e a hierarquização das intervenções. Além disso, possibilitou a identificação das necessidades de adequação e revisão da legislação e a definição dos parâmetros de ocupação de vazios. Estes seriam ocupados com projetos habitacionais, através do Programa "Novas Alternativas", não ultrapassando, entretanto, a 10\% do número de unidades existentes no morro e com prioridade de aquisição para famílias moradoras. (MORRO DA CONCEIÇÃO, 2000, p. 70-80)

Infelizmente, devido a mudanças administrativas, a entraves financeiros e documentais e a algumas divergências conceituais entre brasileiros e franceses, a experiência pouco se desenvolveu no plano executivo. No final de 2000, 
47 Informação prestada pela Gerente do Projeto Porto do Rio, Nina Maria de Carvalho Rabha, em entrevista realizada em $28 \mathrm{fev} .2002$ conseguiu-se deslanchar apenas parte do projeto de melhorias no espaço público, executando-se cerca de $8 \%$ das obras previstas para a área da Pedra do Sal. ${ }^{47}$ Mesmo dispondo-se da experiência positiva do Corredor Cultural, não se iniciou no Morro da Conceição um processo de convencimento dos moradores para investir na recuperação dos imóveis, com base nos incentivos fiscais existentes, ficando a operação muito calcada nos moldes franceses, isto é, baseada na existência de um sistema de financiamento específico para a reabilitação, algo ainda não desenvolvido no Brasil. Mesmo quando a Caixa Econômica Federal entrou no processo, essas limitações impediram a decolagem do projeto.

No começo da década de 2000, o projeto do Morro da Conceição foi integrado ao Projeto Porto do Rio e foi concentrado na execução de melhorias no espaço público. No que toca à dimensão habitacional, o projeto não andou, o que fez com que adquirisse contornos próximos aos das intervenções realizadas no núcleo dinâmico do centro. A experiência teve, entretanto, o mérito de contribuir para despertar o interesse da Caixa Econômica Federal em estudar mais profundamente a criação de linhas de financiamento específicas para reabilitação, destinadas, inclusive, aos proprietários que alugam seus imóveis. Teve o mérito também de estabelecer uma metodologia de análise e montagem de operação de reabilitação urbana inédita no Brasil.

\section{Os projetos de dinamização econômica nos bairros centrais}

Os projetos da prefeitura para a área periférica ao centro, nos anos 1990, foram deflagrados com o avanço do processo de requalificação do seu núcleo mais dinâmico. Surgiram também, como já observado, da tentativa de pensar a área central de modo estratégico, como polo gerador de riqueza mediante investimentos em atividades próprias da economia contemporânea, a exemplo da tecnologia da informação, das telecomunicações, do turismo e lazer. Um dos principais projetos dessa safra foi o chamado "Teleporto" - uma espécie de centro avançado de telecomunicações e informática a ser implantado em um vazio da Cidade Nova (Mapa 10). A prefeitura investiu em infraestrutura e definição de lotes para comercialização junto à iniciativa privada, mas não houve interesse pelo projeto, que, assim, foi temporariamente substituído por outro, denominado 
"Network Access Point", ou NAP, que propunha também um centro de telecomunicações conjugado a edifícios de escritórios, centro de convenções, residências e hotel. Este novo projeto igualmente não decolou. (MAGALHÃES, 2001, p. 155)

No final de 2002, a prefeitura lançou edital de licitação para concessão de uso vinculada à construção do Centro de Convençóes do Teleporto, com base em projeto vencedor do concurso promovido em parceria com o Instituto dos Arquitetos do Brasil. O projeto previa um centro de convenções para três mil pessoas, um prédio de escritórios com 13 mil metros quadrados e um hotel com 150 suítes. Outra intervenção projetada nas proximidades do Teleporto foi o "Projeto Sás", envolvendo as avenidas Estácio, Salvador e Mem de Sá, com o qual se propunha recuperar o casario, criar área de lazer e melhorar a infraestrutura e o sistema viário da área (Mapa 10). (MAGALHÃES, 2001) Mas a proposta mais ambiciosa para a periferia do centro, que polarizou as energias da prefeitura a partir de 2001, foi o Projeto Porto do Rio.

Concebido como plano de longo prazo e de alto impacto, destinado a reverter o quadro de deterioração da zona portuária, o Projeto Porto do Rio criou incentivos para transformar esta área na mais nova fronteira de produção imobiliária da cidade. Há muito tempo, o esvaziamento e a degradação da zona do porto, agravados pela reestruturação das atividades portuárias, preocupam não só o poder público, mas também os profissionais de arquitetura e urbanismo da cidade. Desde o começo dos anos 1980, inúmeras ideias foram lançadas para solucionar o problema, todas elas de perfil grandioso e dependentes de altos investimentos públicos e privados, que geraram, até o começo da década de 2000, iniciativas fragmentadas e de pouco impacto. A iniciativa de maior alcance foi o Projeto SAGAS, de revitalização dos bairros da Saúde, Gamboa e Santo Cristo. Com perfil semelhante ao do Corredor Cultural, o projeto pouco se desenvolveu, em razão da estagnação econômica da área e do baixo investimento privado no local.

Durante os anos 1990, enquanto mantinha um ritmo forte de intervenções no núcleo dinâmico do centro, a municipalidade realizou na área portuária uma política de investimentos e intervenções de pequeno porte, com vistas à melhoria da qualidade urbana dos bairros centrais e como forma de aprofundar sua vocação residencial. A ideia de recuperar a área portuária com um grande projeto, nos moldes dos realizados em Barcelona, Londres ou Buenos Aires, não parecia viável, pois, 
48 A Operação Urbana Consorciada é um instrumento de política urbana criado pela Lei $n^{\circ} 10.257 / 2001-$ também conhecida como Estatuto da Cidade. Possibilita que o capital imobiliário arque, pelo menos em parte, com os custos de preparação de um setor com vistas à sua incorporação à cidade ou à sua recuperação. As Operações Interligadas, por sua vez, decorrem da transferência de potencial construtivo de uma zona urbana para outra ou da interligação de operaçōes entre zonas urbanas distintas. além de outros setores, como a Praça XV, parecerem mais adequadas a planos dessa natureza, a cidade possuía uma relação intensa e consolidada com o mar, havendo mesmo uma certa inflação de áreas de lazer desse tipo. (NASCIMENTO, 2000, p. 76-77) A partir de 2002, entretanto, os planos mudaram, sendo realizados os estudos que desembocaram no Plano de Reestruturação e Revitalização da Região Portuária ou, simplesmente, "Porto do Rio".

O Projeto Porto do Rio surgiu como um plano setorial estratégico, com diretrizes e ações voltadas para romper a estagnação e a inércia da área portuária, atrair investimentos, promover a produção imobiliária e preservar o patrimônio cultural e ambiental. O papel do poder público seria apontar a direção desejada da renovaçãa, mediante ações de adequação da legislação urbanística e de criação de incentivos, assim como executar intervenções estruturais no sistema viário e nos espaços públicos para sinalizar a firme intenção de dinamizar a área. (RABHA; PINHEIRO, 2001, p. 34-37) As mudanças na legislação previam revisão do zoneamento - ainda muito voltado para atividades ligadas ao porto - para incentivar usos que consolidassem a área como espaço multifuncional. Embora se ressaltasse a importância de reforçar e desenvolver o uso residencial na baixada da zona portuária, os projetos habitacionais localizavam-se, predominantemente, nos morros onde ainda havia iniciativas em andamento, como o Projeto Morro da Conceição, o Programa "Novas Alternativas" e o Programa Favela-Bairro do Morro da Providência (Mapa 10). (CENTRO DE ARQUITETURA E URBANISMO, 2001)

A alteração no aparato legal previa novo Plano de Alinhamento para a zona baixa junto ao porto, com vistas a transformar as áreas desativadas da Rede Ferroviária Federal em logradouros e alterar o gabarito vigente de quatro pavimentos para algo em torno de 20 , nas áreas próximas à Av. Perimetral e enseada da Gamboa. Outros pontos de verticalização estavam previstos para as ruas transversais à Avenida Perimetral, que seria progressivamente diminuída na proximidade dos morros. As áreas preservadas foram mantidas, e foram previstos tombamentos para os galpões do porto mais antigos. No projeto não foram previstos benefícios fiscais além dos existentes, nem tampouco o uso de instrumentos, como as Operações Urbanas ou Interligadas. ${ }^{48} \mathrm{~A}$ área, contudo, se beneficiaria dos mecanismos pensados no âmbito do Programa Foco-Local 
para combater a retenção e a subutilização de terrenos, bem como para conceder incentivo fiscal e financeiro a imóveis sem valor histórico ou arquitetônico que fossem destinados ao uso habitacional.

Foi no sistema viário, entretanto, que as ações municipais pretendiam ser mais incisivas. Com vistas a romper o histórico isolamento da área, foram previstas amplas intervenções viárias para melhoria das conexões intrabairros e da zona portuária com a cidade, incluindo a implantação de binário em via paralela ao porto, ${ }^{49}$ reurbanização das ruas Sacadura Cabral e do Livramento, intervenções nos morros da Saúde, Gamboa e Livramento, implantação de sistema VLT, construção de garagem subterrânea na Praça Mauá e de ciclovia entre o Museu de Arte Moderna e esta praça, entre outras medidas. (RIO DE JANEIRO, 2002b)

Os usos propostos para a área a ser renovada estavam mais ou menos vinculados aos sete polos de atividade então estabelecidos ao longo da orla do porto, mas abertos a propostas e negociações com a iniciativa privada, com vistas à formação de parcerias. A viabilidade e o desenvolvimento desse ambicioso plano, entretanto, dependia, no começo dos anos 2000, de vários fatores. O primeiro deles dizia respeito à necessidade de se solucionar o problema fundiário da área, já que a maioria dos terrenos e edificações ociosas pertencia à União, em decorrência dos aterros realizados no início do século XX para a construção do porto. Para viabilizar a cessão ou a venda desses imóveis à iniciativa privada, se discutiu a formação de uma sociedade de propósitos específicos, com a participação da prefeitura, de organismos federais e de investidores privados, mas a ideia encontrou dificuldades jurídicas e políticas para se concretizar. Ao lado disso, na Área Central de Negócios e imediações a dinâmica de renovação e de produção imobiliária foi muito baixa nas duas décadas anteriores, em que pesem os investimentos na recuperação de alguns imóveis. ${ }^{50}$ A despeito dos espaços públicos requalificados, o mercado imobiliário praticamente não se manifestou no centro, a não ser em empreendimentos como o prédio de escritórios RB 1 - edifício "inteligente", próximo à Praça Mauá - e três outros lançamentos semelhantes nas avenidas Rio Branco, Chile e Almirante Barroso. Os autores do projeto Porto do Rio acreditavam, contudo, que havia uma forte vocação dessa área para atividades de entretenimento, lazer e negócios, o que a tornaria adequada para
49 O projeto dessa nova via foi orçado em $\mathrm{R} \$ 640$ mil, e a obra em R\$ 43 milhões. Informações prestadas pela Gerente do Projeto Porto do Rio, Nina Maria de Carvalho Rabha, em entrevista realizada em $28 \mathrm{fev}$. 2002.

50 Com incentivos fiscais do município foram reciclados para uso comercial o prédio do Amarelinho, na Cinelândia, e o que abriga o Candelária Corporate, na Praça Pio X. (MAGALHÃES, 2001, p. 145) 
51 Informações prestadas pela Gerente do Projeto Porto do Rio, Nina Maria de Carvalho Rabha, em 28 fev. 2002. centros de convenções, hotéis e empreendimentos turísticos..$^{51}$ Apesar da clara tendência de crescimento da cidade em direção à Barra da Tijuca, acreditava-se que, no médio e no longo prazo, a renovação do porto ocorreria em decorrência da boa oferta de terrenos grandes e centrais.

A proposta de transformação da área baixa junto ao porto numa extensão da Área Central de Negócios esbarrou, à época, na dinâmica econômica insuficiente e na concorrência já exercida pelo subcentro da Barra da Tijuca - onde haviam sido feitos grandes lançamentos imobiliários de centros empresariais, de comércio e lazer. Já a proposta de implantação de uma filial do Museu Guggenheim no Píer Mauá enfrentou fortes reações contrárias da área cultural carioca, o que acabou por derrubar uma das âncoras do projeto e esfriar os ânimos dos interessados em sua implantação. O Projeto Porto do Rio, pensado nos moldes dos executados em Baltimore, Londres, Nova York e Barcelona, introduziu um novo modelo de intervenção no centro da cidade, mas teve poucas chances de se realizar no momento de sua elaboração.

\section{A revitalização da Praça Tiradentes}

Montado pelo Ministério da Cultura em conjunto com o Banco Interamericano de Desenvolvimento, o Programa Monumenta começou a ser discutido no Rio de Janeiro em 1996. Juntamente com Ouro Preto, Recife, Olinda, Salvador, São Luís e São Paulo, o Rio fez parte da amostra de cidades representativas do patrimônio urbano brasileiro que serviu de base para a concepção e organização desse programa em nível nacional. Após uma polêmica inicial sobre que setor do centro deveria ser escolhido para participar do programa, foram definidos a Praça Tiradentes e seus arredores, onde a Secretaria Municipal de Cultura, na época, pretendia incentivar a atividade teatral, tornando esta praça uma espécie de foyer externo dos teatros existentes. A ideia era transformar o logradouro num lugar aprazível, retirando-se pontos de ônibus e ambulantes, e afugentando prostitutas e pedintes. Parte integrante da zona do Corredor Cultural, os arredores da Praça Tiradentes constituíam um setor deteriorado, o que tornava o projeto oportuno como forma de ampliar a área em processo de requalificação. O local não continha, 
entretanto, monumentos tombados em nível federal, o que, de acordo com o regulamento do Monumenta, o tornava automaticamente inelegível. Para contornar o problema, o IPHAN foi instado a tombar rapidamente a estátua equestre de D. Pedro I, na Praça Tiradentes, e o Solar do Visconde do Rio Seco, ambos já protegidos pelo governo estadual (Fotos 45 e 46).

Apesar de um convênio ter sido assinado entre o Ministério da Cultura e a Prefeitura do Rio de Janeiro em junho de 2000, o Projeto Tiradentes não andou. Inicialmente, porque o município não demonstrou interesse nos recursos pouco vultosos do projeto - cerca de R\$ 12 milhões. Em seguida, porque, apesar de haver investido nos estudos preparatórios exigidos pelo programa, a Prefeitura do Rio não conseguiu fechar um perfil de projeto que garantisse a sustentabilidade da intervenção, conforme exigido pelo BID.52 Por fim, com as eleições do ano 2000, a Unidade Executora do Projeto, instância local de coordenação e execução do Programa Monumenta, foi esvaziada e, no ano seguinte, não foi reorganizada. No final de 2001, chegou-se a cogitar o desligamento do Projeto Tiradentes desse programa, uma vez que o convênio firmado havia sido executado em apenas 11\%. (BRASIL, 2002f) Somente no início de 2002, por iniciativa da nova direção do DGPC, a Unidade Executora do Projeto foi reorganizada, passando a tocar os estudos para a elaboração do perfil definitivo do projeto.

O Projeto de Revitalização da Praça Tiradentes, aprovado pela coordenação central do Programa Monumenta no final de 2002, previu a recuperação de dez imóveis situados no entorno da praça, ${ }^{53}$ a restauração do seu conjunto escultórico, além do financiamento de obras de recuperação de fachadas, coberturas e estruturas de imóveis privados situados no perímetro de atuação do projeto (Mapa 10). ${ }^{54}$ Foram ainda previstas ações de melhoria das condições de acessibilidade e transporte à área e outras que visavam integrar a população residente e usuários ao processo de revitalização. A reurbanização da praça e das ruas localizadas na área de abrangência do projeto constava também do seu escopo, mas, como esses trabalhos já haviam sido realizados pelo município, foram computados como contrapartida.

A ideia da prefeitura, no começo da década de 2000, era abordar o projeto como um plano de valorização da Praça Tiradentes, realizando também ações paralelas de desenvolvimento do uso habitacional através do Programa "Novas
52 Foram investidos cerca de $\mathrm{R} \$ 500$ mil nesses estudos. (SERAPIÃO, 2000, p. 107)

53 Igreja do Santíssimo Sacramento; os sobrados à Rua Luís de Camóes, nº 74 e 76 ; o Teatro Carlos Gomes; - Solar do Barão do Rio Seco; a casa de Bidu Sayão; o imóvel $n^{\circ} 11 \mathrm{da}$ Rua Gonçalves Ledo; os imóveis de $n^{\circ} 71 \mathrm{da}$ Praça Tiradentes e de $n^{\circ} 62$ da Rua Regente Feijó, que seriam recuperados para uso habitacional no âmbito do Programa "Novas Alternativas"; e, por fim, o imóvel situado à Rua Visconde do Rio Branco, esquina com a Rua do Lavradio.

54 Este componente do Monumenta destinava-se ao financiamento da recuperação de imóveis privados a partir da publicação de edital para encaminhamento de propostas. 
Alternativas". Diferentemente de outros projetos do Monumenta, no Rio de Janeiro estavam também previstos cursos de capacitação e qualificação profissional, campanhas de educação patrimonial, atendimento à população em situação de exclusão e a reorganização do comércio informal. O Projeto Tiradentes sofreu, contudo, do mesmo mal que acometia as outras iniciativas públicas na área central que pressupunham a participação do setor privado. Foi difícil, por exemplo, encontrar parceiros para a restauração e ocupação dos imóveis listados na intervenção, e na falta de interessados ou de uma dinâmica aquecida na qual as reabilitações encontrassem mercado, privilegiou-se o uso público e cultural, a despeito da inflação deste tipo de equipamento na área central. O Centro Cultural Hélio Oiticica, por exemplo, situado nas imediações da Praça Tiradentes, enfrentava problemas de baixa frequência. (AZEVEDO, 2002) Mesmo assim, o projeto previa a ocupação de três imóveis com atividades ligadas a este equipamento.

O Projeto Tiradentes não foi um plano específico, pois resultou da combinação de ações que eram elegíveis, segundo o regulamento do Programa Monumenta, o que lhe conferiu uma certa rigidez e dificultou adaptações. Embora contemplasse ações de inclusão social, não tinha escala, recursos e abrangência suficientes para solucionar os problemas complexos que causavam a deterioração urbana do setor. Além disso, na medida em que não havia perspectiva de mais recursos, e em face das dificuldades para estabelecimento de parcerias privadas, a sustentabilidade do projeto não foi garantida. Uma integração com o Programa "Novas Alternativas", ampliando suas fontes de recursos e contribuindo para a solução dos entraves urbanísticos que dificultavam o desenvolvimento do uso habitacional, poderia ter dado mais sentido ao projeto já que estaria vinculado a uma grande demanda reprimida. Um aproveitamento mais intenso da experiência do Corredor Cultural, no que toca ao desenvolvimento de parcerias e à inserção em dinâmicas existentes, também poderia ter aberto melhores perspectivas para o projeto. Ao atacar uma área degradada nas imediações de outros setores cujo processo de requalificação estava mais adiantado, o Projeto Tiradentes contribuiu, entretanto, para expandir a área fisicamente recuperada do centro. 


\section{0 processo de valorização e requalificação do centro nos anos 1990: resultados e sentidos}

A requalificação urbana do centro do Rio de Janeiro, iniciada nos anos 1980 e acelerada na década de 1990, contribuiu para estancar, em seu núcleo mais dinâmico, os efeitos de um processo de deterioração urbana e de esvaziamento funcional que teimava em se instalar, e ajudou a manter a hegemonia dessa centralidade no contexto urbano e metropolitano. Contribuiu ainda para manter, e até aumentar, a valorização do solo nessa área, abrindo caminho, através da reanimação de funções culturais e de lazer, para uma reapropriação do setor por segmentos de renda mais elevada, com reflexos, ainda que discretos, no padrão da ocupação comercial que certos setores apresentavam no começo dos anos 2000. Indicadores fiscais e econômicos já atestavam, à época, que o centro antigo jamais havia deixado de ser a principal centralidade da cidade e da região metropolitana e foi essa condição que, em última análise, possibilitou que a requalificação fosse bem-sucedida. Essa condição explica ainda por que os efeitos benéficos das intervenções se restringiram ao núcleo comercial, financeiro e de negócios, que era (e ainda é) responsável por essa hegemonia.

Como visto ao longo deste capítulo, os bairros periféricos a esse núcleo permaneceram com um perfil degradado, o que demonstrou os limites das políticas de requalificação. Mas o estado deteriorado da periferia do centro se relacionava também ao fato de esses setores não terem recebido, historicamente, e ao longo dos anos 1980 e 90, o mesmo volume de recursos que o núcleo principal e sua zona de transição; e ainda se relacionava a mais dois outros fatores: as políticas habitacionais pensadas para essas áreas não deslancharam, assim como os projetos de dinamização econômica não conseguiram atrair investimentos privados.

Nas imediações do núcleo modernizado e dinâmico do centro, entretanto, proprietários e ocupantes investiram de modo significativo na recuperação de imóveis antigos, com o apoio dos incentivos fiscais municipais que funcionaram como âncoras do processo de conservação do patrimônio e de manutenção do valor 
imobiliário. No Rio de Janeiro, os pequenos investimentos privados sustentaram esse processo e foram potencializados pelas intervenções executadas pelo poder público durante os anos 1990, o que colocou, como observa Magalhães (2001, p. 117), a requalificação promovida pelo poder público num patamar mais elevado.

O centro do Rio apresentava, no começo da década de 2000, como assinalavam Vaz e Silveira (1998, p. 4-9), duas tendências opostas: uma de desenvolvimento do setor terciário na Área Central de Negócios e imediações, com crescente melhoria da qualidade urbana; e outra de estagnação e deterioração do ambiente construído, nos demais bairros centrais. A reversão desse quadro, como notavam essas autoras, dependeria do desenvolvimento do uso habitacional; do aproveitamento adequado dos vazios urbanos existentes; do investimento em melhoria e manutenção dos espaços públicos; e de uma gestão eficiente.

Além dos entraves apontados ao longo deste capítulo, a falta de uma política de subsídios à produção habitacional ocupou, sem dúvida, um lugar central na permanência de uma situação de deterioração urbana nos bairros centrais do Rio de Janeiro. Uma tal política não somente ajudaria a aquecer o mercado e a atrair o interesse de seus operadores, como ainda contribuiria para superar as limitações dos financiamentos existentes. Possibilitaria, ainda, uma preservação mais cuidadosa do patrimônio edificado, proporcionando a sobrevivência de tipologias internas. Ao lado disso, teria sido fundamental a criação de carteiras específicas para o financiamento de intervenções de reabilitação de imóveis antigos, para a regulamentação dos instrumentos do Estatuto da Cidade destinados a combater a especulação imobiliária e a implantação de mecanismos que agilizassem a solução de problemas fundiários, fiscais e cartoriais.

No conjunto das grandes metrópoles brasileiras, o centro da cidade do Rio de Janeiro era o que menos havia perdido hegemonia, nos anos 1990, na estrutura urbana e metropolitana, em decorrência de processos de fragmentação terciária. Vários fatores influenciaram essa situação, como: sua posição geográfica estratégica na articulação das zonas Norte e Sul da cidade, sua posição também "central" em relação à região metropolitana, a concentração de todas as modalidades possíveis de transporte de passageiros em seu âmbito e os investimentos públicos em infraestrutura, melhoramento, embelezamento e acessibilidade, 
que foram feitos ao longo de praticamente todo o século XX no seu núcleo principal. Esses fatores não permitiram, em última análise, que os impactos do crescimento metropolitano e da formação de novos centros fossem tão violentos e desequilibradores para a centralidade mais antiga, como ocorreu em Salvador e São Paulo. Ao lado disso, o planejamento urbano local jamais deixou de tratar o centro antigo como a centralidade principal e jamais promoveu, deliberadamente, seu esvaziamento, como ocorreu em Salvador. Mas, se o crescimento urbano e o deslocamento de funções não chegaram a afetar assim tão violentamente o núcleo dinâmico do centro do Rio, afetaram bastante sua periferia imediata, que, historicamente reservada como área de expansão desse núcleo, em decorrência da estagnação econômica, da execução de intervenções equivocadas e da perda de centralidade administrativa para Brasília, permaneceu em compasso de espera, esvaziada e não renovada.

Até os anos 1970, a história da cidade do Rio de Janeiro foi marcada pela dominação da natureza e pelo apagamento de grandes porções do seu passado construído, o qual foi parcialmente preservado graças apenas à ação do IPHAN e à falta de fôlego da dinâmica modernizadora para abarcar tudo. A retração econômica dos anos 1980 freou mais ainda essa dinâmica e contribuiu decisivamente para transformar o modo usual de intervenção. A crise econômica coincidiu com o surgimento do patrimônio como importante insumo turístico e com as reivindicações dos movimentos de classe média por melhor qualidade de vida na cidade, e esse conjunto de fatos possibilitou a implantação de medidas de preservação dos conjuntos edificados que sobreviveram à modernização do centro do Rio.

Essas medidas, entretanto, não chegaram a promover uma mudança siğnificativa no comportamento do mercado imobiliário, no sentido de impulsionar a reabilitação do estoque construído. Seus efeitos ficaram restritos aos setores protegidos e controlados pelo poder público na área central e em alguns outros bairros, em decorrência, principalmente, de três fatores: 1) a manutenção de uma fronteira dinâmica de reprodução do capital imobiliário no vetor de expansão do Recreio (incluindo Jacarepaguá e Barra da Tijuca); 2) a permanência das alternativas de moradia popular restritas à autoconstrução e à ocupação de áreas desprezadas pelo mercado imobiliário; 3) o baixo apelo que a história, a tradição e a localização central exercem nos hábitos de consumo e moradia dos segmentos 
mais abastados. O reaproveitamento ou a reciclagem de imóveis existentes prosperou, assim, apenas nos setores mais dinâmicos e terciários da área central, não logrando deflagrar nem mesmo um movimento mais generalizado nesse território.

No entanto, o novo modo de intervenção urbana que preserva formas antigas se revelou adequado à situação urbana e econômica configurada no núcleo dinâmico do centro do Rio, contribuindo, nos anos 1990, para a manutenção do valor imobiliário em bons níveis, bem como para diminuir o ritmo de decadência e degradação do seu entorno imediato. Esse processo foi favorecido pelas políticas de preservação implantadas e pela reanimação da função cultural promovida por empresas, mediante incentivos fiscais. Tais iniciativas ajudaram a fixar atividades existentes e a atrair novas, atenuando os impactos sobre o núcleo central de negócios promovidos pela recessão econômica e pela fuga de instituições financeiras para São Paulo. Esses fatores, medidas e processos construíram um equilíbrio funcional entre as várias centralidades da metrópole, que, se não comportou perspectivas de crescimento e expansão do núcleo principal, garantiu a permanência do centro antigo como o principal polo de atividades econômicas e empregos da cidade.

O reforço da posição estratégica da área central e os projetos de ampliação de sua dinâmica econômica se desenvolveram, nos anos 1990, sem mudanças na legislação municipal de cunho preservacionista. Uma característica importante do processo do Rio de Janeiro, que o aproxima do de Salvador e o afasta do de São Paulo, é que não houve movimento para tornar a legislação urbanística mais aberta a um aproveitamento mais intenso e renovado do solo no núcleo dinâmico do centro. Ao contrário, ocorreu uma ampliação das áreas protegidas na II RA durante essa década, o que aumentou o insulamento da sua área modernizada. Esse insulamento não constituiu, contudo, um problema, pois as pressões para a renovação e crescimento da Área Central de Negócios foram quase nulas e o município colocou à disposição do mercado as áreas baixas da zona portuária para eventuais necessidades de expansão.

Em suma, no Rio de Janeiro, a legislação de proteção ao patrimônio funcionou como uma aliada das políticas de requalificação, renovação e valorização do centro. Não promoveu, portanto, desvalorização imobiliária no núcleo dinâmico do centro. Neste setor, o metro quadrado de terreno continuava sendo, 
nos anos 1990, um dos mais caros da cidade, o que mostra que a legislação de proteção é apenas um instrumento que pode influenciar ou potencializar processos, mas que não tem poder para reverter, isoladamente, tendências instaladas.

Nos anos 1990, as principais alterações operadas na legislação urbanística incidente na área central foram a permissão para o desenvolvimento do uso residencial em todo o seu âmbito, inclusive com pequenas unidades, e a proposta de modificação da legislação da zona portuária - esta sim, contendo incentivos a uma produção imobiliária verticalizada. Mas, mesmo nessa zona, foram mantidas as normas de preservação nas áreas dos morros, e até propostos novos tombamentos na baixada. Contudo, os resultados dessa abertura para a verticalização e para a produção imobiliária permaneceram incertos, pois esbarraram numa renitente "indiferença" por parte do mercado.

Tal indiferença decorreu dos altos índices de crescimento e de possibilidades de bons negócios na zona Oeste da cidade - em Jacarepaguá e na Barra da Tijuca-, onde os investimentos públicos em vias de ligação rápida com o centro e com as principais saídas da cidade permitiram a continuidade de um crescimento urbano espraiado. $\mathrm{O}$ aproveitamento mais intenso da infraestrutura urbana instalada, dos vazios e das formas edificadas nos bairros centrais dependeu da reorientação desse movimento centrífugo, o que não ocorreu. Nessa reorientação, desempenhariam papéis importantes o planejamento urbano e territorial, a localização dos investimentos públicos, os incentivos, os subsídios à reabilitação, e, não menos importante, a formação de uma nova mentalidade no seio das classes médias, no sentido da valorização da moradia em imóveis antigos e em bairros próximos ao centro.

Projetos como o Porto do Rio e o Teleporto tiveram também suas possibilidades de sucesso vinculadas a esses aspectos da gestão urbana, bem como ao crescimento da preferência de empresas pela localização central. Estudos da época apontavam que o setor imobiliário, apesar das sinalizações do poder público municipal, ainda não apostava nessa localização e seguia investindo na Barra, com lançamentos importantes, inclusive no ramo dos negócios. (BIENENSTEIN, 2000) O mesmo ocorria com relação aos empreendimentos residenciais de classe média e alta que não tinham qualquer demanda na área central. Por outro lado, assim como em Salvador e em São Paulo, a demanda por habitação popular e de classe média baixa 
na periferia do centro era alta e inadequadamente atendida, apesar dos avanços legais, financeiros e programáticos que foram desenvolvidos no Rio de Janeiro.

A ausência de demanda dos segmentos de maior renda por moradia nas áreas centrais abria, no Brasil dos anos 1990, a possibilidade de criação de um modelo de intervenção que aliasse a reabilitação à promoção do desenvolvimento social. Criava, enfim, a possibilidade de se renovar e otimizar o uso de áreas centrais com inclusão social e com o enfrentamento adequado de problemas urbanos estruturais. Essa é, entretanto, uma opção política, cuja concretização depende ainda da capacidade que atores sociais em jogo têm de implantar seus projetos. É o embate dessas forças que determinará, em suma, se a reabilitação será somente uma questão de mercado ou também o cumprimento de uma reivindicação social.

No conjunto das metrópoles brasileiras, o Rio de Janeiro constituiu, nos anos 1990, o caso mais bem-sucedido e promissor de recuperação do patrimônio edificado numa área central. As intervenções realizadas ao longo dessa década, se não foram capazes de solucionar os graves problemas que afetavam esse território, contribuíram grandemente para a consolidação desse projeto e, ainda que num setor reduzido, para reverter tendências de esvaziamento e deterioração ambiental. Na capacidade de ampliação desse resultado para o restante da área central, ainda degradado e economicamente depreciado, ficou vinculada a possibilidade de sucesso, sustentabilidade e durabilidade do processo iniciado.

A parceria entre o setor público e o setor privado foi um traço característico do processo de requalificação do centro do Rio de Janeiro. Durante os anos 1980, essa parceria foi construída em torno dos incentivos públicos à atividade privada de preservação; da negociação de critérios de intervenção entre instâncias técnicas e interessados; e do apoio e orientação técnica a projetos de reabilitação e reciclagem. Nesse período, o investimento privado foi fundamental para a consolidação de uma nova maneira de intervir na área central, mas é importante ressaltar que esse investimento inseriu-se num projeto formulado, coordenado, implantado e conduzido pelo poder público.

Nos anos 1990, a parceria setor público/privado nas intervenções realizadas no centro adquiriu contornos, de certa forma, distintos do período precedente. A coordenação do processo permaneceu com a municipalidade e a participação 
do pequeno investimento privado na recuperação de imóveis continuou importante, mas a parceria passou também a incluir intervenções no espaço público e a construção de equipamentos, mediante concessões de exploração. ${ }^{55}$ Em alguns casos, essas novas modalidades de ação conjunta resultaram na criação de áreas semiprivatizadas e no controle do acesso ao espaço público. Algumas intervenções realizadas e projetos elaborados no período estudado mostram que essa parceira se desenvolveu no sentido de tentar firmar o "empresariamento" urbano como uma modalidade de intervenção na área central. Contudo, no centro do Rio de Janeiro, ações semelhantes às que ocorreram em cidades como Nova York, por exemplo, onde setores inteiros, como Times Square, foram recuperados em sinergia com grandes corporações, como Disney, Virgin Records, Warner Brothers, e outras do setor de comunicações, não aconteceram. (ZUKIN, 2000a, p. 112-133) Não se registrou, portanto, interesses corporativos reivindicando participação no processo ou buscando influenciar diretamente seus rumos.

Os principais protagonistas da requalificação do centro do Rio nos anos 1990 foram ainda, num primeiro plano, o poder público e, em segundo, pequenos proprietários, empresas estatais e empresários do ramo cultural. A população residente na área central, especialmente em seus bairros periféricos, não foi um ator importante. Diferentemente do que ocorreu em São Paulo, setores populares organizados não reivindicaram espaço para seus interesses. Mesmo as associações de bairro, relativamente atuantes na zona portuária durante os anos 1980, desapareceram ou se retraíram na década de 1990, deixando espaço para que o poder público e os interesses empresariais ou comerciais atuassem sem constrangimentos. Diante disso, foram poucas as chances de que programas habitacionais de cunho social se viabilizassem nessas áreas. De todo modo, como a demanda por habitação popular nos bairros centrais permaneceu alta e o interesse do mercado imobiliário baixo, é possível que esses programas ainda possam se desenvolver.

Apoiada na parceria público/privado estabelecida pelos mecanismos federais de renúncia fiscal, a reanimação cultural do centro reaproximou a área de segmentos sociais de alta renda. Esse processo, apoiado pelo poder público, foi visto como uma das formas mais importantes de dinamização econômica da área central. A cultura, associada ao entretenimento e ao lazer, foi, assim,
55 A exemplo do Centro de Convenções do Teleporto e da garagem subterrânea inaugurada na Cinelândia (ver Apêndice C), além disso, foram previstas parcerias para a recuperação de logradouros como as praças Mauá e Melvin Jones. 
largamente utilizada, nos anos 1990, como plataforma de deslanche de um processo de revalorização do centro do Rio de Janeiro, no qual pobres, moradores de rua e mendigos foram, mais uma vez, retirados do campo de visibilidade sem a contrapartida de programas sociais.

\section{A noção de patrimônio e as características da prática de preservação}

A história da preservação do patrimônio urbano do Rio de Janeiro se desenvolveu paralelamente à construção de um centro moderno para a cidade. A relação com o novo é então parte integrante desse processo, que jamais freou ou buscou frear a transformação. Ao contrário, entre os anos 1930 e 1970, o campo preservacionista dela participou intensamente.

Mesmo quando, nos anos 1980, a natureza da renovação mudou e o seu ritmo caiu, o novo continuou sendo parte do processo de preservação, e a transformação, um de seus aspectos constitutivos. Como visto, as normas estabelecidas pelo Corredor Cultural incluíram essa dinâmica por meio da seleção, nas áreas protegidas, dos elementos essenciais a preservar e dos elementos a transformar. Isso garantiu, em última análise, a presença do novo no interior e no exterior das áreas preservadas, permitindo a renovação do vínculo das formas antigas com a contemporaneidade. Essas normas, somadas ao estabelecimento de graus diferenciados de preservação para os imóveis existentes nas áreas preservadas, contribuíram para a ampliação do território protegido na área central, permitindo flexibilidade de intervenção e incentivando a inserção da arquitetura contemporânea no conjunto preservado. Nos anos 9o, entretanto, com a tendência de apropriação do patrimônio do centro como um valor imobiliário, imóveis passíveis de maior transformação foram, frequentemente, "patrimonializados", mediante a reconstituição ou a recriação de elementos remanescentes, especialmente em suas fachadas. Embora as normas não exigissem reconstituição estilística nesses casos, essa operação foi praticada para valorizar imóveis, tornando-os mais vendáveis. O cuidado com a reconstituição não se verificou, entretanto, no interior das edificações. Estes interiores foram, via de regra, desmanchados para dar lugar a construções inteiramente novos. 
A maior parte das operaçóes de conservação nas áreas protegidas do centro do Rio de Janeiro foi, assim, não de preservação, mas de reciclagem, com a noção de patrimônio restrita, no geral, aos aspectos externos dos edifícios. As linhas de financiamento utilizadas para a produção de habitações contribuíram para reforçar essa prática, ao obrigarem a execução de pequenas unidades e ao não abrirem espaço para a utilização de tecnologias construtivas tradicionais. O processo de reabilitação e de aproveitamento econômico do patrimônio imobiliário da área central, nos anos 1990, serviu, portanto, para reduzir a noção de patrimônio urbano e localizá-la em alguns elementos. Ao invés de estimular, como se acreditava nos anos 1980, o resgate de ofícios antigos, sistemas construtivos e tecnologias tradicionais, trouxe, ao contrário, para o campo do patrimônio a prática mais convencional de construção, sem promover, em contrapartida, nenhum ganho em termos de criatividade ou soluções alternativas.

Com relação ao espaço urbano, a noção de patrimônio também se restringiu a partir das intervenções dos anos 1990. Rigorosamente, apenas a volumetria e a feição externa dos edifícios foram vistas como elementos a preservar. A morfologia do espaço público raramente foi levada em conta, como se as dimensões e os materiais de ruas, calçadas, praças, largos e demais logradouros não constituíssem também testemunhos históricos. Mobiliário urbano, equipamentos, obras de arte, sinalização e materiais de acabamento foram largamente instalados sem considerações dessa natureza, conferindo ao espaço urbano ares ascéticos de shopping center. Esse transbordar da linguagem promocional e da estética controlada dos equipamentos comerciais para o espaço público se relacionou, naturalmente, a estratégias de atração de frequentadores e consumidores, e foram essas estratégias que comandaram, em última instância, o grau de preservação dos referenciais históricos presentes no espaço. (MOTTA, 2000, p. 260-261)

Nos anos 1990, o patrimônio do centro foi chamado a participar intensamente das estratégias de marketing urbano e governamental da cidade do Rio de Janeiro. Foi ainda alçado à condição de insumo fundamental do processo de retomada do desenvolvimento da economia urbana e apropriado, simultaneamente, como um item de valorização imobiliária e como um instrumento de política urbana. Nesse contexto, as operações de seleção e de salvaguarda - de resto, amplamente realizadas nos anos 1980 - não tiveram muita importância, 
ficando submetidas, basicamente, às demandas específicas de projetos urbanos e programas de financiamento. A produção de patrimônio concentrou-se nas operações de conservação, que, no Rio de Janeiro, caracterizaram-se não pela restauração ou pela manutenção, mas, como já mencionado, por uma intensa reciclagem de edifícios e espaços (Fotos 47 e 48). Caracterizaram-se, ainda, por uma redução das noções de patrimônio edificado e urbano no que toca aos elementos que as compõem, e, ao mesmo tempo, por uma extensão dessas noções a todo e qualquer objeto urbano na medida em que significasse incremento de valor ou ampliação do uso econômico.

A análise das intervenções na área central do Rio de Janeiro mostra que, no período focalizado, o projeto de aproveitamento econômico do patrimônio, iniciado nos anos 1970, finalmente começou a encontrar condições de se consolidar. Entretanto, a incapacidade do poder público de deslanchar um repovoamento da área central baseado na intensificação do uso residencial de caráter popular e a ausência de demanda nas faixas de renda mais altas, não permitiram a ampliação desse aproveitamento, mantendo-o restrito ao núcleo comercialmente dinâmico do centro e às estratégias de marketing e formação de imagem deflagradas no período. Nesse núcleo, o projeto de aproveitamento econômico se consolidou razoavelmente, e nessa consolidação desempenharam papéis importantes o sistema de preservação municipal, os incentivos fiscais, os investimentos privados em recuperação de imóveis, o reforço da função de entretenimento e lazer promovido pelos grandes centros culturais, a excelente acessibilidade do centro e as intervenções de requalificação de espaços públicos empreendidas nos anos 1990.

Essa década caracterizou-se então muito mais pela execução de ações sobre o patrimônio do que por reflexões sobre seu papel e sentido. As concepções e normas de intervenção construídas nos anos 1980, entretanto, por sua coerência e fundamentação técnica e histórica, informaram ainda os projetos da maioria das intervenções realizadas no Rio e, embora com reinterpretações ligadas a demandas e apropriações típicas do período, ajudaram a manter o processo carioca de valorização do patrimônio do centro em um patamar de qualidade superior aos desenvolvidos em outras cidades. 
Os anos 1990 assinalaram, no Rio de Janeiro, rupturas e continuidades em relação à prática de preservação desenvolvida nos 1980 e muitos pontos em comum com as ideias desenvolvidas nos anos 1970. Assim, as intervenções realizadas se inseriram no processo de valorização econômica do patrimônio iniciado trinta anos antes, mas a qualidade do trabalho desenvolvido nos anos 1980 também deixou suas marcas. 


\section{São Paulo: patrimônio e centralidade em disputa}

\section{0 centro de São Paulo: formação, hegemonia e fragmentação}

Até meados do século XIX, a cidade de São Paulo ocupava apenas a colina onde nasceu, entre os cursos d'água do Tamanduateí e do Anhangabaú. Essa aglomeração "ilhada”, baixa e quase toda de taipa só começou a se transformar com o crescimento do plantio do café, por volta de 1870. Cidade até então sem grande expressão no cenário nacional, São Paulo deu início naquele momento a um primeiro ciclo de expansão e reconstrução. A posição estratégica entre o porto de Santos e as áreas produtivas do interior favoreceu o desenvolvimento da cidade, que logo se firmou como ponto de reunião da produção cafeeira, centro de negócios e polo de residência dos barões do café. O espaço da chamada "colina histórica" - hoje centro velho - ficou pequeno para as novas atividades, que, a cada dia, iam chegando, e logo a cidade se expandiu para as áreas disponíveis do outro lado do córrego do Anhangabaú, na direção da Igreja de São Bento e do que veio depois a ser conhecido como o bairro da Liberdade. (LEMOS, 1985, p. 91) 
A cidade antiga abrigava todas as funções urbanas mais importantes, inclusive residenciais, mas a escassez de solo e o rápido desenvolvimento do comércio e das finanças foram empurrando as habitações e as pequenas indústrias que iam nascendo para as novas áreas de expansão. Com a implantação da São Paulo Railway, em 1867, as áreas ao norte do núcleo antigo - que despontava como centro da cidade - foram rapidamente urbanizadas, passando a abrigar residências, fábricas e vilas operárias. Além das áreas industriais e operárias ao norte, zonas residenciais mais nobres começaram também a se formar, no final do século XIX, nos Campos Elíseos, em Santa Cecília e ao longo da Avenida Paulista. (SILVA, 2000)

A riqueza gerada pelo café impulsionou um primeiro surto industrial em solo nacional já no século XIX. (MESENTIER, 2001, p. 62) Em São Paulo, as atividades industriais se beneficiaram do excedente de mão de obra oriundo da atividade agrícola, da infraestrutura de transporte ferroviário implantada para escoamento do café e da ampliação do mercado consumidor, que resultou do crescimento populacional e da instituição do regime de trabalho livre. (MESENTIER, 2001, p. 62) Próximo do Rio de Janeiro, à época, o maior mercado urbano do país, São Paulo reuniu todas as condições para se tornar o principal polo industrial do Brasil.

A primeira reestruturação urbana que distinguiu o "centro" do conjunto da cidade se deu sob a influência do urbanismo higienista em voga nas cidades europeias. As pressões do crescimento, aliadas à precariedade em termos de saneamento, coleta de lixo, pavimentação e outros serviços, ensejaram as primeiras intervenções de caráter embelezador e sanitarista já no início do século XX. Datam dessa época a construção de vilas operárias, as medidas para a erradicação de cortiços, a substituição de velhos casarões por edifícios modernos, o alinhamento de ruas, a implantação de iluminação elétrica e do moderno sistema de bondes, bem como a construção de um novo centro do outro lado do Vale do Anhangabaú, conectado ao antigo pelos imponentes viadutos do Chá e de Santa Efigênia.

Num estudo sobre sociedade e cultura na São Paulo dos anos 1920, Sevcenko (1992, p. 37) observa que o desenvolvimento urbano repentino cortou abruptamente os vínculos da cidade com o seu passado, produzindo, "da noite para o dia", uma metrópole complexa, cujo aspecto misturava características de metrópoles europeias e americanas. Essa vontade de ser Paris e, depois, Nova York, acompanhou 
São Paulo desde então, e a materialização desse desejo tornou a realidade local e sua paisagem um obstáculo a ser vencido ou algo a ser constantemente transformado e reconstruído. (SEVCENKO, 1992, p. 116) Mas, com exceção dos planos elaborados para o centro nas primeiras décadas do século XX,' a cidade cresceu sem ordem ou planejamento, pela necessidade e ao sabor da especulação imobiliária, tornando-se uma colcha de retalhos descontínua e, por vezes, sem nexo.

A crescente valorização do solo no conjunto do centro velho/centro novo logo conduziu a uma ocupação intensiva, como forma de se auferir maior rentabilidade. (SILVA, 2000, p. 6-7) As edificações, de início limitadas a quatro pavimentos, cresceram em altura em função das pressões imobiliárias. Com o advento da tecnologia do concreto armado, um novo símbolo de progresso e modernidade foi criado para São Paulo: o arranha-céu. Em 1929, o Edifício Martinelli, com seus 22 andares, antecipava o quadro futuro desejado para o centro. 0 excesso de bondes, a grande concentração de atividades e o uso crescente do automóvel, entretanto, já congestionavam bastante a cidade nos anos 1920. O processo de urbanização fragmentado, resultante do loteamento de chácaras em torno do núcleo antigo, tampouco facilitava a circulação, tornando urgente uma intervenção.

O Plano de Avenidas, de 1930, elaborado pelos urbanistas Ulhôa Cintra e Prestes Maia, enfrentou o congestionamento do centro e a falta de lógica do sistema parcelar e de circulação da cidade por meio da proposição de uma nova estrutura viária. Nessa estrutura, buscava-se facilitar o acesso à área central e conferir mais fluidez ao trânsito, mediante a construção de um anel viário conjugado a um conjunto de avenidas radiais para distribuição e articulação do fluxo entre o centro e bairros adjacentes. O plano continha também diretrizes de zoneamento e desenvolvimento urbano, mas apenas sua componente viária foi sendo executada, aos poucos, nos 40 anos subsequentes.

O Plano de Prestes Maia redesenhou o centro, limitando seu núcleo principal à área contida no interior do anel viário projetado, dando forma ao que hoje se entende como área central da cidade, isto é, ao conjunto que reúne esse núcleo e os bairros contíguos que sofrem diretamente sua influência (Mapas 11 e 12). A implantação das primeiras avenidas provocou um boom imobiliário que acelerou mais ainda a ocupação e o crescimento vertical do centro. (AMADIO, 1998, p. 59; MEYER; IZZO JUNIOR, 1999, p. 27; SOMEKH, 1997) Os anos 1930 marcaram, em 
2 O Plano Sagmacs, de 1956, indicava a descentralização administrativa e 0 deslocamento de funções centrais como solução para os problemas de congestionamento do centro.

3 São exemplos dessas intervenções, além do Elevado Costa e Silva ou "Minhocão", que encobriu parte da Av. São João, o complexo de viadutos no Parque D. Pedro II e na Praça 14 Bis, e a remodelação da Praça Roosevelt, que compõe o sistema viário Leste/ Oeste, entre outras.

4 Lei $n^{\circ} 7805 / 72$.
São Paulo, a passagem definitiva de uma economia agroexportadora para uma economia industrial. A cidade de tijolos da oligarquia cafeeira foi, a partir de então, substituída pela cidade de concreto armado do capital financeiro e industrial, sendo que o Plano de Avenidas buscou dar uma resposta técnica à sua dinâmica. Da cidade do café sobraram apenas remanescentes.

Os anos 1950 podem ser vistos como o período de apogeu do centro antigo de São Paulo, cuja estrutura urbana era ainda inquestionável. A implantação das indústrias automobilística e de bens de consumo duráveis na região metropolitana fortaleceu mais ainda a posição da cidade no cenário econômico do país e reforçou seu centro como principal núcleo comercial e financeiro da região Sudeste. No início dos anos 1960, os congestionamentos e os altos índices de poluição, decorrentes do crescimento exponencial do número de automóveis e ônibus em circulação, demandaram novas intervenções viárias. No entanto, a situação de saturação, reforçada pela falta de investimento num sistema de transporte de massa eficiente, e a concentração dos segmentos sociais mais abastados a Sudoeste do núcleo antigo, já havia provocado um deslocamento de atividades terciárias em direção à Avenida Paulista e imediações. Este movimento foi reforçado por planos que defenderam a descentralização da administração pública ${ }^{2} e$ também pelo setor imobiliário, que, tendo esgotado as melhores localizações e chances de exploração no centro, voltou-se então para os setores da cidade que concentravam camadas de maior poder aquisitivo.

As intervenções rodoviaristas na área central, ${ }^{3}$ dentre as quais o Elevado Costa e Silva é a mais emblemática, ao invés de promoverem a permanência ou a volta de atividades importantes, aprofundaram a queda da qualidade urbana, caracterizando o centro como área de passagem e criando barreiras que desarticularam e separaram setores. Mas as melhorias em termos de fluidez e acessibilidade que essas obras proporcionaram logo se revelaram ineficazes diante da nova avalanche de veículos promovida pelo boom de crescimento econômico dos anos 1970. A rede de metrô proposta pelo Plano Urbanístico Básico do Município de São Paulo, de 1968, começou a ser implantada em seguida, mas chegou tarde. Quando, em 1972, a nova Lei de Zoneamento 4 definiu um coeficiente de aproveitamento menor para o centro, com vistas a controlar seu adensamento e congestionamento, o crescimento do setor já havia estagnado e um processo de 
formação de novas centralidades estava em curso. Os projetos e investimentos públicos realizados no centro, ao longo dos anos 1970 e 1980, não foram capazes de reverter essa tendência.

Os fatores comumente apontados como responsáveis pelo progressivo esvaziamento funcional e pela deterioração do centro a partir dos anos 1960 são a excessiva centralização da estrutura viária desenhada por Prestes Maia e as intervenções que, ao invés de proporcionar fluidez, provocaram mais congestionamento e poluição. Contudo, o fator realmente preponderante foi a perda de valor de mercado da localização frente a outras áreas crescentemente "promovidas" pelo setor imobiliário, (AMADIO, 1998, p. 131) somada à retração da economia paulista a partir de meados dos anos 1970. As tentativas de estancar este processo não tiveram eficácia em razão do caráter contraditório das medidas e da falta de compreensão sobre a transformação urbana que então estava em curso.

As raízes da transformação urbana que aprofundou a desvalorização do centro de São Paulo estão na redistribuição das atividades produtivas no território nacional, implementada com a política federal de desconcentração industrial dos anos 1970, o que promoveu uma relativa estagnação dessa atividade na região Sudeste até a segunda metade dos anos 1980. (MESENTIER, 2001, p. 67-150) Uma consequência direta para a cidade de São Paulo foi, além da perda de atividades produtivas, o crescimento do setor terciário. O processo de formação de novas centralidades deslanchou, portanto, no momento em que a cidade e a própria região Sudeste perdiam dinamismo econômico. Mesmo com o posterior movimento de reconcentração de atividades industriais na região, a partir de 1985, a reestruturação do setor secundário e a crise econômico-financeira do país não permitiram que a economia da cidade crescesse suficientemente para redinamizar o centro antigo e, ao mesmo tempo, as novas centralidades formadas pelas mãos do capital imobiliário. Assim, o conjunto de investimentos públicos e intervenções que buscaram reforçar, melhorar a qualidade urbana e revitalizar o centro antigo, a partir dos anos 1970, não tiveram eficácia diante dessa dinâmica recessiva e de deslocamento de funções que já havia sido posta em marcha.

De fato, nem a implantação das linhas Norte/Sul e Leste/Oeste do metrô, com todas as obras de renovação, reurbanização e remodelação de espaços que implicaram; nem a construção de calçadões em várias ruas para melhorar a 
qualidade urbana; e nem as iniciativas de proteção e valorização do patrimônio histórico, tiveram o poder de reverter a rota de esvaziamento de funções prestigiosas e de popularização da área central, iniciada nos anos 1960. Ao contrário, esses investimentos, involuntariamente, reforçaram esse novo perfil de uso popular ao tornarem o centro a principal área de confluência de todo o sistema de transporte público de massa, ao privilegiarem o trânsito de pedestres e ao inibirem a circulação e o estacionamento de veículos particulares. O processo de perda de hegemonia do centro antigo na nova estrutura policêntrica da cidade foi ainda "ajudado" pelos investimentos públicos em infraestrutura que favoreceram a concentração de atividades e o aumento da produção imobiliária no setor Sudoeste, reforçando as centralidades que aí se formaram, inicialmente, nas imediações da Av. Paulista, depois na Av. Faria Lima e, por fim, na região da Av. Luís Carlos Berrini e da Marginal Pinheiros (Mapa 11). Desnecessário ressaltar que, ao surgimento de cada nova centralidade, as anteriores aprofundaram ou iniciaram processos de esvaziamento e decadência. (FRÚGOLI JÚNIOR, 2000)

Nos anos 1970 e 80, as obras do metrô e os calçadões foram as principais intervenções do poder público no centro de São Paulo. Acreditava-se então que o esvaziamento e a deterioração do centro eram devidos, basicamente, ao excesso de circulação de veículos e à má qualidade dos transportes. Portanto, sua revitalização se daria mediante a solução desses problemas e a reconfiguração e renovação dos espaços deteriorados por terminais de ônibus e estacionamentos de automóveis, que deveriam ter sua circulação no centro limitada ao máximo. Criado nos Estados Unidos, nos anos 1960, como reação do comércio de rua ao sucesso dos shopping malls (LEME; VENTURA, 2000, p. 63), o calçadão de pedestres se tornou uma espécie de modismo no Brasil, sendo visto como a solução para a valorização ambiental, o descongestionamento e a despoluição de áreas centrais. Com a vantagem de ser uma intervenção de custo baixo e grande visibilidade, foi utilizado nas mais diversas situações, conhecendo em São Paulo um vasto emprego. Projetos como o de reurbanização do Vale do Anhangabaú e de trecho da Av. São João utilizaram o calçadão largamente.

No centro, os calçadões favoreceram a apropriação do setor como área de comércio e consumo popular, especialmente quando, nos anos 1980, o desemprego decorrente da reestruturação do setor produtivo os encheu de vendedores 
ambulantes. A grande concentração de pessoas proporcionada pela confluência dos transportes urbanos e espaços pedestrianizados impulsionaram o desenvolvimento das mais diversas formas alternativas de sobrevivência. A desvalorização imobiliária possibilitou também uma nova apropriação da área central como zona de moradia popular e a permanência de vários bolsões de cortiços e outras formas de habitação subnormal. Essa mudança no perfil do usuário contribuiu para a produção de uma imagem deteriorada e degradada do centro, que, por sua vez, também passou a alimentar a desvalorização da localização. (AMADIO, 1998, p. 131)

O empobrecimento da cidade levou de roldão a classe média, fez crescer a periferia e aumentou a ocupação informal do solo urbano. (SILVA, 1997) Quando, em meados dos anos 1980, o processo de abertura ao comércio exterior começou a influenciar a reconcentração de atividades no Sudeste brasileiro, o novo regime de acumulação não mudou esse panorama urbano. (MESENTIER, 2001, p. 202-203) Ao contrário, o aguçou, pois, operando com mais concentração de renda e menos empregos formais, afetou toda a área urbanizada da cidade (Tabelas 27 e 28). Simultaneamente, o setor Sudoeste da cidade - onde se localizaram, desde os anos 1960, as camadas de alta renda -, tendeu a polarizar os investimentos públicos e privados em produção de espaço urbano, o que ocasionou a concentração das novas centralidades terciárias nesse mesmo vetor de desenvolvimento. (FRÚGOLI JÚNIOR, 2000; MARICATO, 2000, p. 121-192)

Nos anos 1990, a fuga de grande parte da atividade financeira (que sempre caracterizou o centro) para a Avenida Faria Lima e para a nova centralidade na região da Avenida Luís Carlos Berrini suscitou novas medidas de revalorização imobiliária do centro antigo, além de voltadas para o retorno de funções. O foco dos investimentos imobiliários, entretanto, já se encontrava restrito ao setor Sudoeste, o que favoreceu as novas centralidades dessa zona e prejudicou as tentativas de reanimar o centro antigo. As medidas e instrumentos urbanísticos criados para captar recursos privados e viabilizar aí uma intervenção pública mais ampla atuaram nesse contexto de restrição, não alcançando os resultados esperados.

A cidade de São Paulo chegou aos anos 1990, portanto, com uma estrutura urbana policêntrica, mas desequilibrada, com as centralidades mais importantes concentradas na área Sudoeste, onde também se localizava o principal vetor de investimentos imobiliário, e, assim, com um destino incerto para o seu antigo 
centro, em termos de mudança do seu perfil de uso e ocupação. Não era, contudo, um espaço abandonado ou desvitalizado. Concentrando parte significativa dos empregos da metrópole (Tabela 29) e sendo o território da cidade melhor dotado de acessibilidade, o centro antigo era então uma área grandemente demandada para habitação, trabalho e consumo popular. O fato de conter bairros demograficamente esvaziados e não disputados pelo mercado residencial formal atraía segmentos de menor renda, pois estes eram e são os que mais sofrem com as longas distâncias e os congestionamentos de tráfego no deslocamento entre casa e trabalho.

Na década de 1990, as políticas e as visões sobre o centro antigo se dividiram e foram influenciadas por essas demandas e por outras diametralmente opostas. De um lado, proprietários urbanos e empresários em busca de valorização para o patrimônio que haviam construído no centro. De outro, os movimentos populares organizados em disputa por moradia permanente numa área de infraestrutura urbana privilegiada, que passaram também a ver como sua. Em ambos os casos, a preservação do patrimônio histórico foi evocada como objetivo e justificação. Em seguida, se analisará como numa cidade construída sob o signo do progresso e da modernização se deu essa transformação.

\section{Patrimônio e progresso}

Modernidade e progresso são ideias que sempre andaram juntas em São Paulo. Perseguindo-as, a cidade se reconstruiu duas vezes, deixando para trás apenas remanescentes. O fio condutor do desenvolvimento urbano sempre foi o novo, o desbravamento de novas atividades, novos espaços, novos meios. São Paulo, entretanto, foi também um dos berços da instituição do patrimônio histórico no Brasil e a primeira cidade a implantar, em 1936, um serviço público - o Departamento Municipal de Cultura - destinado a "traçar, organizar e fazer executar o plano geral do tombamento do patrimônio artístico e histórico do Município". (RODRIGUES, 2000, p. 37)

Criado por intelectuais modernistas interessados em construir um futuro enraizado no passado nacional, o Departamento Municipal de Cultura, contudo, 
não realizou tombamentos por causa de dificuldades no estabelecimento de uma legislação de proteção, sendo, em 1947, abandonado pelo então prefeito Prestes Maia (RODRIGUES, 2000), que estava mais preocupado com os problemas do progresso. As primeiras ações de proteção do patrimônio histórico e artístico em São Paulo foram, assim, empreendidas pelo antigo SPHAN, onde, capitaneados pelo poeta Mário de Andrade, militavam os mesmos intelectuais que deram vida ao departamento municipal.

No plano nacional, a circunstância da instituição da defesa do patrimônio pela mão dos modernistas teve várias consequências. De saída, o fato de ter sido feita sob a égide de suas concepções artísticas e estéticas. Operando com cânones rígidos, nos quais o "caráter nacional” da obra era visto como essencial, baniu-se do rol patrimonial quaisquer manifestações vinculadas a estilos europeus considerados estranhos à tradição e à cultura nacional. Assim, na visão dos modernistas da cidade de São Paulo - cujo núcleo mais antigo já se encontrava, no final dos anos 1930, pleno de exemplares do ecletismo europeu-, praticamente não havia patrimônio a se preservar. Até os anos 1970, foi esse o critério que prevaleceu e, durante quase quatro décadas, apenas um conjunto foi tombado pela instituição federal nessa cidade - a Igreja e o Mosteiro da Luz. Os olhos da instituição estiveram voltados, nesse período, apenas para o interior do estado, e, mesmo assim, com várias precauções. Em passagem célebre, Mário de Andrade, em 1937, estabelecia os seguintes parâmetros para a atuação do antigo SPHAN no território de São Paulo:

O critério para um trabalho proveitoso de defesa e tombamento do que o passado nos legou tem de se pautar, no Estado de São Paulo, quase exclusivamente pelo ângulo histórico [...]. Se écerto que uma pesquisa muito paciente pode encontrar detalhes de beleza ou soluções de interesse técnico, num teto ou torre sineira, num alpendre ou numa janela gradeada, é mais incontestável ainda, a meu ver, que São Paulo não pode apresentar documentação alguma que, como arte, se aproxime sequer da estatuária mineira, da pintura, dos entalhes e dos interiores completos do Rio, de Pernambuco ou da Bahia. 
5 O Programa Monumenta, criado em 1999, considerava elegíveis apenas projetos que envolvessem bens tombados pelo Governo Federal. Por seu turno, o Programa Nacional de Apoio à Cultura PRONAC previa 100\% de renúncia fiscal para investimentos em bens tombados pela União.

6 Parecer de Luis Saia, ex-dirigente do IPHAN em São Paulo e conselheiro do CONDEPHAAT sobre a proposta de tombamento estadual do Palácio do Imperador, em Itapura. (RODRIGUES, 2000 p. 70)
O critério tem de ser outro. Tem de ser histórico, e em vez de se preocupar muito com beleza, há de reverenciar e defender especialmente as capelinhas toscas, as velhices dum tempo de luta e os restos de luxo esburacado que o acaso se esqueceu de destruir. (ANDRADE, 1937, p. 120-121)

Em busca dessas "velhices" e "restos", a ação de proteção do SPHAN no estado de São Paulo foi muito contida, e, na capital, quase inexistente. Até 2002, foram realizados ali somente doze tombamentos, dos quais apenas quatro na área central (Quadro 5). Voltada para remanescentes da arquitetura do período colonial e, depois, para exemplares da arquitetura moderna, essa ação estabeleceu, como observa Rodrigues, uma "ortodoxia" na seleção do patrimônio paulista, que foi, em grande parte, repassada para as instituições locais. (RODRIGUES, 2000, p. 37) Mesmo quando a concepção modernista de patrimônio foi superada, exemplares do ecletismo paulista continuaram a ser definidos por especialistas como de valor artístico duvidoso e, no máximo, de caráter local ou regional. Só nos anos 2000, os tombamentos federais no estado alteraram esse panorama, passando a incluir edifícios ecléticos, mesmo assim, em decorrência de pressões do governo paulista e para efeito de inclusão de edifícios em programas nacionais de financiamento da preservação. ${ }^{5}$

O Conselho de Defesa do Patrimônio Histórico, Artístico, Arqueológico e Turístico - CONDEPHAAT, criado pelo governo de São Paulo em 1968, adotou, de início, uma linha de atuação muito semelhante à do antigo SPHAN. Apesar da presença marcante do ecletismo no cenário urbano paulista, suas manifestações eram desvalorizadas e definidas como importadas e "sem nenhuma vinculação com a arquitetura tradicional do Brasil". ${ }^{6}$ Somente nos anos 1980, com o processo de redemocratização do país e com o crescimento das reivindicações da classe média por melhor qualidade de vida, é que essa ação preservacionista ortodoxa se transformou. A história dos processos econômicos, sociais e culturais impressa nas edificações e no espaço urbano, aliada à qualidade ambiental, surgiu como o principal eixo de estruturação dos critérios de seleção desse conselho estadual. A partir desse momento, sua atuação de caracterizou por uma intensa utilização do tombamento como instrumento de proteção do ambiente urbano e natural, 
procedendo-se ao tombamento de bairros inteiros da cidade de São Paulo, bem como de grandes áreas de valor ambiental, como as Serras do Mar e da Jureia.

Até 2002, o Governo do Estado havia tombado 112 bens imóveis na cidade de São Paulo, dos quais 48 na área central (Quadro 6). Em decorrência da predominância do valor histórico - e não mais do artístico - como critério de seleção, a partir dos anos 1980, boa parte desse acervo foi composta de exemplares do ecletismo arquitetônico e do neocolonial praticados nas primeiras décadas do século XX. Por meio dos organismos estadual e municipal, a cidade de São Paulo, que, até os anos 1970, parecia não ter patrimônio, foi redescoberta nesse sentido. Mas o rol dos bens tombados pelo Governo do Estado revela que a concepção de valor artístico dos pioneiros do serviço federal não chegou a ser totalmente superada, pois nenhum dos edifícios tombados na cidade mereceu inscrição no Livro do Tombo de Belas Artes do CONDEPHAAT?

O Plano Urbanístico Básico de São Paulo, de 1968, e o Plano Diretor de Desenvolvimento Urbano, de 1971, foram os primeiros documentos de planejamento a mencionar a necessidade de se preservar e valorizar a paisagem e os locais de interesse histórico e cultural da cidade, como estímulo para atividades turísticas. (FENERICH, 2000, p. 57) A Lei de Zoneamento do Município de São Paulo, ${ }^{8}$ decorrente deste plano diretor, criou a possibilidade de delimitação de zonas de uso especial sujeitas a regime urbanístico específico - Z8 -, instituindo-se, assim, um primeiro instrumento municipal de controle da transformação e da renovação urbana. O distrito de Bela Vista, na área central, foi, já em 1972, classificado como uma zona desse tipo, seguido, em 1973, pelo bairro da Luz. (FENERICH, 2000, p. 80) Essas classificações ensejaram a realização de estudos urbanísticos detalhados, que encaminharam recomendações para a preservação de vários monumentos. ${ }^{9}$ No estudo elaborado para a Luz, embora muito voltado para a otimização do desempenho funcional da área e para a solução de problemas viários e de tráfego, propunha-se a proteção e a valorização do patrimônio mediante seu aproveitamento para o lazer cultural, como forma de estimular sua utilização pelo conjunto da população. (MEYER; IZZO JUNIOR, 1999, p. 134)

A implantação do metrô, em 1974, ensejou o início de uma ação mais sistemática da prefeitura na defesa do patrimônio da cidade, por meio de instrumentos
7 Dentre os 104 bens tombados pelo CONDEPHAAT até 1999, 94 foram inscritos no Livro do Tombo Histórico e os 10 restantes no Livro do Tombo Arqueológico, Etnográfico e Paisagístico.

8 Lei $n^{\circ} 7.805 / 72$.

9 A exemplo do coordenado pelo Escritório Rino Levi para a área da Luz, em 1974, e do Plano de Renovação Urbana da Bela Vista, também do mesmo ano. (MORAES, 1998, p. 92) 
10 O levantamento foi executado pelos arquitetos Carlos Lemos e Benedito Lima de Toledo, ambos então conselheiros do CONDEPHAAT. do planejamento. Naquele ano, a então Coordenadoria Geral de Planejamento - COGEP, encomendou um levantamento dos bens culturais da área central que, durante toda essa década, orientou a ação municipal..$^{10}$ Nessa listagem, cujo critério de seleção norteador foram os testemunhos das fases socioeconômicas da capital e seus respectivos sistemas construtivos, o ecletismo foi, finalmente, alçado ao status de estilo representativo do patrimônio arquitetônico paulistano, e alguns arranha-céus foram reconhecidos como documentos da industrialização. Menos que a excepcionalidade estética ou a pureza do estilo, a listagem municipal buscava documentar, por meio da arquitetura e dos fragmentos urbanos sobreviventes, o passado e o cotidiano dos vários segmentos sociais da cidade. (RODRIGUES, 2000, p. 72) Com base nesse levantamento, além da identificação de edificações isoladas para proteção, foram também delimitadas áreas de tamanho e configuração variáveis - denominadas "manchas" -, que reuniam bens representativos dos diferentes períodos de desenvolvimento da cidade.

Os objetivos desse trabalho ultrapassavam a mera preservação de exemplares de valor patrimonial. A ideia era que orientasse também a elaboração de uma nova legislação de zoneamento, num momento em que, em consequência das obras do metrô, se esperava um novo surto de renovação nas áreas mais antigas da cidade, o que, afinal, não ocorreu. Com a promulgação da Lei Municipal n 8.328/75, os imóveis e manchas identificados foram classificados como zonas de uso especial, denominadas "Z8-200", estabelecendo-se que, nessas zonas, o remembramento ou o desmembramento de lotes, as demolições, reformas, ampliações, reconstruções ou as novas edificações, ficariam sujeitos a prévia autorização da COGEP, com vistas à preservação de suas características urbanas e ambientais.

As Z8-200 surgiram como instrumentos de preservação vinculados ao planejamento e como uma alternativa ao tombamento, visto, então, como medida ineficaz e estática. Contudo, de modo semelhante a este velho instrumento, as Z8-200 operavam mediante a limitação do direito de propriedade, sem uso de desapropriação ou indenização. Tratava-se, na realidade, de um tombamento efetivado pela aplicação da legislação urbanística, tendo igualmente como justificativa a função social da propriedade. Numa cidade como São Paulo, que, na época, mantinha ainda um ritmo razoável de transformação em sua área consolidada, 
e cujo patrimônio recém-descoberto se encontrava imerso em zonas passíveis de renovação e com parâmetros urbanísticos permissivos, as Z8-200, à semelhança do tombamento federal, também desencadearam protestos e reivindicações no sentido da compensação de um suposto esvaziamento econômico da propriedade, decorrente de sua aplicação. Entretanto, os protestos dos proprietários urbanos só encontraram apoio e solução nas décadas seguintes, quando a crescente insolvência financeira do Estado logrou transformar o sentido original da proteção do patrimônio de um dever cívico feito em nome do interesse público, a um sacrifício que mereceria compensação. As Z8-200 foram delimitadas pela Prefeitura de São Paulo até o final dos anos 1980, quando, por dependerem de processo legislativo para sua efetivação, perderam espaço para o tombamento municipal, instituído em 1985.

A partir do citado levantamento realizado em 1974, foram delimitadas 94 zonas Z8-200, envolvendo cerca de 600 edifícios, classificados isoladamente ou agrupados em "manchas". Posteriormente, imóveis foram assim enquadrados em consequência de estudos de renovação urbana nos bairros Bela Vista e Luz, e na Zona Metrô Leste/Oeste, ou em decorrência da existência de bens tombados pelo CONDEPHAAT. Até 1989," 140 zonas haviam sido classificadas como Z8-200, abrangendo mais de 1000 imóveis, sendo 80\% delas localizadas na área central. ${ }^{12}$

Quando foi concluída a listagem de bens culturais pelo município, em 1976, surgiram as primeiras propostas de utilização pontual do instrumento do "solo criado", com vistas à neutralização das pressões imobiliárias sobre edificações antigas da área central, mas não ainda como forma de compensação econômica. (RODRIGUES, 2000, p. 83) As críticas à proteção do patrimônio como forma de esvaziamento do valor econômico de imóveis aprofundaram-se, em São Paulo, por ocasião do tombamento estadual da Casa Modernista da Rua Santa Cruz, em 1985. Esse ato ensejou contestação por parte do proprietário do bem, que conseguiu decisão judicial inédita, obrigando a Fazenda do estado de São Paulo a indenizá-lo. O episódio marcou uma transformação importante nas práticas de salvaguarda na cidade de São Paulo: a partir de então, estas se tornaram cada vez mais atreladas a medidas voltadas para a criação de mais-valia para os imóveis preservados, geralmente de natureza fiscal, como forma de compensar os proprietários. O entendimento da preservação como uma forma de
11 Último ano do enquadramento de bens como Z8-200. (FENERICH, 2000, p. 53-77)

12 Segundo informação da Secretaria Municipal de Planejamento Urbano SEMPLA, em 2002. 
cumprimento da função social da propriedade, que não gera direito a indenização ou compensação, e sim obrigações para o Estado e proprietários, mudou a partir de então. A conservação do patrimônio passou a ser abordada como atividade que não apenas deveria ser autossustentável, mas também rentável. Naturalmente, a crise financeira do país, aprofundada nos anos 1980, contribuiu para essa mudança. O tombamento como ferramenta de um Estado provedor começou a ser reformulado, sendo complementado por medidas compensatórias e incentivos à ação privada.

Os clamores por essas medidas levaram o município a promulgar, em 1984, a Lei $n^{\circ}$ 9.725, antes mesmo da efetivação de qualquer tombamento. A partir das citadas discussões sobre "solo criado", esta lei instituiu a possibilidade de transferência de potencial construtivo de imóveis enquadrados como Z8-200 para outros situados no seu entorno, tomando-se como base o coeficiente de aproveitamento mais alto da zona de uso contígua. O potencial transferível foi calculado como o produto resultante da área do lote, multiplicada pelo coeficiente de aproveitamento da zona vizinha, descontada a área construída do imóvel preservado. A lei permitia a transferência de 60\% desse potencial de modo integral ou em parcelas, ou 100\%, no caso de imóveis destinados a uso público. Cada imóvel receptor poderia receber, no máximo, $25 \%$ a mais do que o coeficiente previsto para sua zona, e o proprietário beneficiado com a cessão de potencial seria multado caso não promovesse a conservação do imóvel protegido. A lei estabeleceu também a isenção de IPTU e de taxas municipais para imóveis preservados de uso residencial, mas, com base nesse instrumento, apenas uma operação de transferência de potencial foi realizada. Essa baixa utilização foi creditada à falta de divulgação do benefício e, principalmente, à falta de interesse por parte do mercado, pois só eram permitidas transferências dentro da mesma zona. Como a maioria dos imóveis protegidos localizava-se na área central, então já em franco processo de esvaziamento funcional e populacional, o instrumento não atendeu à demanda por ganhos de coeficiente localizada fora dessa área.

Lei $n^{\circ} 10.598$, de 19/08/1988, concedeu desconto de 50\% no IPTU, por um prazo máximo de dois anos, para imóveis restaurados, fossem preservados ou não. Entretanto, também dessa vez, apenas um prédio, na Rua Líbero Badaró, solicitou 
o benefício. ${ }^{13}$ Mas mesmo diante desses fracassos, os incentivos fiscais, a venda de potencial construtivo e, mais tarde, a liberação de índices urbanísticos, não mais deixaram de participar como itens essenciais das políticas de preservação em São Paulo. Contudo, até o começo dos anos 2000, a eficácia desses instrumentos foi baixa, devido à falta de dinâmica imobiliária da área central e à impossibilidade de vincular seus benefícios às demais áreas da cidade onde essa dinâmica era forte.

No entanto, apesar da falta de demanda pelos incentivos e vantagens concedidos, preferiu-se atribuir a maior parte da responsabilidade pelo esvaziamento e desvalorização da área central às restrições dos instrumentos de preservação e aos coeficientes de aproveitamento baixos. Embora o bairro dos Jardins fosse totalmente tombado e continuasse densamente habitado e com boa qualidade urbana, este fato não foi suficiente para se compreender e assumir que a verdade era outra: processos urbanos muito mais poderosos do que aqueles que a legislação de proteção é capaz deflagrar estavam por trás da situação esvaziada do centro. Aos investimentos públicos mal distribuídos, à falta de planejamento urbano global e de freio à ação do capital imobiliário, em sua contínua construção de espaços terciários, não foi atribuída qualquer responsabilidade. Do mesmo modo, a má distribuição de renda e a estagnação econômica tampouco foram culpadas.

Uma proteção mais ampla e conceitualmente mais abrangente do patrimônio paulistano surgiu, portanto, com a ação estadual e municipal desenvolvida a partir dos anos 1970, num contexto marcado pelas intervenções de renovação e de reurbanização decorrentes da implantação do metrô. Contudo, naquele momento, à exceção dos calçadões, então definidos como intervenções de revitalização e recuperação ambiental, pouquíssimas foram as operações de conservação do patrimônio, ${ }^{14}$ podendo-se caracterizar esse período como um momento de levantamentos, estudos e de surgimento de uma consciência preservacionista no meio técnico municipal.

O Departamento do Patrimônio Histórico - DPH, primeiro serviço municipal voltado especificamente para a preservação do patrimônio, foi criado em 1975, mas sua ação efetiva só teve início na década seguinte, com a implantação do Inventário Geral do Patrimônio Ambiental, Cultural e Urbano da Cidade de São Paulo - IGEPAC, e com a criação do Conselho de Preservação do Município de
13 Informação fornecida por Décio Amadio, da Administração Regional da Sé, em entrevista realizada em 28 mar. 2002.

14 Apenas o viaduto de Santa Efigênia foi restaurado em 1978, no contexto das obras de implantação da Estação São Bento, do metrô. 
15 O IGEPAC foi implantado em 1983 e o tombamento municipal, a ser avaliado pelo COMPRESP e instruído pelo $\mathrm{DPH}$, foi instituído pela Lei $n^{\circ} 10.032$, de 27 de dezembro de 1985 .

16 Em 1993, foi aberto o processo de tombamento do bairro da Bela Vista.

17 Resoluçăo $n^{\circ} 11$, do COMPRESP de 16 de julho de 2002.
São Paulo - CONPRESP. ${ }^{15}$ Os primeiros tombamentos municipais, realizados em 1986, focalizaram imóveis de propriedade do município e pedidos originados em movimentos sociais de defesa do patrimônio. Nesse período, foram protegidos apenas pequenos conjuntos na área central, como o Largo de São Francisco e o Pátio do Colégio. Uma ação de proteção mais larga só teve início em 1992, por ocasião da implantação da Operação Urbana Anhangabaú.

O Vale do Anhangabaú foi tombado pelo município para preservar as manchas urbanas e os imóveis de valor histórico ali localizados, que seriam submetidos a essa Operação Urbana. A área protegida cobriu parte do perímetro inventariado pelo IGEPAC no centro e envolveu 292 imóveis ( 53 dos quais já haviam sido classificados como Z8-200, em 1975) e nove logradouros públicos, além de listar 258 imóveis para regulação de volumetria. (FENERICH, 2000, p. 149-150)

O COMPRESP tombou ainda, entre 1991 e 92, os Jardins América, Europa, Paulista e Paulistano, os bairros do Pacaembu e Perdizes e o núcleo da Freguesia do Ó. ${ }^{16}$ Até o final dos anos 1990, o município havia realizado 133 tombamentos, a maioria dos quais correspondendo a bens protegidos pelo CONDEPHAAT, com 75 deles situados na área central. Em 2002, em meio à implantação de um programa de reabilitação do centro que previa várias intervenções urbanísticas, foi aberto o processo de tombamento da área do centro velho, envolvendo 147 edificações, seis praças, o Parque D. Pedro II, 20 obras de arte localizadas em logradouros públicos e os viadutos Boa Vista, 25 de Maio, Brigadeiro Luís Antônio e Dona Paulina. ${ }^{17}$

Tanto as Z8-200 quanto os tombamentos municipais decorreram de situações que não retratavam os estudos desenvolvidos pelos órgãos de preservação do estado e do município, tendo sido bastante influenciados pela necessidade de proteger imóveis e sítios em face de situações de renovação urbana e outras ameaças. (FENERICH, 2000, p. 74) A despeito da efetivação dessas medidas preservacionistas e do seu caráter preventivo, o patrimônio protegido da área central não foi, contudo, seriamente ameaçado nem pelas obras do metrô, nem pelos incentivos à deflagração de processos de renovação e de retomada da produção imobiliária, implementados nos anos 1990. 


\section{A Operação Urbana Anhangabaú}

A reurbanização do Vale do Anhangabaú (Foto 49) foi a primeira intervenção de peso no centro de São Paulo depois da implantação do metrô. Inaugurada em 1991, na gestão da prefeita Luiza Erundina, a iniciativa foi destinada a conter a deterioração do centro, melhorar sua qualidade ambiental e valorizar suas referências culturais. (AMADIO, 1998, p. 62) Ainda em consonância com as ideias de descongestionamento do centro, o projeto do novo Anhangabaú canalizava o tráfego de passagem num túnel construído no fundo do vale, a ser coberto por uma laje-jardim destinada a atividades de lazer, encontros e shows, e que funcionaria, ainda, como conexão de pedestres entre o centro velho e o centro novo. Em continuidade com as propostas dos calçadões nos anos 1970, o trecho que ligaria a Avenida São João ao Vale do Anhangabaú seria também transformado em via de pedestres e denominado "Boulevard São João".

Para a conclusão das obras, o município lançou mão de um instrumento chamado "operação urbana", 18 concebido como ferramenta que possibilitaria dividir com o capital imobiliário e proprietários urbanos os custos de produção ou de recuperação de espaços - liberando recursos orçamentários para a realização de obras sociais. (SOUZA, 2002, p. 277) O uso desse instrumento foi possível com a aprovação da nova Lei Orgânica do Município de São Paulo, em abril de 1990. Os parcos recursos orçamentários do município e o grande número de problemas sociais existentes na cidade justificaram, à época, essa forma de captação. Estimadas em US\$32.086,00 milhões, as obras contemplavam a complementação da reurbanização do vale, a restauração de esculturas e a implantação de mobiliário, além da execução de obras de manutenção e de microdrenagem. ${ }^{19}$ Esperava-se que esses investimentos, que visavam também à preservação dos imóveis de valor histórico e cultural, promovessem um melhor aproveitamento dos imóveis vagos ou subutilizados existentes na área.

A lei que instituiu a Operação Urbana Anhangabaú ${ }^{\circ}$ criou três mecanismos para incentivar investimentos privados e obter recursos para as obras previstas. O primeiro previu a possibilidade de flexibilização da legislação urbanística
18 Exposição de motivos do Projeto de Lei n²26/9o, que encaminhou a minuta de lei da Operação Urbana Anhangabaú à Câmara Municipal.

19 Ver quadro constante do Anexo 1 da Lei $n^{\circ} 11.090$, de 16 de setembro de 1991, que instituiu a Operação Urbana Anhangabaú.

20 Lei n 11.090/91. 
21 De acordo com a Lei de Zoneamento de 1972, o coeficiente de aproveitamento máximo da área (classificada como Z5) era 4. Para os casos de transferência de potencial, esse coeficiente de aproveitamento foi aumentado para 6.

22 Foi previsto um desconto de $40 \%$ para quem realizasse operações de regularização de intervenções no primeiro ano da Operação Urbana.

23 Até 1996, apenas $9.588 \mathrm{~m}^{2}$, em dois terrenos, haviam sido regularizados e sete termos de compromisso haviam sido firmados, correspondendo a uma arrecadação total de R\$7.293.819,93. Informação fornecida por Décio Amadio, da antiga Administração Regional da Sé, em entrevista realizada em 28 mar. 2002.

24 Lei nº 10.209, de 1986, substituída pela Lei $n^{\circ} 11.773$, de 18/05/95. A flexibilização de índices urbanísticos poderia ser feita em locais de interesse do proponente, desde que este construísse determinado número de habitações de interesse social ou depositasse quantia equivalente no Fundo Municipal de Habitação - FMH. vigente, com vistas a um maior aproveitamento do solo e à regularização de intervenções, em troca do pagamento de uma contrapartida financeira ao município. O segundo instituiu a transferência do potencial construtivo de imóveis de valor histórico para outras zonas da cidade, condicionadas à restauração do bem preservado; ${ }^{21}$ e o terceiro possibilitou a cessão onerosa, por parte do município, de espaço aéreo e subterrâneo na área delimitada pela operação. A contrapartida foi fixada em, no mínimo, 60\% do valor econômico atribuído ao benefício concedido e $200 \%$ desse valor para os casos de regularização de intervenções. ${ }^{22}$ No caso de intervenções que envolvessem áreas de habitações subnormais, os proponentes deveriam incluir em seu escopo a solução do problema habitacional dos moradores. Essas disposições deveriam vigorar por apenas três anos.

A Operação Urbana Anhangabaú colocou à disposição do setor privado, dentro do seu perímetro, $150.000 \mathrm{~m}^{2}$ de área construída adicional além do permitido legalmente (Mapa 13). Esse montante foi calculado com base em estimativa técnica otimista relacionada à expectativa de adesão da iniciativa privada, vinculando-se ainda à ideia de se preencher falhas e rupturas existentes na configuração de algumas quadras. A operação foi, entretanto, como observou Rolnik, um "fracasso de bilheteria”. (FRÚGOLLI JÚNIOR, 2000) Não despertou o interesse da iniciativa privada, em que pese o estoque de área oferecido, bem acima do permitido então pelo zoneamento. Até 1996, quando da extinção da operação, apenas $13,12 \%$ desse estoque haviam sido utilizados. ${ }^{23}$

Diferentemente das "Operações Interligadas", que permitiam flexibilizar a regulação urbanística de modo pontual em área de interesse do empreendedor ou proponente, nas Operações Urbanas os benefícios estavam atrelados a uma determinada área, que poderia ou não despertar o interesse de investidores. Parafraseando Rolnik, o relativo "sucesso de bilheteria" das Operações Interligadas, instituídas pela chamada "Lei do Desfavelamento", de 1986, ${ }^{24}$ se vinculou justamente a essa possibilidade. Como mostrava relatório da Secretaria Municipal de Planejamento Urbano - SEMPLA, a maior parte dessas operações 
concentrou-se, então, no setor Sudoeste da cidade, sabidamente a área mais disputada pelo mercado imobiliário. 25

Ainda na gestão da prefeita Luiza Erundina (1989-1992), com Marilena Chauí como Secretária Municipal de Cultura, alguns edifícios importantes do centro foram restaurados, como o Teatro Municipal (Foto 50), a Biblioteca Mário de Andrade, a Casa da Marquesa de Santos (Foto 51) e o Palácio das Indústrias para instalação da sede da prefeitura -, mas sem recursos gerados pela Operação Urbana Anhangabaú. Paralelamente a essas intervenções, a prefeitura desenvolveu o Projeto "Eixo Sé-Arouche”, o primeiro, em São Paulo, a buscar a requalificação e a manutenção de espaços públicos do centro mediante a colaboração de usuários, moradores e iniciativa privada (Foto 52 e 53). ${ }^{26}$ Tomando como modelo a experiência do Corredor Cultural do Rio de Janeiro, o projeto destinava-se a resgatar a feição de imóveis e logradouros por meio da desobstrução e recuperação de fachadas encobertas por anúncios, do ordenamento e da padronização dos elementos que equipam o espaço público. (ABRAHÃO, 1999, p. 54)

Pensado inicialmente para o núcleo principal do centro (distritos Sé e República), o projeto acabou sendo reduzido ao eixo que liga a Praça da Sé ao Largo do Arouche, incluindo a Rua São Bento (Mapa 14). Essa escolha visou à requalificação da expansão do centro velho para o centro novo e a criar sinergia com as obras de reurbanização do Vale do Anhangabaú, ampliando a área requalificada do centro. (AMADIO, 1998, p. 88-89) Desenvolvido entre 1990 e 1992, o Projeto Sé-Arouche foi a primeira intervenção em área do centro antigo a ter explicitamente o patrimônio como foco. O projeto pretendia obter participação ampla dos moradores e usuários, mas acabou contando apenas com a parceria dos comerciantes da Avenida Vieira de Carvalho e da Rua e do Largo do Arouche, que arcaram com os custos de remanejamento de anúncios, recomposições de fachadas e doação de plantas para espaços públicos. As demais intervenções, como recomposição de calçadas, substituição de iluminação e paisagismo, ficaram a cargo da prefeitura. Diferentemente do Corredor Cultural do Rio, o projeto não utilizou incentivos fiscais. Ficaram isentos do pagamento de parte do IPTU apenas os imóveis individualmente preservados, contidos na área do projeto.
25 Até 1995, Operações Interligadas contabilizavam 425 propostas protocoladas, 99 termos de compromisso concretizados e $\mathrm{R} \$$ 46.905.350,00 em contrapartidas aprovadas, correspondendo a 5.548 habitações de interesse social. (SÃO PAULO, 1996, p. 4-7)

260 projeto foi oficialmente instituído pelo Decreto 29.851, de 21 de junho de 1991. 
Nas ruas Direita e de São Bento, o Projeto Sé-Arouche não logrou estabelecer parcerias, e os anúncios foram remanejados apenas a partir da aplicação das multas previstas na legislação implantada pelo projeto. (ABRAHÃO, 1999, p. 59-62) Na Rua do Arouche, os comerciantes participaram porque viram na ação a possibilidade de transformar a via num shopping a céu aberto, voltado para uma clientela mais abastada. Já os comerciantes da Avenida Vieira de Carvalho enxergaram a possibilidade de "limpar" a rua dos usos e usuários indesejáveis, como cines pornôs, fliperamas, camelôs, prostitutas e mendigos, resgatando o glamour que o logradouro tinha nos anos 1950. O projeto melhorou o aspecto geral de algumas vias, mas, onde foi executado, não logrou alterar o perfil dos usuários nem impedir o avanço dos camelôs no espaço público, como desejavam os comerciantes. (ABRAHÃO, 1999, p. 69)

A implantação desse projeto ocorreu no período em que muitas empresas se retiravam do centro em direção ao setor Sudoeste, aumentando o quadro de esvaziamento da área. A participação dos comerciantes no projeto constituiu uma primeira reação da iniciativa privada local a esse êxodo, apoiada pelas várias intervenções públicas em curso. Essas intervenções, ainda que não estivessem articuladas num plano de conjunto, influenciaram o setor privado a formar organizações como a Associação Viva o Centro, criada para estabelecer um canal de interlocução entre empresários e poder público. (AMADIO, 1998, p. 119)

Num folheto produzido pela prefeitura, em 1992, intitulado "Eixo Sé-Arouche - Programa Piloto de Ordenação da Paisagem da Área Central", Ermínia Maricato, então secretária municipal da Habitação e Desenvolvimento Urbano, avaliava que, com esse projeto, haviam sido dados importantes passos para reverter a tendência de deslocamento de atividades do centro para o eixo Sudoeste, impulsionado pela especulação imobiliária. Embora o futuro imediato tenha mostrado que esses passos não resultaram na reversão dessa tendência, as intervenções municipais do começo dos anos 1990 colocaram o centro como um território que valia a pena disputar. Os contornos e atores dessa disputa serão retratados a seguir. 


\section{A Associação Viva o Centro e a "requalificação estratégica" do centro}

Os projetos e investimentos municipais concentrados no início dos anos 1990 sinalizaram uma firme disposição do setor público de investir no centro, fazendo com que alguns empresários locais percebessem a possibilidade concreta de revalorização do seu patrimônio imobiliário. Para participar e influir nos rumos dessa política de requalificação foi fundada, em 1991, a Associação Viva o Centro.

Composta principalmente de empresários do setor financeiro e por escritórios de advocacia que resistiram ao êxodo de instituições do centro, a também chamada "Sociedade Pró-Revalorização do Centro de São Paulo" foi organizada com o objetivo de criar um canal de interlocução entre a sociedade civil e o poder público. Capitaneada e animada por Henrique Meirelles, então presidente do Bank Boston, a associação apresentava-se como uma ONG voltada para a elaboração de diagnósticos e para a sugestão de políticas para o poder público. (FRÚGOLI JÚNIOR, 2000, p. 73) Mediante a promoção de eventos e debates, que reuniam especialistas, empresários, acadêmicos, representantes do setor público e da sociedade, a associação tinha como meta a construção de consensos sobre os rumos da requalificação e da revalorização do centro.

De início, a Viva o Centro adotou uma linha de defesa do caráter metropolitano do centro, baseada numa concepção de São Paulo como cidade mundial. O centro antigo era imaginado como um nó articulado à rede econômica global, que deveria ser capacitado a criar uma imagem positiva da cidade, tanto para o empresariado estrangeiro viajando a negócios como para turistas e visitantes. A associação apostava na tendência mundial de revalorização das áreas centrais, num momento, contudo, em que a própria matriz do Bank Boston, nos EUA, queria transferir o banco para a Av. Berrini. Acreditava-se que, em dez anos, ${ }^{27}$ se poderia reverter o processo de desvalorização da área, desde que se animasse o mercado e se influísse nas políticas públicas. Entre 1993 e 2000, foi isso o que a Associação fez.

A requalificação e a valorização sustentada do centro, do ponto de vista da Viva o Centro, seriam decorrência de um conjunto de medidas e projetos estratégicos
27 A informação de que a matriz queria a ida do banco para a Av. Berrini, em 1991, e que Meirelles pediu dez anos de prazo, foi fornecida por Jule Barreto, editor da Revista URBS, da Associação Viva o Centro, em entrevista concedida em 22/03/2002. Em editorial, Henrique Meirelles confirma a informação. (UMA ARRANCADA...., 1998) 
28 O Programa de Ações Locais, da própria Associação Viva o Centro, o Programa Centro Seguro e o projeto Polo Luz, em parceria com o Governo do Estado, e o Projeto Travessia, de assistência a moradores e crianças de rua, em parceria com outras ONGs.

29 O ProCentro, analisado a seguir, foi criado para ser a agência de desenvolvimento do centro, mas não logrou funcionar como tal, entre outras razóes, por falta de parceiros interessados em novos negócios nessa área. envolvendo modificação da legislação urbanística, implantação de medidas de incentivo, criação de instância especial de gestão do centro, fortalecimento da segurança pessoal e patrimonial, tratamento e limpeza de espaços públicos, eliminação de toda e qualquer forma de comércio informal, solução do problema dos mendigos e moradores de rua, criação de facilidades para a circulação e estacionamento de veículos particulares, preservação de imóveis de valor histórico, criação de polos de consumo cultural e lazer, e promoção do uso residencial de padrão elevado. Em outras palavras, um vasto programa de retomada de funções perdidas ou esvaziadas e de mudança do perfil geral de uso do centro, que era, como já mencionado, marcadamente popular.

Durante as gestões de Paulo Maluf e Celso Pitta (1993-1996 e 1997-2001), entretanto, o centro não constituiu uma prioridade de governo. Notadamente com Maluf, importantes recursos municipais foram canalizados para obras viárias e de infraestrutura no setor Sudoeste, promovendo ainda mais a valorização fundiária e imobiliária dessa área, bem como aprofundando o processo de deslocamento de funções centrais para essa região. (MARICATO, 2000, p. 141-142) Embora não tenha conseguido influenciar a aplicação de recursos públicos significativos na valorização do centro, a Associação Viva o Centro investiu na implantação, por parte do poder público, de medidas consideradas fundamentais, como: a criação de uma agência de desenvolvimento para o centro; de um programa estratégico de requalificação; e de mecanismos para a atração de investimentos e incentivo à ação privada. Outros pontos focais da agenda dessa organização foram o apoio a iniciativas e projetos do governo estadual ou a ações em parceria com outras instituições não governamentais. ${ }^{28}$ Entre esses projetos e iniciativas, o ProCentro, ${ }^{29}$ a Lei das Fachadas, a Operação Urbana Centro e os planos para a área da Luz informam bastante bem sobre as características do projeto de revalorização do centro defendido pela Associação Viva o Centro, e sobre como o poder público, entre 1993 e 1999, se colocou à sua disposição. 


\section{ProCentro}

Em 14 de julho de 1993, o prefeito Paulo Maluf baixou três decretos, ${ }^{30}$ criando, simultaneamente, o Programa de Requalificação Urbana e Funcional do Centro de São Paulo - ProCentro; a Comissão ProCentro, ${ }^{31}$ para coordenação e aprovação das intervenções na área do programa; e 15 polos de recuperação urbana para atuação prioritária (Foto 54). ${ }^{32}$ Montado com um perfil de programa de gestão e intervenção físico-territorial estratégico, o ProCentro previa, além desses polos de intervenção, ações de recuperação de fachadas; elaboração de legislação de incentivos fiscais e outras formas de estímulo à restauração de imóveis privados; elaboração de normas diferenciadas para anúncios; regulamentação de intervenções viárias e de inserção de equipamentos e mobiliário urbano; ampliação da arborização; projeto de iluminação e recomposição de calçadas; aprimoramento da limpeza pública; desenvolvimento de plano de incentivo à cultura, lazer e turismo; e melhoria do sistema de segurança pública. (SÃO PAULO, 1993) O objetivo dessas ações era melhorar as condições ambientais do centro, prevenir a deterioração e a desvalorização imobiliária da área, ordenar a paisagem urbana e dar melhores condições de funcionamento para usos existentes e outros a serem incentivados. O programa previa uma Área Especial de Intervenção que envolvia o setor da Operação Urbana Anhangabaú e estendia seus limites ao Parque D. Pedro II, a Leste, e ao Largo do Arouche, a Oeste (Mapa 15).

A partir de um diagnóstico no qual se analisava a deterioração ambiental e paisagística da área central, as dificuldades de acesso, circulação e estacionamento, bem como a obsolescência e insuficiência do estoque imobiliário, foram estabelecidas diretrizes de intervenção e recomendadas ações específicas. Essas ações e diretrizes revelam que o projeto de preservação do ProCentro - na realidade, uma institucionalização das ideias do setor empresarial e financeiro para o centro - correspondia a um projeto de modernização e renovação. A conservação do patrimônio urbano limitava-se à recuperação de fachadas, recomendando-se "novas construções sofisticadas" como forma de dinamizar o tecido antigo e garantir a "qualidade" do espaço preservado. (SÃO PAULO, 1993, p. 6-7) No item relativo ao estoque imobiliário da área central - que, a despeito do número crescente de edifícios vazios, era definido como insuficiente -, defendia-se a modernização das
30 Decretos $n^{\circ} 33.389 / 93$, $n^{\circ} 33.390 / 93$ e $n^{\circ} 33.391 / 93$.

31 A comissão foi formada pelas Secretarias Municipais de Habitação e Desenvolvimento Urbano-SEHAB, de Cultura-SMC, de Planejamento Urbano-SEMPLA, das Administrações Regionais - SAR; pela Companhia de Engenharia e de Tráfego-CET; pela Empresa Municipal de Urbanização - EMURB; pela Associação Viva o Centro; e pelo Sindicato das Empresas de Publicidade do Estado de São Paulo.

32 Polo 1 - Praça do Patriarca; Polo 2 - Praça Ramos de Azevedo/ Largo do Paissandu; Polo 3 - Avenida São João; Polo 4 - Praça Antônio Prado/Largo do Café; Polo 5 - Largo de São Bento; Polo 6 - Anhangabaú; Polo 7- Praça da Sé/Pátio do Colégio/Largo da Misericórdia; Polo 8 Largo de São Francisco; Polo 9- Largo de Santa Efigênia; Polo 10 - Praça Fernando Costa; Polo 11 - Parque D. Pedro II; Polo 12 - Praça da República; Polo 13 Praça João Mendes/ Viaduto D. Paulina; Polo 14 - Largo do Arouche; Polo 15 - Praça D. José Gaspar. 
33 Depoimento de Helena Menna Barreto Silva, em entrevista concedida em 20/03/2002. edificações existentes e a construção de novas com o porte e a qualidade necessários às empresas que se pretendia manter e atrair para o centro. Para tanto, se recomendava a criação de um ambiente legal adequado, a revisão dos critérios de tombamento incidentes na área e a ampliação da Operação Urbana Anhangabaú para o conjunto dos distritos Sé e República - apesar do seu fracasso financeiro. A nova operação urbana seria, entretanto, mais atraente, com incentivos para a instalação de atividades, com contrapartida reduzida ou nula; isenção de IPTU ou ISS; estímulo ao aumento do número de edifícios com garagens, de vagas nas vias públicas e estímulo à construção de estacionamentos subterrâneos; implantação de solução para o excesso de comércio ambulante e incentivos à preservação de imóveis tombados. (SÃO PAULO, 1993, p. 6-7) Além dessas medidas necessárias à atração de investimentos, propunha-se ainda que a nova iniciativa redefinisse 0 programa de obras da antiga Operação Anhangabaú, de modo a justá-lo ao novo plano estratégico.

O escopo do programa, lançado em 1993, atendia, em suma, a todos os pontos da agenda da Associação Viva o Centro, sendo por isso considerado por alguns um produto de suas concepções. (AMADIO, 1998, p. 125) Durante todo o período de 1993 a 2000, contudo, a Prefeitura de São Paulo manteve uma atitude ambígua com relação ao centro, incentivando as ideias da associação e, ao mesmo tempo, abandonando a área à própria sorte, sem a realização dos investimentos que seriam importantes para a melhoria do seu quadro. Assim, o ProCentro acabou funcionando como uma instância voltada para a administração do dia a dia do setor, decepcionando a própria associação que o concebeu. Para alguns observadores, até 1999, ele funcionou como um mero braço institucional da Viva o Centro, que acompanhava e comandava suas políticas. ${ }^{33}$

O balanço das atividades do ProCentro, até o ano 2000, mostra que o programa se caracterizou pelo incentivo à recuperação de fachadas, pelo apoio à restauração de alguns monumentos e pela reformulação de terminais de ônibus no centro (Apêndice D). Um saldo, portanto, muito aquém do pretendido no seu documento inicial. Sua principal herança foi uma proposta de empréstimo encaminhada ao Banco Interamericano de Desenvolvimento que impulsionou o desenvolvimento de novo programa de reabilitação da área central. Embora muito criticado, 
o ProCentro não foi extinto com o fim da administração de Celso Pitta (1997-2001), permanecendo, apesar de reformulado e com novos objetivos, no governo municipal iniciado em 2001.

\section{A Operação Urbana Centro}

Em 1997, duas importantes medidas defendidas pela Associação Viva o Centro foram viabilizadas: a Lei n ${ }^{12.349}$, de 6 de junho de 1997, que criou a Operação Urbana Centro, e a Lei ${ }^{\circ}$ n. 12.350, da mesma data, que concedeu isenção total de IPTU para quem promovesse a recuperação de fachadas de imóveis localizados no centro.

O fraco desempenho da Operação Anhangabaú não desanimara os defensores desse tipo de estratégia de obtenção de recursos, avaliando-se que o pouco interesse do setor privado pelas vantagens oferecidas naquela operação decorria da situação econômica do país e de uma desconfiança do mercado quanto à firmeza do propósito do poder público de requalificar a área, o que seria perfeitamente superado com o desenvolvimento do programa do ProCentro. Embora este último houvesse avançado muito pouco, em 1997, a Operação Urbana Centro ainda parecia um poderoso agente de transformação do quadro de desvalorização do centro.

A nova operação foi apresentada ao público como instrumento de incentivo à produção imobiliária e à preservação do patrimônio, destinado a reforçar a importância da área central, tornando-a atraente para investimentos. (EMPRESA MUNICIPAL DE URBANIZAÇÃO, [199- ], p. 1) Os limites da Operação Anhangabaú foram ampliados, envolvendo agora os distritos Sé e República, além de trechos de Santa Efigênia, Brás, Bela Vista e Liberdade. A antiga área de atuação do ProCentro tornou-se uma "Área de Especial Interesse" da nova operação (Mapa 16).

As diretrizes urbanísticas e os mecanismos de incentivo da Operação Urbana Centro são semelhantes aos da Operação Anhangabaú, porém com algumas modificações essenciais: enquanto nesta última se admitia uma alteração de coeficiente de aproveitamento que poderia ser vista como discreta, na Operação Urbana Centro se estabeleceu limites bem mais largos, isentando-se ainda os empreendedores do pagamento de contrapartida por três anos. ${ }^{34}$ Na nova lei, foi fixada uma contrapartida menor do que na Operação Anhangabaú, correspondendo a 50\%
34 Durante 36 meses a partir da promulgação da Lei, as propostas de modificação dos novos parâmetros incidentes na Área de Interesse Especial ficariam isentas de qualquer contrapartida, excetuando-se as propostas de regularização e cessão de espaço público. A partir desse prazo, sofreriam descontos decrescentes $(80 \%$ em 2001, e $60 \%$ em 2002; $40 \%$ e $20 \%$ para 2003 e 2004). 
35 Na Operação Anhangabaú, eram $60 \%$ e $200 \%$, respectivamente.

36 Antes dessa ação, quatro propostas de transferência de potencial haviam sido aprovadas, referentes ao Hotel Atlântico, na Av. São João; a três sobrados na Rua Bento Freitas; ao antigo prédio do Estadão; e ao edifício na Rua Álvares Penteado, onde foi instalado o Centro Cultural Banco do Brasil. Entre as propostas em estudo, estavam incluídas as das estações da Luz e Júlio Prestes. do benefício auferido, no caso de propostas de modificação de índices, e a 100\% para as regularizaçóes. ${ }^{35} \mathrm{O}$ coeficiente de aproveitamento foi ampliado de 4 para 6 , nos usos residencial e misto, sem necessidade de pagamento de contrapartida, podendo ser aumentado em mais 6 pontos no caso de construção de garagem. Este coeficiente foi também ampliado para 12 nas instalações hoteleiras, incluindo serviços e garagens. Áreas destinadas a salões de festas, cinemas, teatros e anfiteatros, salas de espetáculos, auditórios, museus e creches, assim como áreas destinadas à fruição pública, foram desconsideradas no cálculo do coeficiente e dispensadas de estacionamentos.

A principal inovação desta operação em relação à do Anhangabaú está no cálculo instituído para a cessão de potencial construtivo de imóveis preservados e na possibilidade de transferência desse potencial para outras áreas da cidade. Tendo como mote a preservação, a lei criou, de fato, vantagens notáveis para investidores interessados em aumentar a possibilidade de aproveitamento do solo em zonas de interesse imobiliário. Para imóveis preservados, cujo coeficiente de aproveitamento efetivo seria igual a 7,5, foi estabelecido o coeficiente 12. Para imóveis cujo coeficiente efetivo ultrapassasse 7,5, foi estabelecida uma possibilidade de transferência correspondente a $60 \%$ da possibilidade de construir até 12 vezes a área do lote, somada a 40\% dessa possibilidade entre 12 e 15 vezes a área do lote, e somada a $20 \%$ do excedente a 15 vezes essa área (Figura 1). Com a Operação Urbana Centro, portanto, um vasto estoque de potencial construtivo foi criado para incentivar a realização de operaç̧óes interligadas entre o centro e outras zonas da cidade. Não é necessário ressaltar o quanto a medida agradou a proprietários de bens tombados do centro e a incorporadores ávidos por mais coeficiente de aproveitamento em áreas de maior dinâmica imobiliária, especialmente depois da extinção das operações interligadas. Contudo, uma ação de inconstitucionalidade, impetrada pelo Ministério Público em 1999, revogou os artigos da lei que regulamentavam esse mecanismo, tornando válidas as transferências de potencial apenas dentro da própria zona da operaçãa. Essa medida suspendeu a tramitação de 25 propostas que já estavam encaminhadas e impediu o surgimento de novas. ${ }^{36}$

Com a aprovação do Plano Diretor Estratégico da cidade, em 2002, o problema da inconstitucionalidade da transferência de potencial entre zonas diferentes foi contornado. Entretanto, como as áreas receptoras que foram 
estabelecidas não correspondiam necessariamente às de grande interesse imobiliário, ${ }^{37}$ a cessão de potencial de imóveis preservados passou a concorrer com a outorga onerosa de área construída que foi instituída neste plano diretor. Como mostra tabela 30, a demanda por compra de potencial construtivo no centro sobre a qual não incidiram questionamentos jurídicos - foi baixa, registrando-se, em cinco anos de vigência da Operação Urbana Centro (1997-2002) apenas 33 propostas encaminhadas, das quais somente cinco puderam ser aprovadas.

As diretrizes urbanísticas dessa operação incentivavam a abertura de praças e passagens para pedestres no interior das quadras e a interligação entre elas, bem como estimulavam o remembramento de lotes. Os remembramentos que alcançassem uma área mínima de $1.000 \mathrm{~m}^{2}$ geravam direito a uma área construída adicional, livre de contrapartida, correspondente a 10\% da área de cada lote original até o limite máximo de 100\% da área total resultante. A construção de habitações e garagens foi também incentivada e o comércio atacadista proibido. A Operação Urbana Centro estabeleceu que propostas que atingissem áreas de cortiços deveriam contemplar a solução do problema habitacional dos moradores num perímetro de $500 \mathrm{~m}$ do local, sem ônus para a prefeitura e sem prejuízo do pagamento da contrapartida. Essa disposição, que visava a desestimular a expulsão de moradores de baixa renda, não foi, entretanto, concebida como um incentivo à solução do problema, pois, diante das vantagens oferecidas em outros setores, as situações que envolvessem habitações subnormais tenderiam a ser evitadas pelos possíveis investidores.

No cômputo geral, como visto, os parâmetros criados pela Operação Urbana Centro foram bem mais permissivos do que os da Operação Anhangabaú e até mais agressivos, em relação às vantagens oferecidas à produção imobiliária. O fracasso financeiro dessa nova operação urbana tornou-se, à época, um importante indicador, tanto dos termos da disputa pelo território do centro e dos limites desse tipo de instrumento quanto da dinâmica de investimentos imobiliários na cidade de São Paulo. Durante o período 1997-2000, ou seja, durante o intervalo que inclui os três primeiros anos da Operação Urbana Centro, a taxa de desocupação no centro dobrou em relação aos anos 1980, (SÃO PAULO, 2001a, p. 83) e as operações realizadas foram, como visto, muito poucas. A Operação Urbana Centro confirmou, portanto, que apenas incentivos, por maiores que sejam, não revertem tendências de urbanização
37 Só poderão, em princípio, receber potencial construtivo de outras áreas faixas de $300 \mathrm{~m}$ ao longo dos eixos de transportes públicos e áreas num raio de $600 \mathrm{~m}$ a partir de estações de metrô ou de transporte ferroviário. 
38 Amadio (1998, p. 129) entende que os investimentos públicos feitos no setor Sudoeste (complexo de túneis e a nova Avenida Faria Lima) canalizaram os negócios imobiliários para o setor, e avalia que a ausência de investimentos no centro, no período Maluf/Pitta, teria sido um fator de não atração do mercado imobiliário. e de produção imobiliária, especialmente se o nível de crescimento econômico geral for baixo e se os investimentos públicos criam situações mais favoráveis em áreas de dinâmica imobiliária consolidada. Mostrou ainda que as operações urbanas só funcionam como instrumentos de obtenção de recursos quando os interesses do setor público e privado coincidem com respeito à produção de determinado espaço ou quando este se insere num vetor de produção imobiliária já instalado. Quando isso não ocorre, a operação simplesmente não cria a dinâmica esperada. Mas mesmo quando esta é bem sucedida, o retorno efetivo para o poder público e para a coletividade pode ser considerado pequeno, em comparação com os benefícios que podem ser auferidos pelo mercado imobiliário. (CARDOSO apud SOUZA, 2002, p. 276-277) Ao lado disso, a perda de status do centro antigo ao longo do processo de formação de novos centros na cidade influencia, de modo não negligenciável, a decisão locacional de empreendimentos e empresas. Esses fatos, somados à mentalidade de valorização da novidade, que é dominante nos segmentos de maior renda, explicam, bem melhor do que a falta de investimentos públicos, o desinteresse da iniciativa privada pela produção imobiliária no centro antigo. Ainda que, no período de 1993 a 2000, tais investimentos tenham, de fato, diminuído, nunca pararam de ser feitos, especialmente em termos de equipamentos culturais. ${ }^{38} \mathrm{Se}$, contudo, a Operação Urbana Centro tivesse sido um sucesso, ao isentar o pagamento de contrapartidas por três anos e ao oferecer descontos por mais três, tampouco teria funcionado como instrumento de obtenção de recursos para que mais investimentos públicos fossem viabilizados. De todo modo, o fato de o Ministério Público ter revogado os mecanismos de transferência de potencial construtivo de imóveis preservados para outras áreas da cidade não permite uma análise completa da eficácia desta operação urbana em termos da produção de recursos para a conservação do patrimônio do centro.

A despeito dos mecanismos de incentivo à conservação do patrimônio, caso tivesse funcionado, a operação urbana teria redundado muito mais em renovação do que em preservação do tecido do centro. Como observa Silva (2000, p. 33-34), a lei não introduziu nenhuma vantagem para a realização de reformas ou reciclagens de edifícios privados, incentivando, na realidade, a demolição e a reconstrução. Os pesados incentivos ao remembramento de lotes è̀ reconstrução de edifícios existentes favorecem, sem dúvida, processos de valorização do solo, mas prejudicam, 
por exemplo, programas de aproveitamento do estoque edificado existente para uso habitacional, por falta de condições de competição na aquisição de prédios vazios e terrenos, com empreendimentos mais rentáveis.

Presentes nas discussões dos anos 1980 sobre a possibilidade de se criar condições para um desenvolvimento urbano socialmente menos desigual e previstas, desde então, em vários documentos de planejamento, as operações urbanas e interligadas começaram a ser implantadas nas grandes cidades somente no final daquela década, e as experiências práticas têm suscitado avaliações mais negativas do que positivas. Se bem conduzidas, essas operações podem ser, de fato, importantes instrumentos para uma distribuição mais igualitária dos custos e benefícios da urbanização, mas, como observa Piccini (1999, p. 128), diante da falta de mecanismos consagrados para o balizamento da relação setor público/ setor privado; das falhas no método de avaliação das contrapartidas; da criação de "nichos de negociação"; e da falta de transparência nos processos, tais operações têm sido avaliadas como instrumentos limitados e problemáticos. Ao lado disso, sem estarem atreladas a estudos que permitam compreender a inserção do território focalizado no conjunto produtivo da cidade, e a dinâmica urbana de expansão e produção imobiliária, tendem a ser inócuas como instrumentos de obtenção de recursos e de revitalização urbana.

Com a aprovação da Operação Urbana Centro, retomou-se a tradição de verticalização do centro e abandonou-se, definitivamente, a ideia de sua saturação, estimulando-se a criação de um novo centro sobre o antigo, como forma de valorizá-lo e capacitá-lo a gerar a receita para sua própria conservação. Mas o desinteresse do mercado pela nova operação abalou os argumentos dos defensores dessa tese e a crença da cúpula da Associação Viva o Centro na inexorável valorização imobiliária da região. Em 2001, o Bank Boston anunciou, finalmente, a mudança de sua sede para a Marginal do rio Pinheiros, deixando seu edifício na Rua Líbero Badaró para uma universidade. O prazo de dez anos para a reversão do "quadro deteriorado" do centro havia se esgotado.

É interessante observar que, à medida que sua agenda para a revalorização do centro foi se implantando e, ao mesmo tempo, por forças superiores, foi se inviabilizando, o discurso da Associação Viva o Centro foi também mudando. Inicialmente calcado no retorno de funções e no resgate do centro como núcleo 
39 Ver Panorama, URBS, São Paulo, 1997-2002 Editoriais publicados no período de ago.1997 a mar./abr. 2002.

40 Lei $n^{\circ} 10.598 / 1988$ metropolitano de uma cidade mundial, o discurso migrou, a partir de 1999, para o reforço de sua vocação turística, cultural e de sede de ensino superior, como solução para uma inserção competitiva num sistema de centralidades urbanas de caráter complementar. Somente no final de 2001, quando uma nova administração municipal começou a divulgar seus planos de desenvolvimento do uso habitacional de interesse social no centro, é que a associação retomou sua proposta inicial para a área, opondo-a ao futuro do centro como um "mero bairro de moradia". 39

Aprovada juntamente com a Operação Urbana Centro, a Lei n 12.350/1997 ampliou as disposições anteriores, ${ }^{40}$ fixando a isenção de $100 \%$ do IPTU, por um prazo de 10 anos, para proprietários ou patrocinadores da recuperação externa de edifícios preservados localizados na Área de Especial Interesse da Operação Urbana Centro. O benefício foi estendido àqueles que já haviam realizado esse tipo de serviço, em data anterior, e estariam mantendo o imóvel conservado. Esta lei introduziu várias novidades com relação às anteriores, que instituíram incentivos fiscais à atividade de preservação na cidade. Em primeiro lugar, vinculou a isenção total do imposto apenas à recuperação e conservação externa dos edifícios e, em segundo, desvinculou o benefício fiscal do bem preservado, permitindo o seu usufruto em outro imóvel qualquer. Para tanto, a conservação das fachadas de um imóvel preservado geraria um "certificado de isenção" que poderia ser usado para pagar ou abater o valor do IPTU de outro imóvel pertencente a quem patrocinasse a intervenção, mesmo se localizado fora do centro. Em suma, instituiu-se uma espécie de operação fiscal interligada, por meio da criação de um papel comercializável no mercado que permitia isenção sobre isenção, aumentava o montante de renúncia fiscal e, na prática, estendia o benefício a imóveis não preservados.

Esta "Lei das Fachadas" - como ficou conhecida - complementou a Operação Urbana Centro em termos da concessão de vantagens à iniciativa privada, dessa vez no plano fiscal. Da forma como foi aprovada, constituiu um verdadeiro plano decenal de drenagem de receita fiscal, em tempos de dinheiro público curto e orçamento comprometido. Foi regulamentada pelo Decreto $n^{\circ} 37.302$, de 27/01/1998, que manteve o seu espírito, especificando-se apenas que a recuperação externa deveria envolver todas as fachadas visíveis do imóvel e ser 
realizada de acordo com a feição original da construção. A "Lei das Fachadas”, entretanto, também não despertou grande interesse no mercado, com apenas 46 solicitações de utilização do mecanismo e cinco concessões efetivadas até 2002. ${ }^{41}$ No final de 2001, a nova administração municipal criou uma comissão, formada por representantes do DPH, da SEHAB e do ProCentro, para analisar a lei e propor modificações. Entre outras modificações, se propôs vincular o benefício ao custo das obras de recuperação, incentivar o patrocínio à conservação de imóveis residenciais cujos proprietários não têm recursos e simplificar os mecanismos operacionais. ${ }^{42}$

\section{A revitalização da região central e o Projeto de Recuperação do Bairro da Luz}

A função cultural sempre foi importante no centro de São Paulo e, até os anos 1960, esta área foi o principal polo desse tipo de atividade, com grande concentração de cinemas e casas de espetáculo nas imediações da Praça da República. Com o processo de deslocamento de funções centrais e com a construção de shoppings e equipamentos culturais em áreas próximas aos bairros de alta renda, as atividades culturais e de entretenimento no centro entraram em decadência.

A revitalização do uso cultural na área central, como uma forma de combater a deterioração, já era indicada nos projetos elaborados nos anos 1970 para o bairro da Luz, concretizando-se de maneira mais efetiva, no início dos anos 1980, com a implantação do Projeto "Luz Cultural”, da Secretaria de Cultura do Governo do Estado.43 Em decorrência desse projeto, foram recuperados espaços como a Praça Fernando Prestes e o Jardim da Luz, propondo-se, em 1985, intervenções em edifícios como a Pinacoteca do Estado (Fotos 55 e 56), o Museu de Arte Sacra, o Mosteiro e o Quartel da Luz, para a promoção de atividades culturais que injetassem um novo ânimo no setor. Por falta de recursos financeiros, o projeto teve vida curta e não foi totalmente implementado.

Nos anos 1990, com a consolidação das leis estaduais e municipais de incentivo à cultura, e, especialmente, com a criação do Programa Nacional de Apoio à Cultura, a captação de recursos para projetos culturais foi bastante facilitada,
41 Secretaria e Habitação e Desenvolvimento Urbano - SEHAB, ProCentro, posição em novembro de 2002.
42 Informação prestada por Helena Menna Barreto Silva, Vice-Presidente do ProCentro, em entrevista realizada em 12 nov. 2002.
$43 \mathrm{O}$ projeto foi desenvolvido entre 1983 e 1984 e destinava-se a integrar monumentos e espaços públicos da área à vida dos moradores e usuários do bairro.


44 A obra, de grande vulto, foi inaugurada em 2006 . pois os investimentos privados puderam ser abatidos diretamente do imposto de renda devido. Além disso, na medida em que a cultura foi se consolidando, no período, como um importante veículo para a formação de imagem e inserção mercadológica de empresas e produtos, a utilização desses incentivos cresceu de modo significativo. Influenciado pelo sucesso dos grandes equipamentos culturais implantados no Rio de Janeiro, o processo de revitalização da função cultural na área central de São Paulo começou um pouco mais tarde. Suas sementes, entretanto, já haviam sido lançadas no Projeto "Luz Cultural” e nas primeiras iniciativas de requalificação empreendidas no início dos anos 1990. Entre 1996 e 2002, vários outros projetos dessa natureza se concretizaram na área central, tendo como principais polos de concentração o núcleo principal do centro e o bairro da Luz.

O boom de intervenções culturais no centro de São Paulo teve início com o lançamento, em 1996, do concurso para a restauração do edifício-sede dos Correios, no Vale do Anhangabaú, para implantação de um centro cultural.44 No ano seguinte, o Governo do Estado anunciou a transformação do Grande Hall da Estação Júlio Prestes em sala de concertos, obra que veio a ser inaugurada em 1999 (Foto 57). A essas duas iniciativas seguiram-se outras, públicas e privadas, entre as quais se destacam a renovação da Pinacoteca do Estado, com a restauração do edifício projetado por Ramos de Azevedo; a nova recuperação do Jardim da Luz; o restauro do Museu de Arte Sacra; a recuperação do Teatro São Pedro e do Teatro Brasileiro de Comédia; a implantação do Memorial do Imigrante, na antiga Hospedaria dos Imigrantes; a Escola do Livro, na Praça da Sé; o Centro Cultural Banco Brasil, na Rua Álvares Penteado; o Museu do Imaginário do Povo Brasileiro, no prédio da antiga Delegacia de Ordem Política e Social - DOPS; e a filial do Museu de Arte de São Paulo, na Galeria Prestes Maia (Mapa 14). Todas essas intervenções contaram com recursos captados por intermédio das leis de incentivo à cultura, tanto na elaboração dos projetos e na execução das obras quanto no desenvolvimento das programações culturais.

As intervenções na Pinacoteca do Estado e na Estação Júlio Prestes lograram grande repercussão e puxaram a implantação de novos equipamentos culturais no centro. Com programação dirigida a um público de altos ingressos, esses equipamentos foram responsáveis pelo aumento, ainda que eventual, dafrequência desses estratos sociais ao centro, numa mudança de comportamento 
que foi reforçada com a inauguração do Centro Cultural dos Correios, no Vale do Anhangabaú, e do SESC, no centro novo.

Ainda que pontuais e, até o começo da década de 2000, sem grandes efeitos na transformação do padrão geral de ocupação do seu entorno, essas intervenções constituíram uma porta de entrada para um processo de valorização e gentrificação da área central de São Paulo. Não foi por outra razão que, juntamente com a implantação da Operação Urbana Centro, como se verá adiante, constituíram, em 1997, o estopim das ocupações de imóveis vazios promovidas por movimentos populares na área central. As intervenções projetadas para o bairro da Luz e os centros culturais implantados ilustram bem os limites e possibilidades do projeto de revalorização do centro pela via cultural, capitaneado pelo Governo do Estado de São Paulo e apoiado pela Associação Viva o Centro.

Entre 1996 e 2002, como visto, cinco bens de valor histórico foram recuperados no bairro da Luz para a implantação ou reanimação de equipamentos culturais. ${ }^{45}$ Essas recuperações não fizeram parte, inicialmente, de um plano integrado, mas sua concentração num mesmo bairro e a necessidade de captação de novos recursos para complementá-las promoveu a elaboração de, pelo menos, dois projetos mais amplos do ponto de vista urbanístico: o Projeto de Recuperação do Bairro da Luz, no âmbito do Programa Monumenta, e o "Polo Cultural Luz", da Secretaria de Estado da Cultura, em parceria com a Associação Viva o Centro. ${ }^{46}$

O Programa Monumenta ${ }^{47}$ começou a ser discutido em São Paulo em 1997, mas devido a problemas financeiros e de estrutura por parte do município, bem como de coordenação, por parte do Governo Federal, só começou a ser executado no final de 2002. ${ }^{48} \mathrm{~A}$ escolha do bairro da Luz como Área de Projeto se vinculou às intervenções que a Secretaria de Estado da Cultura já vinha realizando no setor e à existência de bens tombados em nível federal, pois esta era uma exigência do programa. ${ }^{49} \mathrm{O}$ projeto teve, inicialmente, como foco a restauração da estação e a requalificação do Jardim da Luz (Fotos 58 e 59), mas, ao longo dos anos 2000, foi tomando uma feição mais ampla e cada vez mais próxima do projeto estadual que visava a consolidar no bairro um polo cultural. Entre 1997 e 2001, foi coordenado pelo Departamento de Patrimônio Histórico do município (DPH), e, em seguida, pela Empresa Municipal de Urbanização - EMURB, instância que centralizou, no período em foco, as ações municipais relacionadas à requalificação e à
45 Jardim da Luz,

Pinacoteca do Estado, Estação Júlio Prestes, edifício da antiga Delegacia de Ordem Política e Social - DOPS e Mosteiro da Luz.

46 O Projeto "Polo Cultural Luz" visava a articular os equipamentos culturais da área a outros da cidade, ao aproveitamento da orla ferroviária para atividades de recreação e lazer, e à integração de setores do bairro por meio da reestruturação do sistema viário, de modo a conferir mais integração urbana às intervenções pontuais já realizadas e a ampliar seus efeitos sobre o entorno.

47 Programa do Ministério da Cultura e do IPHAN, cujo contrato de empréstimo com o Banco Interamericano de Desenvolvimento - BID foi celebrado em 1999, tendo sido implementado até 2010.

48 Em julho de 2002 foi assinado convênio entre o Ministério da Cultura e a Prefeitura Municipal para a execução do Programa Monumenta em São Paulo (convênio $n^{\circ} 400 / 2002$ ).

49 Em 1997, a área da Luz tinha apenas dois monumentos tombados pelo Governo Federal: o Mosteiro da Luz e a Estação da Luz. Em 2000, foi realizado o tombamento do Conjunto Arquitetônico e Urbanístico da Luz, o que permitiu incluir na Área de Projeto do Monumenta um número maior de imóveis. 
50 Esses recursos foram repartidos em: $50 \%$ do BID; 20\% do Governo Federal; $15 \%$ do Governo do Estado; e $15 \%$ da Prefeitura Municipal de São Paulo.

51 Os seguintes monumentos tombados do bairro da Luz fizeram parte do projeto: Jardim da Luz, Edifício Paula Souza, Edifício Ramos de Azevedo, Quartel da Luz Hotel Federal Paulista, Hotel Queluz, Antigo Seminário Episcopal, Igreja de São Cristóvão, Estação Júlio Prestes, Estação da Luz, Pinacoteca do Estado, prédio do antigo DOPS, Igreja e Mosteiro da Luz. Os cinco últimos foram os restaurados pelo Governo do Estado.

52 Depoimento de Diana di Giuseppe, da EMURB, coordenadora da Unidade Executora de Projeto - UEP, do Programa Monumenta, em São Paulo, em contato realizado em $12 / 11 / 2002$.

53 Os proprietários do Hotel Federal Paulista, do Hotel Queluz e do antigo Seminário Episcopal, hoje centro de comércio especializado. reabilitação da área central. Sob a responsabilidade da EMURB, grandes modificações foram feitas na proposta inicial do DPH, que punha ênfase na preparação da área para uso residencial, com foco no bairro de Santa Efigênia (Foto 6o). A intenção era integrar as ações do Programa Monumenta à política habitacional que vinha sendo desenvolvida pelo município a partir de 2001. Já o projeto aprovado em 2002 pela EMURB privilegiou a restauração de monumentos e espaços públicos, reforçando os usos cultural, turístico e institucional da área (Mapa 17).

Orçado originalmente em $\mathrm{R} \$ 15.144 .631,00,{ }^{50} \mathrm{o}$ Projeto de Recuperação do Bairro da Luz seguiu o modelo do Programa Monumenta, prevendo intervenções em cinco logradouros públicos e em 14 monumentos tombados (dentre os quais cinco já haviam sido restaurados pelo Governo do Estado e, por isso, foram computados como contrapartida local). ${ }^{51} \mathrm{O}$ projeto previu ainda a implantação de uma linha de bonde turística ligando os monumentos restaurados e equipamentos culturais, e a aplicação de 30\% dos recursos na recuperação dos exteriores, estruturas e instalações prediais de imóveis privados localizados na Área de Projeto. Além disso, foram também previstas ações para a promoção de atividades econômicas, capacitação, programas educativos e fortalecimento institucional. (BRASIL, 2002b)

Como ocorreu em vários outros projetos locais do Monumenta, iniciados no começo dos anos 2000, o do bairro da Luz enfrentou, em sua implementação, duas grandes dificuldades. A primeira se relacionou à excessiva burocracia do programa e à falta de agilidade executiva do município, o que implicou baixa execução e um aproveitamento quase nulo dos recursos oriundos do BID. A obra de arranque do projeto em São Paulo - a restauração de chaminé remanescente de uma antiga fábrica localizada na Luz - foi iniciada com recursos da contrapartida municipal porque a licitação da obra demorou e o recurso vinculado ao empréstimo do BID, que ficava disponível por apenas 60 dias em conta do MinC, foi recolhido. ${ }^{52} \mathrm{~A}$ segunda dificuldade se relacionou à falta de interesse por parte dos proprietários de imóveis no empréstimo oferecido pelo programa, apesar dos juros atraentes. Até o final de 2002, apenas três proprietários haviam firmado compromisso nesse sentido, ${ }^{53}$ o que já demonstrava que, nas grandes cidades, não seria fácil alcançar a meta principal do Programa Monumenta, isto é, implantar nas Áreas de Projeto padrões de preservação sustentáveis, baseados em investimentos públicos estratégicos e 
na adesão da iniciativa privada. De fato, em áreas de tecido urbano deteriorado, como a das imediações da Estação da Luz, já era difícil imaginar que proprietários que, há décadas, não investiam em seus imóveis, ou os abandonaram para terceiros, viessem a tomar empréstimo para recuperá-los, notadamente quando esse empréstimo cobria apenas parte das intervenções. Seria necessário haver uma perspectiva muito clara de valorização do setor para que isso ocorresse, o que, naquele momento, a despeito dos grandes investimentos feitos em equipamentos culturais, ${ }^{54}$ não havia se desenhado com a necessária clareza.

O projeto do Monumenta em São Paulo já mostrava que o programa, por destinar poucos recursos para cada cidade e exigir muita preparação, não seria atraente para as prefeituras de regiões metropolitanas, nem seria adequado à revitalização ou à reabilitação de áreas deterioradas e esvaziadas em grandes cidades. Seus recursos poderiam, no máximo, contribuir para complementar planos mais abrangentes e, dificilmente, de modo isolado, seriam capazes de reverter esse tipo de quadro urbano com consistência e sustentabilidade.

As graves questões sociais do centro, inclusive o comércio de drogas pesadas na chamada "Cracolândia", em Santa Efigênia, foram ignoradas ou tratadas, no âmbito dos projetos de revitalização cultural, como problemas passíveis de solução no processo natural de expulsão de usos e usuários indesejáveis, que decorreria da revitalização do bairro da Luz. Na medida em que não foram injetados recursos em programas sociais de peso, os equipamentos culturais implantados na área permaneceram como "ilhas" isoladas e apartadas da realidade do entorno, dotadas de pesados esquemas de segurança para garantir um público frequentador. Diferentemente do Projeto "Luz Cultural”, dos anos 1980, os projetos da virada dos anos 1990 para 2000 não registraram nenhuma intenção de envolvimento dos moradores do bairro, seja na apreensão dos monumentos históricos, seja no uso dos equipamentos culturais. Estes formaram enclaves para consumo cultural de segmentos de alta renda, numa área social e fisicamente muito degradada. A Sala São Paulo ilustra bastante bem esse tipo de esquizofrenia urbana: uma parede de vidro, sem aberturas, separa a parte ocupada pela suntuosa sala de concertos do restante da estação em funcionamento, marcando concretamente a incomunicabilidade e a disjunção entre dois mundos.
54 Somente a instalação da Sala São Paulo, na Estação Júlio Prestes, custou cerca de $\mathrm{R} \$ 30$ milhões. 
55 De abril a dezembro de 2001, o CCBB/SP registrou um afluxo mensal crescente que somou um público de 207.000 pessoas ao ano ou 950 pessoas por dia. (CENTRO CULTURAL BANCO DO BRASIL, 2001, p. 5)

56 Depois implantado em prédio histórico no centro de Porto Alegre-RS.

\section{Os novos centros culturais de São Paulo}

Os equipamentos culturais implantados por instituições estatais ou privadas no centro da cidade desenvolveram também, no começo dos anos 2000, uma política voltada para a atração de um público de alta renda. Inaugurado em abril de 2001, o Centro Cultural Banco do Brasil de São Paulo (Foto 61) sintetiza bem essa estratégia, bem como o papel que as atividades culturais tiveram, desde então, no marketing das empresas e no processo de revitalização do centro.

A ideia de abrir um centro cultural em São Paulo decorreu do êxito da experiência do Banco do Brasil no Rio de Janeiro e da necessidade de melhorar a imagem da empresa na cidade que constituía o maior mercado nacional e abrigava seus principais concorrentes. A localização do equipamento no centro relacionou-se à existência da antiga sede do banco na Rua Álvares Penteado e aos planos de requalificação da área central. A decisão do BB se provou acertada, pois, enquanto o Instituto Itaú Cultural, na Avenida Paulista, recebia, em 2001, cerca de mil frequentadores por mês, o CCBB/SP recebia, praticamente, o mesmo número por dia. ${ }^{55}$ As pesquisas encomendadas pelo banco mostravam ainda que, além de numerosos, os frequentadores estavam bem de acordo com o público-alvo do centro cultural - situado na faixa de renda acima de $\mathrm{R} \$ 2.000,00$ - e do seu público estratégico, constituído de empresários e autoridades governamentais.

A composição do público dos centros culturais animou, no começo da década de 2000, instituições financeiras e empresas a investir nesse tipo de equipamento, e várias descobriram o centro de São Paulo como uma boa localização. O então Banco Santander/BANESPA, por exemplo, cogitou abrir lá o seu centro cultural,,56 seguindo os passos do Banco do Brasil, da Caixa Econômica Federal, do SESC e dos Correios. Como o centro de São Paulo era uma área de grande concentração de empregos e atividades, com cerca de 2 milhões de pessoas circulando diariamente por lá, os centros culturais se beneficiavam dessa dinâmica. Eles se tornaram, inclusive, uma opção de lazer importante para o trabalhador do centro que aproveita o horário de almoço para ver exposições gratuitas e, na medida em que investem bastante na qualidade da programação, uma opção também para aqueles de fora que não encontram nos circuitos dos shoppings e cinemas multiplex o tipo de produto que oferecem. 
Com a inauguração do megaespaço dos Correios, ${ }^{57}$ esperava-se que o centro da cidade se consolidasse como o polo cultural mais importante da cidade (Tabela 31), o que teria, certamente, um impacto considerável na valorização do solo. Somando-se isso aos investimentos programados è̀s vantagens oferecidas pela Operação Urbana Centro, projeta-se criar um importante vetor de investimentos privados. Os defensores do direito das camadas de menores ingressos de usufruir as vantagens de moradia no centro, contudo, estavam atentos a essas perspectivas de valorização e passaram a denunciar o papel da cultura na produção de áreas gentrificadas e fechadas ao conjunto da população. (ARANTES, 2000, p. 11-74; FELDMAN, 2001, p. 19-21; SILVA, 2000, p. 36) Com a reivindicação dos movimentos populares por espaço habitacional no centro e com a posse de uma nova administração municipal em 2001, essas ideias começaram a ser incorporadas aos planos para a área central.

\section{A nova política habitacional do município e o Plano "Reconstruir o Centro"}

A desvalorização imobiliária decorrente da fuga de funções que esvaziou o centro antigo abriu espaço para a permanência e até para a volta para a área de famílias de baixa renda. Embora pagando aluguéis bem mais altos do que pagariam na periferia, o que representa considerável comprometimento da renda familiar, ${ }^{58}$ essas pessoas encontravam na área central grandes vantagens de localização relacionadas à proximidade do local de trabalho e à diminuição do tempo e do custo dos deslocamentos. Mesmo que os especialistas na questão habitacional em São Paulo apontassem que não havia um cadastro confiável, uma pesquisa da FIPE, de 1993, mostrava que 6\% da população da cidade viviam em cortiços e que 20\% desse contingente encontravam-se na área central. (SILVA, 2000, p. 17-18) Havia, portanto, uma demanda significativa por habitação popular no centro há muito tempo não solucionada. Por essa razão, nos anos 1990, ao perceberem que os projetos de requalificação e reanimação cultural dificultariam ou inviabilizariam o atendimento a essa demanda, e que programas habitacionais prometidos não
57 Que acabou ocorrendo apenas em 2013.

58 Segundo a Fundação Instituto de Pesquisas Econômicas - FIPE, o valor médio de aluguel pago em cortiços na área central, entre agosto e setembro de 1997, era de $\mathrm{R} \$ 200,00$ podendo chegar a

$\mathrm{R} \$ 250,00$ com a inclusão de contas de água, luz e IPTU. Na mesma época, aluguéis cobrados em quitinetes do centro estavam em torno de $\mathrm{R} \$ 300,00$, e de apartamentos quarto e sala, $\mathrm{R} \$ 450,00$. $\mathrm{O}$ aluguel em cortiço, portanto, chegava a R\$ 13,00 por $\mathrm{m}^{2}$, enquanto no mercado formal de aluguel o preço variava entre $\mathrm{R} \$ 9,00$ e $\mathrm{R} \$ 7,00$ por $\mathrm{m}^{2}$. (BONDUKI, 2001, p. 9) 
deslanchavam, os movimentos sociais por moradia iniciaram a invasão de edifícios vazios ou abandonados na área central, como forma de pressionar o poder público.

Entre 1997 e 2001, foram invadidos na área central 19 edifícios, em grande parte pertencentes ao governo estadual, à União e a bancos (Anexo B). (SÃO PAULO, 2001, p. 52) Com o apoio de ONGs especializadas, que prestam assessoria técnica e judicial, os movimentos populares conseguiram pressionar o poder público a iniciar uma ação mais sistemática no sentido da adaptação de imóveis, do aproveitamento de vazios e de áreas industriais desativadas para uso habitacional de interesse social. As invasões de imóveis atestavam a determinação de encortiçados, sem-teto e moradores da periferia de lutar pelo direito de morar no centro. Serviram também para fornecer subsídios à estruturação de políticas e programas habitacionais nesse sentido, e como forma de disputar e garantir espaço para as camadas populares nos projetos de reabilitação que surgiram depois de 2001.

$\mathrm{Na}$ escala nacional, a ação popular organizada nas grandes cidades, sobretudo nos anos 1980, induziu importantes transformações, tanto na política nacional de habitação como na política urbana, influenciando a criação de instrumentos financeiros e urbanísticos que poderiam possibilitar um desenvolvimento urbano socialmente menos segregado e desigual. Com relação à política habitacional, conseguiu-se, pela primeira vez em mais de 50 anos, destinar recursos para investimentos em assentamentos informais e para crédito direto ao usuário, tornando possíveis intervenções na melhoria das condições do habitat. Rompeu-se, assim, no plano institucional, com a velha política de solução do déficit habitacional baseada unicamente na produção de unidades novas na periferia, permitindo-se a organização de linhas de financiamento para lotes urbanizados, compra de material, reforma de edificações existentes etc. Esta abordagem do problema tornou possível colocar a habitação de interesse social no horizonte do pensamento sobre a reabilitação de áreas centrais esvaziadas nas grandes cidades.

A existência de novos instrumentos e programas, entretanto, não garante a transformação da realidade, já que sua efetiva utilização depende, além de conjunturas econômicas, de vontade política, da solução de entraves jurídicos e operacionais, além de outros fatores que influenciam, viabilizando ou não, 
o desenvolvimento de políticas urbanas de cunho social. De todo modo, nos anos 1990, muitos recursos e vários programas de financiamento estavam disponíveis para a produção de habitação social. No estado de São Paulo, considerando-se apenas os dois programas principais - o Programa de Arrendamento Residencial (PAR), da Caixa Econômica Federal, e o Programa de Atuação em Cortiços (PAC), da Companhia de Desenvolvimento Habitacional e Urbano (CDHU) -, estava prevista a aplicação de R\$ 1,8 bilhão. ${ }^{59} \mathrm{Na}$ área central de São Paulo, entretanto, haviam sido concluídas, até o final de 2002, apenas duas obras com recursos do PAR, encontrando-se três outras em andamento com aportes desse programa (Quadro 7). Além desses empreendimentos, até 2001, mais dois haviam sido iniciados pelo PAC. ${ }^{60}$

A produção de habitação social no centro é, de fato, algo complexo, que envolve muitos problemas e fatores que vão além da mera existência de recursos. Como aponta Maricato (SÃO PAULO, 2001, p. 79-81), são várias as dificuldades que levam uma política de habitação social nos centros das cidades a não ultrapassar o nível das experiências pontuais. Uma delas está no rigor das exigências feitas pelas agências de financiamento no que se refere à documentação legal do terreno ou do imóvel, exigências que, muitas vezes, são impossíveis de cumprir. Outro problema diz respeito aos aspectos técnicos e de projeto que influenciam o custo de produção, pois a indústria da construção no Brasil ainda não desenvolveu tecnologia adaptada à reforma de imóveis para habitação popular. Por fim, a falta de mecanismos de controle e regulação de preços não permite evitar a escassez de terrenos e imóveis com preços adequados às operações de financiamento, em decorrência da valorização gerada, muitas vezes, pela própria implantação da política habitacional.

Além disso, como já comentado no capítulo precedente, os programas existentes não possuem linhas de financiamento que respondam adequadamente ao conjunto de problemas colocados pela produção de habitação social nas áreas centrais no que toca a valores de financiamento, subsídios e modalidades de ocupação de moradias. (SÃO PAULO, 2001, p. 79-81) No centro de uma grande cidade, mesmo que se consiga redução de custos, a produção de habitações deve continuar mais cara do que na periferia, o que demanda adequação nos valores do financiamento, o estabelecimento de uma política de subsídios progressivos
59 Os recursos do PAR equivaliam a R\$ 800 milhões, com aplicação prevista para dois anos. Os recursos do PAC R\$ 1 bilhão - tinham horizonte temporal de aplicação fixado em 12 anos. (Pode se tornar a Broadway de SP. BONDUKI, 2001, p. 9-10 e 73-75)

60 No setor 3 desse programa, no bairro da Luz, estava em execução um piloto denominado "pulmão" Pari. A outra obra era o Mutirão Pirineus, em Santa Cecília, onde estava sendo construído um prédio de 5 andares com 28 unidades, em terreno onde antes havia 3 sobrados. (SILVA, 2000, p. 42) 
61 O Plano Diretor Estratégico do Município de São Paulo foi aprovado em 23/08/2002 e sancionado em 13/09/2002. Para a área central foi prevista a delimitação de ZEIS 3 nas áreas que concentram habitações subnormais, determinando-se que $50 \%$ da área construída sejam destinadas a habitações de interesse social, sem outorga onerosa do solo. ou até a deflagração de uma política de desapropriação. A economia que o repovoamento de áreas centrais pode significar, em termos do aumento do consumo da rede instalada e da racionalização dos transportes, justificaria, largamente, o esforço.

A existência de terrenos vagos para construir, muitos imóveis vazios para reformar e uma infraestrutura abundante e subutilizada permitiu ver o centro da cidade de São Paulo, a partir de 2001, retomando-se ideias debatidas no governo municipal de Luíza Erundina (1989-1993), não mais apenas como um território-problema, mas como uma área passível de adensamento e com potencial para o desenvolvimento de programas sociais. O grande número de domicílios particulares vazios ou fechados na área central e a falta de interesse do mercado imobiliário (Tabelas 32, 33 e 34) foram vistos como dados favoráveis pela Prefeitura de São Paulo para a implantação de uma política habitacional em parceria com os programas de financiamento e com os movimentos sociais. (COMPANHIA METROPOLITANA DE HABITAÇÃO DE SÃO PAULO, 2001) Deflagrada em 2001, essa política previa intervenções em terrenos, prédios isolados e em Perímetros de Reabilitação Integrada do Habitat - PRIH, mediante planos elaborados com a participação de moradores e entidades locais. Além das modalidades tradicionais de atribuição, por arrendamento e venda, propunha-se para a população mais carente o desenvolvimento de um programa complementar de locação social, que teria também a finalidade de interferir no mercado popular de aluguel, reduzindo os preços abusivos cobrados nos cortiços do centro (ver nota 59).

A fim de mitigar a alta dos preços dos imóveis que fatalmente seria gerada com o avanço desse plano habitacional, a prefeitura pretendia adequar a legislação urbanística à implementação das Zonas Especiais de Interesse Social ZEIS, criadas pelo Plano Diretor Estratégico do Município. ${ }^{61}$ Foi ainda montado, na Secretaria Municipal de Habitação e Desenvolvimento Urbano - SEHAB, um Grupo Técnico para trabalhar na identificação e qualificação de imóveis passíveis de inclusão no PAR e outros programas; no estudo de soluções arquitetônicas adequadas à adaptação e reforma de vários tipos de imóveis; e em análises de pré-viabilidade econômica. Com vistas à introdução de instrumentos que estimulassem a produção de habitações de interesse social, controlassem os preços imobiliários e estimulassem a reciclagem, se propôs alteração da Operação Urbana 
Centro a fim de que incentivasse a reabilitação e não promovesse demolições, remembramentos e verticalização excessiva. Foram previstos ainda incentivos fiscais adequados às situações dos diferentes bairros compreendidos na operação. Em suma, o programa habitacional da prefeitura pretendia viabilizar uma ação de larga escala baseada na articulação de programas e recursos, no desenvolvimento de parcerias e em estratégias de obtenção de lotes e imóveis.

A reabilitação da área central com inclusão dos segmentos de baixa renda, entretanto, não poderia ser uma tarefa fácil em face do que já havia sido investido, nos anos 1990, visando à valorizaçăo imobiliária de setores, e diante dos entraves de natureza burocrática, documental, financeira e política que o programa habitacional do município enfrentava. $O$ andamento do programa, até 2002, de fato, não autorizava muito otimismo. Apesar dos avanços conseguidos com as alterações empreendidas na legislação de interesse social e no Código de Obras do Município, e com a implantação de um esquema de aprovação rápida de projetos, a produção de habitações sociais no centro andava devagar. Como mostra o Quadro 7, a maioria dos imóveis encontrava-se, no final de 2002, ainda em fase de projeto, de negociação ou emperrado em problemas burocráticos, documentais ou fundiários. O PRIH delimitado em área anexa à Igreja de São Cristóvão, nas proximidades da Estação da Luz, por exemplo, estava, à época, ainda dependendo de negociação com a Cúria Metropolitana, a proprietária da área.

A política habitacional acima descrita deu o tom do primeiro plano municipal de reabilitação da área central apresentado no final de 2001. Denominado "Reconstruir o Centro", foi definido como um plano que assumia o desafio de implantar uma política urbana na área central, com inclusão social. (SÃO PAULO, 2001b, p. 5) Apoiado numa visão de gestão com participação popular e no estabelecimento de parcerias, o plano propunha a criação de oito programas voltados para o tratamento das questóes relativas ao uso e à manutenção do espaço público, à atração de atividades e investimentos, ao desenvolvimento do mercado de trabalho, à preservação do patrimônio e, principalmente, ao desenvolvimento da função habitacional. A concretização desses programas se daria por meio da integração de ações e recursos de diferentes órgãos municipais; da articulação das políticas setoriais municipais e de outros níveis de governo; de intervenções em grandes áreas desocupadas ou ocupadas por usos inadequados; e de mudanças 
na legislação urbanística para garantir o bom uso dos espaços e viabilizar investimentos compatíveis com as características e potencialidades da região.

Eixo principal do Plano "Reconstruir o Centro", o Programa "Morar no Centro" tinha como objetivo viabilizar moradia para a população de baixa renda na área central, abrangendo os distritos localizados na periferia do núcleo principal do centro (Foto 62; Mapas 11 e 12). Em consonância com a nova política habitacional do município, o programa atuaria por meio de intervenções localizadas e em perímetros de reabilitação, executando intervenções integradas de produção habitacional, melhoria de condições de cortiços, reabilitação do patrimônio, criação e requalificação de equipamentos e áreas verdes e criação de espaços para atividades econômicas. Esses perímetros seriam definidos a partir de discussões com movimentos populares e agentes financeiros. (SÃO PAULO, 2001b, p. 27)

No Plano "Reconstruir o Centro", as formas de sobrevivência da população de baixa renda também foram contempladas com diretrizes para o comércio ambulante, definição de áreas exclusivas para essa atividade e apoio à capacitação, com vistas à inclusão de moradores de rua no mercado de trabalho. (SÃO PAULO, 2001b, p. 31) Os projetos para reabilitação do patrimônio se estruturavam na linha de otimização da infraestrutura de turismo, cultura e recreação, prevendo-se a execução de intervenções de tratamento paisagístico, restauração e recuperação de espaços de interesse histórico. (SÃO PAULO, 2001b, p. 33-37) A Operação Urbana Centro e a "Lei das Fachadas" deveriam ser reformuladas com vistas à eliminação das disposições que criavam dificuldades e entraves ao desenvolvimento de uma política de reabilitação conjugada ao uso habitacional de interesse social, e ao redimensionamento dos incentivos fiscais.

Para deslanchar e testar os programas desse plano setorial, foi escolhida uma área compreendida entre ruas Sete de Abril, Conselheiro Crispiniano, Avenida São João e Avenida Ipiranga, denominada de "Quadrilátero Piloto" (Foto 63). A área foi selecionada por conter 67 imóveis tombados e concentrar condições complexas em termos funcionais e de uso, com calçadões, comércio ambulante e situações de apropriação indevida de espaço público. Foi selecionada também por abrigar imóveis pertencentes à Caixa Econômica Federal (que seriam recuperados para uso habitacional com recursos do PAR), e o futuro centro cultural do SESC. Essa área, entretanto, não foi visada apenas pelos planos do município. Vista como 
estratégica pelos setores do Governo do Estado de São Paulo envolvidos com a reanimação da atividade cultural no centro, a área - também conhecida como "Cinelândia" paulistana - era também alvo de um projeto de implantação de um polo turístico e cultural. A ideia era transformá-la em um shopping a céu aberto, com revitalização da hotelaria e da função habitacional para a classe média. ${ }^{62}$ O "Quadrilátero Piloto" refletia, portanto, de modo privilegiado, as diferentes visões que alimentaram os projetos para o centro da cidade de São Paulo na virada do século XXI.

O Plano "Reconstruir o Centro" foi apresentado ao BID para obtenção de empréstimo no início de 2002. No curso das negociações com essa agência multilateral, o plano foi reformulado, enxugado e renomeado como "Programa de Reabilitação do Centro".

\section{Programa de Reabilitação do Centro}

O plano estratégico, originalmente encaminhado pela Prefeitura de São Paulo ao BID, propunha uma série de ações de requalificação urbana, privilegiando a implantação de atividades culturais e de lazer, bem como a construção de várias garagens subterrâneas e estacionamentos. (SÃO PAULO, 1998) Com a nova administração municipal, empossada em 2001, esta proposta foi substituída pelo Plano "Reconstruir o Centro" e reapresentada ao BID no início de 2002. O novo plano da prefeitura, entretanto, foi considerado "sem foco" pelos técnicos dessa agência de financiamento e com ações muito dispersas, devendo ser reformulado no sentido de conter projetos de impacto que permitissem iniciar um processo de reversão do quadro deteriorado do centro. ${ }^{63}$

De fato, o Plano "Reconstruir o Centro" não definia a área central como um "problema", vendo-a mais como um território cujo desempenho urbano necessitava ser melhorado do que como uma área cujo perfil de uso devesse ser transformado. Buscava, na realidade, instituir uma política de repovoamento e melhoria da qualidade urbana da área central, conectada às questôes colocadas à cidade pela estagnação econômica, pelo crescimento da pobreza, pela ocupação desordenada e ilegal da periferia e das áreas de valor ambiental, tirando partido do
62 Ver a reportagem: Velho Paissandu pode se tornar a Broadway de SP, Diário de São Paulo, São Paulo, 21 mar. 2002

63 Depoimento de Nádia Somekh, Vice-presidente da Empresa Municipal de Urbanização EMURB, em entrevista concedida em 12 nov. 2002. 
64 O empréstimo do BID deveria ser pago em 20 anos, com dois anos de carência e juros de $5 \%$ ao ano, prevendo-se o início da execução do contrato para 2003 e sua conclusão em dois ou três anos (informação obtida no site oficial da prefeitura, em 12/08/02). Os recursos seriam destinados a ações sociais (35\%), à circulação e transportes (20\%), à recuperação de edifícios (15\%) e a intervenções urbanísticas (10\%) e de segurança $(20 \%)$. esvaziamento das áreas de urbanização consolidada. Em suma, o esvaziamento dos bairros centrais era visto como uma oportunidade para mudar a direção do vetor de crescimento urbano da periferia para o centro, sendo essencial, para que essa estratégia tivesse sucesso, que o atual perfil da área central não fosse totalmente transformado de modo a deflagrar uma repentina valorização do solo. Com a entrada em cena do BID, cuja principal medida de sucesso de uma intervenção urbana é justamente a valorização imobiliária da área focalizada, essa concepção foi adaptada.

Para viabilizar a obtenção do empréstimo solicitado, o plano municipal teve então de adquirir um perfil de plano de ação, focalizar mais os distritos Sé e República, e incorporar intervenções urbanas de maior impacto e visibilidade. Manteve, entretanto, a ênfase no desenvolvimento de programas sociais que preservaram o seu conteúdo básico, ainda que com adaptações. O "Programa de Reabilitação do Centro", que contaria com US\$ 100 milhões do BID e mais US\$ 65 milhões, divididos entre Prefeitura Municipal de São Paulo e iniciativa privada, foi o resultado da negociação entre essas duas visões. ${ }^{64}$

O novo programa tinha como eixo organizador uma concepção multifuncional do centro como sede do poder municipal, polo de ensino superior, lazer e turismo, e como área propícia à instalação de empresas de alta tecnologia, comércio e serviços sofisticados, que se beneficia da existência de um núcleo financeiro remanescente e de um comércio popular especializado. O plano propunha que na área se desenvolvesse ainda um novo tecido produtivo, de pequenas e médias empresas, bem como o uso residencial para diversas faixas de renda. Para tanto, propunha-se a adoção de medidas administrativas e legais que atacassem os problemas que travavam o desenvolvimento dessas potencialidades da zona central, e sugeria-se a implementação de "projetos motores" envolvendo intervenções de requalificação de espaços públicos, intervenções urbanísticas e ações de desenvolvimento do uso habitacional (Foto 64). (EMPRESA MUNICIPAL DE URBANIZAÇÃO, 2002b)

O tratamento dos espaços públicos focalizava os distritos Sé e República e era composto por ações de zeladoria - como limpeza, drenagem, iluminação, sinalização, instalação de mobiliário, recuperação de ruas, passeios e calçadões - 
e por programas voltados para o ordenamento de ambulantes, ${ }^{65}$ para a assistência a moradores de rua, ${ }^{66}$ geração de trabalho e renda, e melhoria da segurança pública e da circulação de veículos.

As intervenções urbanísticas envolviam o centro velho e o centro novo, o Parque D. Pedro II e o bairro da Luz, onde deveriam ser desenvolvidas ações complementares ao projeto do Programa Monumenta. No centro velho e no centro novo foram retomados e complementados projetos do Plano "Reconstruir o Centro", como o "Quadrilátero Piloto"; o "Corredor Cultural”, entre as Praças D. José Gaspar e do Patriarca; além de intervenções no "triângulo histórico" e de recuperação de edifícios públicos e privados. Na área do Parque D. Pedro II, retomou-se o projeto de recuperação ambiental, proposto no início dos anos 1990, incorporando-se parte da via Diagonal Sul, com vistas a melhorar a integração do setor ao centro velho e a desenvolver sua função recreativa. Em termos de intervenções urbanísticas, propôs-se, ainda, no Projeto "Portas da Cidade", a requalificação dos trechos dos principais corredores viários que dão acesso ao centro, com vistas a sinalizar suas entradas e os limites do território revitalizado. ${ }^{67}$ O Programa "Morar no Centro" foi mantido como eixo principal da ação de desenvolvimento do uso residencial, com reformulações no sentido de abarcar também segmentos de renda média e de concentrar os Perímetros de Reabilitação Integrada do Habitat na periferia imediata do núcleo central (Mapa 18).

O Programa de Reabilitação do Centro manteve, portanto, o formato básico dos programas de revitalização que vinham sendo financiados pelo BID no Brasil, durante os anos 1990, nos quais eram privilegiados projetos que criassem condições para a atração de investimentos privados no setor focalizado, agregando-se, contudo, a esse modelo, programas sociais de peso significativo. $O$ desafio que a Prefeitura de São Paulo se colocava era, assim, o de garantir a diversidade de atividades e de segmentos sociais no centro antigo, equilibrando valorização e presença popular. Para tanto, além das ações sociais já mencionadas, também se propunha a criação do Fórum de Desenvolvimento da Área Central, com vistas a ampliar a participação da sociedade civil no ProCentro, que, por sua vez, foi reestruturado e reforçado como instrumento de gestão compartilhada. ${ }^{68}$

Ao buscar conciliar as diferentes visões do problema e as pressões dos atores que as defendiam, o programa paulistano construiu, na realidade, um modelo
65 Dos 8.000 ambulantes então existentes no centro, apenas os 2.00o cadastrados deveriam permanecer.

66 Entre estas, a de maior peso era a implantação do "Abrigo Boracea”, envolvendo a recuperação de um galpão de antiga oficina de transportes para instalação de equipamento de assistência social com capacidade de atendimento de 2.425 pessoas por dia, com oferecimento de teto, comida e programas de reinserção social e capacitação profissional (informação obtida no site www.prefeitura. sp.gov.br, em maio de 2003).

67 Por falta de envolvimento de atores sociais, esse projeto já foi modificado. Informação prestada por Nadia Somekh, Vice-presidente da EMURB, em novembro de 2003. Fazia parte, entretanto, da proposta avaliada pelo BID em novembro de 2002.

68 Informação prestada por Nadia Somekh, em novembro de 2003. 
69 Informação encontrada no Boletim "Pauta São Paulo", do Vereador Nabil Bonduki, em julho de 2003. híbrido, que conjugava ações típicas de planos estratégicos de valorização com outras de interesse social. Essa conciliação foi, sem dúvida, resultado da conjuntura política particular que caracterizava então o processo de reconquista do centro de São Paulo, onde, como visto, proprietários urbanos, iniciativa privada e movimentos populares organizados funcionavam como instigadores da ação pública.

O Programa de Reabilitação do Centro foi desenhado, assim, como um plano que buscava o consenso entre as forças em jogo, mas que não agradava igualmente a todas elas. Os movimentos populares, por exemplo, o acusavam de esquizofrenia por buscar inclusão social e, ao mesmo tempo, implementar projetos que favoreciam a valorização imobiliária. ${ }^{69}$ Diante do andamento lento da política habitacional do município e dos muitos entraves que eram interpostos, esses movimentos tinham, de fato, razões para preocupação.

\section{Resultados e sentidos das intervenções realizadas nos anos 1990}

Os programas propostos e as intervenções realizadas no centro durante os anos 1990 e começo da década de 2000 surgiram, em grande parte, como visto, de pressóes de empresários e proprietários urbanos preocupados com a desvalorização imobiliária da área, e dos movimentos sociais em luta por espaço e melhores condições de moradia na área central. Refletiram, assim, a disputa dessas forças pela definição do destino do território, segundo visões dificilmente compatíveis. Num extremo, os defensores de um centro metropolitano segregado, gentrificado e inserido na rede global, e, no outro, os que reivindicavam uma centralidade de uso marcadamente popular e habitacional.

Durante toda a década de 1990, independentemente do comprometimento maior com uma ou com outra visão, o poder público atuou de maneira basicamente contraditória, pouco articulada e, frequentemente, ineficaz, verificando-se pouca ou nenhuma mudança no quadro de esvaziamento e subutilização da área central. A disputa entre movimentos populares e setores empresariais e corporativos pelo destino do centro, entretanto, forçou a negociação e promoveu a definição, ao menos em tese, de um papel mais realista e viável para o 
centro antigo no conjunto do sistema de centralidades de São Paulo: o de polo administrativo, produtivo e comercial, conjugado a funções culturais, de lazer; e residenciais, de caráter diversificado. Contudo, para que essas potencialidades se desenvolvessem seria preciso que o poder público exercesse uma ação reguladora firme e decidida, já que, em princípio, valorização imobiliária e acesso amplo e democrático ao solo são reivindicações inconciliáveis e com chances de materialização distintas e desiguais.

A despeito de todas essas dificuldades e das concessões feitas aos modelos de financiamento e aos modismos urbanísticos, a cidade de São Paulo construiu, no começo dos anos 2000, considerando-se o conjunto das maiores cidades brasileiras, a proposta mais democrática de intensificação da dinâmica e do uso da área central. Nessa conquista, desempenharam papel central a organização política dos segmentos populares e a atuação de uma administração municipal comprometida com a inclusão social e com um desenvolvimento urbano mais equilibrado e racional. A partir da análise das intervenções realizadas nos anos 1990, que refletem a disputa pelo patrimônio do centro, se busca, a seguir, apontar quais foram as chances de concretização dessa proposta.

Durante os anos 1990, a área central da cidade de São Paulo foi alvo de vários projetos de requalificação que, invariavelmente, mas nem sempre articuladamente, propuseram intervenções no espaço público, no sistema viário, na recuperação do patrimônio histórico e na implantação de equipamentos culturais, com vistas à atração de novas atividades, investimentos e usuários para o setor. A fórmula, que pode ser denominada de "requalificação ambiental estratégica", apesar de apoiada em amplo sistema de incentivos fiscais e concessões de vantagens urbanísticas, atraiu poucos investimentos privados. As principais intervenções realizadas foram financiadas, basicamente, pelo poder público. Os atraentes incentivos fiscais e os instrumentos urbanísticos de promoção da produção imobiliária, criados no período, não foram capazes de trazer, de modo significativo, novas atividades ou investimentos para o centro, cujo quadro geral de subutilização permaneceu basicamente inalterado. Mesmo o evidente sucesso de público dos equipamentos culturais que foram implantados não produziu impacto perceptível na transformação do padrão de uso e ocupação do solo à sua volta. 
Até o final dos anos 1990, contudo, nenhum dos citados projetos ou estratégias de valorização se inseriram num plano global de cidade que contivesse diretrizes para o estabelecimento de uma relação de equilíbrio entre as centralidades existentes e para o uso racional da infraestrutura urbana implantada. Ao contrário, esses projetos e estratégias conviveram, na maior parte do tempo, com pesados investimentos públicos nos bairros do setor Sudoeste, o que favoreceu a formação e a consolidação de centralidades concorrentes, bem como a concentração de investimentos imobiliários privados naquela região. Os fracassos das Operações Urbanas Anhangabaú e Centro, enquanto instrumentos de captação de recursos privados o que, em última análise, implicaram na não decolagem das estratégias de requalificação do centro - resultaram da falta de dinamismo econômico para investimentos em mais de um vetor de expansão. Em outras palavras, as vantagens criadas para a atração de investimentos para o centro antigo, ainda que fortes, não foram capazes de mudar a direção ou interferir na dinâmica do vetor de investimentos consolidado no setor Sudoeste. Essa incapacidade se vinculou ainda, em grande parte, ao fato de os incentivos da área central se dirigirem à mesma faixa de mercado que demanda o Sudoeste, na qual ainda predomina uma mentalidade de indiferença para com o passado histórico e de preconceito para com a região central, o que, sem dúvida, dificultou os projetos de reconquista da área baseados na atração de segmentos sociais abastados. Como se sabe, só se investe onde há mercado consumidor e o mercado no qual o setor imobiliário formal estava interessado era muito restrito no centro. Aí, a grande demanda existente era de baixa renda.

Muita energia, discurso e investimento foram gastos, entretanto, na identificação das "causas" da deterioração e do esvaziamento da área central, o que foi relacionado à estrutura de uso do solo inadequada para a implantação de empresas modernas; ao excesso de trânsito de passagem e de linhas de transportes públicos; à "absurda" concentração de população; ao excesso de camelôs nas ruas; ao número exagerado de calçadões; aos constrangimentos à circulação e ao estacionamento de veículos privados - enfim, a quase tudo que se relacionava ao centro, tal como ele se encontrava. Entretanto, em que pesassem os sérios problemas urbanos ali existentes, a maior parte das situações acima listadas não era a causa de sua debilitação ou esvaziamento - ao contrário, eram responsáveis 
pelo que o setor continuava tendo de forte e dinâmico, e que poderia funcionar como recurso num processo de reabilitação.

Diagnósticos, como o elaborado por ocasião do lançamento do ProCentro, em 1993, apontavam as restrições ao automóvel e a falta de estacionamentos como responsáveis pela deterioração e fuga de atividades do centro. Procurava-se passar a ideia, igualmente cara às agências de financiamento, de que, se houvesse estacionamento, haveria público e atividade na área central, o que não é, necessariamente, verdade. No centro histórico de Salvador, por exemplo, foram construídos três grandes estacionamentos no mesmo período, que ficavam a maior parte do tempo semivazios, pois o dinamismo de uma área não depende só de facilidade de circulação e disponibilidade de vagas para automóveis particulares. Em situações como a de São Paulo, onde surgiram novas centralidades não planejadas e guiadas unicamente pelo interesse do capital imobiliário, a solução para estancar processos de esvaziamento e fuga de funções do centro antigo é pensar o conjunto da cidade e suas centralidades. Ao invés disso, os projetos propuseram atuar apenas no próprio centro, como se a causa dos seus problemas estivesse ali, e não no Sudoeste ou na periferia da cidade. Em São Paulo, durante os anos 1990, o setor imobiliário continuou operando à solta, e o poder público ainda investiu onde este setor queria. Em contrapartida, o reforço do centro antigo foi tentado essencialmente por meio de intervenções epidérmicas e de liberação de índices urbanísticos, o que, como se viu, não foi suficiente. As operações urbanas da área central demonstraram isso claramente.

De todo modo, o clima criado pelo discurso de requalificação e as vantagens e incentivos oferecidos mobilizaram e atraíram alguns investimentos privados em melhoramento de espaços públicos, na restauração de fachadas e de alguns monumentos, na implantação de espaços culturais e de algumas atividades típicas de área central (Apêndice D). Ainda que poucas, somadas às públicas, essas intervenções constituíram um primeiro movimento no sentido da revalorização do solo do centro e de sua reconquista pelas camadas sociais mais abastadas.

Mas não foram apenas as intervenções da requalificação ambiental e as estratégias de valorização que animaram, nos anos 1990, as esperanças de repovoamento e uso mais intensivo da área central. A reciclagem e a reabilitação para uso habitacional do estoque imobiliário ocioso também surgiram como projetos 
alternativos para a revitalização do centro. O aproveitamento desse estoque surgiu em decorrência de reivindicações de movimentos populares, articulado à demanda habitacional de baixa renda existente e à dinâmica de uso popular da área central. Os resultados dessas iniciativas, entretanto, foram ainda menores do que o das intervenções estratégicas de requalificação. Confrontado com entraves fundiários, documentais, tecnológicos, financeiros e burocráticos, o programa habitacional fechou aquela década com pouquíssimas intervenções concretizadas.

Como visto neste capítulo, além de recursos e instrumentos financeiros adequados, a implantação de uma política pública de produção de habitações sociais depende visceralmente da disponibilidade de terrenos e imóveis a preços compatíveis com os custos de produção de unidades habitacionais de interesse social. Uma vez que, nesse campo, sempre se opera no limite, seja em termos de financiamento, seja em termos de capacidade de endividamento dos mutuários, a obtenção de imóveis e terrenos a preços razoáveis torna-se crucial. Ao criar Zonas Especiais de Interesse Social na área central, o Plano Diretor do município forneceu ao poder público um bom instrumento de controle da valorização artificial do solo, possibilitando a constituição, pela prefeitura, de um banco de terras e imóveis que poderia tornar mais viável, mesmo num contexto de valorização, a produção sistemática de habitações sociais no centro.

Na virada do século XXI, apesar dos esforços em prol de uma conciliação, a área central de São Paulo constituía uma espécie de espólio urbano disputado por forças antagônicas, sem que se pudesse ainda identificar claramente o vencedor. Havia espaço para a reabilitação com inclusão social, mas apenas restrita a determinadas áreas de menor interesse comercial nos bairros centrais e nas ZEIS 3 que foram delimitadas. Por outro lado, embora movimentos de gentrificação pudessem ser identificados nas franjas da área central, era muito pouco provável, em decorrência dos fatores econômicos e de mentalidade já comentados, que o centro de São Paulo se transformasse no centro de Nova York ou mesmo de Barcelona. A realidade mostrava que os modelos de intervenção dos países centrais transplantados para os periféricos davam apenas resultados incompletos.

Nos anos 1990, a necessidade de parceria entre os setores público e privado foi colocada como condição à realização das intervenções de requalificação, em face da crise financeira e fiscal do Estado e das necessidades de manutenção do 
patrimônio requalificado. No entanto, naquele período, o grande investidor no centro foi mesmo o setor público, ainda que, muitas vezes, tenha sido conduzido por projetos e interesses privados. As intervenções mais importantes no centro de São Paulo foram executadas e financiadas com recursos públicos, e o que fugiu dessa regra fez uso maciço de incentivos fiscais. Ou seja, ou o setor público investiu diretamente ou renunciou ao recebimento de impostos. Os investimentos puramente privados, em termos comparativos, foram poucos, como mostra o desempenho dos instrumentos criados para sua captação e para a promoção imobiliária. Assim, "parceria”, como ação compartilhada na qual custos e benefícios são repartidos igualmente entre os participantes, não ocorreu. A ideia serviu muito mais para legitimar a concessão de benefícios a segmentos restritos do que para consolidar o surgimento de uma nova prática.

Os anos 1990 se caracterizaram também por um papel preponderante das instâncias regionais e locais na execução das políticas de preservação e requalificação e, no caso de São Paulo, por uma significativa participação do setor privado na determinação dos seus rumos. Iniciativas importantes e definidoras dos objetivos dessas políticas, como a Operação Urbana Centro e o ProCentro, resultaram de pressões diretas da iniciativa privada, que colaborou, inclusive, na elaboração de seus contornos e conteúdo. A implantação de instrumentos urbanísticos e fiscais compensatórios foi também defendida por esses setores, conciliando-se, assim, capital e patrimônio. Quanto às iniciativas de reabilitação conjugadas ao uso habitacional, os movimentos populares e as organizações que os assessoram desempenharam, igualmente, importante papel de interlocução com o poder público, contribuindo também para a definição dos rumos dessas ações.

A participação da sociedade organizada na gestão do território do centro se deu, nos anos 1990, por meio de instrumentos criados pelo poder público no período, como a Comissão ProCentro, e também através de outros artifícios da iniciativa privada, como os Núcleos de Ação Local. Criado pela Associação Viva o Centro, em 1996, o Programa "Ações Locais" estimulou a formação de núcleos autônomos reunindo moradores, usuários, proprietários e empresários sediados no centro, com vistas à sua participação na administração do cotidiano dos seus setores. Até 2002, haviam sido fundados 40 núcleos desse tipo, dos quais 15 funcionavam 
70 Informação de Terezinha Santana, coordenadora do programa, em entrevista concedida em 22 mar. 2002. em caráter permanente..$^{70}$ Embora acusados de eventualmente exercerem atividade "policialesca" com relação a camelôs e moradores de rua, alguns núcleos realizavam trabalhos importantes de reinserção social de moradores de rua e de apoio a trabalhadores informais. (FRÚGOLI JÚNIOR, 2000, p. 94-95)

A representatividade social das organizações chamadas a participar de instrumentos públicos de gestão variou, contudo, segundo os compromissos políticos das administrações municipais do período. Os movimentos sociais, por exemplo, começaram a fazer parte da Comissão ProCentro apenas em 2001, quando o Partido dos Trabalhadores assumiu o governo da cidade. A atuação de organizações privadas - como os Núcleos de Ações Locais - variou de acordo com seus interesses específicos e com os compromissos assumidos com as administrações municipais: um papel mais policial e fiscalizador no período Maluf/Pitta, e um papel mais de interlocutor na gestão Marta Suplicy (2001-2004). A análise do período mostra, portanto, que os compromissos políticos e os projetos das administrações municipais são essenciais para balizar e orientar a ação e a participação da sociedade civil organizada na reabilitação e na gestão de territórios complexos como o centro de São Paulo. Mostra também que, em contextos suscetíveis a constantes mudanças administrativas, a criação de instrumentos de gestão participativa é essencial para a continuidade de projetos de maior alcance e interesse social.

\section{A noção de patrimônio e a prática de preservação}

Nos anos 1990, não foi em nome da memória e da história urbana que se preservou o patrimônio, embora essas noções tenham sido constantemente evocadas como apoio legitimador de projetos e intervenções. A atividade privada de preservação foi promovida, no período, como um investimento que os incentivos e isenções fiscais tentaram tornar atrativo, e o patrimônio histórico foi abordado como algo que deveria render e obter boa aceitação no mercado. Seu caráter formador, educativo e de utilidade pública ficou em segundo plano. Como já se anunciava nos anos 1970, o patrimônio foi tratado, no plano coletivo, como um fator de promoção de dinamização econômica, mas, na prática, foi individualmente 
apropriado como instrumento de valorização imobiliária, de marketing e de geração de imagem, o que é totalmente diferente de reivindicar que os bens culturais de natureza material tenham usos que promovam e sustentem sua conservação e manutenção.

As operações de seleção, salvaguarda, conservação e promoção do patrimônio, ao longo de todo o período, foram grandemente influenciadas por essas concepções e apropriações. Os tombamentos federais realizados em São Paulo visaram, essencialmente, a facilitar o acesso aos incentivos fiscais e aos programas federais de financiamento implantados na década. Embora esses bens tenham, inegavelmente, valor histórico, ambiental ou artístico, não foram esses aspectos que motivaram a proteção. A motivação principal foi a obtenção de recursos e o desejo de valorização imobiliária e, por isso, as operações de conservação e os instrumentos criados para regulamentá-las, promovê-las e incentivá-las constituem os indicadores que melhor informam sobre a ideia de patrimônio e a preservação praticada no período em foco.

Nos anos 1980, as disposições que regulamentaram as zonas Z8-200 instituíram critérios gerais de intervenção que remetiam à preservação da volumetria e da escala de zonas de concentração de imóveis de interesse, restringindo a altura das edificações próximas a partir das construções mais antigas, com vistas a uma integração volumétrica submetida às características gerais do patrimônio preservado. Nas operações urbanas dos anos 1990, entretanto, se operou com regras de contraste e isolamento entre o novo e o antigo, sem estratégias de transição ou integração, descolando-se muitas vezes a arquitetura do tecido urbano tradicional. Caso tivessem sido bem-sucedidas, essas operações conduziriam ao rompimento de relações de parcelamento e ocupação, que isolariam totalmente o patrimônio do objeto renovado. Intervenções como o Pórtico da Galeria Prestes Maia (Foto 65) seguiram essa tendência, abrigando ainda, como também se verifica neste caso, fortes intenções promocionais e de "renovação" do próprio patrimônio.

As medidas de incentivo fiscal, por seu turno, deixaram bastante claro o foco principal de interesse da preservação então praticada: as fachadas. Mandadas restaurar em sua feição original, as fachadas foram as grandes vedetes do patrimônio em São Paulo. Intervenções de requalificação ou de reabilitação privilegiaram 
principalmente a aparência externa dos imóveis e o ambiente urbano que propiciam. Já o agenciamento interno e os sistemas de circulação, e elementos urbanísticos como o parcelamento, a ocupação do lote, a forma das quadras e as relações entre volumes, não foram considerados merecedores de preservação. Em termos edilícios, o patrimônio preservado foi, basicamente, a fachada que sobrou após a "reciclagem", o "refurbishment" ou o "retrofit", que, invariavelmente, realizaram a construção de um edifício novo dentro do antigo - este, usado apenas como "casca" ou invólucro para construções novas. Em São Paulo, essa prática não atingiu apenas o estoque edilício antigo, mas ocorreu também nas intervenções em grandes monumentos, como a instalação da Sala São Paulo, no desaparecido Grande Hall da Estação Júlio Prestes, e o novo sistema de circulação em construção no antigo prédio dos Correios (Foto 66). O projeto do Museu da Língua Portuguesa, no prédio da Estação da Luz, adotou também partido semelhante, com uso abundante de elementos high tech no reaproveitamento de espaços internos. Em todos esses casos, as fachadas externas foram rigorosamente restauradas.

Em São Paulo, portanto, as estratégias de valorização do patrimônio através da adição de elementos contemporâneos foram largamente utilizadas, nos anos 1990. Assim, no período em que mais se atuou na conservação do patrimônio urbano, menos elementos foram associados a essa ideia. Em decorrência de sua crescente utilização como ativo econômico, a noção de patrimônio urbano sofreu, ao mesmo tempo, uma redução de conteúdo e uma ampliação na quantidade de objetos postos no seu campo de visibilidade. Como qualquer ideia que se massifica, o patrimônio perdeu também profundidade.

O caso de São Paulo mostra que as reivindicações por incentivos e compensações para a atividade de preservação, encaminhadas nos anos 1980, foram largamente atendidas e desenvolvidas nos anos 1990. A concepção do patrimônio como um recurso econômico atingiu, no período, o seu apogeu. Nos anos 1980, a associação do patrimônio à qualidade de vida e à construção da cidadania relacionou-se ao processo de redemocratização então em curso no Brasil, podendo-se caracterizar esse período como um hiato em um processo maior de transformação de uma prática de preservação que começou nos anos 1970 e que veio a se consolidar nos anos 1990. Transformação que, em última análise, diz respeito à função 
do patrimônio na sociedade. Dispositivo de produção de significados que visavam, principalmente, à educação e à formação de cidadãos, o patrimônio se transformou, a partir dos anos 1970, num dispositivo de produção de valor econômico e de construção de imagens e mercadorias para consumo. Utilizado, ao longo dos anos 1980, para conter a especulação imobiliária, evitar transformações e manter a qualidade de vida em bairros de classe média alta, nos anos 1990, o patrimônio participou de modo diverso do processo de urbanização em São Paulo. Nas operações urbanas que foram montadas em seu nome, ele surgiu, ao contrário, como um motivador da renovação, como um atrativo para investimentos transformadores do padrão de urbanização existente. No final da década, surgiu também, secundariamente, como recurso para o repovoamento de áreas esvaziadas e elemento facilitador da racionalização do uso da infraestrutura instalada.

Apesar da importância atribuída à participação do setor privado nas ações de preservação, e a despeito dos incentivos oferecidos, o Estado permaneceu sendo, nos anos 1990, o grande agente financiador e conservador do patrimônio. Nesse aspecto, portanto, nenhuma transformação ocorreu em relação aos outros períodos da trajetória da preservação do patrimônio urbano no Brasil. O que houve de novo foi que, diversamente do que ocorria antes, o investimento público foi, em grande parte, administrado e aplicado pela iniciativa privada por meio de renúncia fiscal ou da influência sobre os rumos da política pública.

Assim, uma importante característica dos anos 1990, em São Paulo, foi a influência de organizações não governamentais e segmentos sociais organizados nas políticas, projetos e intervenções de requalificação ou reabilitação na área central. Profissionalizadas, especializadas e estruturadas de modo permanente, essas organizações assumiram um papel de interlocução com o poder público, sempre que houve espaço. Na área central de São Paulo, confrontaram-se, de um lado, a organização não governamental de defesa dos interesses dos proprietários urbanos e do empresariado, e, de outro, as organizações de defesa dos não proprietários e dos sem-teto, que lutam por melhores condições de vida e moradia. No período em causa, os interesses dos primeiros tiveram mais voz e acolhimento junto ao poder público, dando, assim, o tom geral do discurso e da prática de requalificação de setores do centro antigo. Os incentivos fiscais e urbanísticos 
dirigidos a esses setores foram pródigos, verificando-se uma grande assimetria de tratamento com relação aos subsídios voltados para a melhoria da situação dos que habitam em condições subnormais.

Quanto à noção de patrimônio urbano, os anos 1990 se caracterizaram, em suma, por uma restrição no seu conteúdo e por uma valorização exacerbada de elementos externos e paisagísticos. Em São Paulo, o período foi marcado pelo fachadismo e pela falta de profundidade histórica nas intervenções. Concebido como valor econômico e mercadoria de uso corrente, o patrimônio urbano perdeu, em grande parte, seu poder testemunhal e de representação.

À luz da prática de requalificação e preservação urbana realizada na área central de São Paulo, verifica-se que os anos 1990 se caracterizam também, enfim, por rupturas e continuidades em relação a outros períodos. No cômputo geral, a década pode ser vista como o momento mais recente e consolidado de um processo de aproveitamento econômico do patrimônio urbano que começou anteriormente, mas que só encontrou condições de realização plena no final do século XX. Tal processo foi impulsionado, entre outros fatores, por uma concepção de cidade que não abre mão da sua identidade histórica e que a toma como um item estratégico para a economia urbana. Essa concepção permitiu, por fim, que São Paulo associasse sua imagem urbana ao patrimônio. 


\section{Caderno de imagens}
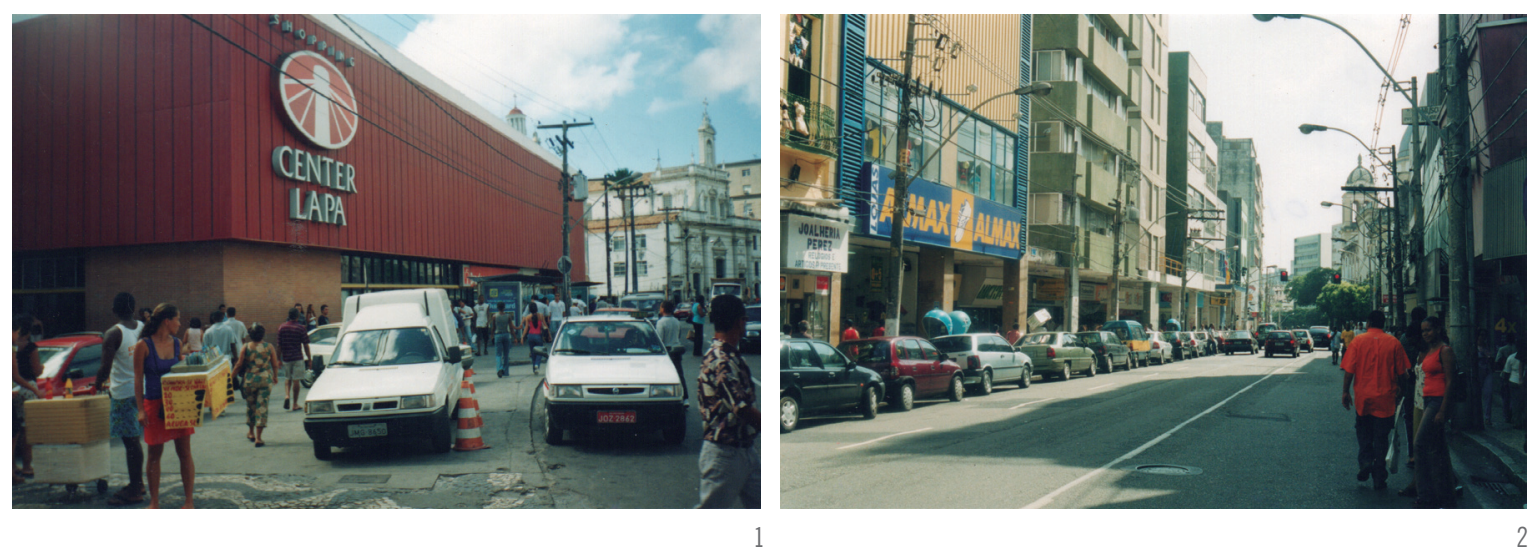

Salvador

Foto 1. Avenida Sete de Setembro:

do varejo fino ao comércio

popular.

Foto 2. Shopping Lapa, que,

juntamente com 0 Shopping

Piedade, polarizava o varejo no

centro.

Foto 3. Edifício vazio na principal

via do setor financeiro do

Comércio proposto para uso

habitacional.

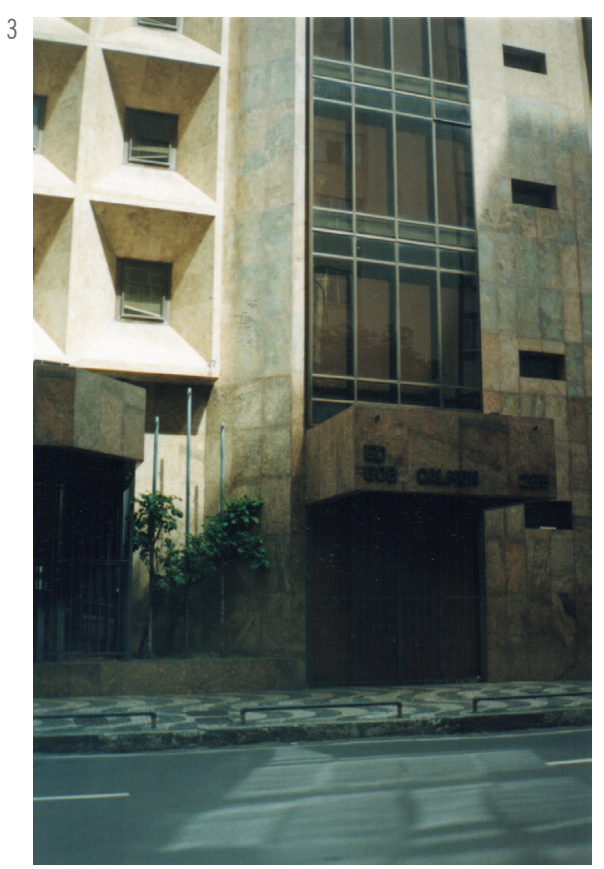


Salvador

Foto 4. Largo do Pelourinho, coração do shopping a céu aberto implantado a partir de 1992.

Foto 5. Pelourinho, uma das inúmeras lojas de artesanato à rua Gregório de Mattos.

Fotos 6 e 7. Palco e áreas utilizadas para shows no interior de quarteirões do Pelourinho.

Foto 8. Sodré, imediações da Ladeira da Preguiça: área considerada propícia ao desenvolvimento do uso habitacional.

Foto 9. Sobrado em ruína na Rua Direita de Santo Antônio (rua Joaquim Távora), incluído no Projeto Rememorar.

Foto 10. Bairro 2 de Julho: imóvel à Rua Areal de Cima (ao fundo) que foi listado para desapropriação no âmbito do Projeto Rememorar.
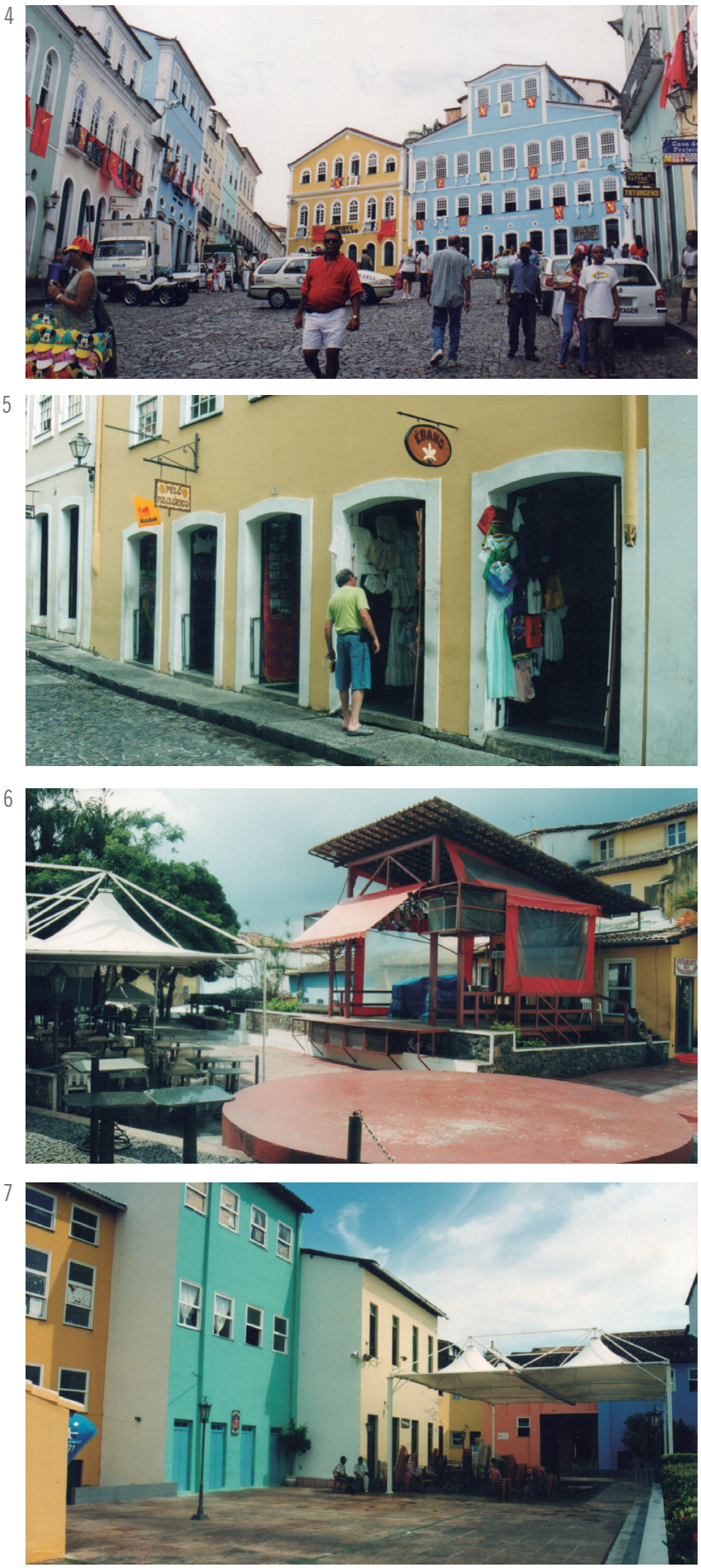

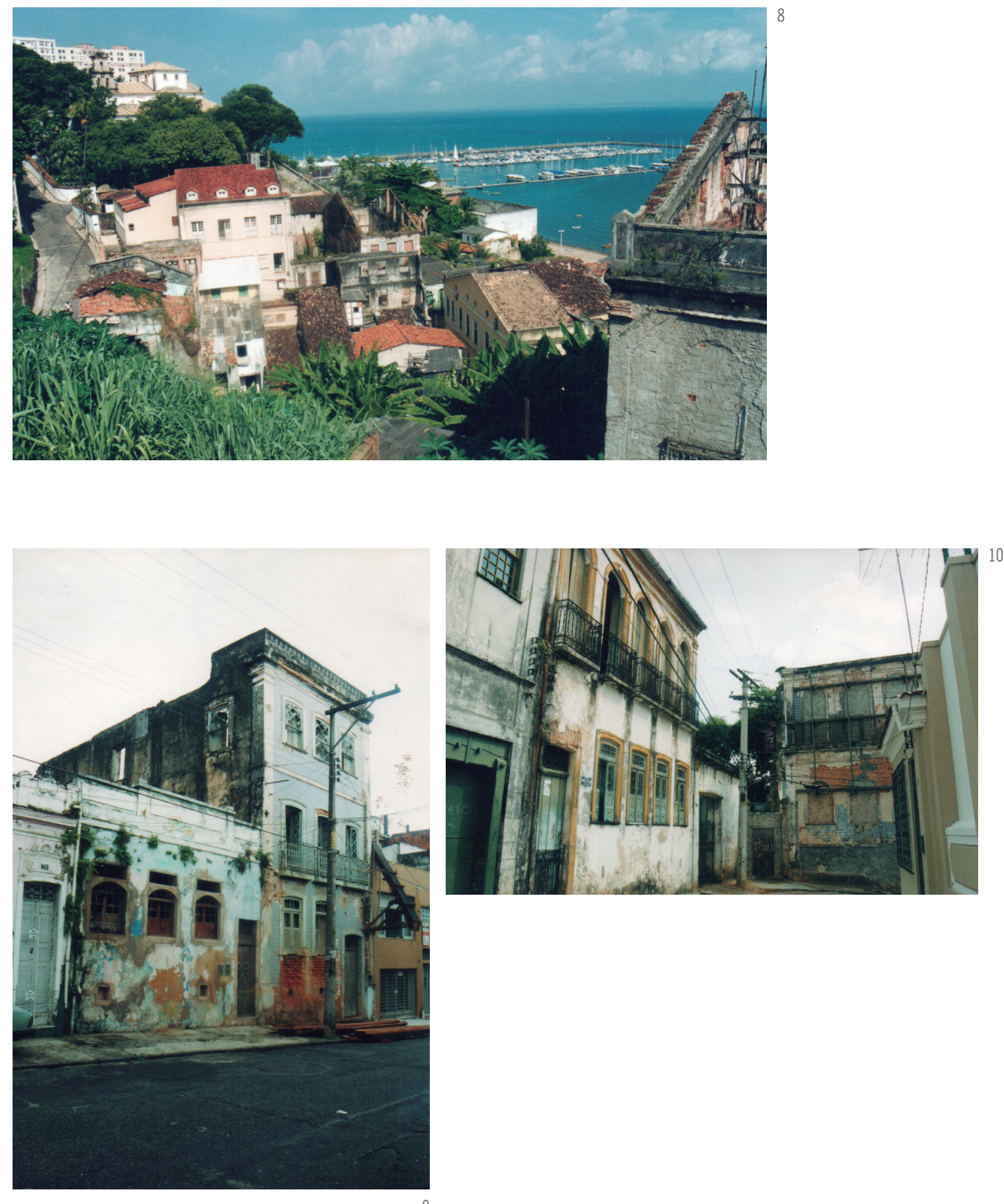

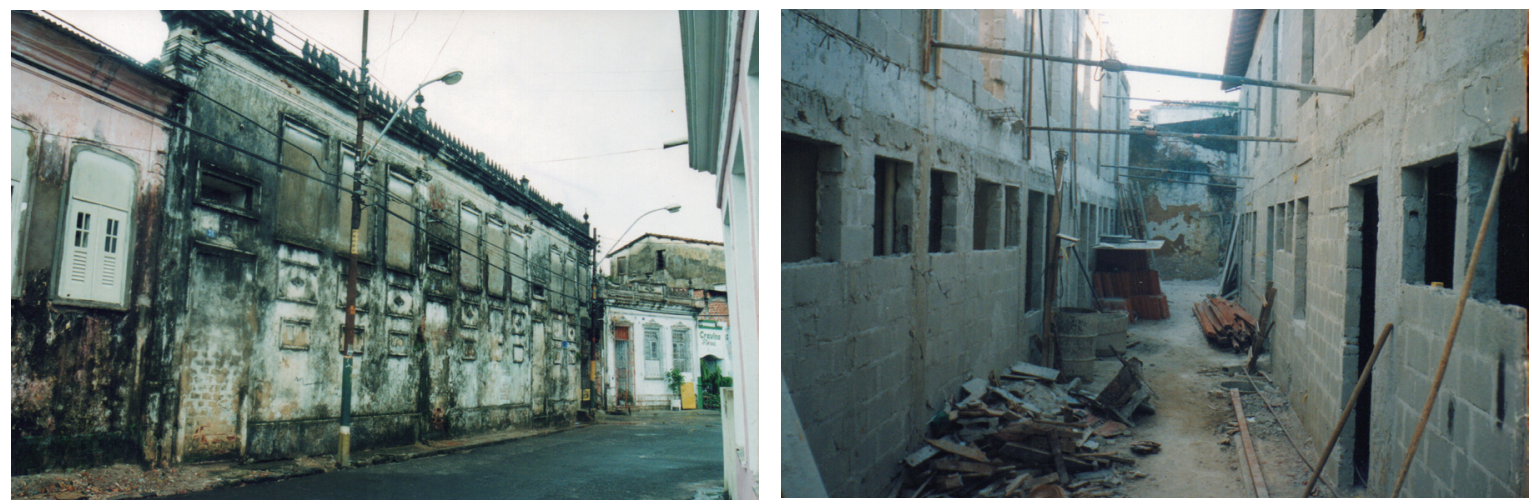

11

12

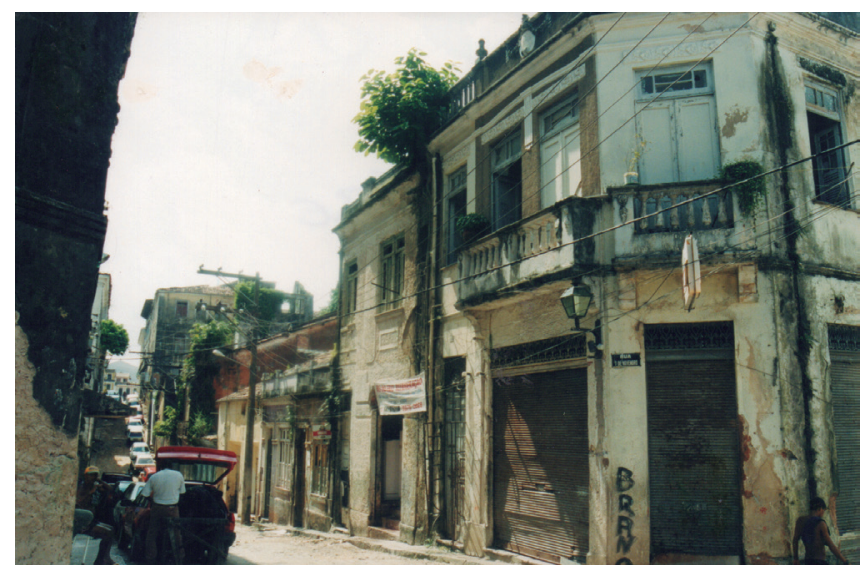

13

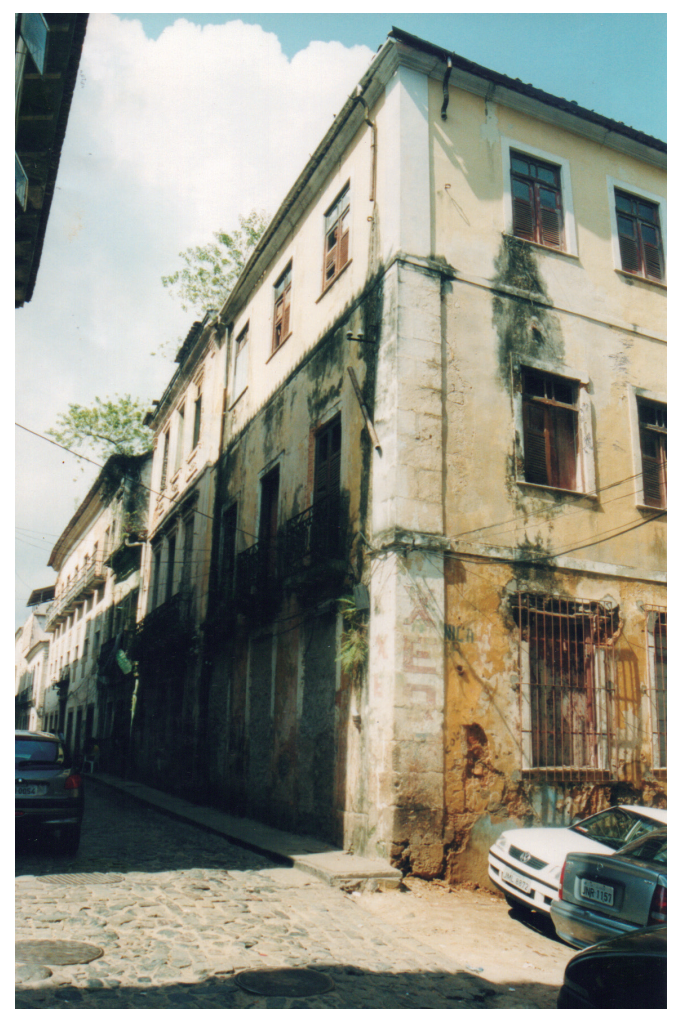



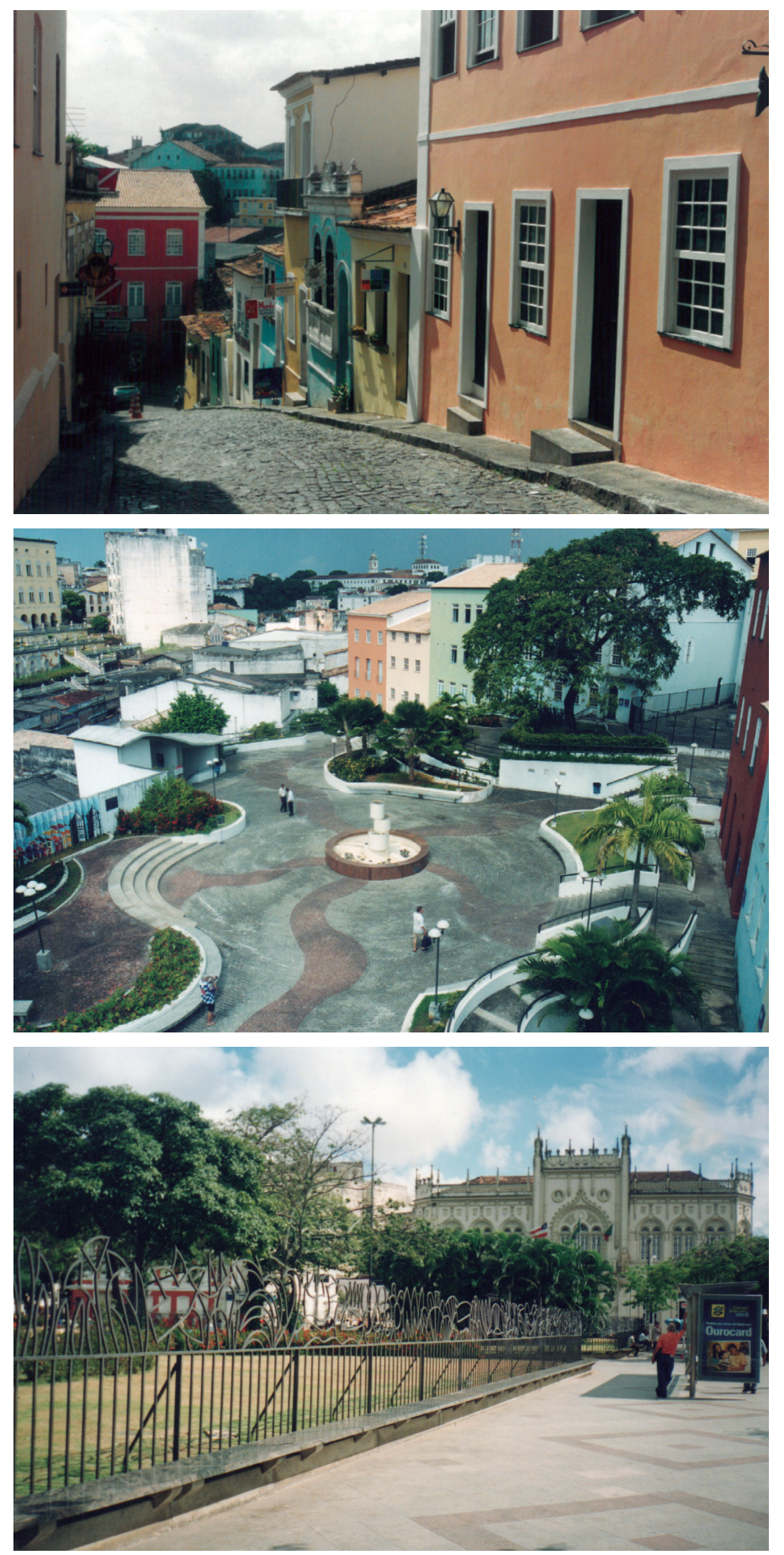

Salvador

Foto 11. Santo Antônio: casas geminadas na Rua Deraldo Dias, cujos lotes foram remembrados para a construção de habitações no âmbito do Projeto Rememorar.

Foto 12. Interior dos lotes remembrados à Rua Deraldo Dias: obra convencional e projeto que preservou apenas as fachadas principais e ignorou as relações de ocupação e parcelamento típicas do conjunto tombado.

Foto 13. Saldanha: a ênfase no uso habitacional na $7^{\mathrm{a}}$ etapa do Programa de Recuperação do Centro Histórico.

Foto 14. Saldanha: imóvel incluído na $7^{\text {a }}$ etapa do Programa de Recuperação do Centro Histórico.

Foto 15 . Cores vivas nas fachadas e conservação permanente para 0 enclave turístico e vitrine governamental.

Foto 16. Área comum no interior de quarteirão do Pelourinho.

Foto 17. Praça da Piedade: Iogradouro requalificado e gradeado em via de acesso ao Centro Histórico. 


\section{Salvador}

Foto 18. Santa Casa,

sede do "Portal da Misericórdia".

Foto 29. Convento do Carmo obras da nova Pousada.

Foto 20. Restaurante na Marina próxima ao Solar do Unhão ocupação de alto luxo na Avenida Contorno.

Fotos 21 e 22. A "gringolândia" na Rua Direita de Santo Antônio.
18

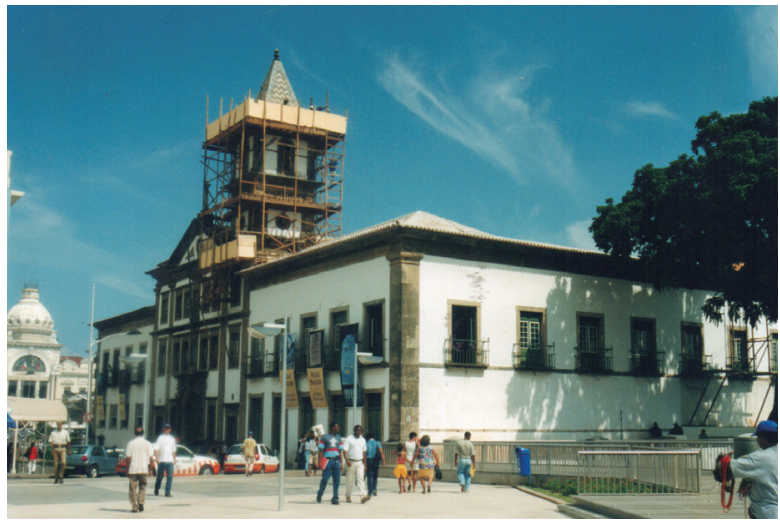

20

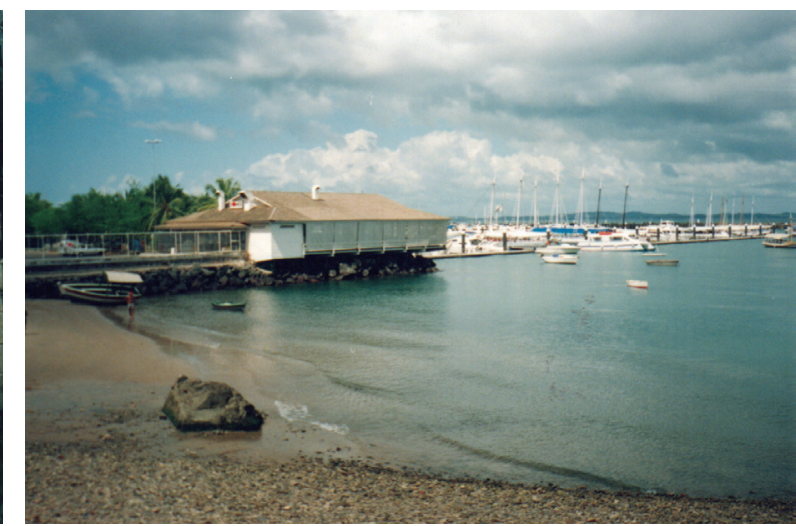

22
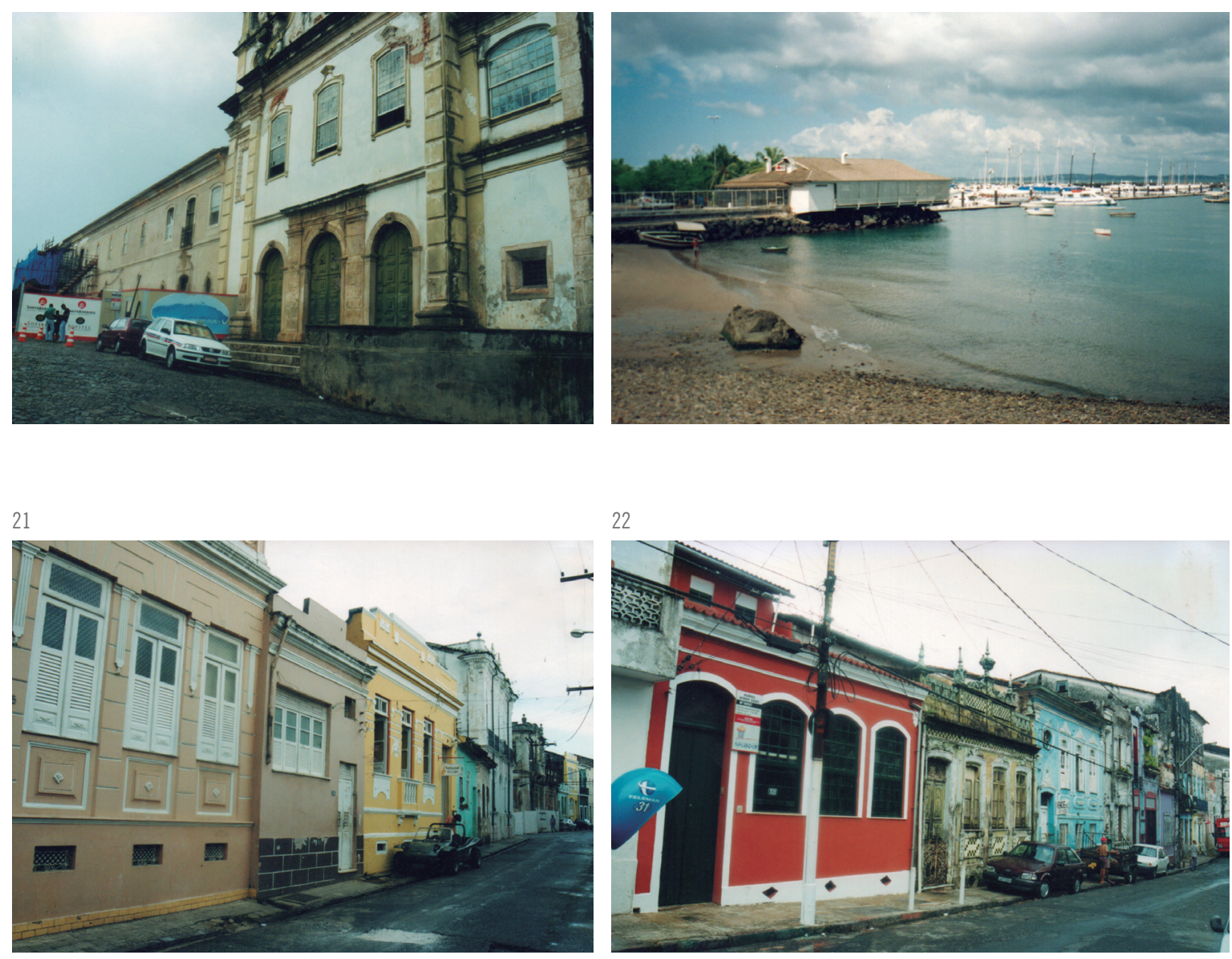


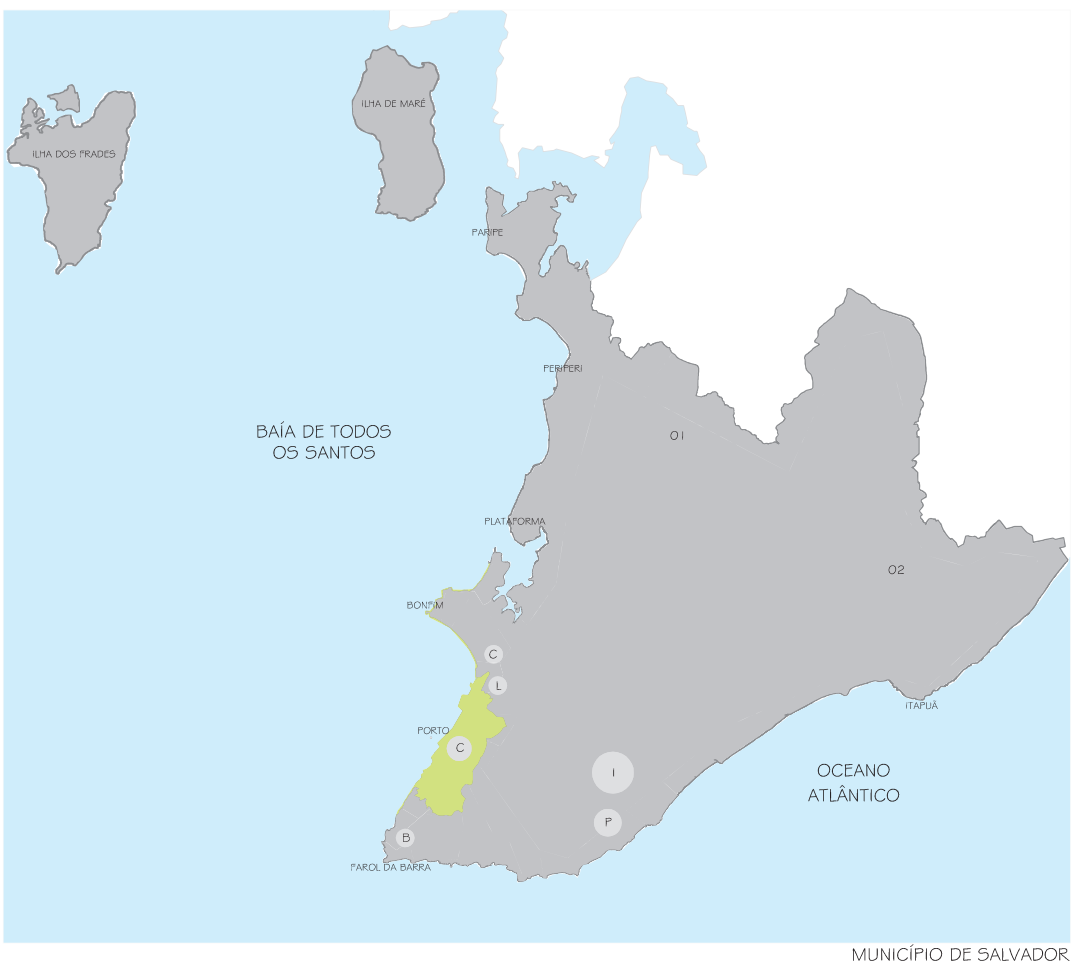

1 Salvador - Mapas

Mapa 1. Limite do município de Salvador e a área central. Fonte: CONDER - Elaborado por Marcia Sant'Anna, A Cidade Atração, tese de doutorado.

CENTROS DE ALCANCE METROPOLITANO

c - centro antigo

(1) - IgUatemi

SUBCENTROS

c - CALÇADA

L - liberdade

B - BARRA

P. PITUBA

PRINCIPAIS VETORES DE EXPANSÃOIDENSIFICAÇÃO

O) - BR 345

O2 - paralela/litoral nORTE

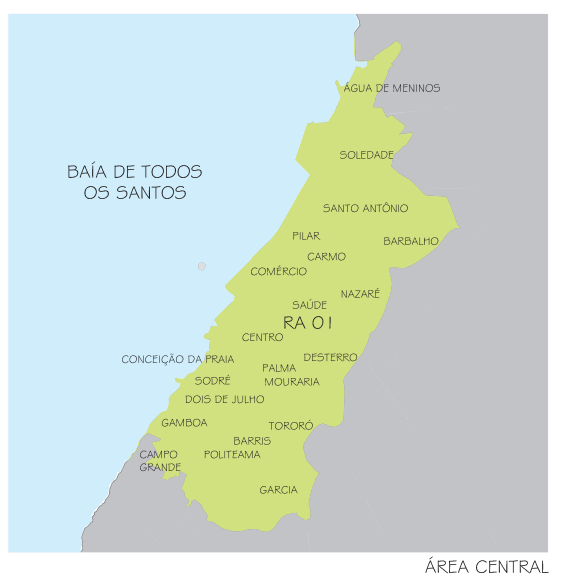

MUNICÍPIO DE SALVADOR

ÁREA CENTRAL

LIMITE DA RA OI 


\section{Salvador - Mapas}

Mapa 2. Limite da área central. Fonte: CONDER - Elaborado por Marcia Sant'Anna, A Cidade Atração, tese de doutorado.
2

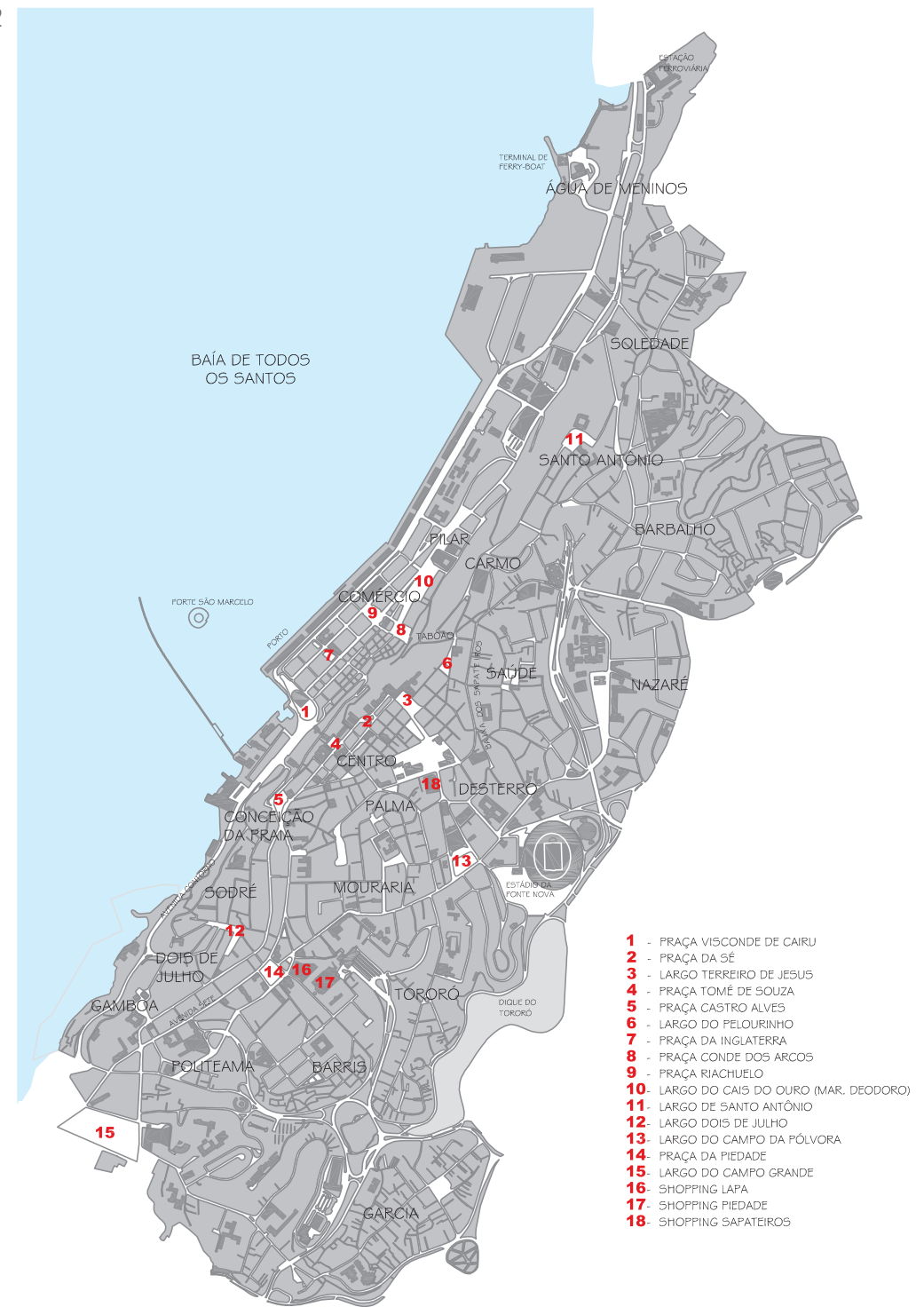




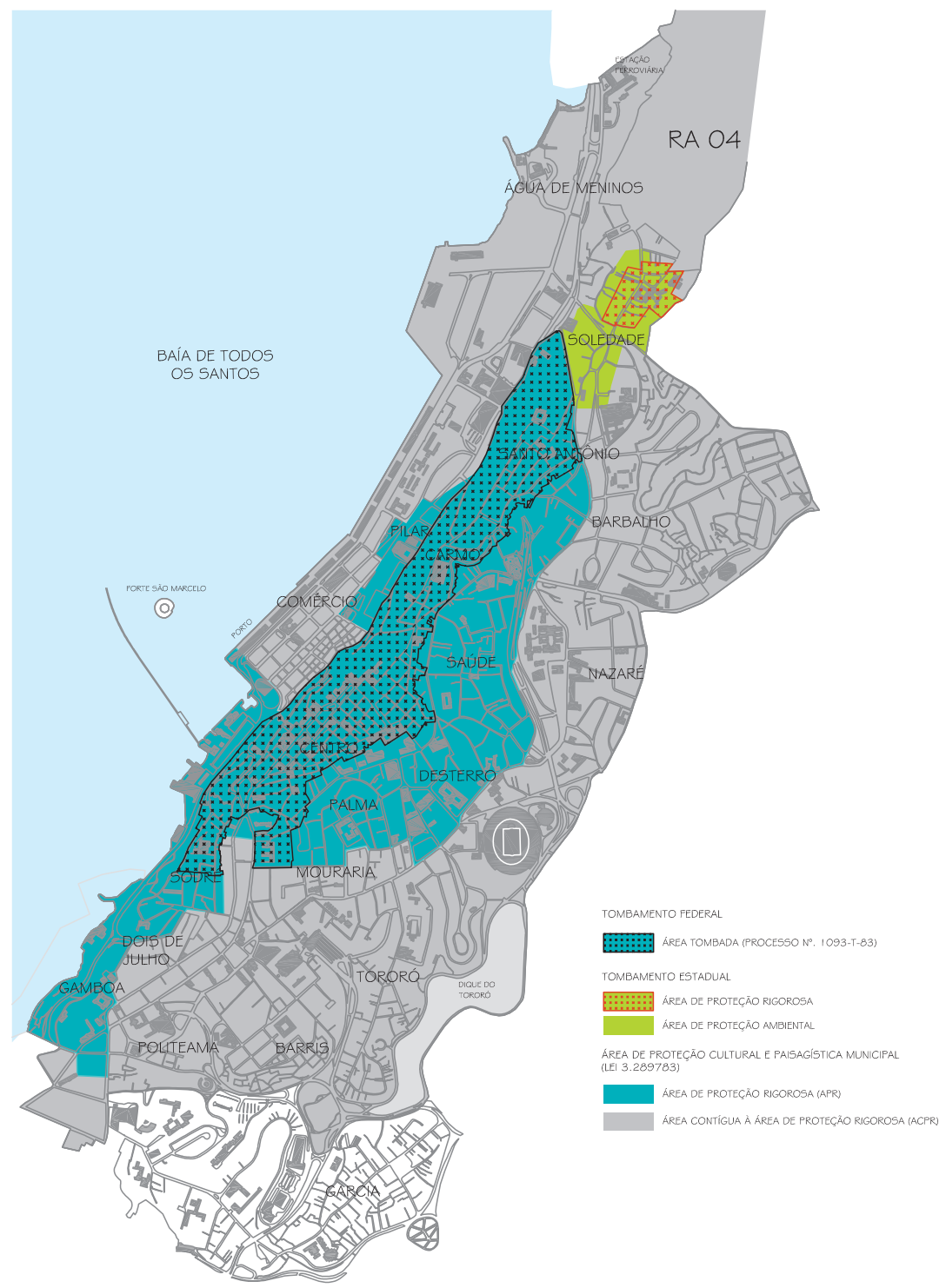

3 Salvador - Mapas

Mapa 3. Legislação específica na área central até 2004. Fonte: IPHAN/ IPAC/ SEPLAM-PMS/ CONDER - Elaborado por Marcia Sant'Anna, A Cidade Atração, tese de doutorado. 


\section{Salvador - Mapas}

Mapa 4. Programa de Recuperação do Centro Histórico.

Fonte: IPAC/ CONDER - Elaborado por Marcia Sant'Anna, A Cidade Atração, tese de doutorado.

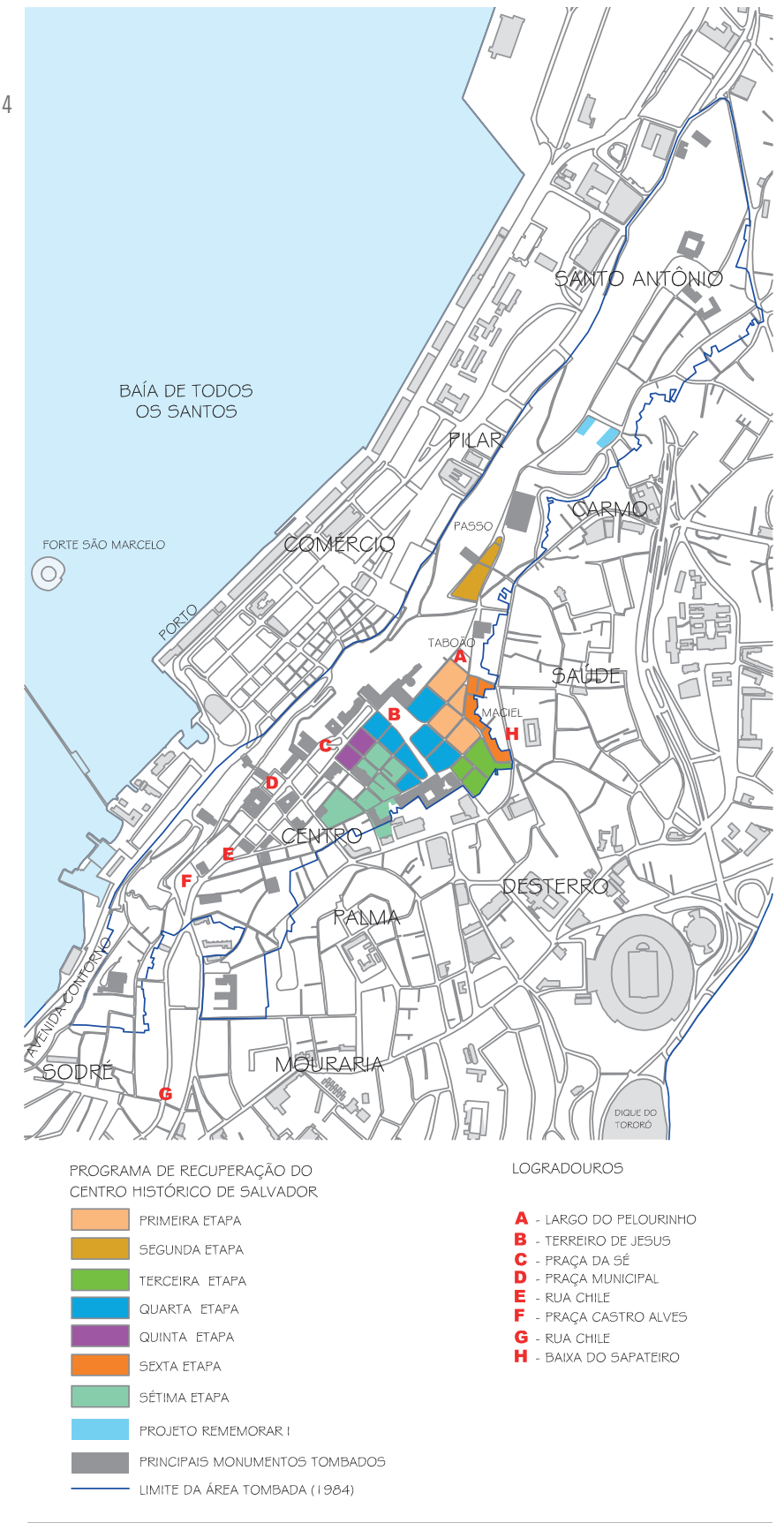

$\stackrel{N}{N}$ 


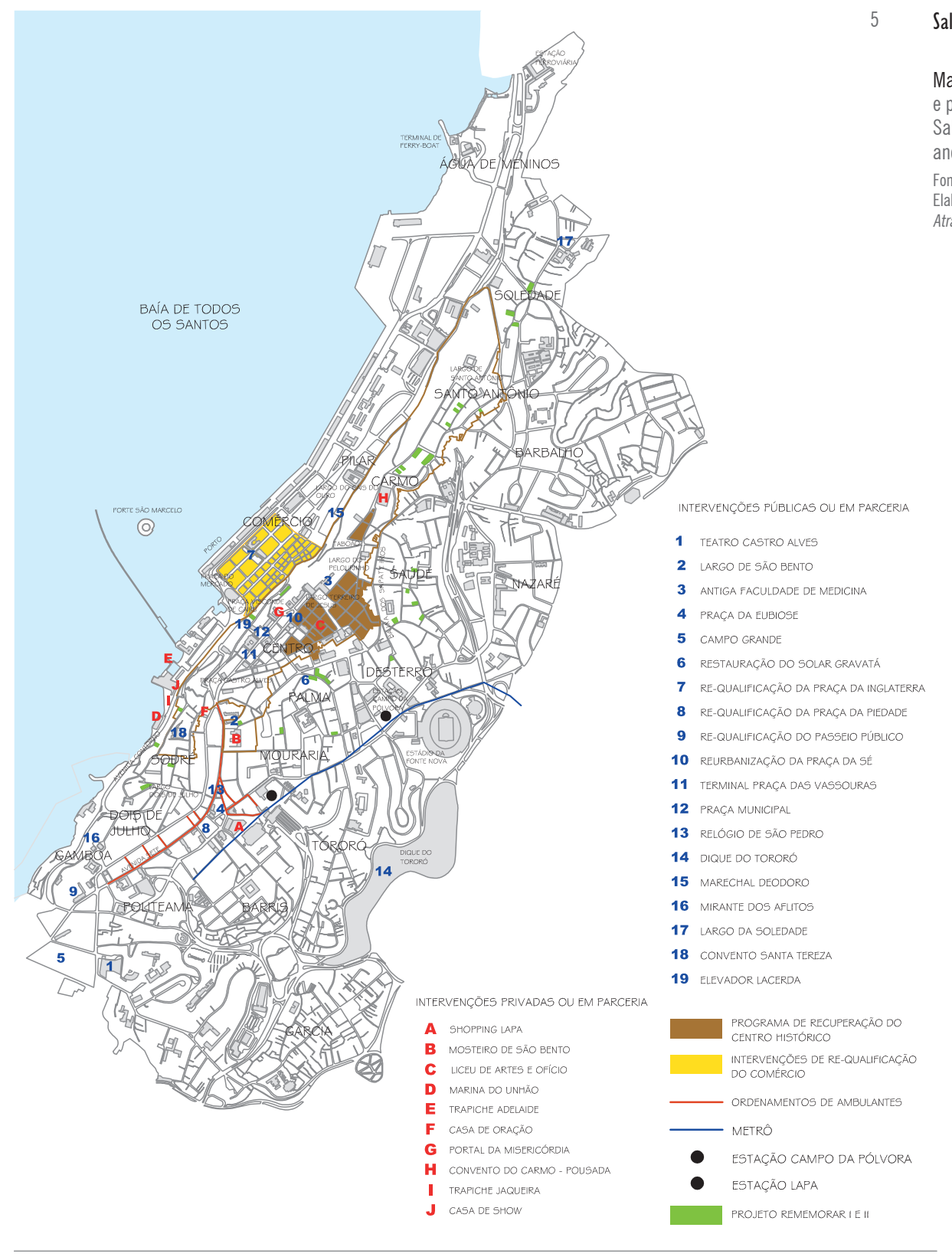

Mapa 5. Intervenções públicas e privadas na área central de Salvador (executadas e em andamento até 2004).

Fonte: SEPLAM-PMS, IPAC e CONDER Elaborado por Marcia Sant'Anna, A Cidade Atração, tese de doutorado. 

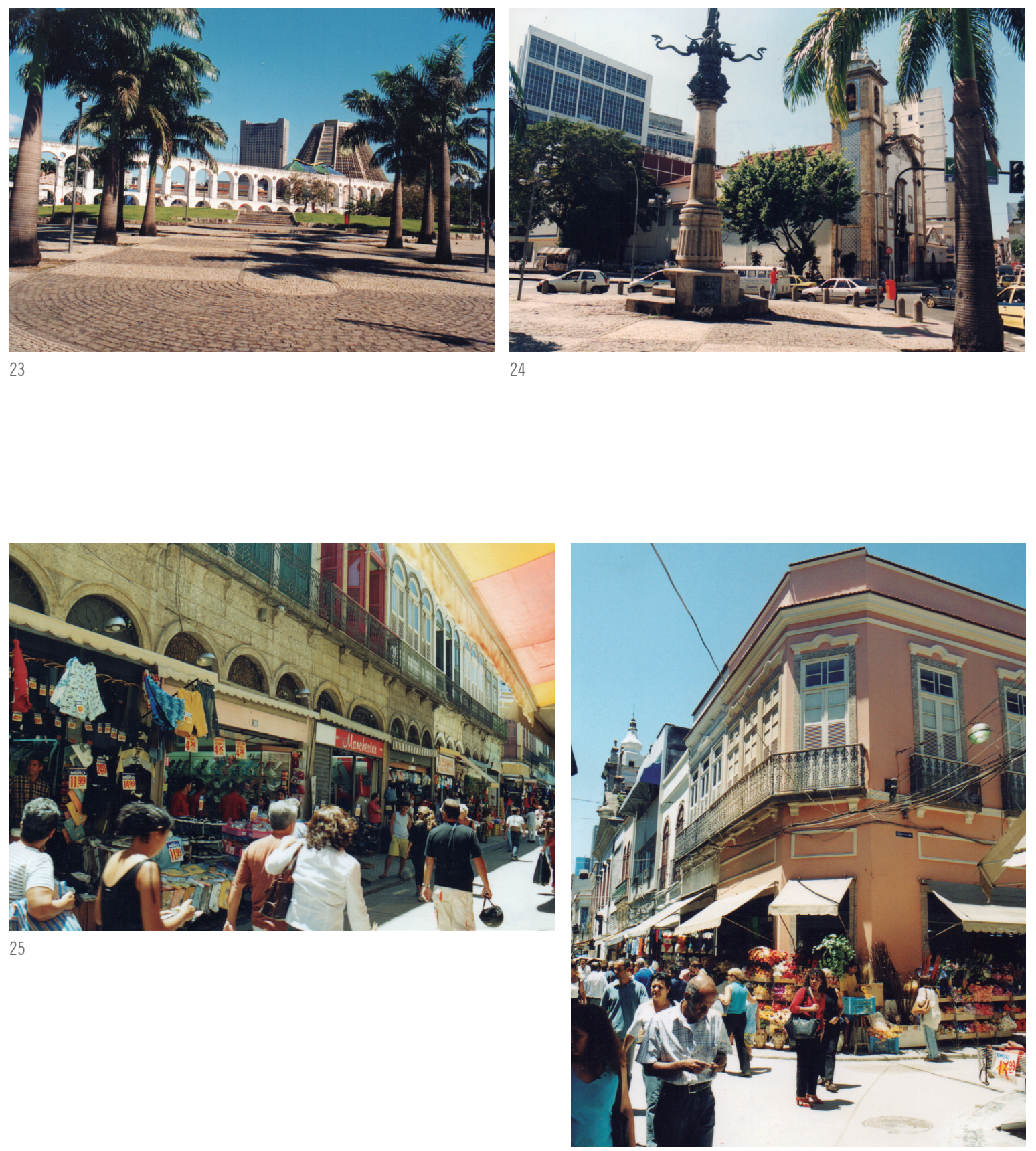

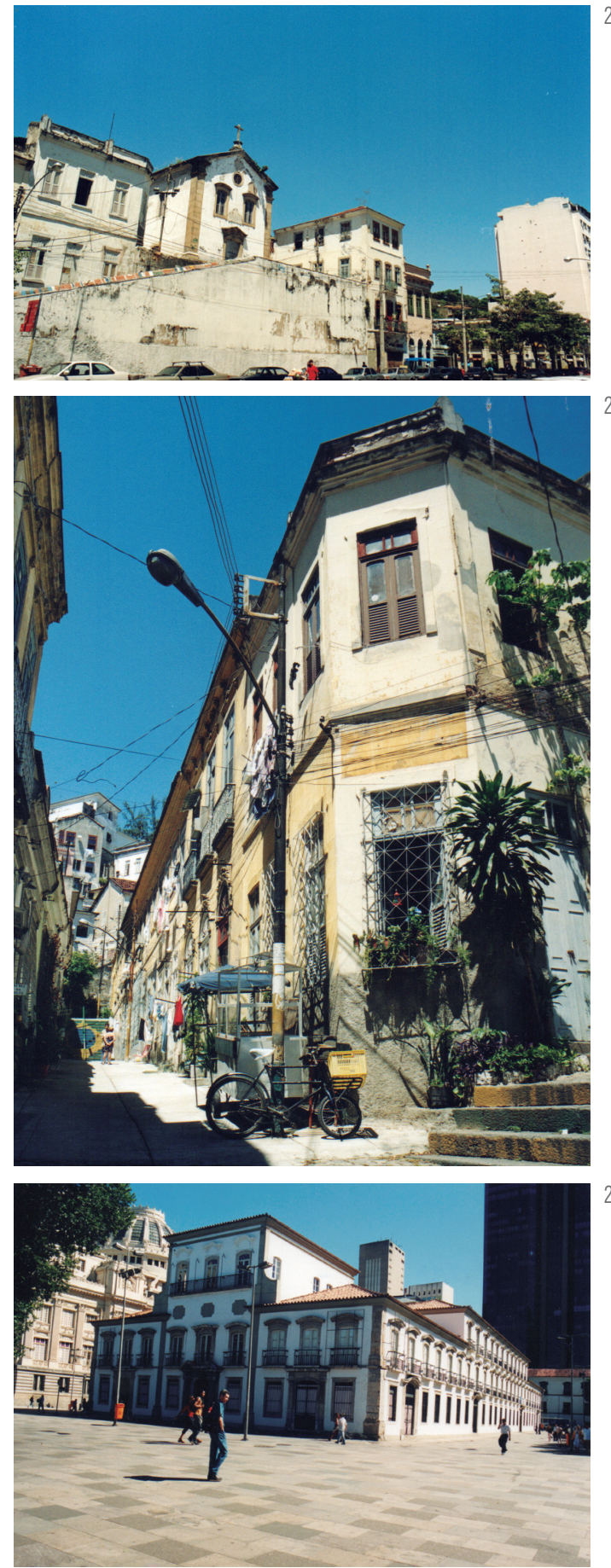

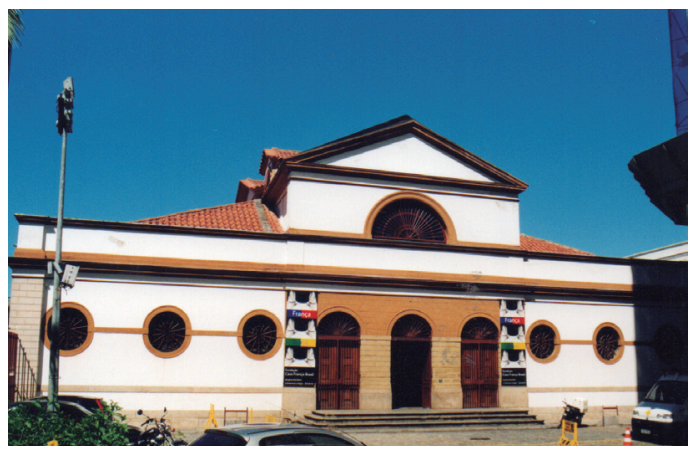

30

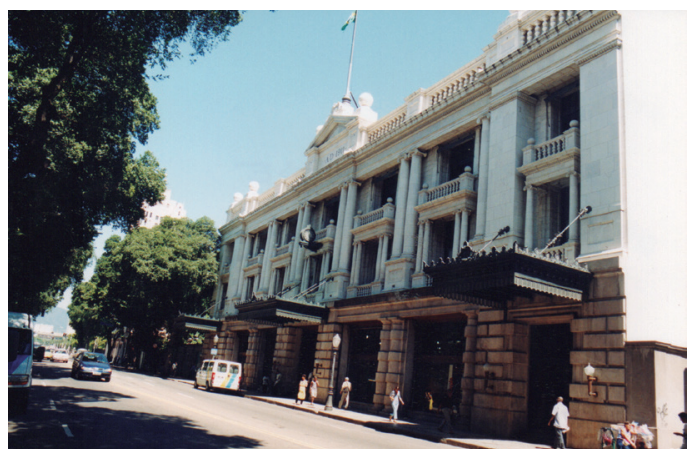

31

Rio de Janeiro

Foto 23. Arcos da Lapa ou

Aqueduto da Carioca. Ao fundo, edifícios modernos construídos na Esplanada de Santo Antônio.

Foto 24. Igreja da Lapa do Desterro: em primeiro plano, 0 Largo aberto para melhorar a circulação e desimpedir a vista da igreja. Ao fundo, o edifício modernista que substituiu 0 prédio do mosteiro.

Foto 25. Corredor Cultural: trecho da Rua da Alfândega no SAARA.

Foto 26. Corredor Cultural: trecho da Rua Senhor dos Passos no SAARA. Preservação e respeito à dinâmica de uso.
Foto 27. Imediações da Igreja de São Francisco da Prainha: trecho da área preservada que envolve os bairros da Saúde, Gamboa e Santo Cristo.

Foto 28. Morro da Conceição: setor incluído na área protegida.

Foto 39. Paço Imperial na Praça XV: 0 centro cultural do IPHAN inaugurado em 1989.

Foto 30. Casa França-Brasil. Foto 31. Centro Cultural da Light. 

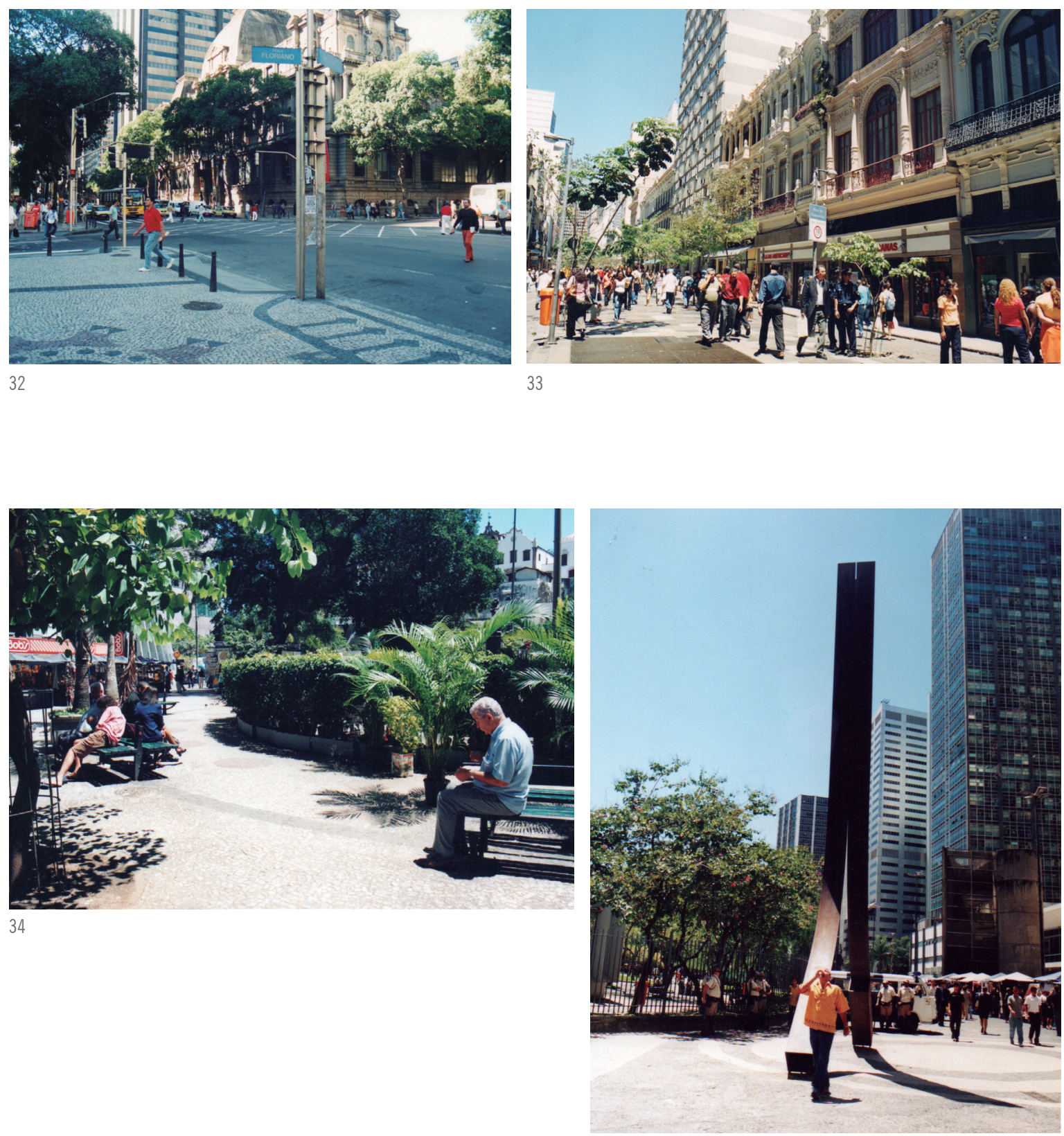
Rio de Janeiro

Foto 32. Projeto Rio-Cidade na Avenida Rio Branco: requalificação da principal artéria do centro.

Foto 33. Rua Uruguaiana: retomada de propostas iniciais do Corredor Cultural.

Foto 34. Largo da Carioca: quiosques de plantas e novo mobiliário.

Foto 35. Largo da Carioca: instalação de esculturas no espaço público.

Foto 36. Praça Mahatma Gandhi: requalificação, grades e construção de estacionamento subterrâneo.

Foto 37. Praça XV: shows e eventos no espaço público.

Foto 38. Praça da Cruz Vermelha: intervenção de requalificação na periferia do núcleo dinâmico do centro.

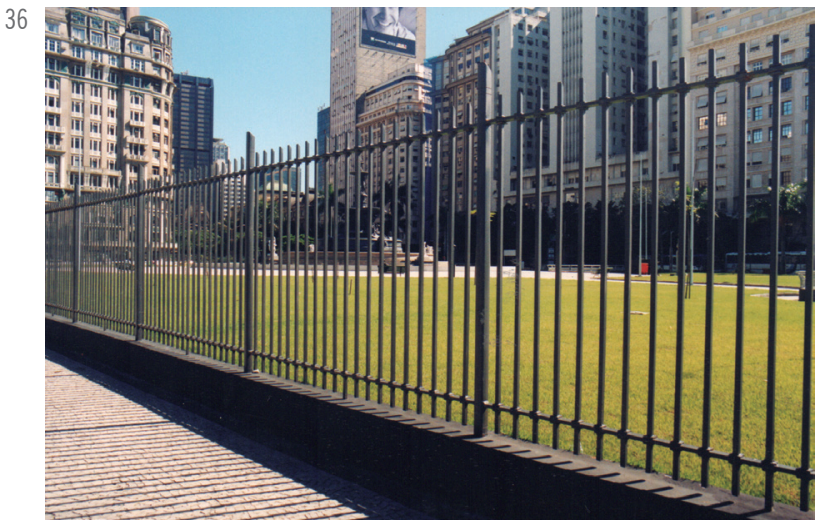

37

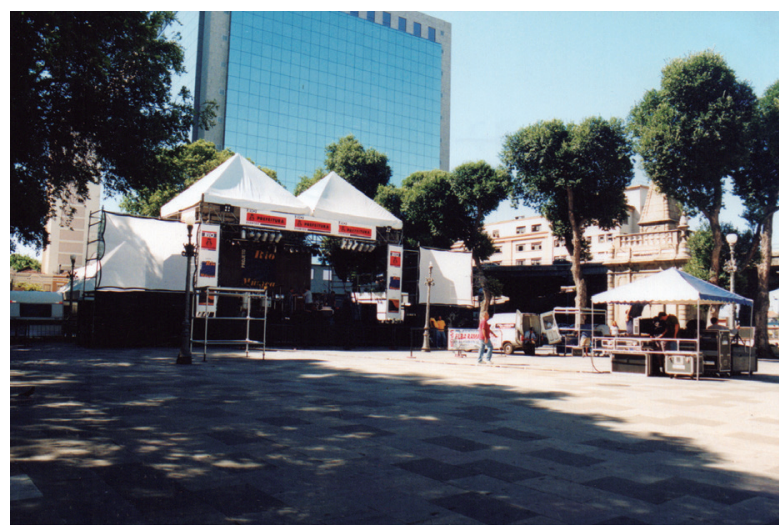

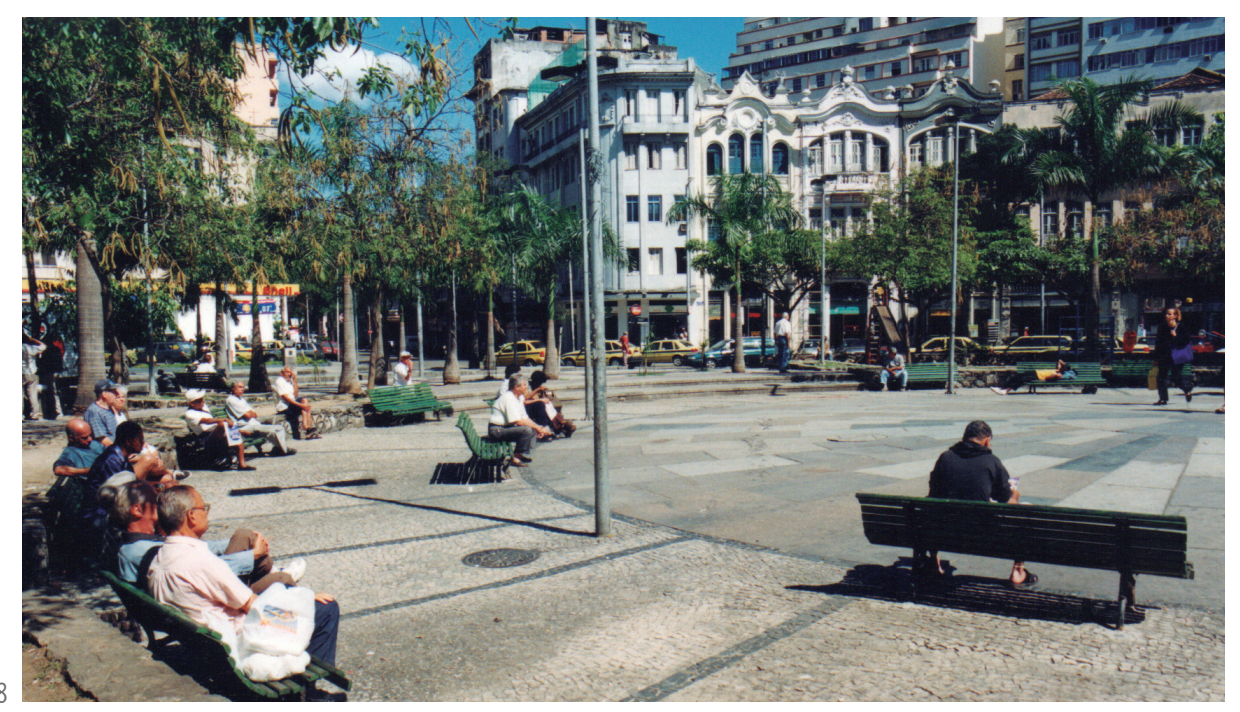




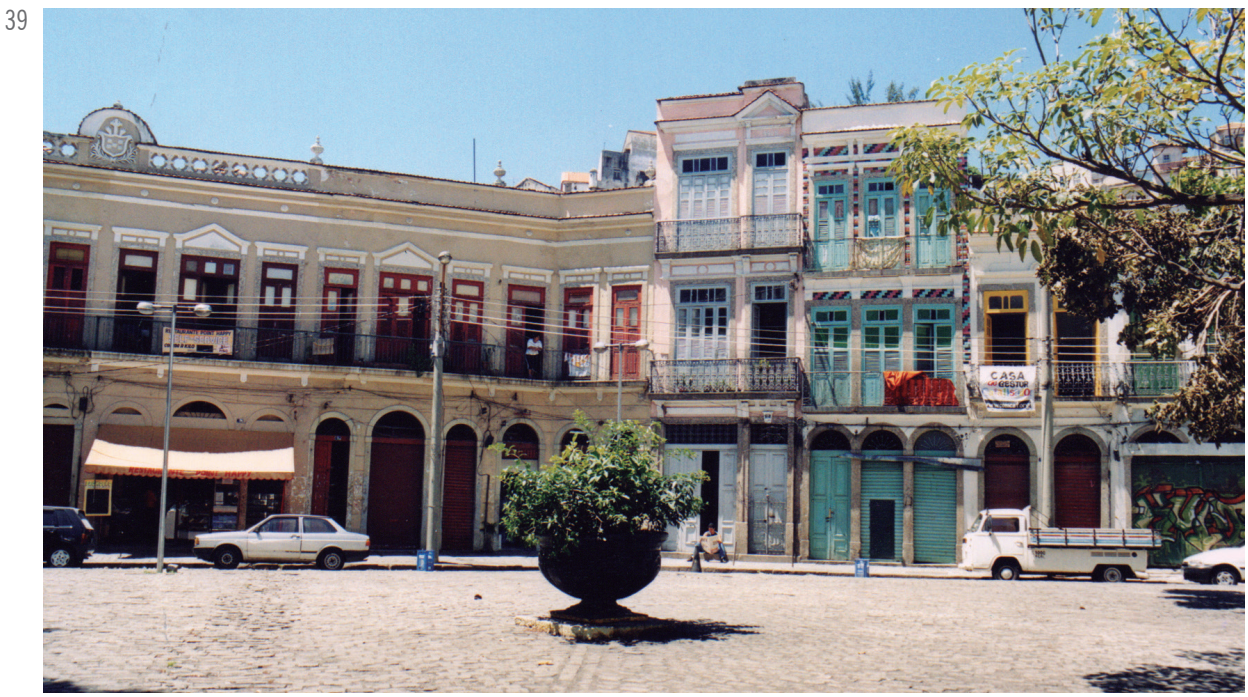

Rio de Janeiro

Foto 39. Largo de São Francisco da Prainha: intervenção de requalificação na área central.

Foto 40. Mercado Popular da Rua Uruguaiana: ordenamento do comércio informal.

Foto 41. Rua do Carmo: grades e controle da presença popular no setor financeiro do centro.

Foto 42. Bairro da Saúde: área focalizada pelo Programa Novas Alternativas.

Foto 43. Empreendimento habitacional do Programa Novas Alternativas construído em vazio urbano próximo à Igreja da Saúde.

Foto 44. Morro da Conceição: imediações da Fortaleza da Conceição, bem tombado pelo Governo Federal.

40

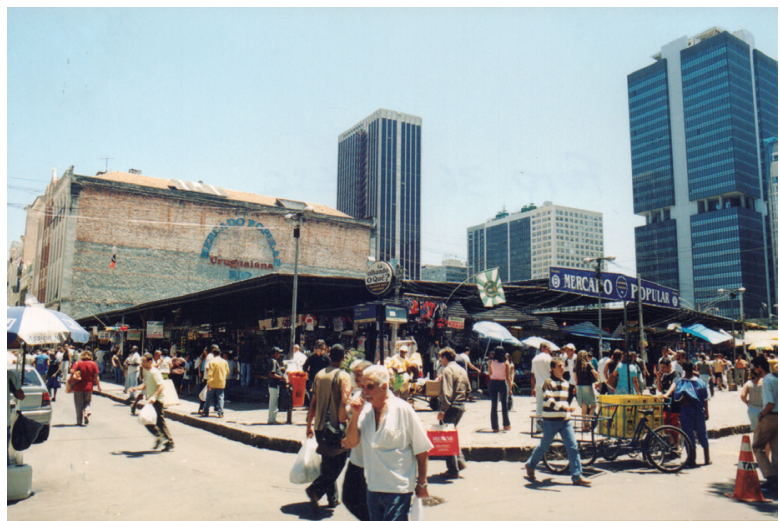

41

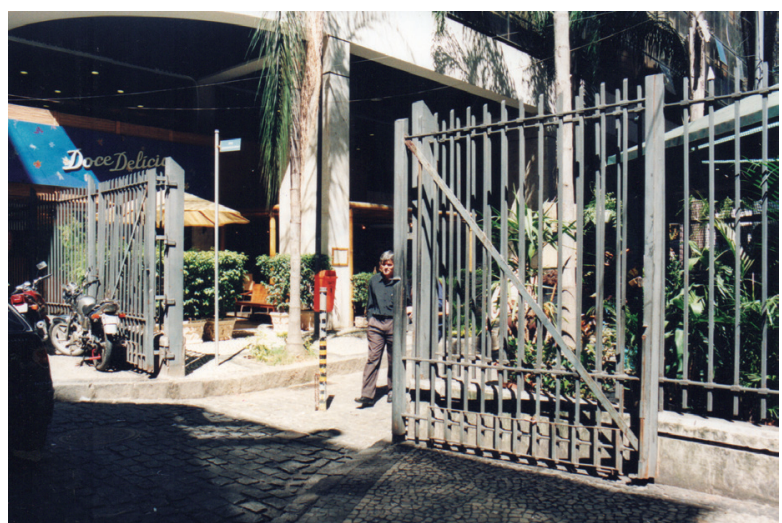



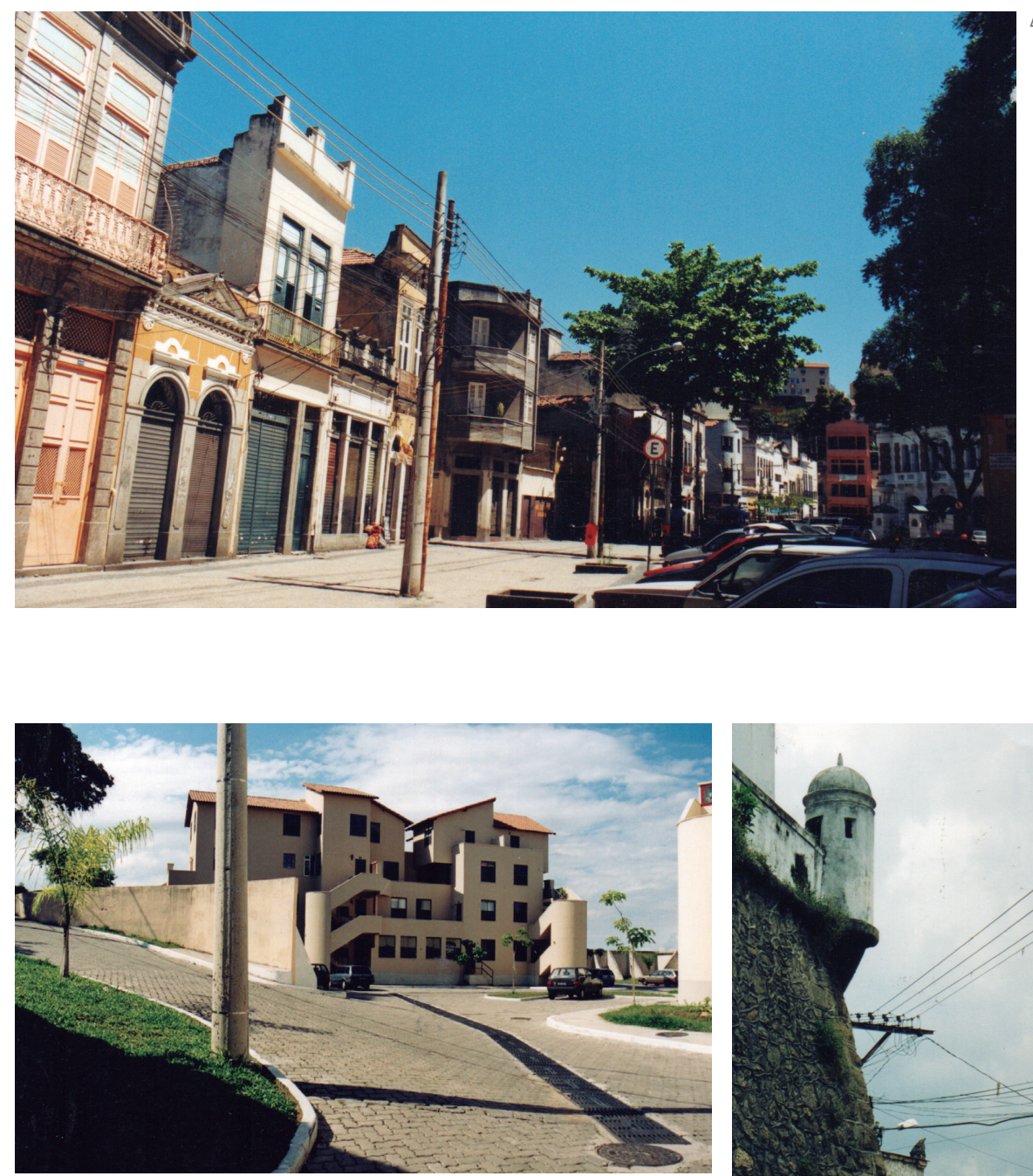

43

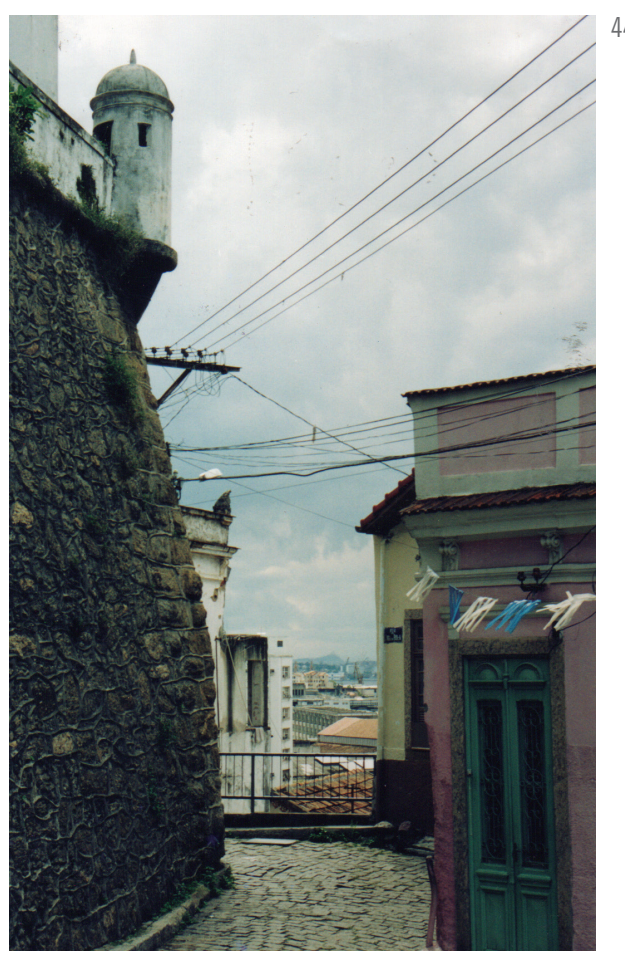



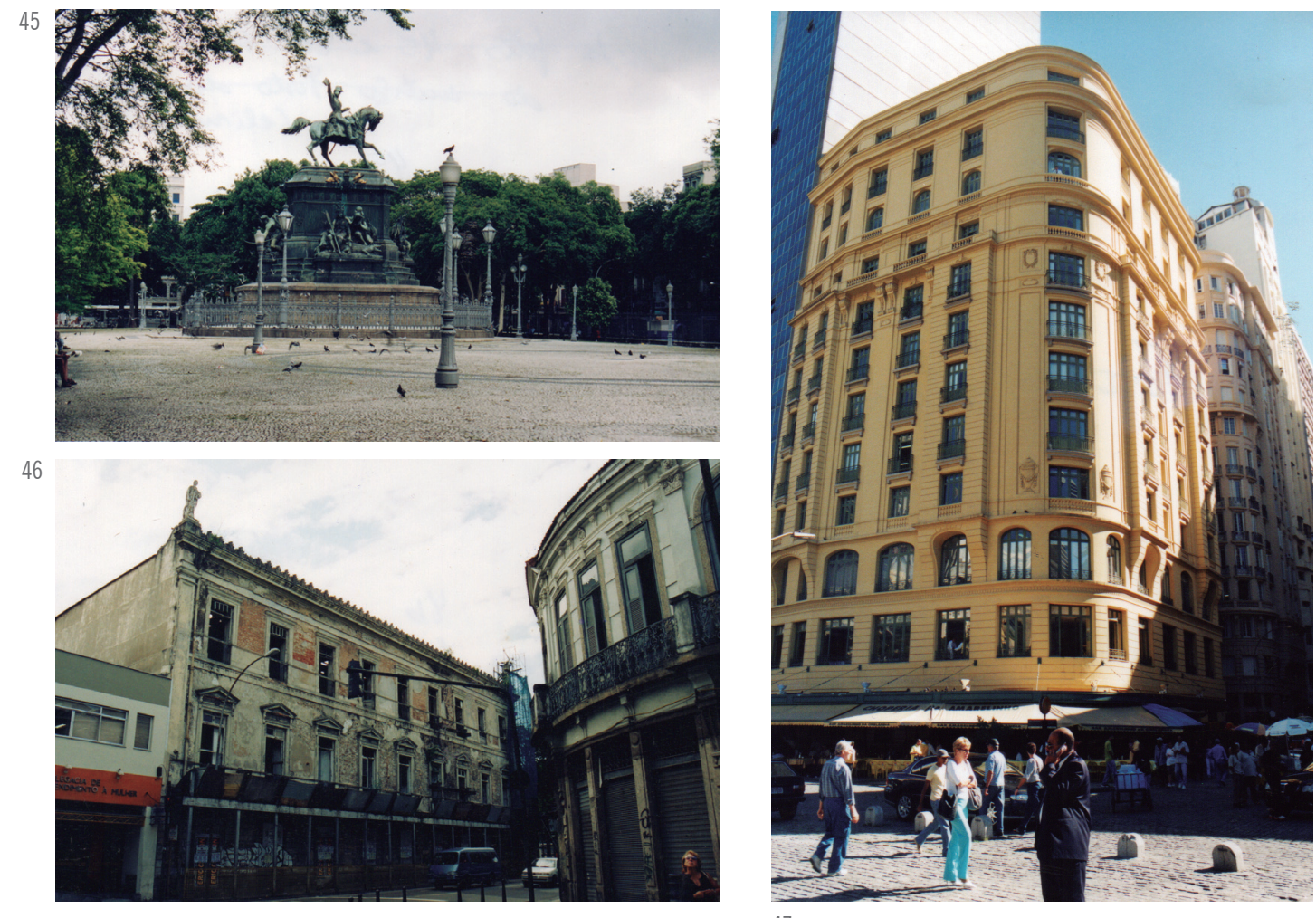

4

\section{Rio de Janeiro}

Foto 45. Praça Tiradentes: conjunto escultórico tombado pelo IPHAN.

Foto 46. Solar do Visconde do Rio Seco.

Foto 47. Cinelândia: prédio do Amarelinho, reciclagem e preservação da fachada. Foto 48. Rua de pedestres no centro do Rio: ambientação de shopping center.
48

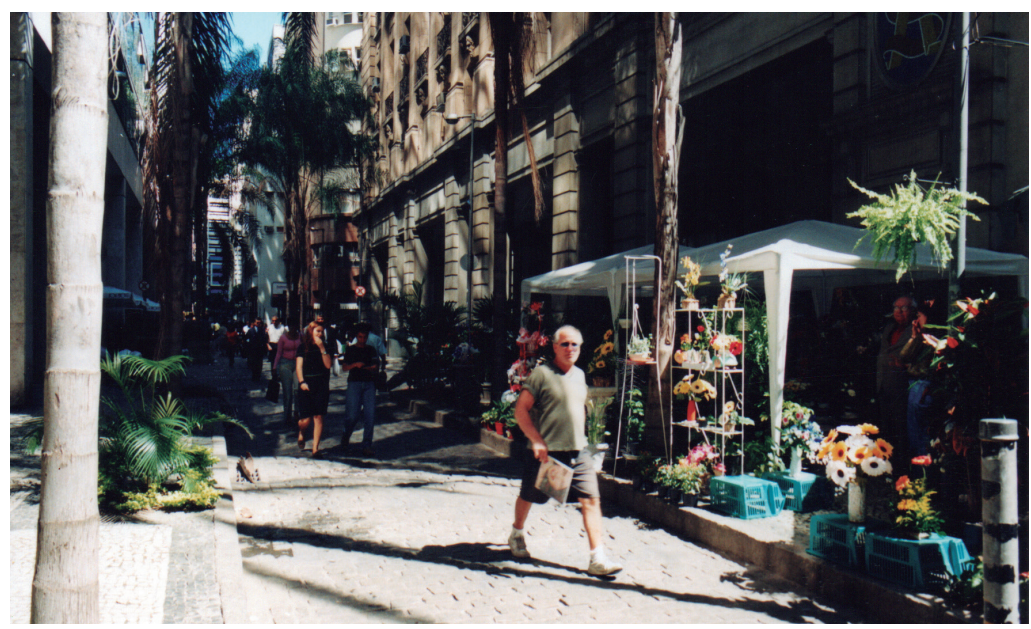




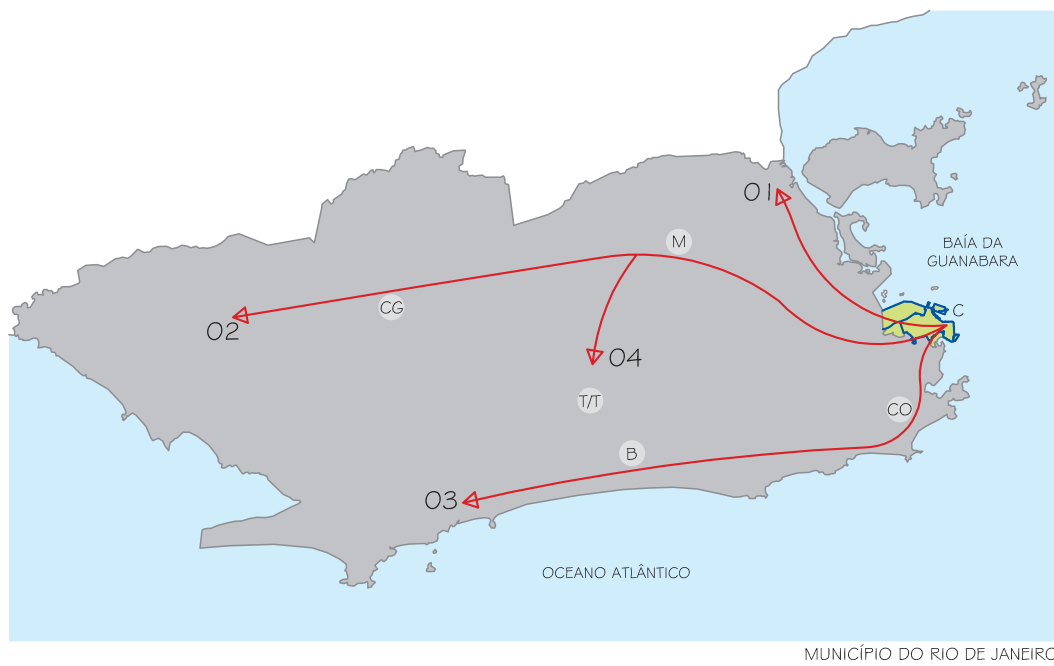

$6 \quad$ Rio de Janeiro - Mapas

Mapa 6. Limite do município do Rio de Janeiro e a área central. Fonte: SMU - IPP - Elaborado por Marcia Sant'Anna, A Cidade Atração, tese de doutorado.

PRINCIPAIS VETORES DE EXPANSÃO

O1 - DUQUE DE CAXIAS (ZONA NORTE)

O2 - santa CRUZ (ZONA OESTE)

O3 - BARRARECREIO*

O4 - JACAREPAGUÁ

- Vetor de EXPANSÁo Do CENTRO

CENTROS DE ALCANCE METROPOLITANO (PDD/92)

CG - CAMPO GRANDE

TIT - tanquettaquara

CO - COPACABANA

M - MADUREIRA

C - CENTRO

B - BARRA DA TIJUCA

- Centro de AlCANCE MUNICIPAL, SEGUNDO PDD/92

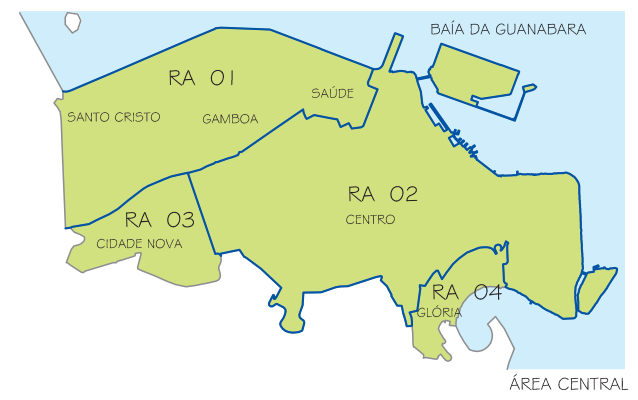

MUNICÍPIO DO RIO DE JANEIRO

ÁREA CENTRAL

LIMITE DE RA

LIMITE DO MUNICÍPIO DO RIO DE JANEIRO 
7

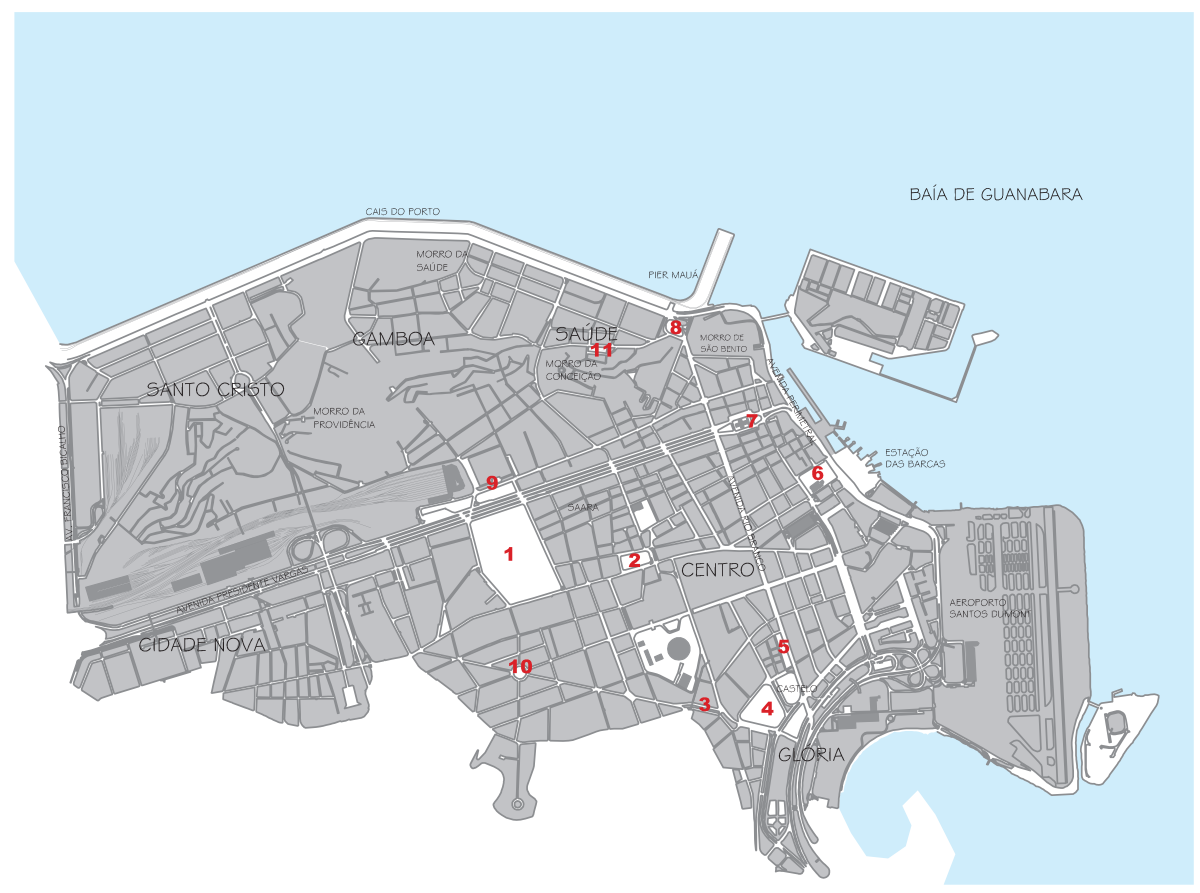

$\mathbf{1}$ - CAMPO DE SANTANA
$\mathbf{2}$ - PRAÇA TIRADENTES
$\mathbf{3}$ - ARCOS DA LAPA
$\mathbf{4}$ - PASSEIO PÚBLICO
$\mathbf{5}$ - CINELANNIA
$\mathbf{6}$ - PRAÇA XV

7 - CANDELÁRIA

8 - PRAÇA MAUÁ

9 - CENTRAL DO BRAsil

10. PRAÇA DA CRUZ VERMELLHA

11. LARGO DE SÃO FRANCISCO DA PRAINHA

\section{Rio de Janeiro - Mapas}

Mapa 7. Limite da área central. Fonte: SMU - IPP - Elaborado por Marcia Sant'Anna, A Cidade Atração, tese de doutorado. 


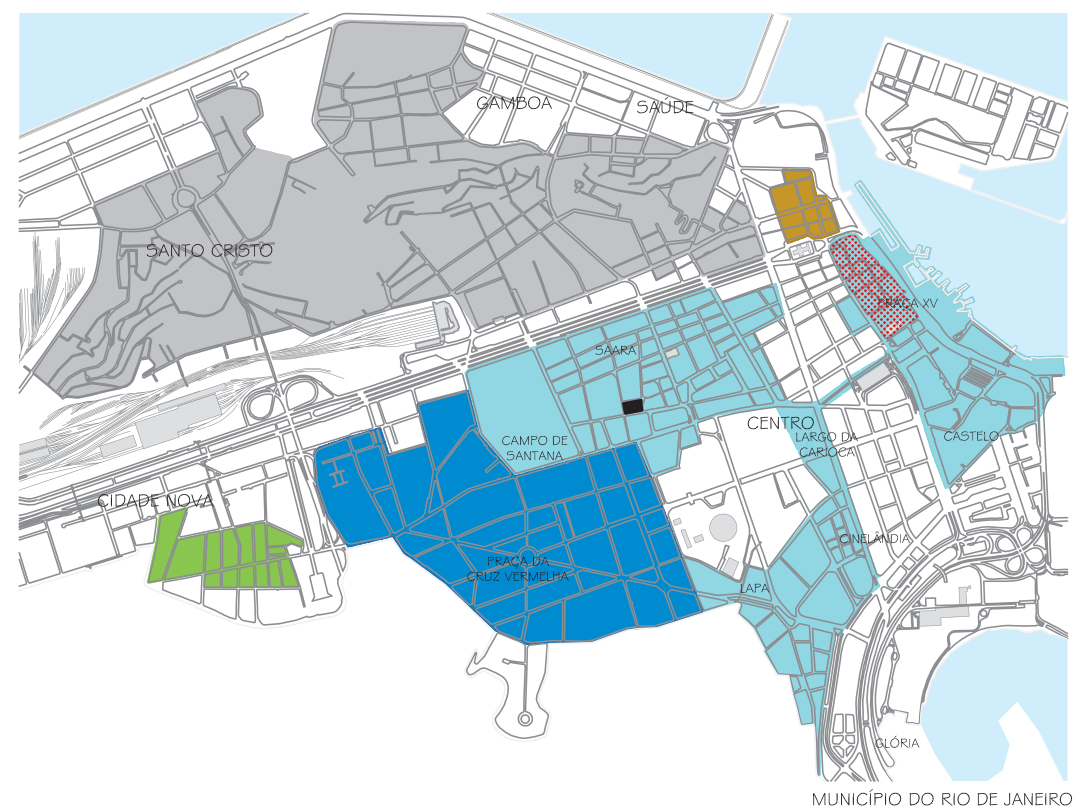

CORREDOR CULTURAL

CONJUNTO TOMBADO DA PRACAXV

(PROCESSO N. $1.213-$ T- $^{\circ} 8$ )

APAC SAGAS

(SAÚDE, GAMBOA E SANTO CRISTO)

APAC TEÓFILO OTON

APAC CIDADE NOVA

APAC CRUZ VERMELHA

QUADRA TOMBADA ENTRE AS RUAS DA CONSTITUIÇÃO E LUIS DE CAMÖES (PROCESSO No. 986-T-78)

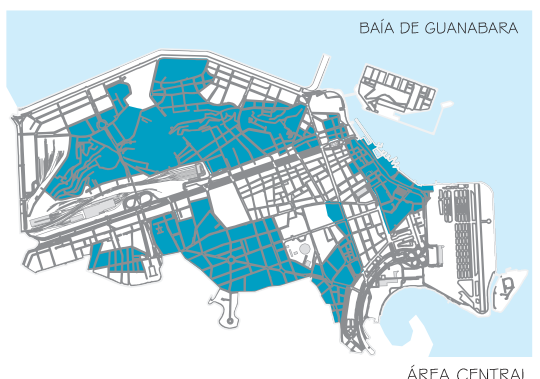

N

Rio de Janeiro - Mapas

Mapa 8. Setores protegidos na área central.

Fonte: SMU, DGPC - SMC - Elaborado por Marcia Sant'Anna, A Cidade Atração, tese de doutorado. 


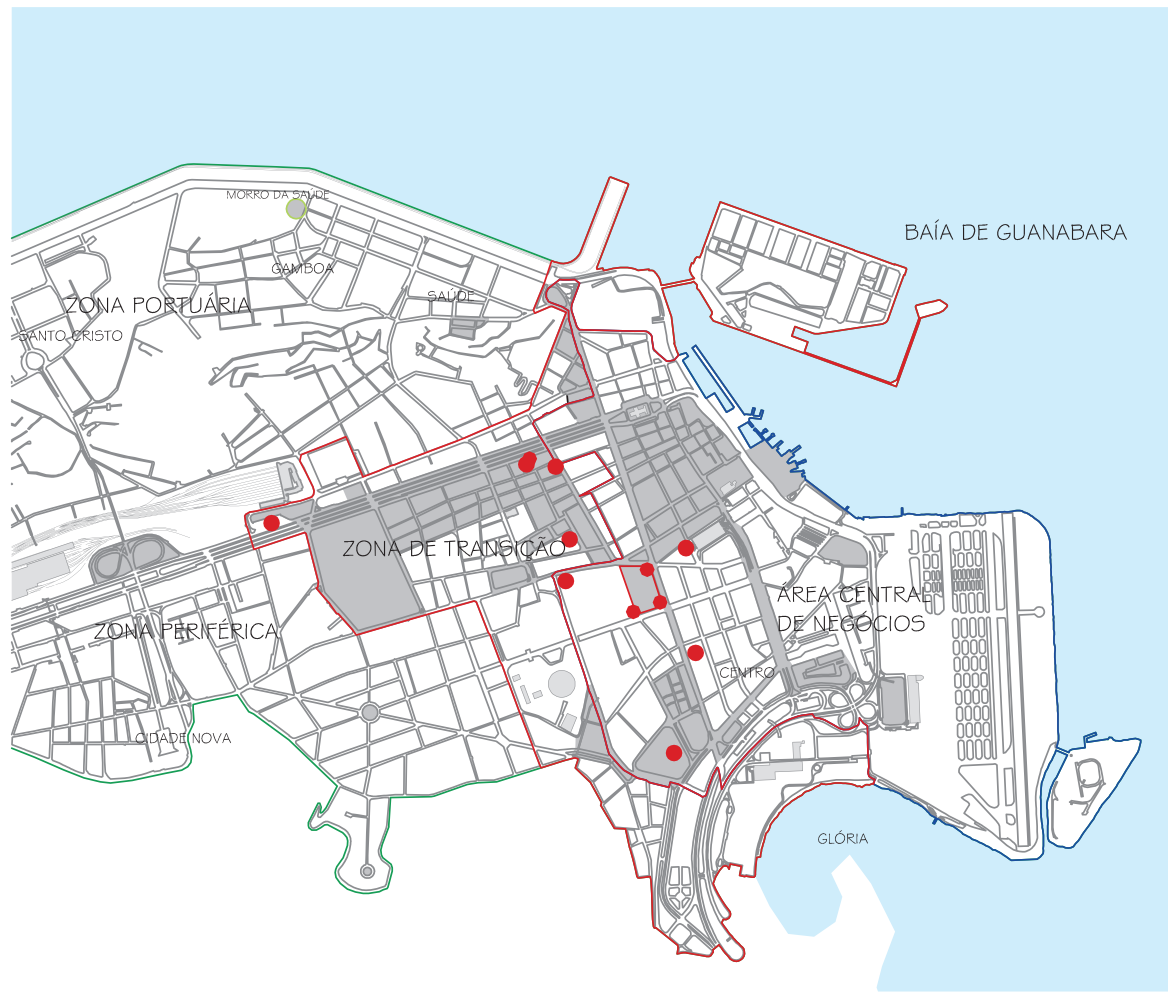

INTERVENÇÕES FISICAS

assentamentos de comércio informal

ÁREA CENTRAL DE NEGÓCIOS

ZONA DE TRANSIÇÃO

ZONA PERIFÉRICA E PORTUÁRIA

\section{Rio de Janeiro - Mapas}

Mapa 9. Intervenções dos anos 90.

Fonte: Iplanrio, Blyth (1991), Rio de Janeiro (1998), Magalhães (2001) -

Elaborado por Marcia Sant'Anna,

A Cidade Atração, tese de doutorado. 


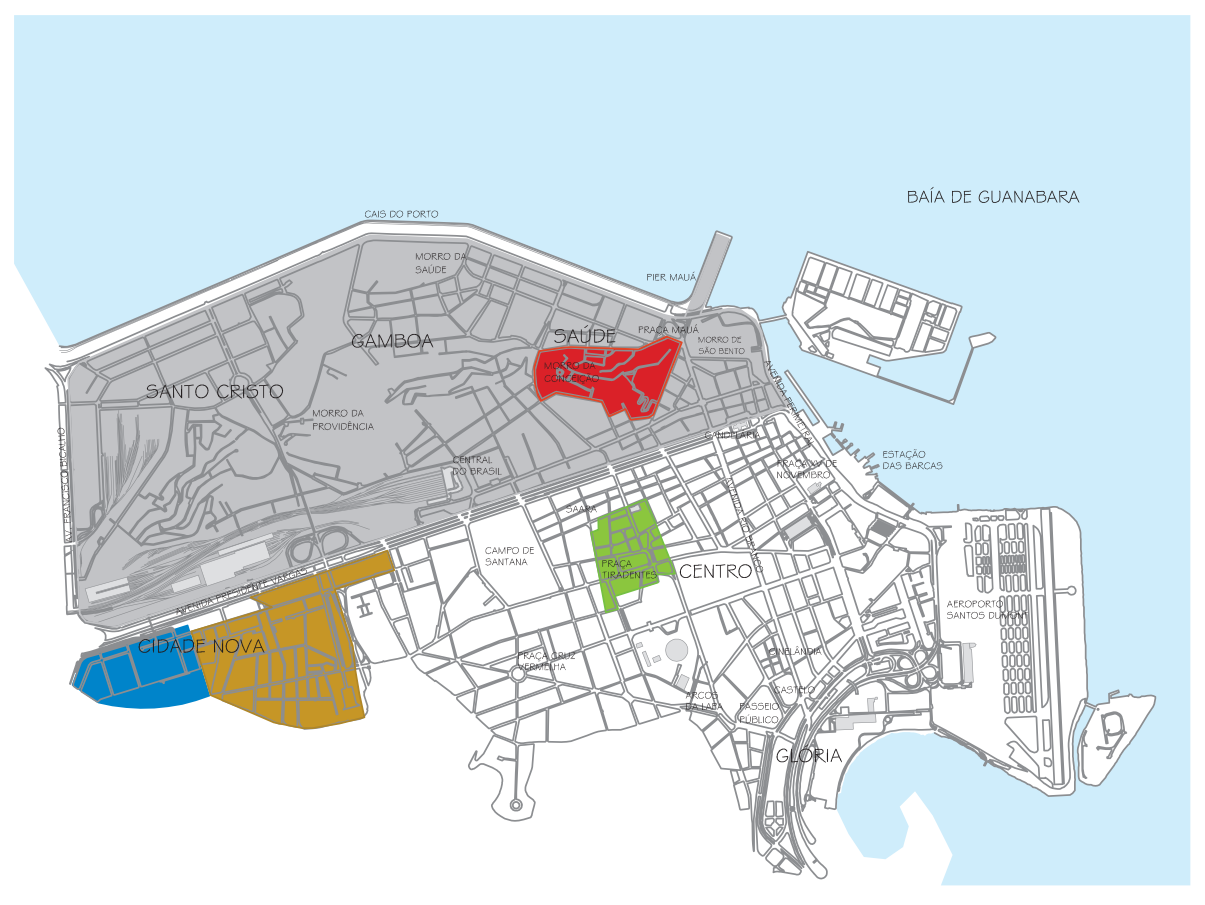

PROJETO MORRO DA CONCEIÇÃO

PROJETO TELEPORTO

PROJETO SÁS

PROJETO TIRADENTES

PROJETO PORTO DO RIO

Rio de Janeiro - Mapas

Mapa 10. Intervenções em andamento na área central até 2004.

Fonte: SMU/ IPP - Elaborado por

Marcia Sant'Anna, A Cidade Atração, tese de doutorado. 
49

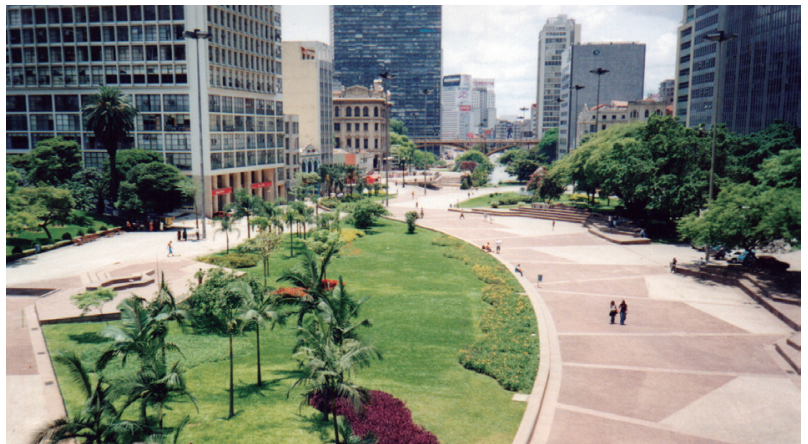

50

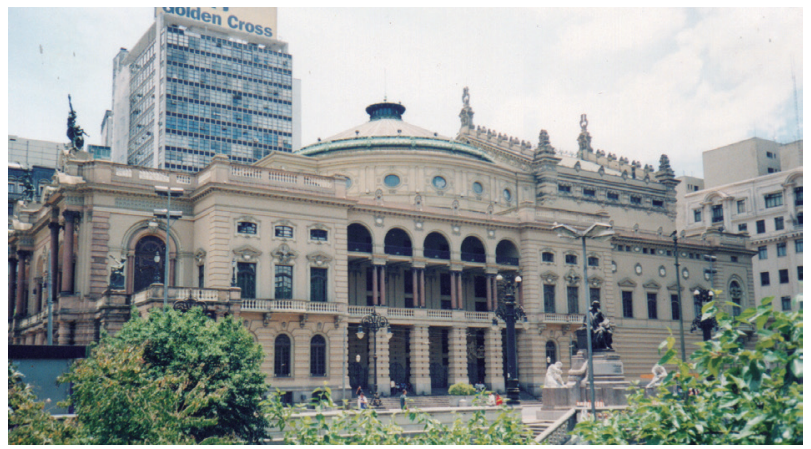

51

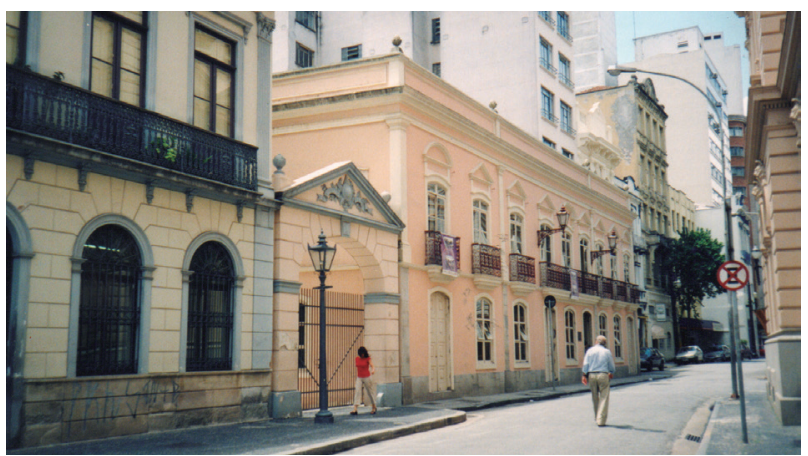

52

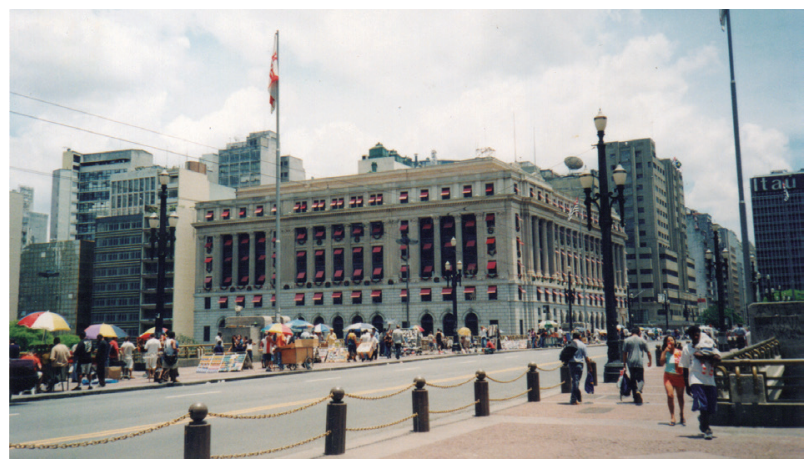

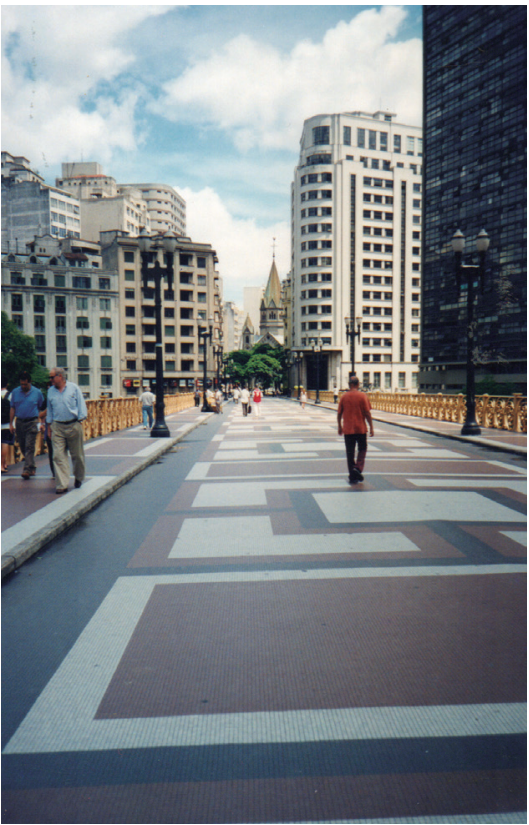

53

54

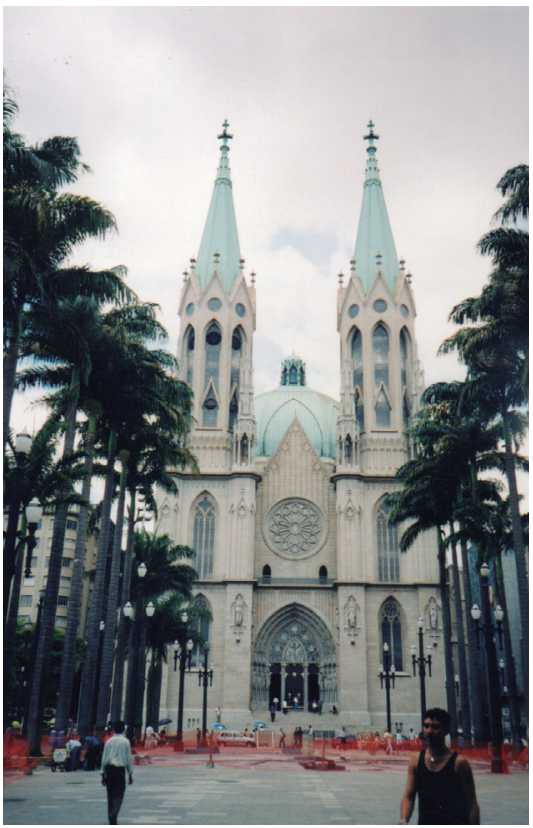




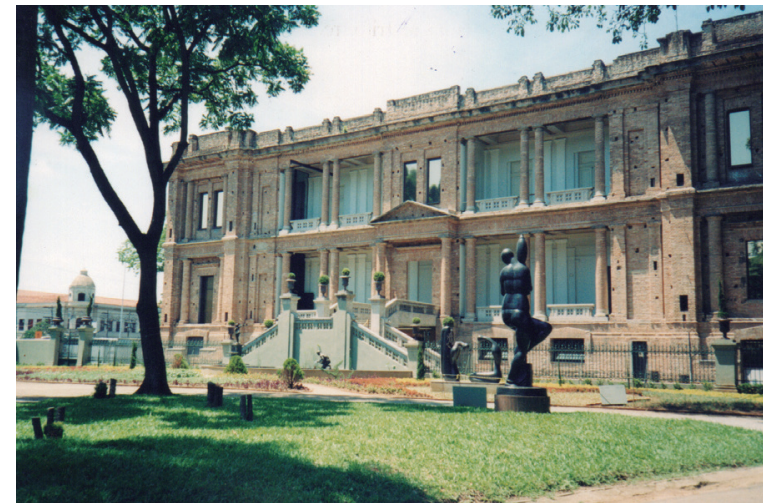

55

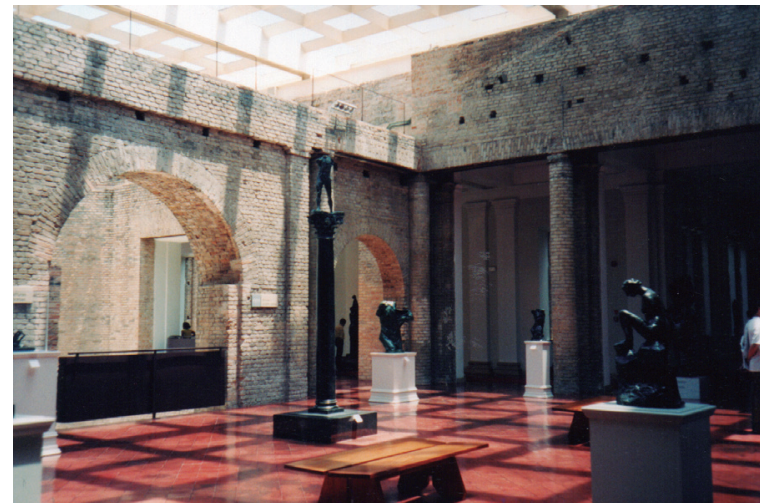

56
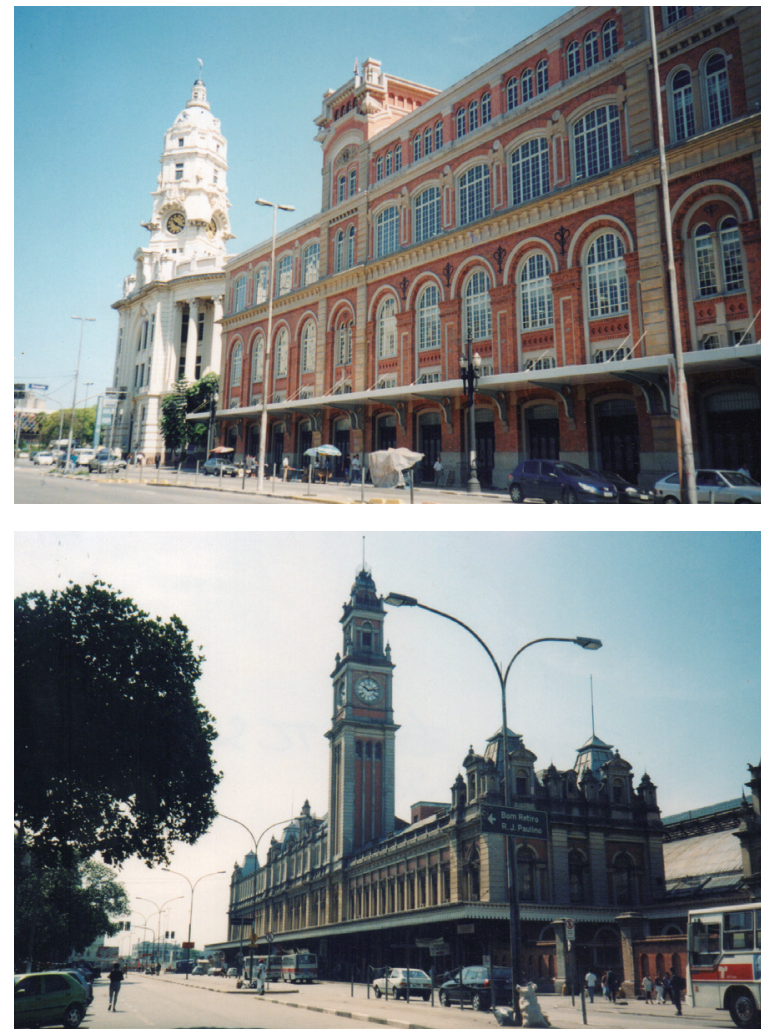

São Paulo

Foto 49. Reurbanização do Vale do Anhangabaú.

Foto 50. Teatro Municipal de São Paulo. Foto 51. Solar da Marquesa de Santos e Casa no 01.

Foto 52. Viaduto do Chá: trecho do projeto Sé - Arouche.

Foto 53. Viaduto de Santa

Efigênia: logradouro recuperado nas proximidades de uma das extremidades do Projeto Sé-Arouche.

Foto 54. Catedral da Sé: edifício restaurado no Polo 7 do ProCentro com 0 do setor privado.

Foto 55. Pinacoteca do Estado de São Paulo e trecho do Jardim da Luz.

Foto 56. Interior da Pinacoteca do Estado de São Paulo.

Foto 57. Prédio que foi sede da antiga DOPS e, ao fundo, a Estação Júlio Prestes. Edifícios recuperados para abrigar atividades culturais.

Foto 58. Estação da Luz: núcleo inicial do Programa Monumenta em São Paulo. 

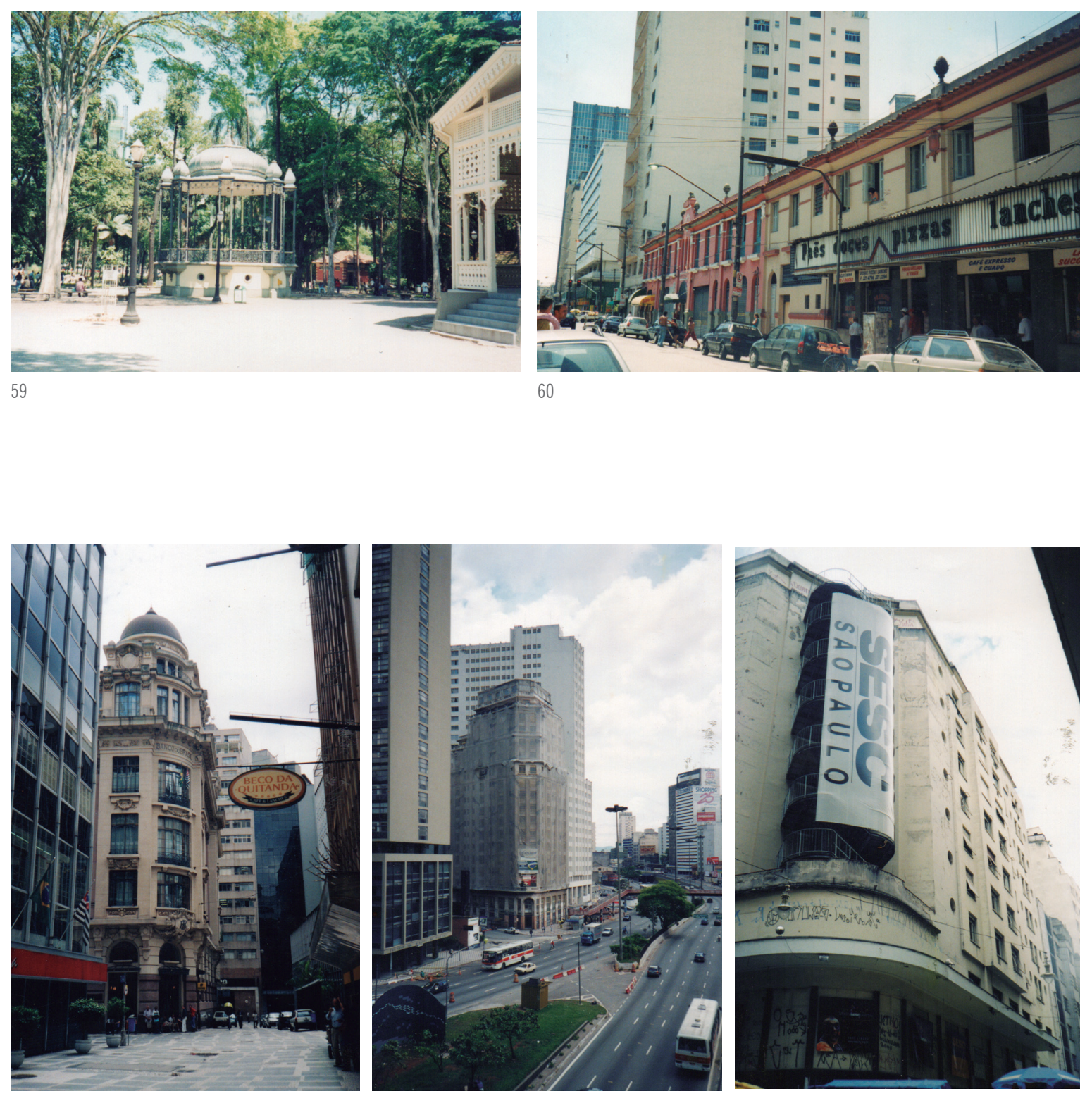
São Paulo

Foto 59. Jardim da Luz: logradouro incluído no Projeto de Recuperação do Bairro da Luz.

Foto 60. Bairro de Santa Efigênia no entorno da Estação da Luz - foco da proposta do DPH para o Programa Monumenta em São Paulo.

Foto 61. Centro Cultural Banco do Brasi de São Paulo, instalado na antiga sede do banco no centro velho.

Foto 62. Programa Morar no Centro: edifício recuperado para uso

habitaiconal no coração do centro de São Paulo.

Foto 63. Programa Reconstruir o Centro, área do Quadrilátero Piloto: edifício do futuro centro cultural do SESC.

Foto 64. Vista do Perímetro de Reabilitação Integrada do Habitat no Bairro da Luz, incluído no Programa de Reabilitação do Centro.

Foto 65. Praça do Patriarca: 0 pórtico da Galeria Prestes Maia.

Foto 66. Edifício dos Correios no Vale do Anhangabaú: fachadas preservadas e demolições internas para a construção de anexos e novo sistema de circulação.
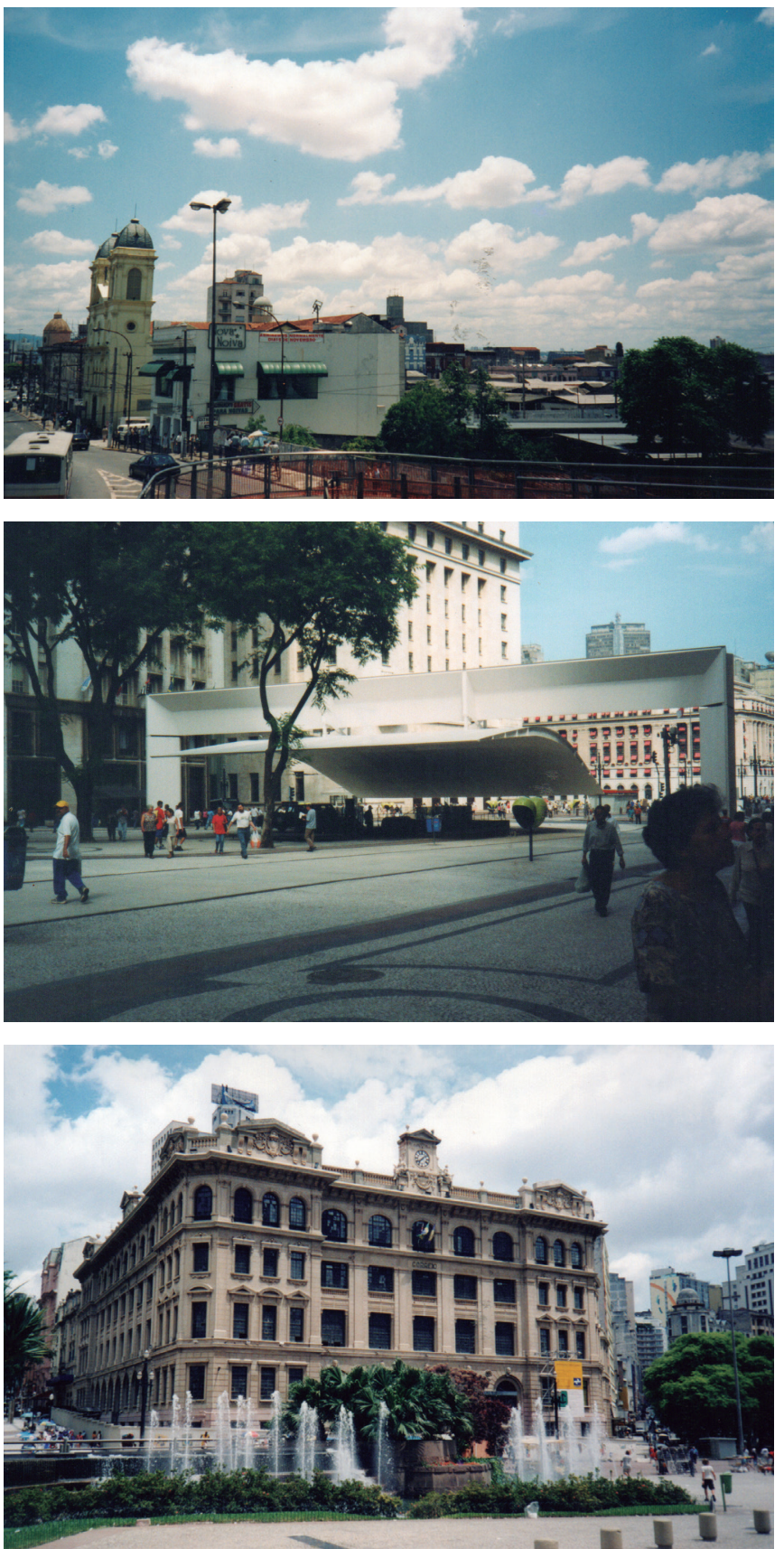


\section{Cálculo do potencial construtivo passível de transferência para imóveis cujo coeficiente de aproveitamento efetivo - CA - seja igual ou inferior a 7,5}

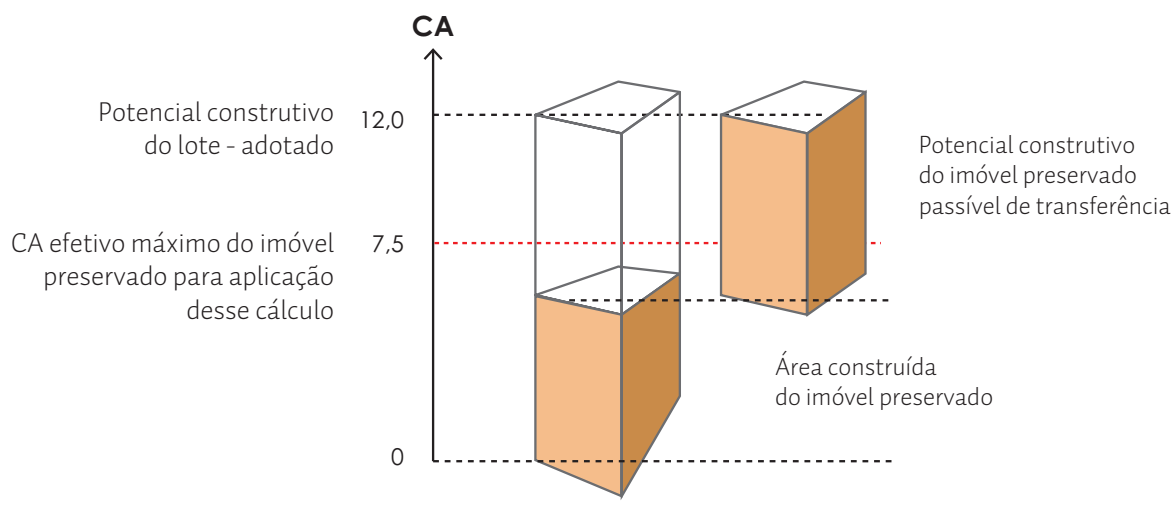

Cálculo do potencial construtivo passível de transferência para imóveis cujo coeficiente de aproveitamento efetivo - CA - seja superior a 7,5

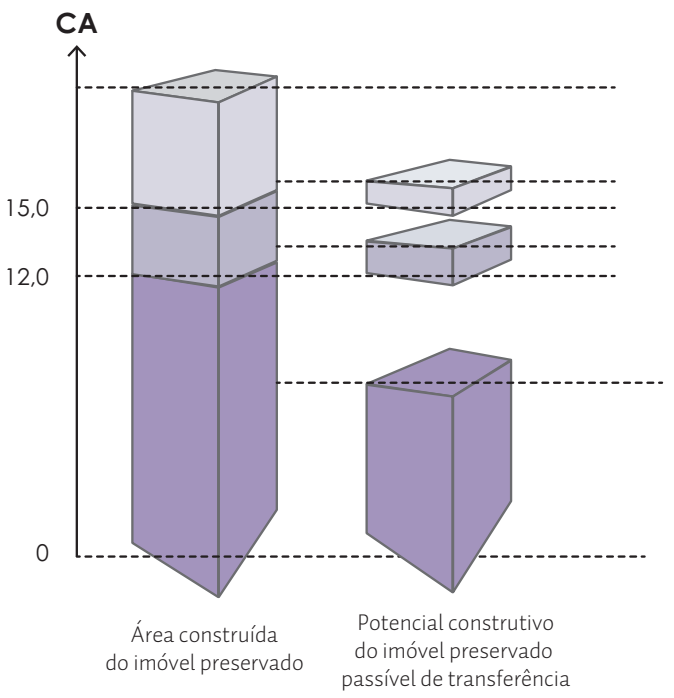

20\% da área construída que exceder 15 vezes a área do lote

$40 \%$ da área construída entre 12 e 15 vezes a área do lote

$60 \%$ da área construída entre 12 vezes a área do lote

Figura 1. Cálculo do potencial construtivo passível de transferência no âmbito da Operação Urbana Centro. Fonte: EMURB, Cartilha da Área Central. 


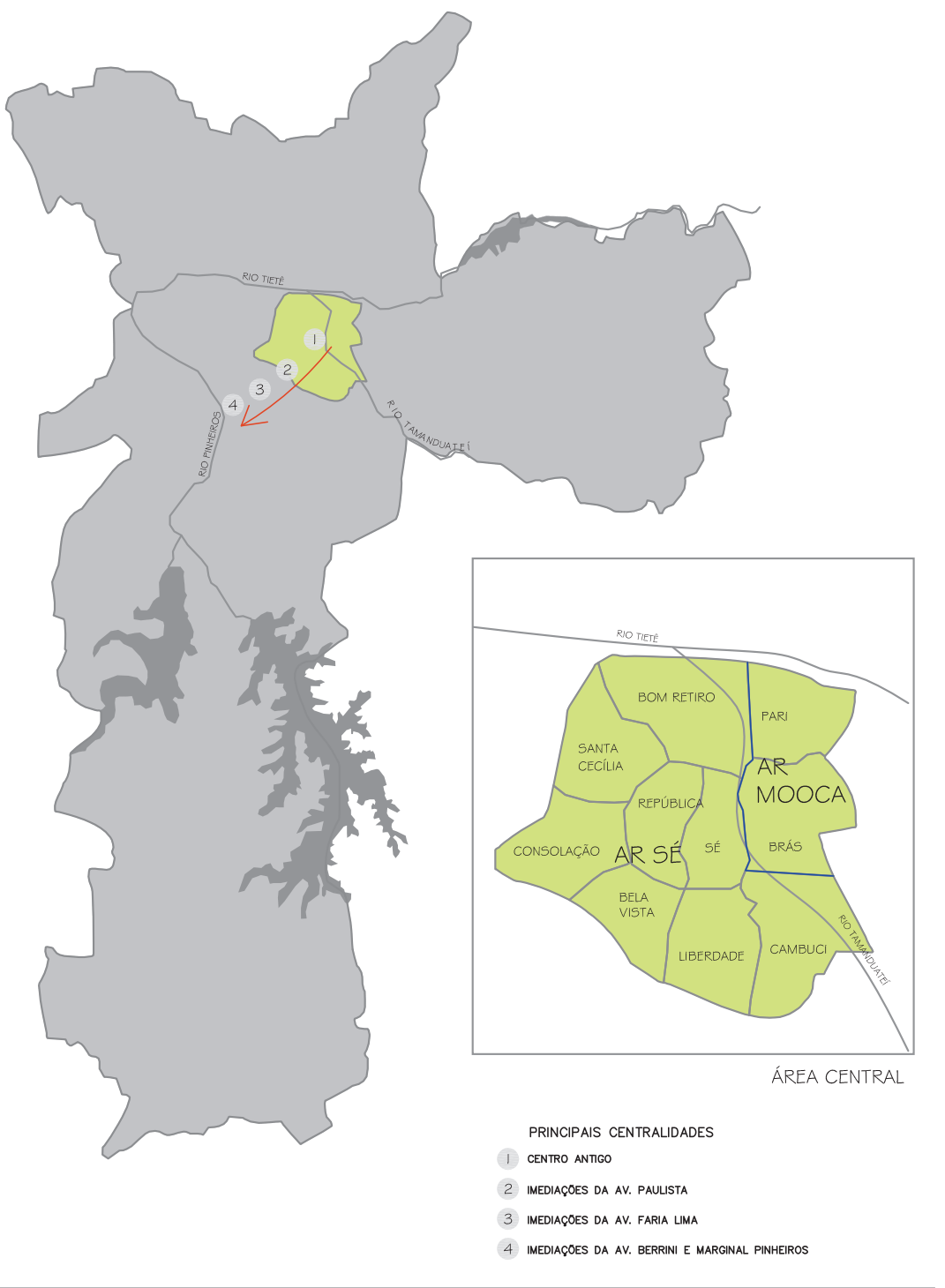

$\stackrel{N}{N}$

MUNICÍPIO DE SÃO PAULO

ÁREA CENTRAL

LIMITE DE AR

VETOR SUDOESTE DE DESLOCAMENTO DO CENTRO

E CONCENTRAÇÃO DE INVESTIMENTOS

\section{São Paulo - Mapas}

Mapa 11. Limite do município de São Paulo e área central.

Fonte: SEMPLA - PMSP - Elaborado por Marcia Sant'Anna, A Cidade Atração, tese de doutorado. 


\section{São Paulo - Mapas}
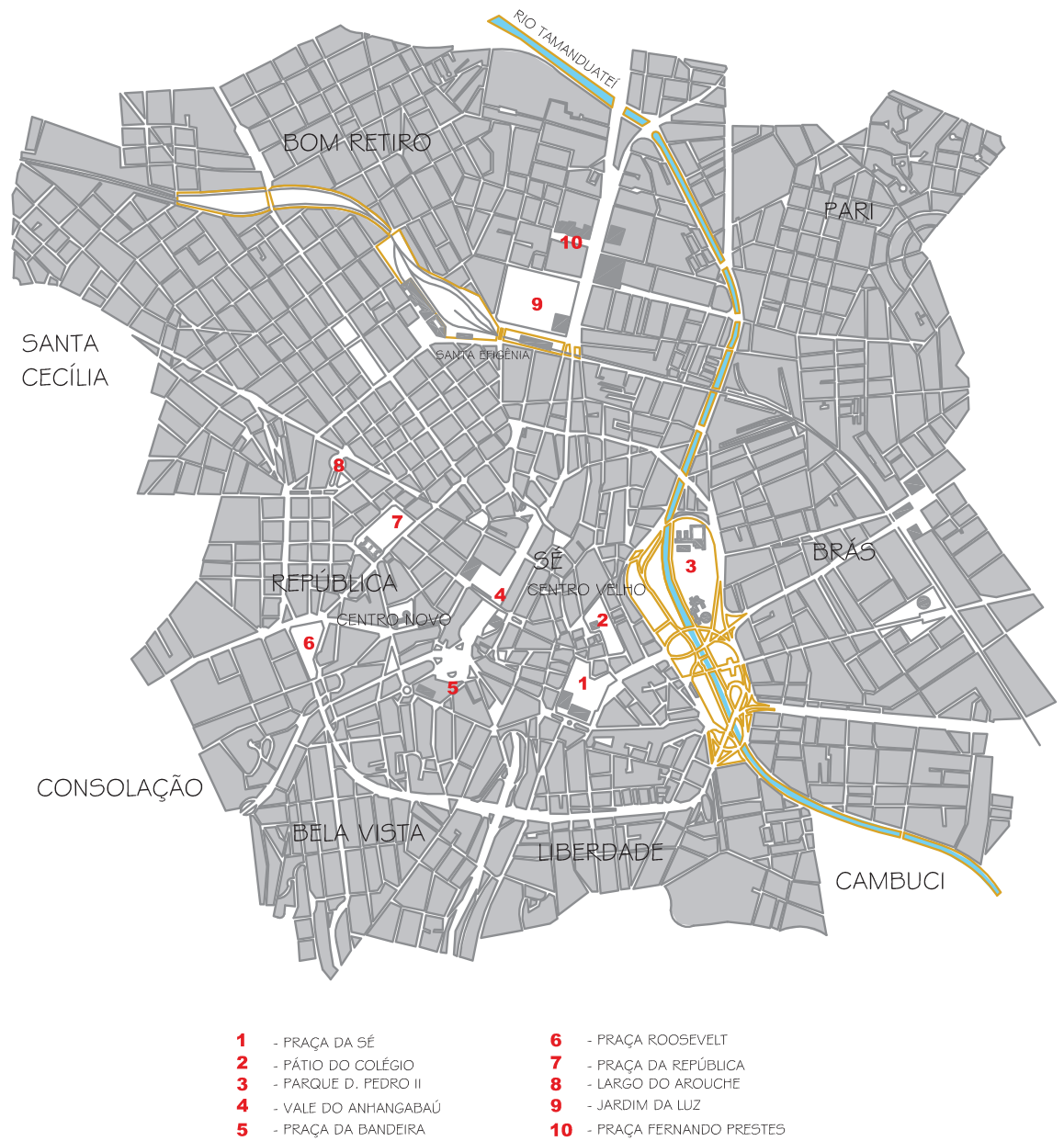

$$
\begin{array}{ll}
\mathbf{6} & \text { - PRAÇA ROOSEVELT } \\
\mathbf{7} & \text { - PRAÇA DA REPÚBLICA } \\
\mathbf{8} & \text { - LARGO DO AROUCHE } \\
\mathbf{9} & \text { - JARDIM DA LUZ } \\
\mathbf{1 0} & \text { - PRAÇA FERNANDO PRESTES }
\end{array}
$$

Mapa 12. Área Central de São Paulo.

Fonte: SEMPLA - PMSP - Elaborado por Marcia Sant'Anna, A Cidade Atração, tese de doutorado. 

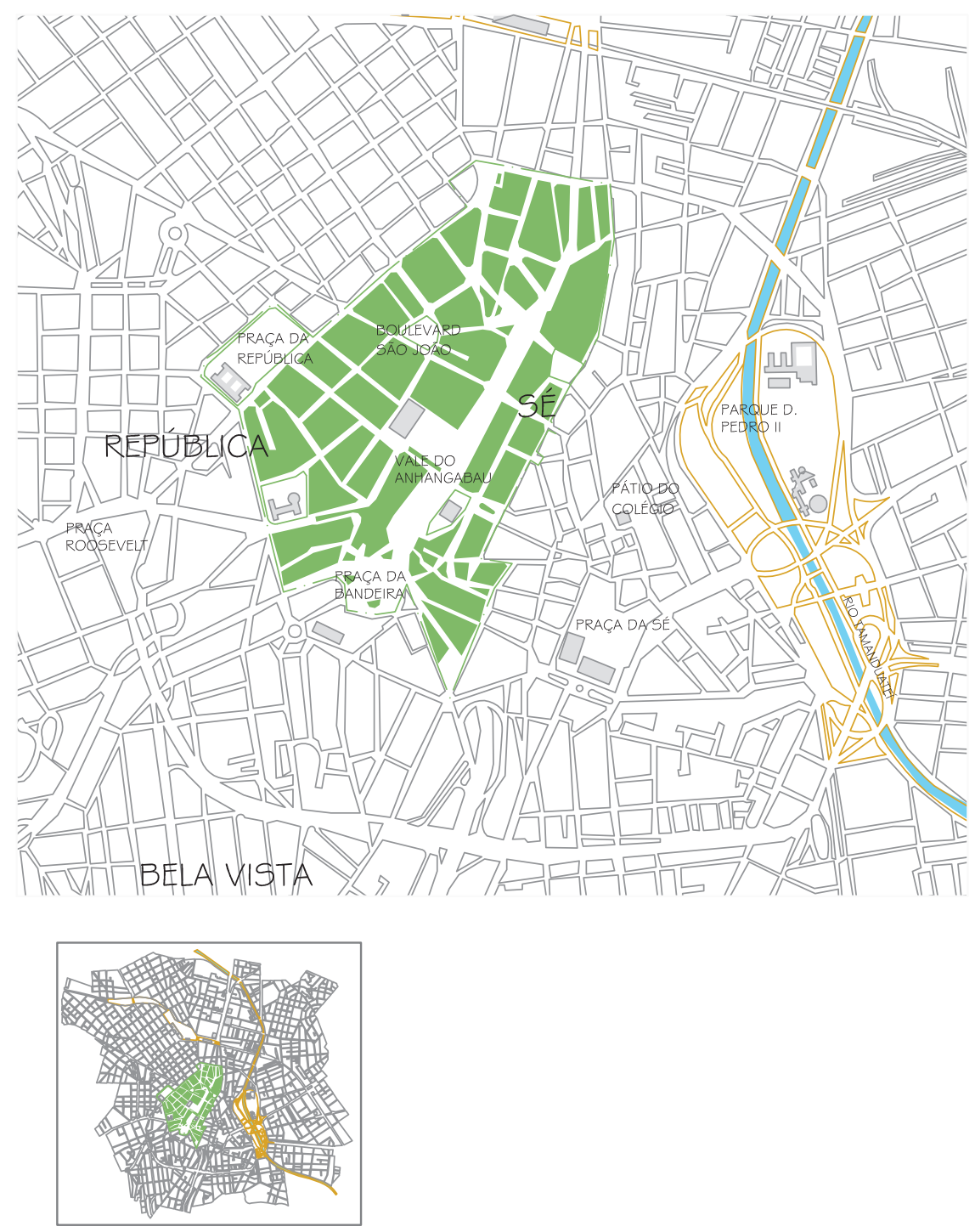

$\stackrel{N}{N}$

ÁREA DA OPERAÇÃO URBANA ANHANGABAU

São Paulo - Mapas

Mapa 13. Operação urbana Anhangabau.

Fonte: SEMPLA - PMSP - Elaborado por Marcia Sant'Anna, A Cidade Atração, tese de doutorado. 
14

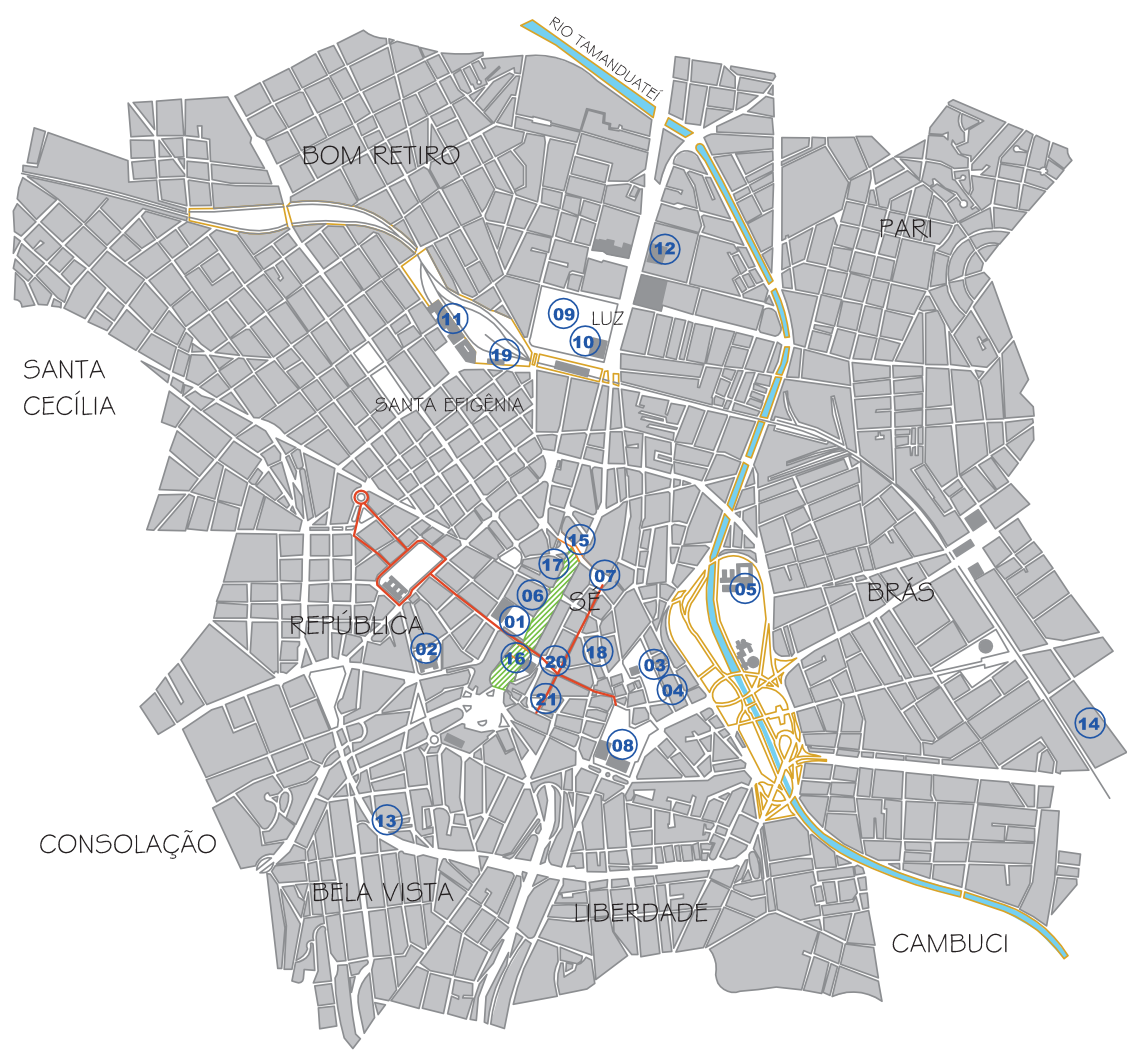

São Paulo - Mapas

Mapa 14. Pricipais intervenções de conservação e re-qualificação na área central de São Paulo na década de 90.

Fonte: Amadio (1998), São Paulo (1999. 2000), Bank Boston (2000) - Elaborado por Marcia Sant'Anna, A Cidade Atração, tese de doutorado.
(10) PINACOteCA do Estado

(111) ESTAÇAO JULIO PREStes (SALA São PAULO)

(12) MOSTEIRO DA LUZ (MUSEU DE ARTE SACRA)

(13) TEATRO BRASILEIRO DE COMEDIAS

(14) MEMORIAL DO IMIGRANTE

(15) VADUTO SANTA EFIGENIA

(16) VADUTO DO CHA

(17) CENTRO CULTURAL DOS CORREIOS

(1B) CENTRO CULTURAL BANCO DO BRASIL

(9) PREDIO DO DEOPS

(20) PRAÇA DO PATRIARCA

(21) MASP DA GALERIA PRESTES MAIA

LARGO DE SÃo beNTO

(9) JARDIM DA LUZ

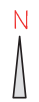

QUADRAS DA ÁREA CENTRAL

PRINCIPAIS EQUIPAMENTOS 

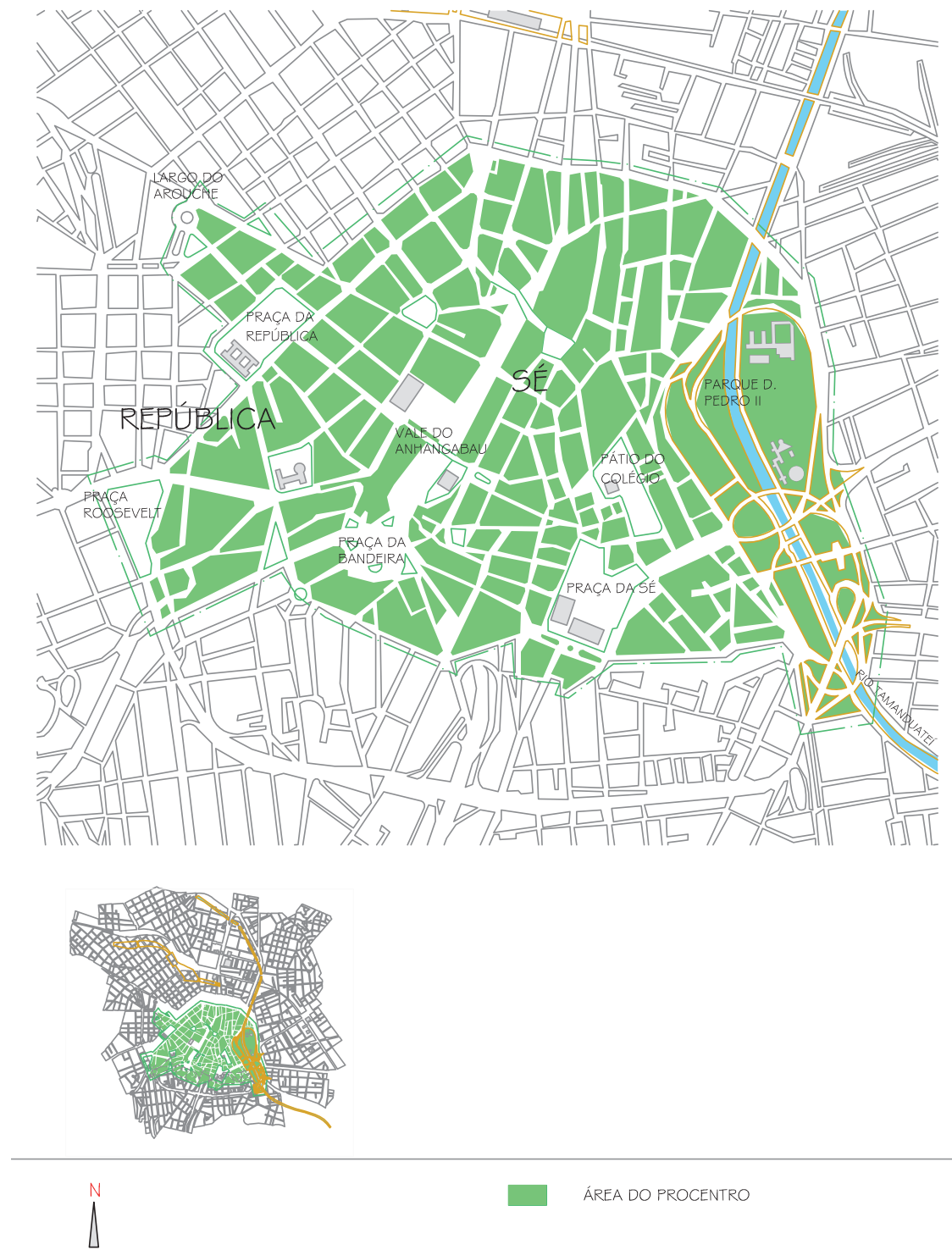

São Paulo - Mapas

Mapa 15. Área do ProCentro.

Fonte: SEMAB/ PROCENTRO/ PMSP

Elaborado por Marcia Sant'Anna, A Cidade Atração, tese de doutorado. 


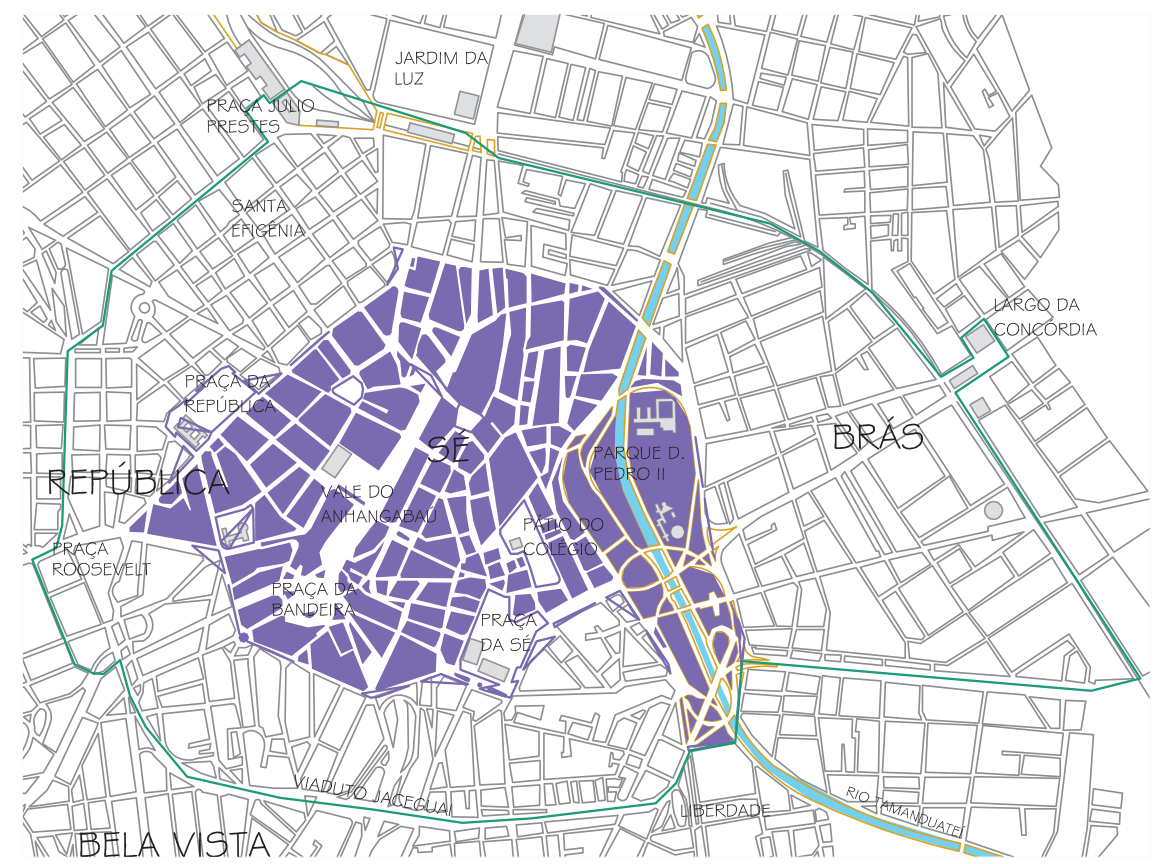

\section{São Paulo - Mapas}

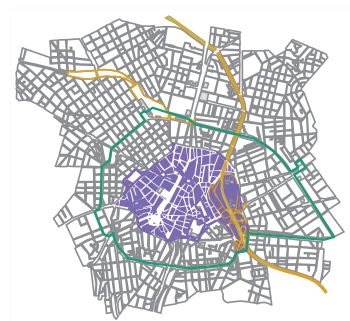

$\Lambda^{N}$

ÁREA DE ESPECIAL INTERESSE

Mapa 16. Operação Urbana Centro.

Fonte: EMURB/ PMSP - Elaborado por Marcia Sant'Anna, A Cidade Atração, tese de doutorado. 

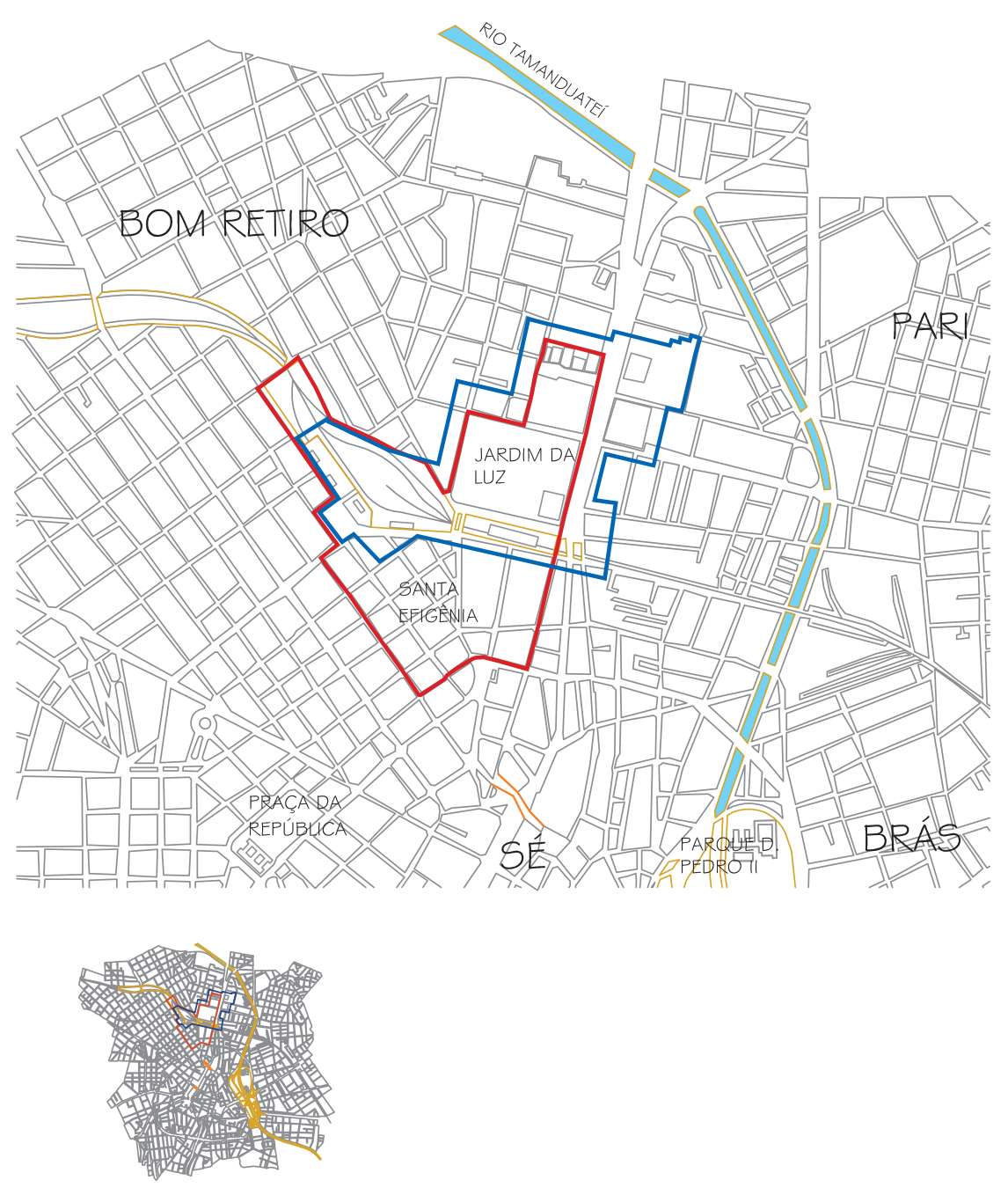


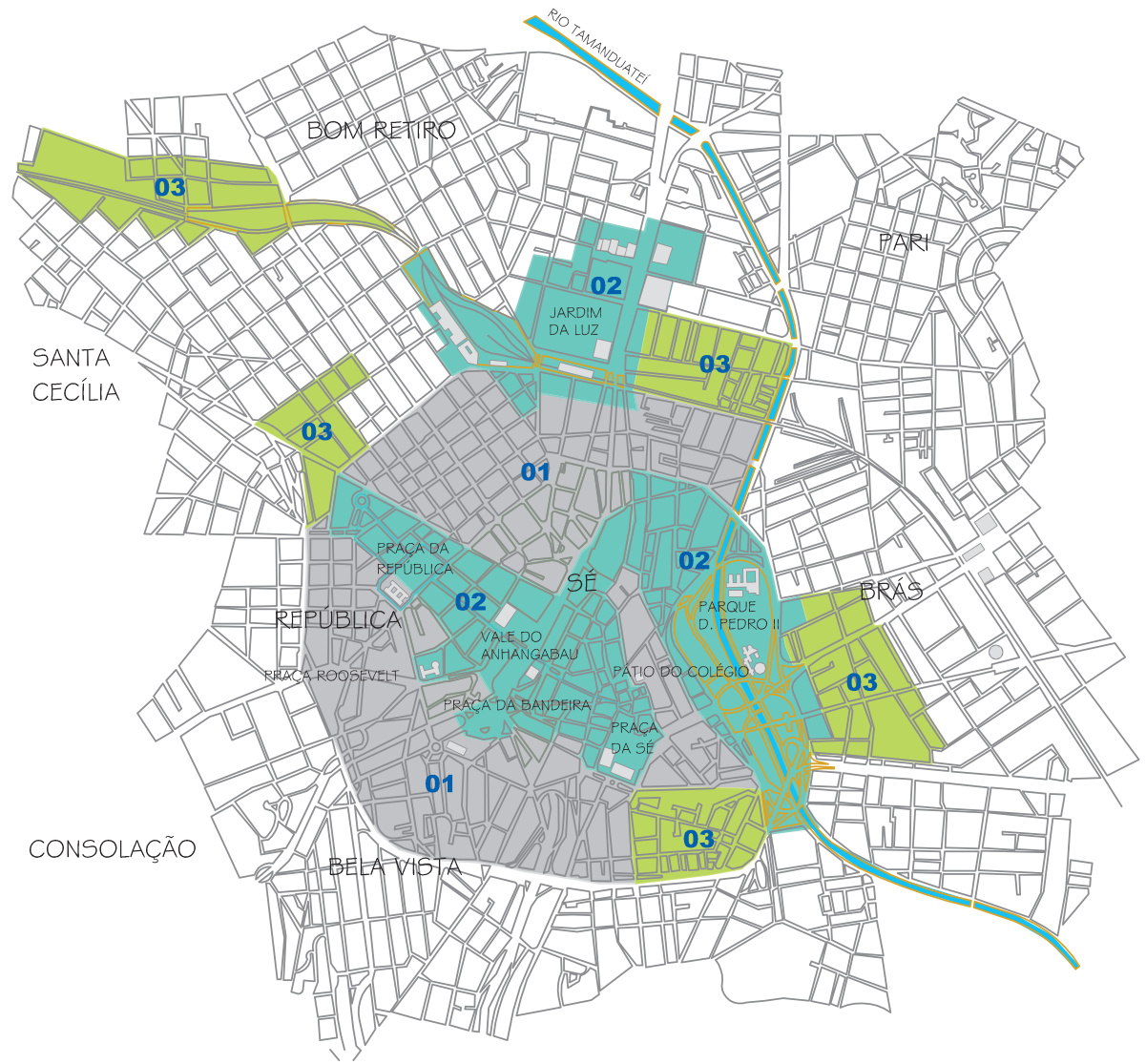

\section{São Paulo - Mapas}

Mapa 18. Programa de Reabilitação do Centro.

Fonte: EMURB/ PMSP - Elaborado por Marcia Sant'Anna, A Cidade Atração, tese de doutorado.
01 INTERVENÇÕES DE RE-QUALIFICAÇÃO DO ESPAÇO PÚBLICO

02 INTERVENÇÕES URBANISTICAS

03 PERÍMETROS DE REABILITAÇĀO INTEGRADA DO HABITAT 
0 patrimônio urbano produzido nos anos 1990

Foto 67. Salvador: interior de quarteirões do Pelourinho. Eliminação de anexos e rompimento de relações de parcelamento.

Foto 68. Rio de Janeiro, Rua Sete de Setembro: Projeto Cores da Cidade e a ênfase na recuperação de fachadas.

Foto 69. Rio de Janeiro, imediações da Praça XV: 0 uso promocional da cor.
67

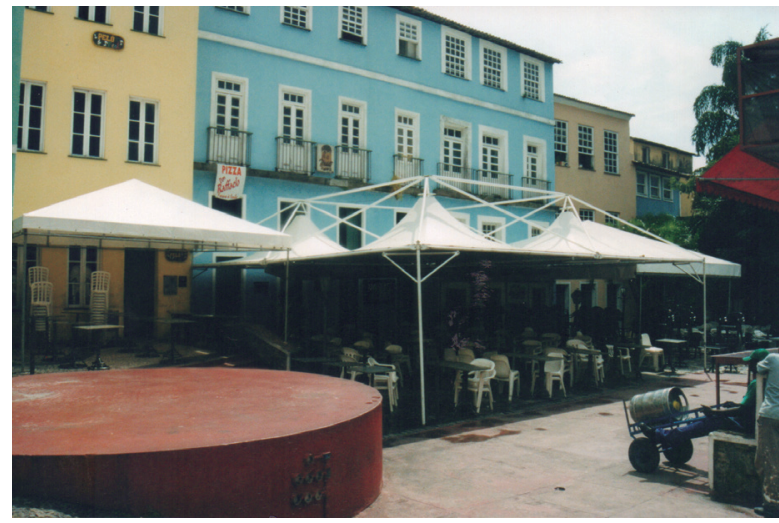

68

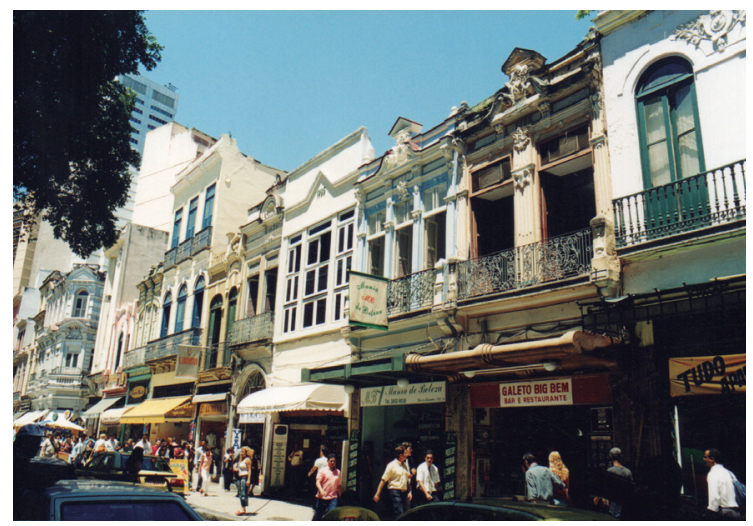

69

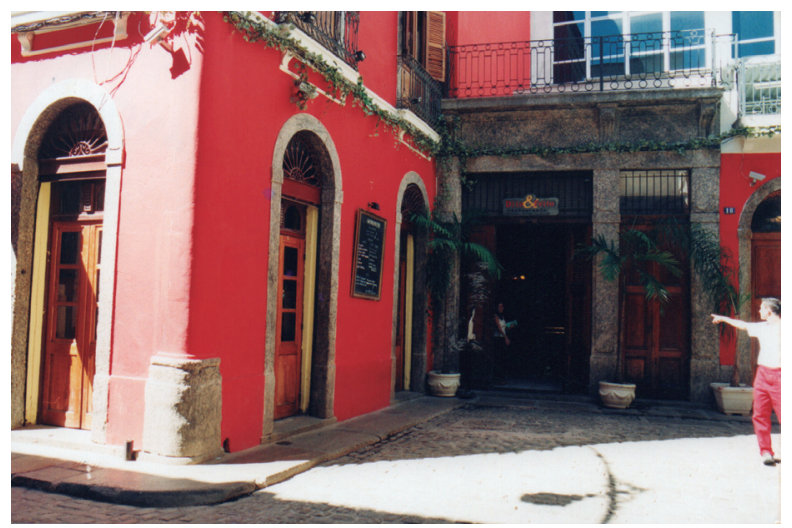

70

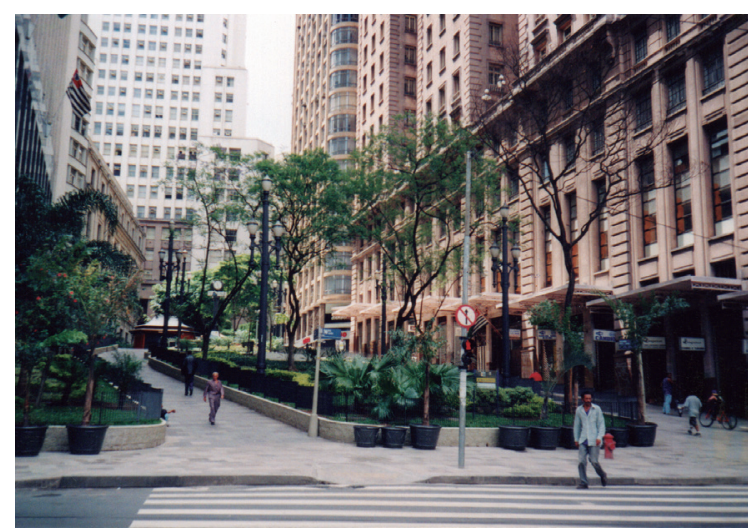

71

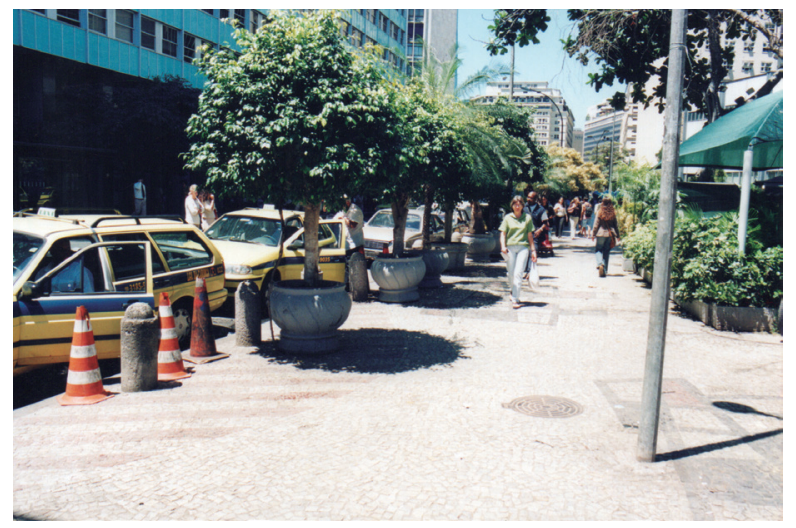




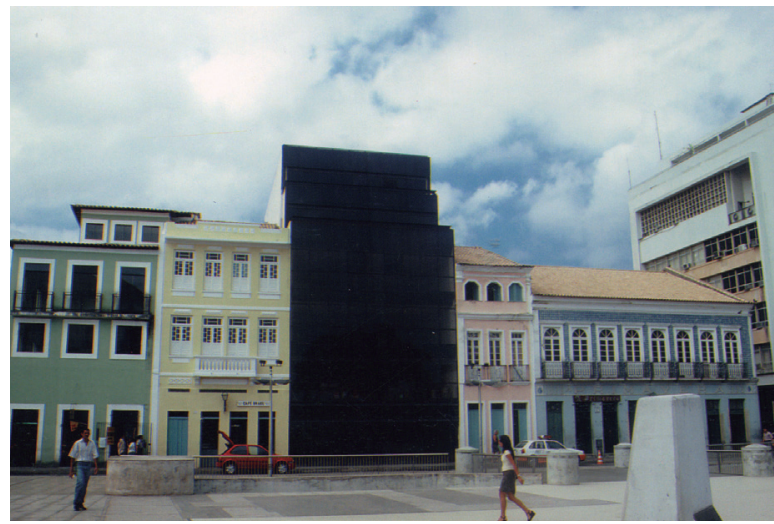

72

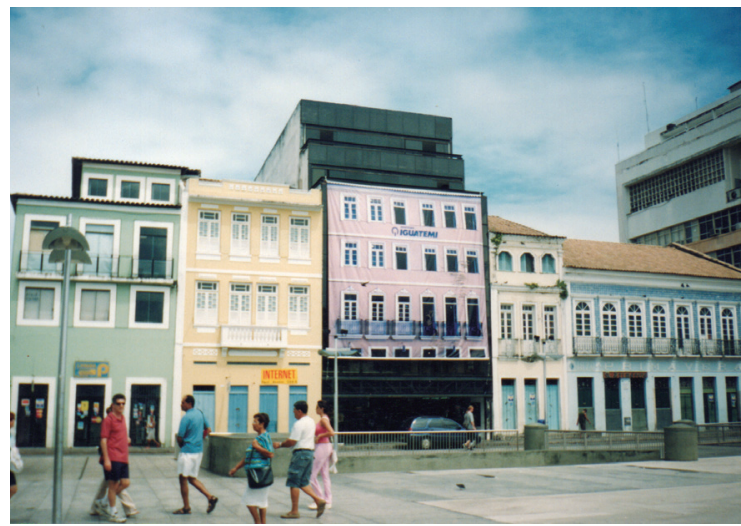

73

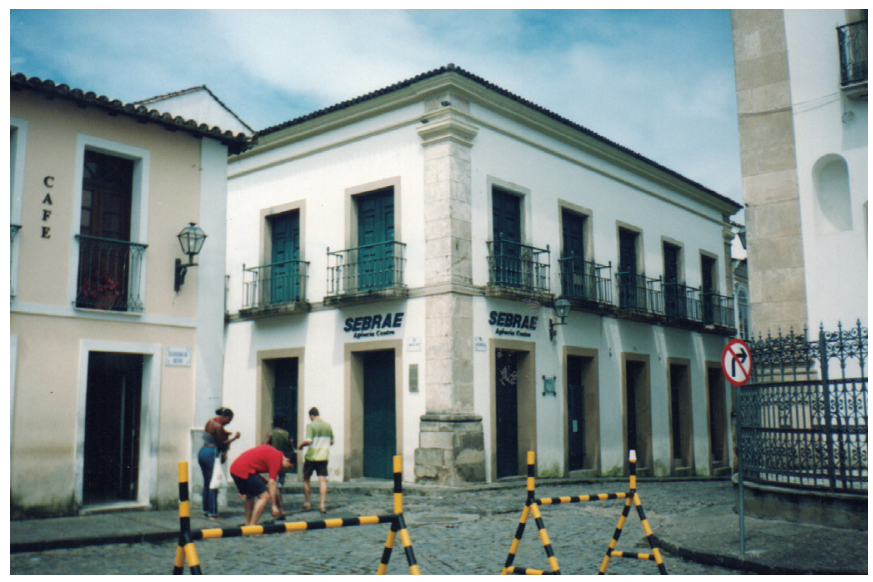

Foto 70. São Paulo, centro velho: 0 valor da aparência do ambiente.

Foto 71. Rio de Janeiro,

Largo da Carioca: a valorização do ambiente.

Fotos 72 e 73. Salvador,

Praça da Sé: contraste ou pastiche.

Foto 74. Pelourinho, imóvel

restaurado em 1993: de volta ao período colonial.

Foto 75. Salvador, Praça da Sé:

introdução de objeto de impacto estético.

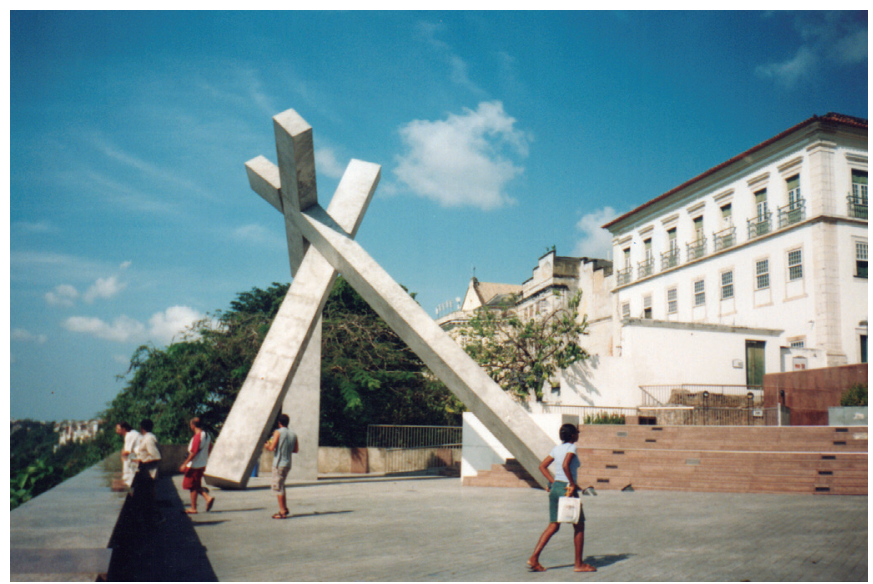


0 patrimônio urbano produzido nos anos 1990

Foto 76. Rio de Janeiro, Largo Alexandre Herculano: introdução de objeto de impacto estético.

Foto 77. São Paulo, Praça do

Patriarca: introdução de objeto de impacto estético.

Foto 78. Rio de Janeiro, praça em frente ao Palácio do Itamaraty: quadra mutilada.

Foto 79. Salvador, Rua d'Ajuda: quadra mutilada para instalação de terminal de ônibus.

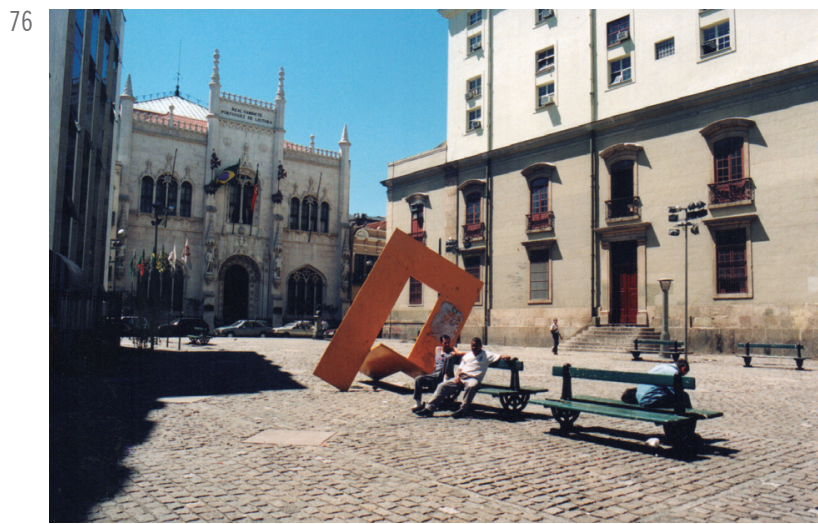

78
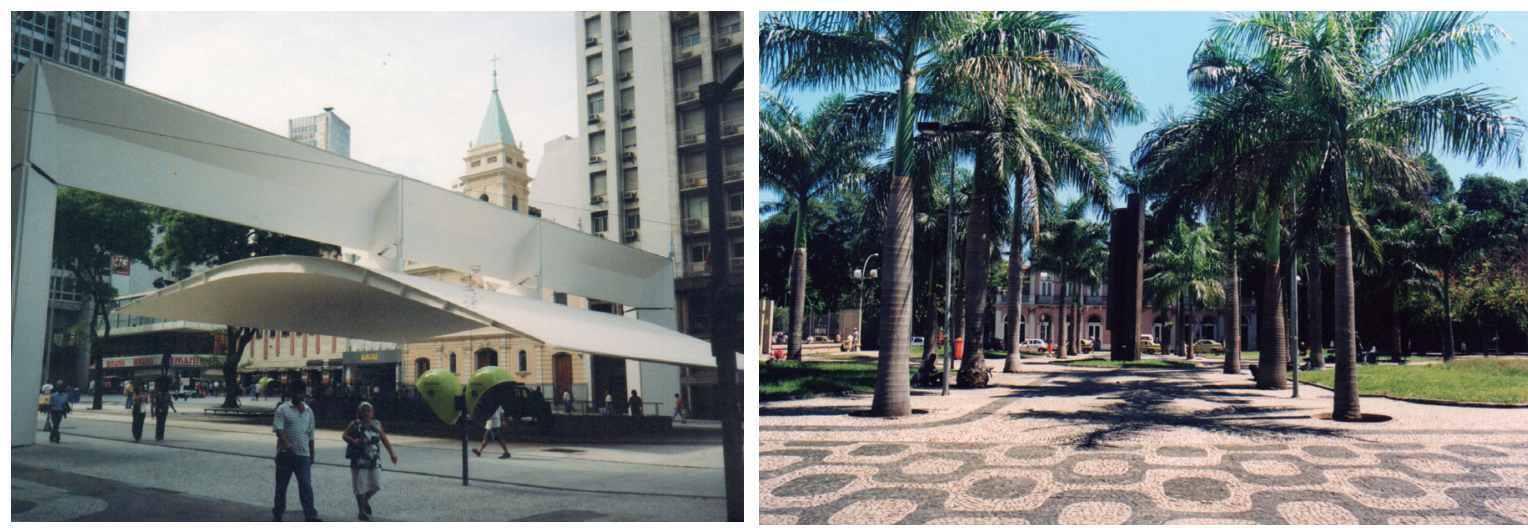

80
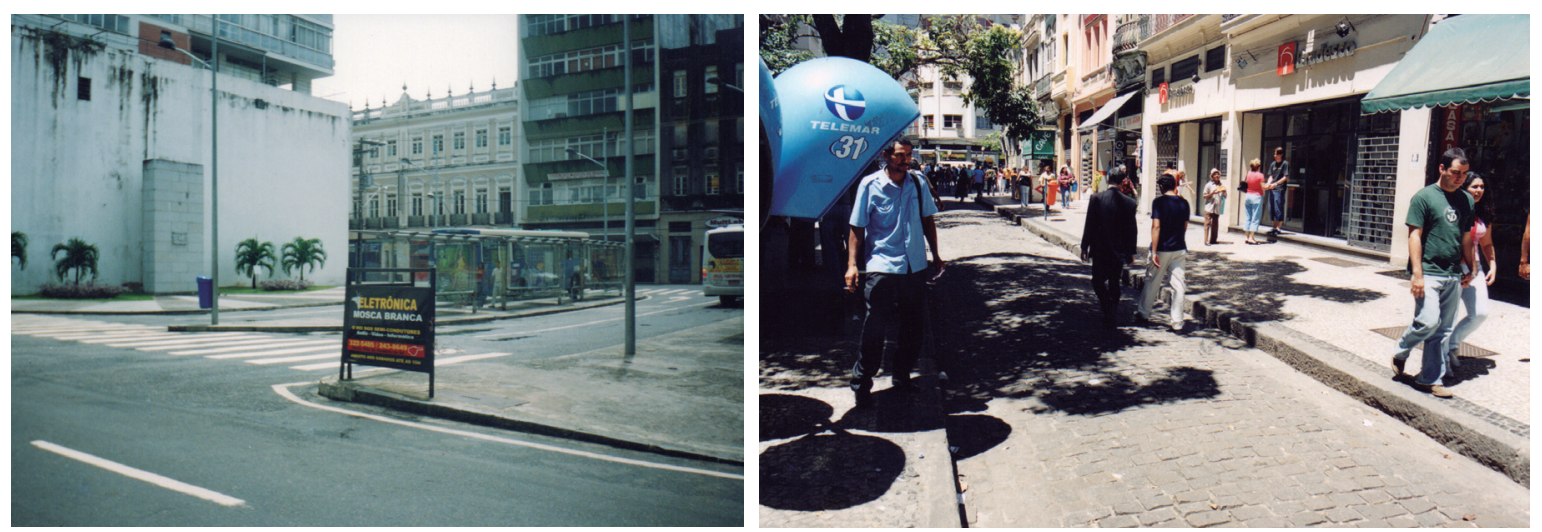


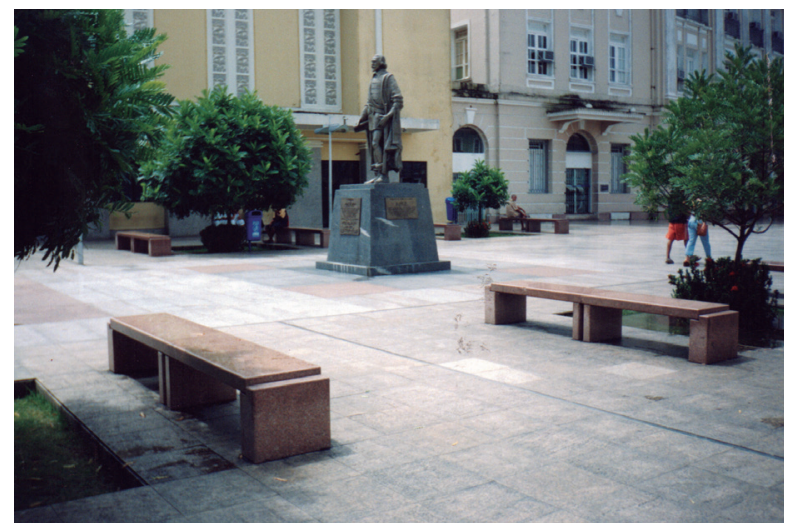

81
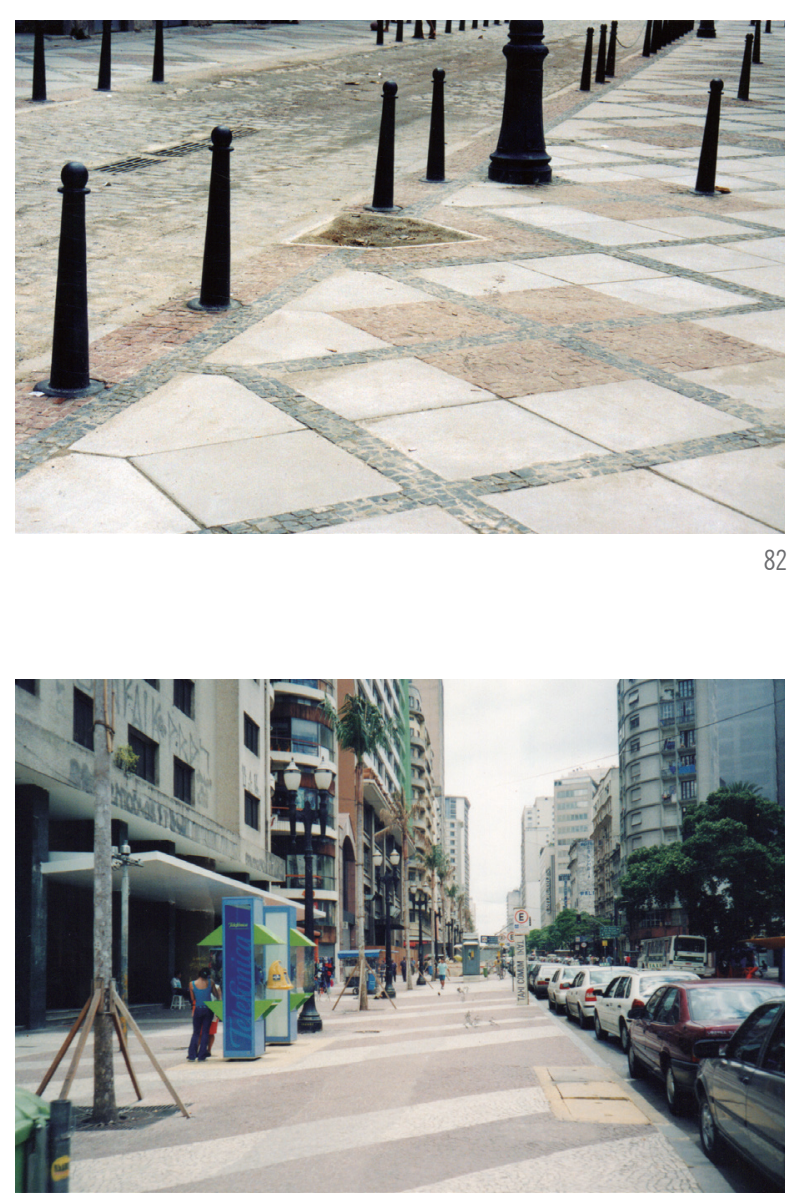

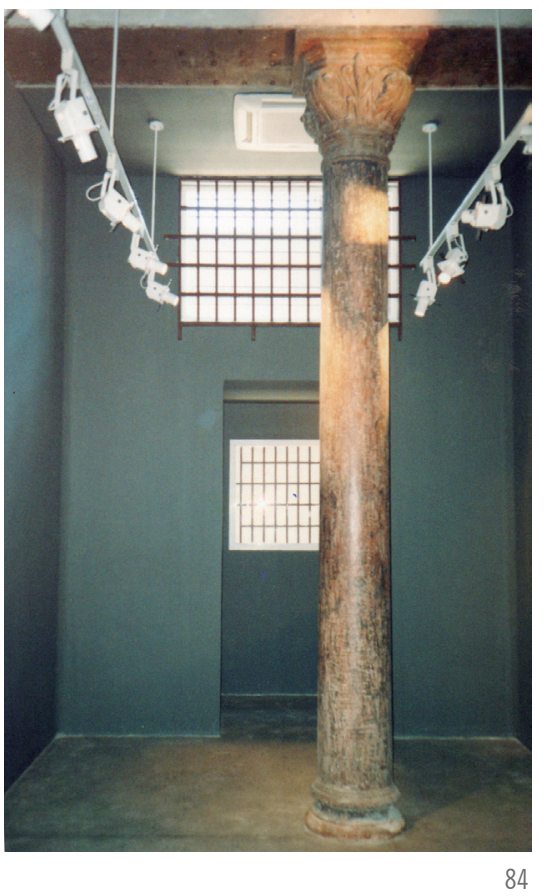

Foto 80. Rio de Janeiro,

Rua Sete de Setembro: alteração da morfologia do logradouro.

Foto 81. Salvador, Praça da Sé: a linguagem de shopping center no espaço público.

Foto 82. Rio de Janeiro, Rua do Lavradio: estetização e alteração da morfologia.

Foto 83. São Paulo,

Av. São João: estetização e alteração da morfologia.

Foto 84. São Paulo: cela da antiga Delegacia de Ordem Política e Social - DOPS, onde, durante 0 regime militar, presos políticos foram mortos e torturados.

Na transformação do edifício em centro cultural, os vestígios dessa história foram apagados. 


\section{Tabelas e quadros}

Tabela 1 - Fluxo global de turistas, segundo residência permanente:

Salvador, 1985/1995

\begin{tabular}{c|c|c|c|c|c}
\hline \multirow{2}{*}{ Ano } & \multicolumn{3}{|c|}{ Número de turistas } & \multicolumn{3}{c}{ Participação \% } \\
\cline { 2 - 6 } & Nacionais & Estrangeiros & Total & Nacionais & 92 \\
\hline 1985 & 993.730 & 90.203 & 1.083 .933 & 92 & 92 \\
\hline 1986 & 1.230 .729 & 109.403 & 1.340 .132 & 98 & 08 \\
\hline 1987 & 1.122 .912 & 101.501 & 1.224 .413 & 91 & 09 \\
\hline 1988 & 980.200 & 97.600 & 1.077 .800 & 90 & 10 \\
\hline 1999 & 1.034 .998 & 117.523 & 1.152 .521 & 90 & 10 \\
\hline
\end{tabular}

Fonte: Companhia de Desenvolvimento da Região Metropolitana de Salvador (1996b).

Tabela 2 - Fluxo turístico global (ampliado), segundo residência permanente: Salvador, 1991/2000

\begin{tabular}{|c|c|c|c|c|c|}
\hline \multirow{2}{*}{ Ano } & \multicolumn{3}{|c|}{ Número de turistas } & \multicolumn{2}{|c|}{ Participação \% } \\
\hline & Nacionais & Estrangeiros & Total & Nacionais & Estrangeiros \\
\hline 1991 & 1.025 .662 & 116.208 & 1.141 .870 & 89,82 & 10,18 \\
\hline 1992 & 892.475 & 134.402 & 1.026 .877 & 86,91 & 13,09 \\
\hline 1993 & 1.071 .655 & 159.337 & 1.230 .992 & 87,06 & 12,94 \\
\hline 1994 & 1.185 .478 & 164.299 & 1.349 .778 & 87,83 & 12,17 \\
\hline 1995 & 1.178 .365 & 167.887 & 1.346 .252 & 87,53 & 12,47 \\
\hline 1996 & 1.474 .160 & 158.448 & 1.632 .608 & 90,29 & 9,71 \\
\hline 1997 & 1.579 .242 & 144.542 & 1.723 .784 & 91,61 & 8,39 \\
\hline 1998 & 1.533 .562 & 155.303 & 1.688 .866 & 90,80 & 9,20 \\
\hline 1999 & 1.623 .068 & 193.543 & 1.816 .611 & 89,35 & 10.65 \\
\hline 2000 & 1.688 .025 & 198.247 & 1.886 .272 & 89,49 & 10,51 \\
\hline Média/Ano & 1.325 .169 & 159.222 & 1.484 .391 & 89,27 & 10,73 \\
\hline $00 / 91 \%$ & 64,58 & 70,60 & 65,19 & 0,37 & 3,27 \\
\hline ০o/99 \% & 4,00 & 2,43 & 3,83 & 0,16 & 1,35 \\
\hline
\end{tabular}

Fonte: Empresa de Turismo da Bahia (2001a) 
Tabela 3 - Receita gerada pelo turismo (fluxo ampliado), segundo residência permanente:

Salvador, $1991 / 2000$

\begin{tabular}{|c|c|c|c|c|c|}
\hline \multirow{2}{*}{ Ano } & \multicolumn{3}{|c|}{ US\$ 1.000} & \multicolumn{2}{|c|}{ Participação \% } \\
\hline & Nacionais & Estrangeiros & Total & Nacionais & Estrangeiros \\
\hline 1991 & $149.521,89$ & $44.596,06$ & $194.117,95$ & 77,03 & 22,97 \\
\hline 1992 & $184 \cdot 967,74$ & $61.482,826$ & $246.450,56$ & 75,05 & 24,95 \\
\hline 1993 & $189.114,41$ & $94.013,79$ & $283.128,20$ & 66,79 & 33,21 \\
\hline 1994 & $276.057,66$ & $88.382,27$ & $364.439,93$ & 75,75 & 24,25 \\
\hline 1995 & $405 \cdot 307,22$ & $119.730,99$ & $525.038,22$ & 77,20 & 22,80 \\
\hline 1996 & $487.245,89$ & $116.819,23$ & $604.065,12$ & 80,66 & 19,34 \\
\hline 1997 & $481.257,60$ & $104.829,04$ & $586.086,63$ & 82,11 & 17,89 \\
\hline 1998 & $447.833,29$ & $92.603,78$ & $540.437,07$ & 82,87 & 17,13 \\
\hline 1999 & $350.610,54$ & $121.708,33$ & $472.318,87$ & 74,23 & 25,77 \\
\hline 2000 & $355.601,45$ & $111.250,92$ & $466.852,37$ & 76,17 & 23,83 \\
\hline Média/Ano & $332.751,77$ & $95 \cdot 541,72$ & $428.293,49$ & 77,69 & 22,31 \\
\hline $00 / 91 \%$ & 137,83 & 149,46 & 140,50 & $-1,11$ & 3,73 \\
\hline o০/99\% & 1,42 & $-8,59$ & $-1,16$ & 2,61 & $-7,52$ \\
\hline
\end{tabular}

Fonte: Empresa de Turismo da Bahia (2001a).

Tabela 4 - Evolução da arrecadação de ICMS

\begin{tabular}{c|c|c}
\hline Ano & Área Central & Iguatemi \\
\hline 1985 & $19,1 \%$ & $3,9 \%$ \\
\hline 1993 & $10,1 \%$ & $15,1 \%$ \\
\hline 1998 & $18,7 \%$ & $33,9 \%$ \\
\hline
\end{tabular}

Fonte: Tabela montada a partir de informações obtidas em Fundação Centro de Projetos e Estudos (1994) e Heinonen (2000, p. 74). 
Tabela 5 - População residente em Salvador e taxa de crescimento média anual, segundo RA

\begin{tabular}{l|c|c|c|c|c|c|c|c}
\hline \multirow{2}{*}{ RA } & \multirow{2}{*}{ Área (ha) } & \multicolumn{4}{|c|}{ População / Ano } & \multicolumn{2}{c}{ Taxa de crescimento geométrico \% } \\
\cline { 3 - 9 } & & 1980 & 1991 & 1996 & 2000 & $1980-1991$ & $1991-1996$ & $1991-2000$ \\
\hline I Centro & 715 & 110.973 & 93.466 & 84.923 & 85.849 & $-1,5$ & $-1,9$ & $-0,9$ \\
\hline II Itapagipe & 719 & 141.464 & 148.922 & 147.620 & 161.052 & 0,5 & $-0,2$ & 0,9 \\
\hline III S. Caetano & 936 & 169.934 & 195.510 & 203.003 & 200.755 & 1,3 & 0,8 & 0,3 \\
\hline IV Liberdade & 696 & 183.543 & 181.156 & 178.357 & 184.194 & $-0,1$ & $-0,3$ & 0,2 \\
\hline V Brotas & 1.159 & 150.824 & 175.871 & 181.707 & 191.513 & 1,4 & 0,7 & 1,0 \\
\hline VI Barra & 547 & 78.738 & 72.530 & 69.375 & 69.566 & $-0,8$ & $-0,9$ & $-0,5$ \\
\hline VII Rio Vermelho & 698 & 147.345 & 162.301 & 165.811 & 173.874 & 0,9 & 0,4 & 0,8 \\
\hline VIII Pituba & 841 & 36.975 & 65.392 & 70.594 & 71.453 & 5,3 & 1,5 & 1,0 \\
\hline IX Boca do Rio & 1.367 & 49.952 & 81.217 & 92.882 & 104.653 & 4,5 & 2,7 & 2,9 \\
\hline X Itapuá & 8.563 & 49.669 & 132.117 & 158.521 & 199.905 & 9,3 & 3,7 & 4,7 \\
\hline XI Cabula & 1.043 & 65.175 & 107.611 & 121.186 & 136.563 & 4,7 & 2,4 & 2,7 \\
\hline XII T. Neves & 1.470 & 71.619 & 152.952 & 168.490 & 190.308 & 7,1 & 2,0 & 2,5 \\
\hline XIII Pau da Lima & 2.465 & 75.485 & 143.688 & 165.357 & 202.773 & 6,0 & 2,8 & 3,9 \\
\hline XIV Cajazeiras & 2.321 & 10.276 & 99.964 & 114.990 & 139.460 & 23,0 & 2,8 & 3,8 \\
\hline XV Valéria & 2.362 & 22.391 & 43.253 & 54.095 & 66.428 & 6,2 & 4,6 & 4,9 \\
\hline XVI Sub. & 4.214 & 127.324 & 217.560 & 232.553 & 262.219 & 5,0 & 2,3 & 2,1 \\
\hline Ferroviário. & 2.325 & 10.326 & 1.763 & 2.075 & 2.542 & $-14,8$ & 3,3 & 4,1 \\
\hline XVII Ilhas & $\mathbf{3 2 . 4 5 0}$ & $\mathbf{1 . 5 0 2 . 0 1 3}$ & $\mathbf{2 . 0 7 5 . 2 7 3}$ & $\mathbf{2 . 2 1 1 . 5 3 9}$ & $\mathbf{2 . 4 4 3 . 1 0 7}$ & $\mathbf{3 , 0}$ & $\mathbf{1 , 3}$ & $\mathbf{1 , 8}$ \\
\hline Total & & & & & & &
\end{tabular}

Fonte: IBGE Censos (1980, 1991), Contagem da População (1996) e Censo (2000). 
Tabela 6 - Programa de Recuperação do Centro Histórico de Salvador (obras executadas)

\begin{tabular}{|c|c|c|c|c|c|}
\hline Obras & $\mathrm{N}^{\circ}$ de imóveis & Período & Fonte dos Recursos & Situação & Valor (R\$) \\
\hline $1^{\mathrm{a}}$ a $4^{\mathrm{a}}$ etapas & 356 & 1992-1995 & Tesouro/BA & Executada & $23.703 .000,00$ \\
\hline $\begin{array}{l}\text { Fachadas Av. Contorno/ } \\
\text { Conceição da Praia ** }\end{array}$ & 01 & 1993 & Tesouro/BA & Executada & $24.766,00$ \\
\hline Estacionamento $10 \mathrm{M}$ - 92 vagas & 01 & 1994 & Tesouro/BA & Executada & $387.218,00$ \\
\hline Monumentos isolados & 09 & $1992-1996$ & Tesouro/BA & Executada & $6.268 .000,00$ \\
\hline Complementares & 43 & 1995-1996 & Tesouro/BA & Executada & $5.777 .596,00$ \\
\hline Obras Emergenciais & 21 & 1995 & $\begin{array}{l}\text { MinC/IPHAN/ } \\
\text { IPAC }\end{array}$ & Executada & 3.000 .000 .00 \\
\hline Estacionamento $14 \mathrm{M}$ - 450 vagas & 01 & 1995 & Tesouro/BA & Executada & $2.957 .778,00$ \\
\hline $5^{\text {a etapa }}$ & 63 & 1996 & Tesouro/BA & Executada & $10.767 .356,00$ \\
\hline Obras Emergenciais - $5^{a}$ etapa & 17 & 1997 & Tesouro/BA & Executada & $1.206 .525,03$ \\
\hline $6^{a}$ etapa - lote or & 30 & 1997 & Tesouro/BA & Não concluída* & $13.397 .591,50$ \\
\hline $6^{a}$ etapa - lote 02 & 52 & 1997 & Tesouro/BA & Não concluída* & $7.953 .427,13$ \\
\hline $\begin{array}{l}\text { Quarteirão Cultural/Praça das Artes/ } \\
\text { Estacionamento - } 200 \text { vagas }\end{array}$ & 19 & 1997-1999 & $\begin{array}{l}\text { PRODETUR/ } \\
\text { BID }\end{array}$ & Executada & $7.190 .795,97$ \\
\hline $\begin{array}{l}\text { Apoio às desocupações, lacrações } \\
\text { e escoramentos emergenciais }\end{array}$ & & $1999-2000$ & Tesouro/BA & Em execução & $790.512,62$ \\
\hline Fiscalização de obras & & 1996-1999 & Tesouro/BA & Executada & $7.082 .563,75$ \\
\hline Total & 613 & & & & $90.507 .130,00$ \\
\hline
\end{tabular}

Fonte: Tabela montada a partir de informaçóes obtidas no Instituto do Patrimônio Artístico e Cultural da Bahia - IPAC (abr. 2002).

* $\mathrm{O}$ aditivo do lote or e o lote 02 da $6^{\mathrm{a}}$ etapa não não haviam sido concluídos em 2002 e, portanto, o valor total dessa etapa não corresponde ao valor pago, segundo informaçãa da CONDER.

** As fachadas que foram pintadas na Conceição da Praia correspondem a 50 imóveis que aqui estão computados como o1, em função do valor da obra.

Tabela 7 - Programa de Recuperação do Centro Histórico de Salvador (indenizações)

\begin{tabular}{|c|c|c|c|c|}
\hline Indenizações & $\mathrm{N}^{\circ}$. de imóveis & $\mathrm{N}^{\circ}$. de famílias residentes & Valor da Indenização (R\$̣) & Valor da Ind./Família (R\$) \\
\hline $7^{\mathrm{a}}$ etapas & 89 & 344 & $500.000,00$ & $1.453,00$ \\
\hline $2^{\text {a }}$ etapa & 47 & 176 & $150.000,00 \backslash a$ & 852,00 \\
\hline $3^{\text {a }}$ etapa & 57 & 374 & $280.000,00$ & 748,00 \\
\hline $4^{\mathrm{a}}$ etapa & 140 & 894 & $900.000,00$ & $1.006,00$ \\
\hline $5^{\text {a }}$ etapa & 49 & 67 & $104.000,00$ & $1.552,00$ \\
\hline Total & 382 & 1.855 & $1.934 .000,00$ & $1.222,00$ (valor médio) \\
\hline
\end{tabular}

Fonte: Tabela montada a partir de informações obtidas no Instituto do Patrimônio Artístico e Cultural da Bahia - IPAC (abr. 2002). 
Tabela 8 - Programa de Recuperação do Centro Histórico de Salvador (obras previstas)

\begin{tabular}{|c|c|c|c|c|c|}
\hline Obras & Imóveis & Período & Recursos - & do (R\$) & Situação \\
\hline \multirow{5}{*}{$7^{\mathrm{a}}$ etapa } & \multirow{5}{*}{13004} & \multirow{5}{*}{$2002-2003$} & Estado da Bahia & $10.900 .000,00$ & \multirow{5}{*}{ Em execuçãc } \\
\hline & & & Ministério da Cultura & $3.900 .000,00$ & \\
\hline & & & BID & $9.800 .000,00$ & \\
\hline & & & CEF & $8.900 .000,00$ & \\
\hline & & & Total & $33.500 .000,00$ & \\
\hline
\end{tabular}

Fonte: Tabela montada a partir de informações obtidas na Companhia de Desenvolvimento Urbano do Estado da Bahia - CONDER (dez. 2002).

Tabela 9 - Programa de Recuperação do Centro Histórico de Salvador (investimentos em atividades permanentes)

\begin{tabular}{c|c|c|c|c}
\hline Atividade & Período & Responsável & Valor (R\$) & Valor médio/ano (R\$) \\
\hline $\begin{array}{c}\text { Animação - "Pelourinho } \\
\text { Dia \& Noite" (shows) }\end{array}$ & $1996-2000$ & SCT/Bahiatursa & $11.600 .000,00$ & $2.320 .000,00$ \\
\hline $\begin{array}{c}\text { Conservação e } \\
\text { Manutenção de Imóveis }\end{array}$ & $1997-2001$ & IPAC/CONDER & $5.450 .520,71$ & $1.090 .000,00$ \\
\hline Total & \multicolumn{3}{|c|}{} & $\mathbf{3 . 4 1 0 . 0 0 0 , 0 0}$ \\
\hline
\end{tabular}

Fonte: Tabela montada a partir de informaçōes obtidas junto à Direção do Instituto do Patrimônio Artístico e Cultural da Bahia - IPAC (abr. 2002) (ver Apêndice E).

Tabela 10 - Número e caracterização dos usuários do Centro Histórico de Salvador, 1995*

\begin{tabular}{c|c|c|c|c}
\hline \multicolumn{5}{c}{ Número de Usuários (média por dia) } \\
\hline Manhã & \multicolumn{2}{c}{ Tarde } & Noite & Total \\
\hline \multicolumn{2}{c|}{8.109} & $\mathbf{1 2 . 1 0 2}$ & $\mathbf{3 0 . 8 6 8}$ \\
\hline \multicolumn{4}{c|}{ Procedência dos Usuários (média por dia) } \\
\hline $\begin{array}{c}\text { Centro da cidade e } \\
\text { adjacências }\end{array}$ & $\begin{array}{c}\text { Outras áreas de } \\
\text { Salvador }\end{array}$ & Interior do estado & Turistas estrangeiros & Turistas nacionais \\
\hline $20 \%$ & $58 \%$ & $3 \%$ & $8 \%$ & $11 \%$ \\
\hline
\end{tabular}

Fonte: Companhia de Desenvolvimento da Região Metropolitana de Salvador (1996a). * Semana anterior ao carnaval. 
Tabela 11 - Número e caracterização dos usuários do Centro Histórico de Salvador, 1996*

\begin{tabular}{c|c|c|c|c}
\hline \multicolumn{5}{c}{ Número de usuários (média por dia) } \\
\hline Manhã & \multicolumn{2}{c}{ Tarde } & Noite & Total \\
\hline $\mathbf{1 6 . 2 3 1}$ & \multicolumn{2}{c|}{$\mathbf{1 9 . 1 0 4}$} & $\mathbf{1 3 . 1 9 4}$ & $\mathbf{4 1 . 4 6 2}$ \\
\hline \multicolumn{4}{c}{ Procedência dos usuários (média por dia) } \\
\hline $\begin{array}{c}\text { Centro da cidade e } \\
\text { adjacências }\end{array}$ & $\begin{array}{c}\text { Outras áreas de } \\
\text { Salvador }\end{array}$ & Interior do estado & Turistas estrangeiros & Turistas nacionais \\
\hline $\mathbf{2 2 \%}$ & $\mathbf{6 1 \%}$ & $\mathbf{1 \%}$ & $\mathbf{7 \%}$ & $\mathbf{9 \%}$ \\
\hline
\end{tabular}

Fonte: Companhia de Desenvolvimento da Região Metropolitana de Salvador (1996c)

*Semana posterior ao carnaval.

Quadro 1 - Perfil da população residente no Pelourinho antes das intervenções (por etapa)

\begin{tabular}{|c|c|c|c|}
\hline Perfil da População & $1^{\circ}$ etapa - (1992) & $6^{a}$ etapa $-(1997)$ & $7^{a}$ etapa $-(2000)$ \\
\hline População residente & 7.154 & 700 & 3.196 \\
\hline Número de famílias & 344 & 218 & 1.674 \\
\hline $\begin{array}{l}\text { Ocupação predominante } \\
\text { do chefe de família }\end{array}$ & vendedor ambulante & v. ambulante/doméstica & v. ambulante/doméstica* \\
\hline Renda média & 1а 2 SM & $3 \mathrm{SM}$ & $2 \mathrm{SM}$ \\
\hline Regime de ocupação do imóvel & Alugado & cessão/invasão & alugado \\
\hline Tempo de moradia na área & mais de 20 anos & mais de 20 anos & mais de 10 anos \\
\hline Motivo de moradia & proximidade do trabalho & proximidade do trabalho & proximidade do trabalho* \\
\hline
\end{tabular}

Fonte: Quadro montado a partir de informações obtidas em Instituto do Patrimônio Artístico e Cultural da Bahia (1992); Compahia de Desenvolvimento da Regiāo Metropolitana de Salvador; Instituto do Patrimônio Artístico e Cultural da Bahia (1997, 1998b); Companhia de Desenvolvimento Urbano do Estado da Bahia (2000). 
Quadro 2 - Relação de Empreendimentos do Projeto Rememorar

\begin{tabular}{|c|c|c|c|}
\hline RA & Bairro & Endereço & Fase \\
\hline \multicolumn{4}{|c|}{ Primeira etapa } \\
\hline \multirow{4}{*}{ I } & \multirow{4}{*}{ Santo Antônio } & Rua Joaquim Távora (antiga Rua Direita), nº 11 & Em obra \\
\hline & & Rua Joaquim Távora, (antiga Rua Direita), $n^{\circ} 19$ & Em obra \\
\hline & & Rua Deraldo Dias, $n^{\circ} 38,40$ e 42 & Em obra \\
\hline & & Rua Ribeiro dos Santos, $n^{\circ} 56$ & Em obra \\
\hline \multicolumn{4}{|c|}{ Número total de imóveis da primeira etapa - 06} \\
\hline \multicolumn{4}{|c|}{ Segunda etapa } \\
\hline \multirow{24}{*}{$\mathrm{i}$} & \multirow{3}{*}{ Perdões e Santo Antônio } & Rua Pedro Americano, $n^{\circ} 12,52$ e 54 & Em desapropriação \\
\hline & & Rua Monsenhor Tapiranga, $n^{\circ} 31$ & Em desapropriação \\
\hline & & Rua Joaquim Távora, nºg e 13 & Em desapropriação \\
\hline & Sodré & Rua Visconde de Mauá, $n^{\circ} 13$ & Em desapropriação \\
\hline & Av. Contorno & Rua Fagundes Varela, nº6 & Em desapropriação \\
\hline & \multirow{2}{*}{ Largo 2 de Julho } & Rua dos Democratas, $n^{\circ} 05,07$ e 23 & Em desapropriação \\
\hline & & Rua Areal de Baixo, $n^{\circ} 15$ & Em desapropriação \\
\hline & \multirow{3}{*}{ Comércio } & Praça Cairu, nº 05 & Em desapropriação \\
\hline & & Rua do Corpo Santo, nº 05 e 07 & Em desapropriação \\
\hline & & Ladeira da Montanha, $\mathrm{n}^{\circ} \mathrm{O} 2$ & Em desapropriação \\
\hline & Misericórdia & Ladeira da Misericórdia, $n^{\circ} 12,14,16,18,20,22$ e 24 & Em desapropriação \\
\hline & São Bento & Ladeira das Hortas, $\mathrm{n}^{\circ} \mathrm{O} 2 \mathrm{e} 04$ & Em desapropriação \\
\hline & \multirow{2}{*}{ Mouraria } & Rua do Castanheda, $n^{\circ} 45,47$ e 49 & Em desapropriação \\
\hline & & Rua da Independência, $n^{\circ} 18$ & Em desapropriação \\
\hline & \multirow{2}{*}{ Gravatá } & Rua do Gravatá, nº5, 07, 16, 20, 22 e 24 & Em desapropriação \\
\hline & & Praça dos Veteranos, $n^{\circ} 30$ & Em desapropriação \\
\hline & Desterro & Ladeira do Desterro, $\mathrm{n}^{\circ} \mathrm{O} 4$ & Em desapropriação \\
\hline & \multirow{4}{*}{ Saúde } & Largo da Saúde, nº 05 & Em desapropriação \\
\hline & & Rua da Glória, nº 14 & Em desapropriação \\
\hline & & Rua Jogo do Carneiro, n² 27 e 49 & Em desapropriação \\
\hline & & Rua do Genipapeiro, nº 04 e 06 & Em desapropriação \\
\hline & \multirow{3}{*}{ Soledade } & Ladeira da Soledade, $\mathrm{n}^{\circ} 116,118$ e 120 & Em desapropriação \\
\hline & & Rua São José de Cima, $n^{\circ} 74$ & Em desapropriação \\
\hline & & Rua São José de Baixo, nº 112 & Em desapropriação \\
\hline \multicolumn{4}{|c|}{ Número total de imóveis da segunda etapa - 48} \\
\hline
\end{tabular}

Fonte: Quadro montado a partir de informações obtidas no Escritório Técnico de Licenças e Fiscalização - ETELF e junto à coordenação do projeto Rememorar na Companhia de Desenvolvimento Urbano do Estado da Bahia - CONDER (nov. 2003). (ver Apêndice E). 
Tabela 12 - Evolução da população residente, segundo Áreas de Planejamento e Regiōes Administrativas da cidade do Rio de Janeiro, 1960/2000

\begin{tabular}{|c|c|c|c|c|c|c|}
\hline \multirow{2}{*}{$\begin{array}{l}\text { Áreas de Planejamento e } \\
\text { Regiōes Administrativas }\end{array}$} & \multicolumn{6}{|c|}{ População Residente } \\
\hline & 1960 & 1970 & 1980 & 1991 & 1996 & 2000 \\
\hline Total & 3.307 .163 & 4.251 .918 & 5.090 .700 & 5.480 .778 & 5.551 .538 & 5.857 .904 \\
\hline AP o1 & 399.599 & 367.470 & 338.531 & 303.695 & 282.544 & 268.280 \\
\hline RA I - Portuária & 54.742 & 51.052 & 50.907 & 44.085 & 40.727 & 39.953 \\
\hline RA II - Centro & 64.263 & 62.595 & 61.088 & 49.095 & 42.239 & 39.135 \\
\hline RA III - Rio Comprido & 115.414 & 95.416 & 86.542 & 82.344 & 81.095 & 73.661 \\
\hline RA VII - São Cristóvão & 94.090 & 90.473 & 86.547 & 80.360 & 72.354 & 70.945 \\
\hline RA XXI - Paquetá & 3.867 & 3.250 & 2.545 & 3.257 & 2.723 & 3.421 \\
\hline XXIII - Santa Tereza & 67.223 & 64.684 & 50.907 & 44.554 & 43.406 & 41.145 \\
\hline $\mathrm{AP} 02$ & 923.417 & 1.021 .165 & 7.130 .135 & 1.034 .612 & 1.004 .785 & 997.478 \\
\hline RA IV - Botafogo & 233.585 & 256.250 & 295.261 & 251.668 & 250.220 & 238.895 \\
\hline RA V-Copacabana & 240.347 & 239.256 & 213.809 & 769.680 & 168.836 & 161.178 \\
\hline RA VI - Lagoa & 157.560 & 175.586 & 239.263 & 177.072 & 174.115 & 174.062 \\
\hline RA VIII - Tijuca & 152.378 & 182.038 & 198.537 & 194.483 & 180.520 & 180.992 \\
\hline RA IX - Vila Isabel & 139.547 & 168.035 & 783.265 & 198.817 & 185.509 & 186.013 \\
\hline RA XXVII - Rocinha & - & - & - & 42.892 & 45.585 & 56.338 \\
\hline $\mathrm{AP}_{03}$ & 1.407 .695 & 1.928 .354 & 2.250 .180 & 2.323 .990 & 2.297 .712 & 2.353 .590 \\
\hline RAX-Ramos & 186.011 & 234.605 & 264.716 & 147.497 & 144.961 & 150.403 \\
\hline RAXI - Penha & 227.347 & 286.892 & 325.805 & 314.981 & 304.200 & 318.505 \\
\hline RA XII - Inhaúma & 136.326 & 179.333 & 193.447 & 137.539 & 127.509 & 130.539 \\
\hline RA XIII - Méier & 289.694 & 318.082 & 402.165 & 423.013 & 398.591 & 398.486 \\
\hline RAXIV - Irajá & 769.403 & 177.714 & 208.719 & 210.889 & 205.893 & 202.967 \\
\hline RAXV - Madureira & 265.348 & 330.040 & 386.983 & 373.753 & 362.442 & 374.157 \\
\hline RA XX - I. Governador & 56.121 & 105.651 & 173.084 & 197.158 & 199.347 & 211.469 \\
\hline RA XXII - Anchieta & 38.408 & 111.858 & 142.540 & 141.587 & 148.590 & 154.608 \\
\hline RAXXV - Pavuna & 39.037 & 121.179 & 152.721 & 179.256 & 197.538 & 197.068 \\
\hline RA XXVIII - Jacarezinho & - & - & - & 41.079 & 38.514 & 36.459 \\
\hline RAXXIX - C. Alemão & - & - & - & 62.037 & 64.037 & 65.026 \\
\hline RAXXX-Maré & - & - & - & 95.201 & 106.096 & 113.807 \\
\hline AP 04 & 766.672 & 241.017 & 356.349 & 526.302 & 575.992 & 682.051 \\
\hline RAXVI - Jacarepaguá & 164.092 & 235.238 & 315.623 & 428.073 & 446.360 & 469.682 \\
\hline RA XXIV - Barra Tijuca & 2.580 & 5.779 & 40.726 & 98.229 & 129.632 & 174.353 \\
\hline $\mathrm{AP} 05$ & 409.780 & 693.912 & 1.015 .595 & 1.292 .179 & 1.390 .505 & 7.556 .505 \\
\hline RA XVII - Bangu & 279.585 & 372.433 & 529.433 & 592.960 & 619.745 & 659.649 \\
\hline RA XVIII - C. Grande & 107.956 & 199.230 & 292.715 & 380.942 & 418.677 & 484.362 \\
\hline RA XIX - Santa Cruz & 55.119 & 92.927 & 147.630 & 254.503 & 277.776 & 311.289 \\
\hline RA XXVI - Guaratiba & 27.120 & 29.322 & 45.817 & 60.774 & 74.307 & 101.205 \\
\hline
\end{tabular}

Fonte: IBGE - Censo Demográfico (1991), Contagem da População (1996) e Censo (2000). 
Tabela 13 - Variação relativa do crescimento demográfico em Regiões Administrativas e Bairros da Área Central e em áreas da periferia da cidade do Rio de Janeiro, 1991/2000

\begin{tabular}{|c|c|c|c|}
\hline \multirow{2}{*}{ Regiōes Administrativas e Bairros } & \multicolumn{2}{|c|}{ População residente } & \multirow{2}{*}{ Variação relativa } \\
\hline & 1991 & 2000 & \\
\hline Total da cidade & 5.480 .778 & 5.857 .904 & 6,88 \\
\hline RA I - Portuária & 44.045 & 39.973 & $-9,33$ \\
\hline Saúde & 2.602 & 2.186 & $-15,99$ \\
\hline Gamboa & 11.507 & 10.490 & $-8,84$ \\
\hline Santo Cristo & 12.340 & 9.618 & $-22,06$ \\
\hline Caju & 17.636 & 17.679 & 0,24 \\
\hline RA II - Centro & 49.095 & 39.135 & $-20,29$ \\
\hline Centro & 49.095 & 39.135 & $-20,29$ \\
\hline RA III - Rio Comprido & 82.344 & 73.661 & $-10,54$ \\
\hline Catumbi & 12.507 & 12.914 & 3,25 \\
\hline Rio Comprido & 41.073 & 34.833 & $-15,19$ \\
\hline Cidade Nova & 7.814 & 5.282 & $-32,40$ \\
\hline Estácio & 20.950 & 20.632 & $-7,52$ \\
\hline RAXVI - Jacarepaguá & 389.864 & 469.682 & 20,47 \\
\hline Jacarepaguá & 62.991 & 100.822 & 60,06 \\
\hline Anil & 17.626 & 21.551 & 22,27 \\
\hline Gardênia Azul & 9.844 & 19.268 & 95,73 \\
\hline Curicica & 20.699 & 24.839 & 20,00 \\
\hline Freguesia & 48.970 & 54.010 & 10,29 \\
\hline Pechincha & 28.816 & 37.615 & 9,71 \\
\hline Taquara & 88.576 & 93.741 & 5,83 \\
\hline Tanque & 29.934 & 32.462 & 8,45 \\
\hline Praça Seca & 54.358 & 59.657 & 9,75 \\
\hline Vila Valqueire & 28.050 & 31.717 & 13,07 \\
\hline RA XXIV - Barra da Tijuca & 98.229 & 174.353 & 77,50 \\
\hline Joá & 823 & 971 & 17,98 \\
\hline Itanhangá & 9.356 & 21.813 & 133,14 \\
\hline Barra da Tijuca & 63.492 & 92.233 & 45,27 \\
\hline Camorim & 145 & 786 & 442,07 \\
\hline Vargem Pequena & 3.394 & 11.536 & 239,89 \\
\hline Vargem Grande & 6.558 & 9.306 & 41,90 \\
\hline Recreio dos Bandeirantes & 14.344 & 37.572 & 161,94 \\
\hline Grumari & 117 & 136 & 16,24 \\
\hline RA XIX - Santa Cruz & 254.500 & 311.289 & 22,31 \\
\hline Paciência & 55.655 & 83.561 & 50,14 \\
\hline Santa Cruz & 172.795 & 191.836 & 11,02 \\
\hline Sepetiba & 26.050 & 35.892 & 37,78 \\
\hline RA XXVI - Guaratiba & 60.774 & 101.205 & 66,53 \\
\hline Guaratiba & 49.295 & 87.132 & 76,76 \\
\hline Barra de Guaratiba & 4.189 & 4.380 & 4,56 \\
\hline Pedra de Guaratiba & 7.290 & 9.693 & 32,96 \\
\hline
\end{tabular}


Tabela 14 - Participação relativa do Rio de Janeiro, São Paulo e demais unidades da Federação no PIB/BR (1947/1995)

\begin{tabular}{c|c|c|c|c|c|c|c}
\hline UF & $\mathbf{1 9 4 7}$ & $\mathbf{1 9 5 5}$ & $\mathbf{1 9 6 8}$ & $\mathbf{1 9 7 5}$ & $\mathbf{1 9 8 5}$ & $\mathbf{1 9 9 0 *}$ & $\mathbf{1 9 9 5}^{*}$ \\
\hline Rio de Janeiro & $\mathbf{1 8 , 7 1 \%}$ & $\mathbf{1 7 , 9 6 \%}$ & $\mathbf{1 5 , 7 1 \%}$ & $\mathbf{1 5 , 3 0 \%}$ & $\mathbf{1 2 , 1 9 \%}$ & $\mathbf{1 0 , 8 9 \%}$ & $\mathbf{1 2 , 7 5 \%}$ \\
\hline São Paulo & $32,45 \%$ & $35,93 \%$ & $35,23 \%$ & $40,08 \%$ & $34,39 \%$ & $35,70 \%$ & $36,27 \%$ \\
\hline Demais UFs & $48,84 \%$ & $46, \mathbf{1 1} \%$ & $49,06 \%$ & $44,62 \%$ & $53,42 \%$ & $53,41 \%$ & $50,98 \%$ \\
\hline Total & $\mathbf{1 0 0 , 0 0 \%}$ & $\mathbf{1 0 0 , 0 0 \%}$ & $\mathbf{1 0 0 , 0 0 \%}$ & $\mathbf{1 0 0 , 0 0 \%}$ & $\mathbf{1 0 0 , 0 0 \%}$ & $\mathbf{1 0 0 , 0 0 \%}$ & $\mathbf{1 0 0 , 0 0 \%}$ \\
\hline
\end{tabular}

Fonte: Tabela montada a partir de dados obtidos em Mesentier (1992-2001), (fonte primária: Centro de Contas Nacionais - FGV) e Anuário Estatístico da Cidade do Rio de Janeiro 1995-1997, disponibilizado pelo Instituto Municipal de Urbanismo Pereira Passos - IPP.

* Totais ajustados pela Diretoria de Informaçăo da Cidade do IPP

Tabela 15 - Arrecadação de ISS (Imposto sobre Serviços) segundo Áreas de Planejamento, com destaque para a participação da II RA (Centro)

\begin{tabular}{c|c|c|c|c|c|c}
\hline \multirow{2}{*}{ Áreas de Planejamento } & \multicolumn{2}{|c|}{1995} & \multicolumn{2}{c|}{1996} & \multicolumn{2}{c}{1997} \\
\cline { 2 - 7 } & (1000) R\$ & \% & (1000)R\$ & \% & (1000)R\$ & \% \\
\hline AP 01 & 274.427 & 46,05 & 325.719 & 46,68 & 353760 & 48,13 \\
II RA (Centro) & $\mathbf{2 1 1 . 2 7 6}$ & $\mathbf{3 5 , 4 5}$ & $\mathbf{2 5 7 . 0 0 7}$ & $\mathbf{3 6 , 8 3}$ & $\mathbf{2 7 4 . 5 0 4}$ & $\mathbf{3 7 , 3 5}$ \\
\hline AP 02 & 168.743 & 28,32 & 196.010 & 28,09 & 209.776 & 28,54 \\
\hline AP 03 & 90.510 & 15,19 & 108.426 & 15,54 & 104.281 & 14,19 \\
\hline AP 04 & 28.738 & 4,82 & 34.375 & 4,93 & 37.010 & 5,04 \\
\hline AP 05 & 13.482 & 2,26 & 17.129 & 2,45 & 17.178 & 2,33 \\
\hline Ignorado & 20.042 & 3,36 & 16.143 & 2,37 & 13.048 & 1,78 \\
\hline Total & $\mathbf{5 9 5 . 9 4 1}$ & $\mathbf{1 0 0 , 0 0}$ & $\mathbf{6 9 7 . 8 0 1}$ & $\mathbf{1 0 0 , 0 0}$ & $\mathbf{7 3 4 . 9 9 3}$ & $\mathbf{1 0 0 , 0 0}$ \\
\hline
\end{tabular}

Fonte: Anuário Estatístico da Cidade do Rio de Janeiro 1995-1997, disponibilizado pelo Instituto Municipal de Urbanismo Pereira Passos - IPP. * *Fonte primária: Secretaria Municipal da Fazenda, posição em fevereiro de 1998.

Tabela 16 - Arrecadação de IPTU, em valores correntes, das dez Regiões Administrativas que mais arrecadam no município do Rio de Janeiro, 1995/1999

\begin{tabular}{|c|c|c|c|c|c|c|c|c|c|c|}
\hline \multirow{2}{*}{$\begin{array}{l}\text { Região } \\
\text { Administrativa }\end{array}$} & \multicolumn{2}{|c|}{1995} & \multicolumn{2}{|c|}{1996} & \multicolumn{2}{|c|}{1997} & \multicolumn{2}{|c|}{1998} & \multicolumn{2}{|c|}{1999} \\
\hline & $\mathrm{R} \$$ & $\%$ & $\mathrm{R} \$$ & $\%$ & $\mathrm{R} \$$ & $\%$ & $\mathrm{R} \$$ & $\%$ & $\mathrm{R} \$$ & $\%$ \\
\hline $\begin{array}{l}\text { XXIV - Barra da } \\
\text { Tijuca }\end{array}$ & 52.004 .912 & 17,13 & 55.071 .122 & 16,10 & 60.178046 & 16,82 & 75.399 .961 & 17,31 & 111.809 .229 & 17,16 \\
\hline VI - Lagoa & 43.801 .741 & 14,43 & 51.166 .521 & 14,96 & 52.372 .187 & 14,64 & 67.409 .153 & 15,48 & 102.392 .233 & 15,72 \\
\hline II Centro & 38.600 .365 & 12,71 & 43.394 .346 & 12,69 & 47.591 .485 & 13,30 & 59.525 .740 & 13,67 & 88.650 .031 & 13,61 \\
\hline IV - Botafogo & 36.700 .750 & 12,09 & 40.654 .657 & 11,89 & 41.120 .578 & 11,49 & 43.873 .523 & 10,07 & 75.786 .775 & 11,63 \\
\hline V-Copacabana & 22.875 .877 & 7,54 & 26.330 .194 & 7,70 & 27.226 .341 & 7,61 & 32.970 .982 & 7,57 & 49.746 .511 & 7,64 \\
\hline VIII - Tijuca & 14.399 .063 & 4,74 & 17.237 .112 & 5,04 & 16.882 .168 & 4,72 & 21.708 .371 & 4,98 & 33.391 .143 & 5,13 \\
\hline XVI - Jacarepaguá & 12.697 .328 & 4,78 & 14.658 .118 & 4,29 & 16.252 .979 & 4,54 & 22.864 .909 & 5,25 & 30.421 .826 & 4,67 \\
\hline IX - Vila Isabel & 11.645 .499 & 3,84 & 11.630 .448 & 3,40 & 13.436 .116 & 3,76 & 16.901 .020 & 3,88 & 27.136 .187 & 4,17 \\
\hline XIII - Méier & 12.197 .585 & 4,02 & 14.509 .506 & 4,24 & 14.995 .191 & 4,19 & 18.334 .542 & 4,21 & 22.168 .118 & 3,40 \\
\hline XV - Madureira & 8.009 .434 & 2,64 & 9.003 .068 & 2,64 & 9.344 .636 & 2,61 & 10.196 .251 & 2,34 & 15.342 .854 & 2,36 \\
\hline
\end{tabular}

Fonte: Diretoria de Informações da Cidade do Instituto Municipal de Urbanismo Pereira Passos - IPP (fonte primária Secretaria Municipal da Fazenda). 
Tabela 17 - Arrecadação do ICMS (Imposto sobre Circulação de Mercadorias e Serviços) segundo Áreas de Planejamento, com destaque para a participação da II RA (Centro)

\begin{tabular}{c|c|c|c|c}
\hline \multirow{2}{*}{ Área de Planejamento } & \multicolumn{2}{|c|}{ 1996 } & \multicolumn{2}{c}{ 1998 } \\
\cline { 2 - 5 } & Total (R\$) & \% & Total (R\$) & \% \\
\hline AP o1 & 1.310 .714 .678 & 43,73 & 1.819 .633 & 43,75 \\
II RA (Centro) & $\mathbf{4 9 1 . 5 3 2 . 8 1 3}$ & $\mathbf{1 6 , 3 9}$ & $\mathbf{6 8 2 . 3 8 3}$ & $\mathbf{1 6 , 4 0}$ \\
\hline AP 02 & 154.639 .966 & 5,18 & 214.683 & 5,16 \\
\hline AP 03 & 952.149 .803 & 31,78 & 1.321 .846 & 31,79 \\
\hline AP 04 & 366.678 .408 & 12,26 & 509.051 & 12,23 \\
\hline AP 05 & 211.599 .496 & 7,05 & 293.758 & 7,07 \\
\hline Total & $\mathbf{2 . 9 9 5 . 7 8 2 . 3 5 0}$ & $\mathbf{1 0 0 , 0 0}$ & $\mathbf{4 . 1 5 8 . 9 7 2}$ & $\mathbf{1 0 0 , 0 0}$ \\
\hline
\end{tabular}

Fonte: Diretoria de Informações da Cidade do Instituto Municipal de Urbanismo Pereira Passos - IPP (fonte primária: Secretaria Municipal da Fazenda).

Nota: Estimativa elaborada com base na arrecadação total aferida em 1998 e na participação percentual observada em cada setor e bairro no ano de 1996.

Tabela 18 - Matriz de viagens, origem e destino - Modo coletivo, segundo Região Administrativa do Rio de Janeiro (hora mais carregada do pico da manhã) - 1994

\begin{tabular}{c|c|c}
\hline Região Administrativa & Total de viagens & Percentual \\
\hline Total & $\mathbf{5 0 3 . 3 0 0}$ & $\mathbf{1 0 0 , 0 0 \%}$ \\
\hline II RA - Centro & $\mathbf{1 2 6 . 5 6 1}$ & $\mathbf{2 5 , 1 4 \%}$ \\
\hline XIII RA - Méier & 31.602 & $6,28 \%$ \\
\hline XVII RA - Bangu & 37.289 & $6,22 \%$ \\
\hline IV RA - Botafogo & 31.057 & $6,17 \%$ \\
\hline VIII RA - Tijuca & 29.993 & $5,96 \%$ \\
\hline XV RA - Madureira & 29.298 & $5,83 \%$ \\
\hline X RA - Ramos & 27.556 & $4,28 \%$ \\
\hline XVI RA - Jacarepaguá & 19.721 & $3,92 \%$ \\
\hline VI RA - Lagoa & 19.544 & $3,88 \%$ \\
\hline XXIV RA - Barra da Tijuca & 17.692 & $3,52 \%$ \\
\hline XVIII RA - Campo Grande & 17.577 & $3,49 \%$ \\
\hline XIX RA - Santa Cruz & 14.256 & $2,83 \%$ \\
\hline V RA - Copacabana & 13.913 & $2,76 \%$ \\
\hline Demais Regiöes Administrativas & $\mathbf{9 9 . 2 4 1}$ & $\mathbf{1 9 , 7 2 \%}$ \\
\hline
\end{tabular}

Fonte: Anuário Estatístico da Cidade do Rio de Janeiro 1995-1997, disponibilizado pelo Instituto Municipal de Urbanismo Pereira Passos - IPP. 
Tabela 19 - Percentagem de imóveis comercializados por Região Administrativa (1991/2000) do Rio de Janeiro - Mercado Imobiliário Formal

\begin{tabular}{|c|c|c|c|c|c|c|}
\hline \multirow{2}{*}{ Região Administrativa } & \multicolumn{6}{|c|}{ Percentagem de Imóveis Comercializados } \\
\hline & Até $0,7 \%$ & De 0,7 a $2,1 \%$ & De 2,1 a $2,9 \%$ & De 2,9 a $4,0 \%$ & De 4,0 a $4,7 \%$ & Acima de $4,7 \%$ \\
\hline \multicolumn{7}{|l|}{ I RA (Portuária) } \\
\hline \multicolumn{7}{|l|}{ II RA (Centro) } \\
\hline \multicolumn{7}{|l|}{ III RA (Rio Comprido) } \\
\hline \multicolumn{7}{|l|}{ IV RA (Botafogo) } \\
\hline \multicolumn{7}{|l|}{ VRA (Copacabana) } \\
\hline \multicolumn{7}{|l|}{ VI RA (Lagoa) } \\
\hline \multicolumn{7}{|l|}{ VII RA (São Cristóvão) } \\
\hline \multicolumn{7}{|l|}{ VIII RA (Tijuca) } \\
\hline \multicolumn{7}{|l|}{ IX RA (Vila Isabel) } \\
\hline \multicolumn{7}{|l|}{ XIII RA (Santa Tereza) } \\
\hline \multicolumn{7}{|l|}{ XVI RA (Jacarepaguá) } \\
\hline \multicolumn{7}{|l|}{ XVII RA (Bangu) } \\
\hline \multicolumn{7}{|l|}{ XVIII RA (Campo Grande) } \\
\hline \multicolumn{7}{|l|}{ XIX RA (Santa Cruz) } \\
\hline \multicolumn{7}{|l|}{ XXI RA (Paquetá) } \\
\hline \multicolumn{7}{|l|}{ XXIV RA (Barra da Tijuca) } \\
\hline \multicolumn{7}{|l|}{ XXVI RA (Guaratiba) } \\
\hline \multicolumn{7}{|l|}{ XXVII RA (Rocinha) } \\
\hline Média da Cidade (2,87\%) & & & & & & \\
\hline
\end{tabular}

Fonte: Instituto Municipal de Urbanismo Pereira Passos - IPP, Divisão de Informações Geográficas. 
Tabela 20 - Lançamentos imobiliários, imóveis residenciais e comerciais segundo Áreas de Planejamento e Regiões Administrativas do Rio de Janeiro, 1994/1998

\begin{tabular}{|c|c|c|c|c|c|c|c|c|c|c|}
\hline \multirow{2}{*}{$\begin{array}{l}\text { A. Planejamento } \\
\text { Região Administrativa }\end{array}$} & \multicolumn{2}{|c|}{1994} & \multicolumn{2}{|c|}{1995} & \multicolumn{2}{|c|}{1996} & \multicolumn{2}{|c|}{1997} & \multicolumn{2}{|c|}{1998} \\
\hline & Resid. & Com & Resid. & Com. & Resid. & Com. & Resid. & Com. & Resid. & Com. \\
\hline II RA - Centro & o & 0 & o & 0 & o & 0 & 0 & 0 & 0 & 135 \\
\hline III RA - R. Comprido & o & 0 & 103 & o & o & 0 & o & 0 & o & o \\
\hline AP 01 & 0 & 0 & 103 & o & 0 & o & $\mathrm{o}$ & 0 & 0 & 135 \\
\hline IV RA - Botagofo & 250 & 0 & 88 & o & 222 & 0 & 408 & 0 & 0 & 8 \\
\hline VRA - Copacabana & 117 & o & 0 & o & 0 & o & 0 & o & 0 & o \\
\hline VI RA - Lagoa & 148 & 0 & 430 & 10 & 215 & 0 & o & 218 & 0 & 10 \\
\hline VIII RA - Tijuca & 468 & 0 & 215 & 0 & 162 & 84 & 328 & 0 & 268 & o \\
\hline IX RA - Vila Isabel & 0 & 0 & 489 & o & $\mathrm{o}$ & 0 & 0 & o & 0 & o \\
\hline $\mathrm{AP} O 2$ & 983 & 0 & 1.223 & 10 & 598 & 84 & 737 & 218 & 268 & 18 \\
\hline XIII RA - Méier & 476 & o & 112 & $\mathrm{o}$ & 237 & 0 & 236 & $\mathrm{o}$ & 638 & 0 \\
\hline XIV RA - Irajá & 0 & 0 & $\mathrm{O}$ & 0 & $\mathrm{o}$ & 1 & 0 & 0 & 0 & 0 \\
\hline AP O3 & 476 & o & 112 & 0 & 237 & 1 & 236 & 0 & 638 & 0 \\
\hline XVI RA - Jacarepaguá & 967 & o & 1.629 & o & 636 & 248 & 536 & 0 & 1.444 & o \\
\hline XXIV RA - B. Tijuca & 4.228 & o & 1.027 & 2.186 & 1.871 & 384 & 1921 & 2.127 & 1.615 & 1.500 \\
\hline $\mathrm{AP} 04$ & 5.195 & 0 & 2.656 & 2.186 & 2.507 & 632 & 2.458 & 2.127 & 3.059 & 1500 \\
\hline XVII RA - Bangu & 936 & o & 103 & 0 & o & 0 & o & 89 & o & 0 \\
\hline XVIII RA - C. Grande & 0 & o & 0 & 0 & 0 & o & 112 & 0 & 242 & o \\
\hline AP 05 & 936 & 0 & 103 & $\mathrm{o}$ & 0 & o & 112 & 89 & 242 & 0 \\
\hline Total & 7.801 & o & 4.891 & 2.196 & 3.764 & 717 & 4.003 & 2.434 & 4.401 & 1.653 \\
\hline
\end{tabular}

Fonte: Anuário Estatístico da Cidade do Rio de Janeiro, 1998-1999, disponibilizado pelo Instituto Municipal de Urbanismo Pereira Passos - IPP (fonte primária: Associação de Dirigentes de Empresas do Mercado Imobiliário - ADEMI). 
Tabela 21 - Imissão de IPTU e taxas por bairro e por classe, com relação ao total da cidade do Rio de Janeiro, 1999

\begin{tabular}{|c|c|c|c|c|c|c|c|c|}
\hline \multirow{2}{*}{ Bairro } & \multicolumn{2}{|c|}{ Residencial } & \multicolumn{2}{|c|}{ Não Residencial } & \multicolumn{2}{|c|}{ Territorial } & \multicolumn{2}{|l|}{ Total } \\
\hline & Valor & $\%$ & Valor & $\%$ & Valor & $\%$ & Valor & $\%$ \\
\hline Barra da Tijuca & $68.369 .285,87$ & 15,57 & 43.551.191,59 & 9,20 & $31.365 .422,36$ & 33,85 & $143.285 .899,82$ & 14,26 \\
\hline Botafogo & $16.459 .425,90$ & 3,75 & $34 \cdot 547 \cdot 313,52$ & 7,30 & $1.056 .060,40$ & 1,14 & $52.062 .799,82$ & 5,18 \\
\hline Caju & $71.794,79$ & 0,02 & $2.295 \cdot 415,43$ & 0,49 & $50.006,48$ & 0,05 & $2.417 .216,69$ & 0,24 \\
\hline Catumbi & $308.877,80$ & 0,07 & $408.498,98$ & 0,09 & $23 \cdot 347,14$ & 0,03 & $740.723,92$ & 0,07 \\
\hline Centro & $3.541 .020,97$ & 0,81 & $121.989 .871,89$ & 25,78 & $2.529 .872,38$ & 2,73 & $128.060 .765,23$ & 12,74 \\
\hline Cidade Nova & $248.137,56$ & 0,06 & $3.055 .698,18$ & 0,65 & $112.131,00$ & 0,12 & $3.415 .966,75$ & 0,34 \\
\hline Copacabana & $43.146 .666,40$ & 9,83 & $24 \cdot 273.728,58$ & 5,13 & $473.751,30$ & 0,51 & $67.894 .146,28$ & 6,76 \\
\hline Gamboa & $263.210,47$ & 0,06 & $2.089 \cdot 576,69$ & 0,44 & $8.690,03$ & 0,01 & $2.361 .477,18$ & 0,23 \\
\hline Ipanema & $28.964 .215,57$ & 6,60 & $12.488 .651,13$ & 2,64 & $359.202,13$ & 0,39 & $41.812 .068,83$ & 4,16 \\
\hline Lagoa & $14 \cdot 665 \cdot 231,88$ & 3,34 & $1.208 .083,00$ & 0,26 & $501.394,08$ & 0,54 & $16.374 .708,96$ & 1,63 \\
\hline Madureira & $1.169 .606,65$ & 0,27 & $7.529 .788,01$ & 1,59 & $709.168,47$ & 0,77 & $9.408 .563,13$ & 0,94 \\
\hline Méier & $3.835 .902,98$ & 0,87 & $6.732 .187,95$ & 1,42 & $90.522,83$ & 0,10 & $10.658 .613,76$ & 1,06 \\
\hline Santa Cruz & $569 \cdot 646,35$ & 0,13 & $3.528 .443,62$ & 0,75 & $1.311 .660,62$ & 1,42 & $5.409 \cdot 750,59$ & 0,54 \\
\hline Santa Tereza & $2.552 .274,77$ & 0,58 & $551.728,55$ & 0.12 & $207.609,20$ & 0,22 & $3.311 .612,52$ & 0,33 \\
\hline Santo Cristo & $350.960,19$ & 0,08 & $2.504 .852,73$ & 0,53 & $13.344,88$ & 0,01 & $2.869 .157,80$ & 0,29 \\
\hline Saúde & $98.725,54$ & 0,02 & $1.388 .767,05$ & 0,29 & $32.580,52$ & 0,04 & $1.520 .073,11$ & 0,15 \\
\hline Tijuca & $28.163 .933,67$ & 6,41 & $17.371 .004,82$ & 3,67 & $1.425 \cdot 753,97$ & 1,54 & $46.960 .692,46$ & 4,67 \\
\hline
\end{tabular}

Fonte: Secretaria Municipal da Fazenda - Anuário do IPTU e Taxa de Coleta Domiciliar de Lixo (1999).

Tabela 22 - Tombamentos realizados na cidade do Rio de Janeiro, 2002

\begin{tabular}{|c|c|c|c|c|}
\hline Região Administrativa & União & Estado & Município* & Total parcial \\
\hline I RA (Caju, Gamboa, Saúde, Santo Cristo) & 07 & 08 & 15 & 30 \\
\hline II RA (Centro) & 55 & 37 & 50 & $142^{* *}$ \\
\hline III RA (Catumbi, Cidade Nova, Rio Comprido) & $\mathrm{O} 2$ & 03 & 04 & $09^{* * *}$ \\
\hline Total na área central & 64 & 48 & 69 & 181 \\
\hline Total no município & 194 & 137 & 267 & 592 \\
\hline Percentual área central & $33 \%$ & $37 \%$ & $26 \%$ & $30,50 \%$ \\
\hline
\end{tabular}

Fonte: Tabela montada a partir de informações obtidas junto ao Arquivo Noronha Santos do IPHAN (para bens tombados após 1994); Instituto do Patrimônio Histórico e Artístico Nacional (1994); junto ao Instituto Estadual do Patrimônio Artístico e Cultural do Estado do Rio de Janeiro - INEPAC (ver Anexo E) e Rio de Janeiro (2001a) * Dados até 1997

** O número total de bens tombados nessa II RA é 140, pois há um mesmo bem tombado pela União e pelo Município e um mesmo bem tombado pelo Estado e pelo Município.

*** O número total de bens tombados na III RA é 08 , pois há um mesmo bem tombado pelo Estado e pelo Município. 
Tabela 23 - Perfil do público frequentador do Centro Cultural Banco do Brasil (Rio de Janeiro)

\begin{tabular}{c|c|c|c}
\hline \multicolumn{2}{c|}{ Faixa de renda (percentual) } & \multicolumn{2}{c}{ Escolaridade (percentual) } \\
\hline $\mathrm{a}_{1}$ & $6,5 \%$ & Superior completo & $57,55 \%$ \\
\hline $\mathrm{A}_{2}$ & $25,4 \%$ & Superior incompleto & $19,20 \%$ \\
\hline $\mathrm{B}_{1}$ & $27,4 \%$ & $2^{\circ}$ grau completo & $14,52 \%$ \\
\hline $\mathrm{B} 2$ & $20,5 \%$ & $2^{\circ}$ grau incompleto & $4,78 \%$ \\
\hline $\mathrm{C}$ & $13,7 \%$ & $7^{\circ}$ grau completo & $2,42 \%$ \\
\hline D e E & $6,5 \%$ & $7^{\circ}$ grau incompleto & $1,53 \%$ \\
\hline Total & $100,0 \%$ & Total & $100,00 \%$ \\
\hline Total das faixas A e B & $\mathbf{7 9 , 8} \%$ & Total nível superior & $\mathbf{7 6 , 7 5 \%}$ \\
\hline
\end{tabular}

Fonte: Centro Cultural Banco do Brasil (1999-a)

Tabela 24 - Captação de recursos para a programação do Centro Cultural Banco do Brasil/RJ através do Programa Nacional de Apoio à Cultura - PRONAC, 1997/2002

\begin{tabular}{|c|c|c|c|c|c|c|}
\hline Número & Nome do projeto & Situação & Solicitado & Aprovado & Captado & $\%$ * \\
\hline 962221 & $\begin{array}{c}\text { Plano Anual de Atividades } \\
\text { do CCBB - } 1997\end{array}$ & Prestação de contas aprovada & $12.004 .938,64$ & $11.050 .639,07$ & $5.400 .644,84$ & 48,87 \\
\hline 970138 & Anima Mundi 97 & Nada captou - projeto arquivado & $2.307 .376,88$ & $2.307 .376,87$ & 0,00 & 0,00 \\
\hline 972481 & Andy Warhol Grande Retrospectiva & $\begin{array}{c}\text { Análise técnica do relatório } \\
\text { final de PC }\end{array}$ & $2.040 .530,47$ & $1.274 .063,57$ & $1.245 \cdot 494,05$ & 97,75 \\
\hline 972866 & $\begin{array}{c}\text { Plano Anual de Atividades } \\
\text { do CCBB - } 1998\end{array}$ & Prestação de contas aprovada & $11.207 .530,65$ & $10.207 .530,19$ & $6.343 .440,63$ & 62,14 \\
\hline 983181 & $\begin{array}{c}\text { Plano Anual de Atividades } \\
\text { do CCBB - } 1999\end{array}$ & Prestação de contas aprovada & $22.397 .280,77$ & $10.233 \cdot 405,48$ & $7.126 .422,39$ & 69,63 \\
\hline 991795 & $\begin{array}{c}\text { Plano Anual de Atividades } \\
\text { do CCBB - } 2000\end{array}$ & Prestação de contas aprovada & $8.726 .379,16$ & $8.166 .876,51$ & $4 . .517 .894,60$ & 55,31 \\
\hline 997861 & $\begin{array}{l}\text { Centro Cultural Banco do Brasil } \\
\text { - São Paulo }\end{array}$ & Nada captou - projeto arquivado & $7.861 .451,00$ & 0,00 & 0,00 & 0,00 \\
\hline 001634 & $\begin{array}{c}\text { Plano Anual de Atividades } \\
\text { do CCBB - } 2000\end{array}$ & Projeto em duplicidade & $18.425 \cdot 453,41$ & 0,00 & 0,00 & 0,00 \\
\hline 003948 & OSurrealismo & Apresentou prestação de contas & $3.336 .935,03$ & $3 . .360 .364,53$ & $3.069 \cdot 259,92$ & 91,33 \\
\hline 004531 & $\begin{array}{c}\text { Aquisição de Equipamentos } \\
\text { para o CCBB - SP }\end{array}$ & $\begin{array}{c}\text { Prestação de contas aprovada } \\
\text { com ressalva formal e sem } \\
\text { prejuízo }\end{array}$ & $1.976 .908,00$ & $1.976 .908,00$ & $1.500 .000,00$ & 75,87 \\
\hline 011501 & $\begin{array}{c}\text { Plano Anual de Atividades } \\
\text { do CCBB - } 2001\end{array}$ & Apresentou prestação de contas & $14.835 \cdot 248,87$ & $13.201 .900,96$ & $7.165 .030,23$ & 54,27 \\
\hline 014264 & $\begin{array}{l}\text { Plano Anual de Atividades } \\
\text { do CCBB RJ - Módulo } 1\end{array}$ & Captação parcial & $5.095 .428,20$ & $5.085 \cdot 238,52$ & $2.276 .401,00$ & 44,76 \\
\hline 014277 & $\begin{array}{l}\text { Plano Anual de Atividades } \\
\text { do CCBB RJ - Módulo } 2\end{array}$ & Captação parcial & $6.919 \cdot 978,73$ & $6.915 \cdot 586,63$ & $4.082 .067,01$ & 59,02 \\
\hline 013216 & Coleção Sérgio Fadel & Captação parcial & $1.749 \cdot 462,02$ & $1.452 .378,79$ & $945.165,37$ & 65,07 \\
\hline 013214 & Jac Leiner - Ad Infinitum & Apresentou prestação de contas & $318.189,91$ & $318.189,91$ & $189.846,68$ & 59,66 \\
\hline \multicolumn{3}{|c|}{ Total (em R\$) } & $149.203 .091,74$ & $72.550 .459,03$ & $43.861 .666,72$ & 60,45 \\
\hline
\end{tabular}

Fonte: Ministério da Cultura, Sistema de Apoio às Leis de Incentivo à Cultura - SALIC

Obs.: não foram computados os projetos apresentados, mas ainda não aprovados pelo Ministério da Cultura.

* Percentual captado em relação ao montante aprovado. 
Tabela 25 - Localização das intervenções de requalificação de espaços públicos na área central do Rio de Janeiro (anos go)

\begin{tabular}{l|c|c}
\hline Área & Intervenções realizadas & Parceria setor público e privado \\
\hline ACN (núcleo dinâmico do centro) & $39,0 \%$ & $8,7 \%$ \\
\hline Zona de Transição (ZT) & $37,0 \%$ & $4,4 \%$ \\
\hline Zona Periférica & $23,0 \%$ & $0,0 \%$ \\
\hline Zona Portuária & $07,0 \%$ & $0,0 \%$ \\
\hline Total & $100,0 \%$ & $13,0 \%$ \\
\hline Total ACN + ZT & $\mathbf{7 0 , 0} \%$ & $\mathbf{1 3 , 0 \%}$ \\
\hline
\end{tabular}

Fonte: Tabela montada a partir de informações obtidas em MAGALHĀES, 2001; Entrevista de Augusto Ivan de Freitas Pinheiro (Apêndice E); Empresa Municipal de Informática e Planejamento (1990a, 1990b, [1992?]); Empresa Municipal de Informática e Planejamento; Instituto Municipal de Arte e Cultura (1989a, 1989b); Rio de Janeiro (1998); Blyth (1991, p.68-69, Apêndice C)

Tabela 26 - Terrenos vazios na II RA do Rio de Janeiro, segundo tipologia e regime de propriedade, 1995/1996

\begin{tabular}{l|c|c|c|c|c|c|c}
\hline Tipologia & $\begin{array}{c}\text { Número } \\
\text { de lotes }\end{array}$ & $\begin{array}{c}\text { Área total } \\
\text { na RA }\left(\mathbf{m}^{2}\right)\end{array}$ & $\%$ & $\begin{array}{c}\text { Governo Federal } \\
\left(\mathbf{m}^{2} / \text { lote }\right)\end{array}$ & $\begin{array}{c}\text { Governo Estadual } \\
\left(\mathbf{m}^{2} / \text { lote }\right)\end{array}$ & $\begin{array}{c}\text { Prefeitura } \\
\left(\mathbf{m}^{2} / \mathbf{l o t e}\right)\end{array}$ & $\begin{array}{c}\text { Particular } \\
\left(\mathbf{m}^{2} / \mathbf{l o t e}\right)\end{array}$ \\
\hline Sem edificação e uso & 56 & 77.747 & 25,30 & $4.475 / 04$ lotes & $17.337 / 11$ lotes & $20.922 / 10$ lotes & $35.013 / 33$ lotes \\
\hline Fachada & 47 & 7.884 & 2,60 & $126 /$ o1 lote & $574 /$ o3 lotes & $660 / 01$ lote & $6.524 / 40$ lotes \\
\hline $\begin{array}{l}\text { Fachada com interior } \\
\text { arruinado }\end{array}$ & 136 & 32.512 & 10,60 & $1.940 / 02$ lotes & $6.476 / 11$ lotes & $3.633 / 08$ lotes & $20.463 / 115$ lotes \\
\hline Estacionamento irregular & 125 & 188.672 & 61,50 & $57.564 / 13$ lotes & $30.017 / 13$ lotes & $28.860 / 72$ lotes & $72.237 / 87$ lotes \\
\hline Total & $\mathbf{3 6 4}$ & $\mathbf{3 0 6 . 8 1 5}$ & $\mathbf{1 0 0 , 0 0}$ & $\mathbf{6 4 . 1 0 5 / 2 1 , 0 0 \%}$ & $\mathbf{5 4 . 4 0 4 / 1 7 , 7 0 \%}$ & $\mathbf{5 4 . 0 7 5 / 1 7 , 6 0 \%}$ & $\mathbf{1 3 4 . 2 3 1 / 4 3 , 7 0 \%}$ \\
\hline
\end{tabular}

Fonte: Neves (1996, p. 79-83). 
Quadro 3 - Espaços e centros culturais na área central e na Cidade do Rio de Janeiro, 2002

\begin{tabular}{|c|c|c|}
\hline Espaço ou centro cultural e Endereço & Localizaç & ro e RA) \\
\hline Casa de Banhos D. João VI, Rua Praia do Caju, n. 385. & Caju & I RA \\
\hline Centro Cultural José Bonifácio, Rua Pedro Ernesto, 8०. & Gamboa & IRA \\
\hline Armazém n. 5. Av. Rodrigues Alves, s/n. & Gamboa & IRA \\
\hline Centro de Artes Hélio Oiticica. Rua Luiz de Camões & Centro & II RA \\
\hline Conjunto Cultural da Caixa. Rua República do Chile, 230 & Centro & II RA \\
\hline Espaço Cultural do CREA, Rua Buenos Aires, 40 & Centro & II RA \\
\hline Espaço Cultural Constituição, Rua da Constituição, 34 & Centro & II RA \\
\hline Centro Cultural da Saúde: Praça Marechal Âncora, 370 & Centro & II RA \\
\hline Centro Cultural Banco do Brasil. Rua Primeiro de Março. & Centro & II RA \\
\hline Centro Cultural da Light, Av. Marechal Floriano & Centro & II RA \\
\hline Espaço Cultural da Marinha. Av. Alfredo Agache, s/n & Centro & II RA \\
\hline Espaço Cultural do BNDES. Av. Chile, 100. & Centro & II RA \\
\hline Espaço Cultural dos Correios, Rua Visconde de Itaboraí, 20. & Centro & II RA \\
\hline Casa França Brasil. Rua Visconde de Itaboraí, 75 & Centro & II RA \\
\hline Paço Imperial, Praça XV, 48. & Centro & II RA \\
\hline Fundiçăo Progresso. Rua dos Arcos, 20 a 54. & Centro & II RA \\
\hline Agência de Organismos Artísticos (Agora), Rua Joaquim Silva,7ı. & Centro & II RA \\
\hline Oficina de Arte Maria Teresa Vieira. Rua da Carioca, 85. & Centro & II RA \\
\hline Condomínio Cultural. Rua Luiz de Camões, 2, Largo de São Francisco. & Centro & II RA \\
\hline Centro Cultural Cândido Mendes. Rua da Assembléia, n. 10 & Centro & II RA \\
\hline Complexo Multicultural da Biblioteca Nacional. Av. Rio Branco, 209. & Centro & II RA \\
\hline Centro Cultural Carioca. Rua do Teatro, 37. & Centro & II RA \\
\hline Centro Cultural da Justiça Federal. Av. Rio Branco. 214. & Centro & II RA \\
\hline Rio Scenarium. Rua do Lavradio, 20. & Centro & II RA \\
\hline Centro Cultural do Brasil (Academia Brasileira de Letras). Av. Presidente Wilson, 231 & Centro & II RA \\
\hline Centro de Arte da FUNARTE. Rua da Imprensa, 16. & Centro & II RA \\
\hline Casarão Cultural dos Arcos. Av. Mem de Sá, 23. & Centro & II RA \\
\hline Esquina do Patrimônio. Av. Rio Branco, 44/46 & Centro & II RA \\
\hline Espaço Maison de France. Av. Presidente Antônio Carlos, 58. & Centro & II RA \\
\hline Novo Conjunto Cultural da Caixa Econômica Federal, Av. Rio Branco, 174* & Centro & II RA \\
\hline Casa de Osório. Rua do Riachuelo, Centro* & Centro & II RA \\
\hline Centro Cultural Calouste Gulbekian, Rua Benedito Hipólito & PraçaXI & III RA \\
\hline \multicolumn{3}{|l|}{ Total da área central 32} \\
\hline \multicolumn{3}{|l|}{ Total da cidade 57} \\
\hline Perentual da área central $56 \%$ & & \\
\hline
\end{tabular}

Fonte: Quadro montado a partir de informaçōes obtidas no Anuário Estatístico da Cidade do Rio de Janeiro 1998-1999, do Instituto Municipal de Urbanismo Pereira Passos; Azevedo (2002) e Magalhães (2001)

*Em fase de conclusão. 
Quadro 4 - Relação de empreendimentos do Programa Novas Alternativas - SMH/ Rio de Janeiro-RJ

\begin{tabular}{|c|c|c|c|c|c|}
\hline RA & Bairro & Processo & Endereço & Unidades & Fase \\
\hline \multirow{13}{*}{ II } & \multirow{13}{*}{ Centro } & 02/003.656/1999 & Rua Regente Feijó 62 & 9 & pode iniciar obras \\
\hline & & $02 / 325.708 / 2000$ & Rua Joaquim Silva 114 & 9 & substituído \\
\hline & & 02/003.654/1999 & Rua Joaquim Silva 122 & 16 & imissão de posse \\
\hline & & $02 / 003.655 / 1999$ & Rua Regente Feijó 57 & 6 & imissão de posse \\
\hline & & $02 / 325.073 / 2000$ & Rua do Teatro 21 & 7 & imissão de posse \\
\hline & & 02/326.657/1999 & Praça Tiradentes 71 & 10 & imissão de posse \\
\hline & & $02 / 325.016 / 2000$ & Rua do Teatro 17 & 9 & imissão de posse \\
\hline & & $02 / 325.273 / 2000$ & Rua Senador Pompeu 156 & 17 & imissão de posse \\
\hline & & $02 / 325.736 / 2000$ & Rua do Lavradio 110 & 8 & imissão de posse \\
\hline & & 02/003.745/1999 & Rua Francisco Muratori 38 & 11 & pode iniciar obras \\
\hline & & $02 / 325.241 / 2002$ & Rua Joaquim Silva 114 -Creche & - & em aprovação \\
\hline & & $02 / 325.336 / 2002$ & Rua dos Inválidos 195 a 203 & 38 & em aprovação \\
\hline & & $02 / 004.801 / 1996$ & Travessa Mosqueira & n.i. & habite-se \\
\hline \multirow{17}{*}{$\mathrm{I}$} & \multirow{7}{*}{ Gamboa } & $02 / 326.447 / 1999$ & Rua do Monte 59 & 7 & pode iniciar obras \\
\hline & & $02 / 325.103 / 2000$ & Rua do Livramento 145 & 6 & pode iniciar obras \\
\hline & & $02 / 325.105 / 2000$ & Rua do Livramento 72 & 8 & imissão de posse \\
\hline & & $02 / 004.142 / 1999$ & Rua do Livramento 147 & 5 & pode iniciar obras \\
\hline & & $02 / 325.106 / 2000$ & Rua do Livramento $74 / 76$ & 12 & imissão de posse \\
\hline & & $02 / 325.838 / 2000$ & Rua do Livramento 67 & 4 & imissão de posse \\
\hline & & $02 / 325.244 / 2002$ & Rua do Livramento 67/69 & 13 & imissão de posse \\
\hline & Santo Cristo & $02 / 325.246 / 2000$ & Rua da Gamboa 363 & 24 & imissão de posse \\
\hline & \multirow{9}{*}{ Saúde } & $02 / 325.988 / 2000$ & Rua Sacadura Cabral 135 & 18 & imissão de posse \\
\hline & & $02 / 326.318 / 2000$ & Ladeira João Homem 41 & 11 & pode iniciar obras \\
\hline & & $02 / 325.192 / 2000$ & Ladeira João Homem 35 & 5 & imissão de posse \\
\hline & & $02 / 325.732 / 2000$ & Ladeira João Homem 66 & 12 & imissão de posse \\
\hline & & $02 / 326.317 / 2000$ & Ladeira Pedro Antônio 31 & 16 & imissão de posse \\
\hline & & $02 / 326.009 / 2000$ & Rua Sacadura Cabral 143 & 9 & imissão de posse \\
\hline & & $02 / 325.990 / 2000$ & Rua Jogo da Bola 110 & 14 & imissão de posse \\
\hline & & $02 / 326.008 / 2000$ & Rua Sacadura Cabral 127 & 24 & imissão de posse \\
\hline & & $02 / 004 / 802 / 1996$ & Rua Sacadura Cabral 295/297 & n.i. & habite-se \\
\hline \multirow{3}{*}{ III } & \multirow{3}{*}{ Cidade Nova } & $02 / 325.040 / 2000$ & Rua Presidente Barroso s/nº & 3 & pode iniciar obras \\
\hline & & $02 / 325.243 / 2002$ & Travessa Pedregais 31/33 & 18 & imissão de posse \\
\hline & & $02 / 325.242 / 2002$ & Travessa Pedregais 39/41 & 16 & em aprovação \\
\hline
\end{tabular}

Fonte: Secretaria Municipal de Habitação e Secretaria Municipal de Urbanismo (2002). 
Tabela 27 - Evolução da população dos distritos da área central, das regiões e do município de São Paulo, 1980/2000

\begin{tabular}{|c|c|c|c|c|}
\hline \multirow{2}{*}{ Unidade Territorial } & \multicolumn{4}{|c|}{ População } \\
\hline & 1980 & 1991 & 1996 & 2000 \\
\hline Área central & 591.768 & 513.512 & 436.555 & 413.896 \\
\hline Bela Vista & 85.416 & 71.825 & 64.895 & 63.190 \\
\hline Bom Retiro & 47.588 & 36.136 & 27.788 & 26.598 \\
\hline Brás & 38.630 & 33.536 & 26.665 & 25.158 \\
\hline Cambuci & 44.851 & 37.069 & 32.089 & 28.717 \\
\hline Consolação & 77.338 & 66.590 & 58.588 & 54.522 \\
\hline Liberdade & 82.472 & 76.245 & 64.349 & 61.875 \\
\hline Pari & 26.968 & 21.299 & 15.434 & 14.824 \\
\hline República & 60.999 & 57.797 & 49.666 & 47.718 \\
\hline Santa Cecília & 94.542 & 85.829 & 75.826 & 71.179 \\
\hline Sé & 32.965 & 27.186 & 21.255 & 20.155 \\
\hline Leste 1 & 1.661 .548 & 1.682 .705 & 1.594 .655 & 1.632 .685 \\
\hline Leste 2 & 1.150 .444 & 1.727 .857 & 1.952 .203 & 2.162 .687 \\
\hline Norte 1 & 882.213 & 905.917 & 881.100 & 887.140 \\
\hline Norte 2 & 906.210 & 1.041 .518 & 1.116 .443 & 1.205 .220 \\
\hline Oeste & 983.455 & 1.002 .489 & 919.082 & 920.509 \\
\hline Sul 1 & 945.783 & 974.276 & 943.563 & 956.366 \\
\hline Sul 2 & 1.371 .805 & 1.797.911 & 1.995 .260 & 2.255 .452 \\
\hline Município de São Paulo & 8.493 .226 & 9.646 .185 & 9.839 .436 & 10.434 .252 \\
\hline
\end{tabular}

Fonte: São Paulo (2002b).* 
Tabela 28 - Taxas de crescimento de distritos centrais e da periferia da cidade de São Paulo, 1980/2000

\begin{tabular}{|c|c|c|}
\hline \multirow{2}{*}{ Unidade Territorial } & \multicolumn{2}{|c|}{ Taxas de Crescimento } \\
\hline & $1980 / 1991$ & $1991 / 2000$ \\
\hline \multicolumn{3}{|c|}{ Distritos da Área Central } \\
\hline Bela Vista & $-1,56$ & $-1,41$ \\
\hline Bom Retiro & $-2,47$ & $-3,35$ \\
\hline Brás & $-7,28$ & $-3,14$ \\
\hline Cambuci & $-1,72$ & $-2,80$ \\
\hline Consolação & $-1,35$ & $-2,20$ \\
\hline Liberdade & $-0,71$ & $-2,29$ \\
\hline Pari & $-2,12$ & $-3,95$ \\
\hline República & $-0,49$ & $-2,11$ \\
\hline Santa Cecília & $-0,88$ & $-2,06$ \\
\hline Sé & $-1,74$ & $-3,29$ \\
\hline \multicolumn{3}{|c|}{ Distritos de outras zonas } \\
\hline Anhanguera (Norte 2) & 7,95 & 13,38 \\
\hline Cidade Tiradentes (Leste 2) & 24,55 & 7,89 \\
\hline Grajaú (Sul 2) & 4,67 & 6,22 \\
\hline Iguatemi (Leste 2) & 5,67 & 6,08 \\
\hline Parelheiros (Sul 2) & 5,24 & 7,07 \\
\hline Vila Andrade (Sul 2) & 5,93 & 6,28 \\
\hline \multicolumn{3}{|c|}{ Município } \\
\hline Município de São Paulo & 1,16 & 0,88 \\
\hline
\end{tabular}

Tabela 29 - Relação de empregos por hectare em São Paulo-SP, 1997

\begin{tabular}{|c|c|c|c|c|}
\hline Distritos & Área urbanizada & Empregos & Empregos/Hectare & $\%$ Empregos \\
\hline Bela Vista & 260 ha & 130.927 & 503,6 & 2,8 \\
\hline Bom Retiro & 400 ha & 63.160 & 157,9 & 1,4 \\
\hline Brás & 350 ha & 70.248 & 200,7 & 1,5 \\
\hline Cambuci & $390 \mathrm{ha}$ & 38.170 & 97,9 & 0,8 \\
\hline Consolação & 370 ha & 98.941 & 267,4 & 2,1 \\
\hline Liberdade & 370 ha & 54.549 & 147,4 & 1,2 \\
\hline Pari & 290 ha & 29.030 & 100,1 & 0,6 \\
\hline República & 230 ha & 158.338 & 688,4 & 3,4 \\
\hline Santa Cecília & 390 ha & 77.207 & 198,0 & 1,7 \\
\hline Sé & 210 ha & 145.247 & 691,7 & 3,1 \\
\hline Total área central & 3260 ha & 865.817 & 265,6 & 18,6 \\
\hline Total município & 90.749 ha & 4.626 .846 & 51,0 & 100,0 \\
\hline
\end{tabular}

Fonte: Companhia Metropolitana de Habitação de São Paulo (2001).* 
Tabela 30 - Propostas de utilização dos benefícios da Operação Urbana Centro, 1997/2002

\begin{tabular}{l|c|c|c|c}
\hline \multirow{2}{*}{ Tipo de Operação } & \multicolumn{4}{|c}{ Proposta } \\
\cline { 2 - 5 } & Protocoladas & Em análise & Indeferidas & Aprovadas \\
\hline Cessão de Potencial & 32 & 26 & 02 & 04 \\
\hline Compra de Potencial & 33 & 08 & 18 & 05 \\
\hline Outras & 32 & 10 & 10 & 07 \\
\hline Total & $\mathbf{9 7}$ & $\mathbf{4 4}$ & $\mathbf{3 0}$ & $\mathbf{1 6}$ \\
\hline
\end{tabular}

Fonte: Empresa Municipal de Urbanização - EMURB, posição em novembro de 2002.

Tabela 31 - Espaços culturais e de entretenimento nas regióes

e município de São Paulo, 2001

\begin{tabular}{l|c|c|c|c|c}
\hline \multirow{2}{*}{ Unidade Territorial } & \multicolumn{5}{|c}{ Equipamento disponível } \\
\cline { 2 - 6 } & Biblioteca Pública & Centro cultural & Salas de Cinema & Museus & Salas de Teatro \\
\hline Área Central & 03 & 16 & 60 & 22 & 76 \\
\hline Leste 1 & 07 & 02 & 46 & 02 & 10 \\
\hline Leste 2 & 05 & 05 & 03 & - & 03 \\
\hline Norte 1 & 04 & - & 07 & 01 & 02 \\
\hline Norte 2 & 02 & 01 & - & - & - \\
\hline Oeste & 02 & 17 & 77 & 30 & 28 \\
\hline Sul 1 & 03 & 07 & 10 & 17 & 12 \\
\hline Sul 2 & 02 & 05 & 34 & - & 07 \\
\hline Total do Município & $\mathbf{2 8}$ & $\mathbf{4 7}$ & $\mathbf{2 3 7}$ & $\mathbf{6 6}$ & $\mathbf{1 3 8}$ \\
\hline
\end{tabular}

Fonte: Secretaria Municipal de Planejamento Urbano - SEMPLA, Departamento de Informaçóes. 
Tabela 32 - Domicílios particulares fechados e vagos na área central de São Paulo, 2000

\begin{tabular}{|c|c|c|c|c|}
\hline Distritos & $\begin{array}{l}\text { Total de domicílios } \\
\text { recenseados }\end{array}$ & Domicílios vagos & Domicílios fechados & $\%$ \\
\hline Bela Vista & 33.848 & 5.479 & 1.862 & $21,7 \%$ \\
\hline Bom Retiro & 10.807 & 1.821 & 522 & $21,7 \%$ \\
\hline Brás & 11.622 & 2.789 & 376 & $26,7 \%$ \\
\hline Cambuci & 11.370 & 1.910 & 286 & $19,3 \%$ \\
\hline Consolação & 29.577 & 3.694 & 1.648 & $18,1 \%$ \\
\hline Liberdade & 29.392 & 5.283 & 804 & $20,7 \%$ \\
\hline Pari & 5.817 & 1.223 & 127 & $23,2 \%$ \\
\hline República & 30.849 & 7.007 & 814 & $25,3 \%$ \\
\hline Santa Cecília & 36.171 & 6.343 & 1.361 & $21.3 \%$ \\
\hline Sé & 11.410 & 3.055 & 294 & $29,3 \%$ \\
\hline Total Área Central & 210.863 & 38.604 & 8.034 & $22,1 \%$ \\
\hline Município de São Paulo & 3.554 .820 & 420.327 & 94.703 & $11,8 \%$ \\
\hline
\end{tabular}

Fonte: São Paulo (2002b). *

Tabela 33 - Lançamentos comerciais no período julho/87 a junho/97

\begin{tabular}{|c|c|c|c|c|c|c|c|}
\hline $\begin{array}{l}\text { Zona de Valor } \\
\text { (bairros)* }\end{array}$ & $\begin{array}{l}\text { Número de } \\
\text { conjuntos }\end{array}$ & $\begin{array}{c}\text { Área total } \\
\text { construída }\left(\mathrm{m}^{2}\right)\end{array}$ & $\begin{array}{c}\text { Terreno } \\
\text { utilizado }\left(\mathrm{m}^{2}\right)\end{array}$ & $\begin{array}{l}\text { Preço médio } \\
\text { (US\$) }\end{array}$ & $\begin{array}{l}\text { Preço médio/m² } \\
\text { área útil }\end{array}$ & $\begin{array}{l}\text { Preço médio/m² } \\
\text { área total }\end{array}$ & $\begin{array}{l}\text { \% da área } \\
\text { lançada }\end{array}$ \\
\hline \multicolumn{8}{|c|}{ Outras áreas } \\
\hline Brooklin & 759 & 295.330 & 49.884 & 534.380 & 3.101 & 1.373 & 13,41 \\
\hline Itaim Bibi & 2222 & 286.466 & 39.561 & 768.055 & 2.752 & 1.304 & 13,01 \\
\hline Vila Olímpia & 1000 & 266.562 & 26.738 & 346.040 & 2.486 & 1.298 & 12,10 \\
\hline Jardins & 1609 & 204.489 & 28.915 & 134.565 & 2.359 & 1.059 & 9,28 \\
\hline Pinheiros & 1480 & 127.832 & 19.373 & 100.204 & 2.420 & 1.760 & 5,80 \\
\hline Paraíso & 969 & 104.012 & 14.420 & 127.286 & 2.769 & 1.186 & 4,72 \\
\hline Higienópolis & 480 & 41.537 & 5.023 & 59.413 & 1.509 & 687 & 1,89 \\
\hline \multicolumn{8}{|c|}{ Área Central } \\
\hline Bela Vista & 684 & 75.126 & 11.002 & 108.026 & 2.253 & 984 & 3,41 \\
\hline Bom Retiro & 230 & 21.941 & 2.208 & 72.481 & 1.862 & 760 & 1,00 \\
\hline Centro & 168 & 18.842 & 2.760 & 111.738 & 2.095 & 996 & 0,86 \\
\hline Liberdade & 270 & 18.109 & 3.287 & 74.960 & 2.180 & 1.118 & 0,82 \\
\hline Consolação & 88 & 15.477 & 2.306 & 337.459 & 3.973 & 1.919 & 0,70 \\
\hline Barra Funda & 112 & 9.346 & 1.400 & 65.622 & 1.455 & 786 & 0,42 \\
\hline Santa Cecília & 52 & 4.130 & 517 & 80.185 & 2.207 & 1.010 & 0,19 \\
\hline Município & 17.130 & 2.202 .654 & 351.724 & 148.354 & 2.461 & 1.154 & 100,00 \\
\hline
\end{tabular}


Tabela 34 - Unidades residenciais lançadas no período 1988/1997 no trecho 1 da área de estudo da linha 4 do metrô

\begin{tabular}{|c|c|c|c|c|c|}
\hline Zona OD & 1 dorm. & 2 dorm. & 3 dorm. & 4 dorm. & Total \\
\hline Sé & - & - & - & - & - \\
\hline Parque D. Pedro & - & - & - & - & - \\
\hline Praça João Mendes & - & 112 & - & - & 112 \\
\hline Ladeira da Memória & 456 & - & - & - & 456 \\
\hline República & 126 & 40 & - & - & 166 \\
\hline Santa Efigênia & - & - & - & - & - \\
\hline Luz & - & - & - & - & - \\
\hline Bexiga & 236 & 372 & - & - & 608 \\
\hline Santa Cecília & 298 & 376 & - & - & 674 \\
\hline Total trecho > (área central) & 1.116 & 900 & - & - & 2.016 \\
\hline Total trecho 2 (Paulista, Jardins, Pinheiros) & 6.314 & 2.286 & 1.873 & 977 & 11.450 \\
\hline Total trecho 3 (Morumbi e Butantã) & 187 & 2.421 & 4.483 & 1.096 & 8.187 \\
\hline Total da área de estudo linha 4 & 7.617 & 5.607 & 6.356 & 2.073 & 21.653 \\
\hline Município de São Paulo & 21.641 & 101.979 & 83.097 & 16.423 & 223.140 \\
\hline
\end{tabular}

Fonte: Silva (2000).

Quadro 5 - Bens imóveis tombados pelo IPHAN na área central da cidade de São Paulo, 1938/2002

\begin{tabular}{|l|c|c|c|}
\hline Bem tombado & Ano do tombamento & Processo & Livro do Tombo \\
\hline Mosteiro da Luz & 1943 & $325-T-43$ & Histórico e das Belas Artes \\
\hline Estação da Luz & 1996 & $944-T-76$ & Histórico e das Belas Artes \\
\hline Igreja da Ordem 3 ${ }^{\text {a do Carmo }}$ & 1999 & $1.176-$ T-85 & Histórico e das Belas Artes \\
\hline Conj. Arquitetônico e Urbanístico da Luz* & 2000 & $1462-$ T-0o & Histórico (indicação) \\
\hline
\end{tabular}

Fonte: Quadro montado a partir de informações obtidas no Arquivo Noronha Santos do IPHAN, no Rio de Janeiro, e da Superintendência do IPHAN, em São Paulo.

* O Conjunto Arquitetônico e Urbanístico da Luz teve seu tombamento aprovado pelo Conselho Consultivo do Patrimônio Cultural em 2000. 
Quadro 6 - Bens imóveis tombados pelo CONDEPHAAT na área central, 1970/2000

\begin{tabular}{|c|c|c|c|}
\hline Bem tombado (até 1999) & Ano do tombamento & Processo & Livro do Tombo \\
\hline Igreja de Santo Antonio & 1970 & $8.576 / 69$ & Histórico \\
\hline Solar da Marquesa de Santos & 1971 & $7.852 / 69$ & Histórico \\
\hline Igreja de Săo Gonçalo & 1971 & $171 / 71$ & Histórico \\
\hline Quartel da Luz & 1972 & $15.268 / 69$ & Histórico \\
\hline Igreja de Nossa Sra. da Boa Morte & 1974 & $18.926 / 70$ & Histórico \\
\hline Largo da Memória & 1975 & $44 / 71$ & Histórico \\
\hline Casa de Mário de Andrade & 1975 & $427 / 74$ & Histórico \\
\hline Inst. de Educaçăo Caetano de Campos & 1976 & $1.456 / 75$ & Histórico \\
\hline Palácio dos Campos Elíseos & 1977 & $16.265 / 70$ & Histórico \\
\hline Capela dos Aflitos & 1978 & $20.125 / 76$ & Histórico \\
\hline Túmulo de Júlio Frank & 1978 & $20.320 / 77$ & Histórico \\
\hline Colégio Porto Seguro & 1979 & $20.063 / 76$ & Histórico \\
\hline Casa de Dona Marieta & 1980 & $535 / 75$ & Histórico \\
\hline Vila Economizadora & 1980 & $20.213 / 77$ & Histórico \\
\hline Jardim da Luz & 1987 & $20.236 / 77$ & Arq. Etnog. e Paisagístico \\
\hline Quartel do $2^{\circ}$ Batalhăo de Guardas & 1981 & $21.740 / 81$ & Histórico \\
\hline Teatro Municipal & 1981 & $21.752 / 81$ & Histórico \\
\hline Palácio da Justiça & 1981 & $21.903 / 81$ & Histórico \\
\hline Pinacoteca do Estado & 1982 & $14.335 / 69$ & Histórico \\
\hline Igreja de Säo Francisco de Assis & 1982 & $40 / 71$ & Histórico \\
\hline Ig. da Ord. $3^{a}$ S. Francisco da Penitência & 1982 & $41 / 71$ & Histórico \\
\hline Mosteiro da Luz & 1982 & $375 / 73$ & Histórico \\
\hline Estação da Luz & 1982 & $20.097 / 76$ & Histórico \\
\hline Estação do Brás & 1982 & $20.699 / 78$ & Histórico \\
\hline Palácio das Indústrias & 1982 & $20.867 / 79$ & Histórico \\
\hline Teatro Brasileiro de Comédias & 1982 & $20.910 / 79$ & Histórico \\
\hline Igreja de Săo Cristóvão & 1982 & $22.078 / 82$ & Histórico \\
\hline Casa de Elias Chaves & 1983 & $20.023 / 76$ & Histórico \\
\hline Teatro Oficina & 1983 & $22.368 / 82$ & Histórico \\
\hline Castelinho da Av. Brig. Luís Antônio & 1984 & $250 / 73$ & Histórico \\
\hline Edifício Alexandre Mackenzie & 1984 & $22.803 / 83$ & Histórico \\
\hline Casa da Rua Pirapitingui & 1985 & $22.365 / 82$ & Histórico \\
\hline Portal do Presídio Tiradentes & 1985 & $23.345 / 85$ & Histórico \\
\hline Casa de Dino Bueno & 1985 & $23.367 / 85$ & Histórico \\
\hline Edifício Saldanha Marinho & 1986 & $23.304 / 85$ & Histórico \\
\hline Fac. de Filosofia, Ciências e Letras - USP & 1988 & $23.394 / 85$ & Histórico \\
\hline Escola Normal do Brás & 1988 & $25.591 / 87$ & Histórico \\
\hline Edifício Esther & 1990 & $23.262 / 85$ & Histórico \\
\hline Escola de Primeiras Letras & 1992 & $26.299 / 88$ & Histórico \\
\hline Instituto Mackenzie & 1993 & $24.020 / 85$ & Histórico \\
\hline Casa de aluguel da Rua Bento Freitas & 1993 & $25.915 / 88$ & Histórico \\
\hline Capela do Menino Jesus e Sta. Luzia & 1995 & $26.007 / 88$ & Histórico \\
\hline Ass. Auxiliadora das Classes Laboriosas & 1995 & $27.943 / 90$ & Histórico \\
\hline Casa de Dona Yayá & 1998 & $21.955 / 82$ & Histórico \\
\hline Estação Júlio Prestes & 1999 & $36.990 / 97$ & Histórico \\
\hline Prédio do antigo DOPS & 1999 & $38.685 / 99$ & Histórico \\
\hline
\end{tabular}

Fonte: Quadro montado a partir de informações obtidas em FENERICH, 200o, e no Conselho de Defesa do Patrimônio Histórico, Artístico, Arqueológico e Turístico do Estado de São Paulo - CONDEPHAAT, em novembro de 2002. 
Quadro 7 - Empreendimentos habitacionais de interesse social na área central, 1968/2002

\begin{tabular}{|c|c|c|c|c|c|}
\hline Empreendimento & Recursos & Proprietário & Unidades & Intervenção & Situação \\
\hline Favela do Gato & $\mathrm{FMH}^{*}$ & Prefeitura & 550 & construção & em projeto \\
\hline Belém & $\mathrm{FMH}$ & Prefeitura & 180 & construção & em projeto \\
\hline Bresser & $\mathrm{FMH}$ & Prefeitura & 150 & construção & em projeto \\
\hline Baronesa P. Carrero & $\mathrm{FMH}$ & Prefeitura & 34 & reforma & em projeto \\
\hline Eiras Garcia & $\mathrm{FMH}$ & Particular & 20 & construção & em projeto \\
\hline Rua do Carmo & $\mathrm{FMH}$ & Prefeitura & 40 & constr./refor. & licitação de projeto \\
\hline V. 25 de Janeiro & $\mathrm{FMH}$ & Particular & 33 & construção & em projeto \\
\hline Rua Sólon, 934 & $\mathrm{FMH}$ & Particular & 74 & reforma & em processo usocapião \\
\hline V. dos Idosos & $\mathrm{FMH}$ & Prefeitura & 20 & construção & solicitando repasse \\
\hline Com. Vicente Marino & $\mathrm{FMH}$ & SP Trans. & 300 & construção & em negociação \\
\hline Vieira de Carvalho & $\mathrm{FMH}$ & SP Trans. & 40 & construção & em negociação \\
\hline Assembleia & $\mathrm{FMH}$ & SJ & 192 & construção & em negociação \\
\hline Praça Carlos Gomes & $\mathrm{FMH}$ & SJ & 66 & construção & em negociação \\
\hline R. Senador Feijó, 126 & $\mathrm{FMH}$ & Particular & 45 & reforma & para aquisição \\
\hline Rua Assunção, 480 & $\mathrm{FMH}$ & Particular & 31 & reforma & para aquisição \\
\hline Av. São João, 1517 & $\mathrm{FMH}$ & Particular & 42 & reforma & para aquisição \\
\hline Hotel São Paulo & $\mathrm{FMH}$ & Particular & 165 & reforma & para desapropriação \\
\hline R. Barata Ribeiro & $\mathrm{FMH}$ & Particular & sem inf. & reforma & em estudo \\
\hline Roberto Simonsen, 13 & $\mathrm{FMH}$ & Cúria & 30 & reforma & em estudo viabilidade \\
\hline R. Fernão Sales & FAR $^{*}$ & CEF & 54 & reforma & concluído \\
\hline R. Riskallah Jorge, 50 & FAR & CEF & 167 & reforma & em obra \\
\hline R. Maria Paula, 171 & FAR & CEF & 75 & reforma & em obra \\
\hline Av. Celso Garcia & FAR & CEF & 84 & reforma & concluído \\
\hline R. Brig. Tobias, 290 & FAR & CEF & 84 & reforma & em obra \\
\hline Av. 9 de Julho & FAR & INSS & 156 & reforma & em negociação \\
\hline R Capitão Salomão, 27 & FAR & particular & 46 & reforma & em orçamento \\
\hline Hotel Cambridge & FAR & particular & 155 & reforma & em negociação \\
\hline R Santa Rosa, 171 & FAR & particular & 49 & reforma & negociação emperrada \\
\hline R Brig. Tobias, 700 & FAR & particular & 194 & reforma & em negociação \\
\hline R Boticário, 39 & FAR & particular & 60 & reforma & aguardando negociação \\
\hline Roberto Simonsen, 94 & FAR & particular & 24 & reforma & em negociação \\
\hline Av. Ipiranga, 313 & FAR & particular & 172 & reforma & em orçamento \\
\hline Av. Rangel Pestana & FAR & INSS & 180 & construção & em negociação \\
\hline R. João Adolfo & FAR & particular & 90 & reforma & em negociação \\
\hline Av. S Joăo/DJ Barros & FAR & particular & 100 & reforma & em negociação \\
\hline R Riachuelo, 275 & FAR & particular & 174 & reforma & para estudo \\
\hline Largo da Concórdia & FAR & CEF & 100 & reforma & em negociação \\
\hline Cristo Rei & FGTS* & particular & sem inf. & reforma & em negociação \\
\hline R França Pinto & FAR & particular & 85 & reforma & em estudo \\
\hline Hotel Comodoro & FGTS & particular & 83 & reforma & em estudo \\
\hline Pça. da Bandeira, 53 & FAR & particular & 64 & reforma & em estudo \\
\hline R Cons. Nébias, 314 & FAR & particular & sem inf. & reforma & em estudo \\
\hline R Joaquim Carlos, 94 & FAR & particular & 92 & reforma & em negociação \\
\hline \multicolumn{6}{|c|}{ Total de empreendimentos - 44} \\
\hline \multicolumn{6}{|c|}{ Total de unidades habitacionais -4.474} \\
\hline \multicolumn{6}{|c|}{ Empreendimentos concluídos - 02} \\
\hline \multicolumn{6}{|c|}{ Empreendimento em obras - 03} \\
\hline
\end{tabular}


Tabela 35 - Gastos Públicos com Cultura, 1985/1995 (em milhões de reais)

\begin{tabular}{|c|c|c|c|c|}
\hline Ano & Governo Federal & Estados & Capitais dos Estados & Subtotal \\
\hline 1985 & 208 & 293 & 76 & 578 \\
\hline 1986 & 254 & 334 & 108 & 696 \\
\hline 1987 & 302 & 288 & 119 & 710 \\
\hline 1988 & 279 & 250 & 96 & 625 \\
\hline 1989 & 296 & 337 & 104 & 737 \\
\hline 1990 & 197 & 403 & 135 & 735 \\
\hline 1991 & 131 & 401 & 141 & 673 \\
\hline 1992 & 222 & 564 & 164 & 951 \\
\hline 1993 & 222 & 398 & 121 & 741 \\
\hline 1994 & 213 & 486 & 134 & 833 \\
\hline 1995 & 245 & 268 & 179 & 692 \\
\hline Total & 2.571 & 4.022 & 1.378 & 7.971 \\
\hline Média anual & 234 & 366 & 125 & 725 \\
\hline Participação \% & 32,28 & 50,48 & 17,24 & 100,00 \\
\hline Taxa linear de crescimento & $-1,35 \%$ & $4,82 \%$ & $8,90 \%$ & $2,81 \%$ \\
\hline
\end{tabular}

Fonte: MOISÉS, 1998a.

Tabela 36 - PRONAC-Mecenato: Projetos aprovados e com captação, 1992/2002 (valores de R\$)

\begin{tabular}{c|c|c|c}
\hline Ano & Aprovados & Captação & \% \\
\hline 1992 & $14.295 .068,36$ & $21.212,78$ & 0,15 \\
\hline 1993 & $12.487 .577,22$ & $150.391,07$ & 1,20 \\
\hline 1994 & $56.375 .251,35$ & $7.149 .128,92$ & 12,68 \\
\hline 1995 & $33.858 .935,50$ & $98.036 .212,94$ & 289,54 \\
\hline 1996 & $1.447 .859 .004,83$ & $188.472 .956,43$ & 13,02 \\
\hline 1997 & $1.286 .790 .501,87$ & $209.188 .966,43$ & 16,26 \\
\hline $\mathbf{1 9 9 8}$ & $1.296 .315 .284,21$ & $203.692 .557,56$ & 15,71 \\
\hline $\mathbf{2 0 0 0}$ & $1.276 .268 .909,72$ & $277.323 .375,49$ & 21,73 \\
\hline $\mathbf{2 0 0 1}$ & $1.130 .919 .220,92$ & $340.746 .314,66$ & 30,13 \\
\hline $\mathbf{2 0 0 2}$ & $1.236 .271 .101,51$ & $225.912 .933,16$ & 18,27 \\
\hline Total & & $\mathbf{1 . 5 5 0 . 6 9 4 . 0 4 9 , 4 4}$ & 19,90 \\
\hline
\end{tabular}

Fonte: Ministério da Cultura, Sistema de Apoio às Leis de Incentivo à Cultura - SALIC, posição em novembro de 2002. 
Tabela 37 - PRONAC - Percentual dos recursos captados, 1996/2002 (por região) (valores de R\$)

\begin{tabular}{l|c|c|c|c|c|c|c|c}
\hline \multirow{2}{*}{ Região } & \multicolumn{7}{|c}{ Percentual por ano } \\
\cline { 2 - 22 } & $\mathbf{1 9 9 6}$ & $\mathbf{1 9 9 7}$ & $\mathbf{1 9 9 8}$ & $\mathbf{1 9 9 9}$ & $\mathbf{2 0 0 0}$ & $\mathbf{2 0 0 1}$ & $\mathbf{2 0 0 2}$ & $\mathbf{1 9 9 6 / 2 0 0 2}$ \\
\hline Norte & 0,42 & 0,48 & 1,36 & 0,38 & 0,05 & 0,13 & 0,62 & 0,45 \\
\hline Nordeste & 2,28 & 4,19 & 3,63 & 5,69 & 4,46 & 5,75 & 6,70 & 4,91 \\
\hline C. Oeste & 4,80 & 3,22 & 3,20 & 2,41 & 3,00 & 2,92 & 2,97 & 3,08 \\
\hline Sudeste & 88,70 & 84,78 & 83,76 & 83,08 & 85,21 & 82,10 & 78,15 & 83,25 \\
\hline Sul & 3,79 & 7,34 & 8,06 & 8,44 & 7,28 & 9,11 & 11,58 & 8,30 \\
\hline Total & $\mathbf{1 0 0 , 0 0}$ & $\mathbf{1 0 0 , 0 0}$ & $\mathbf{1 0 0 , 0 0}$ & $\mathbf{1 0 0 , 0 0}$ & $\mathbf{1 0 0 , 0 0}$ & $\mathbf{1 0 0 , 0 0}$ & $\mathbf{1 0 0 , 0 0}$ & $\mathbf{1 0 0 , 0 0}$ \\
\hline
\end{tabular}

Fonte: Ministério da Cultura, Sistema de Apoio às Leis de Incentivo à Cultura - SALIC, posição em novembro de 2002.

Tabela 38 - PRONAC-Mecenato: Projetos, 1992/2002

\begin{tabular}{|c|c|c|c|c|c|c|}
\hline \multicolumn{7}{|c|}{ Período 1992-1995 } \\
\hline Região & Projetos apresentados & $\%$ & Projetos aprovados & $\%$ & Projetos c/ captação & $\%$ \\
\hline Norte & 5 & 0,568 & 3 & 1,613 & 0 & 0,00 \\
\hline Nordeste & 59 & 6,705 & 4 & 2,151 & 2 & 3,77 \\
\hline Centro-Oeste & 63 & 7,159 & 8 & 4,301 & 2 & 3,77 \\
\hline Sudeste & 594 & 67,5 & 158 & 84,95 & 42 & 79,25 \\
\hline Sul & 159 & 18,07 & 13 & 6,989 & 7 & 13,21 \\
\hline Total & 880 & 100 & 186 & 100 & 53 & 100,00 \\
\hline \multicolumn{7}{|c|}{ Período 1996-2002 } \\
\hline Região & Projetos apresentados & $\%$ & Projetos aprovados & $\%$ & Projetos c/ captação & $\%$ \\
\hline Norte & 299 & 1,133 & 300 & 1,27 & 50 & 0,79 \\
\hline Nordeste & 2.254 & 8,541 & 2.013 & 8,522 & 383 & 6,07 \\
\hline Centro-Oeste & 2.233 & 8,462 & 1.986 & 8,408 & 387 & 6,14 \\
\hline Sudeste & 17.347 & 65,74 & 15.640 & 66,21 & 4.414 & 69,99 \\
\hline Sul & 4.256 & 16,13 & 3.682 & 15,59 & 1.073 & 17,01 \\
\hline Total & 26.389 & 100 & 23.621 & 100 & 6.307 & 100,00 \\
\hline \multicolumn{7}{|c|}{ Período 1992-2002 } \\
\hline Região & Projetos apresentados & $\%$ & Projetos aprovados & $\%$ & Projetos c/ captação & $\%$ \\
\hline Norte & 304 & 1,12 & 303 & 1,28 & 50 & 0,79 \\
\hline Nordeste & 2.313 & 8,48 & 2.017 & 8,47 & 385 & 6,05 \\
\hline Centro-Oeste & 2.296 & 8,42 & 1.994 & 8,37 & 389 & 6,12 \\
\hline Sudeste & 17.941 & 65,79 & 15.798 & 66,36 & 4.456 & 70,06 \\
\hline Sul & 4.415 & 16,19 & 3.695 & 15,52 & 1.080 & 76,98 \\
\hline Total & 27.269 & 100 & 23.807 & 100 & 6.360 & 100,00 \\
\hline
\end{tabular}

Fonte: Ministério da Cultura, Sistema de Apoio às Leis de Incentivo à Cultura - SALIC, posição em novembro de 2002. 


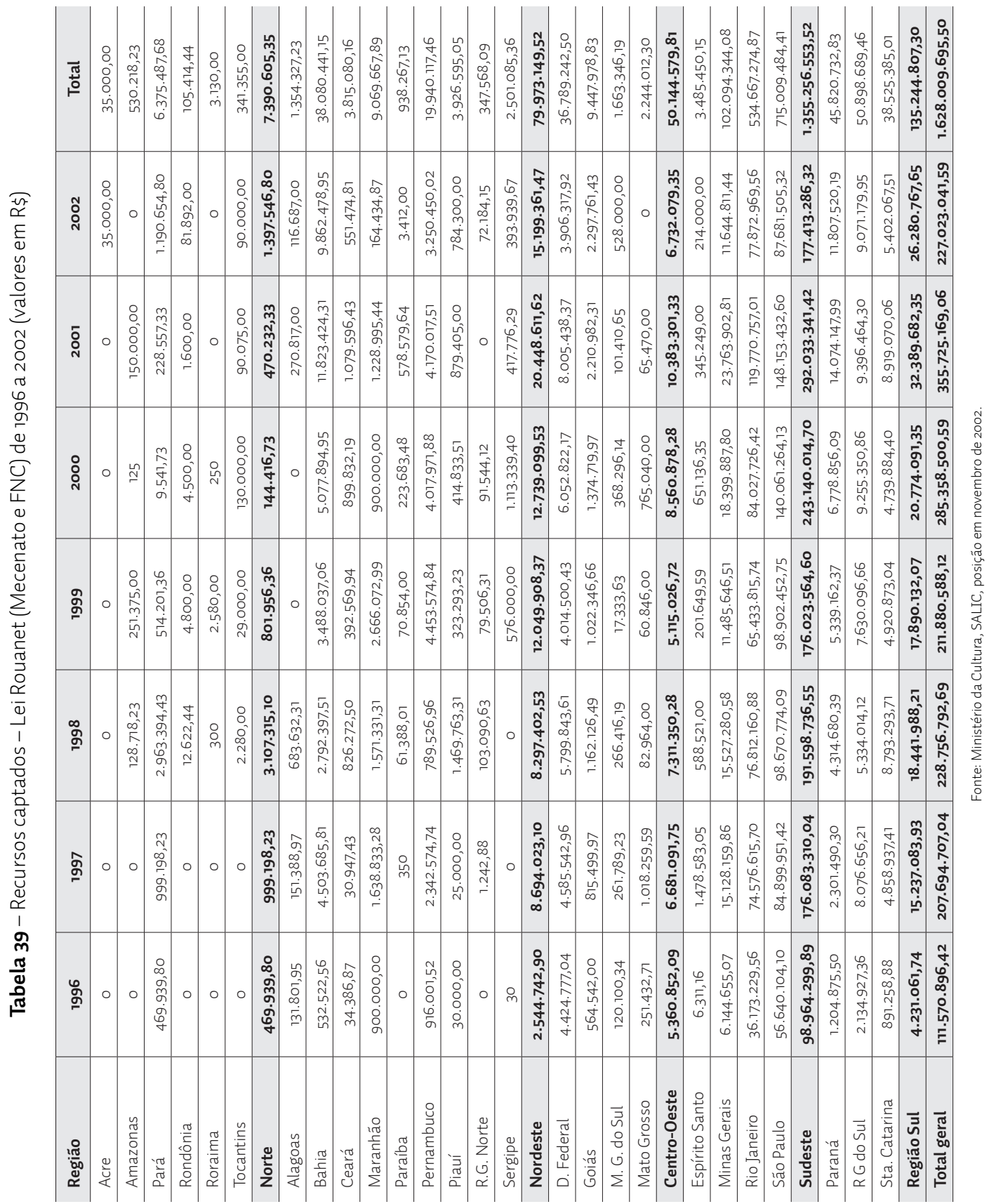


Tabela 40 - PRONAC-Mecenato: Recursos captados por segmento, 1993/2002 (valores em reais)

\begin{tabular}{|c|c|c|c|c|c|c|c|c|}
\hline Ano & $\begin{array}{l}\text { Artes } \\
\text { Cênicas }\end{array}$ & $\begin{array}{c}\text { Artes } \\
\text { Integradas }\end{array}$ & $\begin{array}{c}\text { Artes } \\
\text { Plásticas }\end{array}$ & Audiovisual & Humanidades & Música & Patrimônio & Subtotal \\
\hline 1993 & 0 & o & 0 & 6.303 & 14.909 & o & $\mathrm{O}$ & 21.212 \\
\hline 1994 & o & o & o & 92.242 & 12.888 & o & 45.260 & 150.391 \\
\hline 1995 & 284.350 & 217.650 & 900 & 69.915 & 807.002 & 50.000 & 5.719 .310 & 7.149 .128 \\
\hline 1996 & 15.759 .753 & 20.332 .961 & 7.309 .109 & 3.961 .719 & 5.025 .871 & 20.356 .824 & 25.289 .972 & 98.036 .212 \\
\hline 1997 & 22.677 .873 & 46.208 .096 & 11.936 .924 & 17.214 .643 & 18.942 .711 & 25.425 .905 & 46.066 .802 & 188.472 .956 \\
\hline 1998 & 22.904 .983 & 46.908 .150 & 16.857 .501 & 12.527 .499 & 21.603 .100 & 38.039 .930 & 50.347 .800 & 209.188 .966 \\
\hline 1999 & 29.793 .132 & 35.249 .709 & 17.873 .331 & 11.415 .551 & 27.692 .495 & 42.215 .766 & 39.452 .569 & 203.692 .557 \\
\hline 2000 & 59.044 .982 & 39.258 .018 & 33.840 .637 & 14.391 .549 & 33.070 .452 & 59.907 .428 & 37.810 .313 & 277.323 .375 \\
\hline 2001 & 79.896 .274 & 38.851 .028 & 26.498 .218 & 28.490 .282 & 40.097 .634 & 77.555 .970 & 49.356 .905 & 340.746 .314 \\
\hline 2002 & 51.899 .812 & 34.117 .701 & 18.764 .259 & 27.354 .145 & 21.698 .961 & 37.403 .980 & 34.674 .071 & 225.912 .933 \\
\hline Total & 282.261 .162 & 261.143.317 & 133.080 .875 & 115.523 .853 & 168.966 .027 & 300.955 .806 & 288.763 .007 & 1.550 .694 .049 \\
\hline$\%$ & 18,20 & 16,84 & 8,58 & 7,45 & 10,89 & 19,41 & 18,62 & 100,00 \\
\hline
\end{tabular}

Fonte: Ministério da Cultura, Sistema de Apoio às Leis de Incentivo à Cultura - SALIC, posição em novembro de 2002.

Tabela 41 - PRONAC-Mecenato: Crescimento relativo dos segmentos com relação ao ano precedente de 1997 a 2002

\begin{tabular}{l|c|c|c|c}
\hline Segmento & $\mathbf{1 9 9 7}$ & $\mathbf{1 9 9 8}$ & $\mathbf{1 9 9 9}$ & $\mathbf{2 0 0 0}$ \\
\hline Artes Cênicas & $5 \%$ & $62 \%$ & $80 \%$ & $93 \%$ \\
\hline Música & & $47 \%$ & $70 \%$ & $83 \%$ \\
\hline Artes Plásticas & $2 \%$ & $39 \%$ & $64 \%$ & $90 \%$ \\
\hline Patrimônio & & $4 \%$ & $8 \%$ & $14 \%$ \\
\hline Humanidades & $4 \%$ & $51 \%$ & $77 \%$ & $87 \%$ \\
\hline Artes Integradas & $3 \%$ & $35 \%$ & $29 \%$ & $19 \%$ \\
\hline
\end{tabular}

Fonte: Ministério da Cultura, 2001c, p. 103. 
Tabela 42 - PRONAC - Dez maiores incentivadores por ano, 1996/2000 (valores em reais)

\begin{tabular}{|c|c|c|c|c|c|}
\hline Incentivador & 1996 & 1997 & 1998 & 1999 & 2000 \\
\hline Telesp & 13.287 .624 & 11.205 .858 & 11.439 .038 & & \\
\hline Banco Itaú & 6.522 .038 & 8.872 .185 & & & 7.204 .706 \\
\hline Cia. Real de Cred. Imob. & 5.390 .849 & & & & \\
\hline Souza Cruz & 3.949 .209 & 4.594 .329 & 4.445 .767 & & 5.640 .079 \\
\hline Petrobras Distribuidora & 3.413 .165 & & & 4.356 .321 & 9.565 .738 \\
\hline Telemig & 2.962 .118 & 7.361 .782 & & & \\
\hline Telebras & 2.155 .939 & 12.467 .608 & 4.972 .051 & & \\
\hline Volkswagen & 2.031 .351 & 5.696 .652 & 4.968 .940 & 6.973 .009 & 4.798 .171 \\
\hline Banco Real & 1.975 .454 & & & & \\
\hline Telerj & 1.933 .606 & & & & \\
\hline Petrobrás & & 8.819 .418 & 15.820 .281 & 14.315 .464 & 43.444 .564 \\
\hline Embratel & & 5.218 .972 & 9.866 .424 & & 4.285 .890 \\
\hline Eletrobras & & 4.979 .565 & 11.672 .804 & 10.685 .108 & 10.532 .158 \\
\hline BNDES & & 4.971 .737 & 7.785 .623 & 4.800 .664 & 4.523 .401 \\
\hline Bradesco Seguros & & & 5.685 .374 & & \\
\hline Cia. Bras. Distribuição & & & 5.277 .766 & 7.002 .064 & 10.707 .212 \\
\hline Alfastar Participações & & & & 4.750 .000 & \\
\hline Banco Est. Minas Gerais & & & & 4.315 .000 & \\
\hline UNIBANCO & & & & 4.024.919 & \\
\hline Banco do Brasil & & & & 3.879 .959 & \\
\hline Copel & & & & & 3.715 .029 \\
\hline Total dos 10 maiores & 43.623 .349 & 74.188.106 & 81.934 .068 & 65.102 .508 & 100.701 .919 \\
\hline Total do ano & 111.689 .542 & 207.032 .196 & 227.408 .893 & 210.072 .396 & 266.941 .588 \\
\hline$\%$ dos 10 maiores no ano & $39 \%$ & $36 \%$ & $36 \%$ & $31 \%$ & $38 \%$ \\
\hline
\end{tabular}

Fonte: Ministério da Cultura, 2001c, p. 105.

Tabela 43 - PRONAC - Grandes proponentes de projetos ao Mecenato, $1995 / 2002$ (valores em reais)

\begin{tabular}{l|c|c|c}
\hline Proponente & Solicitado & Aprovado & Captado \\
\hline Fundação Roberto Marinho & 172.506 .503 & 87.404 .699 & 29.423 .888 \\
\hline Assoc. Amigos do CCBB & 179.267 .012 & 92.943 .858 & 43.867 .666 \\
\hline Instituto Itaú Cultural & 140.667 .858 & 122.506 .199 & 89.392 .695 \\
\hline Total & $\mathbf{4 9 2 . 4 4 1 . 3 7 3}$ & $\mathbf{3 0 2 . 8 5 4 . 7 5 6}$ & $\mathbf{1 6 2 . 6 7 8 . 2 4 9}$ \\
\hline Total captado no mecenato & \multicolumn{3}{|c}{$\mathbf{1 . 5 5 0 . 5 2 2 . 4 4 5}$} \\
\hline Total FNC & \multicolumn{1}{|l|}{} \\
\hline
\end{tabular}

Fonte: Ministério da Cultura, Sistema de Apoio às Leis de Incentivo à Cultura - SALIC, posição em novembro de 2002. 
Tabela 44 - PRONAC-Fundo Nacional da Cultura: Projetos e valores aprovados por Região, 1995/2002

\begin{tabular}{l|c|c|c|c}
\hline Região & Valor & \% & $\mathbf{N}^{\circ}$ Projetos & \% \\
\hline Norte & 12.355 .619 & $6,89 \%$ & 142 & $9,24 \%$ \\
\hline Nordeste & 44.555 .784 & $24,86 \%$ & 402 & $26,16 \%$ \\
\hline Centro-Oeste & 14.278 .864 & $7,97 \%$ & 133 & $8,65 \%$ \\
\hline Sudeste & 55.620 .297 & $31,03 \%$ & 423 & $27,52 \%$ \\
\hline Sul & 23.620 .309 & $13,78 \%$ & 300 & $19,52 \%$ \\
\hline Governo Federal & 28.791 .544 & $16,07 \%$ & 137 & $8,91 \%$ \\
\hline Total Geral & $\mathbf{1 7 9 . 2 2 2 . 4 1 7}$ & $\mathbf{1 0 0 , 0 0 \%}$ & $\mathbf{1 . 5 3 7}$ & $\mathbf{1 0 0 , 0 0 \%}$ \\
\hline
\end{tabular}

Fonte: Ministério da Cultura, Coordenação Geral de Projetos do Fundo Nacional da Cultura, posição em dezembro de 2002.

Tabela 45 - PRONAC-Fundo Nacional da Cultura: valor dos projetos aprovados por ano e por regiāo, 1995/2000 (valores em reais)

\begin{tabular}{l|c|c|c|c|c|c|c|c|c|c|c|c}
\hline Região & $\mathbf{1 9 9 5}$ & $\mathbf{\%}$ & $\mathbf{1 9 9 6}$ & $\mathbf{\%}$ & $\mathbf{1 9 9 7}$ & $\mathbf{\%}$ & $\mathbf{1 9 9 8}$ & $\mathbf{\%}$ & $\mathbf{1 9 9 9}$ & $\boldsymbol{\%}$ & $\mathbf{2 0 0 0}$ & $\mathbf{\%}$ \\
\hline Norte & 787.434 & 3,24 & 1.226 .022 & 12,72 & 658.191 & 2,64 & 3.034 .521 & 10,19 & 2.627 .382 & 9,26 & 1.954 .980 & 7,58 \\
\hline Nordeste & 6.947 .333 & 28,56 & 1.327 .785 & 13,78 & 8.256 .331 & 33,13 & 7.393 .743 & 24,84 & 7.891 .709 & 27,79 & 4.745 .178 & 18,41 \\
\hline Centro-Oeste & 5.400 .159 & 22,19 & 150.400 & 1,56 & 765.884 & 3,07 & 2.123 .655 & 7,13 & 1.195 .194 & 4,22 & 1.688 .737 & 6,55 \\
\hline Sudeste & 7.792 .335 & 32,03 & 1.561 .543 & 16,21 & 10.869 .553 & 43,59 & 10.175 .188 & 34,18 & 8.275 .802 & 29,15 & 8.297 .979 & 32,19 \\
\hline Sul & 637.006 & 2,62 & 1.178 .340 & 12,23 & 1.220 .512 & 4,89 & 4.519 .084 & 15,18 & 6.102 .554 & 21,49 & 4.565 .809 & 17,71 \\
\hline União & 2.764 .500 & 11,36 & 4.191 .795 & 43,5 & 3.161 .810 & 12,68 & 2.525 .008 & 8,48 & 2.297 .128 & 8,09 & 4.526 .860 & 17,56 \\
\hline Total & 24.328 .767 & 100 & 9.635 .885 & 100 & 24.932 .281 & 100 & 29.771 .199 & 100 & 28.389 .769 & 100 & 25.779 .543 & 100 \\
\hline
\end{tabular}

Fonte: Ministério da Cultura, Coordenação Geral de Projetos do Fundo Nacional da Cultura, posição em dezembro de 2002.

Tabela 46 - PRONAC - Incentivadores do patrimônio cultural que comparecem no mínimo três vezes no ranking dos 10 maiores, 1995/2002 (valores em reais)

\begin{tabular}{|c|c|c|c|c|c|c|c|c|c|c|}
\hline & Incentivador & 1995 & 1996 & 1997 & 1998 & 1999 & 2000 & 2001 & 2002 & Total \\
\hline 1 & Petrobras & & 252.235 & 3.439 .306 & 4.099 .419 & 671.577 & 3.324 .926 & 15.208 .421 & 11.583 .920 & 38.579 .804 \\
\hline 2 & BNDES & & & 4.471 .737 & 5.111 .723 & 3.834 .870 & 3.238 .401 & 3.885 .391 & 3.480 .500 & 24.022 .622 \\
\hline 3 & Eletrobras & & 352.000 & 1.350 .000 & 1.300 .000 & 2.310 .329 & 2.525 .000 & 6.108 .635 & 3.414 .447 & 17.360 .411 \\
\hline 4 & Telesp & 1.050 .000 & 6.600 .000 & 2.995 .838 & 3.668 .604 & 73.114 & 300.000 & 150.000 & & 14.837 .556 \\
\hline 5 & TELEBRAS & & 1.051 .939 & 3.879 .288 & 1.188 .659 & & & & & 6.119 .886 \\
\hline 6 & TELEMIG S.A. & & 1.543 .924 & 1.970 .000 & 2.161 .840 & & & & & 5.675 .764 \\
\hline 7 & Banco Real & & 1.685 .997 & 1.553 .999 & 1.355 .999 & & & & & 4.595 .995 \\
\hline 8 & TV Globo Ltda & 1.685 .224 & 1.018 .683 & 450.000 & & 500.000 & 850.000 & & & 4.503 .907 \\
\hline 9 & Cia. Real de Crédito Imob. & & 2.521 .000 & 300.417 & & 1.633 .824 & & & & 4.455.241 \\
\hline 10 & Banco Itaú & 200.000 & & 1.492 .499 & 203.463 & 896.359 & 1.449 .417 & 100.000 & & 4.341 .738 \\
\hline 11 & BRADESCO S.A. & 25.000 & 30.000 & 80.000 & & 2.062 .366 & 1.378 .058 & & & 3.575 .424 \\
\hline \multicolumn{10}{|c|}{ Total } & 128.068 .348 \\
\hline
\end{tabular}

Fonte: Ministério da Cultura, Sistema de Apoio às Leis de Incentivo à Cultura - SALIC, posição em novembro de 2002. 
Tabela 47 - Custo e financiamento do Programa Monumenta, 1999 (em milhares de US\$)

\begin{tabular}{|c|c|c|c|c|}
\hline Categoria & BID & Contrapartida Local & Custo total & $\%$ \\
\hline Engenharia e Administração & o & 14.600 & 14.600 & 11,7 \\
\hline Administração e supervisão & $\mathrm{O}$ & 7.700 & 7.700 & 6,2 \\
\hline Estudos e projetos & o & 6.900 & 6.900 & 5,5 \\
\hline Custos Diretos & 36.695 & 16.405 & 53.100 & 42,4 \\
\hline Investimentos Integrados & 36.695 & 16.405 & 53.100 & 42,4 \\
\hline Atividades Concorrentes & 25.180 & 18.785 & 43.965 & 35,2 \\
\hline Fortalecimento institucional & 6.600 & 1.530 & 8.130 & 6,5 \\
\hline Promoção de atividades econômicas & 3.900 & 3.620 & 7.520 & 6,0 \\
\hline Treinamento e formação & 4.080 & 3.790 & 7.870 & 6,3 \\
\hline Programas Educativos & 10.600 & 9.845 & 20.445 & 16,4 \\
\hline Custos Financeiros & 625 & 12.710 & 13.335 & 10,7 \\
\hline Juros & 0 & 11.700 & 11.700 & 9,4 \\
\hline Comissão de Crédito & o & 1.010 & 1.010 & 0,8 \\
\hline Inspeção e supervisão & 625 & $\mathrm{O}$ & 625 & 0,5 \\
\hline Custo Total & 62.500 & 62.500 & 125.000 & 100,0 \\
\hline Parcela do custo & $50 \%$ & $50 \%$ & & 100,0 \\
\hline
\end{tabular}

Fonte: Ministério da Cultura e Banco Interamericano de Desenvolvimento (1999)

Tabela 48 - Programa Monumenta - Orçado e Realizado acumulado em 2000 e 2001 (valores aproximados milhões de reais)

\begin{tabular}{l|c|c|c}
\hline Componente & Orçado & Realizado & \% \\
\hline Administração e Supervisão & $6.800 .000,00$ & $5.000 .000,00$ & $\mathbf{7 3 \%}$ \\
\hline Estudos e Projetos & $3.500 .000,00$ & $840.000,00$ & $\mathbf{2 4 \%}$ \\
\hline Investimentos Integrados & $20.000 .000,00$ & $400.000,00$ & $\mathbf{2 \%}$ \\
\hline Fortalecimento Institucional & $7.500 .000,00$ & $1.050 .000,00$ & $\mathbf{1 4 \%}$ \\
\hline Promoção de Atividades Econômicas & $1.000 .000,00$ & 0 & $\mathbf{0} \%$ \\
\hline Treinamento e Formação & $2.000 .000,00$ & $\mathbf{6 6 \%}$ \\
\hline Programas Educativos & $6.000 .000,00$ & $\mathbf{2} \%$ \\
\hline Juros & $2.000 .000,00$ & $420.000,00$ & $\mathbf{4} \%$ \\
\hline Comissão de Crédito & $600.000,00$ & $2.000 .000,00$ & $\mathbf{3 1 3 \%}$ \\
\hline Inspeção e Supervisão & $250.000,00$ & $600.000,00$ & $\mathbf{2 3 0} \%$ \\
\hline
\end{tabular}

Fonte: Tribunal de Contas da União, 2002f 
Quadro 8 - Listas de Prioridades - Programa Monumenta, 1996/2000 (em ordem alfabética)

\begin{tabular}{|c|c|c|c|c|c|c|c|c|}
\hline \multicolumn{3}{|c|}{$\begin{array}{l}\text { Lista do IPHAN } \\
\text { Proposta em } 1996\end{array}$} & \multicolumn{3}{|c|}{$\begin{array}{l}\text { Cidades da Amostra } \\
\text { Convidadas em } 1997\end{array}$} & \multicolumn{3}{|c|}{$\begin{array}{l}\text { Lista de Prioridades } \\
\text { Convidadas em } 2000\end{array}$} \\
\hline Cidade & Região & UF & Cidade & Região & UF & Cidade & Região & UF \\
\hline Antonina & Sul & PR & Olinda & Nordeste & PE & Alcântara & Nordeste & MA \\
\hline Belém & Norte & PA & Ouro Preto & Sudeste & $M G$ & Antônio Prado & Sul & RS \\
\hline Corumbá & Centro-Oeste & MS & Recife & Nordeste & $\mathrm{PE}$ & Belém & Norte & PA \\
\hline Diamantina & Sudeste & $M G$ & Rio de Janeiro & Sudeste & RJ & Brasília & Centro-Oeste & DF \\
\hline Florianópolis & Sul & SC & Salvador & Nordeste & BA & Cachoeira & Nordeste & BA \\
\hline Laranjeiras & Nordeste & SE & São Luís & Nordeste & MA & Carapicuíba & Sudeste & SP \\
\hline Manaus & Norte & $\mathrm{AM}$ & São Paulo & Sudeste & $\mathrm{SP}$ & Congonhas & Sudeste & MG \\
\hline Mariana & Sudeste & $M G$ & & & & Corumbá & Centro-Oeste & MS \\
\hline Olinda & Nordeste & $P E$ & & & & Diamantina & Sudeste & MG \\
\hline Ouro Preto & Sudeste & $M G$ & & & & Goiás & Centro-Oeste & $\mathrm{GO}$ \\
\hline Penedo & Nordeste & $\mathrm{AL}$ & & & & Icó & Nordeste & $\mathrm{CE}$ \\
\hline Petrópolis & Sudeste & RJ & & & & João Pessoa & Nordeste & PB \\
\hline Porto Alegre & Sul & RS & & & & Laranjeiras & Nordeste & SE \\
\hline Porto Seguro & Nordeste & BA & & & & Lençóis & Nordeste & $\mathrm{BA}$ \\
\hline Recife & Nordeste & $\mathrm{PE}$ & & & & Manaus & Norte & AM \\
\hline Rio de Janeiro & Sudeste & RJ & & & & Mariana & Sudeste & MG \\
\hline Salvador & Nordeste & BA & & & & Natividade & Centro-Oeste & TO \\
\hline São Cristóvão & Nordeste & SE & & & & Oeiras & Nordeste & PI \\
\hline São Luís & Nordeste & MA & & & & Parati & Sudeste & RJ \\
\hline \multirow[t]{6}{*}{ São Paulo } & Sudeste & SP & & & & Pelotas & Sul & RS \\
\hline & & & & & & Penedo & Nordeste & $\mathrm{AL}$ \\
\hline & & & & & & Porto Alegre & Sul & RS \\
\hline & & & & & & Porto Seguro & Nordeste & $\mathrm{BA}$ \\
\hline & & & & & & $\begin{array}{l}\text { S. Franc. do } \\
\text { Sul }\end{array}$ & Sul & SC \\
\hline & & & & & & Tiradentes & Sudeste & MG \\
\hline \multicolumn{9}{|c|}{ Total de cidades por região } \\
\hline Norte & \multicolumn{2}{|l|}{02} & Norte & & & Norte & \multicolumn{2}{|l|}{02} \\
\hline Nordeste & \multicolumn{2}{|l|}{08} & Nordeste & \multicolumn{2}{|c|}{04} & Nordeste & \multicolumn{2}{|l|}{09} \\
\hline Centro-Oeste & \multicolumn{2}{|l|}{01} & Centro-Oeste & & & Centro-Oeste & \multicolumn{2}{|l|}{04} \\
\hline Sudeste & \multicolumn{2}{|l|}{06} & Sudeste & \multicolumn{2}{|c|}{03} & Sudeste & \multicolumn{2}{|l|}{06} \\
\hline Sul & \multicolumn{2}{|l|}{03} & Sul & & & Sul & \multicolumn{2}{|l|}{04} \\
\hline $\begin{array}{l}\text { Cidade } \\
\text { descartada }\end{array}$ & \multicolumn{2}{|c|}{$\begin{array}{l}\text { Cidades convidadas } \\
\text { que constavam da } \\
\text { lista do IPHAN. }\end{array}$} & \multicolumn{3}{|c|}{$\begin{array}{l}\text { Cidades convidadas que não } \\
\text { faziam parte da lista do IPHAN. }\end{array}$} & \multicolumn{3}{|c|}{$\begin{array}{l}\text { Cidades que fazem parte da lista } \\
\text { de prioridades de } 2000 \\
\text { e não foram ainda convidadas. }\end{array}$} \\
\hline
\end{tabular}

Fonte: Quadro montado a partir de informações obtidas em Instituto do Patrimônio Histórico e Artístico Nacional (1996) na Unidade Central de Gerenciamento do Programa Monumenta, em dezembro de 2002 (Apêndice E) e junto ao Grupo Tarefa IPHAN-Programa Monumenta, em dezembro de 2002 (Apêndice E). 
Quadro 9-Cidades participantes do Programa Monumenta, 2002

\begin{tabular}{|c|c|c|c|c|c|c|}
\hline \multirow[b]{2}{*}{ Cidade e UF } & \multirow[b]{2}{*}{ Área de Projeto } & \multirow[b]{2}{*}{ Enfoque do Projeto } & \multirow{2}{*}{$\begin{array}{l}\text { Executor } \\
\text { Local }\end{array}$} & \multicolumn{3}{|c|}{ Situação } \\
\hline & & & & Convênio & Excluídas & $\begin{array}{l}\text { Termo } \\
\text { adesão }\end{array}$ \\
\hline 1. Alcântara-MA & Sem informação & Turístico/cultural & Sem def. & & & Julho 2002 \\
\hline 2. Antônio Prado-RS & & & & & Maio 2002 & \\
\hline 3. Belém-PA & & & & & Maio 2002 & \\
\hline 4. Brasília-DF & $\begin{array}{l}\text { Centro-Rodoviária e } \\
\text { imediaçōes }\end{array}$ & & Gov. DF & & & Julho 2002 \\
\hline 5. Cachoeira-BA & $\begin{array}{l}\text { Centro - Capela d’Ajuda e do } \\
\text { Palácio da Aclamação }\end{array}$ & Turístico/cultural & Estado da Bahia & Julho 2002 & & \\
\hline 6. Carapicuíba-SP & & & & & Maio 2002 & \\
\hline 7. Congonhas-MG & $\begin{array}{l}\text { Santuário e Lad. do Bom Jesus e } \\
\text { imediaçóes }\end{array}$ & Turístico/cultural & Prefeitura & Julho 2002 & & \\
\hline 8. Corumbá-MS & Casario do porto & Turístico & Prefeitura & Julho 2002 & & \\
\hline 9. Diamantina-MG & Centro - Igrejas e Mercado & Turístico/cultural & Prefeitura & Julho 2002 & & \\
\hline 10. Goiás-GO & $\begin{array}{l}\text { Centro - Mercado Municipal } \\
\text { e imediaçóes, Quartel do XXe } \\
\text { Museu das Bandeiras }\end{array}$ & $\begin{array}{l}\text { Revitalização e } \\
\text { conservação de } \\
\text { equipamentos }\end{array}$ & Estado de Goiás & Julho 2002 & & \\
\hline 11. Icó-CE & $\begin{array}{l}\text { Centro - Largo do Theberg ao } \\
\text { Mercado Municipal }\end{array}$ & Turístico & Prefeitura & Julho 2002 & & \\
\hline 12. João Pessoa-PB & & & & & Maio 2002 & \\
\hline 13. Laranjeiras-SE & Em preparação - oficina 09.02 & Sem informação & Sem inf. & & & \\
\hline 14. Lençóis-BA & $\begin{array}{l}\text { Centro - Mercado Municipal e } \\
\text { imediaçōes }\end{array}$ & Turístico/cultural & Estado da Bahia & Julho 2002 & & \\
\hline 15. Manaus-AM & $\begin{array}{l}\text { Porto fluvial, Alfândega, em } \\
\text { preparação - oficina 10.02 }\end{array}$ & Sem informação & Sem informação & & & \\
\hline 16. Mariana-MG & Em preparação - oficina 11.02 & Sem informação & Sem inf. & & & \\
\hline 17. Natividade-TO & $\begin{array}{l}\text { Edifícios representativos dos } \\
\text { dois períodos de formação da } \\
\text { cidade }\end{array}$ & Sem informação & Sem informação & & & Julho 2002 \\
\hline 18. Oeiras-PI & Igrejas e casas & Turístico/cultural & Sem inf. & & & Julho 2002 \\
\hline 19. Olinda-PE & Centro histórico - Colina & Urb. e turístico & Prefeitura & Abril 2000 & & \\
\hline 20. Ouro Preto-MG & Arraiais Pilar e Antonio Dias & $\begin{array}{l}\text { Turístico e } \\
\text { comercial }\end{array}$ & Prefeitura & Abril 2000 & & \\
\hline 21. Parati-RJ & Em preparação - oficina 10.02 & Sem informação & Sem inf. & & & \\
\hline 22. Pelotas-RS & Praça Gal. Osório e imediações & Cultural & Prefeitura & Julho 2002 & & \\
\hline 23. Penedo-AL & $\begin{array}{l}\text { Mercado Municipal, cais e } \\
\text { imediaçōes }\end{array}$ & $\begin{array}{l}\text { Urbanístico e } \\
\text { turístico }\end{array}$ & Prefeitura & Julho 2002 & & \\
\hline 24. Porto Alegre-RS & $\begin{array}{l}\text { Centro - Zona portuária e Pça. } \\
\text { Alfândega }\end{array}$ & Social e cultural & Prefeitura & Julho 2002 & & \\
\hline 25. Porto Seguro-BA & Em preparação - oficina 11.02 & Sem informação & Sem inf. & & & \\
\hline 26. Recife-PE & Centro - Bairro do Recife, & Turismo e lazer & Prefeitura & Fev. 2000 & & \\
\hline 27. Rio de Janeiro-RJ & Centro - Praça Tiradentes & Cultural e social & Prefeitura & Junho 2000 & & \\
\hline 28. Salvador-BA & Centro histórico, Saldanha & $\begin{array}{l}\text { Habitacionale } \\
\text { cultural }\end{array}$ & Estado da Bahia & Julho 2002 & & \\
\hline 29. São Francisco do Sul-SC & $\begin{array}{l}\text { Orla da baía de Barbitonga, } \\
\text { Terminal, Mercado e Museu }\end{array}$ & Turístico & Prefeitura & Julho 2002 & & \\
\hline 30. São Luís-MA & & & & & Maio 2002 & \\
\hline 31. São Paulo-SP & Área central - bairro da Luz & Cultural e social & Prefeitura & Julho 2002 & & \\
\hline 32. Tiradentes-RJ & & & & & Maio 2002 & \\
\hline $\begin{array}{l}\text { Total de cidades no } \\
\text { programa em dez. 2002: }\end{array}$ & & & 6 cidades & & & \\
\hline
\end{tabular}

Fonte: Ministério da Cultura, Banco Interamericano de Desenvolvimento e UNESCO (2002). 
Quadro 10 - Programa de Revitalização de Sítios Históricos: linhas de financiamento, 2002

\begin{tabular}{|c|c|c|c|}
\hline Linha de Financiamento & Destinatário & $\begin{array}{l}\text { Financiamento } \\
\text { (em reais) }\end{array}$ & Encargo Mensal \\
\hline $\begin{array}{l}\text { Carta de Crédito FGTS - individual } \\
\text { (aquisiçẵo de terreno, imóvel ou construção) }\end{array}$ & $\begin{array}{l}\text { Pessoa Física } \\
\text { RF até R\$ } 2000\end{array}$ & $44.000,00$ & 502,69 \\
\hline $\begin{array}{l}\text { Carta de Crédito FGTS - individual } \\
\text { (aquisição de material) }\end{array}$ & $\begin{array}{l}\text { Pessoa Física } \\
\text { RF até R\$ } 2000\end{array}$ & $7.000,00$ & 149,97 \\
\hline $\begin{array}{l}\text { Carta de Crédito FGTS - individual } \\
\text { (conclusão, ampliaçãa, melhoria) }\end{array}$ & $\begin{array}{l}\text { Pessoa Física } \\
\text { RF até R\$ } 2000\end{array}$ & $17.500,00$ & 199,75 \\
\hline Imóvel na planta FGTS (aquisição ou construção) & $\begin{array}{l}\text { Pessoa Física } \\
\text { RF até } \mathrm{R} \$ 3.250\end{array}$ & $55.000,00$ & 627,75 \\
\hline FAT Habitação individual (aquisição ou construção) & Pessoa Física & $180.000,00$ & $3.461,81$ \\
\hline $\begin{array}{l}\text { FAT Habitação imóvel na planta } \\
\text { (aquisiçãao ou construçãa) }\end{array}$ & Pessoa Física & $180.000,00$ & $3.461,81$ \\
\hline $\begin{array}{l}\text { Carta de Crédito Caixa - LH Longa } \\
\text { (aquisiçãa ou construçăo uso com.) }\end{array}$ & Pessoa Física & $180.000,00$ & $5.439,46$ \\
\hline $\begin{array}{l}\text { Carta de Crédito Caixa - LH Longa } \\
\text { (reforma ou ampliaçãa) }\end{array}$ & Pessoa Física & $180.000,00$ & $3.889,46$ \\
\hline Construcard - LH Longa (reforma ou ampliação) & Pessoa Física & $180.000,00$ & $7.189,49$ \\
\hline $\begin{array}{l}\text { Programa de Arrendamento Residencial } \\
\text { (aquisição terreno, construção, reforma ou ampliação) }\end{array}$ & $\begin{array}{l}\text { Pessoa Física } \\
\text { RF até o6 SM }\end{array}$ & $35.000,00$ & 245,00 \\
\hline
\end{tabular}

Fonte: Caixa Econômica Federal, posição em janeiro de 2002. 


\section{0 financiamento da preservação do patrimônio nos anos 1990}

\section{Programa Nacional de Apoio à Cultura - PRONAC}

Investir na produção cultural ou na preservação do patrimônio jamais foi tradição do empresariado brasileiro ou prática disseminada em nossa sociedade. A figura do mecenas como indivíduo de posses que investe, voluntariamente, no desenvolvimento das artes e do saber pouco existiu entre nós. O grande mecenas no Brasil sempre foi o Estado, que, como se viu no capítulo relativo ao Rio de Janeiro, atuou sistematicamente na criação de instituições culturais desde início do século XIX, e, ainda que com muitos reveses e dificuldades, jamais abandonou essa tarefa. O país com mais tradição na filantropia cultural é os Estados Unidos, onde, desde o início do século XX, inúmeras instituições culturais e científicas foram fundadas com recursos privados. Entretanto, mesmo lá, a despeito do sentimento americano de independência com relação ao poder público, o Estado teve, na consolidação dessa cultura filantrópica, um papel muito importante, se não central. Em 1917, a criação de uma legislação de 
Depois transformada em Ministério da Cultura. incentivos fiscais à cultura impulsionou os investimentos privados nesse campo, e criou o forte mercado (MOISÉS, 1998b, p. 5) que hoje tem vida independente da ajuda estatal.

O surgimento de incentivos fiscais destinados a alavancar investimentos privados na área de cultura só ocorreu no Brasil nos anos 1980, em função de um novo modelo de Estado que se buscava implantar e da diminuição dos orçamentos governamentais para a atividade. No plano federal, surgiram também como reação à perda de importância da União como fomentadora da cultura e à sua substituição por estados e municípios, cujos gastos na área cresceram significativamente entre 1985 e 1995 (Tabela 35). Pesquisa encomendada pelo Ministério da Cultura à Fundação João Pinheiro, em 1997, revelou que, naquele período, os estados e municípios mais importantes tomaram o lugar do Governo Federal nos gastos com cultura e mantiveram uma política de investimentos mais estável. (MOISÉS, 1998b, p. 14-16) Os investimentos federais no setor só começaram a se recuperar a partir de reformas realizadas na política de incentivos implantada nos anos 1980.

O documento legal que iniciou a política de incentivos do Governo Federal foi a Lei $n^{\circ}$ 7.505, de 2 de julho de 1986, também conhecida como Lei Sarney, que estabeleceu as bases de um primeiro relacionamento entre o Estado e o setor privado nesse campo. O princípio estabelecido pela Lei Sarney era muito simples: pessoas físicas ou empresas interessadas em investir em cultura poderiam negociar livremente o apoio a projetos de produtores ou entidades culturais cadastrados na Secretaria da Cultura da Presidência da República' e abater essa despesa do imposto de renda devido, mediante apresentação de nota fiscal comprobatória. A lei foi muito criticada por eximir o governo de examinar previamente os projetos e por favorecer abusos, ao permitir que qualquer despesa feita com o produtor ou entidade cultural pudesse ser abatida do imposto de renda. Além disso, a falta de exame dos projetos culturais impedia a distinção entre aqueles que realmente precisavam e os que não careciam de incentivos oficiais. A Lei Sarney foi revogada no início de 1990, mas não em razão de suas imperfeições, e sim como parte da decisão do governo Collor de retirar o Estado da atividade de fomento à cultura, abolindo todos os subsídios à atividade e fechando suas principais instituições. Contudo, o peso da tradição de intervenção estatal nesse campo e os protestos 
de produtores culturais não permitiram que essa diretriz sobrevivesse por muito tempo. Com vistas a corrigir as distorções da Lei Sarney e a restabelecer uma nova política de incentivos, foi promulgada, em 1991, a Lei n 8.313 , que tomou o nome do então secretário da Cultura, Embaixador Sérgio Paulo Rouanet.

\section{A Lei Rouanet, seus mecanismos e transformações}

As principais alterações introduzidas pela Lei Rouanet no sistema implantado pela Lei Sarney foram a obrigatoriedade de aprovaçãa prévia dos projetos por uma comissão de representantes do governo e de instituições culturais, a diversificação das fontes de financiamento e a criação do Programa Nacional de Apoio à Cultura - PRONAC, cuja finalidade seria captar e canalizar recursos para, entre outros objetivos, facilitar e democratizar o acesso às fontes da cultura, estimular a regionalizaçăo da produção cultural e preservar o patrimônio. O programa se estrutura em torno de três mecanismos ou modalidades de financiamento: o Fundo Nacional da Cultura - FNC; o Incentivo a Projetos Culturais, também conhecido como "mecenato"; e os Fundos de Investimento Cultural - FICART. O primeiro éum mecanismo de fomento a fundo perdido, constituído, basicamente, de recursos do Tesouro Nacional e de porcentagens da arrecadação dos Fundos de Investimentos Regionais e das loterias federais. ${ }^{2}$ De acordo com a Lei n ${ }^{\circ}$ 8.313/91, o FNC se destina a estimular uma distribuição regional equânime dos recursos do governo para o desenvolvimento de projetos culturais, e a favorecer projetos que atendam aos interesses da coletividade è às demandas culturais existentes. Em suma, trata-se de um instrumento compensatório, voltado principalmente para atender a demanda que encontra dificuldades de desenvolvimento e atendimento no mercado, e que deve ser apoiada pelo Estado. Os recursos do FNC podem financiar até $80 \%$ dos projetos aprovados.

Já os Fundos de Investimento Cultural - FICART, disciplinados pela Comissão de Valores Mobiliários, se destinam a atrair recursos privados para atividades e produçóes culturais de caráter exclusivamente comercial. Devem funcionar como qualquer fundo de ações existente no mercado e serem formados por condomínio de cotistas interessados em investir em atividades culturais lucrativas. No caso desse mecanismo, a ajuda do governo corresponde à isenção
2 A porcentagem da arrecadação dos Fundos de Investimentos Regionais corresponde a $1 \%$, e a relativa às loterias federais, a $3 \%$, conforme alteração introduzida pela Lei nº.999/00. Ver artigo $5^{\circ} \mathrm{da}$ Lei 8.313/91. O fundo pode ainda receber doações, legados e subvenções. 
3 Ver artigo 14 da Lei $n^{\circ} 8.313 / 91$.

4 A CNIC é formada por instituições públicas e organizações não governamentais atuantes na área de cultura.

5 Ver parágrafo $8^{\circ}$ do Artigo 19 e Artigo 22 da Lei n $8.313 / 91$.

6 Artigos 27 e 28 da Lei $n^{0} 8.313 / 91$. do imposto sobre operações de crédito e do imposto de renda correspondente aos rendimentos e ganhos de capital auferidos por esses fundos. ${ }^{3} \mathrm{O}$ instrumento, contudo, jamais foi efetivado, por ter recebido muitas críticas, por falta de regulamentação específica e de articulação do Ministério da Cultura com o sistema financeiro. (BRASIL, 2001C, p. 96; MOISÉS, 1997a, p. 21)

O mecanismo de financiamento da Lei Rouanet que adquiriu maior popularidade corresponde ao núcleo do antigo sistema instituído pela Lei Sarney. O Incentivo a Projetos Culturais, ou "mecenato", beneficia pessoas físicas e jurídicas com deduçóes variáveis no imposto de renda, relativas a contribuições feitas ao FNC ou ao apoio dado a projetos culturais. São também consideradas as despesas efetuadas por proprietários na conservação ou restauração de imóveis tombados pelo Governo Federal, desde que orientadas e aprovadas pelo IPHAN. O mecenato é, portanto, um mecanismo de financiamento misto, concebido para operar com recursos públicos oriundos de renúncia fiscal e contrapartida privada. Em sua versão inicial, as deduções permitidas variavam de 40\% a 80\% do valor dos projetos apoiados, para o caso de doações, e de 30\% a 40\%, para patrocínios, até o teto máximo de $2 \%$ do total do imposto de renda devido. A lei submete a aprovação dos projetos que se candidatam à renúncia fiscal ao Ministério da Cultura, através da Comissão Nacional de Incentivo à Cultura - CNIC, ${ }^{4}$ que deve observar o princípio de não concentrar recursos por segmento cultural ou beneficiário, vedada, entretanto, a apreciação subjetiva do valor artístico ou cultural do projeto. ${ }^{5} \mathrm{Em}$ sua versão inicial, a lei vedava ainda doações ou patrocínios efetuados a pessoa ou instituição vinculada ao incentivador, assim como a aplicação dos recursos aprovados pelo programa em qualquer tipo de intermediação. ${ }^{6}$

Entre 1991 e 1994, o desempenho desse sistema de financiamento não foi bom, com uma porcentagem mínima de projetos conseguindo captar recursos (Tabela 36). O fato foi atribuído ao processo rígido e burocratizado de avaliação das propostas, ao impedimento da remuneração de profissionais para elaborar projetos e intermediar a atividade de captação e, principalmente, devido ao nível baixo do percentual de imposto a deduzir. (DURAND; GOUVEIA; BERMAN, 1997, p. 43) A partir de 1995, com o objetivo de reverter esse quadro, o Ministério da Cultura modificou a lei. 
A parceria entre o poder público e a iniciativa privada foi, durante a administração Fernando Henrique Cardoso, posta como condição para a consolidação de um sistema permanente e democrático de financiamento da cultura no país. A ação exclusiva do Estado foi definida como própria dos regimes autoritários que procuram determinar a criação cultural (MOISÉS, 1997a, p. 14-16), sendo, portanto, o grande desafio do governo criar um sistema de financiamento eficaz que não fosse exclusivamente dependente de recursos públicos. Ao atrair recursos privados, esse sistema abriria espaço para que a sociedade decidisse também sobre as atividades a serem apoiadas, tornando-se, assim, parceira e participante ativa da execução da política cultural. Com o aumento da percepção dos empresários sobre as vantagens de associar suas empresas a valores permanentes da cultura, os recursos do sistema estariam permanentemente garantidos. (MOISÉS, 1997a, p. 21)

As manifestações culturais que não despertassem o interesse de investidores privados e, portanto, não encontrassem alocação no mercado, seriam apoiadas pelo Estado, a fundo perdido, por meio do FNC. Com recursos significativamente ampliados, o fundo deveria adquirir dimensão semelhante à do mecenato e funcionar como instrumento voltado a corrigir suas distorções. A complementaridade e o equilíbrio entre os dois mecanismos de financiamento seriam, portanto, essenciais para se evitar que os investimentos ficassem concentrados nas regiões com melhores condições de atendimento à demanda cultural e nos mercados mais interessantes para o setor privado. Em suma, o Estado se incumbiria das regiões com mercado cultural menos dinâmico, atuando como administrador dessa necessária complementaridade. (MOISÉS, 1997b, p. 30)

De fato, em 1996, os números apontavam que, acompanhando as desigualdades demográficas e socioeconômicas brasileiras, a região Sudeste concentrava 88,7\% dos recursos totais captados via Lei Rouanet(Tabela 37). (MOISÉS, 1997b, p. 31) Mostravam ainda que 88\% dos projetos conveniados pelo FNC, entre 1993 e 1994, também haviam ficado concentrados nessa região. (MOISÉS, 1997a, p. 33) Assim, os responsáveis pela renovação e modificação do sistema de financiamento defendiam o reforço dos recursos e o direcionamento da ação do FNC, sob pena de se reafirmar, no plano cultural, as desigualdades estruturais do país. (MOISÉS, 1997b, p. 32) Entretanto, nem o FNC foi utilizado dessa maneira, nem o mecenato 
7 O artigo 22 da Lei $n^{\circ} 8.313 / 91$ estabelece que os projetos apresentados ao mecenato não poderão ser avaliados quanto ao seu valor artístico e cultural. Essa norma, que busca evitar juízos preconceituosos ou subjetivos na avaliação de projetos, foi erroneamente interpretada como um obstáculo legal ao estabelecimento de critérios de priorização e avaliação do mérito e do alcance social dos projetos submetidos ao Ministério da Cultura.

8 A Lei n 8.313/91 foi modificada por várias Medidas Provisórias, consolidadas nas Leis n $9.649 / 98$, n $9.974 / 99$ e n० 9.999/00. Foi alterada também pela MP nº 2.228-1/01. A regulamentação da Lei Rouanet, estabelecida pelo Decreto $n^{\circ} 7.494 / 95$, foi igualmente modificada pelos Decretos $n^{\circ} 2.585 / 98, n^{\circ} 4.397 / 02$ e $n^{\circ} 4.483 / 02$ O funcionamento do sistema foi ainda regulado e alterado pela Instrução Normativa $n^{\circ} 85$, de 3 de julho de 1992, pela Instrução Normativa Conjunta $\mathrm{n}^{\circ} \mathrm{Or}, \mathrm{de}$ 13/06/95, e pela Instrução Normativa SRF n ${ }^{\circ} 258$, de 17/12/02.

9 Originalmente, apenas serviços de elaboração de projetos eram permitidos, limitados a $10 \%$ do valor total do projeto. (DURAND; GOUVEIA; BERMAN, 1997, p. 44) manifestou a "natureza democrática" que lhe foi atribuída. Mais gravemente, nem o Estado atuou como administrador do equilíbrio e da equanimidade do sistema, nem controlou, como se defendia, o investimento privado realizado com recursos públicos. A análise de projetos, por força de disposição legal equivocadamente interpretada,? ateve-se apenas ao exame da natureza cultural das propostas e ao realismo dos orçamentos apresentados, sem discutir concentração regional e muito menos o alcance social e cultural das ações incentivadas. Além disso, as alterações e modificações feitas no sistema apenas acentuaram suas distorções de origem. Ao invés de o seu funcionamento traduzir os objetivos da política cultural, esta passou a ser ditada pelo seu mecanismo mais forte: o mecenato. Em outras palavras, com o beneplácito e a chancela das autoridades federais, a política cultural do governo foi conduzida, nos anos 1990, por empresas estatais e corporações privadas sediadas no Sudeste.

Durante o governo Fernando Henrique Cardoso, a Lei Rouanet sofreu uma série de modificações, a maior parte das quais com vistas a dinamizar o mecenato mediante a desburocratização de procedimentos, o direcionamento de alguns incentivos e, principalmente, o aumento das vantagens fiscais oferecidas pelo governo. ${ }^{8}$ As primeiras modificações introduzidas destinaram-se a tornar mais atrativo para o empresariado o uso dos incentivos. A margem total de desconto do imposto devido cresceu de $2 \%$ para $5 \%$ e foi estendida a qualquer pessoa jurídica. Procedimentos burocráticos de recebimento, análise e aprovação de propostas foram simplificados, e liberados os serviços relativos à elaboração, difusão e divulgação de projetos, bem como os relativos à contratação de intermediários para a captação de recursos junto a patrocinadores. ${ }^{9}$

Com essas providências, o Ministério da Cultura incentivou a formação do mercado de intermediação de projetos que passou a dominar a movimentação de recursos do sistema. Muitas instituições se especializaram nessa atividade, funcionando - a exemplo do Centro Cultural Banco do Brasil, do Rio de Janeiro - como museu, galeria, casa de espetáculos e agência de intermediação entre produtores culturais e patrocinadores. O resultado dessas alterações realizadas no sistema foi significativo. Os recursos captados aumentaram sensivelmente, saindo de R\$150.391,07 em 1994, para R\$ 7.149.128,92, em 1995 (Tabela 36). 
Mas, não bastasse a resposta positiva do mercado (que, como mostra a tabela 36, manteve o ritmo crescente de utilização da renúncia fiscal nos anos subsequentes), as margens de desconto e de dedução do imposto devido foram ainda significativamente aumentadas. A partir de 1997, investimentos em projetos de artes cênicas, música erudita e instrumental, edição de livros, exposições de artes plásticas, tratamento de acervos de museus e bibliotecas públicas, assim como para produções cinematográficas e audiovisuais, ${ }^{10}$ passaram a poder fazer jus a uma dedução de 100\% da despesa efetuada. Em 2001, essa vantagem foi estendida a projetos de preservação do patrimônio cultural, " e a margem total de dedução do imposto devido foi aumentada para 6\%. ${ }^{12}$ As ações passíveis de dedução foram também ampliadas, passando a incluir a cessão de espaço ou objetos a projetos incentivados, e a doação de ingressos para eventos culturais a funcionários de empresas.

Outra importante modificação introduzida na Lei Rouanet foi a aceitação de instituições culturais sem fins lucrativos vinculadas a doadores e patrocinadores como proponentes de projetos. Com isso, patrocinadores de peso, como Banco do Brasil, Banco Itaú, Caixa Econômica e outros, dinamizaram ou implantaram seus próprios centros culturais, carreando para estes quase todos os recursos que destinavam ao patrocínio cultural. Essa prática foi, ainda, beneficiada pela equiparação dos planos anuais de atividades de sociedades filantrópicas ${ }^{13}$ e dos plurianuais de instituições "prestadoras de relevantes serviços à cultura" aos projetos culturais que fazem jus a incentivos. ${ }^{14}$ Assim, os centros culturais corporativos passaram a poder não somente montar toda a sua programação anual com base nos incentivos do governo, como também planejá-la e financiá-la para períodos de três a cinco anos.

Paralelamente a essa crescente ampliação das vantagens fiscais para empresas patrocinadoras ocorreu o encolhimento das vantagens para pessoas físicas ${ }^{15}$ e a diminuição do controle social sobre a execução da política de incentivos. Criada pela Lei Rouanet como órgão deliberativo, destinado a supervisionar o PRONAC e a aprovar os projetos culturais encaminhados ao programa, a Comissão Nacional de Incentivo à Cultura - CNIC foi transformada em instância meramente consultiva. ${ }^{16}$ Suas atribuições deliberativas foram transferidas para
10 A Lei do Audiovisual permite descontar do imposto devido $100 \%$ dos recursos relativos ao apoio de produçóes cinematográficas e audiovisuais.

11 Ver a Medida Provisória $n^{\circ} 2.228-1$, de 6 de setembro de 2001.

12 Ver Instrução Normativa SRF n ${ }^{\circ} 258$, de 17 de dezembro de 2002.

13 As conhecidas "Sociedades de Amigos" de museus, fundações e institutos públicos.

14 Ver artigo 28 do Decreto $n^{\circ} 1.494 / 95$ e Decreto $n^{\circ} 4.397 / 02$.

15 A margem de dedução do imposto de renda devido para pessoas físicas que já foi de 10\%, foi equiparado ao das pessoas jurídicas e, portanto, reduzido para $6 \%$.

16 Ver Decreto n 1.494/95 e a Resolução $n^{\circ}$ 01, de 18 de setembro de 2001, do Ministério da Cultura, que instituiu o novo regulamento da CNIC. 
17 Medida autorizada pela MP n ${ }^{0} 1.589 / 97$ cujas disposições foram depois incorporadas à Lei n 9874/99. Em 2001, através da MP $n^{\circ} 2.228-1$, o beneficio foi estendido às produções cinematográficas e vídeográficas de curta e média metragem, e à preservação de bens culturais de natureza material e imaterial. o ministro da Cultura, que, assim, teve instituído o seu poder discricionário de aprovar os projetos e definir as ações que, mesmo não estando previstas na lei, poderiam ser incentivadas.

Com as várias reformas empreendidas no sistema de incentivos, o uso do mecenato cresceu exponencialmente, assim como cresceu significativamente o montante de recursos captados (Tabela 36). Entretanto, as distorções do mecanismo, detectadas em 1996, não foram sanadas. Aproximadamente $82 \%$ dos projetos aprovados continuaram localizados nas regiões Sudeste e Sul (cerca de $66 \%$ e $16 \%$, respectivamente), assim como os $87 \%$ que captaram recursos (respectivamente, $70 \%$ e 17\%, Tabela 38). Quanto ao montante de recursos captados pela Lei Rouanet, a concentração permaneceu igualmente muito alta, com 83\% do total no Sudeste (Tabelas 37 e 39).

Mas a concentração no âmbito do mecenato não aconteceu apenas regionalmente. Ocorreu também por segmento cultural, incentivador e proponente. Como mostra a tabela 40, os segmentos que mais captaram recursos na década de 1990 foram artes cênicas, música e patrimônio, sendo que os dois primeiros foram beneficiados, a partir de 1997, com deduções de 100\% da despesa efetuada, o que foi estendido à preservação do patrimônio cultural e a outros segmentos em 2001. ${ }^{17}$ A partir desse momento, os segmentos mais contemplados cresceram significativamente em importância relativa, o que reforçou a tendência de concentração (Tabelas 40 e 41). Além disso, o aumento da dedução influenciou o critério de decisão das empresas, que, a partir de 1997, tenderam a investir mais nos segmentos melhor aquinhoados com deduções. (BRASIL, 2001c, p. 104)

Os primeiros dez anos de funcionamento do mecenato contribuíram para a constituição de um grupo de grandes patrocinadores, composto por empresas estatais e privadas sediadas no Sudeste. Como se pode verificar na tabela 42, os maiores valores então investidos em projetos, via mecenato, foram oriundos de um reduzido número de empresas que provia, em média, cerca de 35\% de todo o recurso captado pelo mecanismo. Muitas dessas empresas possuíam seus próprios centros culturais, nos quais aplicavam praticamente toda a sua cota de dedução. Essa concentração de patrocinadores rebateu-se, naturalmente, nos projetos beneficiados e seus proponentes, configurando uma situação em que a renúncia fiscal ia, em grande parte, para o mesmo e reduzido grupo de empresas 
e centros culturais, que trabalhavam, basicamente, com um mesmo tipo de projeto. Como mostra a tabela 43, apenas três dos maiores e mais frequentes proponentes de projetos culturais beneficiaram-se, entre 1995 e 2002, de 10\% de todo o recurso captado no mecenato, o que correspondeu a cerca de $90 \%$ dos recursos totais aprovados pelo FNC, no mesmo período. Ou seja, apenas três instituições culturais, vinculadas a três grandes empresas - Rede Globo, Banco Itaú e Banco do Brasil - captaram, via mecenato, recursos correspondentes a praticamente tudo o que o FNC dispôs para, em tese, corrigir as distorções do mercado e viabilizar projetos, a fundo perdido, em todo o Brasil.

O sistema de financiamento da cultura, na modalidade mecenato, promoveu, nos anos 1990, ainda, outra distorção. Uma vez que as instituições públicas são impedidas de se beneficiar dos incentivos do mecenato, para driblar essa norma, casas de cultura, museus e centros culturais estatais adotaram o expediente de constituir organizações privadas, sem fins lucrativos, para apoio às suas atividades. Por meio dessas "associações de amigos", os equipamentos públicos passaram a captar recursos do mecenato e, na prática, privatizaram sua gestão, já que grande parte dos recursos que impulsionam as atividades-fim desses equipamentos provém daquelas organizações e é por elas movimentada. Essas se habilitam ainda aos recursos do FNC e, assim, passaram a executar recursos orçamentários da administração direta, o que caracteriza uma fuga dos controles habituais da aplicação do dinheiro público. A Associação de Amigos da FUNARTE, por exemplo, no ano de 2000, executou quase a totalidade dos recursos destinados a esta autarquia federal pelo FNC e pelo Ministério da Cultura. (BRASIL, 2001c, p. 254-256)

O sistema de financiamento da cultura implantado nos anos 1990 surgiu da ideia, comum a qualquer programa de incentivos fiscais, de aumentar e atrair recursos privados para o setor, além dos correspondentes à renúncia fiscal. Contudo, o que ocorreu no período foi que a proporção de dinheiro realmente privado investido nos projetos culturais foi diminuindo, ao passo que foi crescendo, no financiamento desses projetos, a participação dos recursos públicos. Como mostra relatório elaborado para o Ministério da Cultura, em 1995, (BRASIL, 2001c, p. 102) a contribuição efetivamente privada era, em média, de 66\% da parcela correspondente à renúncia fiscal em cada projeto. Em 2000, essa relação 
18 A porcentagem da arrecadação bruta das loterias federais destinada ao FNC passou de $1 \%$ para $3 \%$ Ver Lei n $9.999 / 00$ era de apenas 35\% do valor dos projetos. De fato, ao aumentar a possibilidade de dedução do valor investido para 100\%, a legislação deixou de estimular o investimento privado para apenas repassar o recurso público, diretamente, às empresas patrocinadoras. (SARKOVAS, 2002) Estas, por sua vez, o aplicavam como bem entendiam.

O FNC foi concebido, como visto, para funcionar como instrumento de incentivo a manifestações culturais que, embora importantes, não encontram apoio no mercado. Em suma, para compensar, nas regiões menos desenvolvidas, as distorções e o desequilíbrio "típicos" do mecenato privado. Essas missões tão importantes não puderam, entretanto, ser cumpridas durante os anos 1990, sobretudo por três razões: (1) não se conseguiu estabelecer uma política de distribuição regional que realmente corrigisse as distorções verificadas; (2) utilizou-se o mecanismo como um balcão de atendimento a demandas localizadas de prefeituras e políticos; e (3) os recursos disponíveis, apesar de terem aumentado no período, foram muito menores do que os movimentados pelo mecenato. ${ }^{18} \mathrm{Como}$ mostra a tabela 44, o FNC operou com o equivalente a cerca $10 \%$ dos recursos captados por essa outra modalidade de financiamento (Tabela 36).

Os números relativos à distribuição regional dos recursos do FNC, no período em foco, mostram que, apesar do discurso do Ministério da Cultura, o desequilíbrio não foi suficientemente compensado. Embora o número de projetos atendidos pelo fundo tenha sido mais equilibrado entre as regiões Nordeste, Sudeste e Sul, a disparidade permaneceu forte com relação às regiões Norte e Centro-Oeste, que, respectivamente, registraram apenas 9\% e 8,5\% dos projetos contemplados (Tabela 44). Se considerarmos que aproximadamente $9 \%$ dos recursos do FNC atenderam às demandas das entidades vinculadas ao Ministério da Cultura, nota-se que, efetivamente, o fundo contou com verba ainda menor para realizar uma política regional compensatória. Ao lado disso, parece não ter sido eficiente o trabalho do Ministério destinado a identificar melhor a demanda das regiões menos contempladas, pois o desequilíbrio regional ocorreu também no âmbito do FNC. Considerando-se a média entre 1995 e 2002, a região Sudeste foi contemplada com $31 \%$ dos recursos do fundo, contra $24 \%$ do Nordeste, $13 \%$ do Sul e, respectivamente, $7 \%$ e 6\% das regiões Centro-Oeste e Norte. Os 16\% restantes foram absorvidos pelas entidades vinculadas do MinC, especialmente IPHAN 
e FUNARTE (Tabela 44). Observando-se a distribuição de recursos do FNC ano a ano, verifica-se que, entre 1995 e 2001, apesar das intenções declaradas de se privilegiar as regiões menos contempladas pelo mecenato, raramente houve uma distribuição mais equilibrada ou uma alteração significativa nesse panorama. Os recursos permaneceram mais concentrados no Sudeste, e o Nordeste foi a única região pouco contemplada no mecenato que teve a situação melhorada no FNC (Tabela 45).

\section{0 financiamento da preservação do patrimônio cultural}

Uma das principais finalidades do PRONAC, tal como definido pela Lei $n^{\circ} 8.313 / 91$, é preservar o patrimônio cultural. ${ }^{19}$ De início, voltada exclusivamente para a conservação e restauração de bens móveis e imóveis tombados pelo Governo Federal, após a promulgação da legislação que instituiu o Registro de bens culturais de natureza imaterial, ${ }^{20}$ essa diretriz foi ampliada para essas expressões da cultura na medida em que componham o patrimônio nacional.

Como mostra a tabela 40, a área de patrimônio sempre despertou o interesse de incentivadores, chegando mesmo a liderar, até 1999, o ranking dos recursos captados no mecenato. Da mesma forma que nas demais áreas, as ações contempladas por meio deste mecanismo ficaram muito concentradas no Sudeste, especialmente nos estados do Rio de Janeiro, Minas Gerais e São Paulo. Entre 1995 e 2000, os incentivadores maiores e mais constantes nessa área foram empresas estatais, destacando-se, inicialmente, as de telecomunicações, como a Telesp e a Telemig. ${ }^{21}$ Depois da privatização das "teles", esse espaço foi preenchido por empresas estatais como Petrobras, BNDES e Eletrobrás (Tabela 46).

A análise dos projetos de patrimônio cultural encaminhados ao PRONAC mostra que a dinâmica de investimentos nessa área foi, em todos os aspectos, extremante concentrada e especializada. Além da já referida concentração regional, os investimentos dirigiram-se especialmente para obras em grandes monumentos ou bens artísticos, localizados nos grandes centros ou em cidades históricas do Sudeste. Esses projetos foram intermediados por grupo igualmente reduzido e especializado de proponentes, destacando-se as Fundações Roberto Marinho, Herbert Levy e Ricardo Espírito Santo. Essa concentração temática
19 Ver artigo $7^{\circ}$ da Lei $n^{\circ} 8.313 / 91$.

20 Decreto $n^{\circ} 3.551$, de 4 de agosto de 2000

21 Empresas de Telecomunicações dos Estados de São Paulo e Minas Gerais. 
22 A FRM foi criada em 1977 com o objetivo de promovere divulgar atividades educacionais e culturais.

23 Informações prestadas por Silvia Finguerut, Gerente de Patrimônio e Ecologia da FRM, em entrevista realizada em 25 fev. 2002.

24 A Fundação Roberto Marinho não trabalhava no começo dos anos $2000 \mathrm{com}$ projetos cujo valor fosse menor do que R\$̦ 1 milhão. (Informações prestadas por Silvia Finguerut, Gerente de Patrimônio e Ecologia da FRM, em entrevista realizada em $25 \mathrm{fev}$. 2002)

25 Informações prestadas por Silvia Finguerut, Gerente de Patrimônio e Ecologia da FRM, em entrevista realizada em 25 fev. 2002 e de proponentes favoreceu o estreitamento do espectro da ação de preservação incentivada, e fez com que o segmento apresentasse uma das mais altas taxas de captação e execução de todo o programa.

Nos anos 1990, toda a área de projetos da Fundação Roberto Marinho' ${ }^{22}$ se sustentou, basicamente, com os recursos captados via leis de incentivo à cultura, sendo o patrimônio cultural o segmento de atuação mais estável. Por ocorrer na Rede Globo, normalmente em horário nobre, a divulgação dos projetos propostos e geridos pela FRM, a organização tornou-se um grande atrativo e um dos intermediários mais procurados tanto por produtores culturais como por patrocinadores. O poder de fogo de sua empresa-mãe e o know-how adquirido ao longo de vinte anos permitiram, inclusive, que a organização também "adotasse" projetos no período. Seus parceiros mais constantes foram as estatais BNDES e Eletrobrás, seguidas do Banco Real, da Bradesco Seguros e das Tintas Ypiranga, esta última patrocinadora do conhecido projeto "Cores da Cidade", por meio do qual fachadas de imóveis históricos foram pintadas em cidades como Rio de Janeiro, Recife e Fortaleza.

Os critérios de seleção de projetos da FRM levavam em conta, em primeiro lugar, o seu potencial de visibilidade, ${ }^{23}$ o que, naturalmente, vinculava-se ao tipo de bem a ser preservado, à sua localização e ao montante financeiro da ação. ${ }^{24}$ Pesavam ainda na decisão a sustentabilidade da proposta e a natureza da intervenção. Neste último caso, apesar de sua larga tradição na administração de obras de restauração em monumentos tombados, a FRM dava, no começo da década de 2000, menos prioridade a esse tipo de ação - vista como trabalhosa, arriscada em termos de orçamento e, a depender da situação, menos visível do que o produto de projetos como, por exemplo, o "Cores da Cidade". Do ponto de vista dessa organização, projetos que envolvessem conjuntos urbanos podiam render muito mais em termos de repercussão, mobilização comunitária e desdobramentos do que obras em monumentos isolados. ${ }^{25}$ Por isso, a promoção do "Cores da Cidade", já que esse tipo de projeto, além de ter um custo muito mais baixo do que as complicadas restaurações, funcionava bem em termos de divulgação e comentário boca a boca, pelo simples fato de ser mais visível e marcante no espaço urbano.

A atuação da Fundação Roberto Marinho nos anos 1990 é exemplo de como a política de incentivos do Governo Federal para a área de cultura permitiu 
a sustentação da atividade de fundações privadas ligadas a grandes corporações e a redução dos custos promocionais de empresas, na medida em que permitiu que recursos incentivados fossem também aplicados na divulgação de projetos culturais. O investimento em marketing cultural já era visto como importante nos anos 1980, e era realizado pelas empresas antes da implantação do sistema de incentivos federais. Ou seja, com suas crescentes vantagens, esse sistema não incentivou um investimento privado que já buscava esses caminhos. Na realidade, possibilitou que este investimento fosse reduzido e que o marketing cultural das empresas patrocinadoras fosse realizado, basicamente, com recursos públicos.

O uso de recursos do PRONAC na recuperação de fachadas e coberturas dos edifícios históricos, sob o argumento de que esses exteriores constituem um bem de valor ambiental, ocorreu no centro histórico de Salvador e constituiu uma primeira utilização do mecanismo do mecenato em ação de cunho social mais amplo. ${ }^{26}$ Como as regras do PRONAC exigiam que o projeto partisse de uma entidade cultural, a Associação de Amigos da Caixa Econômica Federal, que tem em seus estatutos a finalidade de preservar o patrimônio, propôs os projetos ao Ministério da Cultura. Com esse arranjo, que foi aprovado pela CNIC em 2002, a Caixa passou a financiar a construção ou a adaptação de interiores de imóveis localizados em sítios históricos urbanos para uso habitacional, e o PRONAC, a recuperação do exterior, o que possibilitou a manutenção do custo da operação em níveis compatíveis com o financiamento existente e a faixa de renda dos mutuários focalizados.

\section{Desequilíbrios e distorções}

Ao longo de toda a década de 1990, o PRONAC reproduziu, nos projetos culturais incentivados e nos recursos conveniados com outras instâncias públicas, as desigualdades regionais, sociais e econômicas do país. Funcionou, em termos distributivos, exatamente do modo que seus criadores e defensores não queriam, ou seja, com projetos e recursos concentrados no eixo Rio - São Paulo e com investimentos privados decrescentes. As principais causas desse desequilíbrio foram a disparidade entre os recursos disponíveis para o financiamento a fundo perdido e os oriundos da renúncia fiscal, além da falta de um corpo de critérios
26 Ver, neste capítulo, os itens correspondentes ao Programa de Revitalização de Sítios Históricos, da Caixa Econômica Federal. 
para a distribuição dos incentivos que contemplasse não somente a diversidade cultural do país, mas também suas desigualdades sociais e regionais. A opção de deixar a cargo das empresas patrocinadoras a decisão de onde e em quê investir, afinal não se provou democrática em seus resultados globais. Além de produzir concentração de recursos e projetos nas regiões de mercado mais dinâmico, favoreceu, basicamente, grandes nomes do cenário cultural e instituições vinculadas a grandes empresas.

Esses grandes nomes e instituições culturais, por seu turno, revelaram-se, no passar do tempo, cada vez mais dependentes dos incentivos fiscais, que respondiam, no caso de espetáculos de artes cênicas, por exemplo, pelo grosso das produções em circulação nos grandes centros urbanos. Por isso, mesmo com acesso amplo ao mercado, produtores culturais de renome nacional não hesitavam em usar seu prestígio para pressionar o Estado por mais verbas e mais poder de decisão na sua aplicação. (SARKOVAS, 2002; XEXÉO, 2002, p. 10) Como resultado disso, regiões e segmentos culturais que não interessavam aos grandes patrocinadores não eram beneficiados. Em razão das deficiências de recursos - e também de critérios -, essa distorção não foi compensada no âmbito do FNC.

Com a justificativa de se evitar censura artística ou interferência do Estado na temática, conteúdo e forma dos projetos, deixou-se de avaliar o mérito de projetos culturais e também de considerar sua capacidade de alcance social e de atender a segmentos e regiões que o Estado desejava desenvolver. Além disso, até 2002, como já observado, os projetos encaminhados ao mecenato foram aprovados com base em avaliações sumárias e restritas à verificação da justeza dos orçamentos apresentados. A despeito de a CNIC ter por diversas vezes defendido a elaboração de um corpo de critérios que possibilitasse uma avaliação mais consistente dos projetos, no que foi seguida pelas comunidades técnicas do Ministério da Cultura e do IPHAN, nada foi implementado nesse sentido. Assim, o discurso oficial de que a distribuição dos recursos do mecenato foi democrática, por conter negociações no âmbito da sociedade civil entre produtores e patrocinadores e por passar por um "complexo processo de avaliação" no âmbito do Estado, não espelhou, de fato, a realidade. O que ocorreu foi uma 
transferência total da decisão do uso do recurso público para os patrocinadores, que, sem nenhuma orientação ou exigência, selecionaram os projetos culturais unicamente segundo seus interesses comerciais e de marketing.

Essa situação tornou-se ainda mais grave diante do fato de que grande parte dos recursos do mecenato ia para as chamadas instituições culturais "sem fins lucrativos", vinculadas aos grandes patrocinadores. O sistema criou facilidades para que as empresas pudessem investir recursos em suas próprias instituições culturais, as quais, se visto bem de perto, tinham, obviamente, fins lucrativos, já que funcionavam como ferramentas de marketing que ampliavam os mercados e fidelizavam os clientes de suas empresas-mãe. Como visto no capítulo referente ao Rio de Janeiro, a programação dos centros culturais criados na área central dessa cidade era montada para atender a esses objetivos. Todas as vezes que o Estado tenta estabelecer parâmetros para corrigir essas distorções foi acusado de intervencionismo e dirigismo cultural.

A política federal de incentivos fiscais teve, contudo, um saldo positivo nos anos 1990. ${ }^{27}$ Os recursos aplicados em cultura realmente aumentaram, assim como aumentou a oferta, especialmente nos grandes centros do Sudeste, de grandes exposições de artes plásticas, concertos de música erudita e espetáculos de dança e ópera. Novos grupos de teatro foram formados, patrimônios foram recuperados e o cinema brasileiro, após a crise deflagrada em 1990, foi fortalecido, ainda que mantendo sua tradicional dependência do Estado. O PRONAC foi, sem dúvida, um importante instrumento da política cultural e significou efetivamente um envolvimento maior da sociedade nesse campo. Não foi conduzido adequadamente, especialmente porque não atrelou seus recursos a uma política cultural amplamente aceita e discutida. A gestão Weffort, especialmente no segundo mandato, não abriu espaço para essa discussão, tirando de cena inclusive o próprio Conselho de Política Cultural do MinC. Embora prevista na legislação que rege o PRONAC, a avaliação pós-execução dos resultados sociais e culturais dos projetos incentivados não foi feita, realizando-se apenas uma avaliação contábil da aplicação dos recursos. Tampouco se logrou integrar estados e municípios num sistema nacional de financiamento, o que, certamente, colocaria a política cultural em outro patamar de abrangência. 
28 Adota-se para o PCHa periodização proposta por Corrêa (2012).
No que diz respeito ao patrimônio urbano, a contribuição do sistema federal de incentivos fiscais foi reduzida em termos de contribuir para a transformação de sítios históricos atingidos por processos de deterioração e de perda de funções, exceto no caso do centro da cidade do Rio de Janeiro, onde o cluster de centros culturais incentivados por esse sistema, de fato, teve impacto transformador em certos setores. No mais, o sistema favoreceu projetos facadistas, como o "Cores da Cidade", que funcionou em várias cidades como mais um fator de homogeneização espacial. Por outro lado, o uso de incentivos para viabilizar a sempre difícil equação da reabilitação do patrimônio edificado, dando-lhe um uso social mais amplo, foi muito restrito.

\section{Programa Monumenta e seus antecedentes}

O financiamento de ações de conservação e reabilitação do patrimônio histórico não é algo que surgiu recentemente no âmbito dos interesses do Banco Interamericano de Desenvolvimento. Já em 1967, a partir do encontro promovido pela Organização dos Estados Americanos na cidade de Quito, aliar patrimônio histórico e desenvolvimento econômico tornou-se palavra-de-ordem para a América Latina e também para esta instituição financeira: ali foram lançadas as bases do modelo de aproveitamento econômico da herança cultural da região, implementado durante a década de 1970 e início dos anos 1980. Esse modelo se apoiava no turismo como atividade capaz de promover mudanças no cenário econômico e social de áreas depreciadas; no financiamento de intervenções em grandes monumentos, para a instalação de equipamentos culturais; e na implantação de infraestrutura turística nas áreas focalizadas. Os objetivos eram gerar receita para a conservação dos monumentos recuperados e atrair investimentos privados que ampliassem as áreas reabilitadas e garantissem a sustentabilidade do processo de preservação. Programas desse tipo foram implementados em vários países do continente latino-americano com o apoio de organismos como o BID, a OEA e a UNESCO. Em 1974, o BID já financiava um grande projeto de desenvolvimento turístico nas regiões de Cuzco e Puno, no Peru, iniciando outro, em 1977, no Panamá (Anexo C). No Brasil, política semelhante foi implantada com o apoio da UNESCO, resultando, entre outras ações, no desenvolvimento do Programa de Cidades Históricas - PCH (1973-1987). ${ }^{28}$ 
Como observa Paulo Ormindo Azevedo, a experiência ensinou, entretanto, que não era simples conservar o patrimônio apenas desenvolvendo o turismo. (AZEVEDO, 2001, p. 303-304) Os projetos executados durante os anos $1970 \mathrm{em}$ regiões e cidades com graves problemas sociais e econômicos não produziram mais do que zonas artificiais e despovoadas. O turismo, como apontam os especialistas, só prospera em contextos de equilíbrio social e econômico; caso contrário, tende a ser simplesmente predatório ou inócuo como fator de desenvolvimento real.. ${ }^{29}$ As várias experiências realizadas na América Latina o demonstraram e, entre elas, de modo eloquente, o nosso Programa de Cidades Históricas.

O PCH foi o primeiro programa brasileiro de preservação a envolver instituições federais e estaduais em sua coordenaç̧ão e execução. ${ }^{30}$ Em cerca dez anos, financiou 193 projetos em 12 estados brasileiros. ${ }^{31}$ A estratégia então adotada para a conservação dos imóveis recuperados e para a "restauração progressiva" do patrimônio das cidades selecionadas foi o incremento do turismo, mediante implantação de infraestrutura hoteleira mínima; melhoria de acessos; execução de obras de restauração em monumentos para uso institucional, turístico ou cultural; e desenvolvimento de ações de divulgação do patrimônio, das belezas naturais e das manifestações folclóricas do lugar. Foram ainda investidos recursos em aperfeiçoamento técnico e em capacitação de mão de obra, bem como em pesquisas e na elaboração de planos urbanísticos. Entretanto, no que diz respeito à promoção da conservação sustentada do patrimônio, o saldo do programa foi muito baixo. Áreas como o Pelourinho, por exemplo - uma das beneficiadas com recursos do programa - rapidamente retornou ao antigo estado de deterioração. A ideia de que investimentos do Estado atrairiam o interesse privado e um público permanente não se realizou. A principal herança deixada pelo $\mathrm{PCH}$ foi a ampliação e a modernização do campo institucional do patrimônio, com a criação ou a estruturação, nos estados, de organismos de preservação que passaram a complementar a ação pública de preservação, antes restrita ao IPHAN.

As políticas que aliavam preservação e desenvolvimento turístico nos anos 1970 não deram certo por vários fatores. Entre esses, a sazonalidade e a instabilidade próprias da atividade; sua fragilidade diante das crises econômicas que assolaram a América Latina, nos anos 1980; a retração e a descontinuidade dos
29 Comentário de Paulo Henrique de Almeida, em mesa-redonda do II Seminário Internacional "Patrimônio e Cidade Contemporânea", promovido pela Faculdade de Arquitetura da UFBA, de 29 a 31 de maio de 2002

30 Secretaria de Planejamento da Presidência da República - SEPLAN-PR, IPHAN,

EMBRATUR e, num primeiro momento, a Superintendência de Desenvolvimento do Nordeste-SUDENE. No âmbito estadual fundações, institutos ou secretarias vinculados à área cultural, muitos dos quais foram criados para participar do programa. Os recursos eram oriundos do Fundo de Desenvolvimento de Programas Integrados FDPI, também do Governo Federal.

31 Maranhão, Piauí, Ceará, Rio Grande do Norte, Paraíba, Pernambuco, Alagoas, Sergipe e Bahia (no Nordeste), além de Minas Gerais, Rio de Janeiro e Espírito Santo (no Sudeste). Ver Sant'Anna (2014, p. 367) 
investimentos públicos; e a ausência de solução para problemas estruturais ligados ao desenvolvimento econômico e social.

Nos anos 1990, na esteira do sucesso das intervenções de revitalização e requalificação realizadas em cidades europeias e americanas, começou a ganhar corpo uma nova convicção: as experiências latino-americanas não funcionaram porque financiaram exclusivamente o setor público e não souberam atrair corretamente e de modo planejado a iniciativa privada. Ao lado disso, não lograram estabelecer políticas públicas de longo prazo, apoiadas na criação de um ambiente propício à atração de investimentos privados, e não investiram em melhorias que assinalassem clara e inequivocamente a intenção de transformar a situação. (ROJAS, 2001a, p. 15-22; 2001b, p. 199-216) O envolvimento do setor privado e, consequentemente, sua inclusão nos esquemas de financiamento seriam, portanto, a chave para se promover processos sustentáveis de preservação nas cidades históricas latino-americanas.

Com base nessa ideia, e impulsionado também pelo interesse de países centrais em realizar investimentos em serviços urbanos, a partir da abertura das economias latino-americanas para o comércio exterior, o BID retomou e intensificou, a partir de 1994, sua atividade no campo da preservação do patrimônio urbano. Passou então a financiar projetos que previam inversões não somente em infraestrutura, melhoria do espaço público e conservação de monumentos, mas também no fomento à instalação de atividades econômicas nas áreas em processo de revitalização e no financiamento da reabilitação de imóveis privados. De acordo com esse modelo, uma série de projetos foi iniciada em vários países da América Latina, inclusive no Brasil (Anexo C). A experiência que consolidou essas ideias foi realizada na cidade de Quito, a partir de um contrato de empréstimo firmado com o governo do Equador em 1994.

Apesar de ter sido desenhado para viabilizar uma associação equilibrada entre o setor público e o setor privado, o Programa de Reabilitação do Centro Histórico de Quito demonstrou que a atração de investimentos privados para centros históricos longamente debilitados e situados em contextos nacionais sujeitos a crises econômicas e financeiras constantes, não é tarefa simples. Nessa cidade, o poder público teve de se envolver muito mais do que o previsto nos negócios destinados a mostrar a viabilidade de investimentos comerciais no 
centro histórico, assim como teve dificuldades de encontrar parceiros e candidatos para comprar unidades imobiliárias produzidas pela Empresa Centro Histórico empresa de capital misto, criada para promover negócios em parceria com o setor privado e funcionar como braço executivo da municipalidade nesta operação. (ROJAS, [199-], 1999) O desenvolvimento do programa mostrou também que os investimentos na construção de estacionamentos e na recuperação ou instalação de equipamentos culturais e turísticos não tiveram o retorno esperado em ternos de rentabilidade, e que os projetos que surgiram para mitigar impactos, como o programa de habitação social, foram os que mais prosperaram e provaram ter a melhor relação custo-benefício. ${ }^{32}$ No panorama de retração econômica deflagrado pela crise financeira que acometeu o Equador em 1999, o programa de habitação social, ancorado na demanda habitacional existente e em linhas de financiamento adequadas, provou ser o mais capaz de andar com as próprias pernas.

A experiência em Quito demonstrou que, em cenários de endividamento público, estagnação e baixo crescimento econômico, o setor público não tem fôlego financeiro para esperar o tempo necessário para que investimentos privados de monta se materializem, sendo muito difícil direcioná-los para áreas arriscadas. A experiência equatoriana pôs em evidência, em suma, que o modelo ancorado na atração de investimentos privados supõe um cenário de vitalidade econômica, disponibilidade de investimentos, boa distribuição de renda e um valor de mercado do patrimônio que inexistia na maioria dos países da América Latina nos anos 1990.

A expansão das ações do BID no campo da preservação do patrimônio urbano ocorreu, contudo, antes de estarem mais perceptíveis os resultados do programa equatoriano e, portanto, mais claros os limites do modelo adotado. Como mostra o Anexo C, este esquema geral de intervenção foi implantado, com variações, em vários países. Em 1995, pouco depois da assinatura do contrato de empréstimo para Quito, por ocasião de um encontro de países membros do BID (BRASIL, 2002, p. 4), foi proposta a montagem de um programa semelhante no Brasil. Baseado nas mesmas premissas da experiência no Equador, o programa brasileiro, entretanto, adquiriu contornos que colocaram novos desafios ao modelo de preservação sustentável preconizado por esta agência de desenvolvimento.
32 Ver Azevedo )2001, p. 308). 


\section{A preparação (1996-1999)}

O primeiro documento relacionado ao futuro Programa de Preservação do Patrimônio Histórico Urbano ou, simplesmente, Programa Monumenta, data de 1996. (INSTITUTO DO PATRIMÔNIO HISTÓRICO E ARTÍSTICO NACIONAL, 1996) Denominado "Revitalização de Sítios Urbanos Através da Recuperação do Patrimônio Cultural”, propõe ao BID a constituição de um programa centrado na ação conjunta entre União, Estados e Municípios a ser desenvolvido em 20 cidades localizadas em todas as regiões do país. De modo análogo ao $\mathrm{PCH}$, apostava-se no impacto de investimentos públicos coordenados para revitalizar e dinamizar essas áreas, propondo-se um programa de desenho muito simples e em total descompasso com a discussão em curso no BID sobre a constituição de padrões de preservação autossustentáveis. A ideia foi posta de lado, ficando claro, já nas primeiras missões técnicas enviadas pelo banco, que o novo programa deveria ter como principal meta a transformação de uma prática de preservação centrada exclusivamente na ação estatal, sem garantias de retorno do investimento público ou de geração de recursos para a manutenção do patrimônio recuperado. Deveria realizar, em suma, o que nenhuma iniciativa anterior conseguiu plenamente, ou seja, compartilhar mais equitativamente a responsabilidade da preservação do patrimônio com a sociedade e, especialmente, com a iniciativa privada.

A preparação do Programa Monumenta pôs em relevo o extremo despreparo do Estado brasileiro para lidar com a complexa questão da preservação e dinamização de áreas urbanas, tanto em termos da ausência de políticas e instrumentos adequados quanto de projetos minimamente estruturados. Um programa de alcance nacional, com ambições de envolvimento da sociedade, de garantia de sustentabilidade das ações e de transformação da prática demandava, ainda, instituições fortes e preparadas para a tarefa. Mais que isso, instituições capacitadas a atuar de modo ágil e articuladamente. As fragilidades de estrutura do IPHAN e do Ministério da Cultura e a baixa qualidade da maioria dos projetos apresentados pelos municípios contatados colocaram sérias dúvidas sobre a capacidade para se tocar um tal programa no Brasil.

A implantação do Monumenta também pôs em relevo, de modo muito agudo, a situação precária em que se encontrava o IPHAN. Diante disso, entre 1996 e 1998, 
consultores estrangeiros independentes foram contratados pelo BID para avaliar a capacidade da instituição de executar programas complexos e abrangentes, bem como de desenvolver ações de preservação de modo integrado com municipalidades e setor privado. Concluiu-se, à época, que o IPHAN não necessitava propriamente de uma profunda reestruturação interna, mas de melhores condições de trabalho, com pessoal e orçamento adequados ao desempenho de suas tarefas. (MORENO GARCÍA, 1998) Concluiu-se também que a situação dos organismos estaduais e municipais era ainda pior, o que inviabilizava qualquer proposta responsável de descentralização ou de repasse de competências do plano federal para essas unidades. Os consultores externos recomendaram, então, o aparelhamento da instituição federal, sua instalação em todas as cidades participantes do programa e a elaboração de um trabalho de base de documentação do patrimônio e de produçãodenormas, destinadoagarantiraqualidadedasintervenções. (HALÉVY, 1998) Defendeu-se ainda que o IPHAN ocupasse uma posição central na coordenação e na conceituação do programa, cabendo às estruturas terceirizadas, necessárias à sua execução, um papel de reforço e de garantia do caráter interdisciplinar dos trabalhos.

Apesar dessas recomendações, o Ministério da Cultura optou por terceirizar totalmente a coordenação e o gerenciamento do programa, e por manter o IPHAN numa posição de estrito cumprimento de suas funções legais de orientação, aprovação e fiscalização de projetos. A instituição foi autorizada a pensar apenas o componente do programa voltado para o seu próprio fortalecimento, o que, diante das limitações do empréstimo internacional, teve de ficar restrito à proposição de programa de tecnologia da informação e à elaboração de inventários e planos de preservação para áreas tombadas. Em suma, um fortalecimento institucional destinado a tornar mais eficiente a ação do órgão, mas sem capacidade para ampliar sua capacidade operacional. ${ }^{33}$

A necessidade de pôr em marcha, no curto prazo, um programa envolvendo vários níveis de governo, intervenções em várias cidades e a coordenação de diversos atores, pôs também em evidência a situação difícil do próprio sistema institucional brasileiro de preservação e, mais amplamente, de todo o então chamado "setor do patrimônio", ou seja, o conjunto das instituições públicas, das organizações privadas e dos profissionais que atuavam neste campo. A retração,
33 Havia quase 20 anos que não eram autorizados concursos públicos para preencher vagas de pessoal no IPHAN. Diagnóstico da situação apontava que, em 10 anos, 90\% dos funcionários da instituição estariam aposentados. (BRASIL, 2001C) 
na década de 80, dos investimentos públicos em conservação do patrimônio esvaziou instituições públicas e desestruturou a face privada do setor, que passou a contar com um número muito pequeno de empresas e profissionais especializados. Além disso, a situação de penúria e o isolamento das instituições públicas, em todos os níveis, surgiram como um sério entrave para um programa cujo pilar central era a articulação entre vários atores públicos e privados.

Além do problema relacionado às situações do IPHAN e do setor do patrimônio, a preparação do Monumenta pôs ainda em evidência a inexistência, no Governo Federal, de uma política de conservação do patrimônio protegido. O problema surgiu em 1996, quando o IPHAN apresentou uma primeira lista de prioridades para o programa, que, na visão do BID, não explicitava os critérios que a fundamentavam. Assim, a montagem do programa foi também marcada por demandas no sentido do estabelecimento de um "ranking" dos sítios urbanos protegidos pelo IPHAN, com vistas a se estabelecer prioridades de intervenção. Em 1997, foram pré-selecionadas, a partir da lista originalmente apresentada pelo IPHAN e de avaliações políticas, sete cidades: Recife, Olinda, Ouro Preto, Rio de Janeiro, São Paulo, Salvador e São Luís. Pretendia-se, com essa seleção, contemplar situações representativas das problemáticas de conservação existentes no país, englobando setores urbanos degradados, cidades médias tombadas e conjuntos de monumentos em centros metropolitanos.

Entretanto, não se sabe se em razão de a primeira lista do IPHAN encaminhar 20 cidades ou se por pressóes políticas, o programa não se concentrou naquela amostra. Decidiu-se que outras cidades seriam incluídas e, para tanto, estabeleceu-se-diante do fracasso das tentativas anteriores de se montar uma lista a partir da aplicação do método Zopp, então muito utilizado pelo setor financeiro - que uma comissão de especialistas independentes e representantes de instituições de preservação se encarregaria do trabalho. Contudo, a seleção das novas cidades não obedeceu a critérios relacionados aos objetivos do programa eà identificação de problemáticas urbanas e patrimoniais específicas, conforme recomendado pelos consultores do BID. Resultou de avaliações de natureza cultural, política, estética e histórica (BRASIL, 2001j, 2001k) que, embora importantes e pertinentes, não correspondiam a situações adequadas ao modelo de intervenção proposto pelo programa. Por essa razão, algumas cidades selecionadas não conseguiram 
passar pelo crivo econômico-financeiro do programa e outras desistiram de participar (ver Quadro 8). Por fim, cabe ressaltar que todo o demorado processo de estabelecimento de prioridades findou por produzir uma lista não muito diversa da que foi sugerida pelo IPHAN em $19966^{34}$ (Quadro 9).

No processo de estabelecimento da abrangência do Monumenta e de suas prioridades, o BID, assim como os consultores estrangeiros, alertaram as autoridades brasileiras para o risco de se pulverizar recursos com a inclusão de muitas cidades, e de se perder assim a oportunidade de realizar intervenções realmente significativas. Apesar desses alertas, foi mantida a ideia de se desenvolver o programa em 27 cidades.

\section{Características da primeira fase (1999-2003)}

A estrutura, os objetivos e as metas do Programa Monumenta foram delineados ao longo de missões técnicas e reuniões realizadas entre 1996 e $1997^{35}$ - bem antes, portanto, da assinatura do contrato de empréstimo entre a União e o BID. As premissas gerais adotadas foram as mesmas que nortearam a experiência de revitalização do centro histórico de Quito, tendo como princípio fundamental a ideia de que a ação isolada do Estado não é suficiente, no longo prazo, para conservar os bens culturais, sendo, portanto, essenciais o aporte de investimentos privados e a mobilização da sociedade. A sustentabilidade das ações do programa foi, então, condicionada à atração de parceiros desde a montagem das operações, bem como à implementação de ações capazes de promover a dinamização econômica e a renovação dos investimentos privados nas Áreas de Projeto. Os investimentos estratégicos iniciais seriam assumidos pelo Estado, com vistas à criação de um ambiente físico, institucional e legal atraente e adequado ao desenvolvimento dessa parceria. Foi ainda estabelecida como meta a difusão dessa prática de montagem de ações compartilhadas entre Estado, sociedade e iniciativa privada, e a construção de um modelo de intervenção sustentável que pudesse ser tomado como referência e reproduzido em outras situações no país.

O Programa Monumenta foi implementado segundo uma estrutura organizacional que concentrou funções de supervisão, coordenação, gerenciamento, administração, planejamento e parte da execução no plano nacional, além de
34 Apenas três cidades das 20 selecionadas pelo IPHAN - Petrópolis, Florianópolis e

Antonina - não ficaram entre as

32 melhor colocadas no ranking final elaborado pela comissão de especialistas mobilizada pelo Monumenta. As duas primeiras, entretanto, foram classificadas em $38^{\circ}$ e $55^{\circ}$, no conjunto dos 94 sítios históricos priorizados. Apenas Antonina, no Paraná, não foi incluída, pois não possuía sítio ou conjunto de monumentos tombados em nível federal

35 Ver "Ajudas-Memória" das missões do BID realizadas entre $1996 \mathrm{e}$ 1997. 
36 Informação prestada por Cecília Parlato, consultora da UCG, em entrevista realizada em 10 dez. 2002

37 Opinião de Jurema Machado, da UNESCO em entrevista realizada em 11/12/02, e também de Cyro Corrêa Lyra, ex-coordenador do GT IPHAN - Monumenta, em entrevista realizada em $23 \mathrm{fev}$. 2002. funções mais puramente executivas no plano local. No núcleo central, essas funções foram divididas, inicialmente, entre Ministério da Cultura, BID e UNESCOBrasil e, no local, entre estados e municípios, através de unidades especiais. $\mathrm{Na}$ condição de principal fonte de recursos, o BID estabeleceu as regras básicas de funcionamento do programa, tendo em vista os objetivos pactuados. Assim, além de desempenhar funções de supervisão geral e monitoramento, o banco analisava e autorizava todas as despesas relacionadas aos componentes do programa que deveriam ser financiados pelo empréstimo externo.

A participação da UNESCO-Brasil no Monumenta não estava prevista no contrato de empréstimo, constituindo, na realidade, um arranjo do governo brasileiro para evitar as limitações e os controles burocráticos da administração pública direta e assim conferir agilidade à execução do programa. A organização administrava os recursos do Monumenta relacionados aos componentes executados pelo Governo Federal, contratando consultores, especialistas e serviços, e organizando licitações. Também avaliava tecnicamente as ações que eram encaminhadas para contratação ou pagamento, funcionando como mais uma instância de controle e supervisão do programa.

As funções de coordenação, supervisão, orientação e fiscalização do Ministério da Cultura eram realizadas por uma Unidade Central de Gerenciamento - UCG, sediada no próprio MinC. A UCG era responsável pela execução do programa e composta, em fins de 2002, por cerca de 40 consultores contratados através da UNESCO-Brasil, ${ }^{36}$ que eram responsáveis desde o suporte que deveria ser dado aos municípios participantes até o planejamento e acompanhamento da execução de componentes do programa. Essa equipe terceirizada organizava-se em "departamentos", por área de atuação, e relacionava-se com as unidades responsáveis pela execução dos projetos em nível local. O Programa Monumenta foi, inicialmente, um caso de política pública coordenada e executada por estrutura paralela terceirizada e sem vínculo permanente com qualquer instância do Estado.

$\mathrm{Na}$ avaliação de técnicos que acompanharam o Monumenta desde o início, a montagem de uma UCG inteiramente terceirizada e apartada das estruturas estatais permanentes visou à agilidade, mas findou por operar uma ruptura muito radical e isolar a unidade institucionalmente, dificultando sua operação. ${ }^{37}$ Esse tipo de problema foi também, em grande parte, reproduzido no plano local. 
Ao IPHAN, coube, no início, um papel eminentemente técnico, de orientação e fiscalização dos aspectos estritamente relacionados à conservação e à restauração do patrimônio tombado. Era responsável pela execução, através da UNESCO-Brasil, apenas do componente destinado ao seu próprio fortalecimento institucional, relacionando-se com o gerenciamento central do programa por meio de um grupo de trabalho - denominado "Grupo Tarefa" - composto também por consultores contratados. ${ }^{38}$

O Programa Monumenta lidava, portanto, com três burocracias em sua instância central: a do BID, que aprovava a execução de determinadas ações do programa; a da UNESCO, para a efetivação de contratações e pagamentos; e a do Governo Federal, por intermédio do MinC e do IPHAN, no tocante à execução geral e ao acompanhamento de convênios, à análise e à aprovação técnica de intervenções. Além disso, lidava com a burocracia local de cada município na preparação e execução de ações nas Áreas de Projeto. Essa pesada carga burocrática foi uma das principais causas da baixa capacidade executiva do programa na sua primeira fase.

Aos estados e municípios eram consignadas tarefas de preparação e execução de projetos, por meio das Unidades Executoras de Projeto - UEP. A estas cabia coordenar a elaboração de projetos, executar procedimentos licitatórios no âmbito local, controlar e acompanhar a execução de contratos. A ideia inicial era que as UEP tivessem um espectro de atuação mais amplo, funcionando, à semelhança da Empresa Centro Histórico de Quito, como instâncias de compartilhamento com o setor privado da execução de ações nas Áreas de Projeto, incluindo captação de recursos e viabilização de empreendimentos. Diante da impossibilidade legal de implantação de tais organismos no Brasil, o papel das UEP foi bastante reduzido. Vinculadas às instâncias municipais ou estaduais responsáveis pela execução do programa, a depender da estrutura dessas instâncias, contavam com pessoal efetivo. Em vários casos, corresponderam também a estruturas terceirizadas.

Inicialmente, a ideia do programa era restringir os parceiros do setor público ao Governo Federal e aos municípios participantes, mas problemas relacionados à capacidade institucional e financeira de algumas cidades ou a o fato de a questão patrimonial ser competência de administrações estaduais, em algumas regiões,
38 Em 2003, com nova administração federal, esse grupo foi extinto. 
39 Casos dos estados de Goiás, Pará e Bahia.

40 Este foi o caso, como visto no Capítulo 2, da $7^{\text {a }}$ etapa do Programa de Recuperação do Centro Histórico de Salvador, na qual os recursos do Programa Monumenta foram complementados pela Caixa Econômica, através do Programa PAR

41 Ver Capítulo 3 referente à cidade de São Paulo.

42 O contrato de empréstimo estabelecia, na cláusula 1.03, que o mutuário poderia cancelar a parte do financiamento correspondente à contrapartida local não realizada por municípios e setor privado, de modo a ser mantida a paridade de $50 \%$ entre recursos externos e nacionais. (TADDEI NETO, 1998a, p. 152) essas instâncias foram também incluídas como intervenientes ou executoras de projetos locais. ${ }^{39}$ Para garantir a participação do setor privado, o programa previa financiamentos para a promoção de atividades econômicas, para a execução de intervenções em imóveis privados e para treinamento de agentes locais de cultura e turismo.

A Caixa Econômica Federal - que propôs, no período de preparação do Monumenta, uma participação mais ativa por meio da integração de seus fundos especiais aos recursos do programa (AJUDA-MEMÓRIA..., 1997a) - desempenhou o papel secundário de agente financeiro, ou seja, de depositária dos recursos do empréstimo internacional. Entretanto, em decorrência das ações de reabilitação que desenvolveu a partir de 2000, e de algumas situações particulares que se configuraram na execução do Monumenta, a Caixa ampliou essa participação, provendo recursos para a montagem de operações que contemplassem o uso habitacional. ${ }^{40}$

O custo total estimado do Programa Monumenta foi, inicialmente, de US\$ 125 milhões - portanto, menos do que o previsto para o Programa de Reabilitação do Centro de São Paulo. ${ }^{41}$ Metade desses recursos correspondia ao empréstimo concedido pelo BID - que deveria ser pago em 20 anos, com taxa de juros variável e em torno de $6 \%$ ao ano - e a outra metade dizia respeito à contrapartida nacional, distribuída entre União, estados e/ou municípios e setor privado, à razão de, respectivamente, $24 \%, 16 \%$ e $10 \% .{ }^{42} \mathrm{~A}$ contribuição privada poderia se materializar sob a forma de doações, contratação de obras e serviços ou, ainda, por meio do patrocínio de ações do programa através do uso de incentivos fiscais. (BRASIL, 2001f, p. 15)

Em termos de composição financeira, portanto, o Monumenta foi montado como programa de investimentos públicos a fundo perdido, contando apenas com uma pequena parte reembolsável - correspondente ao financiamento das intervenções em imóveis privados - o que equivaleria a aproximadamente $30 \%$ do valor das intervenções previstas para cada projeto local. Em termos globais, o programa operaria, assim, com 90\% de seus recursos advindos do setor público e 10\% - sujeitos a variação - provenientes do setor privado.

Os recursos do Programa Monumenta foram distribuídos entre cinco componentes finalísticos, denominados, respectivamente, Investimentos Integrados 
em Áreas de Projeto, Fortalecimento Institucional, Promoção de Atividades Econômicas, Treinamento e Formação, e Programas Educativos. Esses componentes abarcavam $77,6 \%$ dos recursos do programa, ficando o restante dividido entre atividades de gerenciamento, desenvolvimento de estudos e projetos e demais custos financeiros do programa - juros, comissão de crédito, inspeções e supervisões por parte do BID (Tabela 47).

Os "Investimentos Integrados em Áreas de Projeto" constituíam o principal componente do Programa Monumenta, com 42,4\% dos seus recursos repartidos entre o empréstimo do BID e a contribuição local (ver tabela 47). ${ }^{43}$ Executado pelo município ou pelo estado participante, incluía o financiamento de intervenções de conservação e restauração de monumentos tombados em nível federal; a execução de melhorias no espaço público - incluindo iluminação, paisagismo, sinalização e mobiliário urbano -; construção de estacionamentos, pequenas obras de infraestrutura e o financiamento de intervenções em imóveis privados. ${ }^{44} \mathrm{~A}$ parte reembolsável do financiamento do programa estava, como visto, contida nesse último subcomponente e correspondia aos recursos destinados à concessão de empréstimos a proprietários de imóveis localizados nas Áreas de Projeto para a realização de obras de recuperação de fachadas, coberturas, estabilização estrutural, melhoria de instalações prediais e, ainda, exclusivamente para proprietários com renda de até três salários mínimos, obras de atendimento à legislação sanitária e de adequação do imóvel para geração de renda. ${ }^{45} \mathrm{~A}$ seleção dos beneficiários deveria partir de edital público e foi vinculada à contrapartida proposta pelo proprietário, à importância histórica, artística, cênica ou estratégica do imóvel e à regularidade jurídica da propriedade. O retorno desses financiamentos deveria ser revertido para um Fundo Municipal de Preservação que iria ser, obrigatoriamente, criado pelo município participante.

O fortalecimento institucional dos executores públicos - MinC, IPHAN, estados e municípios participantes - é um componente de praxe em programas financiados por agências multilaterais de desenvolvimento como o BID, correspondendo, no caso do Programa Monumenta, a 6,5\% dos recursos pactuados (Tabela 47). A meta principal desse componente era, sob a liderança do Ministério da Cultura, promover mudanças nos modelos institucional, legal e de gestão do patrimônio no país, com vistas a se repartir melhor as responsabilidades da
43 Respectivamente 36,695\% para a fonte BID e 16,405\% para a contrapartida nacional (federal e local).

$44 \mathrm{O}$ componente contempla ainda a possibilidade de financiamento de $50 \%$ do custo de instalaçóes subterrâneas de rede elétrica e de telefonia, e obras em monumentos públicos protegidos por estados e municípios localizados nas Áreas de Projeto, desde que apresentem comprovação de retorno financeiro.

45 Podiam ser também financiadas neste item ações de regularização fundiária em imóveis selecionados. (BRASIL, 2001f, anexo F) 
46 O recurso total para o fortalecimento institucional do IPHAN foi orçado em R\$ 7.357.000,00, o que, pela taxa de câmbio vigente no início do mês de abril de 2003 correspondia a cerca de US\$2,2 milhões. preservação entre as três esferas de governo e a sociedade. As ações previstas para o IPHAN, ainda que específicas, inseriam-se nessa lógica e envolviam, como visto, o fortalecimento da capacidade técnica e normativa da instituição. ${ }^{46}$ Para estados e municípios foram destinados recursos para atualização legislativa e capacitação de gestores públicos nas áreas relacionadas ao programa.

O componente denominado "Promoção de Atividades Econômicas nas Áreas de Projeto" tinha como executantes o Ministério da Cultura e o setor privado, por meio de fundações, organizações não governamentais ou grupos atuantes nas áreas de produção cultural e turismo. Correspondia a 6,0\% do custo estimado do programa (Tabela 47), prevendo-se nesse item o financiamento de projetos até o valor máximo anual de US\$200.000,00 por município, mediante 50\% de contrapartida do setor privado. Deveriam ser priorizadas propostas que contribuíssem para a intensificação do uso dos imóveis ou da atividade econômica da área focalizada, com vistas ao aumento do tempo de permanência de frequentadores. O item contemplava ainda ações de promoção das Áreas de Projeto no Brasil e no exterior e de montagem de encontros para a captação de parcerias privadas.

O componente "Treinamento e Formação" se destinava à capacitação de mão de obra e envolvia o treinamento de agentes locais de cultura e turismo. Correspondendo a 6,3\% dos recursos do programa, previa o financiamento da implantação de Centros de Formação de Artífices nas regiões das Áreas de Projeto e o treinamento, no exterior, de instrutores para esses centros. A capacitação de agentes de cultura e turismo se destinava a trabalhadores e pequenos empresários sediados nas áreas sob intervenção, devendo abranger aspectos relacionados aos objetivos do programa. Os executores desse componente seriam o MinC, estados e municípios participantes.

Com o objetivo de conscientizar e envolver a sociedade brasileira nas tarefas de preservação, o componente educativo do programa previa a realização de campanhas publicitárias, além da produção de filmes documentários, vídeos escolares e peças de informação turística. Este componente, a ser executado integralmente pelo Ministério da Cultura, abocanhava boa parte dos recursos previstos: US\$20.445.000,00, ou 16,4\% do orçamento total.

Observa-se que o conjunto dos componentes finalísticos do Monumenta dirigia-se, inicialmente, à promoção do uso turístico e cultural, indicando-se que 
a dinamização e o aproveitamento econômico das Áreas de Projeto deveriam se dar, prioritariamente, por meio dessas atividades. O programa implantou, assim, um modelo de intervenção que tendia a homogeneizar funcionalmente essas áreas. Como visto no caso de Salvador, contudo, os enclaves já não se mostravam sustentáveis, o que contradizia sua principal premissa.

O principal instrumento de gestão criado pelo Monumenta foi o Fundo Municipal de Preservação. Este fundo - um dos requisitos para participação no programa - se destinava à conservação dos monumentos recuperados nas Áreas de Projeto, constituindo, portanto, uma peça-chave para a sustentabilidade da intervenção. O instrumento foi concebido para operar com os recursos gerados direta ou indiretamente pelo projeto local, incluindo receitas produzidas pelo uso de imóveis recuperados, pelo aumento de arrecadação fiscal, assim como pelo retorno do financiamento da recuperação dos imóveis privados. Após o atendimento da conservação dos monumentos restaurados, o fundo poderia aplicar recursos na recuperação de outros monumentos selecionados pelo IPHAN e, em seguida, na replicação do projeto em sua área de influência. O fundo seria administrado por um representante do município e por um Conselho Curador, cuja composição, paritária entre setor público e setor privado, previa representantes do MinC, do IPHAN, do estado e do município, além de empresários ligados à Área de Projeto, moradores, universidades e organizações não governamentais. (BRASIL, 2001f, anexo E)

O Fundo Municipal de Preservação deveria ser também um instrumento de controle contábil e da aplicação das receitas geradas pelos projetos em cada localidade, visando a garantir que estas fossem aplicadas, prioritariamente, na conservação dos monumentos cujas características físicas, de uso ou destinação dificultassem a geração de renda própria para manutenção. O fundo não se destinava, portanto, a conservar o parque privado nas Áreas de Projeto ou à realização de qualquer tipo de investimento além dos acima citados. A ideia era que, partindo-se de projetos sustentáveis e dos investimentos públicos realizados, a iniciativa privada fosse atraída e se tornasse efetivamente parceira, investindo na conservação dos imóveis sob sua responsabilidade. ${ }^{47}$

Embora tivesse entre seus objetivos a dinamização econômica e a intensificação do uso das áreas sob intervenção, adotando como principal indicador de
47 Na prática, contudo, essa regra não foi rigidamente observada, pois na lei que criou o FUNDOCENTRO - o fundo de preservação da Área de Projeto do Monumenta em Salvador - se estabeleceu que os recursos poderiam ser aplicados em qualquer imóvel existente na Área de Projeto. Essa adaptação permitiria ao Governo do Estado da Bahia continuar a prática paternalista de conservar as fachadas de imóveis privados no centro histórico de Salvador (Capítulo 2). 
sucesso a valorização imobiliária, o Programa Monumenta não criou nem propôs a adoção de mecanismos de controle da especulação. Além disso, a despeito de lidar com áreas depreciadas e ocupadas por população de baixa renda, os mecanismos que o programa encaminhava para aliviar o impacto das intervenções sobre essas populações se restringiam a Planos de Reassentamento.

O programa possuía um conjunto de procedimentos que se destinavam a propiciar processos de escolha racionais e transparentes, bem como a formulação de propostas consistentes e sustentáveis, mas, na prática, nem tudo se processou assim na sua primeira fase. Injunções políticas exerceram peso considerável na seleção de áreas e no conteúdo de projetos, estudos foram elaborados simplesmente para cumprir exigências, a mobilização do setor privado ficou, em geral, muito aquém do desejado e a participação da sociedade na elaboração das propostas foi superficial e restrita às chamadas "oficinas de planejamento". (BRASIL, 2001l, p. 41-42) Estas, por sua vez, nem sempre conseguiram a representatividade desejada em termos de participação da população local e seguiram uma metodologia que não possibilitou reflexão mais profunda sobre a problemática patrimonial, social e econômica local, a fim de que se pudesse identificar as demandas e as potencialidades capazes de dar sustentabilidade real aos projetos.

O Programa Monumenta instituiu um modelo rígido para a elaboração dos projetos locais. As intervenções físicas passíveis de financiamento deveriam ser as previstas nos "Investimentos Integrados", e as demais ações deveriam estar relacionadas apenas ao fortalecimento institucional local, à capacitação e ao treinamento. O componente destinado à promoção de atividades econômicas nas Áreas de Projeto, bem como o componente educacional, tinham vida independente dos projetos locais. O programa continha ainda várias regras relativas à concepção e à montagem técnica dos projetos que estabeleciam, entre outras exigências, que o trecho urbano selecionado deveria conter os monumentos e logradouros de maior importância do conjunto, abranger uma área que assegurasse a composição de um "conjunto arquitetônico harmonioso" e possibilitasse a implantação de um "conjunto sustentável de atividades econômicas". (BRASIL, 2001f, anexo A) Recomendava-se que a delimitação da Área de Projeto partisse dos monumentos que constituíssem focos das intervenções e envolvesse os imóveis adjacentes de modo tal que seus exteriores contribuíssem para a composição do 
conjunto arquitetônico almejado. Essa mesma consideração norteava a seleção dos demais logradouros do sítio que seria objeto da intervenção. As regras de projeto também recomendavam que os usos previstos favorecessem a intensificação do fluxo de frequentadores e turistas e contribuíssem para a atratividade da área. Intervenções que melhorassem a acessibilidade do lugar eram também aconselhadas.

Analogamente ao modelo geral da intervenção, o modelo de projeto conduzia também a uma concepção das áreas de intervenção como zonas turísticas, incitando os parceiros locais a uma abordagem que não partia de uma problemática urbana ou de preservação a ser resolvida, mas de uma prévia determinação funcional. Em decorrência dessas normas, alguns projetos locais destinaram ao uso turístico e cultural edifícios cuja utilização original ainda seria viável e desejável para a cidade. Em Diamantina e Penedo, por exemplo, os respectivos mercados municipais foram adaptados para abrigar atividades culturais e venda de artesanato, quando sua função como centros de abastecimento dessas cidades ainda tinha vitalidade e era bastante demandada.

A forte preocupação estética contida nas regras de projeto não correspondeu, entretanto, a um cuidado especial para com o patrimônio preservado, no sentido de serem estabelecidas exigências quanto ao desenvolvimento de estudos detalhados sobre as características patrimoniais dos sítios selecionados. Os inventários arquitetônicos e urbanísticos desenvolvidos pelo IPHAN no âmbito do próprio programa não foram vinculados aos projetos locais, constituindo um produto independente que não foi utilizado para fundamentar estes últimos.

Uma rápida análise dos projetos das cidades que assinaram convênio de financiamento até 2002 mostra que as regras do programa, de fato, produziram projetos que, em sua maioria, privilegiaram o uso turístico e cultural nas áreas de intervenção e se limitaram a introduzir melhorias na aparência do espaço em torno de monumentos destacados, com vistas a promover áreas de visitação (Quadro 9). Repetiu-se, assim, em grande parte, o modelo praticado 30 anos antes pelo $\mathrm{PCH}$, o qual, como já comentado, provou não ser sustentável, principalmente em razão de sua grande vinculação à atividade turística. Num país em que o turismo patina, há décadas, num patamar que beira a estagnação, seria, no mínimo, exageradamente otimista imaginar que uma cidade como Icó, no alto 
48 Em 2000,

5,3 milhóes de turistas estrangeiros visitaram o Brasil, contra 4,7 milhões em 2001, e 3,8 milhões em 2002. Apenas o Empire State Building, em Nova York, recebia cerca de 10 milhóes de turistas por ano em 2002.

Dados obtidos no site $<$ www.embratur.gov. br>, acesso em junho 2003 sertão do Ceará, localizada a $400 \mathrm{Km}$ da capital e de economia eminentemente agrária, sustentaria a conservação de seus monumentos por meio de um centro de convenções e de sobrados recuperados para restaurantes e pousadas.

Em várias cidades, o Programa Monumenta lidava com áreas cujos edifícios recuperados em épocas anteriores se deterioraram, em decorrência de situações de estagnação econômica, usos inadequados ou demasiadamente voltados para uma demanda cultural e turística que nunca se configurou. Os números do turismo no Brasil até 2002 tampouco indicavam que a visitação dessas áreas se intensificaria na escala imaginada. Como mostravam dados da EMBRATUR e da OMT, entre 2000 e 2002, o número de turistas estrangeiros no país caíra cerca de 30\% e o turismo interno permanecia estagnado em função da recessão econômica. ${ }^{48}$ O baixo crescimento econômico do país e a situação de crescente violência e de graves problemas sociais nos principais centros nacionais receptores e emissores também não autorizavam perspectivas otimistas.

\section{Execução e resultados na primeira fase (1999-2003)}

Apesar da estrutura terceirizada montada no Ministério da Cultura para gerenciar o Programa Monumenta, um relatório de auditoria do Tribunal de Contas da União, de julho de 2002, detectou sérios problemas relacionados ao gerenciamento e à execução do programa. (BRASIL, 2002f) Os auditores verificaram que, em 2000, somente $11 \%$ das despesas previstas no Plano Operacional foram realizadas, e que, em 2001, executou-se apenas 39\%. Verificou-se também que a maior parte das despesas atendeu ao próprio gerenciamento do programa, com pouquíssimos recursos aplicados nas atividades-fim. Conforme mostra a tabela 48, nos dois primeiros anos de execução, apenas 2\% dos recursos previstos foram aplicados em projetos locais. Essa baixíssima execução do principal componente finalístico do programa acarretou um aumento de $313 \%$ nos gastos previstos com comissão de crédito - a taxa paga ao BID pela disponibilização de recursos.

A auditoria do Tribunal de Contas pôs em relevo um dos principais nós do Programa Monumenta, qual seja, o desenvolvimento de um programa nacional de preservação do patrimônio sem a adoção, por parte do Governo Federal, de qualquer medida no sentido de aparelhar o organismo federal legalmente 
responsável pelo assunto, sequer para exercer as limitadas funções que lhe foram designadas. A esse respeito, o TCU alertou para o risco de descontinuidade do programa por falta de domínio, por parte das estruturas permanentes do Estado, dos seus procedimentos, normas, práticas e do conhecimento produzido, indicando como solução - analogamente aos consultores estrangeiros contratados na época da montagem do Monumenta - a participação de funcionários do MinC e do IPHAN em sua Unidade de Gerenciamento Central.

O Tribunal de Contas concluiu pela necessidade de revisão do Plano Operacional do programa, a fim de se adequar os valores pactuados inicialmente à capacidade executiva demonstrada, evitando-se custos financeiros desnecessários. Por fim, entre outras recomendações, solicitou ao Ministério da Cultura uma avaliação cuidadosa da conveniência de se incluir novas cidades no programa, antes que os convênios em vigor estivessem cumprindo as metas acordadas. (BRASIL, 2002f, p. 2)

Os gastos excessivos com a administração do Programa Monumenta levaram a imprensa nacional a comentar que o programa não estaria preservando o patrimônio, e sim a "culturocracia". (GASPARI, 2002) Um olhar mais atento, entretanto, revelaria que, na realidade, não eram os servidores públicos os beneficiários dessa situação, mas uma rede de consultores e firmas de consultoria que gravitava em torno da UCG e das UEPs, realizando uma verdadeira drenagem de recursos do programa. Em seus três primeiros anos, ao invés de encaminhar mudanças consistentes na prática de preservação, o Monumenta funcionou como um sorvedouro de recursos da contrapartida nacional, apenas para produzir papéis e pagar consultorias que pouco garantiram a desejada sustentabilidade das ações.

Uma das principais contradições do Programa Monumenta na sua primeira fase foi tentar implantar processos de preservação sustentáveis sem investigação mais profunda dos fatores que propiciariam a sustentabilidade em cada local. Essa investigação prévia, de importância fundamental, foi substituída por estudos de viabilidade financeira e oficinas de planejamento, que eram, na realidade, workshops desenvolvidos em dois dias.

Foco central do programa, a participação da iniciativa privada nos projetos locais também deixou muito a desejar nos primeiros três anos. Na maioria das 
cidades que assinaram convênios de financiamento em 2000, o estabelecimento dessas parcerias foi difícil, devido não somente à atitude expectante de um setor privado habituado a ações estatais paternalistas nesse campo, mas também à paralisação dos contatos com esses atores por parte da UCG e UEPs. (BRASIL, 2001l, p. 12) As parcerias foram ainda prejudicadas pela falta de definições gerenciais de caráter fundamental. Em 2001, por exemplo, os projetos em parceria com o setor privado previstos para Ouro Preto aguardavam ainda deliberações da coordenação do programa sobre o processo de seleção dos candidatos. (BRASIL, 2001l, p. 26)

Um outro entrave à execução dos investimentos integrados do Monumenta foi a falta de qualidade dos projetos apresentados, o que acarretou muitas dificuldades para sua aprovação no âmbito do IPHAN. Procedimentos básicos relacionados a levantamentos históricos, arquitetônicos e arqueológicos não eram cumpridos, nem considerados itens obrigatórios nas planilhas de execução. Outra questão foi a inadequação do modelo de intervenção à realidade das cidades, tanto as grandes quanto as menores. Como visto nos casos do Rio de Janeiro e São Paulo, o montante de recursos disponibilizados pelo programa foi muito baixo para cidades desse porte, e a obrigatoriedade de que fossem distribuídos entre componentes pré-determinados não permitia flexibilidade e conduzia à elaboração de projetos que necessitavam de complementação de recursos, ou que, por si só, não tinham chances de transformar quadros de deterioração. Quanto às cidades menores, os critérios de avaliação da sustentabilidade das ações e o percentual de contrapartida exigido eram inadequados, inviabilizando, às vezes, sua participação.

O modelo de intervenção introduzido pelo Programa Monumenta enfrentou, portanto, sérios problemas para se realizar conforme o projetado. Enfrentou ainda entraves consideráveis com relação à consolidação do seu modelo de "intervenção sustentável", devido, principalmente, a equívocos relacionados à metodologia de preparação e identificação das intervenções locais, à rigidez do conteúdo dos seus componentes e à tendência de concentrar os esforços de dinamização e sustentação econômica das Áreas de Projeto no desenvolvimento de atividades turísticas e culturais. Outro desafio se relacionou à decisão de ampliar a atuação do programa para mais 20 cidades, além das sete da amostra inicial, sem que nenhum projeto local tivesse sido executado ou sequer mostrado os primeiros 
resultados. Somada aos problemas inerentes ao modelo de intervenção e aos arranjos institucionais estabelecidos, essa decisão acarretou o aumento da pesada carga de administração do programa e a pulverização de seus recursos, o que ampliou a possibilidade de baixo desempenho, em proporção ao total do investimento realizado.

Experiências anteriores ao Programa Monumenta, como o PCH, já haviam demonstrado que processos sustentáveis de preservação requerem mais do que uma massa de recursos e a execução de intervenções físicas. Requerem conhecimento profundo da realidade patrimonial e urbana focalizada, instrumentos de planejamento, financeiros, de incentivo e de gestão apropriados; mobilização política e social e modelos de intervenção flexíveis e adequados às realidades, vocações e potencialidades das áreas urbanas selecionadas. Requerem, enfim, uma nova prática de preservação urbana que o Programa Monumenta, apesar de aperfeiçoado em sua segunda fase (2003-2010), não logrou construir.

O programa, entretanto, apesar dos problemas relatados e mesmo antes de alcançar o seu pleno desenvolvimento, apresentou saldos positivos. Implantou uma nova política nacional de preservação urbana depois de mais de 20 anos de letargia nesse campo; colocou em evidência as carências técnicas, instrumentais e operacionais do Estado brasileiro para lidar com a questão e induziu a implantação de outros programas do gênero, como se verá em seguida.

\section{Programa de Revitalização de Sítios Históricos - PRSH e seus antecedentes}

O Programa de Revitalização de Sítios Históricos - PRSH, da Caixa Econômica Federal, assim como o PRONAC e o Programa Monumenta, surgiu da retomada de propostas dos anos 1970. Suas raízes estão nos desdobramentos finais do antigo Programa de Cidades Históricas - PCH e em documento divulgado em 1978, no qual se propunha a criação de uma linha de crédito para a recuperação de imóveis históricos para uso habitacional. (AZEVEDO, 1988, p. 35-51) No final da década de 1970, o aproveitamento turístico do patrimônio já apresentava claramente seus limites, o que provocou mudanças nos rumos do $\mathrm{PCH}$ e colocou em pauta a necessidade 
de tratamento dos problemas urbanos e sociais das cidades tombadas. Esse processo fez surgirem as primeiras propostas de criação de um programa nacional de preservação, voltado para questões vinculadas ao desenvolvimento urbano e à política habitacional. No início dos anos 1980, portanto, o tema da habitação em áreas históricas já surgia como uma forma de aliar o aproveitamento econômico do patrimônio urbano à promoção social.

O novo programa seria desenvolvido pelo IPHAN, em parceria com o antigo Banco Nacional da Habitação - BNH, prevalecendo a ideia de se combinar recursos do Tesouro Federal com linhas de crédito do $\mathrm{BNH}$, de modo que mutuários de baixa renda pudessem arcar com os financiamentos. Tendo em vista o perfil socioeconômico médio do morador de sítios históricos, o sistema previa o uso de subsídios na montagem das operações. Para a realização de operações-piloto foram selecionados, preliminarmente, os centros históricos de São Luís, Salvador e Olinda, realizando-se, entretanto, apenas uma experiência nesta última cidade. O papel de agente promotor e mutuário final, assumido pela Prefeitura Municipal de Olinda junto ao banco, viabilizou a realização da experiência, já que a maioria da população do sítio histórico não apresentava renda suficiente para atender às exigências do BNH. A prefeitura montou um esquema de concessão de empréstimos diretamente aos interessados, baseado na assinatura de promissórias resgatáveis em 12 meses. As prestações pagas eram revertidas para um fundo de preservação, propiciando-se, assim, a concessão de créditos a outros moradores. Com esse esquema, se conseguiu contornar os problemas relativos à comprovação de renda, documentação e titularidade, que, normalmente, travam e dificultam o desenvolvimento desse tipo de ação.

Na experiência de Olinda, a partir de estudos socioeconômicos e de reuniões com a população, foram concentrados esforços na melhoria das habitações de baixa renda. Para tanto, foi montado na prefeitura, com apoio de técnicos do IPHAN e do BNH, o "Sistema de Atendimento ao Morador para Serviços de Reparo ao Casario", que prestava serviços de orientação técnica, apoio jurídico e montagem personalizada da proposta de financiamento, tendo em vista a situação do imóvel e a capacidade de endividamento do interessado. Durante o ano de 1985, 
com base nesse esquema, foram realizados serviços de estabilização, pequenos reparos e reformas em vários imóveis do conjunto. O índice de inadimplência foi baixo e a experiência forneceu importantes dados sobre atuação conjunta do poder público em projetos de reabilitação, participação da população e papel dos agentes financeiros.

Os bons resultados da operação-piloto em Olinda permitiram, em 1985, a criação do Programa de Recuperação e Revitalização de Núcleos Históricos PRRNH, colocado então como uma das prioridades sociais do governo. Embora não tenha chegado a ser realmente implantado, em decorrência da extinção do BNH em 1986, o programa deixou subsídios para a criação de carteiras de crédito voltadas à reabilitação de imóveis históricos, assim como para a adoção da participação comunitária como princípio metodológico norteador de intervenções.

Com o fim do BNH, a Caixa Econômica Federal assumiu o espólio do banco, mas os projetos de reabilitação de sítios históricos foram abandonados. Durante os anos 1980, a Caixa financiou apenas obras de infraestrutura no centro histórico de Salvador, em parceria com a prefeitura da cidade. (GALIZA, 2001, p. 2) A presença, no quadro funcional dessa instituição financeira, de técnicos do antigo BNH que haviam acompanhado o trabalho em Olinda impulsionou, contudo, a retomada do tema quando a Caixa foi convidada pelo IPHAN, em 1996, para ser o agente financeiro do Programa Monumenta. Contribuíram também decisivamente para a retomada dessa linha de ação as mudanças empreendidas pelo Governo Federal na política habitacional a partir de 1996, quando ações de melhoria do habitat foram priorizadas, ao invés da produção de novas unidades em zonas periféricas. (MAGALHÃES, 2002) Essa reformulação da política abriu perspectivas para intervenções de reabilitação em bairros antigos encortiçados, bem como em sítios históricos tombados. Participaram ainda da gênese do Programa de Revitalização de Sítios Históricos, nos anos 1990, as iniciativas de reabilitação empreendidas pela Prefeitura do Rio de Janeiro, com o Programa de Recuperação de Cortiços, e as operações iniciadas no centro de São Paulo a partir da invasão de imóveis vazios por movimentos populares. ${ }^{49}$
49 O programa para a recuperação de cortiços foi depois absorvido pelo Programa "Novas Alternativas". Ver mais sobre essas iniciativas que contribuíram para a formulação do PRNH, nos capítulos 3 e 4. 
50 Ver a esse respeito o item deste capítulo relativo ao Programa Monumenta, onde se registra que, após um papel inicialmente secundário, a Caixa foi alçada à condição de parceira, participando da complementação do financiamento de ações desse programa.

51 O Programa de Reabilitação Urbana de Sítios Históricos URBIS foi criado pela Portaria $n^{\circ} 554$ do Ministério da Cultura, em 15 de dezembro de 2000. Este programa gerido pelo IPHAN, teve apenas dois anos de duração e buscava instituir processos de reabilitação de sítios históricos por meio de mecanismos de gestão compartilhada e de planejamento urbano.

52 A colaboração entre governo francês e Prefeitura da Cidade do Rio de Janeiro teve início em seminário organizado, em 1997, sobre o tema "Centros Históricos", sob os auspícios do município e da Embaixada da França. Ver Mission (1998)

\section{Criação e características gerais}

A criação do PRSH também resultou de algumas frustrações. A primeira delas relacionou-se ao fechamento do Programa Monumenta a uma participação mais efetiva da Caixa:50 e a segunda, ao fracasso da tentativa de estabelecer, a partir de 1998, um programa com o IPHAN que funcionaria como uma alternativa ao Monumenta e daria mais ênfase à questão habitacional. A falta de entendimento dessa instituição financeira com o Ministério da Cultura e com o IPHAN findou por produzir dois programas: o Programa de Reabilitação Urbana de Sítios Históricos - URBIS ${ }^{51}$ e o PRSH. Este último foi criado em 30/11/2000 com o objetivo de implementar uma política nacional de revitalização de sítios históricos em parceira com organismos federais, estaduais e municipais, bem como com organizações não governamentais e instituições internacionais. Em março de 2001, logo após o lançamento do programa, um Acordo de Cooperação Técnica foi firmado entre a Caixa e a Embaixada da França.

Desde 1997, o governo francês - através dos seus Ministérios das Relações Exteriores; da Cultura e Comunicação; e de Obras Públicas, Transportes e Habitação - vinha tentando consolidar parcerias no Brasil, com vistas a prospectar negócios no setor de serviços e no repasse de tecnologia. Cultura e patrimônio foram, aparentemente, os setores escolhidos como porta de entrada para o desenvolvimento dessa estratégia que, vale ressaltar, estava voltada para toda a América Latina. Com o apoio do BID, do BIRD, da UNESCO e de organizações não governamentais, o governo francês investia na transposição de sua experiência de reabilitação urbana para países como o Equador, Chile e Colômbia. No Brasil, a primeira aproximação foi feita com a Prefeitura do Rio de Janeiro no Projeto Morro da Conceição. ${ }^{52}$ Nessa experiência se tentou executar uma operação de reabilitação urbana nos moldes dos Setores Salvaguardados franceses, mas sem muitos resultados. O projeto, entretanto, abriu caminho para o entendimento com a Caixa Econômica Federal, impulsionando a criação do PRSH.

A cooperação entre a Caixa e o governo francês envolveu o repasse de conhecimentos no campo das técnicas de reabilitação, da locação social, das intervenções integradas em perímetros estabelecidos e ainda o desenvolvimento de estudos de viabilidade para a reabilitação de imóveis em sítios históricos. Através da Caixa, 
o governo francês estabelecia contatos com estados e municípios e ancorava suas cooperações locais em perspectivas concretas de financiamento através dessa instituição financeira.

Os estudos de viabilidade para a reabilitação de imóveis em sítios históricos objetivavam contribuir na formulação de políticas que enfatizassem o uso habitacional de interesse social. (CAIXA ECONÔMICA FEDERAL, [2001?]) Adotava-se metodologia desenvolvida pelo Ministério de Obras Públicas, Transportes e Habitação francês em conjunto com organizações não governamentais que atuavam no campo da melhoria do habitat e da restauração imobiliária na França, como os PACT-ARIM.53 A ideia era elaborar, a partir desses estudos, instrumentos metodológicos, financeiros e técnicos que permitissem testar, previamente, a viabilidade de empreendimentos, a fim de que proprietários e promotores fossem atraídos e investissem sem grandes riscos. Em cada localidade, eram identificados 15 a 20 imóveis, em situações variadas de propriedade, ocupação e estado de conservação, selecionando-se, posteriormente, cinco deles para estudos aprofundados e montagem de operações de reabilitação. Esses estudos eram desenvolvidos em parceria com prefeituras, contavam com a participação do IPHAN local e com a assessoria e acompanhamento de consultores franceses. (CAIXA ECONÔMICA FEDERAL, [2001?]) Outros órgãos públicos considerados importantes para o desenvolvimento dos trabalhos podiam também ser convidados a participar. No final de 2002, nas cidades de São Luís, Recife e Belém, a primeira etapa dos estudos já havia sido concluída, e em Salvador, João Pessoa, Natal e Porto Alegre, encontrava-se em fase inicial. Em complementação a esses estudos, foram também financiadas pela Caixa pesquisas sobre demanda habitacional em algumas dessas cidades. ${ }^{54}$

Além dos estudos de viabilidade, a cooperação francesa com a CEF previa a realização de ateliês coordenados pelo SIRCHAL, ${ }^{55} \mathrm{com}$ vistas à definição de ações de preservação e revitalização nas cidades parceiras. Até o final de 2002, foram realizados ateliês em Salvador, São Luís, Pirenópolis, Sabará, Araçuaí e Pelotas. Os ateliês eram organizados pelas instâncias estaduais ou municipais envolvidas com a preservação do patrimônio e, com base em diagnóstico previamente elaborado, identificavam-se as ações a serem empreendidas e encaminhava-se, algumas vezes, a realização de estudos de viabilidade. Os ateliês
53 PACT - Propagande et Action Contre le Taudis e ARIM - Associations de Restaurations Immobilières.

54 Em Salvador, Recife, Rio de Janeiro, São Luís e Belém.

55 O Site International sur la Revitalisation des Centres Historiques des villes de l'Amérique Latine et Caraîbes é uma rede de profissionais e instituições engajados na reabilitação de centros históricos na América Latina e no Caribe, patrocinado pelo governo francês, pelo BID e pela UNESCO. 
SIRCHAL pretendiam funcionar como um instrumento para deflagrar processos de reabilitação urbana, mas seus resultados foram incipientes. Funcionaram, na realidade, como instrumentos de aproximação e contato da Caixa e do governo francês com potenciais parceiros locais.

O Programa de Revitalização de Sítios Históricos configurou-se como uma espécie de "guarda-chuva" que abrangia várias linhas de ação e se relacionava com diversos outros programas. Além das mencionadas atividades no âmbito da cooperação com o governo francês, o PRSH participava do Programa Monumenta, complementando recursos nos projetos locais que tinham componentes habitacionais; do Programa de Reabilitação do Centro, da Prefeitura de São Paulo, no que toca ao financiamento da reabilitação de edifícios vazios e aos Perímetros de Reabilitação Integrada do Habitat; do Programa "Novas Alternativas" e dos Projetos Morro da Conceição e Porto do Rio, com a Prefeitura do Rio de Janeiro; do Programa de Recuperação do Centro Histórico de Salvador, através do Projeto Rememorar; e do projeto de Revitalização da Área do Comércio, em parceria com a Prefeitura Municipal de Salvador. Participava, ainda, do Programa URBIS, do Ministério da Cultura e do IPHAN, como uma de suas principais linhas de financiamento. Assim, o PRSH se constituiu num veículo de articulação de parcerias que criava novos empreendimentos e ampliava o raio usual de ação da Caixa. Era, ainda, uma reunião de linhas de financiamento para a reabilitação do estoque imobiliário e, muito em função da cooperação com o governo francês, um laboratório para a elaboração e adaptação de ferramentas metodológicas, técnicas e financeiras nesse campo.

Um dos eixos fundamentais de atuação do PRSH era o da produção de habitações de interesse social nas áreas históricas para fixar famílias de baixa renda nas áreas centrais de grandes cidades. Um dos critérios de seleção de áreas era, então, a existência de uma quantidade significativa de moradias em condições precárias, habitadas por famílias com esse perfil de renda. Provavelmente buscando se inserir melhor nas iniciativas locais em curso, à época em estudo na maioria das capitais brasileiras, o programa passou a focalizar áreas que contavam com estratégias explícitas de reabilitação; que tinham possibilidades de atrair investidores privados e constituíam núcleos de usos e funções urbanas múltiplas. 
Inicialmente, o programa propunha-se a operar exclusivamente com as carteiras de financiamento existentes na Caixa, em especial o Programa de Arrendamento Residencial (PAR), um leasing com opção de compra ao final de 15 anos, destinado a famílias com renda de até seis salários mínimos (Quadro 10). Havia também a intenção - e esse era um dos principais objetivos da cooperação com o governo francês - de se criar, a partir da realização dos já mencionados estudos de viabilidade, linhas de financiamento mais adaptadas à reabilitação de imóveis de valor histórico. Como visto nos capítulos sobre Salvador, Rio de Janeiro e São Paulo, os limites dessa carteira de financiamento (que operava apenas com empresas construtoras e não admite regimes construtivos alternativos; fixava rigidamente os custos de aquisição; ${ }^{56}$ e não financiava proprietários locadores) colocou muitos obstáculos às operações. O sistema de arrendamento do PAR foi montado para eliminar os altos níveis de inadimplência do sistema anterior (baseado na venda das unidades) e também para ser rentável. Considerando-se o perfil socioeconômico da população que demandava habitação nos centros antigos, os altos índices de desemprego e a má distribuição de renda então existente no país, essa carteira de financiamento - que substituía o arrendatário, sem compensações, ao primeiro sinal de inadimplência - dificilmente poderia funcionar como um instrumento de fixação dos segmentos de menor renda nos sítios históricos.

Ao lado disso, as regras do PAR determinavam que o empreendimento financiado deveria ser vendido ao fim do contrato de arrendamento. Como, nos sítios históricos, grande parte dos imóveis é gravada e pertence a ordens religiosas, vê-se que esta última limitação criava também dificuldades. Ademais, como apontado em capítulos anteriores, os limites rígidos para aquisição de imóveis e "revenda" das unidades produzidas, aliados aos altos custos das obras de reabilitação, tornavam aguda a necessidade de subsídios e induziram uma superutilização dos lotes e um superaproveitamento do interior das edificações, o que dificilmente se coadunava com os objetivos da preservação. Embora a Caixa possuísse linhas de financiamento que operavam com recursos do Orçamento Geral da União - portanto, altamente subsidiados e destinados a programas sociais -, apenas o PAR era utilizado. Apesar de os estudos de viabilidade indicarem a necessidade de

56 O valor de aquisição era fixado em teto máximo de R\$35 mil e correspondia à soma do custo do terreno, obras, seguro, imposto de transmissão e despesas com legalização. 
criação de linhas mais adequadas à reabilitação de sítios históricos, nenhuma foi viabilizada, o que frustrou as expectativas de seu principal parceiro internacional, o governo francês.

A carência de instrumentos financeiros, operacionais e de gestão adequados constituiu o principal freio ao desenvolvimento do PRSH. Seu desenvolvimento mostrou ainda a dificuldade de se deslanchar programas habitacionais fora do contexto de uma política nacional e integrada de reabilitação urbana, especialmente em sítios com problemas de esvaziamento e depreciação imobiliária. A experiência demonstrou claramente que, para reabilitar essas áreas, não bastam recursos para financiar a recuperação de imóveis, sendo necessários investimentos em estudos mais amplos e projetos técnicos; na melhoria da infraestrutura existente (em geral, ultrapassada e desgastada); em transportes, equipamentos urbanos e comunitários; no apoio à instalação ou ao reforço de atividades econômicas; e mesmo na aquisição antecipada de imóveis, a fim de se viabilizar financeiramente a intervenção. Em suma, mecanismos de planejamento e programação, operacionais, financeiros e de finalidade econômica e social que permitam a implantação e a execução de uma política nacional de reabilitação urbana, o que, certamente, ultrapassava o raio de atuação do PRSH e mesmo da Caixa. Uma política, enfim, de cunho interministerial e interinstitucional como as que são desenvolvidas na maioria dos países europeus, entre os quais a França, que fornece bons exemplos nesse campo.

Além de termos de compromisso que formalizavam a participação conjunta da Caixa, do governo francês e dos parceiros locais, o PRSH não possuía mecanismos instituídos de gestão compartilhada. A coordenação das operações ficava basicamente a cargo dos parceiros locais, tradicionalmente carentes e pouco experientes nesse assunto. Tampouco foram desenvolvidos ou propostos instrumentos de avaliação pós-operação.

\section{Execução, resultados e dificuldades enfrentadas}

Uma vez que o PRSH articulava parcerias, seu ritmo de execução estava submetido ao andamento das ações locais. No âmbito do Programa Monumenta,

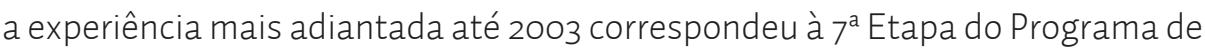


Recuperação do Centro Histórico de Salvador, cujas obras tiveram início no final de 2002, mas não haviam alcançado ainda os imóveis destinados ao uso habitacional. Ainda em Salvador, a primeira fase do Projeto Rememorar, implementado em parceria com o Governo do Estado da Bahia, teve obras iniciadas em imóveis no bairro de Santo Antônio Além do Carmo. ${ }^{57}$ Nessas operações, para se complementar o financiamento do PAR, a recuperação dos exteriores dos edifícios, incluindo fachadas e coberturas, foi financiada com incentivos fiscais do PRONAC, por meio de "projeto cultural" proposto pela Associação de Amigos da Caixa. ${ }^{88}$

No Rio de Janeiro, algumas operações foram concretizadas até 2003 no âmbito do Programa "Novas Alternativas", 59 tendo-se concluído um conjunto habitacional de 150 unidades em terreno vazio no Morro da Saúde. As iniciativas habitacionais no Morro da Conceição e no restante da região portuária não avançaram nesse período. Na área central da cidade de São Paulo, de modo análogo ao Rio de Janeiro, algumas operações foram executadas, em parceria com a Prefeitura Municipal e com movimentos populares por moradia. ${ }^{60}$ Em São Luís, no Maranhão, foi iniciada a recuperação de um casarão pertencente à Caixa.

As experiências concretizadas no âmbito do PRSH até 2003 colocaram em relevo a grande carência nacional de instrumentos de planejamento, gestão, aquisição e financiamento, bem como de subsídios para que a inserção do estoque imobiliário existente em políticas habitacionais e de reabilitação urbana seja possível. Os estudos de viabilidade realizados revelaram a grande dificuldade de integração das instâncias públicas em projetos urbanos e a falta de informações sobre a situação fundiária das áreas a reabilitar e de instrumentos jurídicos para facilitar a solução dessas questões. Além disso, em muitas áreas centrais, as normas urbanísticas eram inadequadas ao desenvolvimento de habitações e faltava, ainda, uma metodologia consolidada para avaliação de custos. O despreparo institucional se revelava também na dificuldade de se convencer os dirigentes locais da necessidade de se investir em diagnósticos mais aprofundados e de se evitar a pulverização de operações, sem obediência a um projeto de conjunto. Como mostrou a segunda fase do Projeto Rememorar, em Salvador, cerca de 40 imóveis espalhados por todo o centro histórico estavam listados para ser recuperados com financiamento da Caixa, sem que se verificasse entre eles qualquer conexão orgânica em termos de projeto urbano.
57 Ver mais a respeito da $7^{\text {a }}$ etapa do PRCHS e do Projeto Rememorar no capítulo 2 .

58 Ver a respeito no item deste capítulo referente ao PRONAC.

59 Ver quadro o4 do capítulo 3, referente à área central da cidade do Rio de Janeiro.

60 Ver quadro 07 do capítulo 4, referente à área central da cidade de São Paulo. 
Foi a falta de interesse e engajamento por parte dos proprietários, entretanto, o maior obstáculo ao desenvolvimento dessa política de reabilitação. Além de não se interessarem pelos financiamentos disponíveis, habituados que estavam às políticas paternalistas tradicionalmente executadas nos sítios históricos, os proprietários esperavam vantagens totais ou mantinham uma atitude expectante e especulativa. Essa atitude não favoreceu, naturalmente, o surgimento de promotores de operações em áreas históricas, além do próprio Estado; não animou a criação de firmas especializadas nos ramos de reforma e reabilitação; e não incentivou a capacitação de mão de obra para esses serviços. Esse conjunto de precariedades, somado às de ordem financeira e à falta de organização das comunidades, dificultou sobremaneira a inserção do patrimônio imobiliário dos bairros antigos na vida e no cotidiano das populações locais. A visão pitoresca e turística que prevaleceu na maioria das intervenções de preservação realizadas nos anos 1990 se relacionou também a essas dificuldades.

Os estudos desenvolvidos em cooperação com consultores franceses revelaram que uma política de financiamento para o proprietário locador privado seria essencial para deslanchar processos de reabilitação que incluíssem moradores de baixa renda, assim como a criação de linhas que contemplassem o uso misto. No primeiro caso, o financiamento permitiria que proprietários, como as ordens religiosas, por exemplo, participassem das operações, e, inclusive, encontrassem meios para administrar seu patrimônio de modo mais sustentável.

A reabilitação de sítios históricos no Brasil enfrentou, nos anos 1990, como já comentado neste trabalho, sérios entraves relacionados à situação fundiária de imóveis antigos e à sua documentação jurídica irregular ou inexistente. Essa situação levou ao uso constante da desapropriação, já que a Caixa exigia situação fundiária regular para financiar qualquer operação. Ao lado disso, em decorrência da falta de uma cultura de reciclagem imobiliária no país e do desconhecimento generalizado de técnicas de reabilitação, o valor das obras em imóveis antigos se manteve muito alto, colocando num patamar muito elevado os custos de produção de unidades habitacionais.

A falta de cultura construtiva de reabilitação teve como efeito colateral uma violenta entrada da tecnologia convencional da indústria da construção no campo 
do patrimônio, fato que, aliado aos limites das linhas de financiamento, levou a se privilegiar, nas intervenções realizadas, ruínas que pudessem ser reconstruídas de modo convencional. Assim, desafios maiores não foram colocados às firmas construtoras e poucos subsídios foram gerados para o aperfeiçoamento nesse campo. Por meio de sua representação de classe, as construtoras divulgaram, à época, que não tinham interesse em operações com margem de lucro de apenas 10\% ou $15 \%$, especialmente se fossem pontuais. Apontavam que operações com uso do PAR só valeriam a pena como negócio se fosse possível operar com economia de escala, o que demandaria intervenções mais abrangentes do que as que estavam programadas. ${ }^{61}$ De fato, num país em que a indústria da construção civil é dominada por grandes empresas que não atuam na produção de moradia social, onde firmas pequenas e médias não sobrevivem porque a classe média ainda é pequena e a pobreza, que é grande, ainda habita por meio de construção autogerida, é difícil criar uma cultura de reabilitação de imóveis históricos nos moldes europeus, isto é, baseada no uso de tecnologias tradicionais e alternativas, no trabalho artesanal e na atuação de pequenos e médios empreendedores.

Experiências internacionais como a da França, contudo, demonstram que a criação de uma cultura e de um mercado de reabilitação não é coisa que se faz da noite para o dia. Exige empenho governamental, visão de longo prazo e implantação de política nacional dotada de instrumentos programáticos, financeiros, operacionais e de gestão adequados. A política de reabilitação urbana francesa, por exemplo, é integrada e interministerial, envolvendo as áreas responsáveis pelas obras públicas, equipamentos urbanos, transportes e habitação, assim como proprietários, locatários, operadores imobiliários, organizações não governamentais e iniciativa privada. (FRANÇA, 1999) Situa-se, ainda, no centro das políticas sociais e urbanas do país. Uma situação muito diferente, portanto, da encontrada no Brasil, onde a reabilitação do patrimônio urbano conta apenas com programas que não geram estruturas permanentes e onde o patrimônio urbano ainda é visto de maneira pitoresca, apartada do planejamento e da vida cotidiana das cidades. Os agentes públicos envolvidos no assunto querem, de modo geral, se beneficiar dos ganhos de imagem proporcionados pelo patrimônio, mas não querem prover os meios necessários para enfrentar sua reabilitação sistemática. Ademais,
61 Fala de Henriqueta Ferreira Alves, representante das empresas de construção civil no Seminário "Requalificação de Imóveis em Sítios Históricos e Antigos Centros Urbanos" promovido pela Caixa, Prefeitura Municipal de Salvador, Associação Comercial da Bahia e governo francês, em 28 nov. 2002. 
$62 \mathrm{Na}$ França, intervenções de reabilitação ou que fazem parte de Operações Programadas para Melhoria do Habitat contam com subvenções que variam de $25 \%$ a $40 \%$ do custo das operações, podendo mesmo fazer jus a $70 \%$ de subvenção, em determinados casos vinculados a programas sociais. (FRANÇA, 1999) os imóveis históricos não têm valor no mercado, o que, em geral, torna a intervenção de restauração ou reabilitação pouco vantajosa para proprietários e operadores. ${ }^{62}$

A Caixa Econômica Federal, ao criar esse programa, teve o mérito de recolocar na ordem do dia a questão da habitação nos centros históricos, que, apesar de universalmente reconhecida como o grande motor das reabilitações urbanas, vinha sendo esquecida ou relegada a um segundo plano nas intervenções realizadas durante os anos 1990. Em meio às promessas fáceis de valorização imobiliária vendidas pelos planos "estratégicos" de revitalização ou requalificação urbana, que trazem como reverso da moeda a deflagração de implacáveis processos de gentrificação ou espetacularização de áreas urbanas, o PRSH constituiu uma esperança de intervenções mais consistentes. 


\section{A prática de preservação urbana nos anos 1990}

\section{Considerações preliminares}

Este capítulo encerra dois objetivos principais. O primeiro é cotejar e comparar as intervenções de revitalização, requalificação e reabilitação executadas nas áreas centrais de Salvador, Rio de Janeiro e São Paulo durante os anos 1990, com vistas a identificar suas especificidades e características comuns. O outro é fazer o mesmo em relação aos programas nacionais de preservação implantados naquela década, identificando suas convergências e divergências, seus inter-relacionamentos e seus vínculos com as intervenções nas cidades selecionadas, avaliando-se os modelos de intervenção que buscaram implantar e os resultados que alcançaram.

As intervenções locais são aqui analisadas a partir: (1) de sua vinculação com experiências anteriores, em termos de continuidade ou rompimento; (2) da influência que sofreram da história urbana, do planejamento urbano e das políticas de preservação do patrimônio; (3) dos seus objetivos e metas; (4) das áreas que atingiram; (5) da natureza e do tipo de trabalho executado; e(6) dos modelos de intervenção e gestão que construíram e seus 
resultados. São ainda identificadas e comentadas as características gerais dos mecanismos financeiros, legais, urbanísticos e de gestão que foram utilizados.

A compreensão da dinâmica urbana, social e econômica das cidades surgiu também como essencial à análise das intervenções, uma vez que estas tiveram por objetivos, mais do que conservar o patrimônio, reverter processos de esvaziamento e deslocamento de funções, atrair novos consumidores e investimentos, promover a renovação de usos e valorizar o setor em foco e seu parque imobiliário. Assim, a avaliação dos resultados dessas intervenções vinculou-se também ao grau de efetividade que apresentaram como instrumentos de potencialização e de transformação de processos instalados.

Os programas nacionais de preservação foram, por sua vez, abordados a partir dos mesmos eixos de análise utilizados no estudo comparativo das intervenções locais, com os objetivos de avaliar sua efetividade como instrumentos de preservação e de reunir evidências sobre a adoção e a influência de padrões estrangeiros na formulação de políticas de preservação no Brasil, bem como na reestruturação do aparato institucional vinculado ao patrimônio. Por fim, avalia-se o papel de organismos internacionais e multilaterais na prática preservacionista desenvolvida durante o período estudado.

\section{Os solos históricos das intervenções nas áreas centrais de Salvador, Rio de Janeiro e São Paulo}

Salvador, Rio de Janeiro e São Paulo, as três cidades mais populosas do Brasil nos anos 1990, têm suas histórias políticas e econômicas entrelaçadas. Fundadas no século XVI, elas foram, pela ordem, como num jogo de passar a bola (e ao sabor das conveniências, oportunidades e circunstâncias políticas e econômicas que pontuaram o desenvolvimento brasileiro), sucessivamente alçadas à condição de maior centro urbano do país. Cada deslocamento de centralidade no plano nacional implicou o esvaziamento e a estagnação de um polo e de sua região, e o crescimento e a dinamização de outro, em processos que, embora de intensidades e durações diversas, imprimiram marcas profundas no desenvolvimento de cada uma das cidades enfocadas. Esses processos influenciaram as decisões políticas e de planejamento que configuraram o que se poderia chamar de "parque 
patrimonial" de cada uma delas, bem como os contornos das políticas de preservação traçadas ao longo do século XX. Os pesos políticos e econômicos diversos de cada uma dessas cidades ensejaram, até os anos 1970, distintas trajetórias de preservação urbana, as quais, ainda que regidas por uma ideia de patrimônio comum, se relacionaram diretamente com as demandas de renovação e expansão de suas áreas centrais e com os constrangimentos colocados por cada acervo patrimonial a esses processos.

A história da modernização urbana e da preservação do patrimônio nas áreas centrais dessas três capitais mostra que, em cada uma delas, esses processos tiveram características comuns e particularidades. Em primeiro lugar, observa-se que a preservação do patrimônio, longe de constituir um ato de resistência, buscou amoldar-se à modernização ou, como ocorreu de modo inaugural em Salvador, atuou preferencialmente em suas "sobras", ou seja, nas áreas não demandadas por essa dinâmica. Preservação e modernização urbana no Brasil foram, na realidade, processos complementares. Em Salvador e no Rio de Janeiro, o "parque patrimonial" existente nas respectivas áreas centrais é resultado da interaçãa e da negociação entre as forças da preservaçãao e as da transformação e, principalmente, da falta de fôlego da dinâmica modernizadora para penetrar em certas áreas que, assim, puderam ir sendo integralmente incorporadas ao patrimônio. Em São Paulo, de modo diverso, o acervo urbano tardiamente preservado foi produto apenas desse segundo fenômeno, correspondendo ao que sobreviveu a mais de um século de reconstruções e substituições.

Nas três cidades, as disposições de proteção do patrimônio incidentes na área central foram ampliadas nos anos 1980, quando a estagnação econômica, o esvaziamento populacional e o deslocamento de funções já estavam instalados. Portanto, quando as pressões de substituição e renovação já eram fracas ou quase inexistentes. A formação de uma opinião pública em prol da preservação contribuiu também para essa ampliação e, assim, para a patrimonialização das derradeiras "sobras" de nossa modernização urbana incompleta. A preservação mais intensiva das áreas localizadas na periferia dos núcleos dinâmicos centrais das três cidades surgiu - inicialmente em Salvador e, depois, sucessivamente, no Rio de Janeiro e em São Paulo - como iniciativa vinculada ao aproveitamento econômico do patrimônio construído. 
Os projetos implementados durante os anos 1990 nas três cidades estudadas foram, assim, marcados por histórias urbanas e de preservação específicas, se bem que pontuadas por aspectos comuns. Todas as suas áreas centrais sofreram, a partir do século XIX, sucessivos processos de deslocamento de funções que configuraram espaços diferenciados, tanto em termos de dinâmica quanto de utilização. Contudo, as três cidades chegaram à metade do século XX com uma estrutura ainda fortemente polarizada em uma única centralidade, que só se tornou inadequada e crítica com o intenso crescimento urbano impulsionado pela aceleração da industrialização nos anos 1950. A fragmentação terciária provocada por esse crescimento formou novas centralidades nas três capitais, mas esse processo teve intensidades e durações distintas e promoveu impactos diversos nas áreas centrais de cada uma delas. A natureza e a abrangência desses impactos decorreram de especificidades locais relacionadas: (a) ao grau de polaridade econômica, regional e nacional de cada cidade; (b) a decisões ou omissões de planejamento, em nível local e regional; (c) ao grau de acessibilidade e de infraestrutura instalada de cada área central; (d) ao volume de investimentos feitos nesse sentido, após a aceleração do processo de deslocamento de funções; (e) aos investimentos em infraestrutura urbana realizados em outras áreas da cidade; (f) à localização dos vetores mais dinâmicos de investimentos imobiliários; e, por fim, ainda que secundariamente, (g) ao grau de constrangimento interposto pelas legislações urbanísticas e de proteção à renovação desses setores centrais.

Em Salvador, o processo de esvaziamento e de perda de hegemonia do centro antigo foi o mais intenso e o mais induzido pelo poder público, tanto por meio dos investimentos realizados em outras áreas da cidade quanto mediante as diretrizes de planejamento que foram implementadas. Decidiu-se construir e incentivar o surgimento de novas centralidades com o objetivo de desafogar o centro antigo e preservá-lo para o turismo, e, nesse contexto, desenvolveram-se ações de revitalização a partir dos anos 1970. Salvador foi também, entre as três cidades, a que menos contou com investimentos em infraestrutura urbana, acessibilidade e mobilidade no centro antigo depois que o processo de deslocamento de funções centrais foi deflagrado. A despeito do crescimento notável da região metropolitana de Salvador nos anos 1970 e 80, a dinâmica industrial não gerou desenvolvimento econômico e mercado suficientes para manter dois centros 
urbanos com características equivalentes de polaridade. O turismo, por sua vez, tampouco se desenvolveu na intensidade esperada, de modo a redinamizar o centro antigo. O efeito do deslocamento de funções e da concentração de investimentos nas novas áreas de expansão foi esvaziar o centro antigo e dinamizar o novo centro do Vale do Camarajipe, completando-se, no final dos anos 1990, o deslocamento da hegemonia de um para o outro, apesar de, em termos simbólicos e de urbanidade, o "centro" ser ainda associado ao centro antigo. Até meados da última década do século XX, as duas centralidades ainda dividiam primazia na estrutura urbana - uma como centro de comércio popular, e a outra como centro de comércio dos segmentos de maior renda. No começo dos anos 2000, a primazia do centro já era incontestável, o que criou grandes dificuldades para a atração de investimentos no centro antigo - que assim adquiria, cada dia mais, características de um subcentro de atendimento a camadas populares.

A morfologia da cidade antiga e as áreas preservadas na capital baiana jamais criaram constrangimentos intransponíveis à modernização e à expansão do centro. Quando as primeiras pressões nesse sentido se instalaram nos anos 1960, o bairro do Comércio, na Cidade Baixa, - que abrigava a área central de negócios da cidade - foi renovado em grande parte. Nesta área, o gabarito das edificações novas foi fixado em 45 m, o que permitiu a renovação do setor, aliviou as pressões e garantiu a preservação dos conjuntos históricos localizados na cidade alta. Em Salvador, como em São Paulo, a transferência de funções centrais para novas áreas de expansão resultou muito mais de uma política de concentração de investimentos nesses setores e do favorecimento do capital imobiliário do que de qualquer outro fator.

Em São Paulo, o esvaziamento do centro antigo foi intenso nos anos 1970, e sua posterior apropriação popular também foi alta. Houve, entretanto, nos anos 1970 e 80, investimento pesado em acessibilidade e, apesar do êxodo de funções para novas centralidades, o centro antigo ainda mantinha, nos anos 1990, algumas características de centralidade principal. São Paulo passou, contudo, por um processo de deslocamento e fragmentação do centro, orientado pelo mercado imobiliário, sem que o poder público fizesse qualquer coisa para impedi-lo. Mesmo mantendo-se como o principal polo urbano e econômico do país ao longo de todo o século XX, a cidade não abrigou dinâmica econômica suficiente 
para manter, em pé de igualdade, três centros com características semelhantes. Assim, o surgimento de cada nova centralidade significou o esvaziamento e a decadência relativa da anterior. No início dos anos 1990, São Paulo apresentava um sistema de centros desequilibrado e sem primazia clara. Foi, inicialmente, contra esse desequilíbrio e no sentido de promover um movimento de retorno de funções para o centro antigo que as ações de requalificação daquela década se estruturaram.

No Rio de Janeiro, a hegemonia do centro antigo na estrutura urbana foi mais preservada, com o setor mantendo-se como um polo de atividades forte no plano municipal, metropolitano e nacional. A cidade possuía, nos anos 1990, o sistema de centralidades mais equilibrado entre os casos examinados, ao ter inviabilizado, com os investimentos feitos no centro antigo a partir dos anos 1980, o projeto de criação de um novo centro metropolitano na Barra da Tijuca. Esse equilíbrio e essa hegemonia, contudo, eram precários, pois dependiam do redirecionamento de investimentos imobiliários para o centro da cidade e do sucesso das iniciativas de inclusão das camadas populares no mercado formal de habitação. De todo modo, no Rio de Janeiro, as intervenções realizadas durante os anos 1990 encontraram um cenário urbano mais favorável do que os de Salvador e São Paulo, que foi gerado também pela qualidade da política de preservação desenvolvida nos anos 1980 e pelo consenso construído a respeito da preservação do patrimônio do centro.

As iniciativas mais amplas de conservação e valorização do patrimônio edificado, que precederam as intervenções dos anos 1990, tiveram início em momentos distintos dos processos recentes de reestruturação urbana e formação de centralidades, em cada uma das três cidades focalizadas. Em Salvador, ocorreram no início desse processo e estiveram integradas ao novo papel de polo turístico, atribuído ao centro antigo pelo planejamento local e estadual. No Rio de Janeiro e em São Paulo, no final. No caso do Rio, essas iniciativas foram voltadas para a reanimação de funções e constituíram uma reação à herança de estagnação e esvaziamento legada por uma visão superdilatada do potencial de expansão do núcleo mais dinâmico do centro. No de São Paulo, objetivaram o retorno e a manutenção de funções importantes no centro antigo, após a fragmentação dessa centralidade. 
Assim, não foi por acaso que, em Salvador, as intervenções de preservação do patrimônio do centro histórico, a partir dos anos 1960, tiveram sempre o objetivo de renovar usos e de re-funcionalizar o setor para o turismo. No Rio de Janeiro e em São Paulo, por sua vez, o objetivo foi reforçar a centralidade. Influenciadas pela história local e pelas características do parque patrimonial constituído em cada cidade, as ações executadas nessas áreas centrais nunca estiveram, entretanto, inseridas em planos globais das respectivas cidades. Constituíram ações localizadas e, de certa forma, "cegas" com relação à totalidade urbana, influenciadas, em grande parte, por uma mentalidade preservacionista que se expandiu nos meios técnicos e em certos setores da sociedade a partir dos anos 1970.

A existência de solo mais fértil ou menos fértil para o desenvolvimento dos projetos de requalificação e valorização iniciados ou ampliados nos anos 1990, nas cidades estudadas, relacionou-se, grandemente, à intensidade dos processos de deslocamento de funções centrais e de esvaziamento populacional ocorridos em cada uma, às consequências que esses processos trouxeram em termos de reestruturação dos espaços centrais e à capacidade que cada projeto teve de lidar com esses fatores. A posição e a função da centralidade na estrutura urbana, bem como a quantidade e qualidade dos investimentos realizados em acessibilidade e infraestrutura ao longo do tempo, desempenharam papéis importantes nas possibilidades de sucesso dos programas iniciados. O Rio de Janeiro, por ter logrado manter mais intacta a dinâmica e a importância de sua área central de negócios, e por ter dado continuidade à política de preservação iniciada nos anos 1980, foi a única das cidades estudadas que conseguiu promover um processo de preservação mais consolidado. Esse sucesso deveu-se à qualidade das estratégias desenvolvidas, mas também ao contexto histórico e urbano em que se implantaram.

No início dos anos 1990, cada cidade já possuía, então, em maior ou menor grau, uma "experiência" de preservação do patrimônio das respectivas áreas centrais, que influenciou as novas intervenções. Cada cidade contava também com uma história de esvaziamento e perda de funções que determinou, em muito, as chances de sucesso dessas novas iniciativas. 


\section{Características comuns e especificidades}

Salvador foi a única das três cidades onde não se não relacionou a intervenção na área central à problemática intraurbana de esvaziamento e deslocamento de funções. Foram focalizados, sem visão mais abrangente, apenas setores do centro histórico há muito depreciados e postos à margem da dinâmica do núcleo central, implantando-se ações que substituíram o perfil residencial dessas áreas e romperam radicalmente com as iniciativas anteriores de desenvolvimento social e melhoria das condições de vida da população moradora. O fracasso dessas iniciativas passadas foi, inclusive, atribuído ao fato de terem buscado manter a população residente na área. A nova intervenção no Pelourinho, iniciada em 1992, teve forte intenção de promoção governamental, integrando-se, em seguida, aos planos estaduais de desenvolvimento do turismo. Não se relacionou, portanto, a questões da cidade, mas a estratégias de desenvolvimento econômico e de comunicação do governo estadual.

No Rio de Janeiro e em São Paulo, o papel do centro antigo nas estruturas policêntricas dessas cidades foi sempre considerado um dado essencial. As intervenções dos anos 1990 destinaram-se a reforçar esse papel e a tornar esses centros antigos atraentes para novos investimentos e atividades de alcance metropolitano e municipal. Numa e noutra cidade, a questão do turismo esteve presente, mas não como eixo principal. O estímulo ao desenvolvimento de atividades culturais e de lazer constituiu um traço importante, mas inseriu-se também na problemática de reforço dessas áreas. Assim, as intervenções no Rio e em São Paulo destinaram-se a fortalecer os centros antigos como áreas estratégicas para o desenvolvimento da economia urbana, por meio do reforço de suas potencialidades e da atração de atividades contemporâneas vinculadas ao chamado "terciário avançado".

Na segunda metade na década de 1990, os "vazios" deixados pelas perdas demográficas e funcionais surgiram, simultaneamente, como um problema a ser enfrentado nos processos de requalificação e uma oportunidade para o desenvolvimento de novos projetos nos bairros centrais do Rio de Janeiro e São Paulo. O reaproveitamento desses espaços acabou tomando, em São Paulo, o caminho do desenvolvimento do uso habitacional de caráter popular e, no Rio, o da implantação 
de projetos multifuncionais baseados no incentivo à produção imobiliária. No final da década, a questão da utilização desses novos "vazios urbanos construídos" e da necessidade de redirecionar o crescimento da cidade para as áreas centrais urbanizadas já suplantava o problema do deslocamento e da fragmentação de funções centrais como móvel das intervenções nessas duas metrópoles. Em Salvador essa questão surgiu mais tardiamente, influenciada pelos projetos de aproveitamento habitacional em andamento no Rio de Janeiro e em São Paulo e pelos programas nacionais de preservação que foram implantados no final da década.

O desenvolvimento do uso habitacional como alternativa para a dinamização e o aproveitamento de setores centrais ganhou peso, em cada cidade, em decorrência de fatores distintos. Em Salvador, como resultado da não sustentabilidade da intervenção comercial e turística realizada no centro histórico; da busca de recursos e alternativas para dar continuidade ao processo de recuperação; e do aprofundamento do esvaziamento da área do Comércio, com a transferência maciça do setor financeiro para o novo centro do Vale do Camarajipe, na segunda metade dos anos 1990. No Rio de Janeiro, como estratégia para sustentar o processo de requalificação e valorização do núcleo dinâmico do centro e, em São Paulo, para atender às reivindicações dos movimentos sociais por moradia que invadiram imóveis no centro antigo. Nos três casos, o movimento em direção ao desenvolvimento do uso habitacional foi propiciado também pelas mudanças implementadas na política nacional de habitação, o que permitiu a implantação de linhas de financiamento destinadas à melhoria do habitat. O movimento de reconquista habitacional de áreas centrais encontrou ainda justificativa na necessidade de intensificação do uso de áreas bem dotadas de infraestrutura e equipamentos, diante do arrefecimento do crescimento demográfico nas grandes metrópoles e do fenômeno de esvaziamento de áreas de urbanização mais antiga e consolidada.

O foco das intervenções no núcleo mais dinâmico do centro e sua extensão posterior aos bairros periféricos é um traço marcante do processo do Rio de Janeiro, surgido da necessidade de se consolidar os investimentos realizados no núcleo principal. O vínculo com o turismo teve, em Salvador, grande influência na concentração das intervenções nos sítios históricos do centro antigo, bem como nos logradouros e corredores viários mais importantes que thes dão acesso. 
A maioria das intervenções nessa cidade localizou-se, assim, ao longo dos "caminhos do turismo", não focalizando nem a área comercialmente mais dinâmica do centro, nem a área central como um todo.

Em São Paulo, intervenções e projetos se concentraram de modo mais ou menos equilibrado no núcleo mais dinâmico do centro e em setores específicos da área central. A depender, entretanto, de sua vinculação ao projeto de dinamização econômica e valorização imobiliária ou ao de reanimação do uso habitacional, focalizaram, preferencialmente, setores distintos. No primeiro caso, o foco foi posto nos distritos que compõem o núcleo funcionalmente mais importante do centro e em determinados sítios históricos da área central, como o bairro da Luz. No segundo, em qualquer setor do centro ou dos bairros centrais que abrigasse edifícios e terrenos vazios ou subutilizados. Neste caso, a localização foi esparsa, descontínua e bastante influenciada por oportunidades de ocupação e aquisição. Só depois do fim da década de 1990 é que as intervenções de desenvolvimento do uso habitacional se vincularam a perímetros delimitados em áreas de concentração de habitações subnormais. Em Salvador, assim como no Rio, a localização dos projetos habitacionais foi comandada por oportunidades de aquisição e ocupação relacionadas à existência de ruínas, imóveis e terrenos vazios. Nessas cidades, a localização desses projetos também foi dispersa e descontínua.

Em termos gerais, contudo, pode-se afirmar que, no Rio e em São Paulo, predominou a tendência de se concentrar as intervenções nos setores de maior dinâmica das áreas centrais. Apenas no final da década de 1990 surgiu a tendência de focalizar ou projetar intervenções para as áreas periféricas esvaziadas que apoiam ou exercem influência na dinâmica dos núcleos principais dessas cidades. Os projetos públicos, tanto numa cidade quanto na outra, passaram a considerar todas as respectivas áreas centrais somente no começo dos anos 2000.

Quanto ao tipo e à natureza das intervenções, verifica-se uma notável semelhança entre as três cidades, embora, em cada uma, a execução de determinado tipo seja mais ou menos intensa, e mais ou menos bem sucedida. Invariavelmente, todas elas realizaram intervenções de natureza física e de controle do uso do solo e dos espaços públicos de modo articulado. Em todas, as intervenções se estruturaram, inicialmente, com vistas à dinamização econômica e à valorização imobiliária das áreas centrais. Ao longo da década, entretanto, a depender da 
maior ou menor viabilidade demonstrada por essas estratégias e da intensidade dos seus resultados, foram surgindo outras voltadas para o desenvolvimento da função residencial.

As intervenções físicas voltaram-se, principalmente, para a realização de "melhorias" na aparência e no funcionamento dos espaços e logradouros públicos, para a reciclagem de imóveis, a recuperação de fachadas, a valorização de objetos arquitetônicos destacados, a inserção de objetos artísticos no espaço público e valorização dos existentes. Incluíram ainda o deslocamento de terminais de transportes públicos, a provisão de estacionamentos privados e a instalação de mobiliário urbano. Em suma, essas intervenções buscaram criar ambientes urbanos agradáveis, ordenados e atraentes para determinados tipos de atividades. O Rio de Janeiro foi a cidade onde as intervenções de requalificação de espaços públicos mais se desenvolveram e, em seu conjunto, atingiram uma área maior e mais contínua no centro antigo. Em São Paulo e em Salvador - em que pese a intervenção maciça no Pelourinho -, as intervenções de requalificação urbana foram mais pontuais, privilegiando vias e logradouros públicos de maior simbolismo e visibilidade.

As intervenções de gestão e controle dos espaços públicos caracterizaram-se pela eliminação ou pelo ordenamento do comércio informal, controle da presença de moradores de rua, melhoria da segurança pública ou implantação de segurança privada; e ainda foram marcadas pelo ordenamento da exibição de publicidade e realização de eventos em praças e ruas. Apenas em São Paulo, no final da década de 1990, as intervenções de controle da presença da pobreza e de suas formas de sobrevivência na área central foram acompanhadas de projetos de assistência e inserção social, capacitação e geração de trabalho e renda.

As intervenções de reciclagem de imóveis para uso habitacional foram muito poucas em todas as cidades estudadas, não apenas porque esses projetos surgiram tardiamente, mas, principalmente, em decorrência de entraves burocráticos, fundiários, documentais, urbanísticos, tecnológicos e vinculados às limitações das linhas de financiamento existentes. A execução limitada desse tipo de intervenção decorreu ainda da falta de interesse do setor imobiliário e da construção civil pelas localizações centrais e também foi resultado da dificuldade de acesso, por parte dos segmentos de menor renda, ao mercado formal de habitação e aos financiamentos disponíveis. As linhas de financiamento para 
a produção habitacional surgiram no final dos anos 1990, mas seu uso foi muito restrito, devido à sua inadequação à reabilitação de imóveis históricos, conforme visto no Capítulo 5. Em Salvador e no Rio de Janeiro, as intervenções voltadas para o uso habitacional de interesse social foram incorporadas aos projetos de dinamização econômica e terciária, com um caráter complementar. Em São Paulo, os projetos de requalificação e reanimação econômica e os de uso habitacional se desenvolveram em campos opostos e antagônicos. Apenas no final daquela década foram realizados esforços no sentido de torná-los complementares.

Nenhum desses conjuntos de intervenções nas áreas centrais das cidades em foco obedeceu a planos globais para esses setores. Em Salvador, a intervenção do Pelourinho constituiu um projeto bastante circunscrito territorialmente e as demais intervenções pontuais de requalificação de vias e logradouros da área central tampouco se articularam a um plano de maior alcance. Contudo, foram guiadas por uma lógica comum, a de valorizar o patrimônio do setor e desenvolver o turismo. Assim, se pode afirmar que se articularam ao plano estratégico de turismo do governo estadual - instância que financiou e se responsabilizou pela maioria das intervenções. No Rio de Janeiro tampouco houve plano global. Os atores públicos e privados se articularam espontaneamente, em decorrência da política desenvolvida pelo município desde os anos 1980 e do já mencionado consenso firmado sobre os rumos da preservação do patrimônio do centro. Esse consenso tornou as ações públicas e privadas complementares e thes imprimiu uma lógica de reforço e valorização da centralidade. (MAGALHÃES, 2001)

São Paulo também executou intervenções pontuais, mas foi a cidade que mais investiu na elaboração de planos para o núcleo do centro e para a área central. Embora praticamente não tenham sido executados no período em foco, esses planos guiaram as intervenções que lograram se concretizar. Apesar do baixo índice de execução, decorrente, em grande parte, de um excesso de otimismo com relação à participação da iniciativa privada nos projetos propostos, esses planos contribuíram para desenvolver e consolidar um pensamento sobre a área central que colocou São Paulo à frente das outras cidades em termos de propostas e possibilidade de viabilização dos seus projetos.

O papel do poder público como formulador, coordenador, financiador, gestor ou executor dos projetos e intervenções nas áreas centrais das cidades estudadas 
foi o tempo todo fundamental. Apenas em São Paulo a formulação, coordenação e gestão dos processos foram compartilhadas com a iniciativa privada e com a sociedade, que, entretanto, não tiveram participação igual no que toca à execução. Na maior parte do período enfocado, o poder público foi posto numa posição de executor dos planos de uma associação de empresários e proprietários urbanos, verificando-se a alteração dessa característica apenas no final da década, quando a municipalidade reassumiu o papel de ente formulador e coordenador do processo. No Rio de Janeiro e em Salvador, ao contrário, a liderança do poder público - municipal, no primeiro caso, e estadual no segundo -, foi clara e inquestionável em todos os momentos. A diferença é que, no Rio, a iniciativa privada contribuiu executando algumas intervenções e, em Salvador, todo o processo ficou a cargo do poder público. De um modo geral, portanto, o principal ator dos processos de "recuperação", "requalificação", "repovoamento" ou "reabilitação" estudados foi mesmo o Estado. Segmentos empresariais, comerciantes, corporações, agências financeiras nacionais e internacionais e sociedade civil organizada se envolveram, mas com intensidades e papéis bem diferentes em cada caso.

A participação da sociedade civil organizada variou muito em cada caso. Em Salvador, a população habitante das áreas que sofreram intervenção não participou do processo, tendo sido, simplesmente, indenizada e empurrada para fora. No Rio de Janeiro, as associações de bairro e de comerciantes, tão atuantes nos anos 1980, ficaram silenciosas. ${ }^{2}$ O setor empresarial carioca, o principal beneficiado, não teve necessidade de se manifestar. Em São Paulo, contudo, a participação da sociedade foi uma das alavancas dos processos de requalificação de espaços públicos e de reabilitação de imóveis para uso habitacional, tendo funcionado como motor da continuidade dessas ações na área central. Os movimentos sociais por moradia e suas assessorias técnicas disputaram espaço com as associações empresariais, contabilizando importantes conquistas no que toca à concretização de operações, à formulação de uma política habitacional para a área central paulistana e à inclusão de ações de interesse social nos programas formulados para o centro.

Os modelos de intervenção construídos, em cada cidade, a partir do somatório das ações realizadas, dos projetos e planos eventualmente propostos, abordaram e buscaram atrair de modo distinto a participação do setor privado,
1 A Associação Viva o Centro. Ver mais a respeito no capítulo 4

2 Apenas uma associação, a ACCRA, ligada aos comerciantes da Rua do Lavradio e arredores, na Lapa, influenciou e participou do projeto de requalificação por meio do encaminhamento de reivindicações à prefeitura e da mobilização da mídia em torno dos problemas dessa via. Pesou no atendimento dessas reivindicações o fato de a Rua do Lavradio vir sendo utilizada periodicamente para a realização de feiras de antiguidades que atraem moradores da Zona Sul, e de estar se transformando, à época, em um ponto de entretenimento dessas camadas. 
mas tiveram, na prática, como traço comum, a predominância de investimentos públicos de modo direto ou mediante incentivos fiscais. Em Salvador, não foram utilizados incentivos fiscais ou instrumentos urbanísticos para a atração de investimentos privados, mobilizando-se apenas, por curto tempo, mecanismos especiais de incentivo à instalação de atividades no setor recuperado. Já no Rio de Janeiro e em São Paulo, o uso de incentivos foi igualmente intenso, mas com resultados muito diversos. No Rio, apoiados no sistema de preservação e apoio técnico montado pela prefeitura nos anos 1980, os incentivos fiscais municipais desempenharam papel fundamental no processo de requalificação do centro, animando o investimento privado nos setores protegidos próximos à área central de negócios. Além desses, os incentivos fiscais do Governo Federal desempenharam igualmente um papel importante na recuperação de edifícios históricos para uso institucional ou cultural. Nessa cidade, o bom funcionamento dos incentivos fiscais como instrumentos de preservação se relacionou ao valor alto do imposto territorial e urbano no centro, à continuidade da política municipal de preservação e à incorporação desses incentivos às dinâmicas de uso comercial e cultural existentes, às quais deram novo impulso. Flexibilizações de legislação e vantagens urbanísticas não foram utilizadas no Rio de Janeiro durante o período estudado.

A flexibilização do aparato legal urbanístico foi, em contrapartida, muito intensa em São Paulo, bem como a relacionada à mobilização de incentivos fiscais. Entretanto, os resultados propiciados por esses instrumentos foram bem menores do que no Rio de Janeiro. Em São Paulo, a iniciativa privada e os proprietários urbanos, de um modo geral, não se interessaram por esses dispositivos, apesar das grandes vantagens oferecidas. Assim, não foram eficazes como instrumentos de preservação e de incentivo à produção imobiliária. Diferentemente do Rio de Janeiro, o valor dos imóveis localizados no centro de São Paulo não é tão alto, e os investimentos do setor privado estiveram mais concentrados fora da área central.

Os instrumentos de política urbana consagrados pelo Estatuto da Cidade no ano 2000 também tiveram presença muito diferenciada em cada modelo local. Em Salvador, não foram mobilizados, fazendo-se apenas um uso mais sistemático do instituto da desapropriação. Em São Paulo, alguns desses instrumentos, como as operações urbanas consorciadas e interligadas, foram ampla e precocemente 
utilizados, mas sem resultados na mudança do quadro da área central. Nessa cidade e no Rio de Janeiro, os dispositivos voltados para o controle e a inibição da especulação imobiliária surgiram apenas em propostas da década de 2000. A estruturação de mecanismos específicos de gestão urbana não chegou a ser uma característica das intervenções nas cidades estudadas. Apenas São Paulo, com a implantação da Comissão ProCentro, apresentou algum avanço nesse sentido.

Embora o uso de recursos públicos tenha predominado em todos os casos estudados, no que toca à estruturação e utilização de instrumentos financeiros, fiscais, legais e urbanísticos, as intervenções não adotaram um formato único e apresentaram variações ligadas às circunstâncias políticas e às dinâmicas locais. Conservaram, entretanto, um traço comum: os incentivos criados se dirigiram, basicamente, a empresas e a proprietários urbanos. Estes, nas diversas combinações resultantes da parceria entre setor público e setor privado, foram os grandes beneficiados e as forças mais incentivadas.

Em geral, todos os processos locais relacionaram-se de modo incipiente com os programas nacionais de preservação, mas, com relação ao PRONAC, seus benefícios fiscais desempenharam papel essencial no Rio de Janeiro e em São Paulo. Nessas cidades, grandes edifícios foram restaurados e funcionaram como importantes equipamentos culturais, graças a esse programa. Somente no final dos anos 1990, o Programa de Revitalização de Sítios Históricos, da Caixa Econômica Federal, e o Programa Monumenta produziram algum impacto nas intervenções locais que estavam em andamento e nos seus planos futuros. O primeiro, no que toca à animação dos projetos relacionados ao desenvolvimento do uso habitacional, e o segundo, na complementação de recursos para ações já em desenvolvimento.

As intervenções em Salvador, no Rio de Janeiro e em São Paulo relacionaram-se de modo distinto com questões urbanas emergentes e com diretrizes estabelecidas para o desenvolvimento regional. Em Salvador, como visto, relacionaram-se ao plano estadual estratégico de desenvolvimento do turismo, no âmbito do fortalecimento e da renovação do "produto turístico Salvador". No Rio de Janeiro, a requalificação do centro sempre foi pensada como uma ação para a cidade, relacionada à sua dinâmica e uso cotidiano. A vinculação das intervenções 
na área central com questões regionais só surgiu em meados da década de 1990, quando alguns projetos, como o Teleporto e o Porto do Rio, buscaram sinergia com programas de dinamização da região, como polo de transporte marítimo, comércio internacional e produção de petróleo. Em São Paulo, por outro lado, entraram na pauta dos projetos para o centro todas as questões urbanas emergentes. Em contrapartida, sua vinculação a questões regionais foi pouco desenvolvida, exceto quanto ao reforço do centro antigo como polo cultural e de negócios de alcance regional, nacional e internacional. Os problemas em torno da questão do uso habitacional de interesse social foram, sem dúvida, as que mais mobilizaram ações contra e a favor, no processo paulistano. Pode-se afirmar, portanto, que o grau de vinculação das intervenções estudadas a problemas locais e regionais foi distinto, assim como foram distintas as questões centrais que os dominaram ao longo da década. Em Salvador, o turismo; em São Paulo, a habitação e os negócios; e no Rio de Janeiro, a cultura e o lazer.

A despeito de suas tendências específicas - ligadas às características, fracassos e conquistas de cada processo local -, verifica-se que os modelos de intervenção construídos nas cidades examinadas buscaram se aproximar, ainda que de modo incompleto e com contornos específicos, das intervenções urbanas realizadas em países desenvolvidos, cujo modelo foi transportado para cá na década em exame. Esse modelo, que tem a cooperação entre os setores público e privado como pilar central do aproveitamento econômico e imobiliário de áreas deterioradas e esvaziadas, foi tentado, de algum modo, em todas as cidades estudadas. Contudo, em contextos de depreciação econômica mais forte, seu poder indutor de transformações revelou-se muito limitado e pouco capaz de promover alterações no quadro urbano. Em compensação, nas áreas em que foram iniciadas ações vinculadas à dinâmica de uso e à demanda habitacional existente, embora incipientes e pouco desenvolvidas, mostraram um grande potencial. Na medida em que o poder de regeneração do modelo importado foi se mostrando fraco, em contato com nossa realidade política, econômica e social, surgiu a tendência de conjugá-lo a ações de produção habitacional para rendas mais baixas. Essa tendência foi se configurando por meio da montagem de um modelo de intervenção híbrido ou do estabelecimento de territórios ou setores específicos para o desenvolvimento de intervenções de uso habitacional. 
Em ambos os casos, as ações vinculadas à dinamização de atividades econômicas e imobiliárias tenderam a se concentrar, preferencialmente, nos núcleos mais dinâmicos dos centros e nas áreas com maior potencial de renovação. Já as relacionadas à produção habitacional tenderam a se localizar nos interstícios dessas áreas, nos bairros periféricos aos núcleos centrais e nos setores de maior concentração de imóveis de valor histórico. ${ }^{3}$

O desafio colocado a esse modelo era o de ser capaz de controlar, eficazmente, os efeitos da valorização imobiliária que fatalmente se desencadearia à medida que os projetos de requalificação avançassem, permitindo que os segmentos de menor renda interessados em morar próximos ao centro pudessem ser beneficiados. O uso dos instrumentos de democratização do acesso ao solo urbano instituídos pelo Estatuto da Cidade tornou-se, assim, importante. A manutenção de um delicado equilíbrio entre valorização e inclusão social, ou entre livre mercado e proteção estatal, surgiu então como a possibilidade mais viável de criação de um modelo de reabilitação urbana adequado às condições urbanas brasileiras.

\section{Resultados projetados e obtidos}

Em comparação com as metas projetadas, verifica-se que os resultados das intervenções em Salvador e em São Paulo ficaram bastante aquém do esperado. No Rio de Janeiro, obtiveram sucesso no núcleo dinâmico do centro e em suas imediações, mas os reflexos nos bairros periféricos foram pequenos. Esses resultados estão relacionados, naturalmente, aos vários fatores "internos" e "externos" que, com intensidades distintas, interagiram com as intervenções realizadas. Os internos se relacionam à concepção das intervenções e aos modelos adotados, a questões políticas locais e à dinâmica econômica e de uso de cada área central. Já os fatores "externos" vincularam-se à economia urbana e regional, à dinâmica de ocupação e expansão da cidade, ao peso da centralidade na estrutura urbana e, não menos importante, ao valor de mercado atribuído ao patrimônio pela população local. Em suma, os resultados das intervenções realizadas decorreram de múltiplos fatores, que ultrapassaram, em muito, a questão da preservação ou da conservação do patrimônio. 
Em Salvador, o fracasso da ocupação turística e comercial do Pelourinho está relacionado a vários desses fatores, mas especialmente ao fato de a intervenção ter sido utilizada, prioritariamente, como instrumento de marketing pelo governo estadual, e de se insistir em sustentá-la a partir do turismo, sem nenhum vínculo com a dinâmica de uso e ocupação do entorno. Trata-se, em suma, de um problema de inadequação do modelo ao meio e à dinâmica local, o que, somado ao equívoco do modo de gestão adotado, resultou em sérias dificuldades para se promover uma preservação sustentada do setor. Em outras palavras, o modelo de intervenção e de gestão construído no Pelourinho - excessivamente centrado no governo estadual e em uma concepção equivocada de empreendimento turístico e comercial - não foi capaz de cumprir a finalidade de conservar o patrimônio edificado, de deflagrar uma dinâmica de ocupação "saudável" no entorno e de exonerar o poder público de investimentos constantes na preservação do conjunto. Fatores "externos", ligados ao peso e ao papel do centro antigo na atual estrutura de Salvador, aos hábitos de compra e de lazer da classe média e às dificuldades de desenvolvimento do turismo no estado também contribuíram para o malogro dessa intervenção.

O fato de o centro antigo de Salvador abrigar cada vez menos funções direcionais e tipicamente centrais, caracterizando-se no âmbito do sistema de centralidades de Salvador como um centro de comércio e serviços de caráter popular, dificulta a atração de atividades com outro perfil, bem como o interesse do seu público correspondente. Com a conclusão do processo de formação de novas centralidades, iniciado nos anos 1960, surgiram na cidade vários polos de comércio, animação e lazer que concorrem fortemente com o novo Pelourinho. Ao lado disso, o número de turistas não foi suficiente para sustentar o empreendimento nos moldes em que foi desenhado.

Embora as iniciativas relacionadas ao desenvolvimento do uso habitacional não tenham saído completamente do papel, seus horizontes, como alternativa para a recuperação sustentada de setores deteriorados do centro histórico de Salvador, pareciam claros no começo dos anos 2000. Pesquisas da época mostravam que havia uma grande demanda de unidades habitacionais para faixas de renda média e baixa na área central, o que a dinâmica residencial e comercial da zona confirmava. Entretanto, essa alternativa foi prejudicada pela ausência 
de articulação dessas ações pontuais a um projeto global, que incluísse a solução dos entraves urbanísticos, ${ }^{4}$ de acessibilidade e de mobilidade urbana que dificultavam o uso residencial na área. Ao lado disso, a falta de propostas no sentido da criação de mecanismos de controle da valorização do solo, caso o uso habitacional se desenvolvesse, criaria, certamente, obstáculos para o acesso dos segmentos de renda que demandavam a área central. ${ }^{5}$ Embora a região não fosse ainda cobiçada pelos segmentos de alta renda, os investimentos em requalificação de vias e logradouros, na valorização de sítios históricos, bem como os que estavam projetados para a Cidade Baixa, reforçaram o processo de gentrificação que já havia começado a se instalar nas bordas do centro histórico voltadas para a Baía de Todos os Santos. Desse processo, davam testemunhos eloquentes o comércio e os serviços ultrassofisticados instalados na Avenida Contorno e a alta no preço dos imóveis da Rua Direita de Santo Antônio, em decorrência de sua ocupação por estrangeiros.

Os projetos de dinamização econômica e intensificação do uso da área central de Salvador enfrentaram, ainda, uma carência que não se verificava nas demais cidades estudadas: a falta de dados organizados que permitissem monitorar a dinâmica comercial, residencial e de serviços do setor, bem como sua relação com as dinâmicas de outras áreas e centralidades da cidade. Diferentemente de São Paulo, onde a municipalidade era pródiga nesse sentido, em Salvador não existiam, no começo dos anos 2000, informações básicas, por exemplo, sobre arrecadação de IPTU, ISS ou ICMS, organizadas por bairros ou regiões administrativas. Conforme observado no capítulo que focaliza essa cidade, as políticas de preservação e valorização do patrimônio urbano foram elaboradas e executadas às cegas, sem visão geral dos processos e dinâmicas em curso na cidade. Esse, sem dúvida, foi um outro fator que prejudicou sua efetividade.

No centro da cidade de São Paulo, as dificuldades de consolidação e ampliação dos projetos de requalificação ambiental, dinamização econômica e valorização imobiliária estiveram relacionadas a uma estratégia excessivamente baseada na atração de investimentos privados de grande monta. Esta opção fez com que ganhassem peso considerável na viabilização das intervenções fatores como o papel atual do centro antigo na estrutura urbana; os vetores de concentração de investimentos imobiliários; a dinâmica econômica da
4 Falta de estruturas de apoio, como comércio de caráter local, áreas de lazer, escolas, postos de saúde e demais equipamentos necessários ao desenvolvimento do uso habitacional.

5 Diferentemente de São Paulo, no projeto de Plano Diretor de Desenvolvimento Urbano e Ambiental de Salvador, iniciado no começo dos anos 2000, não foram propostas Áreas de Especial Interesse Social na área central. 
cidade; e o valor de mercado atribuído à localização central e ao seu patrimônio. A perda de importância do centro antigo de São Paulo como polo de atividades administrativas, direcionais, financeiras, comerciais e de serviços, bem como a adaptação de muitas dessas atividades a um perfil popular, fez com que a área perdesse atratividade como localização preferencial de atividades ligadas aos estratos de renda mais alta, dificultando o redirecionamento de investimentos significativos em reciclagem ou produção imobiliária para o centro. O esforço de requalificação de alguns espaços e a criação de incentivos fiscais e urbanísticos não foram suficientes para atrair esses investimentos, principalmente, em decorrência da ausência de uma ação incisiva que impusesse controles a certos vetores de produção imobiliária que tornavam desinteressantes as vantagens oferecidas no centro. Pesaram, ainda, as dificuldades que sucessivas administrações locais tiveram para equacionar, minimamente, a questão do comércio informal no centro, que, literalmente, ocupava várias de suas vias e praças.

Assim, mesmo com a implantação de uma política de incentivos fiscais e a forte flexibilização operada na legislação urbanística, o quadro de subutilização do centro paulistano permaneceu praticamente inalterado nos anos 1990. Embora novos equipamentos culturais tenham trazido um público mais endinheirado, seu impacto no quadro geral foi baixo. Em vista disso, tornou-se essencial para a reversão do quadro de esvaziamento e desvalorização um plano global de cidade, além de medidas destinadas a estabelecer uma relação mais equilibrada entre as centralidades existentes e um uso mais racional da infraestrutura implantada. O que se verificou, contudo, na maior parte da década de 1990, foi justamente a convivência dos projetos de requalificação do centro com pesados investimentos públicos e incentivos à produção imobiliária nos setores da cidade de maior interesse para o mercado imobiliário formal.

A reversão de quadros de esvaziamento funcional, populacional e econômico em áreas centrais depende, certamente, de muitos fatores, mas o caso de São Paulo mostra, de modo muito claro, o quanto o surgimento de centralidades não planejadas e, ao mesmo tempo, orientadas por interesses imobiliários, pode dificultar ou até inviabilizar esses processos. Mostra claramente, ainda, que, menos do que ao oferecimento de vantagens urbanísticas e fiscais e à realização de intervençóes de melhoria da ambiência, a reversão desses quadros está vinculada a um olhar 
para além do centro e da própria área central. Um olhar, enfim, que abarque não somente os novos centros, mas também a periferia da cidade. Os investimentos do município e do governo estadual nos anos 1990, contudo, atraíram algumas parcerias para a realização de melhoramentos em logradouros públicos, para a restauração de fachadas e de grandes monumentos, assim como para a instalação de centros culturais.

O projeto de uso habitacional de interesse social na área central de São Paulo também encontrou dificuldades para se tornar uma ação sistemática e ampla. Neste caso, contudo, os problemas não se relacionaram à falta de demanda, mas, como já comentado, a entraves fundiários, documentais e burocráticos; às limitações das linhas de financiamento disponíveis e à falta de políticas de subsídios e de desenvolvimento tecnológico. As perspectivas de sucesso do projeto de intensificação do uso e de requalificação do centro de São Paulo aumentaram, entretanto, na medida em que se buscou explorar as potencialidades da área por meio da reanimação de funções tipicamente centrais, como a vinculada à administração municipal, e através do desenvolvimento do uso habitacional. A articulação dessas ações a um plano global para a área central também foi um fator importante que colocou São Paulo, entre os casos estudados, como a cidade que produziu a proposta mais consistente e com melhores chances de viabilização.

No Rio de Janeiro, o projeto de recuperação do patrimônio para reforço e valorização do centro da cidade ajudou a estancar, no seu núcleo mais dinâmico, processos de esvaziamento funcional e deterioração urbana instalados há longa data, contribuindo para manter a hegemonia dessa centralidade na estrutura urbana. O projeto foi importante ainda para manter e até aumentar o valor de mercado dos imóveis, reanimar atividades culturais, de entretenimento e lazer, renovar a ocupação comercial em certas áreas e reaproximar segmentos sociais de renda mais elevada do centro da cidade. O Rio de Janeiro apresentou, entre as cidades estudadas, o caso mais bem-sucedido de recuperação sustentada do patrimônio, embora este sucesso tenha ficado restrito ao seu núcleo mais dinâmico. A periferia do centro, como já observado, manteve o mesmo perfil esvaziado e deteriorado de 20 anos antes.

Vários fatores influenciaram e permitiram o resultado positivo alcançado, nos anos 1990, pela experiência carioca. Entre estes fatores, destacam-se a preservação 
da importância da antiga centralidade no sistema de centros municipais e metropolitanos; a herança legada pelo trabalho educativo e de grande qualidade técnica realizado pelo Corredor Cultural, nos anos 1980; e a continuidade da política de incentivos fiscais municipais então traçada. Essa política impulsionou investimentos privados, gerando um compromisso maior dos ocupantes, proprietários e comerciantes instalados com o projeto do poder público. Por sua vez, os investimentos públicos diretos, realizados nos anos 1990, ampliaram a área recuperada e reforçaram os predicados que, há muito, asseguram a hegemonia do centro antigo na estrutura urbana e metropolitana, isto é, sua posição geográfica estratégica, sua notável acessibilidade e a manutenção de funções institucionais, culturais, financeiras e administrativas importantes.

O alcance restrito dos efeitos positivos ao núcleo dinâmico do centro vinculou-se às características dessas intervenções, mas também às causas históricas do esvaziamento e da deterioração dos demais bairros que compõem a área central da cidade do Rio de Janeiro. Como visto anteriormente, sobre esses bairros se deram os grandes impactos do crescimento urbano orientado para a periferia, bem como do deslocamento de funções que freou a expansão da área central de negócios. A estagnação da economia carioca e fluminense por longo período favoreceu, por seu turno, esse processo de esvaziamento e tornou mais difícil a dinamização dessas áreas com atividades econômicas próprias de uma área central. Paralelamente, os vazios deixados não puderam ser preenchidos pelos segmentos demandantes de moradia central, pois a estrutura fundiária existente, a especulação imobiliária com terrenos centrais e o modelo tradicional de política habitacional não permitiram esse aproveitamento.

Ao lado desses fatores, por assim dizer, estruturais, a periferia do núcleo dinâmico do centro carioca recebeu, historicamente, consideravelmente menos investimentos públicos do que este núcleo, e os programas traçados nos anos 1990 para atendimento à demanda de moradia popular nessa área não deslancharam. Tampouco decolaram, por falta de investidores, os projetos de dinamização econômica e de incentivo à produção imobiliária propostos para essa periferia do núcleo central. A dificuldade de atrair investimentos privados de peso para essa zona se relacionou à permanência de vetores de investimentos dinâmicos e altamente lucrativos na Zona Oeste da cidade, o que foi reforçado pelos investimentos 
públicos em vias de ligação rápida dessa zona com o centro e com as principais saídas da cidade. Além disso, o aproveitamento, a reabilitação e a reciclagem do patrimônio edificado constituíram ações marginais no universo da produção imobiliária brasileira - tendência de mercado que era então determinada (e ainda é) pela permanência, no seio dos segmentos de maior renda, de uma mentalidade que não valoriza a moradia central.

As perspectivas de consolidação, sustentabilidade e durabilidade do processo de intensificação do uso da área central carioca repousavam, portanto, na possibilidade de reabilitar as áreas deterioradas da periferia do centro; na solução dos entraves que impediam o desenvolvimento satisfatório dos programas habitacionais nessas áreas; na criação de mecanismos financeiros e de controle da especulação imobiliária e de subsídios que permitissem atender adequadamente a demanda habitacional existente. Dependiam também da possibilidade de se reorientar vetores de investimentos econômicos e imobiliários por meio de um amplo planejamento territorial e de uma localização criteriosa de investimentos públicos. Faltava, ainda, uma política de subsídios diversificados e adaptados aos vários tipos de produção habitacional que a área central poderia abrigar, além de linhas específicas de financiamento para a reabilitação de imóveis antigos e um programa de desenvolvimento tecnológico no campo da reforma e da reabilitação. Por fim, faltava a delimitação de Áreas de Especial Interesse Social que possibilitassem o reaproveitamento do patrimônio urbano com inclusão dos que, de fato, demandavam moradia no centro.

Os resultados das intervenções realizadas em Salvador, Rio de Janeiro e São Paulo, nos anos 1990, mostram a importância da adequação do modelo de intervenção à realidade econômica e urbana de cada localidade para que processos de utilização intensiva e de dinamização econômica possam alcançar resultados positivos. Mostram também que são fatores essenciais para o sucesso e a sustentabilidade de projetos de aproveitamento do patrimônio edificado: a manutenção de polaridade simbólica e urbana; o reforço de funções centrais, administrativas e habitacionais; a remoção de entraves fundiários e urbanísticos; e uma boa acessibilidade - ou o investimento nesse sentido. O controle e o redirecionamento de vetores de investimento imobiliário, por meio de mecanismos urbanísticos e de investimentos estratégicos, é também essencial, bem como a capacidade de 
6 Salvador constituiu a exceção, com sérios problemas de acessibilidade, mobilidade e oferta de transportes públicos na área central. Os terminais da Lapa, da Barroquinha, do Aquidabã e da França tangenciam o centro histórico, mas não o irrigam. Com a eliminação do Terminal da Sé, o setor teve ainda o número de linhas que percorrem a cumeada do centro histórico reduzidas. Além disso, devido ao Pelourinho ter sido concebido como um enclave turístico, o sistema de transportes públicos remanescente não o atravessava, o que não permitia estabelecer ligação entre os bairros do centro histórico. conter a especulação imobiliária e de planejar o crescimento urbano. A sustentabilidade desses projetos estará ainda relacionada ao solo histórico sobre o qual se implantem, especialmente no que diz respeito à eficiência e à qualidade das políticas urbanas, de preservação e de aproveitamento patrimonial implantadas em épocas passadas. Desempenham também importantes papéis os investimentos públicos e privados historicamente realizados, o nível de organização social existente e a capacidade política dos atores envolvidos de defenderem seus projetos e negociarem espaço. O desenvolvimento de um projeto de cidade que inclua a área central, que encaminhe soluções para problemas de moradia, trabalho, renda e infraestrutura, e contenha uma avaliação correta das potencialidades econômicas de cada localidade, é também fundamental. Em suma, dinamizar, valorizar e reabilitar, com sucesso e durabilidade, o patrimônio de áreas centrais esvaziadas e deterioradas vincula-se à solução de problemas complexos que dizem respeito não apenas a esse setor, mas a toda a cidade. Em outras palavras, a causa dos problemas dos centros históricos está frequentemente localizada fora deles e muito além dos problemas específicos da conservação patrimonial ou da requalificação de ambientes.

As experiências estudadas mostram que os incentivos fiscais, as flexibilizações de aparato legal, o oferecimento de vantagens urbanísticas, a derrogação de normas de proteção ou sua ampliação, embora possam animar investimentos privados, são impotentes, por si só, para redirecionar vetores consolidados de deslocamento funcional e de investimentos imobiliários. Em suma, são incapazes de reverter processos já instalados, provando-se eficientes apenas na consolidação e reforço de tendências configuradas. Ao mesmo tempo, os estudos realizados apontaram para um fato inquestionável: em todas as cidades estudadas, qualquer que tenha sido a intensidade da situação de esvaziamento funcional ou de perda de polaridade econômica, as áreas centrais eram grandemente demandadas como local de moradia pelos segmentos sociais de baixa renda. Assim, a existência, em todas elas, de grande número de imóveis subutilizados ou vazios, de áreas intensamente ocupadas por um comércio de perfil popular, de farta oferta de transportes públicos ${ }^{6}$ e de empregos, as tornava estratégicas para o encaminhamento de soluçôes para os problemas de moradia desses estratos. Diante do crescimento exponencial da habitação informal e precária nos 
grandes centros urbanos, nota-se que a solução desses problemas é estratégica para toda a cidade. Mas o aproveitamento habitacional das áreas centrais para pessoas de renda mais baixa envolve, sem dúvida, a remoção de barreiras legais e burocráticas, que, se houver vontade política, são mais facilmente removíveis do que as interpostas pelo mercado.

A reanimação e a intensificação do uso habitacional nas áreas centrais surgiram nos anos 1990 como o grande desafio das grandes cidades, especialmente diante da impossibilidade de se ocupar todo o território esvaziado dessas áreas com atividades direcionais, administrativas ou produtivas. Se esse uso terá ou não um maior significado social ou contribuirá, efetivamente, para um desenvolvimento mais equilibrado e democrático dessas cidades é uma questão ainda em aberto que se vincula ao nível de organização dos movimentos sociais, e também à adoção de mecanismos de controle da valorização e da especulação imobiliária, e à ampliação ou não dos processos de gentrificação instalados no interior ou nas bordas das áreas centrais estudadas. Enfim, a questão da relevância urbana e social das intervenções em áreas centrais metropolitanas está vinculada a projetos políticos que consigam conciliar a dinamização econômica e a valorização do patrimônio com ações voltadas à melhoria das condições habitacionais e de vida da população.

\section{Os programas nacionais: rupturas, continuidades e identidades}

Todos os programas nacionais de preservação implementados nos anos 1990 possuem antecedentes ou ações correspondentes nos anos 1970, ou seja, no momento em que se firmou no Brasil uma concepção do patrimônio cultural como recurso econômico. De todos os programas, o Monumenta foi o mais vinculado a essa tradição, constituindo, na realidade, uma atualização dos antigos programas de integração do patrimônio a estratégias de desenvolvimento econômico, agora com alicerces fincados na associação entre setor público e setor privado. O vínculo com experiências realizadas nos anos 1980 também foi constante na maioria dos programas. O Programa Nacional de Apoio à Cultura 
- PRONAC se derivou diretamente da antiga Lei Sarney, de 1986, e o Programa de Revitalização de Sítios históricos - PRSH, da Caixa Econômica, inspirou-se na experiência de reabilitação urbana realizada em Olinda, em 1983.

A atração de investimentos privados e a divisão dos encargos da preservação com a sociedade são questões que já estavam presentes nas discussões e iniciativas das décadas de 1970 e 80 . Nessas décadas, entretanto, esse envolvimento foi concebido como uma consequência natural do investimento realizado pelo poder público. Nos anos 1990, foi abordado como algo a ser construído, incentivado e negociado no início das operações. Com exceção do PRONAC, todos os programas daquela década surgiram após dez anos ou mais de retração de investimentos federais nas áreas da preservação do patrimônio e da habitação social.

Os programas anteriores também encaminhavam diferentes modos de aproveitamento econômico e social do patrimônio urbano. Tal como o Monumenta, o Programa de Cidades Históricas (PCH), nos anos 1970, vinculava, prioritariamente, o uso do patrimônio recuperado ao turismo, à cultura e ao lazer, ao passo que o antigo Programa de Recuperação e Revitalização de Núcleos Históricos, assim como o PRSH, propunha um aproveitamento do patrimônio ligado ao desenvolvimento habitacional e ao cotidiano das populaçóes. Vale ressaltar, inclusive, que esta última abordagem surgiu nos anos 1980 como uma evolução do aproveitamento turístico de áreas históricas, decorrente do fracasso do $\mathrm{PCH}$ em promover uma preservação sustentada e progressiva do patrimônio urbano. Nos anos 1990, se assistiu, como resultado do confronto dos novos programas com a realidade urbana, econômica e social do país, ao crescimento da tendência de se privilegiar ações de maior repercussão social, vinculadas à melhoria do habitat e à vida cotidiana das cidades. Não é, portanto, exagerado afirmar que, no que diz respeito aos programas nacionais, os anos 1990 e 2000 repetiram, de modo acelerado e com algumas especificidades, a trajetória dos programas das décadas anteriores.

A implantação da maioria dos novos programas nacionais ocorreu após a explosão de intervenções de requalificação e revitalização de sítios históricos nas maiores cidades brasileiras, as quais foram implementadas e financiadas por instâncias estaduais ou municipais. A federalização dos programas de preservação decorreu, assim, de uma reação do governo central ao fato de ter perdido 
o papel de protagonista no financiamento de ações nesse campo; da renovação do interesse de agências multilaterais de desenvolvimento, como o BID, pelo financiamento de projetos ancorados no aproveitamento econômico do patrimônio; e das mudanças empreendidas na política nacional de habitação, a partir de 1996.

Os interesses do Governo Federal e das agências de financiamento encontraram solo propício e já trabalhado pelas intervenções locais deflagradas no início da década de 1990, o que permitiu que os programas nacionais funcionassem como elementos impulsionadores e, eventualmente, "saneadores" desses processos, e também como deflagradores de novas ações. A retomada de projetos de preservação por parte de agências multilaterais se relacionou, por sua vez, ao crescimento das solicitações de governos locais e também ao surgimento da reabilitação urbana, na América Latina, como um novo campo para a entrada e desenvolvimento de negócios e serviços. ${ }^{7}$ Além dos programas nas áreas de transporte, saneamento e infraestrutura que financiou no Brasil, e em outros países do continente, ${ }^{8}$ o BID, como mostra o Anexo C, concentrou energias e desenvolveu vários programas de incremento do turismo e de preservação do patrimônio na região, alguns dos quais financiados por fundos fiduciários europeus e de outros países desenvolvidos. Essas operações de preservação e revitalização do patrimônio abriram caminho para a formação de parcerias internacionais e, consequentemente, prepararam também o terreno (físico e institucional) para o desenvolvimento de negócios ligados às áreas de transporte, mobiliário urbano, reabilitação imobiliária e outros serviços que buscavam se expandir de países centrais para as recém-abertas economias de países periféricos. A associação do BID ao governo francês no desenvolvimento de ações de reabilitação no Brasil e em outros países da América Latina ilustra bem essa conjuntura e essa articulação de interesses.

Ao lado disso, as mudanças empreendidas na política nacional de habitação propiciaram o direcionamento de linhas de financiamento da Caixa Econômica Federal para o aproveitamento habitacional do estoque imobiliário existente, o que permitiu que o Brasil reunisse algumas das condições básicas para intervir na reabilitação de sítios históricos, e somasse seus recursos aos dos empréstimos externos obtidos junto a agências multilaterais. A transformação da política habitacional em um conjunto de operações submetidas às regras do mercado também
7 Além desses fatores mais visíveis, a neutralização das reivindicações sociais, decorrente das novas relações impostas pela reestruturação do sistema produtivo e da expansão da ideologia neoliberal, permitiu que governos e agências multilaterais de desenvolvimento desviassem energias para projetos não necessariamente vinculados à solução de tensões sociais, e mais voltados para o desenvolvimento da iniciativa privada.

8 No Brasil, por exemplo, o BID financia programas como o Favela Bairro, no Rio de Janeiro, e outros de saneamento e de implantação de transportes de massa, como o "Baía Azul" e o metrô, em Salvador; o projeto de despoluição da Baía de Guanabara; a ampliação do metrô de Belo Horizonte, entre outros. 
facilitou a montagem de programas de reabilitação do patrimônio edilício. Por meio de novas modalidades de atribuição, como o arrendamento, afastou-se o "fantasma" da inadimplência e conferiu-se rentabilidade e viabilidade financeira aos programas habitacionais. De fato, caso não cumprisse com seus encargos mensais, o novo mutuário - agora denominado "arrendatário" - perdia direito à unidade habitacional obtida, que, assim, volta para a Caixa para ser de novamente comercializada sem perdas ou impedimentos.

A mercantilização da habitação popular, a transformação do financiamento habitacional num sistema sem riscos, a privatização de serviços públicos e a abertura ao comércio exterior permitiram, nos anos 1990, o surgimento de novas fontes de financiamento para a preservação do patrimônio e o surgimento de novos programas no plano federal.

\section{Características comuns e especificidades}

a) Quanto às premissas e objetivos

A parceria entre setor público e setor privado foi uma premissa compartilhada pelos programas gestados nos anos 1990, ainda que com diferentes concepções quanto ao conteúdo e ao sentido dessa cooperação. O PRONAC e o Monumenta foram os programas que se estruturaram, de modo mais orgânico, em torno dessa ideia, vista, no primeiro caso, como condição para a consolidação de um sistema permanente e democrático de financiamento da Cultura no país e, no segundo, como condição da conservação do patrimônio no longo prazo. No PRONAC a ação estatal isolada foi, inclusive, definida como nefasta, por conduzir ao dirigismo cultural e por impedir a participação ativa da sociedade na formulação e na execução da política pública. Na concepção que orientou a elaboraçãao do Monumenta, o aporte privado seria o que confere sustentabilidade aos processos de preservação, cabendo ao poder público liderar o processo de incentivo à ação privada e realizar os investimentos estratégicos iniciais. A participação da sociedade no financiamento da produção cultural e da conservação do patrimônio foi, portanto, um pressuposto essencial dos dois programas, cabendo ao Estado incentivá-la por todos os meios. 
No PRSH, a parceria entre Estado e sociedade também foi vista como essencial, mas o foco recaiu mais sobre o papel do poder público como formulador de políticas integradas voltadas para a inserção do patrimônio em processos de desenvolvimento urbano que contemplassem a melhoria do habitat e a diminuição do déficit habitacional. O Programa URBIS, de vida muito curta, tentou compatibilizar as premissas do PRSH e do Monumenta, estruturando em torno do conceito de reabilitação urbana uma proposta de aproveitamento do patrimônio como diferencial propulsor da dinamização econômica e como recurso para um desenvolvimento urbano sustentado.

Todos os programas estudados tiveram como objetivo a preservação do patrimônio cultural, com foco especial naquele protegido pelo Governo Federal. O PRONAC e o PRSH, entretanto, incorporaram uma visão mais abrangente, que se estende também ao patrimônio de interesse local e regional. O PRONAC foi o único programa de incentivo direto à produção cultural em sentido amplo.

Do ponto de vista dos seus objetivos e premissas, os programas dos anos 1990 constituíram tentativas de instituição de uma nova prática de atuação no campo cultural e preservacionista a partir da reunião de atores públicos e privados em torno de objetivos comuns. O valor social e econômico do patrimônio foi o liame dessa construção, que visou, em suma, a dividir e repassar, ainda que sem sucesso, a responsabilidade da preservação do patrimônio do Estado para o setor privado.

b) Quanto ao arranjo institucional, aos atores envolvidos e o seu papel

A maioria dos programas teve como principal ator o setor público. A participação do setor privado, apesar de muito enfatizada, se deu, na prática, de modo muito restrito, reduzido, e, em grande parte, prejudicado pela falta de instrumentos adequados para promovê-la. Os programas favorecem e focalizam, prioritariamente, o setor empresarial, em detrimento de pessoas físicas ou do investimento individual.

Embora a parceria setor público-setor privado tenha sido a pedra-de-toque ou meta fundamental de todos os programas estudados, apenas no PRONAC esta parceria ocorreu de modo efetivo e sistemático, ainda que totalmente 
desvinculado de uma política pública que lhe desse sentido global e social mais amplo. A participação do setor econômico no âmbito deste programa ocorreu por meio de um reduzido grupo de empresas estatais e corporações privadas que atuaram como proponentes e patrocinadores dos projetos financiados. Esses projetos, por sua vez, foram vinculados a produtores culturais consagrados nacionalmente, bem como aos interesses específicos de comunicação social, marketing e expansão de mercados dos patrocinadores. O determinador, portanto, dos rumos da política cultural financiada pelo Estado foi a indústria cultural do eixo Rio-São Paulo e a política de comunicação de grandes empresas. A Comissão Nacional de Incentivo à Cultura - CNIC, instância responsável pela coordenação e supervisão do PRONAC, perdeu, ao longo dos anos, importantes poderes deliberativos e não conseguiu abrir mais o leque do programa.

O setor privado deveria participar do Programa Monumenta pela mobilização de proprietários urbanos, da iniciativa privada e de organizações da sociedade civil. O papel desses atores na formulação e execução de ações foi considerado essencial, mas acabou sendo eventual e secundário. Embora colocada como eixo principal do programa, uma efetiva participação do setor privado pouco se verificou na prática.

No PRSH, os principais atores foram a Caixa Econômica Federal e o governo francês, o que o constituiu como mais um programa de coordenação também exclusivamente estatal. Tendo sido concebido, entretanto, como uma ação de articulação de parcerias, o PRSH buscou envolver vários atores públicos e privados - estes últimos, como executores de ações financiadas pelo programa ou como arrendatários. Assim, o PRSH foi o programa que mais privilegiou o investimento de pessoas físicas.

O Ministério da Cultura se caracterizou, na década de 1990, como a principal instância coordenadora e executora de programas, com participação central no PRONAC, no Programa Monumenta e no URBIS. Ao lado disso, constituiu outra grande novidade institucional do período a participação de parceiros internacionais no Monumenta e no PRSH. O BID e a UNESCO desempenham, em pé de igualdade com o MinC, papéis importantes na formulação, gerência e execução do Programa Monumenta, e o governo francês, por meio de alguns de seus ministérios, realizou a coordenação técnica do PRSH. 
Governos estaduais e municipais foram os principais atores locais na maioria dos programas, mas, em alguns deles, a terceirização foi a saída encontrada para as dificuldades de execução, diante da situação funcional precária da maioria dos seus organismos de preservação ou de obras públicas. No caso do Monumenta, por exemplo, a execução do programa foi realizada por estruturas executivas terceirizadas, tanto no plano central como no local. Em consequência, o programa canalizou grande parte dos seus recursos para a manutenção dessas estruturas, para o pagamento de consultorias e outras despesas administrativas, o que comprometeu, nessa fase, a execução de suas finalidades. No conjunto dos programas nacionais da área de cultura, o Monumenta foi o que mais se inseriu na estratégia do Governo Federal de terceirizar a execução de políticas públicas, com vistas a manter a aura de probidade administrativa e de controle do déficit público requeridos pela política de ajuste fiscal. Entretanto, ao invés de poupar, essa política foi uma fonte de desperdício e má administração dos parcos recursos mobilizados para investimento. Além disso, custou a precarização do aparelho de Estado e o enfraquecimento de diversas instituições públicas.

Ainda no plano institucional, uma novidade dos anos 1990, introduzida pelas intervenções locais e reforçada pelos programas nacionais, diz respeito à exclusão dos organismos públicos de preservação do patrimônio da formulação e coordenação das ações de preservação. Embora essas instituições tenham participado como parceiras da maioria dos programas, as funções centrais de formulação, coordenação e execução foram desempenhadas pelo Ministério da Cultura e pela Caixa Econômica Federal, no plano central, e por instâncias ligadas à execução de obras públicas, no plano local. Aos organismos de preservação foi reservada uma função burocrática, em geral restrita ao cumprimento de suas competências legais. No plano federal, é mesmo possível afirmar que os programas gestados nos anos 1990 marcaram um momento de declínio do IPHAN como protagonista da área de preservação, com a redução do seu papel à execução de tarefas circunscritas a questões de orientação e fiscalização. Os anos 1990 conferiram ao IPHAN um papel protocolar e de legitimação de projetos elaborados e executados, muitas vezes, à sua revelia, papel do qual a instituição não soube nem teve força política para se esquivar ou impor outra visão. Essa redução do papel da principal instituição de preservação do Brasil correspondeu, por outro lado, ao crescimento da importância 
institucional do Ministério da Cultura. Pode-se afirmar que, nos anos 1990, em consequência do crescimento das fontes de financiamento e da importância do patrimônio como instrumento de promoção política e institucional, o MinC e os governos estaduais e municipais assumiram o controle das ações de preservação.

c) Quanto aos recursos, instrumentos financeiros e incentivos

$O$ aporte de recursos externos e do setor privado foi a grande novidade dos programas de preservação dos anos 1990, e o PRONAC e o Monumenta foram os que mais avançaram nesse aspecto. O primeiro, por meio da tentativa de canalização de investimentos privados para projetos culturais, e o segundo, no que toca à captação de recursos externos. Cabe ressaltar, entretanto, que, embora estruturados com composição financeira mista, esses programas foram movidos, basicamente, por recursos públicos. No caso do PRONAC, em decorrência de o investimento privado se dar principalmente por meio do uso de renúncia fiscal. No Monumenta, porque os recursos privados previstos correspondiam a apenas $10 \%$ do montante total a ser movimentado.

No Programa Monumenta, os recursos previstos para o financiamento da conservação de imóveis privados correspondiam a cerca de 30\% do valor dos projetos locais, com aplicação limitada à execução de obras de estabilização estrutural, revisão de instalações e reparos no exterior dos imóveis. Esses recursos destinavam-se, originalmente, apenas a proprietários, na forma de empréstimos com juros subsidiados, mas não chegaram a despertar o seu interesse na primeira fase de execução desse programa.

O único programa que possuía linhas de financiamento de caráter permanente era o PRSH, pois operava por meio das carteiras de financiamento da CEF. Mesmo assim, como apontado anteriormente, essas linhas não eram adequadas aos projetos de reabilitação e não cobriam as várias situações fundiárias, de ocupação e relativas às características do patrimônio que compõem as áreas centrais de grandes cidades. Por essa razão, os recursos do PRSH tiveram que ser complementados com benefícios do PRONAC.

O grosso dos recursos com os quais os programas operaram se originou mesmo do setor público, sob a forma de aplicação do orçamento, empréstimo externo ou renúncia fiscal. O aporte privado foi incipiente. Mesmo no caso do 
PRONAC, no final da década de 1990, a proporção de recursos realmente privados aplicados em projetos culturais era de $35 \%$, contra $65 \%$ de recursos públicos. No âmbito do setor público, o Governo Federal e a União compareceram com a maioria dos recursos colocados à disposição dos programas nacionais, ficando a contrapartida estadual e local em torno de $20 \%$.

Os programas examinados foram, portanto, iniciativas de investimentos públicos na área de cultura e em patrimônio, via incentivos fiscais ou investimentos diretos. A parcela de recursos privados foi pequena e a destinada ao financiamento de pessoas físicas foi precária e não contou com instrumentos financeiros e um sistema de subsídios adequado.

d) Quanto aos mecanismos de planejamento, gestão e avaliação

Os programas estudados foram, de modo geral, muito pobres no que diz respeito a mecanismos de planejamento, programação, gestão e avaliação de ações. O PRONAC não instituiu instrumentos de planejamento para orientar a priorização de ações e, menos ainda, mecanismos de avaliação dos projetos executados. Essa falta, aliás, constituiu o calcanhar de Aquiles do programa e uma das principais fontes de críticas e solicitações de reformulação. Como visto, o PRONAC funcionou em consonância com uma demanda de projetos culturais extremamente concentrada em termos regionais e no tipo de projeto e de proponente. A ação dos principais patrocinadores não foi orientada para outras regiões, o que favoreceu sua concentração no eixo Rio-São Paulo, ou seja, na área de demanda cultural mais aquecida e de maior visibilidade nacional. O principal instrumento de gestão, a CNIC, desempenhou funções apenas consultivas e limitadas pela legislação.

O Programa Monumenta, por sua vez, teve nas "oficinas de planejamento" que ocorreram no início da montagem dos projetos locais o principal instrumento de programação e participação social. Essas oficinas, contudo, foram apenas workshops de identificação de ações que se desenvolveram sem o apoio de estudos ou diagnósticos mais aprofundados da situação urbana focalizada e não tiveram função de acompanhamento ou de gestão dos projetos executados. A Unidade Central de Gerenciamento e as Unidades Executoras de Projeto não constituíram tampouco mecanismos de gestão compartilhada, pois, embora com estrutura 
pesadamente terceirizada, não incorporaram representações da sociedade. No âmbito do Monumenta, os inventários e planos de preservação de sítios históricos constituíram ações exclusivas do componente correspondente ao fortalecimento institucional do IPHAN, sem vínculo ou relacionamento orgânico com os projetos locais. Estes foram definidos e executados independentemente da elaboração desses inventários e planos, que, inclusive, não foram previstos para todas as cidades participantes do programa. O Monumenta também não construiu instrumentos de avaliação dos processos deflagrados, exceto mecanismos burocráticos, como relatórios anuais e de progresso. Na fase de elaboração dos projetos locais eram exigidos estudos de impacto social e ambiental das intervenções projetadas, mas funcionaram mais como mecanismos de legitimação de projetos e intenções, não constituindo, portanto, instrumentos eficazes de avaliação pré e pós-operação.

$\mathrm{O}$ PRSH, no que toca aos instrumentos de planejamento e participação, padeceu de problemas semelhantes ao Monumenta. As "oficinas de planejamento participativo", realizadas no âmbito dos ateliês locais promovidos pelo programa, analogamente ao que ocorreu no Monumenta, não se apoiaram em estudos aprofundados e específicos de cada problemática urbana. O programa, entretanto, em algumas localidades, operou com equipes interinstitucionais que poderiam ter constituído importantes embriões para o desenvolvimento de ações integradas e concertadas, ao menos, no nível do poder público. O PRSH não estabeleceu a necessidade de elaboração de diagnósticos aprofundados ou planos que regulassem e programassem as ações nas áreas enfocadas, mas realizou experimentos de montagem de operações de reabilitação, que funcionaram como instrumentos de produção de conhecimento numa área em que o país não tinha muita experiência. O programa também não construiu instrumentos de gestão compartilhada com a sociedade, nem explicitou mecanismos de avaliação pós-operação.

Assim, no Brasil, os anos 1990 estiveram longe de constituir uma política de preservação e reabilitação urbana verdadeiramente estruturada e aparelhada. Os programas montados, em sua totalidade, ainda privilegiaram a execução de intervenções físicas, atuaram sem planejamento de ações no longo prazo e sem o conjunto de instrumentos necessários à implantação de ações mais eficazes e abrangentes. 
e) Quanto às ações previstas e aos modelos de intervenção

Na medida em que o interesse privado era atraído por ganhos de imagem, o PRONAC induziu à seleção de projetos de grande visibilidade e com boas possibilidades de repercussão na mídia e na opinião pública. Assim, no seu segmento "patrimônio cultural", verificou-se que a grande maioria das ações financiadas e executadas nos anos 1990 correspondeu a obras em grandes monumentos ou relacionadas a bens de excepcional valor artístico, localizados nos grandes centros urbanos e nas cidades históricas da região Sudeste. Essa concentração regional e temática foi acompanhada ainda de uma especialização crescente em termos de proponentes e patrocinadores. O funcionamento do PRONAC, portanto, não promoveu uma prática de investimentos individuais em favor do patrimônio, embora o programa tivesse dispositivos para tanto. ${ }^{9}$ Ao invés de propiciar, incentivar e difundir um uso social mais abrangente do patrimônio urbano, ou criar para este um mercado imobiliário mais dinâmico, o PRONAC favoreceu uma apropriação do patrimônio monumental como equipamento cultural de elite e instrumento de marketing empresarial.

As intervenções consideradas elegíveis no Programa Monumenta foram grandemente voltadas para a promoção do uso turístico e cultural nas Áreas de Projeto. Assim, os componentes do programa e suas ações correspondentes induziram ao tratamento dessas áreas como atrações urbanas nesta fase inicial, enfraquecendo sua apropriação como áreas de vivência da população e de localização de outros usos produtivos. As regras do programa não conduziam, ainda, os parceiros locais a abordar a área de intervenção a partir de uma problemática urbana ou patrimonial existente, o que levou, muitas vezes, a um determinismo funcional desvinculado das demandas e potencialidades locais.

Ao configurar-se como instrumento de articulação de parcerias e linha de financiamento especializada, o PRSH tendeu a adaptar-se aos modelos de intervenção dos programas aos quais se acoplava, não instituindo, propriamente, um modelo próprio. De todo modo, uma vez que se concentrava no financiamento da reabilitação de imóveis para uso habitacional, o programa surge como alternativa de utilização social mais abrangente do patrimônio urbano, com possibilidades, inclusive, de ampliar o alcance dos outros programas nacionais. Como comentado
9 Como visto no capítulo 5, pessoas físicas proprietárias de imóveis tombados pelo Governo Federal, por meio dos incentivos do PRONAC, poderiam abater do imposto de renda despesas com a restauração e conservação desses imóveis. 
no capítulo correspondente, o programa da Caixa implicou uma visão do patrimônio urbano inserido na questão da melhoria do habitat, da diminuição do déficit habitacional e da racionalização do crescimento e do uso do solo urbano. Partia-se, portanto, de uma concepção de intervenção urbana diversa, por exemplo, daquela do Programa Monumenta. Entretanto, em decorrência de seu caráter experimental e de sua natureza adaptável a demandas, o modelo de intervenção induzido pelo PRSH tendia a ser anulado ou diluído pelo de outros programas ou por questões localizadas. O programa incluía duas possibilidades: contribuir para deflagrar a implantação de uma verdadeira política nacional de reabilitação urbana, com instrumentos de planejamento, programáticos, financeiros e de gestão adequados; ou se transformar numa simples linha de financiamento, que funcionaria como reforço ou complementação de outros programas. Essa segunda possibilidade acabou sendo a mais viável.

Do ponto de vista das ações elegíveis e dos modelos de intervenção gerados, os programas implantados nos anos 1990 podem, portanto, ser divididos em duas correntes: a que favorecia um uso do patrimônio como atração urbana e instrumento de marketing; e a que buscava o seu uso social e vinculado a questões urbanas mais amplas. Em suma, o patrimônio urbano como media e commodity ou como elemento de política urbana e habitacional. Em decorrência de um maior vínculo com as forças políticas e econômicas dominantes, e do baixo nível de organização social do país, o modelo media/commodity foi o que prevaleceu e criou norma no período estudado. A falta de mercado nos segmentos mais abastados, contudo, foi o que manteve o modelo voltado para o desenvolvimento urbano e social na disputa pelos centros históricos das cidades estudadas.

\section{Resultados obtidos, avanços e retrocessos}

Considerando-se o nível incipiente de execução em que a maioria se encontrava nos anos 1990, os programas focalizados avançaram pouco com relação aos seus antecedentes dos anos 1970 e 1980. O PRONAC, por exemplo, pouco havia avançado com relação ao sistema instituído pela Lei Sarney, por falta de uma política que estabelecesse critérios de priorização e promovesse uma distribuição de benefícios fiscais mais equilibrada, do ponto de vista da regionalização e do 
tipo de projeto. Se o programa, com uma estrutura mais burocratizada, conseguiu sanear os problemas da antiga lei Sarney relativos à garantia do uso da renúncia fiscal apenas em projetos culturais, não resolveu o problema da concentração de patrocínios na região Sudeste e em determinados segmentos culturais e artísticos consagrados.

Já o Programa Monumenta não havia conseguido até 2003 mobilizar significativamente a iniciativa privada nas Áreas de Projeto, em função da pulverização de recursos, de um modelo de intervenção pouco adaptável aos problemas e demandas locais e da dificuldade para deslanchar o financiamento de imóveis privados. Assim, tudo indicava que o programa dificilmente implantaria o padrão de preservação sustentável pretendido, e, nesse aspecto, apesar de melhor concebido e estruturado, poderia não avançar muito com relação ao programa antecessor, o $\mathrm{PCH}$. No que toca, por exemplo, ao fortalecimento institucional dos vários atores públicos envolvidos, deveria avançar bem menos do que o seu antecessor dos anos 1970. A baixa internalização do programa nas estruturas permanentes do IPHAN e do MinC, em decorrência da sua estrutura organizacional terceirizada, indicava pouco aperfeiçoamento institucional. O Programa Monumenta teve, entretanto, o mérito de reintroduzir a questão da preservação urbana no plano nacional, impulsionando a formulação e a implantação de outros programas. Expôs, ainda, as carências técnicas e o despreparo do governo brasileiro neste campo, introduzindo um modelo de intervenção que, embora tivesse sido muito criticado, funcionou como referência para as outras políticas que foram montadas, como o URBIS e o PRSH.

Retrocessos e avanços são verificáveis de modo mais ou menos proporcional no âmbito do PRSH. Os avanços dizem respeito ao caráter mais permanente do novo programa, que, aparentemente, no começo dos anos 2000, teria mais apoio institucional e mais chances de consolidação do que o seu antecessor, o Programa de Recuperação e Revitalização de Núcleos Históricos do antigo BNH. Ganhos em conhecimento ocorreram a partir do desenvolvimento dos estudos de viabilidade de ações de reabilitação, em parceria com o governo francês e o BID, bem como das poucas operações concretizadas em Salvador, no Rio de Janeiro e em São Paulo. Nessas operações foram gerados importantes subsídios para a implantação de uma política nacional de financiamento da reabilitação imobiliária 
no país. O programa, contudo, pouco avançou no sentido da construção de uma carteira de financiamento específica para a reabilitação de imóveis históricos e da sua transformação numa atividade permanente e sistemática. Avançou pouco também na viabilização de operações de caráter social aliadas à preservação, pois a rigidez das suas linhas de financiamento não favoreceu esse desenvolvimento.

$O$ resultado mais negativo do PRSH se vinculou, de fato, aos limites e às regras das linhas de financiamento com as quais operava. Essas limitações induziram ao retalhamento e ao superaproveitamento de imóveis de valor patrimonial, o que obrigou o programa a atuar preferencialmente em ruínas, que permitiam mais liberdade de projeto. Ao fixar a área máxima da unidade habitacional financiada em $37 \mathrm{~m}^{2}$, o programa se chocava com os objetivos da preservação do patrimônio e trabalhava com uma visão de família de classe média baixa que não correspondia à realidade. Estudos já haviam demonstrado que, no Brasil, esse tipo de grupo familiar não era estável e tem grande necessidade de agregar espaço, o que, certamente, tornava difícil sua adaptação a unidades tão exíguas e sem possibilidade de ampliação. (MAGALHÃES, 2002) Entre os programas em andamento nas cidades estudadas, nos anos 1990, apenas o Novas Alternativas, do Rio de Janeiro, tinha, claramente, a preocupação de direcionar os projetos para famílias compostas por casais idosos ou sem filhos. Na medida, ainda, em que mecanismos de assistência social, educação patrimonial e acompanhamento pós-operação não estavam bem explicitados no escopo do programa, os resultados para a preservação patrimônio urbano chegaram a ser desastrosos.

Em termos conceituais, o Programa URBIS foi, sem dúvida, o que mais avançou em relação aos programas montados nos anos 1990, mas não teve resultados práticos suficientes para se consolidar. O URBIS ensaiou a implantação de uma política de reabilitação urbana inédita no país, ao propor uma estrutura de funcionamento baseada em mecanismos de planejamento participativo e programação, em instrumentos financeiros variados, em mecanismos de gestão compartilhada e num sistema permanente de avaliação. O programa, entretanto, não passou de uma carta de intenções, constituindo apenas uma promessa de transformação da prática em um embrião de política nacional, cujo modelo não gerou desdobramentos futuros. 
A participação da iniciativa privada foi, como visto, uma premissa fundamental de todos os programas iniciados nos anos 1990. Embora destinados a um papel de protagonistas, os atores privados se mantiveram como coadjuvantes pouco interessados no espetáculo da preservação urbana. Em geral, os parceiros privados permaneceram com uma postura passiva em relação aos processos deflagrados e aos projetos, ou, ainda, exibiram uma atitude de beneficiários expectantes. Essa atitude se relacionou à falta de crença no sucesso das intervenções empreendidas pelo poder público, à preferência por investimentos em setores e vetores de exploração imobiliária mais lucrativos e ao paternalismo que tradicionalmente caracterizou as políticas de preservação no país. Aos habitantes e ocupantes de imóveis nos sítios históricos coube, quase sempre, papel secundário. Sua visão como parceiros dos processos que se pretendia impulsionar não foi desenvolvida.

A estrutura dos programas e os atores que, efetivamente, mobilizaram mostram que a reabilitação do patrimônio urbano no Brasil, nos anos 1990, esteve presa à criação de empreendimentos e atrações urbanas e pouco vinculada à vida normal das cidades. Mostram, em suma, que a reabilitação do patrimônio não constituiu uma ação de caráter social, econômico e urbanístico mais amplo, e que, apesar dos avanços, ficou longe de se tornar um modo de urbanização importante. Seu caráter foi episódico, excepcional e extremamente vinculado à ação do Estado.

A execução dos novos programas nacionais de preservação, embora tenha sido incipiente, já mostrava claramente que a carência de instrumentos adequados de planejamento, de financiamento e de gestão reduzia, em muito, sua capacidade de transformação e reversão dos processos negativos instalados nas áreas históricas. Uma grande carência se localizava, sem dúvida, na falta de instrumentos de conhecimento da realidade patrimonial e urbana que permitissem montar diagnósticos consistentes e capazes de orientar o planejamento e a programação de ações significativas e sustentáveis. O grau de inter-relacionamento dos programas evidenciou seu caráter incompleto, mas era também o que lhes dava alguma chance de efetividade em face dos processos complexos que enfrentavam. Na medida em que o desenvolvimento do uso habitacional seria a ação de maior poder sobre esses processos, o PRSH ganhava, naturalmente, 
relevo maior. Embora pouco executado e carente de instrumentos adequados, o programa demonstrou seu potencial em Salvador e em São Paulo, assim como nas parcerias que estabeleceu com outros programas.

A criação dos programas dos anos 1990 como ações temporárias e a não implantação de uma política de reabilitação urbana de caráter permanente, interministerial e integrado é ainda o grande entrave a ser superado para que uma preservação duradoura e um aproveitamento socioeconômico do patrimônio urbano se tornem realidade no Brasil. Nenhum programa focalizado apresentou essas condições, mas, sem dúvida, todos contribuíram, em graus variados, para que essa necessidade ficasse evidente.

\section{As relações entre programas e intervenções}

A participação dos programas nacionais nas intervenções de recuperação, reabilitação e requalificação nas áreas centrais de Salvador, Rio de Janeiro e São Paulo foi pequena, considerando-se o período estudado. Contudo, trouxeram novos recursos para essas intervenções e possibilitaram sua continuidade. Em Salvador, por exemplo, a implantação do Programa Monumenta e do Projeto Rememorar, do PRSH, significou a retomada do Programa de Recuperação do Centro Histórico, que estava paralisado por falta de recursos.

Com ações em Salvador, no Rio de Janeiro e em São Paulo, o PRSH foi o programa que mais trouxe novos aportes aos processos locais instalados. O programa introduziu ou reforçou a questão habitacional, que estava posta de lado ou em segundo plano, ajudando a mantê-la, especialmente em São Paulo, no centro da cena. O poder de influência do programa esbarrou, entretanto, nos limites de suas próprias linhas de financiamento e nos diversos entraves que são interpostos ao desenvolvimento habitacional em áreas centrais.

O Programa Monumenta, por sua vez, se integrou com mais dificuldade nos projetos e processos em curso nas localidades pesquisadas, basicamente, em função do seu formato rígido. O programa ambicionava iniciar processos ou sanear processos existentes, reconduzindo-os para vias economicamente sustentáveis, mas, por atender a um número excessivo de sítios urbanos, a concretização 
dessa ambição tornou-se muito difícil. No caso de grandes metrópoles como Rio de Janeiro e São Paulo, os recursos do programa produziram parcos efeitos e agregaram apenas mais algumas intervenções. Ao lado disso, em decorrência do fato de que cada componente do programa implicava uma porcentagem fixa dos recursos totais, ações importantes - como as de desenvolvimento do uso habitacional no Rio de Janeiro e em São Paulo - não podiam utilizar a totalidade de seus aportes. Apenas em cidades pequenas o Monumenta parecia ter chances de produzir impactos mais significativos. Em Salvador, no entanto, sua inserção no programa estadual de recuperação do centro histórico foi positiva, pois encaminhou uma mudança de rumos importante.

O programa nacional com execução local mais expressiva nos anos 1990 foi o PRONAC. Seus mecanismos foram utilizados de modo intenso no Rio de Janeiro e em São Paulo, onde equipamentos culturais que aproveitaram imóveis antigos foram criados ou mantidos graças ao programa. Esses equipamentos funcionaram como importantes âncoras do processo de dinamização econômica e de atração de usuários de alta renda para os centros dessas duas cidades. Em áreas de dinâmica mais forte, como a Área Central de Negócios do Rio de Janeiro, os centros culturais funcionaram como agentes de substituição do perfil da ocupação, mas, em outras mais depreciadas, como a área da Luz, em São Paulo, promoveram apenas a formação de enclaves frequentados por públicos de alta renda.

\section{Sobre a importação de modelos}

Em muitas cidades do mundo desenvolvido, áreas esvaziadas e deterioradas pela obsolescência edilícia, pela fuga de funções e pela reestruturação do setor produtivo foram, a partir dos anos 1960, reincorporadas ao mercado por meio de empreendimentos habitacionais, comerciais, culturais e de lazer. Frequentemente fazendo apelo à preservação da memória e do patrimônio, essas intervenções - a maioria das quais localizadas em áreas centrais de grandes metrópoles lograram não somente a valorização imobiliária dessas áreas, mas também funcionaram como importantes instrumentos para alavancar ou melhorar sua inserção em circuitos internacionais de comércio, turismo e entretenimento. Esta fórmula 
de sucesso, inventada pelos americanos, se apoia basicamente em dois pilares: na identificação de uma nova função estratégica para o lugar esvaziado, compatível com o contexto urbano e regional existente, e na deflagração de uma operação de reurbanização consorciada entre poder público e setor privado.

Em torno desse projeto comum, a operação de reincorporação da área ao mercado se produz, normalmente, pela promoção de alterações no regime de uso e ocupação do solo, por uma eventual redução de taxas e impostos para os investidores, e pela reciclagem de estruturas antigas, acompanhada da inserção, no lugar, de novos objetos arquitetônicos ou artísticos que funcionam como atração e ajudam a divulgar o empreendimento urbano, nacional e internacionalmente. Essas intervenções constituem, em suma, operações de criação de novas atrações urbanas e novas fronteiras de produção imobiliária, cujo objetivo é transformar áreas que estavam à margem da dinâmica imobiliária e econômica das cidades em setores cobiçados. O resultado dessas intervenções é, quase sempre, a deflagração de um processo de valorização, com o correspondente afastamento de atividades menos rentáveis, assim como de antigos usuários e ocupantes. A cultura e a história desempenham, nesses processos, importantes papéis de legitimação, produção de significados e de valor agregado.

Com maior ou menor ancoragem no patrimônio e em recursos privados, essa fórmula foi reproduzida em várias cidades, constituindo mesmo o grande modelo de intervenção urbana na contemporaneidade. Ele trouxe para o campo do urbano e para o domínio do público uma lógica empresarial típica de empreendimentos privados. O sucesso dessas intervenções, entretanto, não se deveu apenas isso, mas a um conjunto de fatores. Entre estes, destacam-se um bom grau de desenvolvimento econômico - em termos de bons níveis de reprodução e de renda da população com produção de excedente financeiro e disponibilidade de investimentos; fortes mercados internos; e, ainda, o equacionamento de questões básicas relativas a moradia, saúde e educação, pois são fatores que fornecem o lastro necessário ao desenvolvimento pleno de atividades como o turismo e o entretenimento. Assim, a concretização de inversões privadas de monta, e um contexto geral de desenvolvimento econômico, urbano e social, fornecem o solo sobre o qual se assentam esses empreendimentos urbanos - o que garante, em última análise, o seu sucesso. É esse solo, justamente, o que falta nos países menos desenvolvidos. 
Esse modelo, entretanto, foi largamente transportado para países em desenvolvimento e, durante os anos 1990, "vendido" por grupos estrangeiros de consultoria e agências de financiamento como a panaceia capaz de reverter não somente processos de decadência de setores urbanos, mas, até mesmo, a crise econômica de cidades. A transformação se realizaria pelo poder que essas intervenções urbanísticas teriam de gerar e potencializar vantagens comparativas, as quais possibilitariam às cidades em crise competir por uma posição importante no seleto grupo das metrópoles globais ou plugar-se com eficiência em alguma rede ou circuito da economia globalizada. Embora as estratégias utilizadas fossem as mesmas dos países centrais, o desenvolvimento do modelo em contextos urbanos de países periféricos produziu resultados inócuos, parciais ou incompletos, nos anos 1990, e ganhou contornos específicos, relacionados às características de desenvolvimento econômico, político e social de cada lugar em que foi aplicado.

Diferentemente do que ocorreu em países desenvolvidos - onde, muitas vezes, a própria iniciativa privada tomou a dianteira -, nos países periféricos, os governos promovem esses projetos sozinhos, e encontram muita dificuldade para atrair parceiros privados dispostos a fazer investimentos significativos. Estes se materializam apenas quando pesadamente incentivados ou subsidiados, o que tem gerado relações público-privadas desequilibradas, concentradoras de riquezas e, em geral, favorecedoras do mero oportunismo. Observa-se, a partir das experiências brasileiras estudadas nesse trabalho, que essa assimetria tende a aumentar em contextos políticos oligárquicos ou onde a organização social é precária. Esse desequilíbrio tem gerado tanto situações de falta de compromisso por parte do setor privado com intervenções iniciadas quanto dificuldades para que projetos saiam do papel por falta das inversões privadas complementares. Outras dificuldades de funcionamento em contextos periféricos se relacionam ao fato de que, diferentemente do que predomina nos países centrais, o patrimônio urbano - apesar de inserido em estratégias de aproveitamento econômico há muito tempo - não alcançou ainda, nesses contextos, grande valor de mercado. Ao lado disso, a prática de preservação do tecido urbano existente ainda é muito restrita a certas áreas das cidades e não tem grande importância em sua gestão. Como visto em capítulos precedentes, nas grandes cidades brasileiras os investimentos imobiliários mantêm um perfil essencialmente ancorado na produção 
de novos empreendimentos localizados nos vetores de concentração de uma ocupação de classe média alta, fora das áreas de consolidação mais antiga. A reciclagem e a reforma são operações ainda marginais nesse mercado, assim como no âmbito de nossa construção civil.

Mesmo assim, ainda que em graus variados, todas as maiores cidades brasileiras tentaram, nos anos 1990, desenvolver modelos de intervenção dentro dessa lógica e sonharam se tornar, num passe de mágica urbana, novas Barcelona, Bilbao, Lisboa ou Nova York - ou ter, ao menos, sua versão local de Harbour Place. Para tanto, despenderam grandes somas em projetos e consultorias especializadas, desistindo de aperfeiçoar, em alguns casos, modelos locais já estruturados. Apostaram, enfim, em estratégias vinculadas a demandas inexistentes ou artificiais, que implicaram o abandono ou a colocação em segundo plano de projetos ligados ao atendimento de demandas reais. Uma das principais dificuldades de reprodução do modelo dos países desenvolvidos no Brasil tem sido, portanto, a falta de demanda configurada que atraia investimentos privados, o que tem feito com que essas intervenções se viabilizem apenas parcialmente e às custas de recursos públicos.

No mundo desenvolvido, a promoção, pelo Estado, de uma nova fronteira imobiliária em áreas centrais ou em bairros antigos repercute positivamente numa iniciativa privada sedenta por associar ações, marcas e produtos à cultura e ao patrimônio. Repercute, ainda, num amplo mercado que consome bens culturais sob todas as formas e num território já densamente ocupado e com poucas possibilidades de expansão. O caminho "natural" dos investimentos é, portanto, reciclar imóveis e áreas urbanizadas. Nossa realidade é diferente, e faríamos bem em olhá-la mais amplamente ao pensar o repovoamento de áreas centrais. A demanda que temos claramente configurada é de outra natureza e está vinculada a um público diferente daquele que sustenta o tipo de empreendimento urbano produzido por esse modo de intervenção. Assim, para que ações de requalificação, intensificação do uso e dinamização de setores esvaziados e deteriorados tenham sucesso em nosso contexto, é necessário que se vinculem à dinâmica da área focalizada, ampliando-a e dando-lhe melhores condições de desenvolvimento, ou atendam a demandas reais que estão colocadas. Sem isso, os investimentos não produzem os efeitos esperados. 
Os anos 1990 marcaram, no Brasil, o crescimento da influência dos modelos norte-americanos de financiamento da cultura e de intervenções urbanas, mas marcaram também, com as experiências que foram executadas ou propostas, a formação de uma consciência relativa à sua pouca eficácia frente aos quadros sociais, econômicos e urbanos de nossas cidades. Essas iniciativas ilustram, ainda, as tentativas do poder público de se aproximar de novos paradigmas, com vistas a diminuir a influência do modelo de intervenção estatal pura que sempre dominou nossa prática governamental, sempre favoreceu interesses localizados e pouco solucionou problemas. O desenvolvimento desse aspecto positivo, entretanto, foi prejudicado nas intenções e programas estudados por uma avaliação equivocada das potencialidades de nossas áreas centrais e por uma opção generalizada por um caminho aparentemente mais fácil em direção ao sucesso. Nessa quimera, recursos foram desperdiçados e muitas energias foram perdidas. 


\section{0 patrimônio urbano produzido e preservado nos anos 1990}

\section{Os usos do patrimônio}

Nos anos 1990, as políticas de preservação do patrimônio vincularam-se a estratégias de promoção e de marketing; de desenvolvimento econômico e de atração de investimentos; de valorização imobiliária; de controle do uso do espaço público; e também, no final da década, de desenvolvimento urbano e social. Estiveram assim, em maior ou menor grau, vinculadas a apropriações distintas do patrimônio: tanto como commodity e ferramenta de controle, quanto como instrumento de política urbana e promoção social. O uso do patrimônio como recurso rentável e investimento atrativo foi grandemente promovido por incentivos fiscais e vantagens urbanísticas oferecidas pelo poder público, o que facilitou sua inserção nas mais variadas estratégias. Deu-se, contudo, de forma diferenciada segundo os agentes que participaram dessas estratégias - pequenos comerciantes ou grandes corporações, por exemplo - e conforme o maior ou menor grau de atuação do poder público em sua formulação, coordenação e execução. A conservação de espaços e equipamentos e o objetivo 
de atrair novas atividades econômicas justificaram o controle do acesso e do uso de espaços públicos nas áreas que se buscou valorizar e dinamizar, assim como o controle de usuários e ocupantes indesejáveis. As forças que comandaram essas intervenções, entretanto, a depender do nível de organização popular de cada cidade, enfrentaram resistências por parte dos que reivindicaram um uso mais democrático do patrimônio urbano. Por obra desses últimos, o patrimônio foi inserido em estratégias de desenvolvimento social e melhoria do habitat, bem como em projetos destinados à racionalização do crescimento urbano e do uso da infraestrutura instalada. Entretanto, a lógica que dominou as propostas de dinamização econômica e valorização, assim como as relacionadas ao uso habitacional do patrimônio, foi marcadamente financeira, o que dificultou, especialmente nesse segundo caso, o desenvolvimento de ações mais sistemáticas e socialmente significativas, bem como uma apropriação mais disseminada do patrimônio como instrumento de política urbana.

A despeito dos resultados - em geral, fracos - apresentados pelas estratégias de aproveitamento do patrimônio como atração urbana e elemento de valorização imobiliária, o desenvolvimento e a execução dessas estratégias imprimiram mudanças na prática de preservação num aspecto importante. A formulação, a coordenação e a execução de programas e projetos de revitalização, requalificação e reabilitação do patrimônio não foram realizadas pelos organismos ou instituições de preservação existentes nas distintas esferas do poder público, mas por instâncias responsáveis por programas de desenvolvimento econômico, execução de obras públicas, urbanização e habitação. As intervenções realizadas no período em estudo não constituíram, portanto, ações tradicionais de preservação, mas intervenções de outra ordem, que podem ser definidas como operações estratégicas no âmbito da economia, do desenvolvimento urbano e da comunicação social. Objetivos educativos e de formação cultural não foram centrais nessas intervenções, mas foi forte sua carga ideológica no sentido da construção de consensos sobre as formas, definidas como sustentáveis, de aproveitamento e reanimação de áreas de valor patrimonial. As questões preservacionistas clássicas em torno do que, como e para quem preservar saíram de cena no período, e pouco se discutiu sobre valor histórico, artístico e cultural ou, ainda, sobre a autenticidade do objeto patrimonializado. Como consequência, os organismos de 
preservação perderam prestígio, espaço e função, assim como os especialistas em patrimônio. Em contrapartida, muito se discursou sobre viabilidade econômica e financeira, sustentabilidade e valorização imobiliária. Concebidas, montadas e geridas como empreendimentos urbanos, as intervenções de preservação dos anos 1990 mobilizaram outros profissionais, como administradores, economistas, engenheiros, urbanistas, empresários da indústria cultural e publicitários.

O uso do patrimônio que, no período focalizado, apresentou concretamente os melhores resultados foi o vinculado a estratégias de marketing. Os resultados político-eleitorais e mercadológicos que intervenções de recuperação do patrimônio urbano ajudaram a propiciar foram grandes, fato que não somente impulsionou a reprodução acelerada dessas intervenções em várias cidades, mas também imprimiu contornos específicos à sua montagem. Na medida em que o resultado esperado girou muito em torno de ganhos financeiros e de imagem, intervenções e programas tenderam a perseguir objetivos imediatos, a desprezar instrumentos de conhecimento e diagnósticos aprofundados e a minimizar a necessidade de mecanismos e condições que lhes permitissem operar como ações transformadoras e produtoras de impactos econômicos e sociais positivos na situação das áreas urbanas protegidas. Por essa razão, no período em que mais se falou, se agiu e se mobilizou esforços, em todos os planos, em prol da preservação de sítios históricos urbanos, pouco se conseguiu em termos da implantação de uma política de preservação dessas áreas que propiciasse resultados duradouros e significativos.

O "patrimônio cultural" instituído pelo Estado é produto das sociedades capitalistas modernas. É um dispositivo operado pelas forças presentes no corpo social, as quais the dão, a todo o momento, sentido e utilidade. Como um dispositivo de poder, o patrimônio tem uma função política e social constitutiva e primordial, à qual sempre esteve agregada uma função econômica. A depender das forças que estão em interação em cada momento histórico, essas funções podem ser desempenhadas de modo a gerar benefícios sociais distribuídos mais amplamente, ou o dispositivo pode funcionar apenas como um agente de produção de padrões de comportamento e pensamento que favorecem uma apropriação concentrada e desigual de seus efeitos. A função social do patrimônio pode ser desempenhada de modo mais amplo, significativo e progressista quando o produto desse dispositivo informa, produz conhecimento, interroga o passado, 
atua como elemento de emancipação social e de desenvolvimento cultural e, especialmente, quando amplia noções de direito e cidadania. Quando isso não ocorre, é apenas um instrumento que propaga e mantém relações de dominação, ou seja, tem função política e social restrita.

O uso econômico do patrimônio é importante, e não necessariamente anula seus efeitos positivos. Contudo, essa apropriação econômica deve estar submetida ao cumprimento de um papel social mais abrangente e favorecer uma circulação mais ampla e democrática do patrimônio constituído no conjunto da sociedade. No que toca à herança urbana, uma circulação democrática vincula-se à possibilidade de que o sítio urbano patrimonializado exerça um papel na vida cotidiana da cidade; atue como um recurso que torna melhor o meio urbano; desenvolva um valor de uso acessível. O exercício da função social mais abrangente do patrimônio não é, portanto, incompatível com o seu uso econômico se houver o desenvolvimento de uma consciência na sociedade sobre o seu papel político maior e se os elementos por meio dos quais esse papel é desempenhado não forem apagados ou submetidos apenas a caprichos e injunções do mercado. O que impede que o dispositivo atue de modo socialmente positivo e produtivo é a transformação do seu produto em simples mercadoria ou em mero invólucro que facilita e promove um consumo para poucos.

Nos anos 1990, assistiu-se no Brasil a um uso econômico do patrimônio sem função social e educativa maior, pois, como se detalhará em seguida, foi apagada grande parte dos elementos que permitem o exercício desse papel formador e informativo. Este fato não decorreu da simples inserção do patrimônio em estratégias de valorização - mas, antes, da submissão do seu real papel a essas estratégias.

No mundo ocidental, o patrimônio é um produto histórico de sociedades capitalistas e o seu papel social sempre foi desempenhado nesse contexto, ainda que, na maior parte do tempo, com alcance restrito. Sua consolidação como recurso econômico, a partir de meados do século XX, e a expansão dessa apropriação em termos mundiais permitiram que se tornasse, finalmente, objeto de apropriação e de circulação mais amplas na sociedade. O problema é que, em decorrência da excessiva mercadificação desse recurso, isso tem se processado com destruição de conteúdo e concentração de benefícios, o que pode ser evitado se a sociedade se organizar para defender o contrário. 
O que se assistiu nos anos 1990 não foi, certamente, o fim do patrimônio, nem mesmo o anúncio da impossibilidade de sua preservação. O que ocorreu naquele momento foi apenas produto das forças políticas, sociais e econômicas que estavam em interação e apenas mais um episódio da trajetória de uma prática histórica, que, como tal, pode ser transformada.

\section{A noção de patrimônio}

As operações de seleção, salvaguarda, conservação e promoção de bens culturais foram, durante a década em exame, grandemente influenciadas pelos usos dados ao patrimônio e pelas estratégias econômicas e promocionais que o mobilizaram. Em termos gerais, operações de seleção e salvaguarda de novos objetos não foram muito frequentes no período. No caso das cidades de Salvador, Rio de Janeiro e São Paulo, essa diminuição de intensidade teve a ver com o fato de que o seu parque patrimonial já havia sido constituído, em termos gerais, entre os anos 1960 e 80 . Em compensação, as operações de conservação, bastante empreendidas na década, assim como os instrumentos criados para promovê-las, incentivá-las e financiá-las tornaram-se os principais indicadores das características da norma de preservação e produção de patrimônio que foi instituída no período.

De um modo geral, as operações de seleção e salvaguarda de novos imóveis ou conjuntos urbanos oscilaram entre os objetivos de reforçar e atualizar identidades urbanas e os relacionados a facilitar o acesso de municipalidades, governos estaduais e bens culturais aos programas de financiamento e aos incentivos fiscais implantados na década. No geral, o que motivou a seleção e a proteção foi menos o valor cultural, ou o reconhecimento desse valor em um objeto qualquer, e mais a possibilidade de que ele se tornasse fonte de renda e instrumento de promoção. Embora secundariamente, pesou ainda na decisão de salvaguardar, a intenção de proteger determinadas áreas dos desdobramentos de iniciativas de renovação urbana ou dos impactos promovidos por tendências de transformação do padrão de ocupação existente. 
Os programas nacionais de preservação, em decorrência das regras de elegibilidade que instituíram, funcionaram como instrumentos de indução de tombamentos na esfera federal e, consequentemente, de desvalorização de medidas estaduais e municipais equivalentes. A localização estratégica, a aparência, a ambiência produzida e, secundariamente, o potencial de uso e a problemática urbana comandaram a seleção de setores urbanos para intervenção no âmbito desses programas. Tais critérios de priorização influenciaram a proteção legal, retirando essa operação de constituição de patrimônios do registro histórico, memorial e documental privilegiado durante os anos 1980. No que toca às operações de seleção, portanto, os programas dos anos 1990 realizaram um retorno às práticas dos anos 1970, quando o valor econômico, em última análise, também orientava os critérios de escolha.

Os programas nacionais não inovaram nem promoveram alterações nas operações de salvaguarda. A apropriação do patrimônio urbano como media, commodity ou elemento de política urbana e habitacional não promoveu alterações nos instrumentos de salvaguarda existentes, embora a questão tenha sido discutida, especialmente no âmbito do Programa Monumenta. O tombamento federal permaneceu como único instrumento de salvaguarda disponível, pois não se tornou nem um entrave, nem algo essencial para a execução das intervenções programadas. O URBIS e o Monumenta foram os únicos programas que indicaram a necessidade de se rever mecanismos de proteção e gestão, sendo que apenas naquele primeiro se reivindicou a construção de instrumentos mais adaptados à preservação de objetos urbanos. O Monumenta tratou essa questão de modo desvinculado dos projetos de intervenção, e de modo muito preso a aspectos ligados, principalmente, à distribuição de funções entre as esferas públicas e privadas. As preocupações deste último programa com relação à prática de salvaguarda em vigor não se relacionaram, portanto, à adequação do instrumento de proteção à preservação de sítios urbanos, mas aos seus efeitos sobre os entes públicos e privados envolvidos na questão.

É interessante observar, entretanto, que, apesar de os programas e as intervenções analisadas não terem induzido nenhuma transformação nesse aspecto da prática, uma parte importante do funcionamento do mecanismo de salvaguarda foi profundamente atingida. Seus braços executivos, isto é, os organismos federais, 
estaduais e municipais de preservação foram esvaziados e praticamente anulados como instâncias decisórias ou de coordenação de ações. Em suma, no período estudado, as operações de salvaguarda não evoluíram nem se transformaram, em essência, mas seus efeitos foram alterados pelo esvaziamento e pela perda de prestígio dos órgãos de preservação.

As operações de conservação, por seu turno, foram influenciadas, principalmente, pela utilização dada ao patrimônio urbano e pelas estratégias que o envolveram, mas também pela qualidade da prática desenvolvida em cada cidade, nos anos 1980. Por isso, no Rio de Janeiro, as intervenções foram de melhor qualidade técnica, ainda que mantendo características semelhantes às das demais cidades. As operações de conservação caracterizaram-se pela reciclagem de edifícios e espaços públicos e sua adaptação a novos usos e atividades. Nessa empresa, foi norma a eliminação de anexos; o superaproveitamento de espaços internos e lotes; o foco na recuperação, reconstituição e valorização de fachadas principais (Fotos 67 e 68); o uso das cores dos edifícios como estratégia promocional dos setores sob intervenção (Foto 69); o ordenamento e a supervalorização da aparência do ambiente (Fotos 70 e 71). As intervenções operaram, frequentemente, com o contraste e o isolamento entre o novo e o antigo, mas também com uma ênfase obsessiva na reconstituição ou reinvenção de elementos vistos como de especial valor patrimonial, o que implicou uma produção, acima da média histórica, de pastiches (Fotos 72, 73 e 74). Predominou também uma postura de descolamento da arquitetura, nova ou antiga, do tecido urbano existente, bem como uma espécie de retorno a uma estética urbana e patrimonial modernista, baseada na monumentalidade e na introdução de objetos artísticos ou de impacto estético no espaço recuperado (Fotos 75, 76 e 77).

Essas características gerais das operações de conservação foram produzidas, principalmente, pelo uso do patrimônio como veículo de marketing, mas também pelo seu aproveitamento econômico enquanto abrigo de atividades culturais, comerciais, de serviço e residenciais. O patrimônio edilício, em seus agenciamentos internos, foi intensamente adaptado a essas atividades, sem maiores considerações ou preocupações pelas perdas de documentação arquitetônica que as adaptações pudessem causar. Além dos agenciamentos internos, relações de parcelamento, de ocupação de lotes, estratégias de separação entre 
espaço público e espaço privado e a morfologia original de logradouros públicos não constituíram elementos, de um modo geral, julgados merecedores de preservação (Fotos 78,79 e 80). O rompimento de relações morfológicas dessa natureza foi constante em quase todas as intervenções. Imperou, assim, uma concepção geral de patrimônio urbano de caráter fachadista e concentrada em poucos elementos arquitetônicos, o que foi favorecido e reforçado pela lógica financeira e promocional que presidiu a montagem das operações, bem como pela falta de compromisso que imperou com relação ao papel informativo e documental do patrimônio.

A apropriação crescente do patrimônio como commodity, ou objeto utilitário e comerciável, fortaleceu a prática de se realçar e enfatizar elementos arquitetônicos rapidamente percebidos como de valor patrimonial, assim como reforçou a postura de reconstituí-los ou recriá-los onde já não existiam, ou onde se encontravam mutilados. A noção de autenticidade - tão cara ao discurso tradicional do patrimônio - se esgarçou no período e tendeu a acompanhar as injunções do mercado, com crescimento da tendência de se patrimonializar imóveis e áreas urbanas para se aumentar o seu valor ou se conseguir acesso a financiamentos. Verificou-se, por fim, um retorno da restauração como operação corriqueira, ainda que restrita às fachadas.

No que toca ao tratamento do espaço público, as intervenções tenderam a reproduzir a estetização urbana vigente nas cidades do Primeiro Mundo - processo que, no Brasil, teve início nas "praças" e "ruas" dos shopping centers e foi marcado pela estética e pelas estratégias promocionais desses equipamentos. Buscou-se trazer para o exterior as sensações de ordem, segurança e limpeza que caracterizam esses complexos comerciais, que são os grandes concorrentes locais do comércio de rua e do sítio histórico tratado como uma atração urbana (Fotos 81, 82 e 83). Nos espaços requalificados segundo essa concepção, os referenciais de memória foram valorizados no limite e na razão direta de sua capacidade de despertar interesse, de comunicar e de gerar uma imagem positiva do lugar e de sua gestão.

Cabe ressaltar, contudo, que tanto as intervenções de dinamização econômica e valorização imobiliária como as de reabilitação para uso habitacional obedeceram 
a essas linhas gerais, no que toca à conservação. No Brasil, o aproveitamento social e econômico do patrimônio não favoreceu, assim, um maior cuidado com os elementos que possibilitam o exercício de sua função memorial e documental. Tampouco favoreceu o seu uso como fonte de informações para o desenvolvimento de tecnologias construtivas alternativas e para o resgate de ofícios antigos. Esse aproveitamento serviu, principalmente, para animar o consumo e trazer para o campo da preservação as práticas mais convencionais e limitadas da construção civil.

As práticas de conservação foram ainda grandemente induzidas pelos programas nacionais de financiamento montados na década de 1990. De um lado, como observado anteriormente, suas regras e formatos induziram à conservação de monumentos e sítios históricos de grande visibilidade nacional, e, de outro, privilegiaram áreas dotadas de vazios e grande número de ruínas. As limitações das linhas de financiamento e a ausência de um sistema adequado de subsídios para a reabilitação de imóveis antigos promoveram operações de promoção do uso habitacional baseadas num superaproveitamento do volume construído e do lote, reduzindo também a preservação dos elementos de valor patrimonial ao exterior visível das edificações. Assim, os programas nacionais e as intervenções locais realizadas nos anos 1990 se identificaram plenamente no que toca às operações de conservação e coincidiram em termos do efeito final que produziram no patrimônio construído. Uma vez que o suporte físico é o que o corporifica, as operações de conservação, em última instância, determinam o que será ou não preservado e a ideia de patrimônio que entrará em circulação mais ampla. $\mathrm{Na}$ medida em que a maioria das intervenções e programas não se apoiou em um conhecimento fino do patrimônio existente, além de prévio à realização das operações de conservação, funcionaram, ainda que involuntariamente, como instrumentos de redução dessa ideia e de produção de um patrimônio associado a poucos elementos arquitetônicos, e atrelado a uma percepção sensorial fácil e de caráter unicamente ambiental. Investigações e estudos de caráter histórico, arqueológico, arquitetônico, urbanístico ou etnográfico raramente foram usados como ferramentas de apoio às intervenções.

As intervenções de reconquista de áreas centrais promoveram o patrimônio, nos anos 1990, por meio do apoio à realização de eventos e da divulgação das 
áreas "recuperadas" ou "requalificadas" como novas atrações urbanas. Esse tipo de operação mesclou-se às operações de conservação das áreas sob intervenção e utilizou estratégias de projeto que incluíram o uso da cor, técnicas de iluminação, introdução de objetos de impacto visual, de mobiliário e de sinalização que transformaram essas áreas em ambientes familiares e em verdadeiras peças publicitárias em 3D. Essas estratégias, aliadas a usos vinculados ao turismo, ao consumo e ao lazer, permitiram que os sítios recuperados funcionassem como atrações urbanas e instrumentos de marketing do setor, da cidade e de sua administração, neste último caso, com grande sucesso. Assim, a promoção do patrimônio realizou-se, naquele período, também no registro de sua apropriação midiática e econômica, o que fez com que os bens culturais funcionassem, simultaneamente, como objeto e meio de promoção. Essas operações, aliadas às de conservação, produziram as principais visibilidades que atualizaram e concretizaram a ideia de patrimônio urbano nos anos 1990 e induziram a uma concepção de cidade-patrimônio como cidade-atração.

Intervenções locais e programas mostram, por fim, que os anos 1990 constituíram, em grande parte, uma atualização da prática de preservação baseada no uso econômico do patrimônio que foi introduzida no país nos anos 1970. Mostram também que as operações de seleção, salvaguarda, conservação e promoção realizadas nos anos 1980, ancoradas no valor histórico e documental do patrimônio e em sua apropriação como instrumento de cidadania, constituíram um hiato nesse processo maior. Esse hiato se relacionou a dois episódios circunscritos: a redemocratização do país, a partir de 1982, e a redução brusca do investimento público, em decorrência da crise econômico-financeira que acarretou a suspensão temporária dos projetos dos anos 1970. O que há de novo na norma de produção e preservação do patrimônio nos anos 1990, e que é perceptível por meio das operações realizadas no período, é sua vinculação ao uso do patrimônio como veículo de comunicação e como oportunidade para o desenvolvimento e entrada de negócios e serviços no país. A apropriação midiática está perfeitamente inserida no processo de apropriação econômica do patrimônio, pois, como visto no capítulo 1, a imagem e a ideia que a constituem se transformaram, no capitalismo avançado, 
também em mercadorias. Mercadorias que, como visto ao longo deste trabalho, têm na cultura, no patrimônio e no meio urbano importantes fontes de insumos e campos privilegiados de reprodução. Contudo, menos do que um recurso cujo valor de troca foi ampliado em função da formação de um mercado significativo, no Brasil, o patrimônio agregou, durante os anos 1990, mais valor a governos e a imagens urbanas do que a edifícios e localizações. Funcionou economicamente muito mais como instrumento de geração de imagem do que como promotor de uma mercadoria de interesse para o mercado imobiliário.

A noção de patrimônio urbano produzida na década analisada correspondeu, portanto, a tudo o que pudesse rapidamente ser identificado como antigo, adaptado a novos usos e divulgado como patrimônio. Foi construída, em grande parte, pelas operações de conservação realizadas no período, assim como pelos mecanismos e instrumentos criados ou disponibilizados para colocá-las em marcha. Restrita ao poder que um elemento tem de comunicar rápida e eficientemente sua "natureza" patrimonial, a nova concepção operou uma redução e uma estetização da ideia, ao mesmo tempo em que, paralelamente, promoveu a ampliação do território urbano submetido à lógica da preservação. Ocorreu, assim, paradoxalmente, uma redução promovida pela abundância, pelo excesso e, finalmente, pela entrada do patrimônio urbano no circuito da mercadoria. A noção de patrimônio foi, nesse processo, despojada de profundidade histórica e concentrada na superfície dos objetos (Foto 84). O patrimônio perdeu função documental e formadora, e foi usado na produção de cenários devidamente patrocinados para consumo turístico, cultural e de lazer. A preservação tornou-se - como bem observou Mesentier (1992) no início desse processo no Brasil - um novo tipo de renovação urbana, que lança mão da preservação de formas antigas. Um novo fator de homogeneização espacial, realizado por meio de operaçóes que, muitas vezes, fazem tabula rasa de processos culturais, de aspectos imateriais associados ao uso do patrimônio e de atividades existentes, que usa a herança construída para criar atrações comerciais e imobiliárias de apropriação restrita. 


\section{As transformações da prática de preservação}

A análise das intervenções nas áreas centrais de grandes cidades brasileiras e do escopo dos programas nacionais implementados nos anos 1990 mostra que essas iniciativas se inseriram num processo maior de transformação da prática de preservação, que teve início no final dos anos 1960. Transformação que, em última análise, mudou a função dominante do dispositivo de patrimônio na sociedade brasileira. Essa função deixou de ser a de produzir significados necessários à construção de uma identidade nacional, ao desenvolvimento cultural e artístico e à formação de cidadãos brasileiros para se tornar uma função de produção de valor agregado. Na década em exame, a essa nova finalidade veio também se juntar a de produzir significados para a construção de imagens públicas, urbanas e comerciais. A partir dos anos 1960, em suma, o patrimônio deixou de ser um dispositivo primordialmente voltado para a educação e o aprimoramento cultural - ainda que, a maior parte do tempo, com um viés elitista - e passou a ser um dispositivo de valorização. Seu uso como instrumento de política urbana e desenvolvimento social, inaugurado nos anos 1980, não predominou nem construiu norma no período focalizado.

As transformações na norma de preservação se implantaram com diferentes graus de rompimento ou continuidade com relação a práticas anteriores. A partir dos anos 1970, a preservação do patrimônio deixou de ser um fim em si e transformou-se em meio para se alcançar outras metas, relacionadas, no geral, à dinamização econômica. Os anos 1990 consolidaram essa tendência. Nessa última década, a vinculação da preservação ao desenvolvimento da economia urbana concentrou ações nas áreas centrais das grandes cidades, especialmente em seus núcleos dinâmicos, e nos seus sítios de maior potencial do ponto de vista do turismo, da cultura e do lazer. Houve, assim, uma tendência de se privilegiar apenas certas partes da cidade, em oposição à visão mais abrangente que predominou nos anos 1980.

Diferentemente de outras épocas, o patrimônio foi, durante os anos 1990, menos objeto de discurso e mais de intervenção. Para fazer deslanchar tais intervenções, utilizaram-se instrumentos e mecanismos velhos e novos, mas, nesse aspecto, o que marcou e diferenciou a prática, foi a busca e o uso intenso de instrumentos 
de mobilização e envolvimento de recursos privados com vistas à conservação do patrimônio. Novas modalidades de renúncia fiscal e parcerias foram montadas e surgiu como importante moeda de troca, em alguns lugares, a alteração ou a flexibilização do aparato legal. Durante os anos 1990, antigas reivindicações por compensação ou incentivo financeiro à atividade de preservação foram, finalmente, concedidas e ampliadas. Proprietários de imóveis foram, muitas vezes, premiados por terem abandonado e arruinado seu patrimônio localizado nas áreas centrais e empresários foram pesadamente incentivados a instalar novas atividades em setores recuperados pelo Estado. Contudo, a despeito desses incentivos, os resultados em termos de captação de recursos privados não foram os esperados, e a intervenção de preservação permaneceu como atividade financiada, basicamente, pelo poder público. Neste ponto, portanto, não houve transformação de monta com relação aos outros períodos da trajetória da norma de preservação do patrimônio urbano no Brasil. O Estado continuou sendo o grande formulador, coordenador, conservador e financiador dessas ações, embora o investimento público tenha sido, algumas vezes, orientado por demandas da iniciativa privada.

Apesar das muitas vantagens oferecidas para tornar atrativo o investimento em recuperação e conservação do patrimônio, a resposta do setor privado ficou muito abaixo das expectativas, em decorrência da falta de mercado consumidor significativo para o patrimônio. Centradas em metas de dinamização e de valorização imobiliária através do turismo, da cultura, do lazer e da atração de atividades produtivas contemporâneas, as intervenções realizadas em Salvador, no Rio de Janeiro e em São Paulo não se desenvolveram da forma projetada, por ausência de crescimento econômico no país, pela falta de controle sobre vetores de crescimento urbano e de investimento imobiliário e, também, por inadequação dos seus projetos às demandas locais eà realidade urbana. Esse relativo fracasso abriu campo para objetivos de maior alcance, como o provimento de unidades habitacionais para rendas médias e baixas, mas essa nova estratégia de aproveitamento do patrimônio encontrou muitos entraves e resistências, dependendo, para se firmar, da competência e da organização política dos atores mobilizados. De todo modo, configurou-se, no final da década em exame, a tendência de se equilibrar o uso comercial do patrimônio urbano com um uso social mais amplo, o que abriu perspectivas interessantes para sua inserção na vida contemporânea. 
O aproveitamento econômico expandiu o campo institucional do patrimônio, durante os anos 1990, no sentido de que mais organismos públicos e novas organizaçóes da sociedade foram envolvidos. Ao mesmo tempo, entretanto, esse campo institucional sofreu grande esvaziamento no que toca à sua esfera técnica especializada, em decorrência da precarização, esvaziamento e enfraquecimento dos organismos públicos de preservação. Nesse último aspecto houve uma transformação significativa, pois, nos anos 1970, o aproveitamento turístico e econômico do patrimônio ensejou o contrário, ou seja, o fortalecimento, a ampliação e a criação de vários organismos de preservação nos estados da federação.

A participação da sociedade na montagem e execução de políticas de preservação, através de organizações não governamentais, associações civis ou movimentos sociais, foi muito fraca, em comparação com os anos 1980, especialmente em Salvador e no Rio de Janeiro. Já em São Paulo, verificou-se tendência oposta, com a atuação constante de dois tipos de organizações. O primeiro, de defesa de interesses corporativos e de proprietários urbanos, com vistas à valorização do seu patrimônio imobiliário localizado no centro; e o segundo, de defesa de reivindicações das camadas populares por melhores condições de moradia na cidade e pela inclusão dessa questão nos projetos de requalificação, repovoamento e revitalização de áreas centrais.

A noção de patrimônio, como já observado, sofreu redução nos anos 1990, especialmente no que toca aos elementos arquitetônicos, urbanísticos e de natureza imaterial que the são associados. Em contrapartida, foram ampliadas suas fronteiras temporais e tipológicas, bem como o território associado ao parque patrimonial do país. Mais cidades, e até mesmo as que antes se orgulhavam de ser modernas, lançaram-se ao resgate e à valorização de seu legado histórico.

A década de 1990 apresentou, portanto, continuidades e rupturas com relação à prática de preservação de períodos anteriores, mas constituiu, essencialmente, um momento mais recente de desenvolvimento do processo de aproveitamento econômico do patrimônio que foi iniciado no final dos anos 1960 . Essa década propiciou, contudo, as condições para um novo embate de forças, que poderá conduzir, no futuro, a uma nova reestruturação do dispositivo de patrimonialização, desta vez, mais voltada ao uso do patrimônio como instrumento de política urbana e desenvolvimento social. Após vários anos de oferecimento 
intenso ao mercado, na falta deste surgiram perspectivas para a inserção da herança urbana em novos contextos.

A cidade histórica brasileira concebida, em outras épocas, como monumento artístico e como documento histórico da nação, terminou o século XX apropriada como mais uma atração do cenário urbano. O patrimônio preservado nos anos 1990 foi, então, aquele produzido no âmbito e na perspectiva dessa "cidade-atração". 


\section{Posfácio: Depois dos anos 1990}

Este livro divulga uma investigação sobre quem fala, quem faz e quem se beneficia (com que poder e a partir de que lugar) das intervenções que, nos anos 1990, incorporaram o patrimônio das áreas centrais de grandes cidades como um ativo urbano e econômico, e tiveram a sua preservação como um objetivo. Passados mais de dez anos do momento em que essa investigação foi realizada, é possível afirmar que o escopo, as estratégias, os atores e, até mesmo, os efeitos dos projetos e/ou intervenções urbanas propostas ou em curso nas cidades estudadas possuem uma clara linha de continuidade com aquelas dos anos 1990, ou constituem seus desdobramentos. Este posfácio não visa, naturalmente, fazer uma atualização sistemática do que ocorreu entre 2004 e 2016, nem estudar em profundidade as operações de preservação do patrimônio urbano que estão em curso. O seu conteúdo, ademais, não é fruto de investigação exaustiva, mas da observação constante do desenrolar dos processos anteriormente estudados e da leitura do resultado de pesquisas recentes. O objetivo é reunir evidências que corroboram a afirmação de que há um grau importante de vínculo e de continuidade entre as intervenções atuais e as deflagradas nos anos 1990. Outra meta é identificar as mudanças que ajudam a compreender as novas apropriações, estratégias e tendências. 


\section{Capitalismo contemporâneo e produção do espaço urbano}

A pesquisa apresentada neste livro ressaltou a articulação entre os processos de produção, consumo e acumulação capitalista, de um lado, e, de outro, de produção do espaço urbano por meio de intervenções ditas de "regeneração", "recuperação", "reabilitação" ou "requalificação" de setores centrais nos anos 1990, ainda que ressaltando as muitas especificidades locais. A avaliação da continuidade dessas iniciativas e de seus desdobramentos atuais depende, portanto, do entendimento sobre como se processa, atualmente, essa articulação. Um dos autores que fundamentaram o estudo realizado a respeito da última década do século XX, o geógrafo americano David Harvey, apresentou, recentemente, uma análise que ajuda a mapear algumas transformações e nuances importantes. (HARVEY, 2011) Em primeiro lugar, ele assinala uma maior frequência e profundidade nas crises financeiras do capitalismo, a partir do encolhimento de um mercado consumidor progressivamente impactado pela precarização das relações de trabalho desde os anos 1970. A incitação ao consumo e o aumento do endividamento foram estratégias adotadas para a reversão desse quadro e para a manutenção de uma taxa aceitável de acumulação de capital, mas isso implicou crises avassaladoras como a provocada, em 2008, pelo estouro da bolha do setor imobiliário nos Estados Unidos. (HARVEY, 2011, p. 13) Assim, a despeito do deslocamento geográfico da produção industrial, da exportação de capital para países em desenvolvimento, da queda de barreiras alfandegárias, da mundialização do sistema financeiro e dos demais ajustes empreendidos na economia capitalista nas últimas décadas do século passado, as margens de lucro voltaram a cair nos anos 2000, promovendo a entrada de cada vez mais capital na especulação com ativos financeiros. A produção dessa maneira de crescentes excedentes de "capital fictício" em constante busca por aplicações rentáveis estaria na origem das crises financeiras atuais. (HARVEY, 2011, p. 32-33) Nesse cenário, a produção do espaço urbano continuou sendo uma das principais formas de absorção desses excedentes, inserida, entretanto, numa nova dinâmica especulativa. Com a integração dos mercados financeiros, a urbanização tornou-se, ainda, um fenômeno global, impulsionado, nos países capitalistas mais avançados e, em seguida, nos periféricos, por projetos urbanos lastreados em sistemas de crédito e hipotecas abertos a investidores de todo o mundo: 
Com uma economia que depende mais e mais do consumismo e do sentimento do consumidor como força motriz (70\% dos EUA contemporâneos contra 20\% no século XIX), a organização do consumo pela urbanização tornou-se absolutamente central à dinâmica do capitalismo. (HARVEY, 2011, p. 143)

Mas essa forma de acumulação, embora importante, não resolveria o problema central do capitalismo nos dias atuais: a impossibilidade de obtenção de um crescimento composto dos lucros para sempre. As crises frequentes que atingem o mundo, bem como a "criação de ficções de rentabilidade não duradouras" (HARVEY, 2011, p. 185), mostrariam os limites dessa acumulação contínua. No que diz respeito à produção do espaço urbano, a relativa facilidade com que esses projetos urbanos se implantaram nos anos 1990, na esteira do pensamento neoliberal e do ideário do planejamento estratégico, não se verifica mais. Movimentos sociais resistem cada vez mais a eles e se posicionam contra esse modo de produção da cidade e da moradia como meras mercadorias, bem como contra seus efeitos em termos de gentrificação e segregação social.

Tendo como fundamento esta análise de Harvey, Raquel Rolnik (2015, p. 21-129) descreve o processo contemporâneo de destruição da política habitacional como política social e a consequente transformação da moradia em mais um ativo financeiro que produz bolhas imobiliárias, perdas e despejos. Afirma o caráter global desse fenômeno e a possibilidade de interpretá-lo não somente como consequência de fluxos voláteis de capitais que se retiram de investimentos e papéis considerados podres, mas de uma mudança de paradigma. Rolnik avalia que a política habitacional, que era subsidiada, foi "privatizada", ou "financeirizada", e, assim, transformada em mais um sistema de crédito posto à disposição do capital privado.

Mas por que a moradia e o espaço construído surgiram, de modo tão claro, nas primeiras décadas do século XXI, como novas fronteiras de reprodução do capital financeiro? Segundo Rolnik (2015, p. 143-155), na medida em que o imóvel é ativo e, ao mesmo tempo, garantia do investimento, ele exerce importante papel na contabilidade dos fundos de investimento, o que explica o descolamento dessas operações dos usos e demandas reais. Este sistema de crédito teria, então, como uma das suas principais finalidades a remuneração do capital investido, e os processos de restruturação urbana o objetivo de abrir fronteiras para o capital 
financeiro. Sendo isso, em suma, o que tem enchido cidades das mais distintas partes do mundo com os mesmos produtos imobiliários, tanto em suas áreas centrais como em vazios urbanos e áreas de expansão. Produtos que ficam, em grande parte, vazios, o que, como visto, não constitui um problema, pois o que conta é o seu registro contábil, como ativo, no fundo de financiamento.

Anselm Jappe (2015), filósofo e ensaísta alemão, ao examinar a crise financeira de 2008 compartilha da visão de Harvey no que toca ao declínio do atual sistema capitalista de acumulação, que teria sido mascarado, nas últimas décadas, pela expansão massiva do crédito e dos mercados financeiros. Para Jappe (2015, p. 5), o capitalismo atual estaria funcionando por "simulação", ou seja, pela "antecipação de ganhos/lucros futuros" viabilizados pelo sistema de crédito. Nos anos 1990, avalia, as evidências empíricas pareciam contradizer essa tendência, na medida em que o ajuste estrutural da produção e das relações de trabalho, bem como o desenvolvimento tecnológico, pareciam ter contornado a crise dos anos 1970. Depois de 2008, contudo, a profundidade da crise do sistema teria ficado clara, e apenas o crédito tem permitido uma simulação continuada de produção de valor (ou de lucro), já que a acumulação "real" teria quase acabado. (JAPPE, 2015, p. 5-6)

Thomas Piketty, cientista social e economista francês, por sua vez, converge com os autores aqui citados no reconhecimento da situação de profunda crise em que se encontra o capitalismo contemporâneo. Em seu livro O Capital no Século XXI (2014), demonstra, com base em sólida pesquisa histórica, que a taxa de rendimento do capital tem superado o crescimento econômico real, o que se traduz em crescente concentração da riqueza e aumento significativo da desigualdade. Caracterizando o que compõe o capital atualmente, Piketty (2014, p. 171) aponta o "ressurgimento de um novo capitalismo patrimonial", alimentado pela desaceleração do crescimento, pela privatização e transferência gradual (a partir dos anos 1970 e 80) da riqueza pública para a do setor privado, e pela recuperação, em seguida, dos preços dos ativos imobiliários e das ações. Os dois últimos fatores tiveram, segundo ele, seus efeitos reforçados na década de 2000 a 2010.

Uma lição geral dessa pesquisa é que uma economia de mercado deixada à sua própria sorte contém forças importantes, sobretudo no que toca à difusão do conhecimento e das qualificações, mas também forças "potencialmente ameaçadoras" das sociedades democráticas e dos valores relativos à justiça social, pois a 
taxa de rendimento privado do capital pode ficar continuamente mais elevada do que a taxa de crescimento da renda nacional e da produção. Com isso, de acordo com Piketty (2014, p. 555), "o empresário tende a se transformar em rentista e a dominar cada vez mais os que somente possuem sua força de trabalho". A solução para este desequilíbrio, contudo, não seria econômica, e sim política. Para Piketty (2014, p. 556), ela viria sob a forma de um imposto progressivo anual sobre o capital, que se destinaria a conter a espiral de desigualdade e a possibilitar "novas acumulações primitivas" a partir de novas iniciativas e formas de produção e consumo.

Embora com filiações teóricas e ideológicas por vezes distintas, os autores citados concordam que a descentralização e a flexibilização do setor produtivo, a precarização do trabalho e a concentração de centros de decisão e planejamento nos países capitalistas centrais caracterizam ainda o sistema, mas apontam que outras características surgem, atualmente, também como essenciais para sua compreensão. Elas estão relacionadas ao progressivo esgotamento da capacidade global de crescimento econômico e, portanto, de absorção dos excedentes de capital, assim como estão relacionadas à capacidade de incorporar à produção e ao consumo de todo um contingente populacional que se encontra à sua margem. A saída encontrada tem sido, de um lado, explorar mercados consumidores consolidados e emergentes, por meio de uma ampliação desmesurada do crédito aplicado, principalmente, na aquisição de patrimônio imobiliário e na produção do ambiente construído - e, de outro, buscar taxas adequadas de acumulação do capital a partir de outros investimentos financeiros. Com isso, o capitalismo contemporâneo tem, crescentemente, adquirido um caráter patrimonialista, financeiro, especulativo e concentrador. Além disso, com vistas a auferir maiores taxas de lucro, torna-se cada vez mais volátil na busca por investimentos que as proporcionem, os quais, por sua vez, alimentam "bolhas" de capitais fictícios em setores da economia, da reprodução da vida e da produção do ambiente construído, numa espécie de espiral de acumulação irreal e insustentável que poderá levar ao seu próprio fim, como observam Harvey (2011), Jappe (2015) e Piketty (2014).

Quanto ao ambiente construído, o objetivo não é mais lucrar com o seu desenvolvimento e transformação, mas simplesmente lucrar com essa possibilidade, independentemente de que a transformação venha ou não a se realizar. Em outras palavras, o espaço construído é agora acessado pelo capital como mero 
conjunto de ativos passíveis de exploração no mercado financeiro. Ou, ainda, como fonte de produção de papéis negociáveis no mercado, que não mantêm vínculo necessário com demandas reais de transformação ou de provisão de novas estruturas. A base histórica desse processo encontra-se na reestruturação do espaço urbano que refletiu e acompanhou a restruturação do setor produtivo após os anos 1970 e ampliou o alcance das tendências de urbanização que haviam se configurado na década anterior. Essas tendências, especialmente após os anos 1990, passaram, em toda parte, a ser denominadas de "processos de gentrificação".

A ideia de gentrificação está ligada, originalmente, ao fenômeno que surgiu, inicialmente, na Inglaterra e nos EUA, nos anos 1960, vinculado à reversão da suburbanização que caracterizou o desenvolvimento urbano nesses países desde o final do século XIX. (SIQUEIRA, 2014, p. 393) Alimentado por essa volta de setores da classe média para as áreas centrais de grandes cidades, pela falência do ideário do urbanismo moderno e pela crescente valorização de edifícios históricos, esse fenômeno tornou-se, como visto no Capítulo 1, uma forma de urbanização importante nos países capitalistas centrais. A valorização imobiliária gerada por esse movimento alimentava então a gentrificação ou, dito de outro modo, a substituição dos grupos mais pobres e vulneráveis que habitavam o espaço por setores das elites sociais e econômicas que se beneficiavam do processo.

Essa teoria foi largamente utilizada, nas últimas décadas, na análise de processos e projetos que visaram à revalorização imobiliária de setores urbanos deteriorados ou esvaziados por meio da transformação do seu perfil de uso e ocupação, mas não explica, como mostra Siqueira (2014, p. 391-415), como movimentos semelhantes se desenvolveram em contextos distintos dos que a originaram, nem dá conta mais do alcance do fenômeno de extração de mais-valia urbana, que ocorre atualmente. Hoje, a noção de gentrificação abarca operações mais amplas, que envolvem a reestruturação de setores urbanos também por meio de novas construções e envolvem profundamente a ação do Estado, além de outros agentes. (SIQUEIRA, 2014, p. 396) Nessas operações, a substituição de populações e a extração de mais-valia se processam como: 
estratégia de produção de novos produtos imobiliários em localizações fora dos bairros adjacentes aos centros urbanos, com aquisição de novas formas e perda da sua relação original com a reversão do processo de suburbanização, [...] incluindo agentes imobiliários maiores e mais diversificados, direcionando investimentos para projetos de grande porte em áreas mais distantes, incluindo novas construções e com apoio crescente do Estado para compensar riscos, com a justificativa de geração de empregos, impostos e recursos por meio do turismo. (SIQUEIRA, 2014, p. 397)

Este tipo de operação constitui um fenômeno global que opera por meio da "implantação de regimes pró-capital em estruturas locais", legitimados pelo Estado como políticas públicas de dinamização econômica e produção de empregos. (SIQUEIRA, 2014, p. 397) Essa "gentrificação contemporânea" ocorre nas chamadas cidades globais, mas também nas periféricas, como "frentes de expansão do capitalismo global'”. (SIQUEIRA, 2014, p. 397) Os padrões de consumo vinculados a elites sociais e profissionais seguem sendo fundamentais para o seu sucesso, assim como o patrimônio urbano segue sendo um elemento que os alimenta e legitima, mas sem ocupar mais uma posição central.

Siqueira (2014, p. 400-401) propõe que esse tipo de gentrificação seja analisado no plano local a partir de três dimensões: a da possibilidade de obtenção de um potencial de extração de mais-valia superior à que existe em determinado lugar, por meio da realização de um conjunto de intervenções; a da expulsão de populações vulneráveis e da elitização e introdução, no lugar, de padrões de consumo julgados superiores aos existentes; e a da transformação da paisagem construída, mediante introdução de novas infraestruturas urbanas, edificações e usos. Mas alerta que a interação de padrões globais com especificidades locais pode produzir resultados que alteram esses processos, tanto em termos espaciais como temporais, e que "estruturas mediadoras" podem agir, modificando-os. (SIQUEIRA, 2014, p. 392) Assim, a gentrificação pode assumir formas diferentes dentro de uma mesma cidade, de acordo com a existência de mercados imobiliários diferentes, influência política, limites institucionais, formas de combater processos de expulsão, influência de organizações locais, interesses privados, dentre outros fatores. (SIQUEIRA, 2014, p. 401) 
No âmbito do Plano de Reabilitação de Áreas Urbanas Centrais (PRAUC) do Ministério das Cidades.
Assim compreendido, o termo "gentrificação" se aproxima do que Harvey (2011, p. 137-147) denomina de "fenômeno global de urbanização", que se manifesta em projetos urbanos "espetaculares" que buscam atrair investidores de todo o mundo, constituindo uma expressão concreta do papel que o ambiente construído desempenha, atualmente, no processo de acumulação do capital. Se, nos anos 1990, esses projetos pareciam ter um vínculo necessário com o patrimônio urbano ou, mais genericamente, com estruturas urbanas pré-existentes, o que se verifica agora é uma relativa perda de importância desse aspecto. Dito de outro modo, embora o patrimônio e a paisagem sejam ainda elementos que distinguem o espaço urbano, e a sua preservação ainda funcione como um discurso legitimador, verifica-se, nas operações contemporâneas de gentrificação, o crescimento da importância da criação e disponibilização de potenciais construtivos, de uma arquitetura e de um desenho urbano "corporativos" como principais elementos de atração. Os programas, projetos e operações, propostos ou em curso, atualmente, nas áreas centrais de Salvador, Rio de Janeiro e São Paulo ilustram concretamente esse processo.

\section{Salvador}

O grau muito baixo de impacto transformador no quadro de esvaziamento funcional e de despovoamento de setores protegidos como patrimônio na antiga área central de Salvador levou à formulação, em 2010,' do Plano de Reabilitação Participativo do Centro Antigo de Salvador. (BAHIA, 2010) O documento corresponde a um conjunto de proposições abrangentes e voltadas para toda a área central que tratam os seus principais problemas, inclusive no que toca às questões habitacionais e de vulnerabilidade social, mas que ainda enfatizam o turismo cultural como uma das principais formas de reanimação da sua dinâmica. O plano propõe um instrumento de governança para a articulação entre as instâncias de governo e a sociedade, mas, a despeito de conter um extenso diagnóstico e uma lista de projetos, não detalha metas ou estabelece prazos e estratégias para sua implementação. À época de sua divulgação, contabilizava-se na área central a existência de 1.101 imóveis em estado de vacância, dos quais 466 constituíam ruínas, 486 correspondiam a edificações fechadas e 149 a lotes vazios. (GORDILHO-SOUZA, 2010, p. 84) Este sinal concreto 
da incapacidade que os investimentos governamentais, feitos ao longo dos anos 1990, tiveram para atrair novas dinâmicas para a área central foi, contudo, assumido nesse plano como uma oportunidade de reciclagem e de oferta de cerca de 8,6 mil novas unidades habitacionais, das quais 3.000 destinadas às famílias que ocupam habitações precárias ou situadas em áreas de risco no perímetro do Centro Antigo.

Até 2016, contudo, muito pouco havia sido executado. A Diretoria de Reabilitação do Centro Antigo (DIRCAS) - instância criada pelo governo da Bahia para coordenar a implementação desse plano² - tem atuado apenas na articulação desta política pública, de projetos privados propostos para alguns setores do Centro Histórico. Um documento recente de avaliação (BAHIA, 2014, p. 29) mostra a ineficácia do Plano de Reabilitação Participativo e o avanço do processo de despovoamento do centro antigo. Entre 2000 e 2010, a área central perdeu 3.671 habitantes, a maioria moradores do Centro Histórico. Além disso, verificou-se a permanência na população da cidade, especialmente nos segmentos de renda mais alta, da percepção de que esta área é insegura e lugar de drogas e prostituição. (BAHIA, 2014, p. 124-125) O documento de avaliação ainda informa que o número de imóveis em situação de vacância aumentou para 1.400, assim como cresceu em 9,56\% o número de famílias em situação de vulnerabilidade. (BAHIA, 2014, p.164-165) Entre 2010 e 2015, foram, contudo, produzidas apenas 170 unidades habitacionais de interesse social, correspondendo ao atendimento de 5,6\% da demanda total existente. (BAHIA, 2014, p. 175)

Os projetos que, a partir do começo dos anos 2000, foram destinados ao atendimento das demandas de habitação ligadas a setores de renda média/ baixa e de baixa renda, a exemplo da $7^{a}$ etapa do Programa de Recuperação do Centro Histórico de Salvador, encontraram extrema dificuldade para se desenvolver. Esta etapa, financiada em sua maior parte pelo Programa Monumenta (1999-2010), é produto da pressão de moradores desse setor do Centro Histórico 3 que, no começo dos anos 2000, começaram a reagir às expulsões promovidas pelo programa, mobilizando o Ministério Público em sua defesa. Por meio da celebração de um Termo de Ajuste de Conduta (TAC), foi estabelecido que 103 unidades habitacionais de interesse social atenderiam a essa demanda, além das que já estavam destinadas a funcionários públicos com renda até 10 salários mínimos. As obras foram iniciadas e algumas unidades foram entregues, mas,
2 A DIRCAS faz parte da CONDER - Companhia de Desenvolvimento Urbano do Estado da Bahia.

3 Localizado entre a Rua de São Dâmaso e a Ladeira da Praça. 
4 Elaborado no âmbito de parceria entre a CONDER e a Faculdade de Arquitetura da UFBA, este plano foi coordenado por Esterzilda Berenstein de Azevedo, professora da Faculdade de Arquitetura e do Programa de Pós-Graduação em Arquitetura e Urbanismo dessa universidade.

5 Implantação de VLT de alta capacidade na área do Comércio, de um bonde moderno no circuito do Centro Histórico a recuperação dos transportes verticais desse setor e a implantação de novos planos inclinados.

6 Reguladas e fiscalizadas pela Comissão de Valores Mobiliários - CVM. desde então, se arrastam a passos muito lentos. Outra iniciativa nessa direção, que também se desenvolveu com muita dificuldade, foi o Plano de Requalificação Urbana do Pilar-Taboão, elaborado e implementado entre 2003 e 2008. ${ }^{4}$ Este plano envolveu uma área que inclui trechos da encosta, localizados entre a Ladeira do Taboão e a Igreja do Pilar, além de uma área na Cidade Baixa, entre a Praça Marechal Deodoro e a Avenida Jequitaia. O objetivo era produzir habitações de interesse social, recuperar a encosta e implantar comércios e serviços, mediante construções novas e a reabilitação de imóveis antigos. Entretanto, o plano foi executado parcialmente, sendo construído apenas o Conjunto Habitacional Pilar I, na Av. Jequitaia, com 107 unidades habitacionais financiadas pela CEF.

A divulgação do "Masterplan do Centro Antigo", em 2014, pelo Governo do Estado da Bahia, e o detalhamento do projeto do Fundo de Investimentos Imobiliários no ano seguinte, possibilitaram a formação de uma ideia mais clara a respeito da existência de um projeto global para a área central de Salvador, para além do discurso do Plano de Reabilitação Participativo. Esse projeto, ainda que perceptível aos pedaços, comprova a percepção de Rebouças e Mourad (2012, p. 12-15) de que o plano constituiu apenas um primeiro passo para a implementação de uma operação urbana orientada para o mercado, apoiada em um modelo de gestão público-privada e executada por meio de concessão urbanística. O "Masterplan" é composto de 20 ações que deverão ser executadas em três etapas de três anos cada uma. Propõe a ampliação da conectividade urbana da área por meio da melhoria do sistema de transporte urbano e da mobilidade, ${ }^{5}$ bem como a produção de oito mil unidades habitacionais, das quais cinco mil destinadas à classe média. Além disso, prevê: a recuperação de imóveis por meio do Fundo de Investimentos Imobiliários; a construção de belvederes voltados para a Baía de Todos os Santos; a requalificação da zona do porto de Salvador; a construção de novos estacionamentos e a requalificação de ruas, ladeiras e praças.

O Fundo de Investimentos Imobiliários (FII), por sua vez, faz parte das propostas do Plano Participativo de Reabilitação do Centro Antigo, mas somente em 2014 foram divulgados sua composição e objetivos. Esses fundos são estruturas de investimento administradas por instituições financeiras, ${ }^{6}$ criados para captar recursos com vistas ao seu investimento em projetos lastreados em ativos imobiliários. No fundo criado para o centro antigo de Salvador, gerido pela Caixa 
Econômica Federal, os cerca de 1.400 imóveis vacantes dessa zona são tomados como lastro, a partir de sua regularização fundiária, desapropriação ou transferência de posse viabilizadas pelo governo estadual. Para tanto, foram baixados, em 2013, quatro decretos estaduais que instituíram áreas de utilidade pública para fins de desapropriação nos setores do Centro Histórico considerados mais adequados à produção imobiliária.? Proprietários de imóveis que assim o desejarem podem participar como cotistas do FII, e o estado da Bahia, como proprietário de grande número de imóveis no Centro Histórico, é o principal cotista, com prerrogativas de deliberar, acompanhar investimentos, discutir e definir estratégias de investimento, formato de governança, resultados almejados e prazo de duração do fundo. (BAHIA, 2014, p. 186)

A estratégia de investimentos do FII está traçada segundo a seguinte ordem de prioridade: (I) imóveis privados situados entre a Av. Contorno, a encosta do Bairro 2 de Julho e a Ladeira da Misericórdia; (II) imóveis públicos do estado da Bahia situados no Centro Histórico; (III) imóveis públicos e privados situados na Rua do Gravatá e Ladeira da Independência; (IV) imóvel público da União, de uso dos Fuzileiros Navais no Comércio; e (V) imóveis privados avulsos, situados em diversos bairros do Centro Antigo. (BAHIA, 2014, p. 178) Os imóveis que fazem parte da primeira etapa estão destinados a uma produção imobiliária voltada para segmentos de alta renda, com estudos de massa que estabelecem as possibilidades de potencial construtivo e de viabilidade econômica e financeira já realizados. Embora tendo como lastro um conjunto significativo de imóveis de propriedade pública, as Zonas Especiais de Interesse Social (ZEIS) instituídas no Centro Antigo não são sequer mencionadas nessas prioridades, e não se prevêa destinação de recursos para a produção de habitações de interesse social.

O parecer jurídico que aprova a criação do FII e a inclusão dos imóveis pertencentes ao estado da Bahia como seus ativos (BAHIA, 2014, p. 185-187) deixa claro que este fundo é também um artifício que possibilita a alienação de imóveis públicos sem licitação ou leilão. As etapas de investimento previstas mostram, ainda, a articulação entre poder público e capital imobiliário, uma vez que o trecho da orla da Baía de Todos os Santos localizado no entorno do Centro Histórico - primeira prioridade para realização de investimentos - está há, pelo menos, 20 anos na mira do mercado imobiliário. Este trecho, como observado no Capítulo 2, corresponde ao
7 Decretos $n^{\circ} 14.865$ $14.866,14.867$ e 14.868 , de $11 / 12 / 2013$. 
8 Instituído pela Lei $n^{\circ} 9.060$, de 30 de Junho de 2016.

9 A conservação geral de monumentos arquitetônicos destacados, como igrejas e solares, contudo, melhorou.

10 Notícias recentes dão conta da reversão desse projeto como resultado da mobilização e pressão de movimentos sociais e da ação do Ministério Público. setor onde, desde o começo dos anos 2000, já se verificava o desenvolvimento de um processo de extração de mais-valia urbana, ou de "gentrificação", conforme a concepção contemporânea, por meio da apropriação privada de áreas de marinha.

O FII do Centro Antigo tem ainda uma outra função importante: preparar o terreno para o financiamento de operações urbanas consorciadas na área central e em outras zonas de Salvador, conforme estabelecido no Plano Diretor de Desenvolvimento Urbano (PDDU), aprovado em $2016^{8}$ após longa batalha judicial. A operação em curso na zona portuária do Rio de Janeiro é financiada por meio de fundos dessa natureza que operam com os recursos do FGTS - hoje, uma das fontes de financiamento principais dessas operações. A flexibilização da aplicação de recursos do FGTS - antes restritos a políticas urbanas de cunho social - teve início em 2008, e já em 2010 permitia-se sua aplicação em operações imobiliárias de mercado. Esta alteração viabilizou o repasse de R\$ 6 bilhões para a Operação Urbana Consorciada Porto Maravilha. Em 2012, por fim, uma nova resolução da Caixa Econômica Federal assumiu explicitamente a possibilidade de aplicação dos recursos do FGTS em operações dessa natureza, legitimando a compra dos Certificados de Potencial Adicional de Construção (CPAC) que financiam a intervenção na zona portuária do Rio de Janeiro. (GALIZA, 2015, p. 102-103)

Mesmo com os investimentos públicos realizados a partir dos anos 1990 no coração do Centro Histórico de Salvador, o quadro físico de deterioração, abandono e arruinamento é ainda o que predomina na maior parte dessa área e, em especial, no entorno imediato do setor "recuperado" naquela década. ${ }^{9}$ Ações de escoramento e mesmo de demolição de edificações em ruínas são mais ou menos constantes, servindo, por vezes, como pretexto para a retirada de moradores indesejáveis, a exemplo do que se tentou fazer na área da Ladeira da Montanha, em 2015, quando os artesãos ocupantes dos imóveis existentes nos arcos da muralha de contenção, foram ameaçados de remoção para dar lugar a ateliês de artistas. ${ }^{10}$ Os investimentos privados, contudo, pouco se materializaram no Centro Histórico, para além dos empreendimentos de alto luxo localizados no trecho da orla da baía próximo à Av. Contorno e ao Solar do Unhão, e da especulação em torno da aquisição de imóveis e terrenos neste mesmo trecho, no bairro de Santo Antônio e na Rua Chile. Aquisições que têm servido, principalmente, para elevar o preço dos imóveis nesses setores. 
A atração de segmentos de alta renda e os usos ligados ao turismo e ao lazer continuam sendo as principais apostas do poder público e dos investidores privados para "recuperação" do Centro Histórico de Salvador. Um conjunto de propostas nesse sentido tem aparecido na mídia baiana, sendo, atualmente, a mais vistosa delas a que faz parte da tentativa de trazer de volta para a Rua Chile o comércio fino que caracterizou esta via até os anos 1960, com a restauração e reabertura do antigo Palace Hotel, rebatizado agora como "Fera Palace Hotel". A empresa Fera Empreendimentos, numa aposta ousada, adquiriu, além do velho hotel, 123 imóveis em 16 edifícios da Rua Chile, com vistas à atração de outros empreendedores para o local. Se essa aposta será distinta da que foi feita pela empresa proprietária do Shopping da Bahia, que comprou dezenas de imóveis no bairro do Santo Antônio que permanecem fechados, é algo ainda a se verificar.

O Governo da Bahia, por seu turno, após hesitações sobre o que fazer com o malsucedido empreendimento turístico e comercial criado no Pelourinho, voltou a investir na manutenção dos imóveis e na recuperação das praças criadas no interior de quarteirões do setor, como forma, mais uma vez, de reanimar sua função comercial, cultural e de lazer. Além disso, outras iniciativas do poder público dão uma medida do prestígio que ainda gozam as ações voltadas para a substituição do perfil de uso e ocupação popular do Centro Histórico. Entre elas, se destaca a Manifestação de Interesse Privado (MIP) aprovada pela Prefeitura Municipal de Salvador, em 2013," por meio da qual, a Odebrecht Properties (braço da holding voltado para negócios imobiliários) foi autorizada a elaborar plano urbanístico para a área central, setores da cidade baixa e orla marítima. Outras iniciativas em curso mostram, ainda, uma inédita articulação ou convergência entre os governos federal e o estadual, e a Prefeitura, em torno da transformação do quadro atual do Centro Histórico e da área central.

Lançado em 2009 pelo Governo Federal com o objetivo de suceder e dar continuidade, de modo aperfeiçoado, ao Programa Monumenta, o Programa de Aceleração do Crescimento - Cidade Históricas (PAC-CH) começou a ser discutido na Bahia no mesmo ano do seu lançamento. Prevendo-se, inicialmente, no Centro Histórico de Salvador um conjunto de ações que incluía a melhoria da gestão do patrimônio e o financiamento da reabilitação e da conservação de imóveis privados, o projeto foi reduzido a obras de restauração de alguns monumentos
11 A Manifestação de Interesse Privado foi instituída em Salvador por meio do Decreto $n^{\circ} 23.935$, de 17 de maio de 2013. 
12 Catedral Basílica e Ordem Terceira de São Domingos, no Terreiro de Jesus; Igrejas do Corpo Santo e de Nossa Senhora do Pilar, no Comércio (Cidade Baixa); Igreja do Santíssimo Sacramento da Rua do Passo, no Passo; Igreja de Nossa Senhora da Saúde e da Glória, na Saúde; e Forte de São Marcelo, na Baía de Todos os Santos. religiosos e militares localizados de modo disperso nessa área, ${ }^{12}$ e ao financiamento de intervenções na Barroquinha e na encosta voltada para a baía. Estas últimas estão destinadas à melhoria da acessibilidade entre a Cidade Baixa e a Cidade Alta, por meio da recuperação dos ascensores urbanos implantados no século XIX e da construção de um novo plano inclinado articulando Praça Castro Alves e Rua da Conceição. Prevê-se ainda a instalação de um receptivo turístico no Viaduto da Sé; a instalação de um elevador panorâmico ligando o Belvedere da Sé à Ladeira da Misericórdia; e uma passarela ligando o Museu de Arte Moderna, no Solar do Unhão, ao Forte da Gamboa - localizado em área de ocupação popular -, cuja restauração também está prevista. Além disso, há a previsão de iluminação cênica e recuperação paisagística da encosta, com restauração do conjunto de imóveis edificados sob os arcos da Ladeira da Montanha.

$\mathrm{Na}$ Ladeira da Barroquinha, em sinergia com equipamentos culturais do município, prevê-se a recuperação de imóveis para usos culturais e institucionais e a recuperação do Teatro Gregório de Mattos. Na vizinhança desse conjunto, propõe-se também a recuperação do prédio do Palácio dos Esportes, situado na Praça Castro Alves, para abrigar o Centro de Referência do Centro Antigo. Como se verifica, as ações do programa federal estão em perfeita sintonia com os investimentos do governo estadual e com os planos da Prefeitura e da iniciativa privada para o Centro Histórico e setores adjacentes.

O interesse pela animação da produção imobiliária na área central e a inédita confluência entre as esferas de governo ficam patentes também no PDDU 2016. Nesta lei, o Centro Antigo é definido como território estratégico para o desenvolvimento da cidade, cuja centralidade, classificada como de alcance metropolitano, deve ser fortalecida mediante o resgate e a incorporação de novas funções. (SALVADOR, 2016, Art. 175, inciso I) As prioridades são os usos residenciais e atividades complementares nas áreas degradadas, bem como o estímulo a empreendimentos multirresidenciais e de uso misto nas áreas adjacentes, (SALVADOR, 2016, Art. 175, inciso II) mas a revitalização do Centro Antigo é ainda ancorada na inserção de usos ligados ao turismo e ao lazer. (SALVADOR, 2016, Art. 175, inciso III, letra a) Outras diretrizes são a implantação de novas articulações entre as Cidades Alta e Baixa, ligadas ao sistema de transporte; a implantação de terminais turísticos na Cidade Baixa; a requalificação urbanística 
de logradouros e espaços públicos; a criação de espaços de convivência na orla da Baía de Todos os Santos; a implantação de estacionamentos; e, por fim, o ordenamento do comércio informal. (SALVADOR, 2016, Art. 175, incisos III e IV)

Essas diretrizes correspondem, em grande parte, à incorporação ao PPDU 2016 de propostas elaboradas pela iniciativa privada que vêm circulando há alguns anos em Salvador, como o Projeto Salvador 500, que propõe preparar a cidade para a celebração de seu quinto centenário, e da já citada MIP encaminhada pela Odebrecht Properties, que encontra agora no PPDU 2016 um agasalho legal mais sólido. No artigo 325 desse plano diretor ficam determinadas as áreas para implementação de operações urbanas consorciadas, as quais praticamente repetem as previstas nessa MIP, e compreendem: toda a zona entre a Calçada e o Lobato, incluindo, na Península de Itapagipe, os bairros da Ribeira, Bonfim, Monte Serrat e Baía de Itapagipe (OUC ๆ); o Centro Histórico, o Dique do Tororó, o Vale dos Barris e os bairros adjacentes do Engenho Velho de Brotas, Nazaré, Garcia, Tororó, e Barris (OUC 2); e, por fim, o trecho da orla do Atlântico correspondente aos bairros da Boca do Rio, Armação, Imbuí, Patamares e Jaguaribe, incluindo o Parque Metropolitano de Pituaçu (OUC 3 ).

Com isso, boa parte da cidade, incluindo todas as áreas de maior valor cultural e paisagístico, fica em suspenso no que toca às regras que efetivamente deverão reger o seu desenvolvimento e preservação. Cabe observar que todas as áreas sujeitas à realização de operações urbanas consorciadas, conforme o PDDU 2016, são grandemente ocupadas por população de baixa renda com a qual será preciso lidar. Para tanto, o plano diretor prevê que a lei que regulamentará essas operações deverá incluir também um "perímetro expandido", no qual poderão ser atendidas essas necessidades habitacionais, além da melhoria de condições de drenagem, saneamento e mobilidade da área. (SALVADOR, 2016, Art. 328, inciso II) Como normalmente ocorre, o novo PDDU estabelece que as obras, desapropriações e aquisições necessárias à execução das OUCs serão financiadas mediante a emissão de Certificados de Potencial Adicional de Construção (CPAC) pelo município de Salvador (SALVADOR, 2016, Art. 329), dedicando-se, contudo, apenas 10\% dos recursos obtidos dessa forma à produção de habitações de interesse social. (SALVADOR, 2016, Art. 328, inciso XI, parágrafo 1²) 
Seguindo a tendência de outras grandes cidades brasileiras, o PDDU 2016 cria também, por fim, a possibilidade de que o município de Salvador estabeleça, mediante legislação específica e concorrência pública, regimes de concessões urbanísticas. (SALVADOR, 2016, Art. 336) Nesses regimes, delega-se a empresas ou a consórcios de empresas a realização de intervenções urbanísticas e obras públicas com seus próprios recursos, permitindo-se, em contrapartida, que os concessionários recuperem o seu investimento e se remunerem a partir da exploração dos imóveis públicos ou privados e dos equipamentos resultantes da operação. (SALVADOR, 2016, Art. 337) Embora os dois dispositivos não sejam obrigatoriamente vinculados, a concessão urbanística deverá, certamente, ser utilizada nas operações urbanas consorciadas que já estão previstas nessa lei.

O novo Plano Diretor, plenamente afinado com os planos do mercado imobiliário, coloca todas as zonas da cidade que desfrutam do visual da paisagem marítima e dos aspectos mais importantes do seu patrimônio urbano como território de reprodução e acumulação desse capital. Observa-se ainda que os projetos públicos e privados se articulam nesse sentido, fazendo com que a borda da baía, setores do Centro Histórico e da Cidade Baixa surjam como áreas para o desenvolvimento imobiliário destinado a faixas de renda mais alta. Os projetos divulgados para a área dos antigos armazéns do Porto e as perspectivas que se abrem com a possível implantação da ponte Salvador-Itaparica, em termos da criação de um vetor de desenvolvimento imobiliário na maior ilha da baía, podem tornar a parte mais antiga da cidade em um bom investimento. Esse inventário de projetos, ações e intenções mostra que estão sendo construídas, de modo articulado e sistêmico, as condições para a transformação do atual perfil de uso e ocupação dessas áreas da cidade. Resta somente indagar se, dessa vez, essas intenções se concretizarão ou se, como tem ocorrido, permanecerão no plano da especulação.

De todo modo, no Centro Antigo de Salvador, como já se verificava no final dos anos 1990, os projetos de gentrificação continuam tendo mais apoio do setor público e mais chances de viabilização do que os voltados para o atendimento das demandas ligadas aos moradores e usuários de baixa renda. Entretanto, o conjunto 
dos planos e operações atuais mostra uma relativa perda de protagonismo da parte alta do Centro Histórico para sua encosta, para a Cidade Baixa e para a orla da baía onde os interesses imobiliários e especulativos se concentram, impulsionados ainda pelas promessas de investimentos públicos.

Contudo, cabe ressaltar uma mudança importante que vem se verificando desde o começo dos anos 2000. Se, até então, em Salvador, as populações carentes e marginalizadas do Centro Antigo eram deslocadas sem resistência, agora esse panorama mudou totalmente. Um conjunto expressivo de associações e movimentos sociais, que lutam por permanência na área central, tem atuado nos últimos anos e, com o apoio de organizações de assessoria técnica e jurídica, tem constituído uma forte resistência popular às ameaças de expulsão e gentrificação. Esses movimentos têm se colocado como pedras difíceis de contornar no caminho desses projetos, devendo-se esperar, no momento atual, no mínimo, a judicialização e a dificuldade de execução de projetos e planos que trilhem esse caminho.

Embora o Governo do Estado da Bahia, através da CONDER, ${ }^{13}$ ainda seja um ator importante na definição dos rumos do Centro Histórico, verifica-se uma atuação mais intensa e expressiva da Prefeitura de Salvador e o crescimento de sua importância nessa definição, bem como no seu prolongamento na Cidade Baixa. Quanto ao setor privado, se, até o começo dos anos 2000, ele apenas assistia passivamente à implementação de políticas públicas nessas zonas, atualmente vem adotando uma postura cada vez mais proativa, não somente explicitando planos e projetos para a área, como, ainda que numa postura especulativa que se traduz em poucas ações de reabilitação, realizando aquisições importantes no Centro Histórico. Como já mencionado, resta saber, contudo, se a dinâmica econômica dos próximos anos, a situação política e as contradições do planejamento urbano - que reaquece novamente a orla do Atlântico como fronteira de investimentos com a ampliação do metrô, a complementação do sistema viário e o crescimento do potencial construtivo dessa orla - permitirão que os projetos de gentrificação da área central se realizem.
13 O Instituto do Patrimônio Artístico e Cultural da Bahia (IPAC) manteve, nesse caso, o mesmo papel secundário que teve no final dos anos 1990. 
14 O Condomínio Cores da Lapa, lançado em 2005 e com 688 apartamentos, foi todo vendido em menos de duas horas (BRODE; SAMPAIO, 2012, p. 16), o que pode indicar o crescimento de uma demanda por residência na área central ou um processo de investimento ainda especulativo nesse sentido.

\section{Rio de Janeiro}

No estudo realizado nos anos 1990, foi possível observar a situação privilegiada do Rio de Janeiro em relação às demais cidades analisadas, no que toca à dinâmica da sua Área Central de Negócios (ACN), e também a importância do desenvolvimento do uso habitacional no seu entorno para o fortalecimento da centralidade. Por outro lado, foi também possível observar que, no começo dos anos 2000, nada indicava uma tendência de crescimento ou de expansão desse coração dinâmico do centro antigo do Rio.

Atualmente, observa-se que esta área central vem passando por transformações importantes, a partir da política de fortalecimento do "centro histórico" deflagrada em 2009 pela Prefeitura da Cidade do Rio de Janeiro, com a implementação da Operação Urbana Consorciada Porto Maravilha e com a escolha da cidade para sediar importantes eventos ligados à Copa do Mundo de 2014 eàs Olimpíadas de 2016. Esse conjunto de iniciativas promoveu a realização de obras públicas de infraestrutura que, por sua vez, atuaram como elemento de atração de investimentos privados, especialmente na Lapa. (BRODE; SAMPAIO, 2012, p. 1-5; ROSA, 2014, p. 155-161)

Observa-se, contudo, que a liberação do uso residencial na área central do Rio, a partir da instituição da Área Especial de Interesse Urbanístico do Centro, em 1994, tem tido uma repercussão lenta, com o lançamento de empreendimentos isolados e sem configuração de uma situação de fortalecimento desse tipo de apropriação. (BRODE; SAMPAIO, 2012, p. 4) 14 O Programa de Reabilitação de Áreas Centrais do Ministério das Cidades, iniciado em 2003, e o Plano de Reabilitação e Ocupação dos Imóveis do Estado do Rio de Janeiro na Área Central, lançado em 2011, constituíram políticas nesse sentido, mas não chegaram a mudar o quadro. Avalia-se, entretanto, que está em curso uma mudança no mercado habitacional da área central, expressa numa oferta maior de unidades, num significativo aumento de preço e num aumento no número de transações imobiliárias dessa natureza da ordem de 2\% entre 2000 e 2010. (MOSCIARO, 2012, p. 77-79) Essa dinâmica imobiliária, entretanto, pode ser considerada incipiente se comparada à de outras áreas da cidade como Botafogo, Copacabana e Méier. Verifica-se também que o número de moradores por domicílio no centro expandido caiu entre 1991 e 2010. (MOSCIARO, 2012, p.81) 
A dinâmica imobiliária para usos comerciais na área central, por outro lado, dá sinais de aquecimento, com aumento significativo de unidades comerciais ofertadas em 2011, após décadas de estagnação. Além disso, com a ocupação de vazios na Av. Presidente Vargas e na Cidade Nova. (BRODE \& SAMPAIO, 2012, p. 16), alguns lançamentos comerciais importantes, como a nova sede da Petrobras na Rua do Senado, concluída em 2007, imprimiram mudanças no entorno, promovendo a reabilitação de imóveis para uso comercial e uma significativa valorização imobiliária - neste caso, da ordem de 450\%. (ROSA, 2014, p. 197-198)

Nos bairros que compõem a área central do Rio de Janeiro foi registrado, ainda, um aumento da renda média de R\$ 1.419,97, em 2000, para R\$2.819,99, em 2010, embora não se saiba se esse fenômeno é devido à chegada de novos moradores ou se corresponde a um aumento de renda dos existentes. (MOSCIARO, 2012, p. 83) Considerando-se o período entre 1991 e 2010, verifica-se, por fim, uma mudança significativa no nível educacional da população residente, com aumento, respectivamente, da ordem de $30 \%$ e 20\%, no que toca aos níveis médio e superior completo. (MOSCIARO, 2012, p. 95)

As transformações acima descritas não ocorrem de modo homogêneo na área central e vinculam-se claramente a determinados setores que, ao longo dos anos 2000 e da presente década, foram alvo de políticas específicas e investimentos públicos, como a Lapa. Em relação a este bairro, embora haja dificuldade na obtenção de dados específicos sobre o setor, estudos recentes dão conta do impacto das políticas municipais de revitalização nessa área, mostrando o conjunto de transformações pelas quais vem passando. Mosciaro (2012, p. 81-83) informa, por exemplo, sobre uma tendência de mudança no perfil da população residente, com a chegada de pessoas mais jovens, sem filhos, com mais instrução e de maior poder aquisitivo. Rosa (2012, p. 144-147), por sua vez, corrobora essa observação, mas assinala que parte desses novos moradores vêm da Zona Sul em busca de moradia mais barata. De todo modo, esse desenvolvimento residencial, que também se alimenta do sucesso recente da Lapa como polo de lazer e entretenimento, tem estimulado o surgimento de estabelecimentos como academias e lavanderias, o que se adequa ao perfil dos novos moradores. (ROSA, 2012, p. 148) Contudo, a alta de preços já instalada, bem como as mudanças ocorridas no comércio local, que vem se tornando mais caro e sofisticado, não estimulam um desenvolvimento habitacional para esses estratos sociais. 
15 Como as remoções que ocorreram no prédio abandonado do INSS, do qual 60 famílias foram retiradas, e no Hotel Bragança, de onde foram removidas outras 70 famílias, ambas em 2010. (ROSA, 2012, p. 102-106)
O crescimento comercial da Lapa tem sido muito significativo. Lá, os estabelecimentos cresceram $24 \%$ em 2011 , contra $9 \%$ no restante da cidade. (ROSA, 2012, p. 101) Trata-se, contudo, de um comércio centrado principalmente em restaurantes, bares e casas de espetáculos, relacionado à constituição do bairro como um polo cultural, gastronômico e de entretenimento. Esse sucesso comercial tem promovido não somente a vinda de alguns novos empreendimentos residenciais e comerciais, mas tem animado o desenvolvimento de um polo hoteleiro nos seus arredores, o que, certamente, foi incentivado pela realização da Copa do Mundo e das Olimpíadas. (ROSA, 2012, p. 140-141)

As transformações pelas quais a Lapa vem passando decorrem das intervenções implementadas pela Prefeitura do Rio de Janeiro no setor com o objetivo de servirem como referência para outras áreas de interesse histórico e cultural da cidade. Denominado de "Lapa Legal”, esse conjunto de intervenções ensejou a recuperação de monumentos, ordenamento e requalificação do espaço público, com foco na iluminação de vias, logradouros e monumentos, limpeza de galerias, melhoria da pavimentação, ampliação e conservação de calçadas, instalação de rampas e de novo mobiliário urbano, delimitação de estacionamentos noturnos e pontos de táxis, além do ordenamento de ambulantes e quiosques de venda nos Arcos da Lapa. (ROSA, 2012, p. 155-161)

Mas o sucesso de público da nova Lapa boêmia e também de sua exploração comercial e turística tem gerado conflitos com a população moradora, que é obrigada a conviver com os problemas, como acúmulo de lixo, barulho, sujeira e falta de segurança, que este sucesso de fim de semana tem gerado. De fato, a revitalização tem buscado mais o fortalecimento de uma dinâmica comercial do que qualquer outra meta. $\mathrm{O}$ impacto dessa situação nos moradores tem feito surgir um conjunto de movimentos sociais, como o "Eles não amam a Lapa" e o "Ocupa Lapa", que protestam contra o desrespeito aos habitantes, contra a repressão policial a manifestações políticas e contra a gentrificação do bairro. (ROSA, 2012, p. 93-97 e 150-152)

Para além dos protestos, a revitalização da Lapa tem implicado a remoção de moradores de ocupações irregulares, ${ }^{15}$ o fechamento de escolas públicas e o descaso para com equipamentos, como o Hospital do Carmo, cujo funcionamento tem sido submetido aos constrangimentos impostos pelo trânsito e pelo 
barulho gerados pela dinâmica noturna do bairro. (ROSA, 2012, p. 100-101 e 142-145) Em suma, aspectos importantes da vida cotidiana têm sido desconsiderados em benefício do funcionamento comercial e turístico. Rosa (2012, p. 263) observa que se realizou na Lapa uma espetacularização que rejeita a vida local e se apropria da história de modo raso e instrumental, apagando os vestígios do bairro familiar que também existiu no passado, e que ainda existe, para explorar o seu lado boêmio. (ROSA, 2012, p. 263)

A revitalização do Centro Histórico empreendida pela prefeitura, além das intervenções na Lapa, tem como âncora a Operação Urbana Consorciada Porto Maravilha (OUCPM). Sucedânea de uma série de projetos que remontam ao começo dos anos 1990, ${ }^{16}$ a operação atual teve início em 2009, com a promulgação de um conjunto de leis complementares ${ }^{17}$ que modificaram o Plano Diretor vigente, instituíram novos parâmetros urbanísticos para a Área de Especial Interesse Urbanístico da zona portuária e criaram a Companhia de Desenvolvimento Urbano do Porto (CDURP) - empresa de economia mista controlada pela prefeitura e criada para gerir a operação.

O Porto Maravilha surge como uma espécie de ponto culminante dos projetos anteriores e do "imaginário" que desenvolveram sobre a revitalização da zona portuária. (DINIZ, 2013, p. 89-93) Este imaginário gira em torno da definição da zona como um vetor de expansão da Área Central de Negócios, da apropriação estetizada do seu patrimônio histórico para a produção de vantagens competitivas, da implantação de usos múltiplos, da gestão público-privada, da modernização viária, da implantação de novos sistemas de transporte e, por fim, da inserção de empreendimentos-âncora na Praça e no Pier Mauá. Mas há também aspectos que poderiam ser vistos como novidades nesta operação: a produção de um discurso de viabilidade apoiado no bom momento econômico do país, do estado e do município do Rio de Janeiro em 2009, e a absorção, na íntegra, pelo projeto de lei que institui a operação urbana de documento elaborado pelo consórcio de empresas - constituído por OAS, Odebrecht e Carioca Christiani-Nielsen Engenharia - que, em seguida, ganhou a licitação. (DINIZ, 2013, p. 87-88; GALIZA, 2015, p. 86)

A OUC Porto Maravilha se organiza em torno de um componente denominado de "Programa Básico de Ocupação da Área", que envolve obras viárias,
16 Proposta de

Revitalização da Área Portuária da Gamboa (1991); Projeto de Estruturação Urbana da Área Portuária e Área de Especial Interesse Urbanístico da Zona Portuária (1992): Programa Nacional de Revitalização de Áreas Portuárias e Projeto Pier Mauá (1993); Porto do Rio: Plano de Recuperação e Revitalização da Região Portuária do Rio de Janeiro (2001-2006); e Programa Nacional de Reabilitação de Áreas Urbanas Centrais e GT Interministerial para a Região Portuária do Rio de Janeiro (2003).

17 Leis Complementares $\mathrm{n}^{\circ} 001 / 2009 \mathrm{e}$ $002 / 2009$. 
18 A União é proprietária de $62 \%$ dos imóveis, o estado do Rio de Janeiro é dono de $7 \%$ e o município, de $6 \%$, perfazendo um total de $75 \%$. Os $25 \%$ restantes pertencem a particulares. (GALIZA, 2015, p. 95)

19 O FIRP atua como pagador (tem natureza fiduciária) e o FIPM é o fundo de investimento que comprou, em leilão, todos CPACs disponíveis. (GALIZA, 2015, p. 108-117) implantação de sistema de transporte, mobilidade, saneamento, ampliação e construção de túneis, mudanças no sistema viário decorrentes da demolição do antigo Elevado da Perimetral, implantação de ciclovias e a construção de projetos-âncoras como a sede da Câmara Municipal, o Museu de Arte do Rio de Janeiro (MAR) e o Museu do Amanhã. (DINIZ, 2013, p. 83-84)

Embora definido como uma operação urbana, o Porto Maravilha não continha, em sua versão inicial, qualquer componente ligado à produção habitacional para faixas de renda mais baixa, à regularização fundiária ou à participação social, apesar de a maior parte dos imóveis da área ser de propriedade pública. ${ }^{18}$ Novos componentes, como os programas "Porto Maravilha Cidadão" e "Porto Maravilha Cultural", foram introduzidos depois, em resposta a pressões sociais. (DINIZ, 2013, p. 89-93)

Licitadas em 2010, as obras são executadas em regime de parceria público- privada pelo consórcio de empresas já mencionado, que assumiu a denominação de "Consórcio Porto Novo". A partir de 2011, com base em concessão urbanística, este grupo de empresas incorporou as tarefas de manutenção, operação e administração dos serviços municipais e dos decorrentes da revitalização da zona. (GALIZA, 2015, p. 90)

O financiamento da OUC Porto Maravilha baseia-se na emissão de 6.436.022 CPACs, correspondentes a cerca de 5 milhões de $\mathrm{m}^{2}$ de potencial construtivo criados na área, o que ancorou o discurso municipal de que a execução das obras não comprometeria recursos públicos e que dividiria riscos com a iniciativa privada. Contudo, como informa $\operatorname{Diniz}(2013$, p. 85-86), R 139 milhões, provenientes de recursos municipais e federais, já foram investidos na operação e boa parte do restante previsto - cerca de R\$ 8 bilhões - foi viabilizada por meio da compra de todos os CPACs disponíveis pela Caixa Econômica Federal (CEF), com uso de R\$3,5 bilhões do FGTS. Para que o custo total da operação seja financiado, portanto, é preciso que esses títulos se valorizem no mercado, atingindo um preço unitário correspondente $\mathrm{a}$, aproximadamente, o dobro do preço inicial de compra, que foi de $\mathrm{R} \$ 545,00$. Galiza (2015, p. 98) informa que um setor específico foi criado na CEF para administrar os recursos dos fundos imobiliários do Porto Maravilha, que esta instituição financeira administra, o Fundo Imobiliário da Região do Porto (FIRP) e o Fundo Imobiliário do Porto Maravilha (FIPM). ${ }^{19}$ 
É fácil concluir, portanto, que os riscos da operação foram assumidos integralmente pela CEF e pelo FGTS.

Apesar de ainda não concluída e ainda muito distante do seu fim, a OUCPM já vem produzindo transformações na zona portuária, além de alguns impactos negativos. A nova Praça Mauá e os museus-âncoras, MAR e do Amanhã, têm levado um grande público ao setor, o que foi magnificado durante os Jogos Olímpicos. As duas linhas de VLT instaladas, especialmente a que liga a rodoviária ao Aeroporto Santos Dumont, têm sido muito utilizadas pela população, minimizando a falta de transporte público de alta capacidade neste trecho da cidade. A demolição do elevado produziu também uma nova paisagem, permitindo a visão desimpedida de um patrimônio arquitetônico art déco e moderno, até então encoberto por esta via. Mas os impactos negativos sobre a população residente também são visíveis na alta nos aluguéis, no deslocamento de locatários e num aumento geral nos preços dos imóveis e terrenos da região da ordem de 500\%. (GALIZA, 2015, p. 92-93)

A grave crise política e econômica que se instalou no Brasil, a partir de 2014, coloca, certamente, sérias dúvidas sobre o futuro da operação, especialmente no que toca à valorização esperada dos CPACs, bem como no que diz respeito à concretização dos investimentos imobiliários previstos. Galiza (2015, p. 93-94) informa que, em 2014, analistas já apontavam as taxas altas de vacância em imóveis comerciais no Rio de Janeiro e em São Paulo. Dúvidas também ainda são levantadas quanto à possibilidade de um desenvolvimento residencial de classe média alta na região portuária. Contrariamente à expectativa inicial de que, em 2013, 25\% dos CPACs estivessem vendidos (GALIZA, 2015, p. 112), segundo o site oficial dessa operação urbana, até 29/04/2016, apenas 564.601 dos CPACs disponíveis haviam sido comercializados, o que equivale a $8,74 \%$ do total. Desse total, $17,42 \%$ (98.306 títulos) foram destinados ao uso residencial e 82,58\% (464.295 títulos) ao uso comercial. ${ }^{20}$

Apesar desses números, que colocam em xeque a viabilidade econômicofinanceira da operação, moradores do Morro da Providência foram removidos numa ação violenta que foi denunciada no filme Casas Marcadas. ${ }^{21}$ Pessoas sem-teto foram também expulsas de prédios públicos vazios, o que levou Galiza (2015, p. 46) a avaliar que, no Porto Maravilha, o componente habitacional é "rebaixado para dar lugar à produção de imóveis corporativos e comerciais", com benefícios
20 Informações extraídas da planilha constante de <http://www. portomaravilha. com.br/conteudo/ canalinvestidor/ planilha_estoques-2tı6. $\mathrm{pdf}>$, acesso em: 20 nov. 2016.

21 Filme dirigido por Adriana Barradas, Alessandra Schimite, Ana Clara Chequetti, Carlos R. S. Moreira, Éthel Oliveira e Juliette Lizeray, disponível em: <https://www. youtube.com/ watch?v=xao_4b8DJ_k>. 
exclusivos para a Caixa e para os parceiros privados da operação. Esta autora define, ainda, a operação como um o

projeto-piloto de uma nova modalidade de atuação da política urbana nacional, apoiada no instrumento Operação Urbana Consorciada e sustentada pelos investimentos do Fundo de Garantia por Tempo de Serviço (FGTS), uma fonte robusta de recursos financeiros. (GALIZA, 2015, p. 46)

O componente "Habitação no Porto Maravilha", que surgiu em 2014 para responder às críticas relativas ao descaso com a população local e para incorporar o lançamento de incentivos fiscais para projetos habitacionais de classe média, incorpora em seu discurso a manutenção dos atuais moradores. Pode ser visto também como uma resposta às pressões do Ministério das Cidades, que exigiu a elaboração de um plano de habitações de interesse social na área da operação, sob pena de não liberar mais recursos. (GALIZA, 2015, p. 115)

O patrimônio urbano existente na zona portuária é apropriado na OUC Porto Maravilha de modo semelhante ao que já ocorria nas operações dos anos 1990, ou seja, como elemento de distinção e de atração de atividades comerciais, turísticas, de serviços e lazer. Mas o discurso mobilizado agora para justificar esta renovação da relação entre desenvolvimento urbano e o patrimônio das áreas centrais, conforme observa Leopoldo Pio (2014, p. 2-4), se estrutura em torno das ideias de "reconhecimento" e de "conquista". "Reconhecimento" no sentido de que o patrimônio faz parte do direito de minorias e segmentos sociais populares à memória social, ao revelar o "esquecido" e o "ocultado". "Conquista", como discurso que unifica as várias memórias fragmentadas associadas ao espaço urbano e insere distintos testemunhos espaciais numa mesma lógica, para justificar e legitimar a retomada de espaços degradados da cidade dos seus habitantes.

No Porto Maravilha, essa função legitimadora, instrumentalizadora e pacificadora da memória e do patrimônio surge de modo claro no discurso que fundamenta, por exemplo, o "Circuito Histórico e Arqueológico da Celebração da Herança Africana”. Este é um roteiro turístico que articula diversos espaços de origem, destinação e apropriação distintas (como o Cais do Valongo, o Cemitério dos Pretos Novos, o Jardim do Valongo, a Pedra do Sal e o atual Centro Cultural 
José Bonifácio) a uma narrativa de valorização desses testemunhos urbanos que ignora as mazelas sociais e o racismo legados pela escravidão, desvinculando esses espaços da população pobre e afrodescendente que habita bairros e favelas do setor e inserindo-os numa apropriação museológica e de lazer urbano.

A OUC Porto Maravilha surge de modo referencial e emblemático no contexto atual das intervenções em áreas centrais e portuárias no Brasil, não somente pela sua "arquitetura" legal, projetual e financeira, ou pela função que nela assume a iniciativa privada, ou ainda pelo papel estratégico desempenhado pelo poder público na sua viabilização, mas também como demonstração da permanência, na década de 2010, da tendência, que já se verificava nos anos 1990, de crescimento da importância dos poderes executivos, particularmente o municipal, como instâncias viabilizadoras desse tipo de intervenção lastreada na apropriação do patrimônio público e legitimada pela preservação do patrimônio cultural. O "projeto" do PACCidades Históricas no Rio de Janeiro reforça essa observação e ilustra, por meio do seu caráter pontual e complementar das ações municipais na área central, a reconfiguração do papel do Governo Federal como instância financiadora e apoiadora, inclusive, por meio da modificação de aparatos legais. A OUCPM mostra ainda o fortalecimento e a consolidação do papel formulador e executor que a iniciativa privada - por meio de consórcios de empresas que atuam, simultaneamente, no ramo da construção e da produção imobiliária - vem adquirindo na formulação e execução de intervenções dessa natureza.

As chances de concretização das expectativas de atração de novas atividades, de novos usuários e de novos moradores para a zona portuária do Rio, contudo, permanecem incertas, a despeito de todo o investimento público realizado até agora e a despeito das alterações já promovidas na paisagem urbana. A crise política e econômica atualmente instalada coloca novamente em dúvida a expansão da $\mathrm{ACN}$ carioca e a permanência de uma postura contraditória da prefeitura que, ao continuar a incentivar vetores de produção imobiliária na Zona Sul e na Barra, diminui as chances da operação. Some-se a isso o resultado das ações de revitalização, cujo emblema atual é a Nova Lapa, onde ao invés do reforço do uso residencial, há muito considerado estratégico para a reabilitação e dinamização da área central, o que se vê é a promoção de um processo de gentrificação comercial. 
22 Escola de Dança e a Escola Municipal de Música.
Mas o Porto Maravilha e a Nova Lapa mostram também o crescimento da importância dos movimentos sociais de resistência, de reivindicação de participação e de afirmação de direitos relacionados à cidade e à cultura - algo incipiente nos anos 1990 no Rio e em Salvador. Sob diversas formas, e com o apoio e assessoria de organizações e setores da sociedade, esses movimentos têm denunciado ilegalidades e afrontas ao interesse público, expulsões de moradores e a concentração de benefícios privados em decorrência de intervenções financiadas pelo poder público. As chances que têm, contudo, de prevalecer e de modificar o rumo dessas ações permanecem pequenas.

\section{São Paulo}

O panorama geral da área central de São Paulo e, em particular, o relativo à preservação do patrimônio urbano que contém, não mudou muito em relação ao quadro verificado no começo dos anos 2000, após a deflagração dos programas de requalificação dos anos 1990. O conflito então verificado permanece o mesmo: de um lado, as operações e projetos urbanos que buscam animar a produção imobiliária e promover a gentrificação de alguns setores sem sucesso; e, de outro, os movimentos sociais por moradia na área central continuam resistindo e ocupando alguns espaços, mas sem grandes conquistas.

Um uso mais intenso do espaço público por artistas e pela juventude, contudo, pode ser contabilizado como um saldo positivo das ações de requalificação do centro, mas, de certa forma, também como um reflexo do seu fracasso, já que a ocupação de imóveis antigos arruinados por coletivos artísticos não tem se traduzido em ações de reabilitação ou de conservação do patrimônio. A Praça das Artes, concluída no final de 2012 no entorno do Teatro Municipal, que abriga espaços ligados ao teatro e um conjunto de equipamentos culturais e educacionais do município, ${ }^{22}$ contribuiu para essa intensificação do uso do espaço público, já que conjuga edifícios e espaços abertos à população.

Um outro desdobramento das iniciativas dos anos 1990 foi a apropriação dos parâmetros urbanísticos instituídos pela Operação Urbana Centro - que permaneceu como legislação específica da área - pelos novos programas e projetos inseridos em seu perímetro, que surgiram ou foram alterados após 2004, 
como ilustra o processo de transformação do Programa Ação Centro no Projeto Nova Luz. Mas essa apropriação, mais uma vez, não logrou atrair investimentos privados significativos em termos de produção imobiliária, por falta de interesse do mercado. (SOMEKH; FRAGONEZZI, 2016, p. 8)

O Programa de Parcelamento Incentivado (PPI), criado na gestão municipal Serra-Kassab (2005-2008), por sua vez, repercutiu negativamente nas iniciativas de produção de habitações de interesse social na área central, como propunha o Programa Morar no Centro. O PPI possibilitou que proprietários com dívidas com o município pudessem renegocia-las e parcela-las com descontos da ordem de $75 \%$ em relação às multas e com eliminação dos juros de mora. Com isso, imóveis abandonados e que já haviam sido destinados à produção de habitações de interesse social foram resgatados por seus donos, ou comprados, diminuindo a disponibilidade de imóveis para esses programas sociais.

No que toca aos programas de requalificação e revitalização do centro, cabe ressaltar a concentração dos esforços na área da Luz, onde o Programa Ação Centro, iniciado em 2003, foi muito alterado e transformado no mencionado Projeto Nova Luz. Como visto no Capítulo 4, este programa colocava uma forte ênfase no desenvolvimento do uso residencial nos bairros da periferia imediata do centro de São Paulo, contendo a delimitação de perímetros para melhoria do habitat. Na gestão Serra-Kassab, o seu perfil foi totalmente modificado, passando a focalizar apenas a área da Luz com uma ênfase maior em obras de requalificação do espaço urbano.

Essa alteração obedeceu a uma estratégia de concentração de esforços numa área onde já haviam sido feitos muitos investimentos por parte do governo estadual, cuja repercussão positiva vinha sendo prejudicada pela permanência de problemas, como a chamada Cracolândia. A despeito da absorção dos parâmetros urbanísticos estabelecidos na Operação Urbana Centro - que disponibiliza um farto estoque de potencial construtivo - o Projeto Nova Luz ficou estagnado. Começou a sair dessa situação somente quando da aprovação das Leis $n^{\circ} 14.917$ e $n^{0} 14.918$, ambas de 7 de maio de 2009, que instituíram, respectivamente, a concessão urbanística no município de São Paulo e a possibilidade de o executivo municipal aplicar este instrumento na área desse projeto. (SOMEKH; FREGONEZZI, 2016, p. 6) Como esta área contém uma ZEIS nas proximidades da 
23 Instituídos pela Lei $n^{\circ} 13.430$.
Estação da Luz, o número de quadras foi aumentado, com a inclusão daquelas próximas à Av. São João, a fim de se ampliar o potencial de atração da intervenção. O consórcio de empresas que venceu a licitação neste mesmo ano ficou responsável pela execução do projeto, pela compra e venda dos imóveis necessários à sua viabilização, pelo exercício do direito de preempção e pelo recebimento de doações, em suma, por todas as competências dessa esfera pública. (SOMEKH; FREGONEZZI, 2016, p. 6)

Numa área de comércio popular, especializada em eletroeletrônicos e acessórios para veículos, com mais de 10 mil moradores na faixa de renda média de 3 salários mínimos, além da Cracolândia, o foco do projeto são comércios e serviços voltados para faixas de renda mais altas e a promoção de uma ocupação residencial de classe média alta, focalizando profissionais liberais e artistas. (MAQUIAVELI, 2012, p. 150) Quando da audiência pública destinada à apresentação desse projeto urbano pelo consórcio vencedor, em 2011, conflitos entre a prefeitura e a associação dos comerciantes do bairro de Santa Efigênia levaram à judicialização do projeto e, por fim, à sua suspensão pelo Ministério Público. (MAQUIAVELI, 2012, p. 151) Com isso, os esforços para a gentrificação desse setor permanecem com resultados incertos, assim como permanecem sem grandes chances de desenvolvimento os projetos de fortalecimento de um uso habitacional de perfil popular.

Em relação, de um modo geral, ao patrimônio da cidade, permaneceu igualmente sem muita alteração o quadro de descompasso entre preservação e política urbana, que caracteriza a maioria das cidades brasileiras. Como observa Figueiredo (2014, p. 2-3), em São Paulo esse descompasso tem impedido que o patrimônio urbano possa desempenhar papel importante no desenvolvimento da cidade. O Plano Diretor Estratégico (PDE) e o Sistema de Planejamento de Gestão do Desenvolvimento de São Paulo, de 2002, ${ }^{23}$ propagaram a visão de que a função do patrimônio é apenas estética e de animação turística. (FIGUEIREDO, 2012, p. 2-3) Além disso, as Zonas Especiais de Preservação Cultural (ZPEC), que foram então instituídas, não estão articuladas aos planos e às demais categorias criadas pelo PDE - como as Áreas de Intervenção Urbana (AIU), os Projetos de Intervenção Estratégicos (PEIU), as Operações Urbanas Consorciadas (OUC) e as ZEIS -, propagando-se uma situação de superposição de categorias e instrumentos, o que promove contradições entre a legislação urbanística e a de 
preservação. (FIGUEIREDO, 2014, p. 9) Essa situação cria inúmeros problemas e desencontros, uma vez que a cidade de São Paulo, atualmente, possuiu cerca de 3 mil imóveis e 10 bairros tombados pelo município, com grande parte desse conjunto localizada na área central. (SOMEKH, 2015, p. 1)

São Paulo foi uma das primeiras cidades brasileiras a utilizar o instrumento da Transferência de Potencial Construtivo (TPC) em prol da preservação do patrimônio, instituindo essa possibilidade com a Lei nº 9.725, de 1984. Entretanto, como ocorreu em várias cidades brasileiras de grande e médio porte, nas quais o favorecimento de vetores consolidados de investimentos imobiliários e/ou a impossibilidade de transferir o potencial de imóvel protegido para esses vetores foram estabelecidos, esse instrumento pouco foi utilizado com vistas à preservação. Em São Paulo, até 2004, haviam sido realizadas apenas três transferências dessa natureza, e, até 2014, mesmo após modificações introduzidas pela Lei de Zoneamento, foram concluídas 44, o que é pouco, se confrontado com o número de imóveis protegidos. (SOMEKH, 2015, p. 14-15) O novo Plano Diretor, aprovado em 2014, ampliou as possibilidades de aplicação da TPC para além da conservação de bens tombados, possibilitando seu uso em áreas de preservação ambiental e de produção de habitações de interesse social, que, assim, passarão a competir com as zonas de preservação do patrimônio. (SOMEKH, 2015, p. 17) Assim, a conservação do patrimônio protegido, como nos anos 1990, segue sendo tratada no âmbito das operações e projetos urbanos, articulados agora às concessões urbanísticas.

Como observado por Siqueira (2014, p. 404), essas operações e instrumentos têm atuado como formas de promoção e acumulação de mais-valias urbanas geradas pelo capital imobiliário, e não como modo de compartilhar os custos da renovação, requalificação ou reabilitação do espaço urbano entre setor público e setor privado. Os CPACs que geram não chegam a capturar a valorização imobiliária que pode decorrer dessas intervenções em favor do setor público, uma vez que são negociados, normalmente, com base em um valor cerca de $30 \%$ mais baixo do que o necessário para tanto. (SIQUEIRA, 2014, p. 404) Além disso, esses títulos não são vinculados a um terreno por um período determinado, o que permite que investidores os retenham até a sua valorização, num movimento especulativo que prejudica o próprio mercado imobiliário, mas permite ligar essas operações aos mercados financeiros globais. (SIQUEIRA, 2014, p. 405) Contudo, esse tipo 
de processo tem ocorrido apenas nas áreas onde há um interesse prévio do mercado imobiliário. Nos centros antigos eles não têm funcionado dessa forma, ficando sem utilização a maior parte do potencial ofertado e sem transformações significativas dos quadros existentes. Em São Paulo, operações como Faria Lima, Águas Espraiadas e a Operação Urbana Centro corroboram essa afirmação. Mas o funcionamento pleno das operações urbanas consorciadas como instrumentos de gentrificação não depende só dos interesses do mercado. Vincula-se também à existência ou não de resistências a essas operações e ao quadro legal geral que as enquadra, o que abre brechas para o seu questionamento e para a eventual reversão dos seus efeitos de expulsão de populações vulneráveis, como ilustram algumas operações deflagradas em São Paulo.

\section{Breve balanço e perspectivas do momento atual}

O rápido relato da situação atual dos projetos e operações urbanas que envolvem a preservação do patrimônio em Salvador, no Rio de Janeiro e em São Paulo mostra que a década de 2010 corresponde ao desdobramento dos processos iniciados nos anos 1990, consolidando as áreas centrais dessas cidades como ativos urbanos e sua paisagem histórica como diferencial competitivo ofertado à exploração imobiliária e financeira. Corresponde, ainda, a um momento de aperfeiçoamento dos instrumentos financeiros, legais e urbanísticos para concretizar esses objetivos, o que fortaleceu o setor público como ator fundamental dessa estratégia e viabilizou a formulação e execução das operações necessárias pelo setor privado. Uma das medidas essenciais para a consecução desses objetivos foi a transformação dos programas e projetos dos anos 1990 em operaçóes urbanas consorciadas articuladas à exploração dos produtos dessas intervenções mediante concessões urbanísticas.

Se, nos anos 1990, ainda não estava clara a articulação das intervenções em áreas centrais patrimonializadas com a apropriação da produção desses espaços em operações ligadas aos mercados financeiros globais, essa articulação está, agora, fortemente evidenciada. A especulação com ativos e títulos vinculados a operações e projetos de reabilitação e produção imobiliária nessas áreas, por 
exemplo, ajuda a explicar, em Salvador, a compra de imóveis e terrenos para não se fazer nada com eles e os empréstimos subsidiados que são tomados para a implementação de empreendimentos que, na realidade, são aplicados em fundos de investimento, embolsando-se o lucro. O funcionamento contábil que esses fundos obtêm com operações desse tipo ajuda também a entender o exagero de potencial construtivo posto à disposição do mercado, mesmo que se saiba que este dificilmente será utilizado. O Estado, por seu turno, que deveria resguardar a política urbana como política pública, não o faz, e acolhe alegremente essas propostas, pois constituem também formas de promoção política e governamental.

Como observa Siqueira (2014, p. 402-406), o instrumento "operação urbana" tem origem internacional e se vincula à construção de um novo modelo de planejamento calcado na extração de mais-valia urbana, do qual elites locais tornaram-se aprendizes e executoras. No Brasil, atualmente, o uso do instrumento está basicamente voltado para a produção de infraestrutura urbana em áreas de interesse do mercado imobiliário. É o nível desse interesse o que explica o sucesso de uma operação dessa natureza e o seu malogro, ou funcionamento num nível meramente especulativo, em setores históricos centrais onde esse interesse não está plenamente configurado.

Como já se percebia no começo dos anos 2000, as especificidades de cada situação e a possibilidade que outros atores sociais prejudicados pelo resultado dessas operações possam ter de mobilização e resistência têm também um peso importante na determinação da capacidade de essas operações transformarem o quadro urbano pré-existente. Movimentos sociais, como visto, podem atuar de modo decisivo na inviabilização de projetos que ameaçam populações moradoras e usuários de expulsão. Embora sem a mesma força e efetividade dos movimentos paulistanos, que conseguiram cancelar a concessão urbanística do Projeto Nova Luz, o crescimento dessas forças e de sua atuação em Salvador e no Rio de Janeiro é inegável, devendo-se a elas o pouco que se conseguiu, até o momento, em termos do atendimento de demandas sociais e frenagem de processos que buscaram a gentrificação de setores centrais nessas cidades. Se, nos anos 1990, projetos de expulsão de moradores se desenvolveram nessas urbes praticamente sem resistência, a situação agora é outra, embora os atores dessa resistência sigam sendo os mais frágeis. 
Nos anos 1990, foi estabelecido o vínculo dos programas e projetos de requalificação, recuperação ou revitalização de setores centrais com o discurso do planejamento estratégico e com modelos de projetos urbanos desenvolvidos em países centrais. Atribuiu-se, então, grande parte de seu insucesso ou estagnação ao modo incompleto e fragmentado com que esses modelos eram implementados; ao seu divórcio com relação às demandas reais de uso e ocupação existentes; ao seu caráter pontual e desarticulado de dinâmicas socioeconômicas em curso; e, por fim, ao desinteresse das classes mais abastadas pelas localizações centrais, secundado pelo desinteresse de um mercado imobiliário acostumado a trabalhar apenas para elas. Na década atual, apesar das especificidades locais que interferem nos resultados de cada operação, assiste-se, a partir da referência criada pelo Porto Maravilha, o surgimento de uma espécie de adaptação nacional desses modelos fundamentada na aplicação do instrumento operação urbana consorciada a vastas áreas dotadas de apelos culturais e paisagísticos; no financiamento dessas operações por meio da negociação de títulos mobiliários no mercado, securitizados por fundos públicos; na mobilização de ativos e recursos públicos para o desenvolvimento da operação; na implementação de planos urbanísticos formulados por empresas privadas, dotados de projetos-âncoras voltados para usos culturais e comerciais; e, por fim, na concessão da exploração de serviços urbanos e ativos gerados pela operação à iniciativa privada.

Embora com nova roupagem e com instrumentos aperfeiçoados, as operações urbanas projetadas ou em curso nas cidades estudadas ainda estão por demonstrar sua capacidade real de transformação dos quadros existentes nos moldes projetados. Deflagrada num momento de euforia política e econômica, a operação na zona portuária do Rio de Janeiro - a mais emblemática das atuais - desenvolve-se a passos lentos, com fracas chances de continuidade, em face da crise econômica e política instalada. A despeito das mudanças pontuais ocorridas no perfil comercial e populacional de áreas como a Lapa carioca, a substituição de moradores de bairros centrais por segmentos mais abastados ainda está por ocorrer no Brasil. Mas, apesar de se manterem ainda num patamar fundamentalmente especulativo, a firme e articulada atuação dos poderes executivos no sentido da viabilização dessas operações thes dá, atualmente, mais chances de concretização do que no passado. 
É possível também perceber, nas intervenções e projetos contemporâneos, a continuidade de uma concepção de patrimônio urbano construída nos anos 1990, que dá proeminência às fachadas e desconsidera os demais elementos materiais e imateriais que o compõem. Percebe-se, ainda, um certo rebaixamento da importância da preservação do patrimônio no discurso legitimador das atuais operações, ainda que essa questão continue promovendo, como avalia Pio (2014), a construção das noções de "reconquista" e de reconhecimento patrimonial que estruturam seu discurso. Mas a criação de uma nova paisagem urbana caracterizada pela presença de objetos arquitetônicos destacados por sua ousadia formal, pelo padrão internacional fálico e lúdico das torres corporativas, tem suplantado o patrimônio urbano como chamariz visual. A ele tem sido dado um papel, cada vez mais coadjuvante, de elemento que promove o contraste que permite ressaltar a imponência dos feitos arquitetônicos atuais. Mesmo em áreas onde esses voos arquitetônicos não são possíveis, como o Centro Histórico de Salvador, a inserção de volumes que apelam para este contraste, como forma de renovar o ambiente urbano, tem sido constante.

Em termos mais especificamente urbanísticos, a renovação de setores históricos ou centrais por meio da implantação de transportes urbanos, como o VLT, tem sido recorrente. Independentemente da melhoria efetiva que possam trazer para a mobilidade urbana, a implantação desses bondes modernos tem gerado oportunidades de intervenções paisagísticas, de redesenho de vias, pavimentação e mobiliário urbano, que seguem um padrão internacional e têm funcionado como elemento homogeneizador. Em toda parte, têm constituído, ainda, oportunidades mais baratas de fazer parecer que graves problemas urbanos do setor dos transportes estão sendo resolvidos, bem como de promoção e marketing urbano. A produção dessas paisagens, que conjugam patrimônio, arquitetura fantástica e tecnologia de ponta no campo dos transportes, favorece, certamente, a atração e a renovação do interesse por áreas esvaziadas ou deterioradas, mas não favorece a função social e a densidade histórica do patrimônio urbano. Esses aspectos continuam ignorados e suplantados pela sua apropriação como insumo de projetos de gentrificação, pelo mero consumo visual e pela sua articulação a quimeras históricas de integração e harmonia social. 
Nos anos 1990, já se percebia que as intervenções urbanas implementadas nas áreas centrais de grandes cidades teriam como um dos seus efeitos despertar a consciência social sobre sua incapacidade de acolher e solucionar demandas sociais e urbanas, bem como de reverter processos de esvaziamento funcional e de degradação da qualidade urbana. Os últimos anos têm mostrado que isso de fato ocorreu e que os segmentos sociais afetados negativamente por essas intervenções não são mais simples espectadores passivos, mas, cada vez mais, atores fundamentais das conjunturas onde essas novas atrações/explorações urbanas tentam se implantar. 


\section{Referências}

ABRAHÃO, S. L. Cooperação entre o poder público e a iniciativa privada: uma relação delicada. 1999. 137 f. Dissertação (Mestrado em Arquitetura e Urbanismo) - Faculdade de Arquitetura e Urbanismo, Universidade de São Paulo, São Paulo, 1999.

ABREU, M. de A. Evolução urbana do Rio de Janeiro. Rio de Janeiro: Zahar, 1987.

ACORDO de Cooperação Técnica entre Ministério da Cultura, IPHAN e Caixa Econômica Federal para estabelecimento de parceria no âmbito do Programa de Reabilitação Urbana de Sítios Históricos - URBIS e do Programa de Revitalização de Sítios Históricos. Brasília, 2000.

AJUDA-MEMÓRIA: missão de identificação: programa de Recuperação do Patrimônio Histórico e Cultural, Brasil. Brasília, 16-25 set. 1996. (Programa Monumenta/BID, BR-0261).

AJUDA-MEMÓRIA: missão de identificação II: programa de Preservação do Patrimônio Histórico e Cultural Urbano, Brasil. Brasília, 13-27 jan. 1997a. (Programa Monumenta/ BID, BR-0261).

AJUDA-MEMÓRIA: missão de orientação: programa de Recuperação do Patrimônio Histórico e Cultural Urbano, Brasil. Brasília, 15-29 set. 1997b. (Programa Monumenta/ BID, BR-0261).

AJUDA-MEMÓRIA: visita do Dr. Pedro Taddei Neto a Washington: programa de Preservação do Patrimônio Histórico e Cultural Urbano, Brasil. Washington, D.C., 05-06 maio 1997C. (Programa Monumenta/BID, BR-0261). 
AJUDA-MEMÓRIA: missão de análise: programa de Recuperação do Patrimônio Histórico e Cultural Urbano, Brasil. Brasília, 30 nov./16 dez. 1998a. (Programa Monumenta/BID, BR-0261).

AJUDA-MEMÓRIA: missão de orientação II: programa de Recuperação do Patrimônio Histórico e Cultural Urbano, Brasil. Brasília, 22 maio-2 jun. 1998b. (Programa Monumenta/BID, BR-0261).

AJUDA-MEMÓRIA: missão de orientação III: programa de Recuperação do Patrimônio Histórico e Cultural Urbano, Brasil. Brasília, 5-9 out. 1998c. (Programa Monumenta/ BID, BR-0261).

AMADIO, D. Alguma coisa acontece...: uma investigação sobre o Centro de São Paulo. 1998. 142 f. Dissertação (Mestrado em Arquitetura e Urbanismo) - Faculdade de Arquitetura e Urbanismo, Universidade de São Paulo, São Paulo, 1998.

ANDERSON, P. As origens da pós-modernidade. Rio de Janeiro: Zahar, 1999.

ANDRADE, M. A capela de Santo Antônio. Revista do Patrimônio Histórico e Artístico Nacional, Rio de Janeiro, n. 1, p. 120-125, 1937.

ARANTES, O. Uma estratégia fatal: a cultura nas novas gestões urbanas. In: ARANTES, O.; VAINER, C.; MARICATO, E. A cidade do pensamento único: desmanchando consensos. Petrópolis: Vozes, 2000. p. 11-74. (Coleção Zero à esquerda).

ARANTES, O. O lugar da arquitetura depois dos modernos. São Paulo: EDUSP: Studio Nobel, 1993.

ARANTES, O. Urbanismo em fim de linha e outros estudos sobre o colapso da modernização arquitetônica. São Paulo: EDUSP, 1998.

(UMA) ARRANCADA segura. URBS, São Paulo, p. 7, jan. 1998.

ASSIS, D. Revitalizar: fruto da conscientização. URBS, São Paulo, p. 40-43, out. 1997.

ASSOCIAÇÃO DOS SERVIDORES DO IPHAN. Patrimônio histórico e política cultural. Rio de Janeiro, 1999.

ASSOCIAÇÃO VIVA O CENTRO. Camelôs: subsídios para o equacionamento do problema do comércio informal de rua e sua solução. São Paulo, 1994.

ASSOCIAÇÃO VIVA O CENTRO. A rua no Centro: uma discussão sobre a rua e seus atores sociais. São Paulo, 1995.

ASSOCIAÇÃO VIVA O CENTRO. Relatório de Atividades 1996. São Paulo, 1996.

ASSOCIAÇÃO VIVA O CENTRO. Relatório de Atividades 1997. São Paulo, 1997.

ASSOCIAÇÃO VIVA O CENTRO. Relatório de Atividades 1998. São Paulo, 1998. 
ASSOCIAÇÃO VIVA O CENTRO. Relatório de Atividades 1999/2000. São Paulo, 2000.

ASSOCIAÇÃO VIVA O CENTRO. Estatuto da Associação Viva o Centro. São Paulo, [200o?].

ASSOCIAÇÃO VIVA O CENTRO. Núcleo de participação local: estatuto padrão.

São Paulo, $2001 \mathrm{a}$.

ASSOCIAÇÃO VIVA O CENTRO. O Programa de ações locais: conceitos e estratégias.

São Paulo, 2001b.

AZEVEDO, E. Quem consome tanta cultura? Jornal do Brasil, Rio de Janeiro, o7 fev. 2002.

Caderno B, p. 1-5.

AZEVEDO, P. O. D. de. O caso do Pelourinho. In: ARANTES, A. A. (Org.). Produzindo o passado: estratégias de construção do patrimônio cultural. São Paulo: Brasiliense, 1984. p. $219-255$.

AZEVEDO, P. O. D. de. A recuperação do patrimônio habitacional. Revista de Arquitetura e Urbanismo, Salvador, v. 1, n. 1, p. 35-51, 1988.

AZEVEDO, P. O. D. de. La lenta construcción de modelos de intervención en centros históricos americanos. In: CARRIÓN, F. (Ed.). Centros históricos de América Latina y el Caribe. Quito: FLACSO, 2001. p. 297-315.

BAHIA. Companhia de Desenvolvimento Urbano do Estado da Bahia. CONDER.

Centro Antigo de Salvador: plano de reabilitação participativo: Avanços. Salvador, 2014.

BAHIA. Secretaria da Cultura e Turismo; FUNDAÇÃO DO PATRIMÔNIO ARTÍSTICO E CULTURAL DA BAHIA. Pelourinho: levantamento sócio-econômico. 2. ed. Salvador, 1997.

BAHIA. Secretaria de Cultura. Fundação Pedro Calmon. Centro Antigo de Salvador: plano de reabilitação participativo. Salvador, 2010.

BALABAN, M. D. Os indicadores quantitativos da cultura. Brasília: Ministério da Cultura, 1998.

BANCO INTERAMERICANO DE DESENVOLVIMENTO. Una obra en marcha: el Banco Interamericano de Desarrollo y la protección del patrimonio cultural. Washington, D.C., 2001.

BANCO INTERAMERICANO DE DESENVOLVIMENTO. Mission de Coopération Technique: réhabilitation de l'habitat en Centre Historique: Salvador de Bahia et João Pessoa. [S.L.], 2002. (Rapport de Mission, n. 1).

BANCO INTERAMERICANO DE DESENVOLVIMENTO. Mission de Coopération Technique: réhabilitation de l'habitat en Centre Historique: Salvador de Bahia et João Pessoa. [S.L.], 2003. (Rapport de Mission, n. 2).

BANKBOSTON. Centro de São Paulo 1999/2000: a grande virada. São Paulo, 2000. 
BIENENSTEIN, G. Espaços metropolitanos em tempos de globalização: um estudo de caso do Rio de Janeiro. 200o. Tese (Doutorado em Planejamento Urbano e Regional) Instituto de Pesquisa e Planejamento Urbano e Regional, Universidade Federal do Rio de Janeiro, Rio de Janeiro, 2000.

BLYTH, A. Cristalização espacial e identidade cultural: uma abordagem da herança urbana: o SAARA, na área central da Cidade do Rio de Janeiro. 1991. Dissertação (Mestrado em Geografia) - Instituto de Geociências, Universidade Federal do Rio de Janeiro, Rio de Janeiro, 1991.

BONDUKI, N. Habitação na área central de São Paulo: uma opção por uma cidade menos segregada, por um centro sem exclusão social. In: SÃO PAULO (Estado). Câmara Municipal. Comissão de Estudos sobre Habitação na Área Central: relatório final. São Paulo, 2001. p. 3-10.

BORGES, L. D. O turismo em Salvador e as imposições externas. Bahia Análise \& Dados, Salvador, v. 12, p. 135-140, dez. 2002.

BOSI, V. Núcleos históricos: recuperação e revitalização: a experiência de Olinda. Revista do Patrimônio Histórico e Artístico Nacional, Rio de Janeiro, n. 21, p. 134-146, 1986.

BOSI, V. Participação e pesquisa na preservação do patrimônio cultural. Revista do Patrimônio Histórico e Artístico Nacional, Rio de Janeiro, n. 22, p. 138-144, 1987.

BOSI, V.; SILVA, T. R. da. Compatibilização entre demanda e oferta de recursos. Brasília: Fundação Nacional Pró-Memória: Banco Nacional da Habitação, 1982. Xerografado.

BOTELHO, I. A diversificação das fontes de financiamento para a cultura:

um desafio para os poderes públicos. In: MOISÉS, J. A.; BOTELHO, I. (Org.). Modelos de financiamento da cultura: os casos do Brasil, França, Inglaterra, Estados Unidos e Portugal. Rio de Janeiro: FUNARTE, 1997. p. 95-106.

BRASIL. Ministério da Cultura. Secretaria de Apoio à Cultura. Orçamentos de projetos da área do patrimônio cultural. Brasília, [199-].

BRASIL. Congresso. Câmara dos Deputados. Relatório: a situação do Instituto do Patrimônio Histórico e Artístico Nacional (IPHAN) e a atual política de preservação do Patrimônio Cultural no Brasil. Brasília: Diretoria Legislativa, 1999a.

BRASIL. Ministério da Cultura. Grupo Tarefa IPHAN - Programa Monumenta. Relatório de Atividades 1999. Brasília, 1999b.

BRASIL. Secretaria de Desenvolvimento Urbano. Plano de ação para o desenvolvimento urbano: julho/1999. Brasília, 1999c.

BRASIL. Ministério da Cultura. Relatório das atividades do G.T. Programa Nacional do Patrimônio Imaterial. Brasília, $2000 a$. 
BRASIL. Ministério da Cultura. URBIS - Programa de Reabilitação Urbana de Sítios Históricos: ações estruturadoras de política. Brasília, 2000 b.

BRASIL. Ministério da Cultura. URBIS - Programa de Reabilitação Urbana de Sítios Históricos: ações executivas de curto prazo. Brasília, 2000c.

BRASIL. Ministério da Cultura. Grupo Tarefa IPHAN - Programa Monumenta. Relatório de Atividades 2000. Brasília, 2000d.

BRASIL. Departamento de Aviação Civil. Divisão de Estatística e Gestão do Sistema. Anuário do Transporte Aéreo. 2001a. v. l. Disponível em: <www.dac.gov.br>. Acesso em: maio 2003.

BRASIL. Ministério da Cultura. Atas de Reunião do Grupo de Trabalho instituído pelo Acordo de Cooperação Técnica MinC/IPHAN/CEF. Brasília, $2001 b$.

BRASIL. Ministério da Cultura. Diagnóstico estratégico do MinC e entidades vinculadas. Brasília, 2001c.

BRASIL. Ministério da Cultura. Missão de Arranque: programa de Preservação do Patrimônio Histórico Urbano - Monumenta. Brasília, 20oıd.

BRASIL. Ministério da Cultura. Programa de Preservação do Patrimônio Cultural Urbano Monumenta: regulamento operativo. Brasília, $2001 e$.

BRASIL. Ministério da Cultura. Programa de Preservação do Patrimônio Cultural Urbano Monumenta: Regulamento operativo. Brasília, $2001 f$.

BRASIL. Ministério da Cultura. Termo Geral de Referência para Plano de Preservação de Sítio Histórico. Brasília, 2001g. (URBIS, Documento o1).

BRASIL. Ministério da Cultura. URBIS - Programa de Reabilitação Urbana de Sítios Históricos: estratégia operacional. Brasília, 2001h.

BRASIL. Ministério da Cultura. URBIS - Programa de Reabilitação Urbana de Sítios Históricos: guia informativo. Brasília, 2001i.

BRASIL. Ministério da Cultura. Grupo Tarefa IPHAN - Programa Monumenta.

Prioridades de Conservação: volume I - Norte, Nordeste e Centro-Oeste. Brasília, 2001j. (Caderno Técnico, n. 4).

BRASIL. Ministério da Cultura. Grupo Tarefa IPHAN - Programa Monumenta. Prioridades de Conservação: volume II - Sul e Sudeste. Brasília, 2001k. (Caderno Técnico, n. 5).

BRASIL. Ministério da Cultura. Grupo Tarefa IPHAN - Programa Monumenta. Relatório de Atividades 2001. Brasília, 2001 .

BRASIL. Ministério da Cultura. $7^{a}$ Missão de Administração: programa de Preservação do Patrimônio Histórico Urbano - Monumenta. Brasília, 2002a. 
BRASIL. Ministério da Cultura. Projeto de Recuperação do Bairro da Luz - São Paulo: UEP-São Paulo: resumo executivo. São Paulo, 2002b.

BRASIL. Ministério da Cultura. Projeto de Revitalização da Praça Tiradentes.

Rio de Janeiro, 2002C.

BRASIL. Ministério da Cultura. URBIS - Programa de Reabilitação Urbana de Sítios Históricos: relatório de gestão 2001. Brasília, 2002d.

BRASIL. Ministério da Cultura. Grupo Tarefa IPHAN - Programa Monumenta. Relatório de Atividades 2002. Brasília, 2002e.

BRASIL. Ministério da Cultura; BANCO INTERAMERICANO DE DESENVOLVIMENTO. Contrato de Empréstimo n 1200/OC-BR entre a República Federativa do Brasil e o Banco Interamericano de Desenvolvimento, Programa de Preservação do Patrimônio Histórico Urbano (Monumenta). Brasília, 1999.

BRASIL. Ministério da Cultura; BANCO INTERAMERICANO DE DESENVOLVIMENTO; UNESCO. Programa Monumenta. Brasília, 2002.

BRASIL. Ministério do Turismo. Anuário estatístico de turismo - 2014 - Ano-base 2013. Brasília, 2014. Disponível em: <http://www.dadosefatos.turismo.gov.br/dadosefatos/ anuario>. Acesso em 25 abr. 2015.

BRASIL. Tribunal de Contas da União. Relatório de auditoria operacional no Programa de Preservação do Patrimônio Histórico Urbano - Monumenta. Diário Oficial [da] República Federativa do Brasil, Brasília, 13 ago. $2002 f$.

BRODE, A. de L. P.; SAMPAIO, A. da R. Políticas Urbanas e Patrimônio Cultural: paradoxos e diálogos na área urbana central do Rio de Janeiro. In: CONGRESSO INTERNACIONAL DE AMERICANISTAS - CONSTRUYENDO DIÁLOGOS EN LAS AMERICAS, 54., 2012, Viena, AUT. Anais... Viena, AUT, 1-20 Jul. 2012.

CABRAL, S. L. Operação urbana consorciada da região do porto do Rio de Janeiro Porto Maravilha. 2011. Trabalho de Conclusão de Curso (Especialização) -. IBMEC, Brasília, 2011.

CAIXA ECONÔMICA FEDERAL. Estudos de viabilidade de reabilitação de imóveis de uso habitacional em sítios históricos. [S.L.], [2001?].

CAIXA ECONÔMICA FEDERAL. Reabilitação urbana de áreas centrais: ações estratégicas para o desenvolvimento urbano. [S.L.], 2003.

CAMPELLO, G. Ações pelo Patrimônio. In: WEFFORT, F.; SOUZA, M. (Org.). Um olhar sobre a cultura brasileira. Rio de Janeiro: Associação de Amigos da FUNARTE, 1998. p. 123-144.

CARDOSO, A. L. Mercado imobiliário e segregação: a cidade do Rio de Janeiro. In: RIBEIRO, L. C. de Q. (Org.). O futuro das metrópoles: desigualdades e governabilidade. Rio de Janeiro: IPPUR: FASE: Revan, 2000. p. 319-350. 
CARVALHO, E. A questão da população no centro histórico de Salvador. Revista de Arquitetura e Urbanismo, Salvador, v. 1, n. 0, p. 63-72, 1988.

CARVALHO, I. M. A centralidade em Salvador: parâmetros para um debate. 1997. $165 \mathrm{f}$. Dissertação (Mestrado em Arquitetura e Urbanismo) - Faculdade de Arquitetura e Urbanismo, Universidade Federal da Bahia, Salvador, 1997.

CARVALHOSA, M. Weffort deu "golpe". Folha de S. Paulo, São Paulo, 3 fev. 1999.

Ilustrada, p. 6.

CASTELLS, M. O poder da identidade. São Paulo: Paz e Terra, 1999a. (Coleção A era da informação: economia, sociedade e cultura).

CASTELLS, M. A sociedade em rede. São Paulo: Paz e Terra, 1999b. (Coleção A era da informação: economia, sociedade e cultura).

O CENTRO além dos trilhos. URBS, São Paulo, p. 8-16, fev./mar. 2001.

CENTRO CULTURAL BANCO DO BRASIL. Associação de Amigos do CCBB.

[Rio de Janeiro, 199-a].

CENTRO CULTURAL BANCO DO BRASIL. Guia para a formação e utilização de espaços culturais. [Rio de Janeiro, 199-b].

CENTRO CULTURAL BANCO DO BRASIL. Relatório anual de atividades 2001.

São Paulo, 2001.

CENTRO CULTURAL LIGHT. Relatório Anual de Atividades e Custos. Rio de Janeiro, 1998.

(OS) CENTROS das metrópoles: reflexões e propostas para a cidade democrática do século XXI. São Paulo: Viva o Centro, 2001.

CENTRO DE ARQUITETURA E URBANISMO (RJ). Porto do Rio. Rio de Janeiro, 2001.

CHASTEL, A. La notion du patrimoine. In: NORA, P. (Org.). Les lieux de memoire. Paris: Gallimard, 1984.

CHOAY, F. Mondialization ou dynamisation du patrimoine culturel bâti. [S.L.: S.n., 199-?.]. Xerografado.

CHOAY, F. L'allégorie du patrimoine. Paris: Éditions du Seuil, 1996.

COCCO, G. et al. (Org.). A cidade estratégica: novas e velhas práticas no planejamento do Rio de Janeiro: a impostura do Porto de Sepetiba. Rio de Janeiro: DP\&A, 2001.

COMPANHIA DE DESENVOLVIMENTO DA REGIÃO METROPOLITANA

DE SALVADOR. Centro Histórico de Salvador. Salvador, 1992.

COMPANHIA DE DESENVOLVIMENTO DA REGIÃO METROPOLITANA

DE SALVADOR. Avaliação do impacto dos investimentos na recuperação do Pelourinho: sinopse. Salvador, 1995. 
COMPANHIA DE DESENVOLVIMENTO DA REGIÃO METROPOLITANA

DE SALVADOR. Opinião no Centro Histórico de Salvador: relatório analítico. Salvador, 1996a.

COMPANHIA DE DESENVOLVIMENTO DA REGIÃO METROPOLITANA DE SALVADOR. Projeto Linha Turística. Salvador, 1996b.

COMPANHIA DE DESENVOLVIMENTO DA REGIÃO METROPOLITANA DE SALVADOR. Proposta de gerenciamento para o Centro Histórico de Salvador. Salvador, 1996C.

COMPANHIA DE DESENVOLVIMENTO DA REGIÃO METROPOLITANA

DE SALVADOR. Descritivo técnico dos projetos de patrimônio do Centro Histórico de Salvador. Salvador, 1997.

COMPANHIA DE DESENVOLVIMENTO DA REGIÃO METROPOLITANA DE SALVADOR. Relatório de análise crítica da pesquisa sócio-econômica do Projeto Centro Histórico: $7^{a}$ etapa e Barroquinha (versão final). Salvador, 1998.

COMPANHIA DE DESENVOLVIMENTO DA REGIÃO METROPOLITANA

DE SALVADOR. Programa de Recuperação do Centro Histórico de Salvador - Bahia, $7^{a}$ Etapa: avaliação econômica, estudo de pré-viabilidade (versão final). Salvador, [1999?].

COMPANHIA DE DESENVOLVIMENTO DA REGIÃO METROPOLITANA DE SALVADOR; INSTITUTO DO PATRIMÔNIO ARTÍSTICO E CULTURAL DA BAHIA. Análise crítica da pesquisa sócio-econômica da $6^{a}$ etapa do Centro Histórico de Salvador. Salvador, 1997.

COMPANHIA DE DESENVOLVIMENTO DA REGIÃO METROPOLITANA DE SALVADOR; INSTITUTO DO PATRIMÔNIO ARTÍSTICO E CULTURAL DA BAHIA. Avaliação sócio-econômica e estudo de alternativas dos projetos da $6^{a}$ etapa e Quarteirão Cultural do Centro Histórico de Salvador. Salvador, 1998a.

COMPANHIA DE DESENVOLVIMENTO DA REGIÃO METROPOLITANA DE SALVADOR; INSTITUTO DO PATRIMÔNIO ARTÍSTICO E CULTURAL DA BAHIA. Plano preliminar de reassentamento: centro Histórico de Salvador: Projetos $7^{\mathrm{a}}$ etapa e Barroquinha. Salvador, 1998b.

COMPANHIA DE DESENVOLVIMENTO URBANO DO ESTADO DA BAHIA. Relatório da pesquisa sócio-econômica e ambiental: recuperação da $7^{a}$ etapa do CHS Pelourinho. Salvador, 2000.

COMPANHIA DE DESENVOLVIMENTO URBANO DO ESTADO DA BAHIA. Relatório de pesquisa: $7^{\text {a }}$ etapa habitacional/comercial. Salvador, 2001.

COMPANHIA DE DESENVOLVIMENTO URBANO DO ESTADO DA BAHIA; INSTITUTO DO PATRIMÔNIO ARTÍSTICO E CULTURAL DA BAHIA. Dinâmica urbana para oportunidades de investimentos no Centro Histórico de Salvador. Salvador, $1999 a$. 
COMPANHIA DE DESENVOLVIMENTO URBANO DO ESTADO DA BAHIA; INSTITUTO DO PATRIMÔNIO ARTÍSTICO E CULTURAL DA BAHIA. Estudos para a $7^{a}$ etapa do Programa de Recuperação do Centro Histórico de Salvador -BA: avaliação de impactos ambientais e sociais. Salvador, $1999 b$.

COMPANHIA DE DESENVOLVIMENTO URBANO DO ESTADO DA BAHIA; INSTITUTO DO PATRIMÔNIO ARTÍSTICO E CULTURAL DA BAHIA. Projeto executivo: adaptação/ reutilização de imóveis no Centro Histórico de Salvador para uso habitacional multifamiliar: relatório de seleção dos imóveis (7ª etapa). Salvador, 1999C.

COMPANHIA METROPOLITANA DE HABITAÇÃO DE SÃO PAULO. Habitação no Centro: o Programa da Prefeitura. São Paulo, 2001.

CONSELHO INTERNACIONAL DE MONUMENTOS E SÍTIOS. Seção Francesa. Brasil. Amélioration de l'habitat dans les centres anciens de Recife et São Luis de Maranhão (Brésil): Mission octobre 2001. [S.L.], 2001 .

CONSELHO INTERNACIONAL DE MONUMENTOS E SíTIOS. Seção Francesa. Brasil. Mission de Coopération Technique - Réhabilitation de l'Habitat du Centre Historique: Belém, 30 oct./o3 nov. 2001. [S.L.], 2001b. (Rapport de Mission, n. 2).

CONSELHO INTERNACIONAL DE MONUMENTOS E SÍTIOS. Seção Francesa. Brasil. Patrimoine historique et revitalization des sites urbains: petites et moyenne villes - Minas Gerais, 18-26 sept. 2001. [S.L.], 2001c. (Rapport de Mission d’Expertise)

CONSELHO INTERNACIONAL DE MONUMENTOS E SÍTIOS. Seção Francesa. Brasil. Réhabilitation urbaine, coopération technique: Rapport de Mission de Nancy Bouché. [S.L.], 2001d.

CONSELHO INTERNACIONAL DE MONUMENTOS E SÍTIOS. Seção Francesa. Brasil. Villes de Recife et São Luis: 18-24 jul. 2001. [S.L.], 2001e. (Rapport de Mission).

CONSELHO INTERNACIONAL DE MONUMENTOS E SÍTIOS. Seção Francesa. Brasil. Rapport de Mission des 7 et 8 mars 2002. [S.L.], 2002.

CORRÊA, S. R. M. O Programa de Cidades Históricas (PCH): por uma política integrada de preservação do patrimônio cultural - 1973-1979. 2012. 288 f. Dissertação (Mestrado em Arquitetura e Urbanismo) - Faculdade de Arquitetura e Urbanismo, Universidade de Brasília, Brasília, 2012.

COSTA, J. F. Ordem médica e norma familiar. Rio de Janeiro: Graal, 1989.

COSTA, L. Lucio Costa: documentos de trabalho. Rio de Janeiro: IPHAN, 1999.

CRUZ, A. B. de S. O uso habitacional e a identidade cultural na revitalização de sítios históricos urbanos: o bairro Cruz Vermelha-RJ. 2000. Dissertação (Mestrado em Arquitetura e Urbanismo) - Faculdade de Arquitetura e Urbanismo, Universidade Federal do Rio de Janeiro, Rio de Janeiro, 2000. 
DECIA, P. Advogado denuncia favorecimento no IPHAN. Folha de S. Paulo, São Paulo, 3 fev. 1999. Ilustrada, p. 6.

DECIA, P. Conselho repudia mudança no IPHAN. Folha de S. Paulo, São Paulo, 30 jan. 1999. Ilustrada, p. 5.

DELEUZE, G. Foucault. 2. ed. São Paulo: Brasiliense, 1991.

DELEUZE, G. Conversações 1972-1990. Rio de Janeiro: Ed. 34, 1992.

DEUTSCHE, R. Evictions: art and spatial politics. Chicago: Graham Foundation for Advanced Studies in the Fine Arts; Cambridge: MIT Press, 1996.

DINIZ, N. Da emergência do imaginário da revitalização ao Porto Maravilha. 2013. 123 f. Dissertação (Mestrado em Planejamento Urbano e Regional) - Instituto de Pesquisa e Planejamento Urbano e Regional, Universidade Federal do Rio de Janeiro, Rio de Janeiro, 2013.

DURAND, J. C.; GOUVEIA, M. A.; BERMAN, G. Patrocínio empresarial e incentivos fiscais à cultura no Brasil: análise de uma experiência recente. In: MOISÉS, J. A.; BOTELHO, I. (Org.). Modelos de financiamento da cultura: os casos do Brasil, França, Inglaterra, Estados Unidos e Portugal. Rio de Janeiro: FUNARTE, 1997. p. 39-50.

EMBRATUR. Evolução do turismo no Brasil: 1992-2002. [2002?]. Disponível em: <www.embratur.gov.br>. Acesso em: 18 nov. 2003.

EMBRATUR; FUNDAÇÃO INSTITUTO DE PESQUISAS ECONÔMICAS (SP). Estudo do mercado interno de turismo 2001. Brasília, [2002?].

EMPRESA DE TURISMO DA BAHIA. Pesquisa de demanda turística. Salvador, 2000.

EMPRESA DE TURISMO DA BAHIA. Desempenho do turismo baiano 1991-2000: versão síntese. Salvador, 2001a. (Informativo gerencial série E, n. 02).

EMPRESA DE TURISMO DA BAHIA. Pesquisa de demanda turística. Salvador, 20016.

EMPRESA MUNICIPAL DE INFORMÁTICA E PLANEJAMENTO (RJ). Cinelândia: projeto de Reestruturação Urbana. Rio de Janeiro, 1990a.

EMPRESA MUNICIPAL DE INFORMÁTICA E PLANEJAMENTO (RJ). Largo de São Francisco: projeto de Reestruturação. Rio de Janeiro, 199ob.

EMPRESA MUNICIPAL DE INFORMÁTICA E PLANEJAMENTO (RJ). Centro: programa de Fortalecimento e Recuperação. Rio de Janeiro, [1992?].

EMPRESA MUNICIPAL DE INFORMÁTICA E PLANEJAMENTO (RJ); INSTITUTO MUNICIPAL DE ARTE E CULTURA (RJ). Reestruturaçâo do Largo da Lapa. Rio de Janeiro, 1989. 
EMPRESA MUNICIPAL DE INFORMÁTICA E PLANEJAMENTO (RJ); INSTITUTO MUNICIPAL DE ARTE E CULTURA (RJ). Reestruturação da Rua Uruguaiana.

Rio de Janeiro, $1989 b$.

EMPRESA MUNICIPAL DE URBANIZAÇÃO (SP). Cartilha da Área Central - Operação Urbana Centro. 2. ed. São Paulo, [199-].

EMPRESA MUNICIPAL DE URBANIZAÇÃO (SP). Programa de Reabilitação do Centro. São Paulo, maio 2002a.

EMPRESA MUNICIPAL DE URBANIZAÇÃO (SP). Programa de Reabilitação do Centro. São Paulo, out. 2002b.

EWALD, F. Foucault, a Norma e o Direito. 2. ed. Lisboa: Vega, 2000.

FAUSTO, B. A Revolução de 1930: historiografia e história. São Paulo: Brasiliense, 1969.

FELDMAN, S. Tendências recentes de intervenção em centros metropolitanos.

In: SÃO PAULO (Estado). Câmara Municipal. Comissão de estudos sobre habitação na área Central: relatório final. São Paulo, 2001. p. 19-21.

FENERICH, A. R. L. Preservação em São Paulo: análise de procedimentos metodológicos. 2000. Dissertação (Mestrado em Arquitetura e Urbanismo) - Faculdade de Arquitetura e Urbanismo, Universidade de São Paulo, São Paulo, 2000.

FERNANDES, A. Neotraditional cities: an example?. In: ZANCHETI, S. et al. (Org.). Conservation and urban sustainable development: a theoretical framework. Recife: Ed. UFPE, 1999. p. 163-170.

FERNANDES, A. S. Empresarialismo urbano em Salvador: a recuperação do Centro Histórico Pelourinho. 1998. Dissertação (Mestrado em Desenvolvimento Urbano e Regional) - Departamento de Arquitetura e Urbanismo, Universidade Federal de Pernambuco, Recife, 1998.

FIGUEIREDO, V. G. B. Patrimônio, cidade e política urbana: hiatos e equívocos na legislação urbanística de São Paulo. Arquitextos, ano 14, maio 2014. Disponível em: <http://www.vitruvius.com.br/revistas/read/arquitextos/14.168/5219>. Acesso em: 11 abr. 2016.

FONSÊCA, A. Comércio varejista está fechando as portas. A Tarde, Salvador, 14 out. 2002. Caderno 5, p. 4.

FONSÊCA, A. Nobre ou pobre, o Comércio resiste. A Tarde, Salvador, 23 jul. 2003. Local, p. 3. A FORÇA da rua. URBS, São Paulo, p. 32-33, jun./jul. 2000.

FOUCAULT, M. Governamentalidade. In: FOUCAULT, M. Microfísica do Poder. 10. ed. Rio de Janeiro: Graal, 1984a. p. 277-293. 
FOUCAULT, M. Soberania e disciplina. In: FOUCAULT, M. Microfísica do Poder. 10. ed. Rio de Janeiro: Graal, 1984b. p. 179-192.

FOUCAULT, M. Sobre a história da sexualidade. In: FOUCAULT, M. Microfísica do Poder. 10. ed. Rio de Janeiro: Graal, 1984C. p. 243-276.

FOUCAULT, M. Vigiar e punir: nascimento da prisão. 10. ed. Petrópolis: Vozes, 1987.

FOUCAULT, M. História da sexualidade 1: a vontade de saber. Rio de Janeiro: Graal, 1988.

FOUCAULT, M. Resumo dos Cursos do Collège de France (1970-1982). Rio de Janeiro: Zahar, 1997.

FOUCAULT, M. Em defesa da sociedade: curso no Collège de France (1975-1976). São Paulo: Martins Fontes, 2000.

FRANÇA. Ministère de l'Équipement, des Transports et du Logement; FRANÇA. Ministère de la Culture et de la Communication; AGENCE NATIONALE POUR L’AMÉLIORATION DE L'HABITAT (France). Intervenir en quartiers anciens: enjeux, demarches, outils. Paris: Moniteur, 1999.

FRANCO, A. Não só de referência cultural (sobre) vive o centro de Salvador. In: GOMES, M. A. A. F. (Org.). Pelo Pelô: história, cultura e cidade. Salvador: EDUFBA, 1995. p. 31-46.

FRIDMAN, F. Donos do Rio em nome do rei: uma história fundiária da cidade do Rio de Janeiro. 2. ed. Rio de Janeiro: Zahar: Garamond, 1999.

FRÚGOLI JÚNIOR, H. Centralidade em São Paulo: trajetórias, conflitos e negociações na metrópole. São Paulo: Cortez: EDUSP, 2000.

FUNDAÇÃO CASA FRANÇA-BRASIL. Release para a inauguração da Casa França-Brasil. Rio de Janeiro, 1990.

FUNDAÇÃO CENTRO DE PROJETOS E ESTUDOS (BA). Pelourinho após-recuperação. Salvador, 1994.

FUNDAÇÃO DO PATRIMÔNIO ARTÍSTICO E CULTURAL DA BAHIA. Plano geral de recuperação da área do Pelourinho na Cidade do Salvador, Estado da Bahia, Brasil. Salvador, 1970.

FUNDAÇÃO DO PATRIMÔNIO ARTÍSTICO E CULTURAL DA BAHIA. Projeto de restauração, conservação e adaptação do Quarteirão 10 do Maciel. Salvador, 1979.

FUNDAÇÃO DO PATRIMÔNIO ARTÍSTICO E CULTURAL DA BAHIA; COMPANHIA DE DESENVOLVIMENTO DA REGIÃO METROPOLITANA DE SALVADOR. Centro Histórico de Salvador: programa de Recuperação. Porto Alegre: Pallotti, 1995.

FUNDAÇÃO GETÚLIO VARGAS. Relatório Final: programa Monumenta - BID. São Paulo: EAESP, 1999. 
FUNDAÇÃO GREGÓRIO DE MATTOS (BA). Recuperação do Centro Histórico de Salvador. Salvador, 1987.

FUNDAÇÃO MÁRIO LEAL FERREIRA (BA). Plano de diretrizes urbanísticas para as áreas de influência do metrô de Salvador: relatório final. Salvador, 2001.

FUNDAÇÃO MÁRIO LEAL FERREIRA (BA). Pesquisa sobre mercado imobiliário no Comércio. Salvador, 2002.

FUNDAÇÃO ROBERTO MARINHO. Escritura pública de constituição da Fundação Roberto Marinho. Rio de Janeiro, 1977.

FUNDAÇÃO ROBERTO MARINHO. Fundação Roberto Marinho: 20 anos que valeram a pena. Rio de Janeiro: GMT Editores, 1998.

GALIZA, H. Reabilitação de áreas centrais sem gentrificação. 2015. 191 f. Tese (Doutorado em Urbanismo) - Faculdade de Arquitetura e Urbanismo, Universidade Federal do Rio de Janeiro, Rio de Janeiro, 2015.

GALIZA, H. Reabilitação urbana dos sítios históricos brasileiros. Rio de Janeiro:

Caixa Econômica Federal, 2001.

GASPARI, E. O Monumenta preserva a culturocracia. Folha de S. Paulo, São Paulo, 15 set. 2002.

GAUDENZI, P. Turismo no Século XXI: cluster de entretenimento. Salvador: Secretaria da Cultura e Turismo, 2001.

GIOVANNONI, G. L'urbanisme face aux villes anciennes. Paris: Éditions du Seuil, 1998.

GOMES, M. A. A. F.; FERNANDES, A. Pelourinho: turismo, identidade e consumo cultural. In: GOMES, M. A. A. F. (Org.). Pelo Pelô: história, cultura e cidade. Salvador: EDUFBA, 1995. p. 47-58.

GORDILHO-SOUZA, Â. Ocupação urbana e habitação. In: BAHIA. Secretaria de Cultura. Fundação Pedro Calmon. Centro Antigo de Salvador: plano de reabilitação participativo. Salvador, 2010. p. 72-101.

GUERRA, A. C. P. D. Fragmentos de época, de eventos e a Legislação do Solo Criado em Salvador - Bahia. 1996. 174 f. Dissertação (Mestrado em Arquitetura e Urbanismo) Faculdade de Arquitetura e Urbanismo, Universidade Federal da Bahia, Salvador, 1996.

GUIMARAENS, M. da C. A. de. Paradoxos entrelaçados: as torres para o futuro e a tradição nacional: a arquitetura do Patrimônio no centro do Rio. 1999. Tese (Doutorado em Planejamento Urbano e Regional) - Instituto de Pesquisa e Planejamento Urbano e Regional, Universidade Federal do Rio de Janeiro, Rio de Janeiro, 1999. 
HALÉVY, J. P. Note sur une "Problématique de la Conservation du Patrimoine Culturel Urbain qui permette d'identifier des priorités d'intervention": première version. [S.l: S.n.], 1997.

HALÉVY, J. P. Programa BID e fortalecimento do IPHAN. [S.L: s.n.], 1998.

HALL, P. Cidades do amanhã: uma história intelectual do planejamento e do projeto urbanos no século XX. São Paulo: Perspectiva, 1995.

HARVEY, D. Condição pós-moderna. São Paulo: Loyola, 1993.

HARVEY, D. O enigma do capital: as crises do capitalismo. São Paulo: Boitempo, 2011.

HEINONEN, N. M. Cidade Alta em alta? Circuitos e cenários das dinâmicas comerciais do Centro Velho de Salvador. 2000. Dissertação (Mestrado em Geografia) - Instituto de Geociências, Universidade Federal da Bahia, Salvador, 2000.

HUYSSEN, A. Escapando da amnésia: o museu como cultura de massa. Revista do Patrimônio Histórico e Artístico Nacional, Rio de Janeiro, n. 23, p. 34-57, 1994.

HUYSSEN, A. Seduzidos pela memória: arquitetura, monumentos, mídia. Rio de Janeiro: Aeroplano, 2000.

IDÉIA boa, vontade zero. URBS, São Paulo, p. 18-24, jun./jul. 2000.

INSTITUTO DE PLANEJAMENTO MUNICIPAL (RJ); INSTITUTO MUNICIPAL DE ARTE E CULTURA (RJ). Como recuperar, reformar ou construir seu imóvel no Corredor Cultural. 3. ed. Rio de Janeiro, 1995.

INSTITUTO DO PATRIMÔNIO ARTÍSTICO E CULTURAL DA BAHIA. Levantamento sócioeconômico do Centro Histórico de Salvador: ruínas e imóveis arruinados. Salvador, 1985.

INSTITUTO DO PATRIMÔNIO ARTÍSTICO E CULTURAL DA BAHIA. Recuperação do Bairro do Maciel, Centro Histórico de Salvador - Bahia. Salvador, 1989.

INSTITUTO DO PATRIMÔNIO ARTÍSTICO E CULTURAL DA BAHIA. Termo de Referência: plano de ação integrada do Centro Histórico de Salvador. Salvador, 1991.

INSTITUTO DO PATRIMÔNIO ARTÍSTICO E CULTURAL DA BAHIA. Uso do solo e levantamento sócio econômico: quarteirões 2M, 5M, 6M e 10M. Salvador, 1992.

INSTITUTO DO PATRIMÔNIO ARTÍSTICO E CULTURAL DA BAHIA. Estudo do uso do solo: centro Histórico de Salvador. Salvador, 1998.

INSTITUTO DO PATRIMÔNIO ARTÍSTICO E CULTURAL DA BAHIA. Cadastro imobiliário do Pelourinho: mapa dos imóveis por tipo de serviço. Salvador: GEPAI, 2002.

INSTITUTO DO PATRIMÔNIO HISTÓRICO E ARTÍSTICO NACIONAL (Brasil). Bens móveis e imóveis inscritos nos livros do tombo do Instituto do Patrimônio Histórico e Artístico Nacional. 4. ed. Rio de Janeiro, 1994. 
INSTITUTO DO PATRIMÔNIO HISTÓRICO E ARTÍSTICO NACIONAL (Brasil).

Revitalização de sítios urbanos através da recuperação do patrimônio cultural. Brasília, 1996.

INSTITUTO MUNICIPAL DE ARTE E CULTURA (RJ). A cor - Corredor Cultural. Rio de Janeiro, 1990.

INSTITUTO MUNICIPAL DE URBANISMO PEREIRA PASSOS (RJ). Novas tendências demográficas: resultados preliminares do Censo 2000. Rio de Janeiro, 2001.

INSTITUTO MUNICIPAL DE URBANISMO PEREIRA PASSOS (RJ). Uma nova estimativa para o PIB carioca. Rio de Janeiro, 2002.

JAMESON, F. Pós-modernismo: a lógica cultural do capitalismo tardio. São Paulo: Ática, 1997.

JAPPE, A. We gotta get out of this place. Sept. 2015. Disponível em: <http://www. brooklynrail.org/2015/og/field-notes/anselm-jappe-with-alastair-hemmens>.

Acesso em: 13 abr. 2016.

JEUDY, H. P. La machinerie patrimoniale. Paris: Sens \& Tonka, 2001.

KING, R. Brunelleschi's Dome. New York: Penguin Books, 2000.

KLEIN, N. No Logo: taking aim at the brand bullies. New York: Picador, 2002.

LAGO, L. C. O que há de novo na clássica dualidade núcleo-periferia: a metrópole do Rio de Janeiro. In: RIBEIRO, L. C. de Q. (Org.). O futuro das metrópoles: desigualdades e governabilidade. Rio de Janeiro: IPPUR: FASE, 2000. p. 201-228.

LEME, M. B.; VENTURA, D. O calçadão em questão: 20 anos de experiência do calçadão Paulistano. São Paulo: Belas Artes, 2000.

LEMOS, C. A. C. Alvenaria burguesa: breve história da arquitetura residencial de tijolos em São Paulo a partir do ciclo econômico liderado pelo café. São Paulo: Nobel, 1985.

LESSA, C. O Rio de todos os brasis: uma reflexão em busca de auto-estima. Rio de Janeiro: Record, 2000.

LIGHT: 100 anos cheios de energia. Semana Light, Rio de Janeiro, jun. 1999.

MAGALHÃES, A. A política habitacional no Governo FHC 1996-2001: impossibilidades de uma prática nova. 2002. 305 f. Dissertação (Mestrado em Arquitetura e Urbanismo) - Faculdade de Arquitetura e Urbanismo, Universidade Federal da Bahia, Salvador, 2002.

MAGALHÃES, R. A. de M. A requalificação do centro do Rio de Janeiro na década de 1990. 2001. Dissertação (Mestrado em Arquitetura e Urbanismo) - Faculdade de Arquitetura e Urbanismo, Universidade Federal do Rio de Janeiro, Rio de Janeiro, 2001.

MARCONDES FILHO, C. (Coord.). Pensar-pulsar: cultura comunicacional, tecnologias, velocidade. São Paulo: NTC, 1996. 
MARICATO, E. As idéias fora do lugar e o lugar fora das idéias: planejamento urbano no Brasil. In: ARANTES, O.; VAINER, C.; MARICATO, E. A cidade do pensamento único: desmanchando consensos. 2. ed. Petrópolis: Vozes, 2000. p. 121-192.

MAQUIAVELI, J. Passando a limpo: um passeio pelos processos e pelos projetos de revitalização urbana do Meatpacking District, em Nova York, e da Região da Luz, em São Paulo. EURE, Santiago, v. 38, n. 115, p. 137-158, set. 2012. Disponível em: <http:// dx.doi.org/10.4067/S0250-71612012000300007>. Acesso em: 14 ago. 2016.

MELLO FILHO, C. L. do V. A reforma urbana e o Plano Diretor do Rio de Janeiro. 1995. Dissertação (Mestrado em Planejamento Urbano e Regional) - Instituto de Pesquisa e Planejamento Urbano e Regional, Universidade Federal do Rio de Janeiro, Rio de Janeiro, 1995.

MENDONÇA, L. K. O desempenho do turismo baiano nos anos 90. 2002. Trabalho de Conclusão de Curso (Especialização) - Faculdade de Ciências Econômicas, Universidade Federal da Bahia, Salvador, 2002.

MESENTIER, L. M. de. A cidade e a juventude. Jornal do Commercio, Rio de Janeiro, 2 jun. 1997.

MESENTIER, L. M. de. A renovação preservadora: um estudo sobre a gênese de um novo modo de urbanização no centro do Rio de Janeiro, entre 1967 e 1987. 1992. Dissertação (Mestrado em Planejamento Urbano e Regional) - Instituto de Pesquisa e Planejamento Urbano e Regional, Universidade Federal do Rio de Janeiro, Rio de Janeiro, 1992.

MESENTIER, L. M. de. No limiar da transformação: as mudanças na distribuição territorial das atividades produtivas no Brasil, na virada do século XX. 2001. Tese (Doutorado em Planejamento Urbano e Regional) - Instituto de Pesquisa e Planejamento Urbano e Regional, Universidade Federal do Rio de Janeiro, Rio de Janeiro, 2001.

MEYER, R. M. P.; IZZO JÚNIOR, A. Pólo Luz: sala São Paulo, cultura e urbanismo. São Paulo: Viva o Centro, 1999.

MICELI, S. Intelectuais e classe dirigente no Brasil (1920-1945). São Paulo: DIFEL, 1979.

MISSÃO de negociação para acerto final dos termos do contrato para implementação do Programa de Preservação do Patrimônio Histórico Urbano (Monumenta): relatório. Washington, D.C.: [s.n.], 1999.

MISSION Française à Rio du 2 au 8 novembre 1997: rapport de Daniel Duché, janvier, 1998. [S.L.: S.n.], 1998.

MOISÉS, J. A. Democracia e financiamento da cultura no Brasil. In: MOISÉS, J. A.; BOTELHO, I. (Org.). Modelos de financiamento da cultura: os casos do Brasil, França, Inglaterra, Estados Unidos e Portugal. Rio de Janeiro: FUNARTE, 1997a. p. 13-22. 
MOISÉS, J. A. Diversidade cultural, parceria e financiamento da cultura no Brasil. In: MOISÉS, J. A.; BOTELHO, I. (Org.). Modelos de financiamento da cultura: os casos do Brasil, França, Inglaterra, Estados Unidos e Portugal. Rio de Janeiro: FUNARTE, 1997b. p. 22-37. MOISÉS, J. A. Economia da cultura. Brasília: Ministério da Cultura, 1998a. Xerografado MOISÉS, J. A. Mecenato privado e democratização da cultura. Brasília: Ministério da Cultura, 1998b. Xerografado.

MORAES, F. Chatô: o rei do Brasil. São Paulo: Companhia das Letras, 1994.

MORAES, S. T. Uma luz na cidade: um estudo de revitalização urbana. 1998. Dissertação (Mestrado em Arquitetura e Urbanismo) - Faculdade de Arquitetura e Urbanismo, Universidade de São Paulo, São Paulo, 1998.

MORENO GARCÍA, J. R. Informe diagnostico sobre el Instituto de Patrimonio Histórico y Artístico Nacional de Brasil (IPHAN). Sevilla, 1998.

MORRO da Conceição: da memória ao futuro. Rio de Janeiro: Sextante: Instituto Pereira Passos, 2000.

MOSCIARO, M. R. Gentrificação na Lapa? um estudo sobre mudanças na área central do Rio de Janeiro. 2012. 115 f. Dissertação ( Mestrado em Urbanismo) - Universidade Federal do Rio de Janeiro, Rio de Janeiro, 2012.

MOTTA, L. A apropriação do patrimônio urbano: do estético-estilístico nacional ao consumo visual global. In: ARANTES, A. A. (Org.). O espaço da diferença. Campinas: Papirus, 2000. p. 256-287.

MOURAD, L. N.; REBOUÇAS, T. M. Elegia dos Vacantes: considerações acerca do plano de reabilitação do centro antigo de Salvador. In: SEMINÁRIO INTERNACIONAL URB/ CENTROS, 3., 2012, Salvador. Anais... Salvador: Faculdade de Arquitetura/UFBA, 2012. p. 1-19.

NASCIMENTO, A. G. do. Degradação urbana: questões sobre sua permanência e transitoriedade: o caso da zona portuária do Rio de Janeiro. 2000. Dissertação (Mestrado em Arquitetura e Urbanismo) - Faculdade de Arquitetura e Urbanismo, Universidade Federal do Rio de Janeiro, Rio de Janeiro, 2000.

NASCIMENTO, C. J. S. Economia baiana: em compasso de recuperação. Bahia Análise \& Dados, Salvador, v. 12, p. 71-84, dez. 2002.

NEVES, L. Vazios urbanos na II RA, na área central do Rio de Janeiro: identificação e possibilidades. 1996. Dissertação (Mestrado em Planejamento Urbano e Regional) Instituto de Pesquisa e Planejamento Urbano e Regional, Universidade Federal do Rio de Janeiro, Rio de Janeiro, 1996. 
NOGUEIRA, S. A. Memória e planejamento urbano: um estudo sobre o centro histórico do Rio de Janeiro no século XX. 2000. Dissertação (Mestrado em Arquitetura e Urbanismo) - Faculdade de Arquitetura e Urbanismo, Universidade Federal do Rio de Janeiro, Rio de Janeiro, 2000.

(AS) NOVAS regras que podem mudar o centro. URBS, São Paulo, v. o, p. 26-29, ago. 1997.

OLIVEIRA, L. dos R. A História na vitrine: novas estratégias e convenções no ritual de preservação do espaço urbano. 1998. 129 f. Dissertação (Mestrado em Arquitetura e Urbanismo) - Faculdade de Arquitetura e Urbanismo, Universidade Federal da Bahia, Salvador, 1998.

OLIVEIRA, M. A. A. J. de. Associação Viva o Centro: estratégias, propostas e compromissos para São Paulo. 1999. Dissertação (Mestrado em Arquitetura e Urbanismo) - Faculdade de Arquitetura e Urbanismo, Universidade Presbiteriana Mackenzie, São Paulo, 1999.

PANORAMA. URBS, São Paulo, ago. 1997/ abr. 2002.

PARENT, M. Protection et mise en valeur du patrimoine culturel brésilien dans le cadre du développement touristique et économique. Paris: Unesco, 1968.

PICCINI, A. Cortiços na cidade: conceito e preconceito na reestruturação do centro urbano de São Paulo. São Paulo: Annablume, 1999.

PIKETTY, T. O capital do século XXI. Rio de Janeiro: Intrínseca, 2014.

PINHEIRO, A. I. de F. Corredor Cultural, um projeto de preservação para o centro do Rio de Janeiro. Desenho urbano: anais do II SEDUR - Seminário sobre Desenho Urbano no Brasil. 2. ed. Brasília: CNPq; Rio de Janeiro: FINEP, 1987.

PIO, L. G. Do Corredor Cultural ao Porto Maravilha: mudança de paradigma? In: SEMINÁRIO INTERNACIONAL - POLÍTICAS CULTURAIS. 5., 2014, Rio de Janeiro. Anais... Rio de Janeiro: Fundação Casa de Rui Barbosa, 7-9 maio 2014.

RIO DE JANEIRO. Prefeitura. Rio de Janeiro: preservação e modernidade. Rio de Janeiro: Sextante, 1998.

PINHEIRO, A. I. de F. Lições do centro do Rio. URBS, São Paulo, p. 36-42, jun./jul. 2000.

RABHA, N. M. de C. E. Cristalização e resistência no centro do Rio de Janeiro. 1984.

Dissertação (Mestrado em Geografia) - Instituto de Geociências, Universidade Federal do Rio de Janeiro, Rio de Janeiro, 1984.

RABHA, N. M. de C. E.; PINHEIRO, A. I. Um projeto para a região portuária do Rio. Cadernos de Urbanismo, Rio de Janeiro, v. 3, n. 4, p. 34-37, 2001. 
RÉHABILITATION du centre historique de São Luis: Mission d'évaluation du 11 au 15 novembre 1999. [S.L.: S.n.], 2000.

RENOVAÇÃO urbana: ações culturais, patrimônio e centro histórico. In: BRASIL. Presidente (1995-2002: Fernando Henrique Cardoso). Avança Brasil: mais 4 anos de desenvolvimento para todos: proposta de governo. Brasília, 1998.

A REVOLUÇÃO dos centros das metrópoles. URBS, São Paulo, v. o, p. 7, ago. 1997.

RIBEIRO, L. C. de Q. Cidade desigual ou cidade partida? Tendências da metrópole do Rio de Janeiro. In: RIBEIRO, L. C. de Q. (Org.). O futuro das metrópoles: desigualdades e governabilidade. Rio de Janeiro: FASE: Revan, 2000. p. 63-98.

RIO DE JANEIRO. Secretaria Especial de Turismo. Plano de Turismo da Cidade do Rio de Janeiro: plano Maravilha - Diagnóstico I: informe Executivo. Rio de Janeiro, [1997 ?].

RIO DE JANEIRO. Secretaria Municipal de Planejamento e Coordenação Geral. Corredor Cultural. Rio de Janeiro, 1979.

RIO DE JANEIRO. Secretaria Municipal de Urbanismo. Plano Diretor Decenal da Cidade. Rio de Janeiro, 1993.

RIO DE JANEIRO. Secretaria Municipal da Cultura. Departamento Geral de Patrimônio Cultural. Guia do patrimônio cultural carioca: bens tombados. Rio de Janeiro, $2000 a$.

RIO DE JANEIRO. Secretaria Municipal de Habitação. Novas Alternativas: projetos e propostas habitacionais para o Rio de Janeiro. Rio de Janeiro, $2000 \mathrm{~b}$.

RIO DE JANEIRO. Secretaria Municipal de Urbanismo. Relatório de Gestão da Coordenadoria Técnica de Urbanismo - CTU. Rio de Janeiro, $2000 \mathrm{c}$.

RIO DE JANEIRO. Secretaria Municipal de Urbanismo. Relatório Final - Equipe FocoLocal Centro (Decreto n 27.424/02). Rio de Janeiro, 2002a.

RIO DE JANEIRO. Secretaria Municipal de Urbanismo. Relatório Final - Grupo de Trabalho para a Avaliação do Potencial Imobiliário dos bairros da Saúde, da Gamboa e do Santo Cristo (Decreto $n^{\circ}$ 21.536/o2). Rio de Janeiro, 2002 b.

RODRIGUES, J. J. O Olodum e o Pelourinho. In: GOMES, M. A. F. (Org.). Pelo Pelô: história, cultura e cidade. Salvador: EDUFBA, 1995. p. 81-91.

RODRIGUES, M. Imagens do passado: a instituição do patrimônio em São Paulo 1969/1987. São Paulo: Imprensa Oficial do Estado, 2000.

RODRIGUES VILLAESCUSA, E. Missão no Rio de Janeiro, Recife, Olinda, Salvador e Brasília. Barcelona, 1996.

ROJAS, E. Old cities, new assets: preserving Latin America's urban heritage. Washington, D.C.: Inter-American Development Bank, 1999. 
ROJAS, E. Revitalization of historic cities with private sector involvement: lessons from Latin America. Washington, D.C.: Inter-American Development Bank, [199-].

ROJAS, E. Financiando la conservación del patrimonio urbano en América Latina y el Caribe: la acción del Banco Interamericano de Desarrollo. In: CARRIÓN, F. (Ed.). Centros históricos de América Latina y el Caribe. Quito: FLACSO, 2001a. p. 15-22.

ROJAS, E. El sector privado en la conservación del patrimonio urbano en América Latina y el Caribe: lecciones de tres experiencias. In: CARRIÓN, F. (Ed.). Centros históricos de América Latina y el Caribe. Quito: FLACSO, 2001b. p. 199-216.

ROLNIK, R. Guerra dos lugares: a colonização da terra e da moradia na era das finanças. São Paulo: Boitempo, 2015.

ROSA, R. de M. Espetáculo urbano ou urbano como espetáculo: a Lapa (en) cena. 2014. 180 f. Tese (Doutorado em Planejamento Urbano e Regional) - Instituto de Pesquisa e Planejamento Urbano e Regional, Universidade Federal do Rio de Janeiro, Rio de Janeiro, 2014.

SALVADOR. Secretaria Municipal do Planejamento, Meio Ambiente e Desenvolvimento Econômico. Plano Diretor de Desenvolvimento Urbano. Salvador, 1985.

SALVADOR. Centro de Planejamento Municipal. Relatório Anual. Salvador, 1991.

SALVADOR. Centro de Planejamento Municipal. Relatório 1990-1992. Salvador: GEDEM, 1992.

SALVADOR. Centro de Planejamento Municipal. Proposta de ação para a área central da Cidade do Salvador: criação, conservação e transformação da vida urbana. Salvador, 1993.

SALVADOR. Centro de Planejamento Municipal. Relatório de Atividades: março 93 - fevereiro 94. Salvador, 1994.

SALVADOR. Centro de Planejamento Municipal. Relatório de Atividades 1994. Salvador, 1995.

SALVADOR. Centro de Planejamento Municipal. Relatório de Atividades. Salvador, 1996.

SALVADOR. Prefeitura Municipal Do Salvador. Lei nº 9.069/2016. Dispõe sobre o Plano Diretor de Desenvolvimento Urbano do Município de Salvador - PDDU 2016 e dá outrasprovidências. Diário Oficial, Salvador, 2016.

SALVADOR. Secretaria Municipal do Planejamento, Meio Ambiente e Desenvolvimento Econômico. Relatório Anual 1997. Salvador, 1997.

SALVADOR. Secretaria Municipal do Planejamento, Meio Ambiente e Desenvolvimento Econômico. Relatório Anual 1998. Salvador, 1998.

SALVADOR. Secretaria Municipal do Planejamento, Meio Ambiente e Desenvolvimento Econômico. Relatório Anual 1999. Salvador, 1999. 
SALVADOR. Secretaria Municipal do Planejamento, Meio Ambiente e Desenvolvimento Econômico. Relatório Anual 2000. Salvador, 2000.

SAMPAIO, A. H. Formas urbanas: cidade real \& cidade ideal: contribuição ao estudo urbanístico de Salvador. Salvador: Quarteto, 1999.

SANT’ANNA, M. El Centro Histórico de Salvador de Bahia: paisaje, espacio urbano y patrimônio. In: CARRIÓN, F. (Ed.). Centros históricos de América Latina y el Caribe. Quito: FLACSO, 2001. p. 177-197.

SANT’ANNA, M. Da cidade-monumento à cidade-documento: a trajetória da norma de preservação de áreas urbanas no Brasil (1937-1990). Salvador: Oiti Editora, 2014.

SANTOS, B. de S. Pela mão de Alice. São Paulo: Cortez, 2000.

SANTOS, M. O centro da Cidade do Salvador: estudo de geografia urbana. Salvador: Progresso, 1959.

SANTOS, M. Por uma outra globalização: do pensamento único à consciência universal. Rio de Janeiro: Record, 2001.

SANTOS, M. Salvador: centro e centralidade na cidade contemporânea. In: GOMES, M. A. A. F. (Org.). Pelo Pelô: história, cultura e cidade. Salvador: EDUFBA, 1995. p. 11-29.

SANTOS NETO, I. de C. Centralidade urbana: espaço e lugar: esta questão na cidade do Salvador. 1991. Tese (Doutorado em Arquitetura e Urbanismo) - Faculdade de Arquitetura e Urbanismo, Universidade de São Paulo, São Paulo, 1991.

SANTOS NETO, I. de C. Salvador: cara \& coroa. Salvador: Universidade Federal da Bahia, 1993. (Série Pretextos, n. 3).

SÃO PAULO. Secretaria das Administrações Regionais. Eixo Sé-Arouche - Programa Piloto de Ordenação da Paisagem da Área Central. São Paulo, 1992.

SÃO PAULO. Secretaria de Habitação e Desenvolvimento Urbano. ProCentro - Programa de Requalificação Urbana e Funcional do Centro de São Paulo. Diário Oficial do Município de São Paulo, São Paulo, v. 38, n. 131, 15 jul. 1993.

SÃO PAULO. Secretaria de Habitação e Desenvolvimento Urbano. Programa Direito à Moradia. Diário Oficial do Município de São Paulo, São Paulo, v. 41, n. 56, 23 mar. 1996.

SÃO PAULO. Secretaria de Habitação e Desenvolvimento Urbano. ProCentro - Plano Estratégico 1998-2002. São Paulo, 1998.

SÃO PAULO. Secretaria Municipal de Planejamento Urbano. Coletânea das leis de parcelamento, uso e ocupação do solo. São Paulo, [199-].

SÃO PAULO. Secretaria de Habitação e Desenvolvimento Urbano. ProCentro: balanço de atividades 1993-1999. São Paulo, 1999. 
SÃO PAULO. Câmara Municipal. Comissão de Estudos sobre Habitação na Área Central: relatório final. São Paulo, 2001 .

SÃO PAULO. Secretaria das Administrações Regionais. Administração Regional da Sé; SÃO PAULO. Secretaria de Habitação e Desenvolvimento Urbano. ProCentro. Reconstruir o Centro: reconstruir a cidade e a cidadania. São Paulo, $2001 b$.

SÃO PAULO. Secretaria Municipal de Planejamento Urbano. Departamento de Planejamento Urbano. Estudo e proposta inicial para estabelecimento de objetivos, diretrizes e ações para o Plano Diretor - Cultura e Patrimônio Histórico. [São Paulo], 2001c. Xerografado.

SÃO PAULO. Secretaria Municipal de Implementação das Subprefeituras. Administração Regional da Sé; SÃO PAULO. Secretaria de Habitação e Desenvolvimento Urbano. ProCentro. Guia para reconstruir as calçadas do Centro e dos bairros centrais. São Paulo, 200za. SÃO PAULO. Secretaria Municipal de Planejamento Urbano. BDP - Base de Dados para Planejamento. São Paulo, 2002b.

SARKOVAS, Y. Incentivos são repassadores perdulários do recurso público. In: Marketing cultural online. 2002. Disponível em: <www. marketingcultural.com.br>. Acesso em: out. 2002.

SASSEN, S. As cidades na economia mundial. São Paulo: Studio Nobel, 1998.

SCHWARCZ, L. M. As barbas do Imperador: D. Pedro II, um monarca nos trópicos. São Paulo: Companhia das Letras, 1998.

SERAPIÃO, C. de A. Praça Tiradentes e arredores: um lugar e seus atores sociais. 2000. Dissertação (Mestrado em Arquitetura e Urbanismo) - Faculdade de Arquitetura e Urbanismo, Universidade Federal do Rio de Janeiro, Rio de Janeiro, 2000.

SERRA, O. J. T. O simbolismo da cultura. Salvador: Centro Editorial e Didático da UFBA, 1991.

SEVCENKO, N. Orfeu extático na metrópole: São Paulo, sociedade e cultura nos frementes anos 20. São Paulo: Companhia das Letras, 1992.

SILVA, H. M. M. B. Habitação no centro de SP: como viabilizar essa idéia? São Paulo: [s.n.], 2000.

SILVA, H. M. M. B. Terra e moradia: que papel para o município? 1997. 260 f. Tese (Doutorado em Arquitetura e Urbanismo) - Faculdade de Arquitetura e Urbanismo, Universidade de São Paulo, São Paulo, 1997.

SILVA, J. A. S. O desempenho do turismo em Salvador na década de '80: a relevância da ação do Estado. 1991. Dissertação (Mestrado em Administração) - Escola de Administração, Universidade Federal da Bahia, Salvador, 1991. 
SILVEIRA, C. B. Uso residencial na área central do Rio de Janeiro: um estudo na periferia do centro. 1995. Dissertação (Mestrado em Geografia) - Instituto de Geociências, Universidade Federal do Rio de Janeiro, Rio de Janeiro, 1995.

SIQUEIRA, M. T. Entre o fundamental e o contingente: dimensões da gentrificação contemporânea nas operações urbanas em São Paulo. Cadernos Metrópole, São Paulo, v. 16, n. 32, p. 391-415, nov. 2014.

SISSON, R. Patrimônio histórico, uma experiência no Rio de Janeiro: o inventário de bens imóveis de interesse histórico e artístico: objetivos, métodos e resultados. Rio de Janeiro: Lidador, 1982.

SOMEKH, N. A cidade vertical: São Paulo 1920 -1939. São Paulo: Studio Nobel, 1997.

SOMEKH, N. Patrimônio cultural em São Paulo: resgate do contemporâneo? Architextos, [São Paulo], ano 16, out. 2015. Disponível em: <http://www.vitruvius.com. br/revistas/read/arquitextos/16.185/5795> Acesso em: 11 abr. 16.

SOMEKH, N.; FREGONEZI, B. Regenerating São Paulo's city center: three intervention projects. $7^{\text {th }}$ IPHS Conference: InternationaL Planning History Society Conference, Delft, v. 3 , July 2016.

SOUZA, M. L. de. Mudar a cidade: uma introdução crítica ao planejamento e à gestão urbanos. 3. ed. Rio de Janeiro: Bertrand Brasil, 2002.

TADDEI NETO, P. Os grandes projetos. In: WEFFORT, F.; SOUZA, M. (Org.). Um olhar sobre a cultura brasileira. Rio de Janeiro: Ministério da Cultura, 1998a. p. 145-170.

TADDEI NETO, P. Programa Monumenta/BID. Trabalho apresentado no Seminário Estratégias de Preservação do Patrimônio - Núcleos Históricos, Florianópolis, 1998b.

UNIVERSIDADE FEDERAL DA BAHIA. Evolução física de Salvador. Salvador: Prefeitura Municipal, 1998. (Edição Especial).

VAN WILDERODE, D. J. Desregulamentação urbana: as operações interligadas. 1994. Dissertação (Mestrado em Arquitetura e Urbanismo) - Faculdade de Arquitetura e Urbanismo, Universidade de São Paulo, São Paulo, 1994.

VASCONCELLOS, L. M. de; MELLO, M. C. F. de. Terminologias em Busca de uma Identidade. Revista de Arquitetura e Urbanismo, Salvador, v. 7, n. 8, p. 60-63, 2003.

VAZ, L. F. Modernidade e moradia: habitação coletiva no Rio de Janeiro, séculos XIX e XX. Rio de Janeiro: 7 Letras, 2002.

VAZ, L. F.; SILVEIRA, C. B. O papel da habitação em 100 anos de urbanismo: de "problema" a "solução" da questão da área central da cidade do Rio de Janeiro. In: SEMINÁRIO DE HISTÓRIA DA CIDADE E DO URBANISMO, 4., 1996, Rio de Janeiro. Anais... Rio de Janeiro: Universidade Federal do Rio de Janeiro, 1996. 
VAZ, L. F.; SILVEIRA, C. B. Transformações e permanências na área central do Rio de Janeiro. Arquitetura, Rio de Janeiro, n. 81, p. 4-9, jun. 1998.

VELHO Paissandu pode se tornar a Broadway de SP. Diário de São Paulo, São Paulo, 21 mar. 2002.

VIDA nova ao Edifício dos Correios. URBS, São Paulo, p. 30-35, jan. 1998.

VIEIRA, N. M. O lugar da História na cidade contemporânea: revitalização do Bairro do Recife x recuperação do Pelourinho. 2000. 262 f. Dissertação (Mestrado em Arquitetura e Urbanismo) - Faculdade de Arquitetura e Urbanismo, Universidade Federal da Bahia, Salvador, 2000.

WEFFORT, F. C. Cultura e democracia. Brasília: Ministério da Cultura, 1998.

WEFFORT, F. C. Patrimônio histórico. Folha de S. Paulo, o4 fev. 1999. Painel do Leitor, p. 3.

XEXÉO, A. O jogo de cartas marcadas: patrocínio no Brasil só beneficia os medalhões. O Globo, 24 fev. 2002. Segundo Caderno, p. 10.

ZUKIN, S. Paisagens do século XXI: notas sobre a mudança social e o espaço urbano. In: ARANTES, A. A. (Org.). O espaço da diferença. Campinas: Papirus, 2000a. p. 104-115.

ZUKIN, S. Paisagens urbanas pós-modernas: mapeando cultura e poder. In: ARANTES, A. A. (Org.). $O$ espaço da diferença. Campinas: Papirus, 200ob, p. 80-103. 


\section{Apêndice A}

\section{Intervenções públicas e privadas na área central de Salvador, $1982 / 2003$}

\begin{tabular}{|c|c|c|c|c|c|}
\hline Ano & Intervenção pública & Instância & Intervenção privada & Localização & Situação \\
\hline 1982 & Estação da Lapa & Gov. do Estado & & Lapa & Concluída \\
\hline 1985 & & & Shopping Piedade & & Concluído \\
\hline $1986 / 1989$ & $\begin{array}{l}\text { Obras no âmbito do Programa } \\
\text { de Recuperação dos Sítios } \\
\text { Históricos de Salvador: } \\
\text { - complementação de } \\
\text { infraestrutura em rede; } \\
\text { - estabilização de ruínas; } \\
\text { - recuperação de casas na } \\
\text { Ladeira da Misericórdia; } \\
\text { - Casa do Benin; } \\
\text { - Casa do Olodum; } \\
\text { - Cine Glauber Rocha. }\end{array}$ & Prefeitura & & $\begin{array}{l}\text { Centro histórico - } \\
\text { Pelourinho, } \\
\text { Misericórdia, } \\
\text { Barroquinha. }\end{array}$ & Concluído \\
\hline $1992 / 2002$ & $\begin{array}{l}\text { Programa de Recuperação do } \\
\text { Centro Histórico de Salvador }\end{array}$ & Gov. do Estado & & $\begin{array}{l}\text { Centro Histórico, } \\
\text { Pelourinho }\end{array}$ & $\begin{array}{l}\text { Concluídas as etapas } \\
\text { 1, 2, } 3 \text { e } 4 \text {. Parcialmente } \\
\text { concluídas as etapas } 5 \\
\text { e 6. Etapa } 7 \text { e Projeto } \\
\text { Rememorar em } \\
\text { andamento. }\end{array}$ \\
\hline 1993 & $\begin{array}{l}\text { Recuperação do Teatro Castro } \\
\text { Alves }\end{array}$ & & & Campo Grande & Concluída \\
\hline 1994 & $\begin{array}{l}\text { Reurbanização do Largo de } \\
\text { São Bento }\end{array}$ & Prefeitura & & São Bento & Concluído \\
\hline $1995 / 2002$ & Antiga Faculdade de Medicina & $\begin{array}{l}\text { BNDES e } \\
\text { Governo } \\
\text { Espanhol }\end{array}$ & & Terreiro de Jesus & Em andamento \\
\hline 1995 & IPRAJ (Anexo ao Fórum) & Justiça Estadual & & Campo da Pólvora & Concluído \\
\hline 1996 & & & Shopping Lapa & Piedade & Concluído \\
\hline 1996 & Praça da Eubiose & Prefeitura & & Piedade & Concluída \\
\hline 1997 & & & $\begin{array}{l}\text { Restauração do Mosteiro } \\
\text { de São Bento (Odebrecht e } \\
\text { PRONAC) }\end{array}$ & São Bento & Concluída \\
\hline 1997 & $\begin{array}{l}\text { Organização dos ambulantes } \\
\text { na Av. Sete com determinação } \\
\text { de } 14 \text { áreas para relocação } \\
\text { provisória. }\end{array}$ & Prefeitura & & $\begin{array}{l}\text { Av. Sete de } \\
\text { Setembro }\end{array}$ & Concluída \\
\hline 1997 & $\begin{array}{l}\text { Iluminação cênica do } \\
\text { Monumento do } 2 \text { de Julho }\end{array}$ & Prefeitura & & Campo Grande & Concluída \\
\hline 1997 & $\begin{array}{l}\text { Restauração da Cruz e Marco } \\
\text { Comemorativo Miguel Fróes }\end{array}$ & Prefeitura & & Largo dos Aflitos & Concluída \\
\hline 1997 & & & $\begin{array}{l}\text { Restauração do Liceu de } \\
\text { Artes e Ofícios (PRONAC) }\end{array}$ & Saldanha & Concluída etapa \\
\hline
\end{tabular}




\begin{tabular}{|c|c|c|c|c|c|}
\hline Ano & Intervenção pública & Instância & Intervenção privada & Localização & Situação \\
\hline 1997/1998 & $\begin{array}{l}\text { Recuperação da fonte } \\
\text { luminosa do Monumento à } \\
\text { cidade do Salvador }\end{array}$ & Prefeitura & & Mercado Modelo & Concluído \\
\hline 1998 & Restauração do Solar Gravatá & $\begin{array}{l}\text { Gov. do Estado } \\
\text { e PRONAC }\end{array}$ & & $\begin{array}{l}\text { Baixa dos } \\
\text { Sapateiros }\end{array}$ & Concluída \\
\hline 1998 & & & Marina do Unhão & Cidade Baixa & Concluída \\
\hline 1998 & $\begin{array}{l}\text { Requalificação da Praça da } \\
\text { Inglaterra }\end{array}$ & Prefeitura & $\begin{array}{l}\text { Parceria com Banco Excel/ } \\
\text { Econômico }\end{array}$ & Comércio & Concluída \\
\hline 1998 & $\begin{array}{l}\text { Restauração do Monumento } \\
\text { em homenagem a Dodô e } \\
\text { Osmar }\end{array}$ & Prefeitura & & Praça Castro Alves & Concluída \\
\hline 1998 & $\begin{array}{l}\text { Recuperação do pedestal do } \\
\text { Monumento a L. L. Zamenhof }\end{array}$ & Prefeitura & & $\begin{array}{l}\text { Largo de São } \\
\text { Bento }\end{array}$ & Concluída \\
\hline 1998 & $\begin{array}{l}\text { Requalificação da Praça da } \\
\text { Piedade e restauração do } \\
\text { monumento e fonte }\end{array}$ & Prefeitura & & Piedade & Concluída \\
\hline 1998 & $\begin{array}{l}\text { Instalação de placas } \\
\text { toponímicas em azulejos } \\
\text { portugueses }\end{array}$ & Prefeitura & & Centro Histórico & Concluída \\
\hline 1998 & & & $\begin{array}{l}\text { Reciclagem do Trapiche } \\
\text { Adelaide (lojas e } \\
\text { restaurantes) }\end{array}$ & $\begin{array}{l}\text { Av. Contorno, } \\
\text { Cidade Baixa }\end{array}$ & Concluída \\
\hline 1998 & $\begin{array}{l}\text { Requalificação do Passeio } \\
\text { Público }\end{array}$ & Prefeitura & & Campo Grande & Concluída \\
\hline 1998/1999 & $\begin{array}{l}\text { Reagenciamento e execução } \\
\text { de gradil no Monumento do } \\
\text { Barão do Rio Branco }\end{array}$ & Prefeitura & & São Pedro & Concluído \\
\hline $1998 / 2000$ & $\begin{array}{l}\text { Reurbanização da Praça da Sé } \\
\text { com relocação e instalação de } \\
\text { monumentos }\end{array}$ & Prefeitura & & Sé & Concluída a $7^{\mathrm{a}}$ etapa. \\
\hline $1998 / 2000$ & $\begin{array}{l}\text { Desmontagem, limpeza e } \\
\text { remontagem do Monumento } \\
\text { ao } 4^{\circ} \text { Centenário na Praça das } \\
\text { Vassouras (construída na Rua } \\
\text { Chile para implantação de } \\
\text { terminal de ônibus) }\end{array}$ & Prefeitura & & Rua Chile & Concluída \\
\hline $1998 / 2002$ & $\begin{array}{l}\text { Restauração do gradil e do } \\
\text { Monumento aos Irmãos } \\
\text { Pereira }\end{array}$ & Prefeitura & & $\begin{array}{l}\text { Cidade Baixa } \\
\text { Conceição }\end{array}$ & Em andamento \\
\hline 1999 & $\begin{array}{l}\text { Restauração da balaustrada, } \\
\text { relocação de lampiões e } \\
\text { execução de calçadão na } \\
\text { Praça Municipal }\end{array}$ & Prefeitura & & Praça Municipal & Concluída \\
\hline 1999 & $\begin{array}{l}\text { Restauração, relocação e } \\
\text { urbanização do entorno do } \\
\text { Relógio de São Pedro }\end{array}$ & Prefeitura & & São Pedro & Concluída \\
\hline 1999 & $\begin{array}{l}\text { Reurbanização do Dique do } \\
\text { Tororó e restauração de fonte } \\
\text { à sua margem }\end{array}$ & $\begin{array}{l}\text { Prefeitura e Gov. } \\
\text { do Estado }\end{array}$ & & Tororó & Concluída \\
\hline 1999 & & & $\begin{array}{l}\text { Restauração da antiga } \\
\text { Casa de Oração (CEF e } \\
\text { PRONAC) }\end{array}$ & Carlos Gomes & Concluída \\
\hline $1999 / 2000$ & $\begin{array}{l}\text { Restauração do Chafariz do } \\
\text { Terreiro de Jesus }\end{array}$ & Prefeitura & & Terreiro de Jesus & Concluída \\
\hline
\end{tabular}




\begin{tabular}{|c|c|c|c|c|c|}
\hline Ano & Intervenção pública & Instância & Intervenção privada & Localização & Situação \\
\hline $1999 / 2002$ & & & $\begin{array}{l}\text { Projeto Portal da } \\
\text { Misericórdia (Odebrecht } \\
\text { com apoio do PRONAC e } \\
\text { Fazcultura) }\end{array}$ & $\begin{array}{l}\text { Praça da Sé, } \\
\text { Misericórdia }\end{array}$ & Em andamento \\
\hline 2000 & $\begin{array}{l}\text { Requalificação das Praças } \\
\text { e Espaços Públicos, com } \\
\text { restauração de monumentos: } \\
\text { - Marechal Deodoro; } \\
\text { - Mirante dos Aflitos; } \\
\text { - Largo da Soledade; } \\
\text { - Conselheiro Almeida Couto. }\end{array}$ & Prefeitura & & Centro e Nazaré & Concluídas \\
\hline 2000 & $\begin{array}{l}\text { Intervenções emergenciais no } \\
\text { Comércio: } \\
\text { - pavimentação; } \\
\text { - rede de drenagem; } \\
\text { - iluminação pública; } \\
\text { - controle da ocupação de } \\
\text { logradouros; } \\
\text { - otimização da limpeza } \\
\text { urbana; } \\
\text { - paisagismo; } \\
\text { - ampliação do número de } \\
\text { vagas para carga e descarga } \\
\text { e em estacionamentos zona } \\
\text { azul; } \\
\text { - substituição de } \\
\text { controladores de tráfego. }\end{array}$ & Prefeitura & & $\begin{array}{l}\text { Comércio, } \\
\text { Cidade Baixa }\end{array}$ & Concluídas \\
\hline $2000 / 2002$ & $\begin{array}{l}\text { Restauração da Fonte do } \\
\text { Taboão }\end{array}$ & Prefeitura & & Centro histórico & Em andamento \\
\hline $2000 / 2002$ & $\begin{array}{l}\text { Restauração da Fonte das } \\
\text { Pedreiras ou da Preguiça }\end{array}$ & Prefeitura & & Centro histórico & Em andamento \\
\hline 2001 & $\begin{array}{l}\text { Obras de conservação no } \\
\text { Convento de Santa Tereza }\end{array}$ & IPHAN & & & Concluídas \\
\hline $2000 / 2002$ & $\begin{array}{l}\text { Restauração do gradil e do } \\
\text { Monumento a Visconde de } \\
\text { Cayru }\end{array}$ & Prefeitura & & $\begin{array}{l}\text { Conceição da } \\
\text { Praia, Cidade Baixa }\end{array}$ & Em andamento \\
\hline $2001 / 2002$ & & & Pousada do Carmo & Carmo & Em andamento \\
\hline $2001 / 2002$ & $\begin{array}{l}\text { Implantação de Monumento } \\
\text { do Pe. Vieira na Praça Pe. } \\
\text { Vieira. }\end{array}$ & Prefeitura & & Ajuda & Concluída \\
\hline $2001 / 2003$ & $\begin{array}{l}\text { Reurbanização da Praça da Sé } \\
\text { (2 } 2^{\mathrm{a}} \text { etapa) }\end{array}$ & Prefeitura & & Sé & Concluída \\
\hline 2003 & $\begin{array}{l}\text { Restauração do Elevador } \\
\text { Lacerda }\end{array}$ & Prefeitura & & Praça Municipal & Concluída \\
\hline 2003 & $\begin{array}{l}\text { Restauração do Monumento } \\
\text { ao } 2 \text { de Julho e requalificação } \\
\text { da praça }\end{array}$ & Prefeitura & & Campo Grande & Em andamento \\
\hline $2001 / 2003$ & $\begin{array}{l}\text { Implantação de linha do } \\
\text { metrô de Salvador, com } \\
\text { estaçóes na Lapa e no Campo } \\
\text { da Pólvora }\end{array}$ & $\begin{array}{l}\text { Gov. Federal, } \\
\text { Gov. do Estado e } \\
\text { Prefeitura }\end{array}$ & & $\begin{array}{l}\text { Desterro, Campo } \\
\text { da Pólvora, } \\
\text { Mouraria, Lapa, } \\
\text { Piedade. }\end{array}$ & Em andamento \\
\hline $2002 / 2003$ & & & $\begin{array}{l}\text { Reciclagem do Trapiche } \\
\text { Jaqueira }\end{array}$ & $\begin{array}{l}\text { Av. Contorno, } \\
\text { Cidade Baixa }\end{array}$ & Concluída \\
\hline
\end{tabular}

Fonte: Quadro montado a partir de informaçōes obtidas em Heinonen (2000); Fernandes (1998); no Escritório Técnico de Licenças e Fiscalização

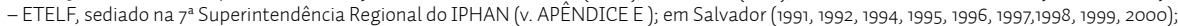
em Fundação Mário Leal Ferreira (BA) (2001); e em listagem elaborada pela Fundação Gregório de Matos, em 2002. 


\section{Apêndice B}

\section{Intervenções públicas e privadas projetadas para a área central de Salvador (década de 1990)}

\begin{tabular}{|c|c|c|c|c|}
\hline $\begin{array}{l}\text { Projeto } \\
\text { Setor público }\end{array}$ & $\begin{array}{c}\text { Projeto } \\
\text { Setor privado }\end{array}$ & Proposta & Área & Situação \\
\hline & Antigo Cine PAX & $\begin{array}{l}\text { Reforma para instalação de casa } \\
\text { de espetáculos }\end{array}$ & Baixa dos Sapateiros & $\begin{array}{l}\text { Projeto aprovado, em fase } \\
\text { de captação de recursos }\end{array}$ \\
\hline & $\begin{array}{l}\text { o3 imóveis na Rua Areal } \\
\text { de Cima, no Sodré }\end{array}$ & $\begin{array}{l}\text { Reabilitação dos imóveis para } \\
\text { instalação de pousada }\end{array}$ & Sodré & Projeto aprovado \\
\hline & $\begin{array}{l}\text { Imóvel no Largo da } \\
\text { Palma }\end{array}$ & $\begin{array}{l}\text { Reabilitação para implantação } \\
\text { de pousada }\end{array}$ & Palma & Projeto aprovado \\
\hline $\begin{array}{l}\text { Largo de Santo Antônio } \\
\text { Além do Carmo } \\
\text { (Prefeitura) }\end{array}$ & & $\begin{array}{l}\text { Reurbanização do largo, } \\
\text { com introdução de equipamentos } \\
\text { de lazer }\end{array}$ & $\begin{array}{l}\text { Centro histórico, } \\
\text { Santo Antônio }\end{array}$ & Em análise no IPHAN \\
\hline $\begin{array}{l}\text { Praça Cayru } \\
\text { (Prefeitura) }\end{array}$ & & $\begin{array}{l}\text { Requalificação da praça com } \\
\text { modificação do sistema viário para } \\
\text { integração com o metrô e com VLT }\end{array}$ & Comércio & $\begin{array}{l}\text { Realizado concurso } \\
\text { público, projeto em análise } \\
\text { no IPHAN }\end{array}$ \\
\hline Projeto VLT & & $\begin{array}{l}\text { Alternativa de utilização do leito } \\
\text { ferroviário da região do subúrbio, } \\
\text { com opção de acesso direto à Área } \\
\text { Central }\end{array}$ & $\begin{array}{l}\text { Cidade Baixa e } \\
\text { subúrbios }\end{array}$ & Projeto \\
\hline $\begin{array}{l}\text { Recuperação de } \\
\text { ascensores }\end{array}$ & & $\begin{array}{l}\text { Recuperação dos ascensores para } \\
\text { melhorar a ligação entre Cidades } \\
\text { Alta e Baixa }\end{array}$ & $\begin{array}{l}\text { Cidade Alta } \\
\text { e Cidade Baixa }\end{array}$ & Projeto \\
\hline Avenida Sete & & $\begin{array}{l}\text { Transformação da avenida em via } \\
\text { exclusiva para circulação de ônibus }\end{array}$ & Centro - Cidade Alta & Projeto \\
\hline $\begin{array}{l}\text { Trecho Praça da Sé - } \\
\text { Praça Castro Alves }\end{array}$ & & $\begin{array}{l}\text { Requalificação das vias; rede } \\
\text { subterrânea, alarg. de calçadas, } \\
\text { paviment., drenagem, fachadas e } \\
\text { Praça Castro Alves }\end{array}$ & Centro - Cidade Alta & Projeto \\
\hline $\begin{array}{l}\text { Trecho Pça. Castro Alves } \\
\text { - Praça da Aclamação }\end{array}$ & & $\begin{array}{l}\text { Requalificação Av. Sete e } \\
\text { transversais, com reconst. } \\
\text { fachadas, rede subterrânea, etc. }\end{array}$ & Centro - Cidade Alta & Projeto \\
\hline $\begin{array}{l}\text { Trecho Praça da } \\
\text { Aclamação - Campo } \\
\text { Grande }\end{array}$ & & $\begin{array}{l}\text { Idem, com requalificação do trecho } \\
\text { e da Pça. da Aclamação }\end{array}$ & Campo Grande & Projeto \\
\hline $\begin{array}{l}\text { Trecho Baixa do. } \\
\text { Sapateiro - Aquidabã }\end{array}$ & & $\begin{array}{l}\text { Idem, com requalificação da Pça. } \\
\text { Veteranos, Barroquinha e S. Miguel }\end{array}$ & Centro - Cidade Alta & Projeto \\
\hline $\begin{array}{l}\text { Rampa do Mercado } \\
\text { Modelo }\end{array}$ & & $\begin{array}{l}\text { Requalificação da antiga rampa do } \\
\text { Mercado }\end{array}$ & Cidade Baixa & Projeto \\
\hline Transporte público & & $\begin{array}{l}\text { Implantação de linhas de ônibus } \\
\text { para atendimento exclusivo do } \\
\text { centro antigo, com previsão de } \\
\text { implantação de sistema } \\
\text { de micro-ônibus. }\end{array}$ & Centro & Projeto \\
\hline Estacionamento & & $\begin{array}{l}\text { Plano de estacionamento para } \\
\text { a área central com política de } \\
\text { utilização de vagas públicas e } \\
\text { privadas }\end{array}$ & Área central & Projeto \\
\hline
\end{tabular}




\begin{tabular}{|c|c|c|c|c|}
\hline $\begin{array}{l}\text { Projeto } \\
\text { Setor público }\end{array}$ & $\begin{array}{c}\text { Projeto } \\
\text { Setor privado }\end{array}$ & Proposta & Área & Situação \\
\hline Sistema Viário & & $\begin{array}{l}\text { Novas ligações verticais ligando o } \\
\text { Largo } 2 \text { de Julho à Av. Contorno e } \\
\text { Praça Castro Alves à Praça Cayru. } \\
\text { Ligação em desnível interligando } \\
\text { os terminais da Lapa e } \\
\text { Barroquinha. } \\
\text { Nova ligação viária (túnel) entre } \\
\text { Vale dos Barris e Av. Contorno }\end{array}$ & $\begin{array}{l}\text { Centro } \\
\text { Cidade Alta e Baixa }\end{array}$ & Projeto \\
\hline Metrô & & $\begin{array}{l}\text { Nova linha complementando o anel } \\
\text { central da Linha 2, tangenciando a } \\
\text { linha } ~ \text { no Largo da Piedade }\end{array}$ & Centro & Projeto \\
\hline Via Náutica & & $\begin{array}{l}\text { Sistema de transporte público } \\
\text { marítimo ligando várias áreas da } \\
\text { cidade entre a Ribeira e a Barra }\end{array}$ & Orla da baía & $\begin{array}{l}\text { Projeto executivo, } \\
\text { parcialmente implantado. } \\
\text { Realizada a estação da } \\
\text { Ponta de Humaitá, em } \\
\text { Monte Serrat. }\end{array}$ \\
\hline \multirow[t]{3}{*}{ Circuito da Identidade } & & $\begin{array}{l}\text { Tratamento do espaço público na } \\
\text { faixa ao longo do litoral desde a } \\
\text { Ribeira até o Farol da Barra }\end{array}$ & Centro e orla & Projeto \\
\hline & Prédio do Jornal A Tarde & $\begin{array}{l}\text { Projeto de implantação de hotel } \\
\text { com centro de convençóes }\end{array}$ & Ajuda & Projeto \\
\hline & $\begin{array}{l}\text { Projeto para implantação } \\
\text { de shopping center de } \\
\text { médio porte no prédio } \\
\text { do antigo Supermercado } \\
\text { Paes Mendonça }\end{array}$ & & $\begin{array}{l}\text { Av. Contorno, Cidade } \\
\text { Baixa }\end{array}$ & $\begin{array}{l}\text { Projeto aprovado pelo } \\
\text { IPHAN, em análise pela } \\
\text { SET }\end{array}$ \\
\hline
\end{tabular}

Fonte: Quadro montado a partir de informações obtidas em Salvador (1996, 1997, 1998, 1999, 2000); e no Programa de Investimentos de 1998, da Fundação Mário Leal Ferreira. 


\section{Apêndice C}

\section{Principais intervenções de requalificação do espaço público na área central do Rio de Janeiro (1980 e 2002)}

\begin{tabular}{|c|c|c|c|c|c|}
\hline Localização & Período & Intervenção & Execução & Investimento & Situação \\
\hline \multicolumn{6}{|c|}{ Anos 80} \\
\hline $\begin{array}{l}\text { SAARA, Uruguaiana } \\
\text { Zona de Transição } \\
\text { Centro - II RA }\end{array}$ & $1979 / 1984$ & $\begin{array}{l}\text { Iluminação do Largo de São } \\
\text { Francisco }\end{array}$ & $\begin{array}{l}\text { PCRJ - Corredor } \\
\text { Cultural }\end{array}$ & Investimento público & Concluída \\
\hline $\begin{array}{l}\text { Praça XV } \\
\text { ACN } \\
\text { Centro - II RA }\end{array}$ & $1979 / 1984$ & $\begin{array}{l}\text { Iluminação do núcleo histórico } \\
\text { da Praça XV }\end{array}$ & $\begin{array}{l}\text { PCRJ - Corredor } \\
\text { Cultural }\end{array}$ & Investimento público & Concluída \\
\hline $\begin{array}{l}\text { ACN } \\
\text { SAARA } \\
\text { Centro - II RA }\end{array}$ & $1979 / 1984$ & $\begin{array}{l}\text { Transformação de ruas em vias } \\
\text { exclusivas de pedestres }\end{array}$ & PCRJ e metrô & Investimento público & Concluída \\
\hline $\begin{array}{l}\text { SAARA } \\
\text { Uruguaiana } \\
\text { Praça XV } \\
\text { Lapa } \\
\text { Centro - II RA }\end{array}$ & $1984 / 2002$ & $\begin{array}{l}\text { Recuperação de fachadas de } \\
\text { cerca de } 1000 \text { imóveis na área do } \\
\text { Corredor Cultural }\end{array}$ & $\begin{array}{l}\text { PCRJ - Corredor } \\
\text { Cultural e iniciativa } \\
\text { privada, com } \\
\text { incentivos fiscais }\end{array}$ & $\begin{array}{l}\text { Investimento privado: } \\
\text { R\$30 a } 40 \text { milhões } \\
\text { (R\$30 a } 40 \text { mil por imóvel) }\end{array}$ & Concluída \\
\hline \multicolumn{6}{|c|}{ Anos 90} \\
\hline \multicolumn{6}{|c|}{ Primeiro grupo } \\
\hline $\begin{array}{l}\text { Lapa } \\
\text { Zona Periférica Centro } \\
\text { - II RA }\end{array}$ & 1991/1992 & $\begin{array}{l}\text { Reestruturação do Largo } \\
\text { da Lapa - reorganização do } \\
\text { trânsito, sinalização, iluminação, } \\
\text { arborização e construção de } \\
\text { largo }\end{array}$ & $\begin{array}{l}\text { PCRJ - IPLANRIO } \\
\text { e RIOARTE }\end{array}$ & $\begin{array}{l}\text { Investimento público. } \\
\text { Custo estimado no projeto: } \\
\text { U\$2.000.000,00 }\end{array}$ & Concluída \\
\hline $\begin{array}{l}\text { Presidente Vargas } \\
\text { ACN e Zona de Transição } \\
\text { Centro - II RA }\end{array}$ & 1991/1994 & $\begin{array}{l}\text { Av. Presidente Vargas - criação } \\
\text { de canteiros centrais }\end{array}$ & PCRJ & $\begin{array}{l}\text { Investimento público. } \\
\mathrm{R} \$ 401.304,00\end{array}$ & Concluída \\
\hline $\begin{array}{l}\text { Uruguaiana } \\
\text { Zona de Transição } \\
\text { Centro - II RA }\end{array}$ & 1991 & $\begin{array}{l}\text { Reestruturação e reformulação } \\
\text { paisagística da Rua Uruguaiana }\end{array}$ & PCRJ & $\begin{array}{l}\text { Investimento público. } \\
\text { Custo estimado no projeto: } \\
\text { U\$ 700.000,00 }\end{array}$ & Concluída \\
\hline $\begin{array}{l}\text { Carioca } \\
\text { ACN } \\
\text { Centro - II RA } \\
\end{array}$ & 1991 & $\begin{array}{l}\text { Largo da Carioca - novo projeto } \\
\text { paisagístico com implantação de } \\
\text { mobiliário urbano }\end{array}$ & PCRJ & Investimento público & Concluída \\
\hline $\begin{array}{l}\text { Cinelândia } \\
\text { ACN } \\
\text { Centro - II RA }\end{array}$ & $1991 / 1993$ & $\begin{array}{l}\text { Cinelândia - recuperação } \\
\text { da antiga praça, revisão de } \\
\text { calçamento e colocação de } \\
\text { quiosques }\end{array}$ & PCRJ & $\begin{array}{l}\text { Investimento público. } \\
\text { Custo estimado do projeto: } \\
\text { U\$1.800.000,00 }\end{array}$ & Concluída \\
\hline $\begin{array}{l}\text { SAARA, Uruguaiana } \\
\text { Zona de Transição } \\
\text { Centro - II RA }\end{array}$ & $1991 / 1993$ & $\begin{array}{l}\text { Largo de São Francisco - retirada } \\
\text { do estacionamento, fechamento } \\
\text { para veículos, mobiliário urbano } \\
\text { e iluminação }\end{array}$ & PCRJ & $\begin{array}{l}\text { Investimento público. } \\
\text { Custo estimado do projeto: } \\
\text { US\$ } 1.000 .000,00 \text {. }\end{array}$ & Concluída \\
\hline
\end{tabular}




\begin{tabular}{|c|c|c|c|c|c|}
\hline Localização & Período & Intervenção & Execução & Investimento & Situação \\
\hline \multicolumn{6}{|c|}{ Anos 90} \\
\hline \multicolumn{6}{|c|}{ Segundo grupo } \\
\hline $\begin{array}{l}\text { Saúde } \\
\text { Zona periférica } \\
\text { Zona Portuária - I RA }\end{array}$ & 1993 & $\begin{array}{l}\text { Largo de São Francisco } \\
\text { da Prainha - tratamento } \\
\text { paisagístico, troca de calçamento } \\
\text { e instalação de mobiliário urbano }\end{array}$ & $\begin{array}{l}\text { PCRJ - COMLURB, } \\
\text { DGVU e Fundação } \\
\text { Parques e Jardins }\end{array}$ & Investimento público & Concluída \\
\hline $\begin{array}{l}\text { ACN } \\
\text { (Aeroporto) } \\
\text { Centro - II RA }\end{array}$ & $1994 / 1996$ & $\begin{array}{l}\text { Praça Salgado Filho - } \\
\text { ampliação, ordenamento do } \\
\text { estacionamento, reforma } \\
\text { dos jardins, iluminação e } \\
\text { implantação de controle da } \\
\text { Guarda Municipal }\end{array}$ & $\begin{array}{l}\text { PCRJ em parceria com } \\
\text { INFRAERO }\end{array}$ & $\begin{array}{l}\text { Investimento público e } \\
\text { privado }\end{array}$ & Concluída \\
\hline $\begin{array}{l}\text { Zona de Transição } \\
\text { (imediações da } \\
\text { Uruguaiana e Praça } \\
\text { Tiradentes) } \\
\text { Centro - II RA }\end{array}$ & 1994 & $\begin{array}{l}\text { Rua Sete de Setembro - } \\
\text { recuperação e pintura de } \\
\text { fachadas - Projeto Cores da } \\
\text { Cidade }\end{array}$ & $\begin{array}{l}\text { PCRJ - Corredor } \\
\text { Cultural, proprietários } \\
\text { e lojistas. Tintas } \\
\text { Ypiranga e Fundação } \\
\text { Roberto Marinho } \\
\end{array}$ & $\begin{array}{l}\text { Investimento privado. } \\
\text { Custo para proprietários } \\
\text { e ocupantes reduzido em } \\
40 \%\end{array}$ & Concluída \\
\hline $\begin{array}{l}\text { Cinelândia } \\
\text { ACN } \\
\text { Centro - II RA }\end{array}$ & $\begin{array}{l}1994,1996 \text { e } \\
1999\end{array}$ & $\begin{array}{l}\text { Passeio Público - limpeza, } \\
\text { retirada de moradores, } \\
\text { alteamento da calçada, } \\
\text { iluminação e recuperação de } \\
\text { equipamentos, restauração de } \\
\text { gradil e quiosques }\end{array}$ & PCRJ & $\begin{array}{l}\text { Investimento público. } \\
\mathrm{R} \$ 358.823,00 \text { (referentes } \\
\text { à reforma das calçadas, } \\
\text { restauração de portóes, } \\
\text { gradil e quiosques) }\end{array}$ & Concluída \\
\hline $\begin{array}{l}\text { Central do Brasil } \\
\text { Zona Periférica } \\
\text { Centro - II RA }\end{array}$ & 1994/1996 & $\begin{array}{l}\text { Praça do Itamaraty - criação da } \\
\text { praça por meio do desmanche do } \\
\text { quarteirão com agenciamento e } \\
\text { iluminação }\end{array}$ & PCRJ & $\begin{array}{l}\text { Investimento público. } \\
\mathrm{R} \$ 253.843,00\end{array}$ & Concluída \\
\hline $\begin{array}{l}\text { ACN } \\
\text { (áreas da Praça XV, } \\
\text { Quadrilátero Financeiro, } \\
\text { Cinelândia, Castelo e } \\
\text { Praça Mauá) } \\
\text { Centro - II RA }\end{array}$ & $1994 / 2001$ & $\begin{array}{l}\text { Reurbanização* das ruas } \\
\text { Trav. do Comércio, Alfândega, } \\
\text { Candelária, do Carmo, Treze de } \\
\text { Maio, Senador Dantas, acesso } \\
\text { à estação de bondes de Sta. } \\
\text { Tereza, Trav. do Ouvidor, Heitor } \\
\text { de Melo, do Ouvidor, do Rosário, } \\
\text { da Quitanda, Sete de Setembro, } \\
\text { Rodrigues Silva, São José, dos } \\
\text { Andradas, Manuel Carvalho, } \\
\text { Vieira Fazenda, Av. Silvio } \\
\text { Noronha, D. Gerardo, Av. Pres. } \\
\text { Wilson, Primeiro de Março e Av. } \\
\text { Pres. Antonio Carlos }\end{array}$ & $\begin{array}{l}\text { PCRJ - Parceria com: } \\
\text { Banco Multiplic, } \\
\text { em trecho das Ruas } \\
\text { da Alfândega e } \\
\text { Candelária; Cia. Sul } \\
\text { América de Seguros } \\
\text { em trecho da Rua do } \\
\text { Carmo; Comerciantes } \\
\text { na Trav. do Ouvidor; } \\
\text { Consulado dos EUA } \\
\text { na Av. Pres. Wilson. }\end{array}$ & $\begin{array}{l}\text { Investimento público e } \\
\text { privado. R\$12.010.989,00 } \\
\text { (valor referente apenas } \\
\text { às intervençóes nas Ruas } \\
\text { Imperatriz Leopoldina, } \\
\text { Heitor de Melo, do Carmo, } \\
\text { do Ouvidor, do Rosário, } \\
\text { da Quitanda, Sete de } \\
\text { Setembro, Miguel Couto, } \\
\text { Treze de Maio, Manuel de } \\
\text { Carvalho, Vieira Fazenda, } \\
\text { Buenos Aires, D. Gerardo, } \\
\text { Av. Silvio Noronha, } \\
\text { Primeiro de Março e Av. } \\
\text { Pres. Antonio Carlos) }\end{array}$ & Concluídas \\
\hline $\begin{array}{l}\text { Zona de Transição e } \\
\text { Periférica (áreas nas } \\
\text { imediações do SAARA, } \\
\text { da Uruguaiana e da } \\
\text { Praça Tiradentes) } \\
\text { Centro - II RA }\end{array}$ & $1994 / 1996$ & $\begin{array}{l}\text { Reurbanização* das Ruas } \\
\text { Alexandre Herculano, do Teatro, } \\
\text { Luiz de Camões, Imperatriz } \\
\text { Leopoldina, do Ouvidor, do } \\
\text { Rosário, da Quitanda, Sete } \\
\text { de Setembro, Miguel Couto, } \\
\text { Conceição, Rodrigues Silva, } \\
\text { São José, dos Andradas } \\
\text { e Buenos Aires }\end{array}$ & PCRJ & Sem informação & Concluídas \\
\hline $\begin{array}{l}\text { Quadrilátero financeiro } \\
\text { ACN } \\
\text { Centro - II RA }\end{array}$ & 1995 & $\begin{array}{l}\text { Praça Melwin Jones - retirada } \\
\text { de lago artificial e criação } \\
\text { de anfiteatro, arborização, } \\
\text { recuperação de infraestrutura e } \\
\text { iluminação }\end{array}$ & $\begin{array}{l}\text { PCRJ em parceria } \\
\text { com McDonnald's e } \\
\text { AMISAJE }\end{array}$ & $\begin{array}{l}\text { Investimento público } \\
\text { e privado. } \mathrm{R} \$ 634.098,00\end{array}$ & Concluída \\
\hline
\end{tabular}




\begin{tabular}{|c|c|c|c|c|c|}
\hline Localização & Período & Intervenção & Execução & Investimento & Situação \\
\hline \multicolumn{6}{|c|}{ Anos go } \\
\hline \multicolumn{6}{|c|}{ Segundo grupo } \\
\hline $\begin{array}{l}\text { SAARA } \\
\text { Zona de Transição } \\
\text { Centro - II RA }\end{array}$ & 1995 & $\begin{array}{l}\text { Praça do Mascate, na Rua } \\
\text { Regente Feijó - implantação da } \\
\text { praça, arborização, mobiliário } \\
\text { urbano e iluminação }\end{array}$ & $\begin{array}{l}\text { PCRJ em parceria com } \\
\text { comércio local }\end{array}$ & $\begin{array}{l}\text { Investimento público } \\
\text { e privado }\end{array}$ & Concluída \\
\hline $\begin{array}{l}\text { Praça XV } \\
\text { ACN } \\
\text { Centro - II RA }\end{array}$ & $1995 / 1996$ & $\begin{array}{l}\text { Praça XV - obras de } \\
\text { reestruturação viária, } \\
\text { agenciamento paisagístico, } \\
\text { nova pavimentação, retirada de } \\
\text { ambulantes, remanejamento de } \\
\text { infraestrutura }\end{array}$ & PCRJ - RIOURBE & $\begin{array}{l}\text { Investimento público. } \\
\mathrm{R} \$ 19.394 .728,00\end{array}$ & Concluída \\
\hline $\begin{array}{l}\text { Praça Tiradentes } \\
\text { Zona de Transição } \\
\text { Centro - II RA }\end{array}$ & $1995 / 1996$ & $\begin{array}{l}\text { Praça Tiradentes - ordenamento } \\
\text { de terminais, gradeamento e } \\
\text { recuperação do calçamento da } \\
\text { praça, ampliação de calçadas }\end{array}$ & PCRJ - RIOURBE & $\begin{array}{l}\text { Investimento público. } \\
\mathrm{R} \$ 2.484 .504,00\end{array}$ & Concluída \\
\hline $\begin{array}{l}\text { Cinelândia } \\
\text { ACN } \\
\text { Centro - II RA }\end{array}$ & 1996 & $\begin{array}{l}\text { Praça do Monroe - gradeamento, } \\
\text { reforma do chafariz, iluminação } \\
\text { e implantação de controle pela } \\
\text { Guarda Municipal }\end{array}$ & PCRJ & Investimento público & Concluída \\
\hline $\begin{array}{l}\text { Esplanada de Santo } \\
\text { Antônio } \\
\text { ACN } \\
\text { Centro - II RA }\end{array}$ & 1996 & $\begin{array}{l}\text { Praça Estado da Guanabara - } \\
\text { reforma, com ordenamento de } \\
\text { ambulantes, reforma do chafariz, } \\
\text { iluminação, mobiliário urbano }\end{array}$ & PCRJ & Investimento público & Concluída \\
\hline $\begin{array}{l}\text { Esplanada de Santo } \\
\text { Antonio } \\
\text { ACN } \\
\text { Centro - II RA }\end{array}$ & 1996 & $\begin{array}{l}\text { Praça Espaço Guignard na Av. } \\
\text { Rep. do Paraguai - criação de } \\
\text { praça gradeada, arborização e } \\
\text { mobiliário urbano }\end{array}$ & $\begin{array}{l}\text { PCRJ em parceria com } \\
\text { Petrobras }\end{array}$ & $\begin{array}{l}\text { Investimento público } \\
\text { e privado } \mathrm{R} \$ 498.843,00\end{array}$ & Concluída \\
\hline $\begin{array}{l}\text { Central do Brasil } \\
\text { Zona Periférica } \\
\text { Centro - II RA }\end{array}$ & 1996 & $\begin{array}{l}\text { Terminal Américo Fontenelle } \\
\text { - Retirada de invasões e } \\
\text { ambulantes do entorno e } \\
\text { recuperação da área }\end{array}$ & PCRJ & $\begin{array}{l}\text { Investimento público. } \\
\mathrm{R} \$ 1.616 .395,00\end{array}$ & Concluída \\
\hline $\begin{array}{l}\text { Castelo } \\
\text { ACN } \\
\text { Centro - II RA }\end{array}$ & 1996 & $\begin{array}{l}\text { Praça dos Professores na Rua } \\
\text { Pedro Lessa - eliminação de } \\
\text { calçadão, iluminação, canteiros, } \\
\text { implantação de rua de serviço, } \\
\text { infraestrutura e ordenamento de } \\
\text { ambulantes }\end{array}$ & PCRJ & Investimento público & Concluída \\
\hline $\begin{array}{l}\text { Castelo } \\
\text { ACN } \\
\text { Centro - II RA } \\
\end{array}$ & 1996 & $\begin{array}{l}\text { Praça Virgílio de Melo Franco } \\
\text { - criação da praça, mobiliário } \\
\text { urbano e arborização }\end{array}$ & PCRJ & Investimento público & Concluída \\
\hline $\begin{array}{l}\text { Central do Brasil } \\
\text { Zona Periférica } \\
\text { Centro - II RA }\end{array}$ & 1996 & $\begin{array}{l}\text { Praça Procópio Ferreira - } \\
\text { ordenamento de ambulantes, } \\
\text { gradeamento, iluminação, } \\
\text { arborização, implantação e } \\
\text { controle pela Guarda Municipal }\end{array}$ & & $\begin{array}{l}\text { Investimento público. } \\
\mathrm{R} \$ 894.881,00\end{array}$ & Concluída \\
\hline $\begin{array}{l}\text { Avenida Rio Branco } \\
\text { e Cinelândia (entre } \\
\text { Quadrilátero e } \\
\text { Cinelândia) } \\
\text { ACN } \\
\text { Centro - II RA }\end{array}$ & 1996 & $\begin{array}{l}\text { Execução do Programa Rio } \\
\text { Cidade - novo posteamento e } \\
\text { iluminação, nova pavimentação, } \\
\text { revisão da arborização, } \\
\text { reurbanização da Praça Floriano } \\
\text { e criação do Largo do Pequeno } \\
\text { Jornaleiro }\end{array}$ & PCRJ & $\begin{array}{l}\text { Investimento púbico. } \\
\mathrm{R} \$ 13.450 .940,00\end{array}$ & Concluída \\
\hline
\end{tabular}




\begin{tabular}{|c|c|c|c|c|c|}
\hline Localização & Período & Intervenção & Execução & Investimento & Situação \\
\hline \multicolumn{6}{|c|}{ Anos go } \\
\hline \multicolumn{6}{|c|}{ Segundo grupo } \\
\hline $\begin{array}{l}\text { Castelo, SAARA, } \\
\text { Tiradentes } \\
\text { ACN e Zona de Transição } \\
\text { Centro - II RA }\end{array}$ & 1996 & $\begin{array}{l}\text { Implantação de esculturas na } \\
\text { Rua Uruguaiana, Av. Antonio } \\
\text { Carlos, Largo da Carioca, Rua } \\
\text { Alexandre Herculano, Trav. Belas } \\
\text { Artes }\end{array}$ & PCRJ & Investimento público & Concluída \\
\hline $\begin{array}{l}\text { Cruz Vermelha } \\
\text { Zona Periférica } \\
\text { Centro - II RA }\end{array}$ & 1996 & $\begin{array}{l}\text { Praça da Cruz Vermelha - } \\
\text { urbanização com criação de } \\
\text { praça na rótula viária, mobiliário } \\
\text { urbano, iluminação e reforma de } \\
\text { infraestrutura }\end{array}$ & PCRJ & $\begin{array}{l}\text { Investimento público } \\
\mathrm{R} \$ 1.210 .915,00\end{array}$ & Concluída \\
\hline $\begin{array}{l}\text { ACN, Zona de Transição } \\
\text { e Zona Periférica } \\
\text { Centro - II RA }\end{array}$ & 1996 & $\begin{array}{l}\text { Iluminação pública de vários } \\
\text { monumentos e logradouros *** }\end{array}$ & PCRJ & Investimento público & Concluída \\
\hline $\begin{array}{l}\text { Cruz Vermelha } \\
\text { Zona Periférica } \\
\text { Centro - II RA }\end{array}$ & 1998 & $\begin{array}{l}\text { Túnel Martins Sá - recuperação } \\
\text { estrutural }\end{array}$ & PCRJ & $\begin{array}{l}\text { Investimento público. } \\
\mathrm{R} \$ 859.078,00\end{array}$ & Concluída \\
\hline $\begin{array}{l}\text { Castelo, SAARA, } \\
\text { Tiradentes } \\
\text { ACN e Zona de Transição } \\
\text { Centro - II RA }\end{array}$ & 1996 & $\begin{array}{l}\text { Implantação de esculturas na } \\
\text { Rua Uruguaiana, Av. Antonio } \\
\text { Carlos, Largo da Carioca, } \\
\text { Rua Alexandre Herculano, Trav. } \\
\text { Belas Artes }\end{array}$ & PCRJ & Investimento público & Concluída \\
\hline $\begin{array}{l}\text { Cruz Vermelha } \\
\text { Zona Periférica } \\
\text { Centro - II RA }\end{array}$ & 1996 & $\begin{array}{l}\text { Praça da Cruz Vermelha - } \\
\text { urbanização com criação de } \\
\text { praça na rótula viária, mobiliário } \\
\text { urbano, iluminação e reforma de } \\
\text { infraestrutura }\end{array}$ & PCRJ & $\begin{array}{l}\text { Investimento público } \\
\mathrm{R} \$ 1.210 .915,00\end{array}$ & Concluída \\
\hline $\begin{array}{l}\text { ACN, Zona de Transição } \\
\text { e Zona Periférica } \\
\text { Centro - II RA }\end{array}$ & 1996 & $\begin{array}{l}\text { Iluminação pública de vários } \\
\text { monumentos e logradouros *** }\end{array}$ & PCRJ & Investimento público & Concluída \\
\hline $\begin{array}{l}\text { Cruz Vermelha } \\
\text { Zona Periférica } \\
\text { Centro - II RA }\end{array}$ & 1998 & $\begin{array}{l}\text { Túnel Martins Sá - recuperação } \\
\text { estrutural }\end{array}$ & PCRJ & $\begin{array}{l}\text { Investimento público. } \\
\mathrm{R} \$ 859.078,00\end{array}$ & Concluída \\
\hline $\begin{array}{l}\text { Campo de Santana } \\
\text { Zona de Transição } \\
\text { Centro - II RA }\end{array}$ & 1999 & $\begin{array}{l}\text { Campo de Santana - restauração } \\
\text { do gradil, quiosques e sinalização }\end{array}$ & PCRJ & $\begin{array}{l}\text { Investimento público. } \\
\text { R\$ } 133.134,00\end{array}$ & Concluída \\
\hline $\begin{array}{l}\text { SAARA, Uruguaiana } \\
\text { Zona de Transição } \\
\text { Centro - II RA }\end{array}$ & 2000 & $\begin{array}{l}\text { Largo Alexandre Herculano - } \\
\text { alteamento do nível da praça, } \\
\text { fechamento de trecho ao } \\
\text { trânsito, novo piso }\end{array}$ & PCRJ & $\begin{array}{l}\text { Investimento público. } \\
\text { R\$ } 167.925,00\end{array}$ & Concluída \\
\hline $\begin{array}{l}\text { Lapa } \\
\text { Zona Periférica } \\
\text { Centro - IIRA }\end{array}$ & 2000 & $\begin{array}{l}\text { Reurbanização da Rua do } \\
\text { Lavradio com aumento } \\
\text { de calçadas, iluminação, } \\
\text { fechamento de trecho e reforma } \\
\text { da infraestrutura (galerias } \\
\text { pluviais e esgotos) }\end{array}$ & $P C R J * *$ & $\begin{array}{l}\text { Investimento público. } \\
\mathrm{R} \$ 4.683 .532,00\end{array}$ & Concluída \\
\hline $\begin{array}{l}\text { Castelo } \\
\text { ACN } \\
\text { Centro - IIRA }\end{array}$ & 2000 & $\begin{array}{l}\text { Praça Itália - reforma com } \\
\text { retirada de canteiros }\end{array}$ & PCRJ & $\begin{array}{l}\text { Investimento público. } \\
\text { R\$160.919,00 }\end{array}$ & Concluída \\
\hline $\begin{array}{l}\text { Aeroporto } \\
\text { ACN } \\
\text { Centro - II RA }\end{array}$ & 2000 & $\begin{array}{l}\text { Praça } 22 \text { de Abril - reforma dos } \\
\text { canteiros e calçamento }\end{array}$ & PCRJ & $\begin{array}{l}\text { Investimento público. } \\
\mathrm{R} \$ 164.117,00\end{array}$ & Concluída \\
\hline
\end{tabular}




\begin{tabular}{|c|c|c|c|c|c|}
\hline Localização & Período & Intervenção & Execução & Investimento & Situação \\
\hline \multicolumn{6}{|c|}{ Anos go } \\
\hline \multicolumn{6}{|c|}{ Segundo grupo } \\
\hline $\begin{array}{l}\text { Cruz Vermelha } \\
\text { Zona Periférica } \\
\text { Centro - II RA }\end{array}$ & 2000 & $\begin{array}{l}\text { Praça Aguirre Cerda - } \\
\text { alteamento do meio fio e } \\
\text { recuperação de mobiliário }\end{array}$ & PCRJ & Investimento público & Concluída \\
\hline $\begin{array}{l}\text { Morro da Conceição } \\
\text { Zona Periférica } \\
\text { Zona Portuária - I RA }\end{array}$ & 2000 & $\begin{array}{l}\text { Programa ProRio Morro da } \\
\text { Conceição - recuperação de } \\
\text { espaço público na área da Pedra } \\
\text { do Sal, correspondente a } 8 \% \text { das } \\
\text { intervenções previstas }\end{array}$ & PCRJ & Investimento público & $\begin{array}{l}\text { Em andamento } \\
\text { (projeto global } \\
\text { licitado) }\end{array}$ \\
\hline $\begin{array}{l}\text { Saúde, Livramento e } \\
\text { Gamboa } \\
\text { Portuária - I RA }\end{array}$ & 2000 & $\begin{array}{l}\text { Melhoramentos no espaço } \\
\text { público nos Morros da Saúde, } \\
\text { Livramento e Gamboa }\end{array}$ & PCRJ & Investimento público & Concluída \\
\hline $\begin{array}{l}\text { Praça Tiradentes, Zona } \\
\text { de Transição } \\
\text { Centro - II RA }\end{array}$ & $2000 / 2001$ & $\begin{array}{l}\text { Projeto Tiradentes - } \\
\text { Programa Monumenta (obras } \\
\text { emergenciais) }\end{array}$ & MinC/BID/PCRJ & Investimento público & Em andamento \\
\hline $\begin{array}{l}\text { Cinelândia } \\
\text { ACN } \\
\text { Centro - II RA }\end{array}$ & 2002 & $\begin{array}{l}\text { Construção de garagem } \\
\text { subterrânea na Praça do Monroe, } \\
\text { com dois pavimentos, } 1000 \text { vagas } \\
\text { internas e } 500 \text { externas }\end{array}$ & $\begin{array}{l}\text { Estacionamento } \\
\text { Cinelândia S/A, com } \\
\text { fiscalização da PCRJ }\end{array}$ & $\begin{array}{l}\text { Investimento privado. } \\
\text { A construção, em regime } \\
\text { de concessão pela } \\
\text { Prefeitura, foi realizada } \\
\text { pelo consórcio de } \\
\text { empresas que irá explorar } \\
\text { a garagem durante } 35 \\
\text { anos. R\$ } 25.000 .000,00\end{array}$ & Concluída \\
\hline
\end{tabular}

Fonte: Quadro montado a partir de informaçōes de MAGALHÃES, 2001; Entrevista de Augusto Ivan de Freitas Pinheiro (Apêndice E); Empresa Municipal de Informática e Planejamento (1990a, 1990b, [1992?]); Empresa Municipal de Informática e Planejamento; Instituto Municipal de Arte e Cultura (1989a, 1989b); Rio de Janeiro (1998) e Blyth (1991) p. 68-69.

* Intervenções que contemplam criação e melhoria de calçadões, eliminação de calçadões, alteamento e alargamento de calçadas, criação de ruas de serviço, instalação de mobiliário urbano, substituição de calçamento, iluminação e revisão de infraestrutura, gradeamento. ** A reurbanização da Rua do Lavradio foi resultado de pressão da Associação dos Comerciantes do Centro do Rio Antigo e Amigos - ACCRA.

*** Monumentos e logradouros iluminados: Arcos da Lapa, Quadra da Cultura, Biblioteca Nacional, Teatro Municipal, Escola Nacional d e Música, Palácio Duque de Caxias, Monumento ao Marechal Floriano, Espaço Cultural da Marinha, Igreja da Lapa do Desterro,

Lampadário da Lapa, Chafariz do Mestre Valentim, Chafariz do Monroe, IFCS, Igreja de São Francisco de Paula, Igreja de Santa Rita, Real

Gabinete Português de Leitura, Museu Histórico Nacional, Igreja da Candelária, Museu Nacional de Belas Artes, Estátua de D. Pedro I. 


\section{Apêndice D}

\section{Intervenções de conservação e requalificação na área central de São Paulo, 1990/2002}

\begin{tabular}{|c|c|c|c|c|c|}
\hline Ano & Intervenção pública & Instância & Intervenção privada & Área & Situação \\
\hline $1990 / 92$ & Teatro Municipal & Prefeitura Municipal & & Centro & Concluída \\
\hline $1990 / 92$ & $\begin{array}{l}\text { Biblioteca Municipal Mário } \\
\text { de Andrade }\end{array}$ & Prefeitura Municipal & & Centro & Concluída \\
\hline $1990 / 92$ & Casa da Marquesa de Santos & Prefeitura Municipal & & Centro & Concluída \\
\hline $1990 / 92$ & Casa no or & Prefeitura Municipal & & Centro & Concluída \\
\hline 1990/91 & Palácio das Indústrias & Prefeitura Municipal & & Centro & Concluída \\
\hline 1991 & $\begin{array}{l}\text { Reurbanização do Vale } \\
\text { do Anhangabaú }\end{array}$ & Prefeitura Municipal & & Centro & Concluída \\
\hline 1991 & Boulevard São João & Prefeitura Municipal & & Centro & Concluída \\
\hline 1992 & Eixo Sé-Arouche & Prefeitura Municipal & $\begin{array}{l}\text { Comerciantes da Av. Vieira } \\
\text { de Carvalho, Rua e Largo } \\
\text { do Arouche }\end{array}$ & Centro & Concluído \\
\hline 1995 & $\begin{array}{l}\text { Lavagem e iluminação da } \\
\text { fachada da Igreja e Mosteiro } \\
\text { São Bento }\end{array}$ & $\begin{array}{l}\text { Prefeitura Municipal - } \\
\text { ProCentro }\end{array}$ & Philips & Centro & Concluída \\
\hline 1995 & $\begin{array}{l}\text { Restauro de Painel Artístico no } \\
\text { Largo de São Bento }\end{array}$ & $\begin{array}{l}\text { Prefeitura Municipal - } \\
\text { ProCentro }\end{array}$ & & Centro & Concluída \\
\hline 1995 & $\begin{array}{l}\text { Construção de Passagem } \\
\text { Subterrânea no cruzamento } \\
\text { das Av. Prestes Maia e Senador } \\
\text { Queirós }\end{array}$ & $\begin{array}{l}\text { Prefeitura Municipal - } \\
\text { ProCentro }\end{array}$ & & Centro & Concluída \\
\hline 1996 & $\begin{array}{l}\text { Reformulação dos terminais } \\
\text { de ônibus da Praça da Bandeira, } \\
\text { Parque D. Pedro II e Largo do } \\
\text { Paissandu }\end{array}$ & $\begin{array}{l}\text { Prefeitura Municipal - } \\
\text { ProCentro }\end{array}$ & & Centro & Concluída \\
\hline 1996 & $\begin{array}{l}\text { Tratamento do túnel } \\
\text { Anhangabaú }\end{array}$ & $\begin{array}{l}\text { Prefeitura Municipal - } \\
\text { ProCentro }\end{array}$ & & Centro & Concluída \\
\hline 1996 & $\begin{array}{l}\text { Construção de passarela } \\
\text { de pedestres na Av. Tiradentes }\end{array}$ & $\begin{array}{l}\text { Prefeitura Municipal - } \\
\text { ProCentro }\end{array}$ & & Luz & Concluída \\
\hline 1996 & $\begin{array}{l}\text { Restauração de fachadas } \\
\text { da Rua Florêncio Abreu }\end{array}$ & $\begin{array}{l}\text { Prefeitura Municipal - } \\
\text { ProCentro e DPH }\end{array}$ & $\begin{array}{l}\text { Associação dos Lojistas da } \\
\text { Florêncio Abreu - ALFA }\end{array}$ & Centro & Iniciada \\
\hline 1996 & $\begin{array}{l}\text { Pintura de fachadas de edifícios } \\
\text { do Largo de São Francisco }\end{array}$ & Prefeitura Municipal & Anhembi e patrocinadores & Centro & Iniciada \\
\hline 1996 & $\begin{array}{l}\text { Instalação de dez painéis } \\
\text { informativos }\end{array}$ & $\begin{array}{l}\text { Prefeitura Municipal - } \\
\text { ProCentro }\end{array}$ & & Centro & Concluída \\
\hline 1997 & $\begin{array}{l}\text { Restauração da Igreja } \\
\text { de São Francisco }\end{array}$ & & $\begin{array}{l}\text { Patrocinadores: Empresa } \\
\text { Yvone Capuano, } \\
\text { CAP Empreendimentos } \\
\text { e Tintas Ypiranga }\end{array}$ & Centro & $7^{\mathrm{a}}$ etapa \\
\hline 1997 & $\begin{array}{l}\text { Obras de recuperação } \\
\text { do Largo de São Bento }\end{array}$ & $\begin{array}{l}\text { Prefeitura Municipal - } \\
\text { ProCentro }\end{array}$ & $\begin{array}{l}\text { Philips, BankBoston } \\
\text { e Mosteiro de São Bento }\end{array}$ & Centro & Concluída \\
\hline 1997 & $\begin{array}{l}\text { Pintura da fachada do Colégio } \\
\text { Caetano de Campos }\end{array}$ & $\begin{array}{l}\text { Prefeitura Municipal - } \\
\text { ProCentro }\end{array}$ & Tintas Coral & & Concluída \\
\hline
\end{tabular}




\begin{tabular}{|c|c|c|c|c|c|}
\hline Ano & Intervenção pública & Instância & Intervenção privada & Área & Situação \\
\hline 1998 & $\begin{array}{l}\text { Pintura da Catedral da Sé e início } \\
\text { da restauração do edifício }\end{array}$ & $\begin{array}{l}\text { Prefeitura Municipal - } \\
\text { ProCentro }\end{array}$ & Tintas Coral & Centro & $\begin{array}{l}\text { Concluída a } \\
\text { pintura, demais } \\
\text { obras em } \\
\text { andamento }\end{array}$ \\
\hline 1998 & $\begin{array}{l}\text { Reforma do Jardim da Luz com } \\
\text { reativação do chafariz }\end{array}$ & $\begin{array}{l}\text { Prefeitura Municipal - } \\
\text { ProCentro }\end{array}$ & & Luz & Concluída \\
\hline 1998 & $\begin{array}{l}\text { Restauração da Igreja } \\
\text { de Santo Antônio }\end{array}$ & & $\begin{array}{l}\text { Obra realizada com venda } \\
\text { de potencial construtivo }\end{array}$ & Centro & Concluída \\
\hline 1998 & $\begin{array}{l}\text { Restauração da Pinacoteca do } \\
\text { Estado }\end{array}$ & $\begin{array}{l}\text { Governo do Estado e } \\
\text { Ministério da Cultura }\end{array}$ & & Luz & Concluída \\
\hline 1999 & $\begin{array}{l}\text { Shopping Light no Edifício } \\
\text { Alexandre Mackenzie }\end{array}$ & & $\begin{array}{l}\text { Light (com benefícios da } \\
\text { Operação Urbana Centro) }\end{array}$ & Centro & Concluído \\
\hline 1999 & $\begin{array}{l}\text { Restauro do edifício da Mappin } \\
\text { para instalação do Magazine } \\
\text { Extra Mappin }\end{array}$ & & Grupo Pão de Açúcar & Centro & Concluída \\
\hline 1999 & $\begin{array}{l}\text { Obras de construção da Sala São } \\
\text { Paulo na Estação Júlio Prestes }\end{array}$ & Governo do Estado & $\begin{array}{l}\text { Projetos em parceria com } \\
\text { Associação Viva o Centro }\end{array}$ & Luz & Concluída \\
\hline 1999 & Restauração do Teatro São Pedro & Governo do Estado & & Barra Funda & Concluída \\
\hline 1999 & $\begin{array}{l}\text { Restauração do Museu de Arte } \\
\text { Sacra, no Mosteiro da Luz }\end{array}$ & & & Luz & Concluída \\
\hline 1999 & $\begin{array}{l}\text { Restauração do prédio do Teatro } \\
\text { Brasileiro de Comédias }\end{array}$ & & Vários patrocinadores & Bexiga & Concluído \\
\hline 1999 & Escola do Livro & UNESP & Câmara Brasileira do Livro & Centro & Concluída \\
\hline 1999 & $\begin{array}{l}\text { Recuperação da Hospedaria dos } \\
\text { Imigrantes para instalação do } \\
\text { Memorial do Imigrante }\end{array}$ & Governo do Estado & & Brás & Concluída \\
\hline 2000 & $\begin{array}{l}\text { Obras de recuperação } \\
\text { do Viaduto Santa Efigênia }\end{array}$ & $\begin{array}{l}\text { Prefeitura Municipal - } \\
\text { ProCentro }\end{array}$ & & Centro & Concluída \\
\hline 2000 & $\begin{array}{l}\text { Obras de recuperação } \\
\text { do Viaduto do Chá }\end{array}$ & $\begin{array}{l}\text { Prefeitura Municipal - } \\
\text { ProCentro }\end{array}$ & & Centro & Concluída \\
\hline 2000 & Edifício-sede da BM\&F & & Bolsa Mercantil e Futuros & Centro & Concluída \\
\hline 2000 & $\begin{array}{l}\text { Início das Obras do Centro } \\
\text { Cultural dos Correios }\end{array}$ & & Correios & Centro & Em andamento \\
\hline 2000 & $\begin{array}{l}\text { Recuperação e manutenção } \\
\text { da Praça Ramos de Azevedo }\end{array}$ & Prefeitura Municipal & $\begin{array}{l}\text { Grupo Votorantim e Núcleo } \\
\text { de Ação Local Praça Ramos }\end{array}$ & Centro & Concluída \\
\hline 2000 & $\begin{array}{l}\text { Restauração da fachada do } \\
\text { edifício das Secretarias Estaduais } \\
\text { de Viação e Obras e de Recursos } \\
\text { Hídricos para instalação da sede } \\
\text { do Ministério Público Estadual }\end{array}$ & Ministério Público Estadual & & Centro & \\
\hline 2000 & $\begin{array}{l}\text { Restauração dos edifícios das } \\
\text { Secretarias da Justiça e da } \\
\text { Cidadania }\end{array}$ & Governo do Estado & & Centro & \\
\hline 2000 & $\begin{array}{l}\text { Restauração da fachada da Casa } \\
\text { da Boia }\end{array}$ & & $\begin{array}{l}\text { Incentivos da Lei das } \\
\text { Fachadas }\end{array}$ & Centro & \\
\hline 2001 & Centro Cultural Banco do Brasil & & Banco do Brasil & Centro & Concluída \\
\hline 2002 & $\begin{array}{l}\text { Restauro e Adaptação do Prédio } \\
\text { do DEOPS }\end{array}$ & Governo do Estado & & Luz & Concluída \\
\hline 2002 & $\begin{array}{l}\text { Requalificação da Praça } \\
\text { do Patriarca }\end{array}$ & Prefeitura Municipal & & Centro & Concluída \\
\hline
\end{tabular}




\section{Apêndice $E$}

\section{Lista de Contatos}

\section{Salvador}

\section{Bahiatursa}

Luciano Diniz Borges

Gerente de Estudos Econômicos

Contato realizado em 19/04/02.

\section{Caixa Econômica Federal}

Beatriz Cerqueira Lima

Gerente de Desenvolvimento Urbano

Contato realizado em 05/04/02.

\section{Companhia de Desenvolvimento Urbano do Estado da Bahia - CONDER}

Alfredo Júlio Machado

Coordenador do Projeto Habitacional do Centro Histórico ou Projeto Rememorar

Contato realizado em 15/04/02.

Maurício Augusto Aragão de Araújo

Coordenador Executivo do Centro Histórico

Contato realizado em 04/04/02.

Valfredo de Assis Ribeiro

Coordenador da Unidade Executora do Programa Monumenta

Contato realizado em 04/04/O2.

\section{Fundação Gregório de Matos}

Francisco Soares Senna

Presidente

Contato realizado em 03/05/02. 


\section{Instituto do Patrimônio Artístico e Cultural da Bahia - IPAC}

Adriana Almeida Couto de Castro

Diretora Geral do IPAC

Contato realizado em 08/04/02.

José Augusto Leal

Diretor Adjunto

Contato realizado em 08/04/02.

Paulo Damasceno Silva

Consultor Jurídico

Contato realizado em 08/04/02.

\section{Instituto do Patrimônio Histórico e Artístico Nacional}

\section{$7^{a}$ Superintendência Regional}

Adalgiza Maria Bonfim d’Eça

Superintendente Regional

Contato realizado em 04/04/02.

Eduardo Furtado de Simas

Chefe da Divisão Técnica

Contato realizado em 04/04/02.

Rita Márcia Sacramento

Representante do IPHAN no ETELF

Contatos realizados em 09/04/02 e julho de 2003.

\section{Secretaria da Cultura e Turismo do Estado da Bahia}

Etelvina Rebouças

Arquiteta da Unidade Executora de Projeto do Programa Monumenta para Lençóis e Cachoeira.

Contato realizado em 15/04/02. 


\section{Secretaria Municipal do Planejamento, Meio Ambiente e Desenvolvimento}

\section{Econômico e Fundação Mário Leal Ferreira}

Maria das Graças Torreão Ferreira

Coordenadora Central de Desenvolvimento Urbano

Contato realizado em 23/04/02.

Terezinha Lúcia Gonçalves Rios

Chefe de Gabinete da FMLF

Contato realizado em 22/04/02.

Elisabeth Lepikson

Assessora

Contato realizado em 13/08/03.

\section{Contatos não institucionais}

Dimitri Ganzelevicth

Morador da Rua Direita de Santo Antônio, n 177, e proprietário de mais dois imóveis no centro histórico

Contato realizado em 15/04/02.

Olympio Serra

Proprietário da Livraria "Sabor dos Saberes" - Rua Francisco Muniz Barreto, $n^{\circ}$ 05, Pelourinho

Contato realizado em 05/04/02.

\section{Rio de Janeiro}

Associação dos Comerciantes do Centro do Rio Antigo e Amigos - ACCRA

Plínio Fróes

Presidente

Contato realizado em 22/02/02. 


\section{Caixa Econômica Federal}

Helena Galiza

Coordenação do PRSH

Contato realizado em 25/02/02.

\section{Centro Cultural Banco do Brasil}

José Eduardo Dias de Oliveira

Gerente de Comunicação e Marketing

Contato realizado em 27/02/02.

\section{Centro Cultural Light}

Luciane Mandarino Bacil

Gerente do Centro Cultural

Contato realizado em 01/03/02.

\section{Departamento Geral de Patrimônio Cultural - DGPC}

André Zambelli

Diretor

Contato realizado em 22/02/02.

Maria Helena MacLaren Maia

Escritório Técnico do Corredor Cultural

Contato realizado em 22/02/02.

Cristina Lodi Dias.

Unidade Executora do Programa Monumenta - Rio

Contato realizado em 25/02/02 e, pelo telefone, em fevereiro de 2003.

\section{Espaço Cultural dos Correios}

Marcelle Pithom

Diretora

Contato realizado em 27/02/02. 


\section{Fundação Casa França-Brasil}

Mariana Várzea

Diretora de Projetos e Educação

Contato realizado em $01 / 03 / 02$.

\section{Fundação Roberto Marinho}

Silvia Fingerut

Gerente Geral de Patrimônio e Ecologia

Contato realizado em 25/02/02.

Lucia Basto

Gerente de Projetos

Contato realizado em 25/02/02.

\section{Instituto Estadual do Patrimônio Artístico e Cultural - INEPAC}

Dina Lerner

Arquiteta e Conselheira do Conselho Estadual de Cultura

Contato realizado em $01 / 03 / 02$.

\section{Instituto Light}

Augusto Ivan de Freitas Pinheiro

Secretário Geral

Contato realizado em 20/02/02.

Instituto do Patrimônio Histórico e Artístico Nacional - IPHAN

\section{$6^{a}$ Superintendência Regional do IPHAN}

Thays Pessoto de Mendonça Zugliani

Superintendente Regional

Contato realizado em 21/02/02.

Claudia Maria Storino

Chefe de Gabinete

Contato realizado em 21/02/02. 
José Belmont Pessoa

Arquiteto

Contato realizado em 21/02/02.

Paulo Vidal

Arquiteto, responsável pelo acompanhamento do Programa Monumenta no Rio

Contato realizado em 21/02/02.

José Luiz C. Sahione

Responsável pela análise de Projetos PRONAC

Contato realizado em 21/12/02.

\section{Departamento de Proteção do IPHAN (RJ)}

Cyro Correa Lyra

Assessor junto ao Programa Monumenta e ex-Coordenador do Grupo Tarefa

Contato realizado em 23/02/02.

Leonardo Mesentier

Arquiteto e Urbanista

Contato realizado em 25/02/02.

Meise Paes

Arquiteta

Contato realizado em 25/02/02.

Joyce Kurrels

Arquiteta

Contato realizado em 25/02/02.

\section{Departamento de Identificação e Documentação}

Lia Motta

Arquiteta e Conselheira do Conselho Estadual de Cultura

Contato realizado em 20/02/02. 


\section{Secretaria Municipal de Habitação}

Ahmed Nazih Murad Helou

Subgerente do Programa "Novas Alternativas"

Contato realizado em 27/02/02.

\section{Secretaria Municipal de Urbanismo}

Alice Reis

Urbanista

Contato realizado em 22/02/02.

\section{Instituto Pereira Passos}

Nina Maria de Carvalho Rabha

Coordenadora de Desenvolvimento de Projetos

Contato realizado em 28/02/02.

\section{São Paulo}

\section{Administração Regional da Sé}

Irene Iyda

Assessora da Administradora Regional

Contato realizado em 22/03/02.

Décio Amadio

Arquiteto

Contato realizado em 28/03/02.

\section{Associação Viva o Centro}

Kátia Canova

Relações Públicas

Contato realizado em 22/03/02.

Jule Barreto

Editor da Revista URBS

Contato realizado em 22/03/02. 
Terezinha Santana

Coordenadora do Programa de Ações Locais

Contato realizado em 22/03/02.

\section{Centro Cultural Banco do Brasil - São Paulo}

Marcelo Martins Mendonça

Gerente de Comunicação

Contato realizado em 28/03/02.

\section{CONDEPHAAT - Secretaria de Estado da Cultura}

Antonio Augusto Arantes

Ex-Presidente do CONDEPHAAT em 1981-1982

Contato realizado em 21/03/02.

\section{Departamento de Patrimônio Histórico - DPH, Secretaria Municipal de Cultura}

Cássia Magaldi

Coordenadora

Contato realizado em 13/11/02.

Walter Pires

Assistente da Diretoria

Contatos realizados em 20/03/02 e 25/03/02.

Mirthes Baffi

Arquiteta

Contatos realizados em 20/03/02 e 11/07/02 (esta última em Salvador).

\section{Empresa de Urbanização de São Paulo - EMURB}

Nádia Somekh

Vice-presidente

Contato realizado em 12/11/02.

Diana di Giuseppe

Unidade Executora de Projeto - Programa Monumenta

Contato realizado em 12/11/02. 
Rita Gonçalves

Coordenadora do Grupo Técnico da Operação Urbana Centro

Contato realizado em 20/03/02.

\section{Espaço Cultural dos Correios}

\section{Aparecida Segre}

Arquiteta, responsável pela obra

Contato realizado em 13/11/02.

\section{ProCentro - Secretaria Municipal de Habitação e Desenvolvimento Urbano}

Helena Menna Barreto Silva

Vice-Presidente do ProCentro

Contatos realizados em 20/03/02 e em 12/11/03.

Gustavo Partezani

Técnico

Contato realizado em 20/03/02.

Sérgio Luis Abrahão

Coordenador

Contato realizado em 20/03/02.

Alejandra Devecchi

Grupo de Avaliação de Imóveis

Contato realizado em 26/03/02.

\section{Secretaria Municipal de Planejamento Urbano}

Tuca Siqueira Alves

Socióloga

Contato realizado em 20/03/02.

Evany de Souza

Arquiteta

Contato realizado em 20/03/02. 
Sylvia Luz Fré

Supervisor de Estudos e Áreas Especiais

Contato realizado em 25/03/02.

Instituto do Patrimônio Histórico e Artístico Nacional

$9^{a}$ Superintendência Regional do IPHAN

Cecília Rodrigues

Ex-Superintendente Regional até 1999

Contato realizado em 21/03/02.

Marcos Carrilho

Arquiteto

Contato realizado em 28/03/02.

José Saia Neto

Arquiteto

Contato realizado em 28/03/02.

Universidade de São Paulo

Regina Prosperi Meyer

Professora da FAU

Contato realizado em 26/03/02.

Sarah Feldman

Professora da FAU - São Carlos

Contato realizado em 26/03/02.

\section{Brasília}

Instituto do Patrimônio Histórico e Artístico Nacional

Departamento de Proteção (BSB)

Bernadete Porto

Coordenadora do PRONAC no IPHAN

Contato realizado em 10/12/02. 
Marcelo Brito

Coordenador do Programa URBIS

Contato realizado em 10/12/02.

\section{Grupo Tarefa - Programa Monumenta}

Marco Antônio Galvão

Coordenador do Grupo Tarefa

Contato realizado em 10/12/02.

Sylvia Nelo Braga

Consultora do Grupo Tarefa

Contato realizado em oو/12/02

José Hailon Gomide

Consultor do Grupo Tarefa

Contato realizado em 09/12/02.

\section{Ministério da Cultura}

\section{Secretaria de Apoio à Cultura}

Eneida Braga Rocha de Lemos

Coordenadora do Mecenato

Contato realizado em 10/12/02.

Raymundo Drummond

Coordenador Geral de Projetos do Fundo Nacional da Cultura

Contato realizado em 10/12/02.

\section{Secretaria do Patrimônio Museus e Artes Plásticas}

Cecília Londres Fonseca

Assessora

Contato realizado em 12/12/02.

Elisa Leonel

Coordenadora

Contato realizado em 12/12/02. 
Unidade Central de Gerenciamento do Programa Monumenta

Cecília Parlato

Consultora

Contato realizado em 10/12/02.

A. de Pádua Paz de Andrade

Consultor

Contato realizado em 13/12/02

UNESCO

Jurema Machado

Coordenadora

Contato realizado em 11/12/02. 


\section{Anexo A}

\section{Tombamentos municipais na área central do Rio de Janeiro - bens imóveis e naturais, 1983/1997}

\begin{tabular}{|c|c|c|c|}
\hline \multirow[b]{2}{*}{ Ano } & \multirow[b]{2}{*}{ Bem } & \multicolumn{2}{|c|}{ Localização } \\
\hline & & $\begin{array}{l}\text { Bairros } \\
\text { Área Central }\end{array}$ & $\begin{array}{c}\text { Região } \\
\text { Administrativa } \\
\end{array}$ \\
\hline \multicolumn{4}{|c|}{1983} \\
\hline & Escola Municipal José Bonifácio & Gamboa & I RA \\
\hline \multicolumn{4}{|c|}{1984} \\
\hline & Teatro Carlos Gomes & Centro & II RA \\
\hline & Farmácia Cordeiro, Rua da Constituição, 45 & Centro & II RA \\
\hline \multicolumn{4}{|c|}{ 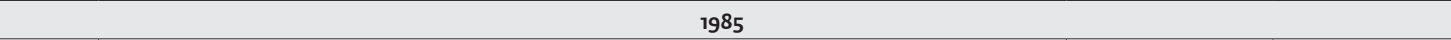 } \\
\hline & Sobrados à Rua Sete de Setembro, 182,184 e 186 & Centro & II RA \\
\hline & Vila Operária, Conjunto Salvador de Sá & Cidade Nova & III RA \\
\hline \multicolumn{4}{|c|}{1986} \\
\hline & Solar à Rua Barão de São Félix, 94 & Centro & II RA \\
\hline & Vila "Avenida Caruso", Rua Barão de São Félix, 97 & Centro & II RA \\
\hline & $\begin{array}{l}\text { Prédio do Sindicato dos Condutores de Veículos Rodoviários } \\
\text { e Trabalhadores em Transportes Urbanos }\end{array}$ & Centro & II RA \\
\hline & Cortiço à Rua Costa Ferreira, 70 & Centro & II RA \\
\hline & Real e Benemérita Sociedade Portuguesa Caixa de Socorros D. Pedro V & Centro & II RA \\
\hline & Sobrado à Rua Senador Pompeu, 32 & Centro & II RA \\
\hline & Cortiço à Rua Senador Pompeu, 34 & Centro & II RA \\
\hline & Cortiço à Rua Senador Pompeu, 43 & Centro & II RA \\
\hline & Cortiço à Rua Senador Pompeu, 51 & Centro & II RA \\
\hline & Sobrado à Rua Visconde de Itaboraí, 8 & Centro & II RA \\
\hline & Escadaria na Rua Costa Barros, entre Rua Rosa Saião e Trav. do Livramento & Gamboa & IRA \\
\hline & Moinho Fluminense & Gamboa & I RA \\
\hline & Galpões da Estrada de Ferro Central do Brasil, pátio de manobras da RFF & Santo Cristo & I RA \\
\hline & Vila Operária da Gamboa, Rua Barão da Gamboa, 150/160 & Santo Cristo & I RA \\
\hline & Edifício à Rua Barão da Gamboa, n. 164/184 & Santo Cristo & I RA \\
\hline & Igreja de São Pedro (ruínas) & Santo Cristo & IRA \\
\hline & Hospital N. S. da Saúde & Santo Cristo & I RA \\
\hline & Conjunto de edificações na Rua Farnese, 45,49 e 51 & Santo Cristo & I RA \\
\hline & Trapiche Modesto Leal & Santo Cristo & IRA \\
\hline & Vila na Rua Marquês de Sapucaí , 14 & Santo Cristo & I RA \\
\hline & Oratório no topo do Morro da Providência & Saúde & I RA \\
\hline & Estrebaria, Rua Sacadura Cabral, 145 & Saúde & IRA \\
\hline & Fundição Manuel Costa Lino & Saúde & IRA \\
\hline
\end{tabular}




\begin{tabular}{|c|c|c|c|}
\hline \multirow[b]{2}{*}{ Ano } & \multirow[b]{2}{*}{ Bem } & \multicolumn{2}{|c|}{ Localização } \\
\hline & & $\begin{array}{l}\text { Bairros } \\
\text { Área Central }\end{array}$ & $\begin{array}{c}\text { Região } \\
\text { Administrativa }\end{array}$ \\
\hline \multicolumn{4}{|c|}{1987} \\
\hline & Hospital da Cruz Vermelha & Centro & II RA \\
\hline & Vila à Rua General Caldwel, 206. & Centro & II RA \\
\hline & Garagem Poula, Rua Gomes Freire, 306 & Centro & II RA \\
\hline & Sobrado à Av. Gomes Freire, 773 & Centro & IIRA \\
\hline & Casa Daniel, Rua Gonçalves Dias, 13 & Centro & II RA \\
\hline & Igreja de Santo Antônio dos Pobres & Centro & II RA \\
\hline & Cortiço Chora Vinagre, Rua dos Inválidos 124 & Centro & II RA \\
\hline & Conjunto de sobrado e vila na Rua do Lavradio, 122 & Centro & II RA \\
\hline & Dispensário São Vicente de Paula, Av. Mem de Sá, 271 & Centro & II RA \\
\hline & Primeira Circunscrição do Serviço Militar, Praça da República, 123 & Centro & II RA \\
\hline & Hospital da Venerável Ordem Terceira da N. S. do Monte do Carmo & Centro & II RA \\
\hline & Clube dos Democráticos, Rua do Riachuelo, 91/93 & Centro & II RA \\
\hline & Casas geminadas na Rua do Riachuelo, 354/356 & Centro & II RA \\
\hline & Grande Templo Israelita do Rio de Janeiro, Rua Tenente Passolo, 8 & Centro & II RA \\
\hline & Perfumaria Kanitz, Rua Washington Luís, 117 & Centro & II RA \\
\hline \multicolumn{4}{|c|}{1988} \\
\hline & Chafariz do Jardim do Monroe, Praça Mahatma Ghandi & Centro & II RA \\
\hline & Prédio da Justiça Federal, Avenida Rio Branco, 241 & Centro & II RA \\
\hline \multicolumn{4}{|c|}{1989} \\
\hline & Sobrado à Rua da Candelária, 2 & Centro & II RA \\
\hline & $\begin{array}{l}\text { Conjunto Arquitetônico da Cinelândia (fachadas dos prédios situados na Praça Floriano, 55, } \\
\text { Rua Francisco Serrador, 2, Rua Álvaro Alvim, } 24 \text { a 48, e Praça Mahatma Ghandi, 2) }\end{array}$ & Centro & II RA \\
\hline & Buraco do Lume, Praça Melvin Jones & Centro & II RA \\
\hline \multicolumn{4}{|c|}{1990} \\
\hline & Escola Municipal Estados Unidos, Rua Itapiru, 452. & Catumbi & III RA \\
\hline & Escola Municipal República da Colômbia, Rua Camerino & Centro & II RA \\
\hline & Escola Municipal Celestino Silva (prédio do antigo Teatro Apolo), Rua do Lavradio & Centro & II RA \\
\hline & Prédio onde funcionou a EMBRAFILME, Rua Mayrink Veiga, 28 & Centro & II RA \\
\hline & Escola Municipal Rivadávia Correa, Av. Pres. Vargas, 1314. & Centro & II RA \\
\hline & Escola Municipal Campos Salles, Praça da República, s/n & Centro & II RA \\
\hline & Escola Municipal Tiradentes, Rua Visconde do Rio Branco, 48 & Centro & II RA \\
\hline \multicolumn{4}{|c|}{1992} \\
\hline & Prédio da Subestação Elétrica da Light, Rua Frei Caneca, 363 & Catumbi & III RA \\
\hline & Palácio Tiradentes, Prédio da Assembleia do Estado & Centro & II RA \\
\hline \multicolumn{4}{|c|}{1993} \\
\hline & Confeitaria Manon, Rua do Ouvidor, 187/189 & Centro & II RA \\
\hline & Tribunal Regional Eleitoral, Rua Primeiro de Março, 42. & Centro & II RA \\
\hline & $\begin{array}{l}\text { Arquivo e Museu Judiciário do Tribunal de Justiça do Estado do Rio de Janeiro, Praça da } \\
\text { República, } 26 .\end{array}$ & Centro & II RA \\
\hline & Edifício de Apartamentos à Rua Washington Luís, 10/10A. & Centro & II RA \\
\hline
\end{tabular}




\begin{tabular}{|c|c|c|c|}
\hline \multirow[b]{2}{*}{ Ano } & \multirow[b]{2}{*}{ Bem } & \multicolumn{2}{|c|}{ Localização } \\
\hline & & $\begin{array}{l}\text { Bairros } \\
\text { Área Central }\end{array}$ & $\begin{array}{c}\text { Região } \\
\text { Administrativa }\end{array}$ \\
\hline \multicolumn{4}{|c|}{1994} \\
\hline & Escola de Música da UFRJ, Rua do Passeio, 98 & Centro & II RA \\
\hline & Casa à Rua da Quitanda n. 21 & Centro & II RA \\
\hline & Galpão Industrial, Rua Aníbal Benévolo, 315 & Cidade Nova & III RA \\
\hline \multicolumn{4}{|c|}{1995} \\
\hline & Casas Vila São Lázaro, Ruas da Indústria, 18 e Mestre Camargo, 3. & Caju & IRA \\
\hline & Conjunto de prédios das ruas São José $(8,16,54,56,76,78,80,86)$ e D. Manuel, 14 & Centro & II RA \\
\hline \multicolumn{4}{|c|}{1996} \\
\hline & Estação Ferroviária D. Pedro II, Praça Cristiano Ottoni & Centro & II RA \\
\hline \multicolumn{4}{|c|}{1997} \\
\hline & Ministério da Fazenda, Av. Pres. Antonio Carlos, 375 & Centro & II RA \\
\hline & Portaria à Rua Senador Dantas, 74 & Centro & II RA \\
\hline \multicolumn{4}{|c|}{ Total de 69 bens tombados na área central } \\
\hline \multicolumn{4}{|c|}{ Total de 267 bens tombados no município } \\
\hline \multicolumn{4}{|c|}{ Porcentagem de $26 \%$ de bens tombados na área central } \\
\hline
\end{tabular}

Fonte: Rio de Janeiro (2000a) 


\section{Anexo B}

\section{Imóveis ocupados por Movimentos Populares na área central de São Paulo - (posição em setembro de 2001)}

\begin{tabular}{|c|c|c|c|c|c|}
\hline ENDEREÇO & $\begin{array}{l}\text { PROPRIETÁRIO } \\
\text { ATUAL }\end{array}$ & $\begin{array}{l}\text { DATA DA } \\
\text { OCUPAÇÃO }\end{array}$ & MOVIMENTO RESPONSÁVEL & ASSESSORIA TÉCNICA & $\begin{array}{l}\text { Nº DE FAMÍLIAS } \\
\text { NA OCUPAÇÃO }\end{array}$ \\
\hline Rua Sólon, 934 & Particular & ocupação antiga & Unificação das Lutas de Cortiços & Não há & 74 \\
\hline Rua Joaquim Murtinho, 252 & Particular & ocupação antiga & Fórum de Cortiços (Assessoria) & Fábrica Urbana & 34 \\
\hline Rua Baronesa Porto Carrero & PMSP & ocupação antiga & Fórum de Cortiços & Ambiente & s/inf \\
\hline Rua da Mooca, 3420 & Governo do Estado & 1960 & Unificação das Lutas de Cortiços & Não há & 125 \\
\hline $\begin{array}{l}\text { Rua General Góes } \\
\text { Monteiro, } 89\end{array}$ & Particular & 1997 & Fórum de Cortiços (Assessoria) & $\begin{array}{l}\text { Integra Cooperativa de } \\
\text { Trabalho Interdisciplinar }\end{array}$ & 40 \\
\hline $\begin{array}{l}\text { Al. Cleveland, 601, } \\
\text { Santa Cecília }\end{array}$ & Governo do Estado & 1997 & Fórum de Cortiços & Ambiente & 57 \\
\hline $\begin{array}{l}\text { Rua Pirineus, com Brig. } \\
\text { Galvão }\end{array}$ & Governo do Estado & 1997 & Fórum de Cortiços & Ambiente & 30 \\
\hline Av. 9 de Julho, 570/84. & INSS & 1997 & Mov. Sem-Teto do Centro & Ambiente & 86 \\
\hline Rua do Ouvidor, 63, Centro & $\begin{array}{l}\text { Governo do Estado } \\
\text { (SMC) }\end{array}$ & 1997 & Mov. Moradia no Centro & $\begin{array}{l}\text { Labhab } \\
\text { FAUUSP }\end{array}$ & 87 \\
\hline Rua Floriano Peixoto, 60 & CEF & 1998 & Mov. Moradia no Centro & Helena Saia & 47 \\
\hline Rua Ana Cintra, 123 & Governo do Estado & 1999 & Mov. Sem-Teto do Centro & $\mathrm{CDHU}$ & 71 \\
\hline Rua 21 de Abril, Brás & $\begin{array}{l}\text { Hospital N. Sra. } \\
\text { da Conceição }\end{array}$ & 1999 & Unificação das Lutas de Cortiços & $\mathrm{CDHU}$ & 213 \\
\hline Rua Paulino Guimarães, 224 & Governo do Estado & 1999 & Mov. Sem-Teto do Centro & Não há & 97 \\
\hline $\begin{array}{l}\text { Rua da Abolição, 431, } \\
\text { Bela Vista }\end{array}$ & Governo do Estado & 1999 & Fórum de Cortiços & Fábrica Urbana & 110 \\
\hline $\begin{array}{l}\text { Rua Brigadeiro Tobias, } \\
\text { 290/298/300 }\end{array}$ & $\begin{array}{l}\text { Fundação } \\
\text { Rede Ferroviária de } \\
\text { Seguridade Social }\end{array}$ & 1999 & $\begin{array}{l}\text { Mov. Sem-Teto do Centro } \\
\text { e UMM/Oeste }\end{array}$ & $\begin{array}{l}\text { Integra Cooperativa de } \\
\text { Trabalho Interdisciplinar }\end{array}$ & 40 \\
\hline Av. Celso Garcia, 787, Brás & BANESPA & 1999 & Unificação das Lutas de Cortiços & $\begin{array}{l}\text { Integra Cooperativa de } \\
\text { Trabalho Interdisciplinar }\end{array}$ & $\begin{array}{c}250 \text {, mas apenas } \\
80 \text { moraram até a } \\
\text { reforma }\end{array}$ \\
\hline $\begin{array}{l}\text { Rua das Olarias com } \\
\text { Araguaia }\end{array}$ & PMSP & 1999 & Fórum de Cortiços (assessoria) & Fábrica Urbana & 17 \\
\hline $\begin{array}{l}\text { Av. Presidente Wilson, } \\
3652 / 3674\end{array}$ & Governo do Estado & 2000 & Mov. Moradia do Centro & $\begin{array}{l}\text { Labhab } \\
\text { FAUUSP }\end{array}$ & 100 \\
\hline $\begin{array}{l}\text { Rua Ganges, } \\
\text { Vila Manchester }\end{array}$ & Governo do Estado & 2000 & Unificação das Lutas de Cortiços & Não há & 120 \\
\hline
\end{tabular}




\section{Projetos financiados pelo Banco Interamericano de Desenvolvimento na área de preservação do patrimônio cultural(*), 1974/2000}

$\left.{ }^{*}\right)$ Estes programas e projetos não são os únicos que o Banco Interamericano de Desenvolvimento - BID financia na América Latina. Correspondem apenas a uma linha de financiamento, entre outras voltadas para saneamento, transportes, infraestrutura urbana etc.

\begin{tabular}{|c|c|c|c|c|}
\hline Ano/País & Tipo & Projeto/ Localização & $\begin{array}{l}\text { Conteúdo e custo } \\
\text { do componente (us\$) }\end{array}$ & Custo Total (us\$) \\
\hline $\begin{array}{l}1974 \\
\text { Peru }\end{array}$ & $\begin{array}{l}\text { Projeto que inclui } \\
\text { componente de recuperação } \\
\text { do patrimônio cultural }\end{array}$ & $\begin{array}{l}\text { Desenvolvimento Turístico } \\
\text { Integral - Plano COPESCO } \\
\text { Região de Cuzco e Puno }\end{array}$ & $\begin{array}{l}\text { Recuperação de sítios arqueológicos } \\
\text { e monumentos } \\
\text { Estabelecimento de museus } \\
\text { em } 27 \text { monumentos } \\
\text { Custo: US\$ 5,5 milhões }\end{array}$ & US\$72,4 milhões \\
\hline $\begin{array}{c}1977 \\
\text { Panamá }\end{array}$ & $\begin{array}{l}\text { Projeto que inclui } \\
\text { componente de recuperação } \\
\text { do patrimônio cultural }\end{array}$ & $\begin{array}{l}\text { Projeto de Desenvolvimento } \\
\text { Turístico } \\
\text { Centro histórico da cidade do } \\
\text { Panamá e Panamá Viejo }\end{array}$ & $\begin{array}{l}\text { Restauração e Desenvolvimento do centro } \\
\text { histórico - custo US\$6,9 milhões } \\
\text { Restauração e desenvolvimento } \\
\text { de Panamá Viejo - US\$7,1 milhões } \\
\text { Museu de Panamá Viejo - US\$373 mil }\end{array}$ & US\$ 43,8 milhões \\
\hline $\begin{array}{l}1994 \\
\text { Brasil }\end{array}$ & $\begin{array}{l}\text { Projeto que inclui } \\
\text { componente de recuperação } \\
\text { do patrimônio cultural }\end{array}$ & $\begin{array}{l}\text { Programa de Desenvolvimento } \\
\text { Turístico do Nordeste-- } \\
\text { PRODETUR } \\
\text { Região Nordeste }\end{array}$ & $\begin{array}{l}\text { Recuperação de infraestrutura e espaços } \\
\text { públicos, melhoramento de acessibilidade, } \\
\text { restauração de monumentos } \\
\text { e revitalização de centros históricos } \\
\text { da região - US\$ } 80 \text { milhões }\end{array}$ & $\begin{array}{l}\text { US\$ } 800 \text { milhões } \\
\text { BID }-400 \text { milhões } \\
\text { Locais }-400 \text { milhões }\end{array}$ \\
\hline $\begin{array}{l}1994 \\
\text { Equador }\end{array}$ & $\begin{array}{l}\text { Projeto de preservação de } \\
\text { centro histórico }\end{array}$ & $\begin{array}{l}\text { Programa de Reabilitação do } \\
\text { Centro Histórico de Quito }\end{array}$ & $\begin{array}{l}\text { Infraestrutura urbana - US\$ } 3,8 \text { milhões } \\
\text { Construção de estacionamentos - } \\
\text { US\$ 9,6 milhões } \\
\text { Centro Cultural e Museu da Cidade - } \\
\text { US\$ 4,6 milhões } \\
\text { Projetos de reabilitação com setor } \\
\text { privado - US\$ } 15 \text { milhões } \\
\text { Fortalecimento institucional e estudos - } \\
\text { US\$ } 3 \text { milhões }\end{array}$ & $\begin{array}{l}\text { US\$ } 51,3 \text { milhões } \\
\text { BID }-41 \text { milhões } \\
\text { Locais }-10,3 \text { milhões }\end{array}$ \\
\hline $\begin{array}{l}1995 \\
\text { Bolívia }\end{array}$ & $\begin{array}{l}\text { Projeto que inclui } \\
\text { componente de recuperação } \\
\text { do patrimônio cultural }\end{array}$ & $\begin{array}{l}\text { Programa de Cooperação para o } \\
\text { Desenvolvimento do Turismo }\end{array}$ & $\begin{array}{l}\text { Recuperação e acondicionamento de cinco } \\
\text { sítios arqueológicos - US } 1,8 \text { milhões }\end{array}$ & $\begin{array}{c}\text { US } \$ 6 \text { milhões } \\
\text { BID }-4,8 \text { milhões } \\
\text { Locais }-1,2 \text { milhões } \\
\end{array}$ \\
\hline $\begin{array}{l}1995 \\
\text { Brasil }\end{array}$ & $\begin{array}{l}\text { Projeto de Cooperação } \\
\text { Técnica com financiamento } \\
\text { de fundo fiduciário }\end{array}$ & $\begin{array}{l}\text { Desenvolvimento do Parque } \\
\text { da Capivara } \\
\text { São Raimundo Nonato - Piauí }\end{array}$ & $\begin{array}{l}\text { Preservação de Sítios e Monumentos } \\
\text { Arqueológicos do Parque Nacional } \\
\text { da Serra da Capivara }\end{array}$ & $\begin{array}{l}\text { US\$1,7 milhões } \\
\text { (Fundo Japonês) }\end{array}$ \\
\hline $\begin{array}{c}1995 \\
\text { Guatemala }\end{array}$ & $\begin{array}{l}\text { Projeto de Cooperação } \\
\text { Técnica com financiamento } \\
\text { de fundo fiduciário }\end{array}$ & $\begin{array}{l}\text { Desenvolvimento Sustentável } \\
\text { de Petén } \\
\text { Petén }\end{array}$ & $\begin{array}{l}\text { Recuperação e desenvolvimento de sítios } \\
\text { históricos do Petén - US\$ } 310 \text { mil } \\
\text { Formação de pessoal indígena local } \\
\text { para gestão e manutenção dos sítios } \\
\text { arqueológicos - US\$ } 49,8 \text { mil }\end{array}$ & $\begin{array}{l}\text { US\$359,8 mil } \\
\text { (Fundo Norueguês) }\end{array}$ \\
\hline $\begin{array}{l}1996 \\
\text { Guatemala }\end{array}$ & $\begin{array}{l}\text { Projeto que inclui } \\
\text { componente de recuperação } \\
\text { do patrimônio cultural }\end{array}$ & $\begin{array}{l}\text { Programa para o } \\
\text { Desenvolvimento Sustentável } \\
\text { do Petén } \\
\text { Petén }\end{array}$ & $\begin{array}{l}\text { Recuperação e proteção de sítios } \\
\text { arqueológicos maias e centros históricos } \\
\text { coloniais e outros elementos do } \\
\text { patrimônio cultural e artesanal local e } \\
\text { de tradições indígenas - US\$ } 4 \text { milhões }\end{array}$ & $\begin{array}{l}\text { US } \$ 22 \text { milhões } \\
\text { BID }-19,8 \text { milhões } \\
\text { Locais }-2,2 \text { milhões }\end{array}$ \\
\hline
\end{tabular}




\begin{tabular}{|c|c|c|c|c|}
\hline Ano/ País & Tipo & Projeto/Localização & $\begin{array}{l}\text { Conteúdo e custo } \\
\text { do componente (us\$̦) }\end{array}$ & Custo Total (us\$) \\
\hline $\begin{array}{c}1996 \\
\text { Argentina }\end{array}$ & $\begin{array}{l}\text { Projeto que inclui } \\
\text { componente de recuperação } \\
\text { do patrimônio cultural }\end{array}$ & $\begin{array}{l}\text { Recuperação ambiental da } \\
\text { Cuenca Matanza-Riachuelo } \\
\text { Buenos Aires }\end{array}$ & $\begin{array}{l}\text { Recuperação de áreas patrimoniais nos } \\
\text { bairros de La Boca, Isla Maciel e Barracas } \\
\text { - US\$ } 18 \text { milhóes }\end{array}$ & $\begin{array}{l}\text { US\$ } 500 \text { milhões } \\
\text { BID }-250 \text { milhões } \\
\text { Locais }-250 \text { milhões }\end{array}$ \\
\hline $\begin{array}{l}1996 \\
\text { Regional }\end{array}$ & $\begin{array}{l}\text { Projeto de Cooperação } \\
\text { Técnica com financiamento } \\
\text { de fundo fiduciário }\end{array}$ & $\begin{array}{l}\text { Apoio ao Mundo Maia } \\
\text { Vários países }\end{array}$ & $\begin{array}{l}\text { Apoio à preparação de um projeto de } \\
\text { desenvolvimento sustentável do Mundo } \\
\text { Maia, com identificação de etapas e } \\
\text { investimentos necessários }\end{array}$ & $\begin{array}{l}\text { US\$ } 12 \text { mil } \\
\text { (Fundo Sueco) }\end{array}$ \\
\hline $\begin{array}{c}1996 \\
\text { Uruguai }\end{array}$ & $\begin{array}{l}\text { Projeto de Cooperação } \\
\text { Técnica com financiamento } \\
\text { de fundo fiduciário }\end{array}$ & $\begin{array}{l}\text { Programa Nacional de } \\
\text { Recuperação Urbana } \\
\text { Montevidéu }\end{array}$ & $\begin{array}{l}\text { Estudos preliminares para o programa de } \\
\text { investimentos na recuperação da estação } \\
\text { ferroviária General Artigas e do bairro de } \\
\text { La Aguada }\end{array}$ & $\begin{array}{l}\text { US\$ } 77 \text { mil } \\
\text { (Fundo Suíço) }\end{array}$ \\
\hline $\begin{array}{l}1997 \\
\text { Regional }\end{array}$ & $\begin{array}{l}\text { Projeto de Cooperação } \\
\text { Técnica com financiamento } \\
\text { de fundo fiduciário }\end{array}$ & $\begin{array}{l}\text { Preservação do Patrimônio } \\
\text { Histórico Urbano } \\
\text { Vários países }\end{array}$ & $\begin{array}{l}\text { Análise da problemática do setor } \\
\text { habitacional nos projetos de recuperação } \\
\text { de áreas históricas e patrimoniais. Análise } \\
\text { do potencial de adaptação de modelos } \\
\text { europeus em projetos na América Latina }\end{array}$ & $\begin{array}{l}\text { US\$20,5 mil } \\
\text { (Fundo Italiano) }\end{array}$ \\
\hline $\begin{array}{c}1997 \\
\text { Venezuela }\end{array}$ & $\begin{array}{l}\text { Projeto que inclui } \\
\text { componente de recuperação } \\
\text { do patrimônio cultural }\end{array}$ & $\begin{array}{l}\text { Programa de Apoio ao Centro de } \\
\text { Ação Social para a Música } \\
\text { Venezuela }\end{array}$ & $\begin{array}{l}\text { Consolidação do Sistema Nacional de } \\
\text { Orquestras e Coros Juvenis e Infantis para } \\
\text { combater marginalização e violência em } \\
\text { comunidades carentes }\end{array}$ & $\begin{array}{l}\text { US\$ } 16 \text { milhões } \\
\text { BID }-8 \text { milhões } \\
\text { Locais }-8 \text { milhões. }\end{array}$ \\
\hline $\begin{array}{l}1998 \\
\text { Uruguai }\end{array}$ & $\begin{array}{l}\text { Projeto de Preservação de } \\
\text { Centros Históricos }\end{array}$ & $\begin{array}{l}\text { Programa Nacional de } \\
\text { Recuperação Urbana } \\
\text { La Aguada, Montevidéu }\end{array}$ & $\begin{array}{l}\text { Reabilitação e equipamento da Estação } \\
\text { Ferroviária General Artigas para usos } \\
\text { mistos e culturais, com setor privado - } \\
\text { US\$ 8,2 milhões } \\
\text { Melhoramento de infraestrutura básica e } \\
\text { espaços públicos da La Aguada - } \\
\text { US\$11,8 milhões } \\
\text { Equipamento para desenvolvimento } \\
\text { de atividades culturais na Estação Gen. } \\
\text { Artigas e no novo Complexo Cultural do } \\
\text { Serviço Oficial de Difusão, Radiotelevisão } \\
\text { e Espetáculos - US\$10,6 milhões } \\
\text { Assistência técnica para a gestão cultural } \\
\text { da estação e do novo complexo cultural - } \\
\text { US\$2,9 milhões }\end{array}$ & $\begin{array}{l}\text { US\$ } 40 \text { milhões } \\
\text { BID - US\$ } 28 \text { milhões } \\
\text { Locais - } 12 \text { milhões }\end{array}$ \\
\hline $\begin{array}{l}1998 \\
\text { Brasil }\end{array}$ & $\begin{array}{l}\text { Projeto que inclui } \\
\text { componente de recuperação } \\
\text { do patrimônio cultural }\end{array}$ & $\begin{array}{l}\text { Desenvolvimento do Turismo } \\
\text { Ecológico na Amazônia }\end{array}$ & $\begin{array}{l}\text { Fortalecimento das culturas indígenas } \\
\text { locais e valorização do seu patrimônio } \\
\text { cultural - US\$ 2,4 milhões }\end{array}$ & $\begin{array}{l}\text { US\$ } 12 \text { milhões } \\
\text { BID }-10 \text { milhões } \\
\text { Locais }-2 \text { milhões }\end{array}$ \\
\hline $\begin{array}{l}1998 \\
\text { Peru }\end{array}$ & $\begin{array}{l}\text { Projeto de Cooperação } \\
\text { Técnica com financiamento } \\
\text { de fundo fiduciário }\end{array}$ & $\begin{array}{l}\text { Programa de Promoção Turística } \\
\text { do Peru }\end{array}$ & $\begin{array}{l}\text { Identificação de prioridades para a } \\
\text { elaboração de planos de recuperação e } \\
\text { gestão de centros históricos }\end{array}$ & $\begin{array}{l}\text { US\$ } 100 \text { mil } \\
\text { (Fundo Francês) }\end{array}$ \\
\hline $\begin{array}{l}1998 \\
\text { Peru }\end{array}$ & $\begin{array}{l}\text { Projeto de Cooperação } \\
\text { Técnica com financiamento } \\
\text { de fundo fiduciário }\end{array}$ & $\begin{array}{l}\text { Promoção do Turismo no } \\
\text { Departamento de Ayacucho. }\end{array}$ & $\begin{array}{l}\text { Capacitação técnica de jovens em } \\
\text { serviços turísticos, capacitação e } \\
\text { promoção de emprego juvenil em } \\
\text { preservação do patrimônio e atividades } \\
\text { de conscientização comunitária sobre } \\
\text { a importância do patrimônio histórico e } \\
\text { suas possibilidades de uso }\end{array}$ & $\begin{array}{l}\text { US\$ 2,3 milhões } \\
\text { Fundo para } \\
\text { Operações Especiais - } \\
\text { 1,6 milhões } \\
\text { Local - 70o mil }\end{array}$ \\
\hline $\begin{array}{c}1998 \\
\text { Brasil }\end{array}$ & $\begin{array}{l}\text { Projeto de Cooperação } \\
\text { Técnica com financiamento } \\
\text { de fundo fiduciário }\end{array}$ & $\begin{array}{l}\text { Melhoramento da acessibilidade } \\
\text { em áreas históricas } \\
\text { São Luís e Ouro Preto }\end{array}$ & $\begin{array}{l}\text { Estudo sobre melhoramento de } \\
\text { acessibilidade e ordenamento de tráfego } \\
\text { nos centros históricos de São Luís e Ouro } \\
\text { Preto }\end{array}$ & $\begin{array}{l}\text { US\$59 mil. } \\
\text { (Fundo Português) }\end{array}$ \\
\hline $\begin{array}{l}1998 \\
\text { Brasil }\end{array}$ & $\begin{array}{l}\text { Projeto de Cooperação } \\
\text { Técnica com financiamento } \\
\text { de fundo fiduciário }\end{array}$ & $\begin{array}{l}\text { Recuperação de Sítios Históricos } \\
\text { e Culturais }\end{array}$ & $\begin{array}{l}\text { Estudos para a recuperação de } \\
\text { infraestrutura, edifícios e espaços } \\
\text { púbicos em centros históricos e apoio ao } \\
\text { setor privado na realização de obras de } \\
\text { restauração e manutenção de edifícios } \\
\text { patrimoniais }\end{array}$ & $\begin{array}{l}\text { US\$ } 65 \text { mil } \\
\text { Fundo Especial } \\
\text { Europeu }\end{array}$ \\
\hline
\end{tabular}




\begin{tabular}{|c|c|c|c|c|}
\hline Ano/País & Tipo & Projeto/ Localização & $\begin{array}{l}\text { Conteúdo e custo } \\
\text { do componente (us\$̧) }\end{array}$ & Custo Total (us\$) \\
\hline $\begin{array}{c}1998 \\
\text { Colômbia }\end{array}$ & $\begin{array}{l}\text { Projeto de Cooperação } \\
\text { Técnica com financiamento } \\
\text { de fundo fiduciário }\end{array}$ & $\begin{array}{l}\text { Renovação da Cidade de } \\
\text { Manizales }\end{array}$ & $\begin{array}{l}\text { Estudos preliminares para um programa } \\
\text { de renovação urbana no centro histórico } \\
\text { de Manizales }\end{array}$ & $\begin{array}{l}\text { US\$ } 72 \text { mil } \\
\text { (Fundo Japonês) }\end{array}$ \\
\hline $\begin{array}{c}1998 \\
\text { Argentina }\end{array}$ & $\begin{array}{l}\text { Projeto de Cooperação } \\
\text { Técnica com financiamento } \\
\text { de fundo fiduciário }\end{array}$ & $\begin{array}{l}\text { Programa de Recuperação de } \\
\text { Sítios Históricos }\end{array}$ & $\begin{array}{l}\text { Análise de cinco sítios históricos, } \\
\text { identificaçãa de potencial e prioridades de } \\
\text { intervenção }\end{array}$ & $\begin{array}{c}\text { US\$ } 70 \text { mil } \\
\text { Fundo Italiano }\end{array}$ \\
\hline $\begin{array}{l}1999 \\
\text { Brasil }\end{array}$ & $\begin{array}{l}\text { Projeto de Preservação de } \\
\text { Centros Históricos }\end{array}$ & $\begin{array}{l}\text { Programa de Preservação do } \\
\text { Patrimônio Histórico Urbano - } \\
\text { Programa Monumenta } \\
\text { Vários estados }\end{array}$ & Ver Quadro 04 do Capítulo 6 & $\begin{array}{l}\text { US\$ } 125 \text { milhões } \\
\text { BID }-62,5 \text { milhões } \\
\text { Locais }-62,5 \text { milhões }\end{array}$ \\
\hline $\begin{array}{c}1999 \\
\text { República } \\
\text { Dominicana }\end{array}$ & $\begin{array}{l}\text { Projeto de Cooperação } \\
\text { Técnica com financiamento } \\
\text { de fundo fiduciário }\end{array}$ & $\begin{array}{l}\text { Revitalização da cidade colonial } \\
\text { de Santo Domingo }\end{array}$ & $\begin{array}{l}\text { Estudos para a elaboração de um } \\
\text { programa de revitalizaçãa da cidade } \\
\text { colonial de Santo Domingo }\end{array}$ & $\begin{array}{c}\text { US\$ } 160 \text { mil } \\
\text { Fundo Espanhol- } \\
130 \text { mil } \\
\text { BID }-30 \text { mil }\end{array}$ \\
\hline $\begin{array}{l}1999 \\
\text { Panamá }\end{array}$ & $\begin{array}{l}\text { Projeto de Cooperação } \\
\text { Técnica com financiamento } \\
\text { de fundo fiduciário }\end{array}$ & $\begin{array}{l}\text { Plano Diretor para a Recuperação } \\
\text { e Preservação do Casco Antigo } \\
\text { da Cidade do Panamá }\end{array}$ & $\begin{array}{l}\text { Estudo para estabelecer um programa de } \\
\text { melhoramento da infraestrutura urbana, } \\
\text { de circulaçáo de veículos e pedestres na } \\
\text { área histórica e elaboração de perfis de } \\
\text { projetos específicos para melhoria da } \\
\text { qualidade de vide e da oferta turística do } \\
\text { Casco Antigo }\end{array}$ & $\begin{array}{l}\text { US\$94 mil } \\
\text { Fundo Sueco }\end{array}$ \\
\hline $\begin{array}{c}1999 \\
\text { El Salvador }\end{array}$ & $\begin{array}{l}\text { Projeto de Cooperação } \\
\text { Técnica com financiamento } \\
\text { de fundo fiduciário }\end{array}$ & $\begin{array}{l}\text { Fortalecimento da administração } \\
\text { e recursos turísticos de El } \\
\text { Salvador } \\
\text { San Juan Opico, Libertad }\end{array}$ & $\begin{array}{l}\text { Recuperação do sítio arqueológico Jóias do } \\
\text { Cerén e apoio institucional a comunidades } \\
\text { locais para gestão e manutenção do sítio }\end{array}$ & $\begin{array}{c}\text { US\$ } 150 \text { mil } \\
\text { Fundo de Operações } \\
\text { Especiais }\end{array}$ \\
\hline $\begin{array}{l}1999 \\
\text { Regional }\end{array}$ & $\begin{array}{l}\text { Projeto de Cooperação } \\
\text { Técnica com financiamento } \\
\text { de fundo fiduciário }\end{array}$ & $\begin{array}{l}\text { Desenvolvimento Sustentável do } \\
\text { Mundo Maia } \\
\text { Belize, El Salvador, Guatemala, } \\
\text { Honduras e México }\end{array}$ & $\begin{array}{l}\text { Desenho de um programa de turismo } \\
\text { regional para o desenvolvimento } \\
\text { socioeconômico de populações locais e } \\
\text { em particular de comunidades indígenas e } \\
\text { grupos de baixa renda. } \\
\text { Tem componentes de desenvolvimento } \\
\text { do turismo }\end{array}$ & $\begin{array}{l}\text { US\$ 1,73 milhões } \\
\text { Fundos Norueguês, } \\
\text { Japonês, Sueco, de } \\
\text { Operações Especiais. } \\
\text { Locais: } 150 \text { mil }\end{array}$ \\
\hline $\begin{array}{l}1999 \\
\text { Uruguai }\end{array}$ & $\begin{array}{l}\text { Projeto de Cooperação } \\
\text { Técnica com financiamento } \\
\text { de fundo fiduciário }\end{array}$ & $\begin{array}{l}\text { Desenvolvimento dos Planos } \\
\text { de ordenação Urbana de Áreas } \\
\text { Patrimoniais de Montevidéu }\end{array}$ & $\begin{array}{l}\text { Apoio à Intendência Municipal no } \\
\text { desenvolvimento de planos especiais } \\
\text { para áreas patrimoniais requeridos pelo } \\
\text { Plano de Ordenamento Territorial de } \\
\text { Montevidéu }\end{array}$ & $\begin{array}{l}\text { US\$ } 150 \text { mil } \\
\text { Fundo Italiano }\end{array}$ \\
\hline $\begin{array}{l}2000 \\
\text { Honduras }\end{array}$ & $\begin{array}{l}\text { Projeto de Preservação de } \\
\text { Centros Históricos }\end{array}$ & $\begin{array}{l}\text { Programa Piloto Integral de } \\
\text { Reabilitaçáo do Centro Histórico } \\
\text { de Tegucigalpa }\end{array}$ & $\begin{array}{l}\text { Intervenção-piloto de atenção a grupos } \\
\text { vulneráveis (inclui recuperação de obras } \\
\text { de infraestrutura básica, capacitação para } \\
\text { trabalho, e recuperação de edifícios para } \\
\text { usos sociais) - US\$ 8,3 milhões. } \\
\text { Desenho, avaliação e execução de } \\
\text { programa de reabilitação do centro para } \\
\text { usos comerciais, turísticos e de recreação } \\
\text { - US\$1,3 milhões }\end{array}$ & $\begin{array}{l}\text { US\$ } 11,1 \text { milhões } \\
\text { BID }-10 \text { milhões } \\
\text { Locais: } 1,1 \text { milhão }\end{array}$ \\
\hline $\begin{array}{l}2000 \\
\text { Belize }\end{array}$ & $\begin{array}{l}\text { Projeto que inclui } \\
\text { componente de recuperação } \\
\text { do patrimônio cultural }\end{array}$ & Desenvolvimento do Turismo & $\begin{array}{l}\text { Conservação de sítios arqueológicos } \\
\text { da cultura maia, melhoramento de sua } \\
\text { acessibilidade e criação de infraestrutura } \\
\text { e serviços. Valor do componente ainda não } \\
\text { determinado }\end{array}$ & $\begin{array}{l}\text { US\$ } 14 \text { milhões } \\
\text { BID - } 11 \text { milhões } \\
\text { Locais - } 3 \text { milhões }\end{array}$ \\
\hline
\end{tabular}


ESTE LIVRO FOI IMPRESSO NO FORMATO $192 \times 234$ MM,

COM AS FONTES HUMNST 777 LT BT E ITC OFFICINA SANS BOOK,

EM PAPEL OFFSET $75 \mathrm{G} / \mathrm{M}^{2}$ (MIOLO) E EM PAPEL TRIPLEX $300 \mathrm{G} / \mathrm{M}^{2}$

(CAPA), NA GRÁFICA BIGRAF.

TIRAGEM DE 500 EXEMPLARES

SALVADOR, 2017 